Page 1 of 1

1. EDT Gंट्ठ\%

\section{To: (Receiving Organization) \\ Distribution \\ 5. Proj./Prog./Dept./Div.: \\ Immobilized Waste/RPP}

8. Originator Remarks:
3. From: (Originating Organization)

6. Design Authority/Design Agent/Cog. Engr.:
FFS / SA\&NE

$+2$

eng Authorty/Design AgenUCog. Engr.

\section{Related EDT No.: \\ 628757 \\ 7. Purchase Order No: \\ $\mathrm{N} / \mathrm{A}$ \\ 9. Equip./Component No.: \\ $\mathrm{N} / \mathrm{A}$ \\ 10. System/Bldg./Facility: \\ $\mathrm{N} / \mathrm{A}$ \\ 12. Major Assm. Dwg. No.: \\ $\mathrm{N} / \mathrm{A}$}

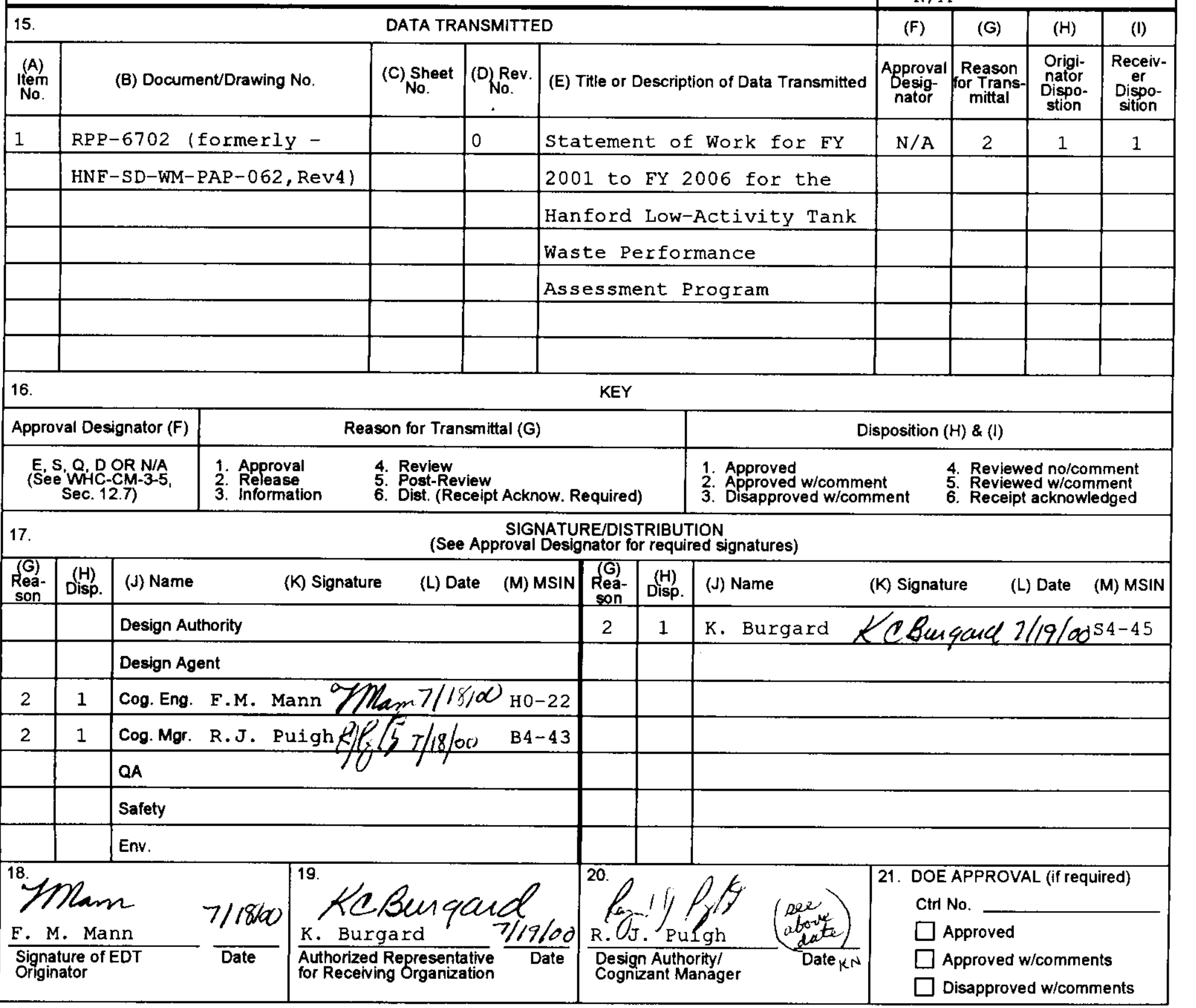

BD-7400-172-2 (10/97)
13. Permit/Permit Application No.:

$\mathrm{N} / \mathrm{A}$

14. Required Response Date:

$\mathrm{N} / \mathrm{A}$

11A. Design Baseline Document? $\square$ Yes $\bigotimes$ No

Disposition (H) \& (l)

Reviewed no/comment . Reviewed w/comment 2. Approved w/comment 3. Disapproved w/comment

Receipt acknowledged

See Approval Designator for required signatures) 


\section{DISTRIBUTION SHEET}

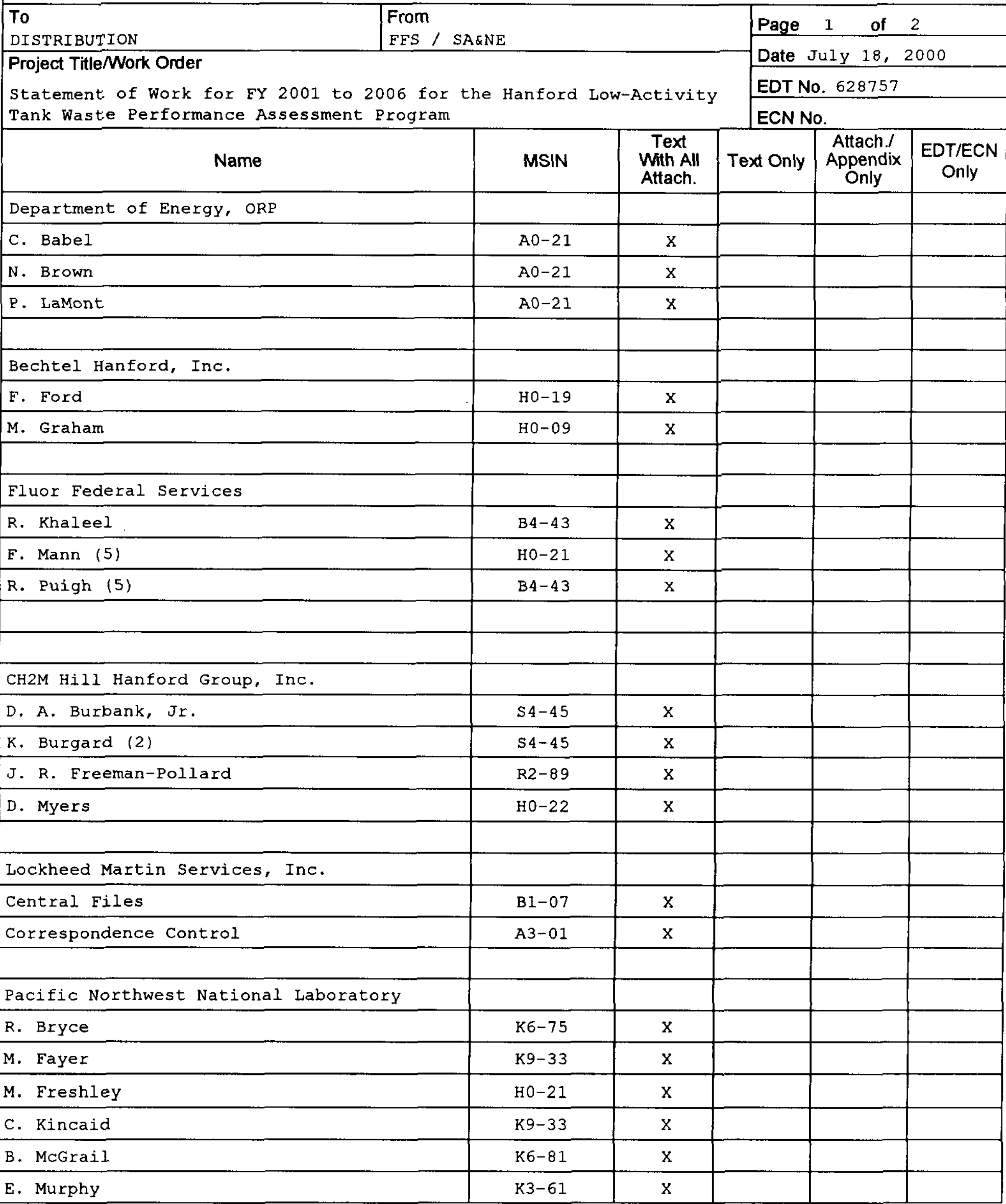




\section{DISTRIBUTION SHEET}

To

DISTRIBUTION

Project Title/Work Order

Statement of Work for FY 2001 to 2006 for the Hanford Low-Activity

Tank Waste Performance Assessment Program

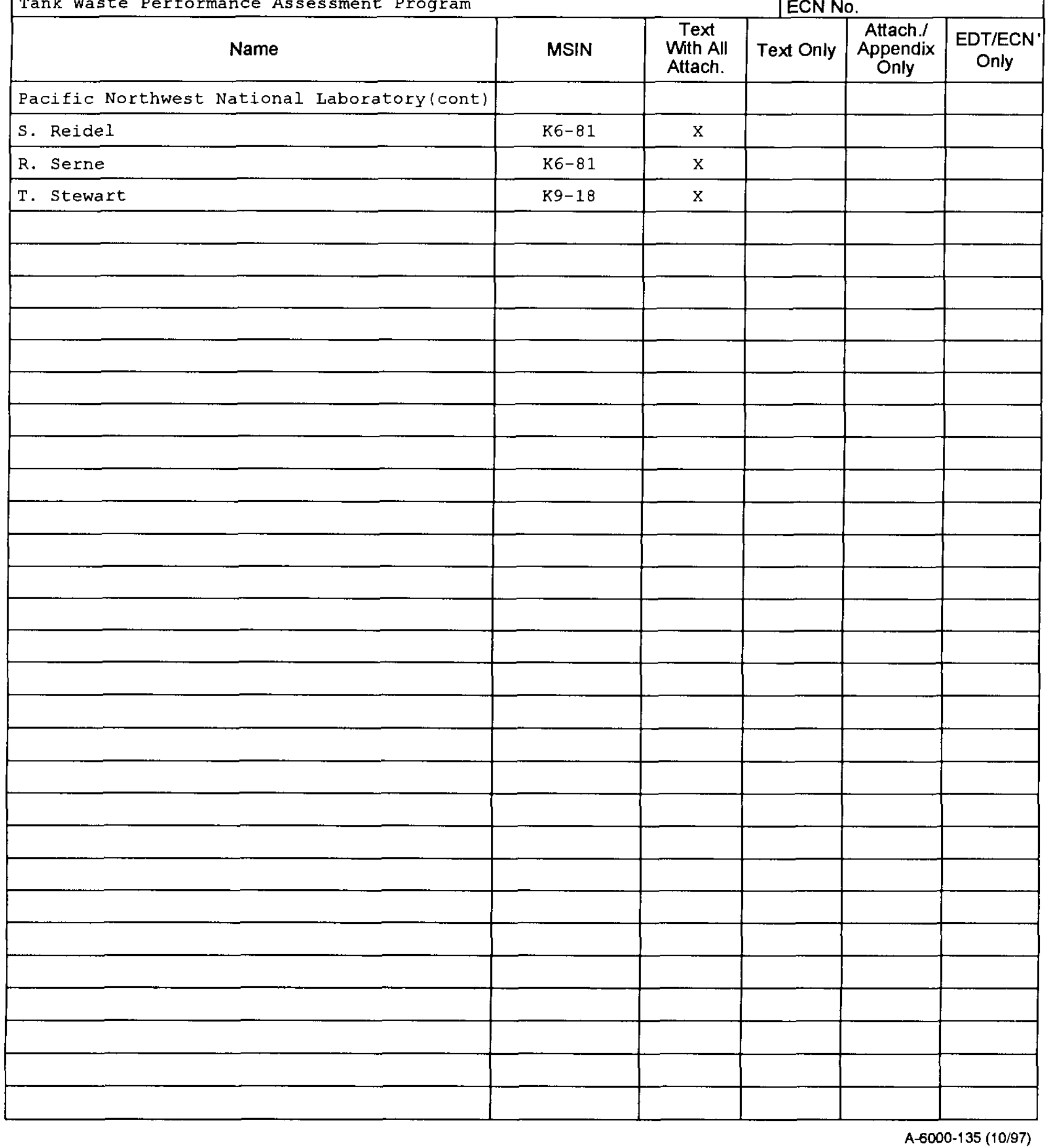

Page 2 of 2

Date July 18,2000

EDT No. 682757

ECN No.

From
FFS SA\&NE

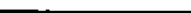




\title{
Statement of Work for FY 2001 to 2006 for the Hanford Low-Activity Tank Waste Performance Assessment Program
}

\author{
R. J. Puigh II \& F. M. Mann \\ Fluor Federal Services \\ Richland, WA 99352 \\ U.S. Department of Energy Contract DE-AC06-99RL14047
EDT/ECN: $628757 \quad$ UC:
Cost Center: $403 \quad$ Charge Code: $105867 \mathrm{BA} 10 / \mathrm{H} M L M 0221$
B\&R Code:
Total Pages: 337 \\ Key Words: Statement of Work, immobilized waste, ILAW
}

\begin{abstract}
Statement of Work for Hanford Immobilized Low-Activity Tank
Waste Performance Assessment Program has been updated to reflect

planning requests for fiscal year 2001 . Work description, justification, scheduling and cost information.
\end{abstract}

TRADEMARK DISCLAIMER. Reference herein to any specific commercial product, process, or service by trade name, trademark, manufacturer, or otherwise, does not necessarily constitute or imply its endorsement, recommendation, or favoring by the United States Government or any agency thereof or its contractors or subcontractors.

Printed in the United States of America. To obtain copies of this document, contact: Document Control Services, P.O. Box 950, Mailstop H6-08, Richland WA 99352, Phone (509) 372-2420; Fax (509) 376-4989.

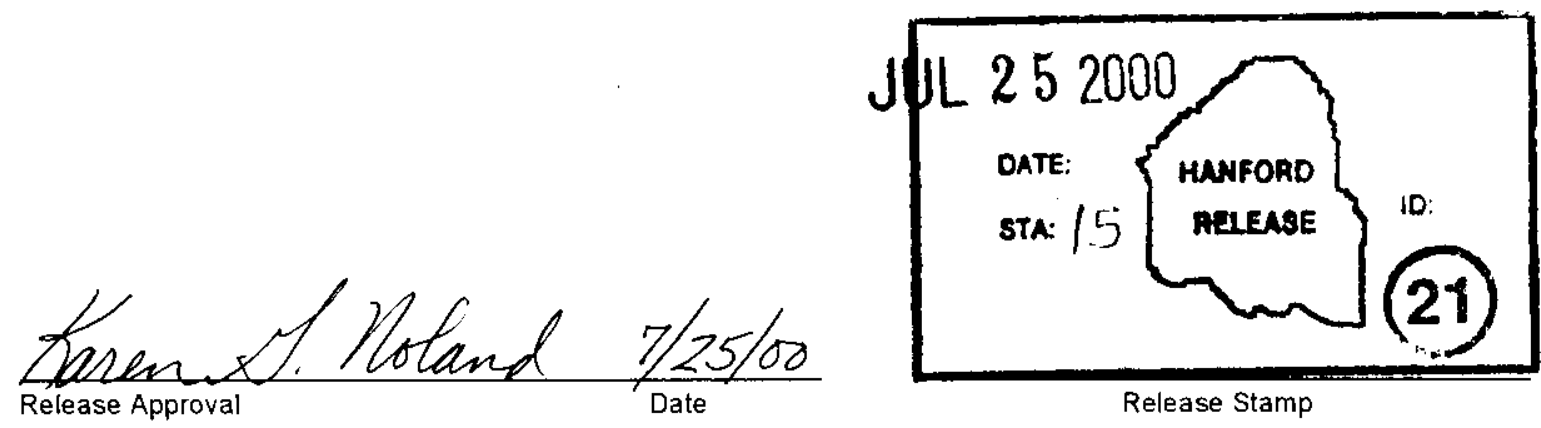

Approved For Public Release 
RPP-6702, Rev. 0

Formerly HNF-SD-WM-PAP-062 Rev. 4

\section{Statements of Work}

\section{For FY 2001 to 2006}

\section{For the Hanford Low-Activity Tank Waste \\ Performance Assessment Program}


RPP-6702, Rev. 0

Formerly HNF-SD-WM-PAP-062 Rev. 4

This page intentionally left blank 
RPP-6702, Rev. 0

Formerly HNF-SD-WM-PAP-062 Rev. 4

\section{EXECUTIVE SUMMARY}

This document describes the tasks included in the Hanford Low-Activity Tank Waste Performance Assessment activity though the close of the project in 2028. Near-term (2001 2006) tasks are described in detail, while tasks further in the future are simply grouped by year. The major tasks are displayed in the table below. The major goals of the performance assessment activity are to provide the technical basis for the Department of Energy to continue to authorize the construction of disposal facilities, the onsite disposal of immobilized low-activity Hanford tank waste in those facilities, and the closure of the disposal facilities. Other significant goals are to provide the technical basis for the setting of the specifications of the immobilized waste and to support permitting of the disposal facilities.

Table ES-1

Major Tasks of the Performance Assessment Activity

\begin{tabular}{|c|c|c|}
\hline Task [Major Highlights] & $\begin{array}{c}\text { Cost } \\
(\$ 1,000,000)\end{array}$ & Duration \\
\hline $\begin{array}{l}\text { Write1998 Performance Assessment } \\
\text { [Issue } 1998 \text { PA } \\
\text { [Receive Modified Authorization Disposal Statement from HQ } \\
\text { done] }\end{array}$ & 0.10 & $10 / 97-09 / 99$ \\
\hline $\begin{array}{l}\text { Create Data Packages for } 2001 \text { Performance Assessment (2001 } \\
\text { PA) } \\
\text { [Publish 2001 PA Data Packages }\end{array}$ & 6.75 & $10 / 96-12 / 99$ \\
\hline $\begin{array}{lr}\text { Write } 2001 \text { Performance Assessment } \\
\text { [lssue } 2001 \mathrm{PA} \\
\text { [Receive Modified Authorization Disposal Statement from } \mathrm{HQ} \\
03 / 02]\end{array}$ & 0.55 & $01 / 00-03 / 02$ \\
\hline $\begin{array}{l}\text { Create Data Packages for } 2005 \text { Performance Assessment }(2005 \\
\text { PA) } \\
\text { [Publish 2005 PA Data Packages }\end{array}$ & 18.54 & $10 / 98-1 / 04$ \\
\hline $\begin{array}{lr}\text { Write } 2005 \text { Performance Assessment } \\
\text { [Issue } 2005 \text { PA } & 01 / 05] \\
\text { [Receive Modified Disposal Authorization Statement from } \mathrm{HQ} \\
& 01 / 06]\end{array}$ & 0.46 & $02 / 04-01 / 06$ \\
\hline Provide Maintenance Performance Assessments & 6.26 & $10 / 03-09 / 25$ \\
\hline $\begin{array}{l}\text { Write Closure Performance Assessment } \\
\text { [Receive permission to close last facility }\end{array}$ & 0.45 & $10 / 24-09 / 28$ \\
\hline Overall Coordination & 2.96 & $10 / 96-01 / 06$ \\
\hline
\end{tabular}


RPP-6702, Rev. 0

Formerly HNF-SD-WM-PAP-062 Rev. 4

This page left intentionally blank 
RPP-6702, Rev. 0

Formenly HNF-SD-WM-PAP-062 Rev. 4

TABLE OF CONTENTS

1.0 INTRODUCTION $1-1$

A. PURPOSE

B. BACKGROUND $1-1$

C. GOALS 1-3

D. INTERFACES WITH OTHER PARTS OF THE TWRS IMMOBILIZED WASTE PROGRAM

1. Introduction

2. TWRS Immobilized Waste Program

3. Waste Form Specifications

E. ORGANIZATION OF PERFORMANCE ASSESSMENT ACTIVITY

F. IMPORTANT FEATURES FOUND IN THE PREVIOUS ILAW PERFORMANCE ASSESSMENTS

G. $\quad$ INTEGRATION WITH OTHER HANFORD PROGRAMS $\quad 1-7$

H. $\quad$ CONTENTS OF THIS REPORT $\quad 1-8$

$2.0 \quad 1998$ PERFORMANCE ASSESSMENT

A. SUMMARY $\quad 2-1$

B. INTERFACE WITH HQ

3.0 DATA PACKAGES FOR 2001 PERFORMANCE ASSESSMENT 3-1

A. SUMMARY $3-1$

B. ISSUE DATA PACKAGES FOR HANFORD LOW-LEVEL TANK WASTE PERFORMANCE ASSESSMENT

3.1 WASTE FORM PERFORMANCE DATA AND TOOLS 3-6

A. SUMMARY 3-6

B. GENERAL $3-6$

C. TASK DESCRIPTIONS

i. Summary List of Tasks

ii. Vendor Glass Screening

iii. Vendor Glass Testing 3-13

iv. Contaminant Release Model

v. Source-Term Simulations

vi. Waste Form Data Package for 2001 Performance Assessment $3-28$

vii. Procure and Install X-ray Microtomography Equipment

viii. Procure and Install High Performance Workstation

ix. Collect Waste Form Hydraulics Data

$x$. Collect Other Near-Field Chemical Data

3.2 GEOTECHNICAL DATA 3-38

A. SUMMARY $3-38$

B. GENERAL

C. TASK DESCRIPTIONS

i. Summary List of Tasks

ii. Obtain and Document Borehole Samples

iii. Determine Geologic Lavers at Disposal Sites $\quad 3-45$

iv. Determine Recharge at Disposal Sites

v. Determine Hydraulic Parameters for Disposal Facility Materials 3-60 
RPP-6702, Rev. 0

Formerly HNF-SD-WM-PAP-062 Rev. 4

vi. Determine Hydraulic Parameters for Soils at Disposal Sites 3-70

vii. Determine Geochemical Parameters for Disposal Facility Materials 3-78

viii. Determine Geochemical Parameters for Soils at Disposal Sites

ix. Select and Upgrade Vadose Zone Moisture Flow and Contaminant Transport Simulation Code

x. Interact with Hanford Groundwater Project Conceming Hanford Site Groundwater

Simulation Code Package

3.3 OTHER DATA COLLECTION

A. SUMMARY

$3-93$

B. GENERAL

3-93

C. TASK DESCRIPTIONS

3-95

i. Summary List of Tasks

3-95

ii. Determine Waste Form Inventory

3-95

iii. Determine Disposal Facility Conceptual Model

3-99

iv. Determine Dosimetry Data

3-102

v. Determine Performance Objectives

3-105

vi. Determine Scenarios and Pathways to be Analyzed

3-108

4.0 2001 PERFORMANCE ASSESSMENT

A. SUMMARY

B. GENERAL

4-1

C. TASK DESCRIPTIONS

4-3

i. Summan List of Tasks

4-3

ii. Establish 2001 PA Base Analysis Case and Sensitivity Cases

4-3

iii. Perform Calculations for the 2001 Performance Assessment

4-6

iv. Write the 2001 Performance Assessment

4-11

v. HQ-2001 PA interaction

4-14

5.0 DATA PACKAGES FOR 2005 PERFORMANCE ASSESSMENT 5-1

A. SUMMARY

B. ISSUE DATA PACKAGES FOR HANFORD LOW-ACTIVITY TANK WASTE 2005

PERFORMANCE ASSESSMENT

5.1 WASTE FORM PERFORMANCE DATA AND TOOLS

A. SUMMARY $\quad$ 5-4

B. GENERAL

C. TASK DESCRIPTIONS

i. Summary List of Tasks $\quad$ 5-6

ii. Perform Waste Form Measurements

iii. Perform Waste Form Simulations

iii. Perform Waste Form Simulations

iv. Upgrade Waste Form Simulation Code

vi. LAW Glass Analog Field Test Data Collection and Modeling 5-21

Vii. Document Waste Form Data for 2005 Performance Assessment

ix. Procure and Install Scanning Laser Raman System 5-27

5.2 GEOTECHNICAL DATA $\quad 5-29$

A. SUMMARY $\quad 5-29$

B. GENERAL $\quad$ 5-29

C. TASKDESCRIPTIONS 
RPP-6702, Rev. 0

Formerly HNF-SD-WM-PAP-062 Rev. 4

i. Summary List of Tasks

ii. Obtain and Document Borehole Samples

iii. Determine Geologic Information at Disposal Sites

iv. Determine Recharge at Disposal Sites

v. Determine Hydraulic Parameters for Disposal Facility Materials

vi. Determine Hydraulic Parameters for Soils at Disposal Sites

vii. Determine Geochemical Parameters for Disposal Facility Materials

viii. Determine Geochemical Parameters for Soils at Disposal Sites

ix. Upgrade Vadose Zone Moisture Flow and Contaminant Transport Simulation Code5107

5.3 OTHER DATA COLLECTION $\quad$ 5-109

A. SUMMARY $\quad 5-109$

B. GENERAL 5-109

C. TASK DESCRIPTIONS

i. Summary List of Tasks $\quad 5-110$

ii. Determine Waste Form Inventory $\quad$ 5-110

iii. Determine Disposal Facility Conceptual Model

iv. Determine Dosimetry Data

v. Determine Performance Objectives $\quad$ 5-118

vi. Determine Scenarios and Pathways to be Analyzed

6.0 2005 PERFORMANCE ASSESSMENT

A. SUMMARY $6-1$

$6-1$

C. TASKDESCRIPTIONS

i. Summary List of Tasks

ii. Establish 2005 PA Base Analysis Case and Sensitivity Cases

iii. Perform Calculations for the 2005 Performance Assessment

iv. Write the 2005 Performance Assessment $6-8$

v. HQ-2005PA Interaction $\quad 6-10$

7. MAINTENANCE PERFORMANCE ASSESSMENTS

A. SUMMARY $7-1$

B. GENERAL $7-1$

8.0 CLOSURE PERFORMANCE ASSESSMENT

A. SUMMARY $\quad 8-1$

B. GENERAL 8-1

9.0 ACTIVITY SUPERVISION AND REVIEW

A. SUMMARY $\quad 9-1$

B. GENERAL $9-1$

C. TASK DESCRIPTIONS

i. Summany List of Tasks

ii. Provide Administration Support

iii. Prepare Statements of Work $\quad 9-8$

iv. Provide Interaction with the Hanford Site Technical Representative/Composite Analysis Team

v. Support External Advisory Board

vi. Reissue Interim Performance Assessment $\quad$ 9-17 
RPP-6702, Rev. 0

Formerly HNF-SD-WM-PAP-062 Rev. 4

vii. Provide Support to the Waste Integration Team

9-19

vii. Provide Support to the Hanford Site Groundwater / Vadose Zone Project

10.0 REFERENCES

10-1

APPENDIX A FORMATS AND CONTENTS

A-1 


\section{RPP-6702, Rev. 0 \\ Formerly HNF-SD-WM-PAP-062 Rev. 4 \\ LIST OF TABLES}

ES-1 MAJOR TASKS OF THE PERFORMANCE ASSESSMENT ACTIVITY

ES-1

1.0-1 IMPORTANT MILESTONES FOR THE PERFORMANCE ASSESSMENT (PA) ACTIVITY

1.0-2 SCHEDULE FOR ILAW DISPOSAL FACILITIES

2.0-1A LIST OF DELIVERABLES FOR INTERFACE WITH HQ ON 1998 PA 2-1

2.0-1B COST SUMMARY FOR INTERFACE WITH HQ ON 1998 PA 2-2

2.0-1C INTERFACES FOR INTERFACE WITH HQ ON 1998 PA $2-2$

3.0-1A LIST OF DELIVERABLES FOR CREATE 2001 PA DATA PACKAGES 3-2

3.0-1B COST SUMMARY FOR CREATE 2001 PA DATA PACKAGES 3-2

3.0-1C INTERFACES FOR CREATE 2001 PA DATA PACKAGES 3-3

3.0-1D DETAILED COST AND SCHEDULE FOR CREATING 2001 DATA PACKAGE 3-5

3.1-1A LIST OF MAJOR DELIVERABLES FOR 2001 PA WASTE FORM DATA PACKAGE

3.1-1B COST SUMMARY FOR WASTE FORM DATA FOR 2001 PA 3-9

3.1-2A LIST OF DELIVERABLES FOR VENDOR GLASS SCREENING SUBTASK 3-11

3.1-2B COST SUMMARY FOR VENDOR GLASS SCREENING SUBTASK FOR 2001 PA

3.1-2C DETAILED COST AND SCHEDULE FOR VENDOR GLASS SCREENING 3-12

3.1-3A LIST OF DELIVERABLES FOR VENDOR GLASS TESTING SUBTASK 3-13

3.1-3B COST SUMMARY FOR VENDOR GLASS TESTING FOR 2001 PA 3-14

3.1-3C DETAILED COST AND SCHEDULE FOR VENDOR GLASS TESTING FOR 2001 PA

3.1-4A LIST OF DELIVERABLES FOR WASTE FORM SIMULATION CODE 3-19

3.1-4B COST SUMMARY FOR WASTE FORM COMPUTER SIMULATION CODE (2001 PA)

3.1-4C DETAILED COST AND SCHEDULE FOR CONTAMINANT RELEASE CODE (2001 PA) 
RPP-6702, Rev. 0

Formerly HNF-SD-WM-PAP-062 Rev. 4

3.1-5B COST SUMMARY FOR SOURCE-TERM SIMULATIONS (2001 PA) $\mathbf{3 - 2 5}$

3.1-5C DETAILED COST AND SCHEDULE FOR SOURCE-TERM SIMULATIONS (2001 PA)

3.1-6A LIST OF DELIVERABLES FOR 2001 PA WASTE FORM DATA PACKAGE 3-28

3.1-6B COST SUMMARY FOR 2001 PA WASTE FORM DATA PACKAGE 3-29

3.1-6C DETAILED COST AND SCHEDULE FOR 2001 PA WASTE FORM DATA PACKAGE

3.1-7A LIST OF DELIVERABLES FOR X-RAY MICROTOMOGRAPHY EQUIPMENT (CENRTC)

3.1-7B COST SUMMARY FOR X-RAY MICROTOMOGRAPHY EQUIPMENT (CENRTC) 3-33

3.1-7C DETAILED COSTT AND SCHEDULE FOR X-RAY MICROTOMOGRAPHY EQUIPMENT (CENRTC)

3.1-8A LIST OF DELIVERABLES FOR HIGH-PERFORMANCE WORKSTATION (CENRTC)

3.1-8B COST SUMMARY FOR HIGH-PERFORMANCE WORKSTATION (CENRTC) $\quad \mathbf{3 - 3 5}$

3.1-8C DETAILED COST AND SCHEDULE FOR HIGH-PERFORMANCE WORKSTATION (CENRTC)

3.2-1A LIST OF MAJOR DELIVERABLES FOR 2001 PA GEOTECHNICAL SUBACTIVITY

3.2-1B COST SUMMARY FOR CREATING 2001 PA GEOTECHNICAL DATA PACKAGES

3.2-2A LIST OF DELIVERABLES FOR 2001 PA BOREHOLE SUBTASKS $\mathbf{3 - 4 2}$

3.2-2B COST SUMMARY FOR 2001 PA BOREHOLE TASKS $3-43$

3.2-2C DETAILED COST AND SCHEDULE FOR BOREHOLE TASK $\quad 3-44$

3.2-3A LIST OF DELIVERABLES FOR 2001 PA GEOLOGY DATA PACKAGE 3-45

3.2-3B COST SUMMARY FOR 2001 PA GEOLOGY TASK 3-45

3.2-3C DETAILED COST AND SCHEDULE FOR GEOLOGY TASK

3.2-4A LIST OF DELIVERABLES FOR 2001 PA RECHARGE TASK 3-49

3.2-4B COST SUMMARY FOR 2001 PA RECHARGE TASK

3.2-4C DETAILED COST AND SCHEDULE FOR RECHARGE TASK $\quad 3-57$ 


$$
\begin{aligned}
& \text { RPP-6702, Rev. } 0 \\
& \text { Formerly HNF-SD-WM-PAP-062 Rev. } 4
\end{aligned}
$$

3.2-5A LIST OF DELIVERABLES FOR 2001 PA NEAR-FIELD HYDRAULICS DATA PACKAGE

3.2-5B COST SUMMARY FOR 2001 PA NEAR-FIELD HYDRAULICS DATA PACKAGE 3-61

3.2-5C DETAILED COST AND SCHEDULE FOR 2001 PA NEAR-FIELD HYDRAULICS DATA PACKAGE

3.2-6A LIST OF DELIVERABLES FOR 2001 PA FAR-FIELD HYDRAULICS DATA PACKAGE

3.2-6B COST SUMMARY FOR 2001 PA FAR-FIELD HYDRAULICS DATA PACKAGE 3-71

3.2-6C DETAILED COST AND SCHEDULE FOR 2001 PA FAR-FIELD HYDRAULICS DATA PACKAGE

3.2-7A LIST OF DELIVERABLES FOR 2001 PA NEAR-FIELD GEOCHEMICAL DATA PACKAGE

3.2-7B COST SUMMARY FOR 2001 PA NEAR-FIELD GEOCHEMICAL DATA PACKAGE

3.2-8A LIST OF DELIVERABLES FOR 2001 PA FAR-FIELD GEOCHEMICAL DATA PACKAGE

3.2-8B COST SUMMARY FOR 2001 PA FAR-FIELD GEOCHEMICAL DATA PACKAGE3-84

3.2-8C DETAILED COST AND SCHEDULE FOR 2001 PA FAR-FIELD GEOCHEMICAL DATA PACKAGE

3.2-9A LIST OF DELIVERABLES FOR 2001 PA VADOSE ZONE SIMULATION CODE DATA PACKAGE

3.2-9B COST SUMMARY FOR 2001 PA VADOSE ZONE SIMULATION CODE DATA PACKAGE

3.2-9C DETAILED COST AND SCHEDULE FOR 2001 PA VADOSE ZONE SIMULATION CODE DATA PACKAGE

3.3-1A LIST OF MAJOR DELIVERABLES FOR 2002 PA OTHER DATA COLLECTION SUBACTIVITY

3.3-1B COST SUMMARY FOR 2001 PA OTHER DATA COLLECTION

3.3-2A LIST OF DELIVERABLES FOR 2001 PA INVENTORY DATA PACKAGE $\quad 3-96$

3.3-2B COST SUMMARY FOR 2001 PA INVENTORY DATA PACKAGE

3.3-2C DETAILED COST AND SCHEDULE FOR 2001 PA INVENTORY DATA PACKAGE 
RPP-6702, Rev. 0

Formerly HNF-SD-WM-PAP-062 Rev. 4

3.3-3A LIST OF DELIVERABLES FOR 2001 PA CONCEPTUAL MODEL DATA PACKAGE

3.3-3B COST SUMMARY FOR 2001 PA CONCEPTUAL MODEL DATA PACKAGE 3-99

3.3-3C DETAILED COST AND SCHEDULE FOR 2001 PA CONCEPTUAL MODEL DATA PACKAGE

3.3-4A LIST OF DELIVERABLES FOR 2001 PA DOSIMETRY DATA PACKAGE 3-102

3.3-4B COST SUMMARY FOR 2001 PA DOSIMETRY DATA PACKAGE 3-102

3.3-4C DETAILED COST AND SCHEDULE FOR 2001 PA DOSIMETRY DATA PACKAGE

3.3-5A LIST OF DELIVERABLES FOR 2001 PA PERFORMANCE OBJECTIVES DATA $\begin{array}{ll}\text { PACKAGE } & \text { 3-105 }\end{array}$

3.3-5B COST SUMMARY FOR 2001 PA PERFORMANCE OBJECTIVES DATA PACKAGE 3-105

3.3-5C DETAILED COST AND SCHEDULE FOR 2001 PA PERFORMANCE OBJECTIVES DATA PACKAGE

3.3-6A LIST OF DELIVERABLES FOR 2001 PA SCENARIOS DATA PACKAGE 3-108

3.3-6B COST SUMMARY FOR 2001 PA SCENARIOS DATA PACKAGE 3-108

3.3-6C DETAILED COST AND SCHEDULE FOR 2001 PA SCENARIOS DATA PACKAGE

4.0-1A LIST OF MAJOR DELIVERABLES FOR CREATING THE 2001 PA 4-2

4.0-1B COST SUMMARY FOR CREATING 2001 PA 4-2

4.0-2A LIST OF DELIVERABLES FOR 2001 PA BASE ANALYSIS CASE DEFINITION 4-3

4.0-2B COST SUMMARY FOR 2001 PA BASE ANALYSIS CASE DEFINITION 4-3

4.0-2C DETAILED COST AND SCHEDULE FOR 2001 PA BASE ANALYSIS CASE DEFINITION 4-5

4.0-3A LIST OF DELIVERABLES FOR 2001 PA PERFORM CALCULATIONS 4-6

4.0-3B COST SUMMARY FOR 2001 PA PERFORM CALCULATIONS 4-7

4.0-3C DETAILED COST AND SCHEDULE FOR 2001 PA PERFORM CALCULATIONS 4-10

4.0-4A LIST OF DELIVERABLES FOR WRITE 2001 PA 4-11

4.0-4B COST SUMMARY FOR WRITE 2001 PA 4-11 
RPP-6702, Rev. 0

Formerly HNF-SD-WM-PAP-062 Rev. 4

4.0-4C DETAILED COST AND SCHEDULE FOR WRITE 2001 PA 4-13

4.0-5A LIST OF DELIVERABLES FOR 2001 PA-HQ INTERACTION 4-14

4.0-5B COST SUMMARY FOR 2001 PA-HQ INTERACTION 4-14

4.0-5C DETAILED COST AND SCHEDULE FOR 2001 PA-HQ INTERACTION 4-15

5.0-1A LIST OF DELIVERABLES FOR CREATE 2005 PA DATA PACKAGES 5-1

5.0-1B COST SUMMARY FOR CREATE 2005 PA DATA PACKAGES 5-2

5.0-1C INTERFACES FOR CREATE 2005 PA DATA PACKAGES 5-2

5.1-1A LIST OF MAJOR DELIVERABLES FOR 2005 PA WASTE FORM DATA PACKAGE

5.1-1B COST SUMMARY FOR WASTE FORM DATA FOR 2005 PA 5-5

5.1-2A COST SUMMARY FOR WASTE FORM MEASUREMENTS FOR 2005 PA $\quad 5-8$

5.1-2B DETAILED COST AND SCHEDULE FOR WASTE FORM MEASUREMENTS FOR 2005 PA $\quad 5-9$

5.1-3A COST SUMMARY FOR KINETIC RATE LAW DEVELOPMENT FOR 2005 PA 5-11

5.1-3B DETAILED COST AND SCHEDULE FOR KINETIC RATE LAW DEVELOPMENT FOR 2005 PA $\quad 5-12$

5.1-4A COST SUMMARY FOR MEASUREMENT OF SOLID-WATER INTERFACIAL AREA FOR 2005 PA $\quad$ 5-14

5.1-4B DETAILED COST AND SCHEDULE FOR MEASUREMENT OF SOLID-WATER INTERFACIAL AREA $\quad \mathbf{5 - 1 5}$

5.1-5A COST SUMMARY FOR WASTE FORM SIMULATIONS FOR 2005 PA 5-16

5.1-5B DETAILED COST AND SCHEDULE FOR WASTE FORM SIMULATIONS FOR 2005 PA $\quad 5-17$

5.1-6A LIST OF DELIVERABLES FOR UPDATE WASTE FORM SIMULATION CODE FOR 2005 PA

5.1-6B COST SUMMARY FOR UPDATE WASTE FORM SIMULATIONS CODE FOR 2005 PA

5.1-6C DETAILED COST AND SCHEDULE FOR UPDATE WASTE FORM SIMULATION CODE FOR 2005 PA

5.1-7A ILAW GLASS ANALOG FIELD TEST DATA COLLECTION AND MODELING 
RPP-6702, Rev. 0

Formerly HNF-SD-WM-PAP-062 Rev. 4

5.1-7B COST SUMMARY FOR GLASS ANALOG FIELD TEST DATA COLLECTION AND MODELING

5.1-7C DETAILED COST AND SCHEDULE FOR GLASS ANALOG FIELD TEST DATA COLLECTION AND MODELING

5.1-8A LIST OF DELIVERABLES FOR 2005 PA WASTE FORM DATA PACKAGE

5.1-8B COST SUMMARY FOR DOCUMENTING WASTE FORM DATA FOR 2005 PA $\quad \mathbf{5 - 2 4}$

5.1-8C DETAILED COST AND SCHEDULE FOR DOCUMENTING WASTE FORM DATA FOR 2005 PA

5.1-9A COST SUMMARY FOR PROCURE AND INSTALL SCANNING LASER RAMAN SYSTEM

5.1-9B DETAILED COST AND SCHEDULE FOR PROCURE AND INSTALL SCANNING LASER RAMAN SYSTEM

5.2-1A LIST OF MAJOR DELIVERABLES FOR 2005 PA GEOTECHNICAL SUBACTIVITY

5.2-1B COST SUMMARY FOR CREATING 2005 PA GEOTECHNICAL DATA PACKAGES

5.2-2A LIST OF DELIVERABLES FOR 2005 PA BOREHOLE SUBTASKS

5.2-2B COST SUMMARY FOR 2005 PA BOREHOLE TASKS

5.2-2C DETAILED COST AND SCHEDULE FOR 2005 BOREHOLE TASKS

5.2-2D DRILLING CAPITAL COSTS (BHI)

5.2-3A LIST OF DELIVERABLES FOR 2005 PA GEOLOGY DATA PACKAGE

5.2-3B COST SUMMARY FOR 2005 PA GEOLOGY TASK

5.2-3C DETAILED COST AND SCHEDULE FOR 2005 PA GEOLOGY TASK

5.2-4A LIST OF DELIVERABLES FOR 2005 PA RECHARGE TASK

5.2-4B COST SUMMARY FOR 2005 PA RECHARGE TASK

5.2-4C DETAILED COST AND SCHEDULE FOR RECHARGE TASK

5.2-5A LIST OF DELIVERABLES FOR 2005 PA NEAR-FIELD HYDRAULICS DATA PACKAGE

5.2-5B COST SUMMARY FOR 2005 PA NEAR-FIELD HYDRAULICS DATA PACKAGE 5-61

5.2-5C DETAILED COST AND SCHEDULE FOR 2005 PA NEAR-FIELD HYDRAULICS DATA PACKAGE 


\section{RPP-6702, Rev. 0 \\ Formerly HNF-SD-WM-PAP-062 Rev. 4}

5.2-6A LIST OF DELIVERABLES FOR 2005 PA FAR-FIELD HYDRAULICS DATA PACKAGE

5.2-6B COST SUMMARY FOR 2005 PA FAR-FIELD HYDRAULICS DATA PACKAGE 5-74

5.2-6C DETAILED COST AND SCHEDULE FOR 2005 PA FAR-FIELD HYDRAULICS DATA PACKAGE

5.2-7A LIST OF DELIVERABLES FOR 2005 PA NEAR-FIELD GEOCHEMICAL DATA PACKAGE

5.2-7B COST SUMMARY FOR 2005 PA NEAR-FIELD GEOCHEMICAL DATA PACKAGE

5.2-7C DETAILED COST AND SCHEDULE FOR 2005 PA NEAR-FIELD GEOCHEMICAL DATA PACKAGE

5.2-8A LIST OF DELIVERABLES FOR 2005 PA FAR-FIELD GEOCHEMICAL DATA PACKAGE

5.2-8B COST SUMMARY FOR 2005 PA FAR-FIELD GEOCHEMICAL DATA PACKAGE

5.2-8C DETAILED COST AND SCHEDULE FOR 2005 PA FAR-FIELD GEOCHEMICAL DATA PACKAGE

5.2-9A LIST OF DELIVERABLES FOR 2005 PA VADOSE ZONE SIMULATION CODE DATA PACKAGE

5.2-9B COST SUMMARY FOR 2005 PA VADOSE ZONE SIMULATION CODE DATA PACKAGE

5.2-9C DETAILED COST AND SCHEDULE FOR 2005 PA VADOSE ZONE SIMULATION CODE DATA PACKAGE

5.3-1A LIST OF MAJOR DELIVERABLES FOR 2005 PA OTHER DATA COLLECTION SUBACTIVITY

5.3-1B COST SUMMARY FOR 2005 PA OTHER DATA COLLECTION

5.3-2A LIST OF DELIVERABLES FOR 2005 PA INVENTORY DATA PACKAGE

5.3-2B COST SUMMARY FOR 2005 PA INVENTORY DATA PACKAGE

5.3-2C DETAILED COST AND SCHEDULE FOR 2005 PA INVENTORY DATA PACKAGE

5.3-3A LIST OF DELIVERABLES FOR 2005 PA CONCEPTUAL MODEL DATA PACKAGE 
RPP-6702, Rev. 0

Formerly HNF-SD-WM-PAP-062 Rev. 4

5.3-3C DETAILED COST AND SCHEDULE FOR 2005 PA CONCEPTUAL MODEL DATA PACKAGE

5.3-4A LIST OF DELIVERABLES FOR 2005 PA DOSIMETRY DATA PACKAGE $\quad \mathbf{5 - 1 1 6}$

5.3-4B COST SUMMARY FOR 2005 PA DOSIMETRY CODE DATA PACKAGE 5-116

5.3-4C DETAILED COST AND SCHEDULE FOR 2005 PA DOSIMETRY DATA PACKAGE

5.3-5A LIST OF DELIVERABLES FOR 2005 PA PERFORMANCE OBJECTIVES DATA PACKAGE

5.3-5B COST SUMMARY FOR 2005 PA PERFORMANCE OBJECTIVES DATA PACKAGE

5.3-5C DETAILED COST AND SCHEDULE FOR 2005 PA PERFORMANCE OBJECTIVES DATA PACKAGE

5.3-6A LIST OF DELIVERABLES FOR 2005 PA SCENARIOS DATA PACKAGE

5.3-6B COST SUMMARY FOR 2005 PA SCENARIOS DATA PACKAGE

DETAILED COST AND SCHEDULE FOR 2005 PA SCENARIOS DATA PACKAGE

6.0-1A LIST OF MAJOR DELIVERABLES FOR CREATING THE 2005 PA

6.0-1B COST SUMMARY FOR CREATING 2005 PA

6.0-2A LIST OF DELIVERABLES FOR 2005 PA BASE ANALYSIS CASE DEFINITION

6.0-2B COST SUMMARY FOR 2005 PA BASE ANALYSIS CASE DEFINITION

6.0-2C DETAILED COST AND SCHEDULE FOR 2005 PA BASE ANALYSIS CASE DEFINITION

6.0-3A LIST OF DELIVERABLES FOR 2005 PA PERFORM CALCULATIONS

6.0-3B COST SUMMARY FOR 2005 PA PERFORM CALCULATIONS

6.0-3C DETAILED COST AND SCHEDULE FOR 2005 PA PERFORM CALCULATIONS 6-7

6.0-4A LIST OF DELIVERABLES FOR WRITE 2005 PA 6-8

6.0-4B COST SUMMARY FOR WRITE 2005 PA 6-8

6.0-4C DETAILED COST AND SCHEDULE FOR WRITE 2005 PA 6-9

6.0-5A LIST OF DELIVERABLES FOR HQ-2005 PA INTERACTION $\quad 6-10$

6.0-5B COST SUMMARY FOR HQ-2005 PA INTERACTION 6-10 
RPP-6702, Rev. 0

Formerly HNF-SD-WM-PAP-062 Rev. 4

6.0-5C DETAILED COST AND SCHEDULE FOR HQ-2005 PA INTERACTION

7.0A LIST OF DELIVERABLES FOR MAINTENANCE PAS

7.0B COST SUMMARY FOR MAINTENANCE PAS

7.0C DETAILED COST AND SCHEDULE FOR MAINTENANCE PAS

8.0A LIST OF DELIVERABLES FOR CLOSURE PA

8.0B COST SUMMARY FOR CLOSURE PA

8.0C DETAILED COST AND SCHEDULE FOR HQ-2005 PA INTERACTION

9.0-1A LIST OF DELIVERABLES FOR ACTIVITY SUPERVISION

9.0-1B COST SUMMARY FOR SUPERVISION TASK

9.0-2A COST SUMMARY FOR PROVIDE ADMINISTRATIVE SUPPORT

9.0-2B DETAILED COST AND SCHEDULE FOR SUPERVISION TASK

9.0-3A LIST OF DELIVERABLES FOR PREPARE STATEMENTS OF WORK

9.0-3B COST SUMMARY FOR PREPARE SOWS

9.0-3C DETAILED COST AND SCHEDULE FOR PREPARE SOWS

9.0-4A COST SUMMARY FOR PRPICA INTERACTION

9.0-4B DETAILED COST AND SCHEDULE FOR PRPICA INTERACTION

9.0-5A LIST OF DELIVERABLES FOR ADVISORY BOARD $\mathbf{9 - 1 4}$

$\begin{array}{llr}\text { 9.0-5B COST SUMMARY FOR ADVISORY BOARD } & \mathbf{9 - 1 4}\end{array}$

9.0-5C DETAILED COST AND SCHEDULE FOR ADVISORY BOARD $\quad \mathbf{9 - 1 6}$

$\begin{array}{lll}9.0-6 A & \text { LIST OF DELIVERABLES FOR REISSUE IPA } & \mathbf{9 - 1 7}\end{array}$

$\begin{array}{lll}9.0-6 B & \text { COST SUMMARY FOR REISSUE IPA } & \mathbf{9 - 1 7}\end{array}$

9.0-6C DETAILED COST AND SCHEDULE FOR ISSUE IPA 9-18

$\begin{array}{llr}\text { 9.0-7A } & \text { COST SUMMARY FOR SUPPORT WIT } & \mathbf{9 - 1 9}\end{array}$

9.0-7B DETAILED COST AND SCHEDULE FOR SUPPORT WIT $\quad \mathbf{9 - 2 0}$

9.0-8A LIST OF DELIVERABLES FOR SUPPORT HANFORD SITE INTEGRATION $\quad \mathbf{9 - 2 1}$

9.0-8B COST SUMMARY FOR 2001 PA GROUNDWATER CODE DATA PACKAGE 9-21 
RPP-6702, Rev. 0

Formerly HNF-SD-WM-PAP-062 Rev. 4

9.0-8 DETAILED COST AND SCHEDULE FOR SUPPORT HANFORD INTEGRATION PROJECT 


\section{RPP-6702, Rev. 0 \\ Formerly HNF-SD-WM-PAP-062 Rev. 4 \\ List of Acronyms}

ANL

Argonne National Laboratory, national laboratory providing professional services

BNFL British Nuclear Fuels, Limited, vendor formerly responsible for designing the facility for initial ILAW production

BHI Bechtel Hanford Company, the environmental restoration contractor for the Hanford Site

CENTRC Capital Expenditures Not Related to Construction

CHG $\quad \mathrm{CH} 2 \mathrm{M}$ Hill Hanford Group, Incorporated, the Hanford Site contractor responsible for carrying out the River Protection Protection (formerly TWRS).

DOE

Department of Energy, owner of the Hanford Site and the Hanford tank wastes

FFS

Fluor Federal Services, an Hanford Site alliance company responsible for architect/engineer activities and providing other professional services

ILAW

Immobilized Low-Activity Waste, the vendor product received for disposal

LMHC

Lockheed Martin Hanford Co.,contractor at the Hanford Site formerly responsible for the Tank Remediation System.

LMSI Lockheed Martin Services, Inc., an Hanford Site alliance company responsible for information management

MYWP Multiyear Work Plan, the documents describing work at Hanford Site.

ORP Office of River Protection, DOE field office responsible for the management of tank waste

PA Performance Assessment, the document presenting the estimated long-term impacts from the disposal of low-level radioactive waste

PCT Product Consistency Test, a test used to measure dissolution rates of glasses

PNNL Pacific Northwest National Laboratory, national laboratory at the Hanford Site responsible for research and development

PUF Pressurized Unsaturated Flow [Test], a test used to measure dissolution rates of glass under unsaturated moisture conditions

RCRA Resource and Conservation Recovery Act

RPP River Protection Project supercedes Tank Waste Remediation System

SNL Sandia National Laboratory, national laboratory providing professional services 


\section{RPP-6702, Rev. 0 \\ Formerly HNF-SD-WM-PAP-062 Rev. 4}

SPFT Single Pass Flow Through tests, which are used to determine the maximum dissolution rate of glass as a function of $\mathrm{pH}$ and temperature

TWRS Tank Waste Remediation System, that function of the Hanford Site Complex responsible for the storage and disposal of Hanford Site tank waste

WMNW Waste Management Northwest, a Hanford Site company with expertise in providing services associated with well drilling 


\author{
RPP-6702, Rev. 0 \\ Formerly HNF-SD-WM-PAP-062 Rev. 4
}

\title{
1.0 INTRODUCTION
}

\section{A. PURPOSE}

The goal of the Hanford Low-Activity Tank Waste Performance Assessment Program is to provide decision makers with the information on the long-term impact on human health and on the environment of the disposal of low-activity Hanford Site tank waste to allow them to make decisions concerning the disposal of such waste. Such decision makers range from engineers designing the disposal facility or formulating the waste form to Department of Energy officials responsible for the disposal of such waste to Hanford Site stakeholders concerned about the cleanup of the Hanford Site. In addition, the information provided by the performance assessment will form part of the technical supporting data for obtaining permits from the Washington State Department of Ecology under the Resource and Conservation Recovery Act (RCRA). Thus, the performance assessment activity supports both a regulatory function as well as providing information for sound management and technical decisions. The major deliverables from this activity are performance assessments required by Department of Energy (DOE) regulations (DOE 1988, superceded by DOE 1999) which are a key part of the authorization to dispose of radioactive waste. The performance assessment activity started in 1994 when the immobilized waste form of the low-activity part of the Hanford Site tank waste was changed from grout to glass. The activity is slated to end around 2030 when the authorization to close the waste disposal site is expected.

\section{B. BACKGROUND}

The Hanford Site underground tanks contain the largest volume of radioactive waste in the country. The current plan (TWRS ROD 1997) is to separate the waste into a high-activity fraction (having relatively little volume but most of the radioactivity) and a low-activity fraction (having most of the volume but relatively little radioactivity). Both fractions will be immobilized for disposal with the high-activity fraction being disposed in a federal geological repository. The low-activity immobilized fraction is planned to be disposed in a near-surface engineered facility in the Hanford Site 200 East Area. High-activity waste produced by the vendors will be disposed of separately and is not the subject of this program.

DOE Order 435.1 (DOE 1999) covers the management of low-level radioactive waste in the DOE complex. This order requires that a performance assessment be written, approved, and maintained that demonstrates compliance with performance objectives that protect public health and safety, that protect inadvertent intruders, and that protect environmental resources. The tools and information generated in writing these documents also allow others to make decisions on the most cost-effective ways to reach the desired final state of the Hanford Site. The importance of this activity is demonstrated by Tri-Party Agreement Milestone 90-05 (Ecology 1997) which covers the publication of the performance assessment.

The Hanford low-activity tank waste performance assessment program has already issued five major sets of documents:

- Impacts of Disposal System Design Options on Low-Level Glass Waste Disposal System Performance (Rev. 1 = Mann 1995a and Rev $0=$ Rawlins 1994),

- Hanford Low-Level Tank Waste Interim Performance Assessment (Mann 1996 and Mann 1997a) as well as Data Packages for the Hanford Low-Level Tank Waste 


\section{RPP-6702, Rev. 0 \\ Formerly HNF-SD-WM-PAP-062 Rev. 4}

Interim Performance Assessment (Mann 1995b) and Definition of the Base Analysis Case of the Interim Performance Assessment, (Mann 1995c),

- Hanford Low-Activity Tank Waste Performance Assessment (Mann 1998),

- Maintenance Plan for the Hanford Immobilized Low-Activity Tank Waste Performance Assessment (Mann 2000b), andData Packages for the Hanford Immobilized Low-Activity Tank Waste Performance Assessment: 2001 ILAW Version (Mann/Puigh 2000), and

- White Paper Updating the Conclusions of the 1998 ILAW Performance Assessment (Mann 2000a).

The first two documents provided information to disposal facility designers on the effect on long-term performance of various facility components and design philosophies. The second set of documents provide to Hanford Site management, regulators, and other interested parties the projected long-term impact of disposal using current understandings of the designs and philosophies for the disposal of Hanford low-activity tank waste. The first version (Mann 1996) was revised based on comments received, particularly from an external review board consisting of technical experts and a Hanford Site stakeholder.

The interim performance assessments were further revised based on interim DOE guidance (Guimond 1996) to form the basis for requesting DOE headquarters to issue the Disposal Authorization Statement for the modification of existing disposal vaults, the use of those vaults, the construction of new disposal facilities, and the use of those new facilities. In October 1999, DOE (DOE 1999b) conditionally approved the 1998 ILAW PA (Mann 1998) and issued a waste disposal authorization statement to the Hanford Site that included ILAW disposal (DOE 1999c). The two conditions for approval were the submittal of additional information on waste form performance (completed by French 1999 and French 2000) and the addressing of secondary issues in future performance assessments.

The DOE order on radioactive waste management requires that performance assessments be maintained and that a formal maintenance plan be written and approved. This was done shortly after receiving the disposal authorization statement (Mann 2000a).

ILAW disposal is undergoing rapid change. The disposal facility is now to be trench disposal rather than a concrete vault (Taylor 1999). Also, the glass waste form is a different composition that used in the 1998 ILAW PA. Finally, significant amount of site-specific data have been obtained. This new information has been documented in a set of data packages for the 2001 ILAW PA and combined into Mann/Puigh 2000. Limited analyses based on this information were published in a white paper this year (Mann 2000b).

This revision of the statement of work for the low-activity tank waste performance assessment activity follows five earlier versions (Mann 1994, Mann 1995d, Mann 1997b, Mann 1998c, Puigh 1999a). Because of budget constraints, many of the tasks in Mann 1995d and Mann 1998c were not carried out. A statement of work was not published in 1996 because of limited funding. Guidance on future year funding was not received prior to publication of this document. Therefore, the activities presented may have to be modified based on future budget guidance. 
RPP-6702, Rev. 0

Formerly HNF-SD-WM-PAP-062 Rev. 4

\section{GOALS}

The major goal of the performance activity is to assure that the Disposal Authorization Statement (DOE 1999c) covering the disposal of the low-activity fraction of the Hanford Site tank waste remains in effect. The Disposal Authorization Statemnent not only allows the disposal of vendor-supplied immobilized low-activity tank waste (ILAW), but also forms the technical basis for the setting of performance specifications for the waste form to be generated in the second (the major) phase of River Protection Project (RPP) Privatization. By setting the performance specifications using the best technical information, the government can reach the best balance between protection and cost.

A nearer term goal is to support the DOE decision to proceed with the first phase contract to provide the first ILAW product for disposal. Other goals are to receive Disposal Authorization Statements for future facilities and to receive RCRA permits to build and operate the disposal facilities.

Important milestones in the performance assessment activity are displayed in Table 1.0-1.

Table 1.0-1 Important Milestones for the Performance Assessment (PA) Activity

\begin{tabular}{|l|l|l||}
\hline Number & Milestone & Date \\
\hline done & Issue Document on Effects of Disposal Facility Options & Sept. 1995 \\
\hline done & Issue Data Packages for Interim PA & Sept. 1995 \\
\hline done & Issue Interim Performance Assessment & Sept. 1996 \\
\hline done & Reissue Interim Performance Assessment & Sept. 1997 \\
\hline done & Issue 1998 ILAW Performance Assessment & March 1998 \\
\hline--- & Receive Authorization to Modify Existing Disposal Vaults & Oct. 1999 \\
\hline--- & Receive Authorization to Dispose of Wastes & Oct. 1999 \\
\hline 3.0 & Issue Data Packages for 2001 ILAW Performance Assessment & Feb. 2000 \\
\hline 4.0 & Issue White Paper on Waste Form and Disposal Facility to & April 2000 \\
& Support DOE Decision of BNFL, Inc. Contract Extension & \\
\hline 4.0 & Issue 2001 ILAW Performance Assessment & Mar. 2001 \\
\hline 5.0 & Issue Data Packages for 2005 ILAW Performance Assessment & Feb. 2005 \\
\hline 6.0 & Issue 2005 ILAW Performance Assessment & Jan. 2005 \\
\hline 7.0 & Issue Maintenance Performance Assessments & 2010, \\
& & 2015, \\
& & 2020, \\
\hline 8.0 & Issue Closure Performance Assessment & 2025 \\
\hline-- & Receive Authorization to Close Disposal Site & Sept. 2030 \\
\hline
\end{tabular}

Because of the potentially large impacts of the disposal of such large volumes of radioactive waste near surface, there is a strong emphasis in the performance assessment 


\section{RPP-6702, Rev. 0 \\ Formerly HNF-SD-WM-PAP-062 Rev. 4}

activity on the defensibility of data and the justification of conclusions. Guidance on the content and extent of the program have been derived from

(1) Critical Assumptions for Department of Energy Low-Level Waste Disposal Facility Performance Assessments (AIm 1997)

A Compilation of DOE Performance Assessment Peer Review Panel Comments and Recommendations (RWSTP 1994)

the guidance documents (format and contents of performance assessments and maintenance plan guides) that are part of DOE O 435.1

\section{INTERFACES WITH OTHER PARTS OF THE RPP IMMOBILIZED WASTE PROGRAM}

1. Introduction

The River Protection Project (RPP) Immobilized Waste Program is responsible for building, operating, and closing the facilities used to dispose of the immobilized lowactivity Hanford Site tank waste and for building, operating, and decommissioning facilities used to store immobilized high-level Hanford Site tank waste. Currently the plan is to separate the Hanford Site tank waste into low- and high-activity fractions and then immobilize each fraction of the tank waste. The low-activity tank waste will be disposed at the Hanford Site, while the high-activity fraction will be stored at the Hanford Site until a national geologic repository is available.

\section{RPP Immobilized Waste Program}

The RPP is the organization at the Hanford Site responsible for the safe underground storage of the liquid waste from previous Hanford Site operations, the storage and disposal of the immobilized tank waste, and the closure of the underground tanks. The RPP Immobilized Waste Program is responsible for

Designing the disposal facilities for the immobilized low-activity tank waste

Operating the disposal facilities

Closing the disposal facilities

Designing, using, and decommissioning of the facilities for storing the immobilized high-level waste until it is shipped to a federal geologic repository.

Only one set of disposal facilities is now planned (Taylor 1999) for the disposal of ILAW waste. These will be trenches located in the south central part of the 200 East Area. Table 1.0-2 presents the schedule for the design of these activities. 


\section{RPP.6702, Rev. 0 \\ Formerly HNF-SD-WM-PAP-062 Rev. 4}

\section{Waste Form Specifications}

The DOE is procuring the services to immobilize the low-activity tank waste. The first phase of the procurement will take place from 2002 to about 2018 . The waste form specifications for this phase were based on the very conservative approximation of placing the immobilized waste directly into soil. For the second phase of the procurement during which $87-95 \%$ of the tank waste will be processed and disposed, the waste form specifications will be based on future performance assessments.

Table 1.0-2. Schedule for ILAW Disposal Facilities

\begin{tabular}{|l|lr|}
\hline Description & Date \\
\hline Issue engineering studies (Done) & October & 1997 \\
\hline Issue conceptual design & September & 2001 \\
\hline Issue Part B RCRA Permit Application to state regulatory authority & August & 2002 \\
\hline Issue detailed design for first set of facilities & September & 2004 \\
\hline Complete construction of first set of facilities & July & 2006 \\
\hline Start use of first set of facilities & March & 2008 \\
\hline Fill first set of facilities & September & 2018 \\
\hline Construct and use additional disposal facilities & $\ldots$ & \\
\hline Receive last container of waste & September \\
\hline Close last disposal facility & 2026 \\
\hline
\end{tabular}

\section{E. ORGANIZATION OF PERFORMANCE ASSESSMENT ACTIVITY}

The performance assessment activity is organized among its major milestones (see Table 1.0-1). Each of the subactivities is summarized below:

a 1998 Performance Assessment (Interact with DOE-Headquarters so that a Disposal Authorization Statement is issued allowing modification of the existing disposal vaults.) (Completed in FY99).

D Data Packages for 2001 Performance Assessment (Collect data on waste form performance, on how contaminants move through the environment, and from others to determine inventory, disposal facility design, and environmental pathways. Also computer simulation tools are selected and developed to predict how waste forms will behave and how contaminants will move as a function of time. Document data.) (Completed in FYOO).

- 2001 Performance Assessment (Perform the calculations, write the document, and interface with the review bodies. In addition, a white paper supporting DOE's decision on continuing the effort was issued in FY00.)

- Data Packages for 2005 Performance Assessment (Continue the data collection activities concluded once the data packages for the 2001 performance assessment are issued. 


\section{RPP-6702, Rev. 0 \\ Formerly HNF-SD-WM-PAP-062 Rev. 4}

a 2005 Performance Assessment (Perform the calculations, write the document, and interface with the review bodies.)

- Maintenance Performance Assessments (Reissue the performance assessments every 5 years as required under current DOE guidance. Limited data collection efforts are expected for the first maintenance PA. Interface activities covering inventory and facility performance will continue throughout this subactivity.)

- Closure Performance Assessment (Write the last performance assessment, the approval of which would allow the closure of the disposal facility.)

a Activity Supervision and Review (Coordinate overall performance assessment activity as well as interfacing with regulatory and oversight bodies.)

\section{F. IMPORTANT FEATURES FOUND IN THE PREVIOUS ILAW PERFORMANCE ASSESSMENTS}

The Hanford Low-Level Tank Waste Interim Performance Assessment (Mann 1996 and Mann 1997a), the Hanford Low-Activity Tank Waste Performance Assessment (Mann 1998), the Data Packages for the Hanford Immobilized Low-Activity Tank Waste Performance Assessment : 2001 version (Mann/Puigh 2000), and the White Paper Updating the Conclusions of the 1998 ILAW Performance Assessment (Mann 2000a) identified key data collection and methodologies needed for the evaluation of the disposal of low-activity tank waste.

For the protection of groundwater, the most important data are

the amount of technetium (normally found as the pertechnate ion), the release rate of contaminants from the waste form, the disposal facility geometry, and the flow of groundwater.

The length of time for contaminants to reach the groundwater depends on a great number of parameters with recharge rate and geochemical parameters being the most important. For intrusion, the important data are the amount of ${ }^{126} \mathrm{Sn},{ }^{239} \mathrm{Pu}$, and ${ }^{241} \mathrm{Am}$ and various dosimetry parameters.

The critical methodologies identified in the ILAW Performance Assessment deal with planning and computer code simulation. The base analysis case as well as uncertainty and sensitivity cases must be identified as early as possible. In addition, because of the inability to measure data over the thousands of years important to a performance assessment, computer code simulation is critical. In particular, the modeling of contaminants from glass must follow, over long periods of time, the changing of chemical and physical environments.

This statement of work carefully follows the lessons leamed from the ILAW Performance Assessment and earlier Hanford Site performance assessments. 
RPP-6702, Rev. 0

Formerly HNF-SD-WM-PAP-062 Rev. 4

\section{G. INTEGRATION WITH OTHER HANFORD PROGRAMS}

Other programs at the Hanford Site are either doing similar work to that of the Hanford Low-Activity Tank Waste Performance Assessment Program or are doing working on which this program depends. The two most important programs belonging to the first category are the Tank Farm Vadose Zone Program and the Hanford Groundwater / Vadose Zone Integration Program. The most important programs in the second category are sister programs in the Immobilized Waste Program, the Tank Farm Characterization Program, and the Hanford Groundwater Program.

The goal of the Tank Farm Vadose Zone Program is to understand contaminant distribution and movement in the vadose zone from past and potential future tank farm events. Thus, this program will gather data, develop understandings, and test predictions in a manner very similar to the ILAW program. The main difference between the two programs are the waste forms (tank waste in the form of liquid, salt cake, or sludge versus vitrified waste of the ILAW program) and the more narrow spatial interest of the ILAW program (the entire 200 Area versus the southem part of the 200 East Area for the ILAW program). Close cooperation is maintained between the two programs by having the technical lead of the ILAW PA program be an active member of the Tank Farm Vadose Zone Program.

The goal of the Hanford Groundwater / Vadose Zone Integration Project is to ensure that all data and analyzes used to support environmental impacting decisions have common and defensible bases. The Integration Project is beginning to develop standards that will lead to common databases and methods. Under the System Assessment Capability, the Integration Project will develop models and tools that may be of interest to the ILAW program. Under the Science and Technology activity, new data and tools may be developed that may provide better understanding to the ILAW Program. Close cooperation is maintained between the Integration Project and the ILAW PA program by having the technical lead of the ILAW PA Program physically located with the Integration Project staff. This document notes those activities which have significant site-wide interest and, hence, are suitable for funding from the Hanford Groundwater / Vadose Zone Integration Project.

The ILAW PA Program obtains data from a number of other programs. Obviously, disposal facility design and disposal operations information comes from the sister groups in the Immobilized Waste Programs. The sister groups also provide scenarios to be studied and requirements to be meet. The inventory in the ILAW package is based on data from tank waste inventories provided by the In-tank Characterization Program as well as separation and treatment plans. Close ties are also maintained with the Hanford Groundwater Program (to understand and predict groundwater flows), with the Hanford Surveillance Program (to understand future dosimetry scenarios), and with DOE's Waste Integration Team (to understand their requirements on waste packages). 
RPP-6702, Rev. 0

Formerly HNF-SD-WM-PAP-062 Rev. 4

\section{H. CONTENTS OF THIS REPORT}

The remainder of this report contains statements of work for each of the tasks in the performance assessment activity in fiscal years 2001 through 2006 . The format and contents of each task are the same and described in Appendix A.

Functions, background, deliverables, costs, and interfaces are summarized at the beginning of each chapter. Thus to obtain an overview of the entire performance assessment activity, it is sufficient just to read the first few pages of each chapter.

The costs for tasks and subtasks presented in this statement of work are in FYOO dollars. No attempt has been made to escalate costs due to inflation. Funds for work performed by non-Hanford Site national laboratories are assumed to be transferred by DOE Intra-agency work orders and hence no Hanford Site adders are applied. All other work assumes an adder of $18 \%$. For work not performed by a Hanford Site contractor or subcontractor, an additional $6.3 \%$ charge is added. 
RPP-6702, Rev. 0

Formerly HNF-SD-WM-PAP-062 Rev. 4

\subsection{PERFORMANCE ASSESSMENT (Complete)}

\section{A. SUMMARY}

Interface with Office of Environmental Management (OEM) at DOE-Headquarters and with the team that OEM establishes to review the Hanford Low-Activity Tank Waste Performance Assessment, Rev. 0. The goal was to receive a Disposal Authorization Statement allowing at a minimum the modification of the existing disposal facilities but also the use of those facilities, the authorization to construct new facilities, and the use of those new facilities. This goal was achieved (DOE 1999c).

\section{B. INTERFACE WITH HQ}

i. $\quad$ Background

The Hanford Low-Activity Tank Waste Performance Assessment (DOE/RL 1998) was sent to DOE-Headquarters by the Richland Operations in 1998 for review and approval. DOE has conditionally approved the 1998 ILAW PA (DOE 1999b). The two conditions were to submit additional information on waste form performance (completed by French 1999 and French 2000) and to address secondary conditions of the review group in future performance assessments.

ii. List of Deliverable

Table 2.0-1a List of Deliverables for Interface with HQ on 1998 PA

\begin{tabular}{|l|c|c|c|}
\hline Description & $\begin{array}{c}\text { Due } \\
\text { Date }\end{array}$ & Level & $\begin{array}{c}\text { MYWP } \\
\text { Identifier }\end{array}$ \\
\hline Issue paper on PA strategy & done & 7 & $\begin{array}{c}46140 \mathrm{AOD} \\
{[46140 \mathrm{A01}]}\end{array}$ \\
\hline Issue draft performance assessment & done & 5 & $\begin{array}{c}46140 \mathrm{AOC} \\
{[46140 \mathrm{A01}]}\end{array}$ \\
\hline $\begin{array}{l}\text { Issue Hanford Low-Activity Tank Waste } \\
\text { Performance Assessment }\end{array}$ & done & 5 & $\begin{array}{c}46140 \mathrm{AOB} \\
{[46140 \mathrm{AO} 1]}\end{array}$ \\
\hline $\begin{array}{l}\text { Receive Disposal Authorization Statement } \\
\text { allowing modification of existing disposal vaults }\end{array}$ & done & 6 & $\begin{array}{c}46140 \mathrm{~A} 1 \mathrm{~A} \\
{[46140 \mathrm{~A} 11]}\end{array}$ \\
\hline
\end{tabular}


RPP-6702, Rev. 0

Formerly HNF-SD-WM-PAP-062 Rev. 4

iii. $\quad$ Cost Summary

WBS: $1.1 .1 .3 .4 \cdot 1.3 .1$

TPCN: D4DM1

Table 2.0-1b Cost Summary for Interface with $\mathrm{HQ}$ on $1998 \mathrm{PA}$

\begin{tabular}{|c|c|c|}
\hline $\begin{array}{l}\text { Fiscal } \\
\text { Year }\end{array}$ & Organization & $\begin{array}{l}\text { Amount } \\
(1000 \$)\end{array}$ \\
\hline \multirow[t]{4}{*}{1998} & Fluor Federal Services (FFS) & 60. \\
\hline & $\begin{array}{l}\text { Lockheed Martin Hanford Company } \\
\text { (LMHC) }\end{array}$ & 13. \\
\hline & $\begin{array}{l}\text { Pacific Northwest National Laboratory } \\
\text { (PNNL) }\end{array}$ & 10. \\
\hline & Total & 83. \\
\hline \multirow[t]{3}{*}{1999} & FFS & 12. \\
\hline & LMHC & 5. \\
\hline & Total & 17. \\
\hline \multicolumn{2}{|c|}{ Grand Total } & 100. \\
\hline
\end{tabular}

iv. Interfaces

This task continued the interaction with headquarters begun in FY98 after the performance assessment was submitted. Comments received from the review of the 1998 PA will be incorporated into the program.

Table 2.0-1c Interfaces for Interface with HQ on 1998 PA

\begin{tabular}{||c|l|l|l||}
\hline Number & Interface & Description & Date \\
\hline \multicolumn{2}{||l|}{ Input } & \multicolumn{2}{|c|}{ Finish } \\
\hline 46140A02 & FY98 & Interface with HQ & $9 / 30 / 98$ \\
\hline Output & -- & $\begin{array}{l}\text { Whichever tasks are affected by } \\
\text { requirements or } \\
\text { recommendations issued by } \\
\text { DOE-HQ }\end{array}$ & $1 / 16 / 99$ \\
\hline Various & & Start \\
\hline
\end{tabular}




\author{
RPP-6702, Rev. 0 \\ Formerly HNF-SD-WM-PAP-062 Rev. 4
}

\title{
3.0 DATA PACKAGES FOR 2001 PERFORMANCE ASSESSMENT
}

\section{A. SUMMARY}

Issue a report documenting the current state of knowledge needed for the 2001 performance assessment. The main body of the report shall summarize the data with appendices containing a detailed description of the data and the justification for the selected data. The report shall serve a similar function as the Data Packages for the Hanford Low-Level Tank Waste Interim Performance Assessment (Mann 1995b). Data collection activities are described in Sections 3.1, 3.2, and 3.3.

Data packages have been issued and summarized in Mann/Puigh 2000. The individual data packages are

- Performance Objectives (Mann 1999a)

- Scenarios (Mann 1999b)

- $\quad$ Selection of a Waste Form Release Computer Code (McGrail 1998b)

- $\quad$ Verification of Selected Waste Form Release Code (Bacon 2000)

- $\quad$ Selection of a Vadose Zone Simulation Compute Code (Voogd 1999)

- Verification and Validation of Vadose Zone Code (Finfrock 2000)

- Geology (Reidel 1999)

- Inventory (Wootan 1999)

- Facility Data (Puigh 1999b)

- Recharge (Fayer 1999)

- Waste Form Release (McGrail 1999)

- $\quad$ Near-Field Hydrology (Meyer 1999)

- Far-Field Hydrology (Khaleel 1999)

- Geochemistry (Kaplan 1999)

- Dosimetry (Rittmann 1999)

- $\quad$ Future Potential Agricultural Uses of the Hanford Site (Evans 2000)

B. ISSUE DATA PACKAGES FOR HANFORD LOW-LEVEL TANK WASTE PERFORMANCE ASSESSMENT

i. Background

In order to provide a justified and defensible performance assessment, much data must be collected and analyzed. The performance assessment for the disposal of low-activity tank waste faces greater difficulties than most other performance assessments because the large inventory of the proposed disposal action leads to consequences nearly at the level of the performance objectives. In addition, although the geological structure underneath the disposal facility plays a major role in the timing of the disposal impacts, the role of the long-term performance of the waste form is more important in determining the amount of the impact, a situation unique in the DOE complex or in waste disposal.

Therefore a major data collection activity is included as part of the performance assessment. For most other performance assessment activities, such data collection 


\section{RPP-6702, Rev. 0 \\ Formerly HNF-SD-WM-PAP-062 Rev. 4}

has occurred prior to the start of the performance assessment activity. Hanford has the advantage of choosing the most cost-effective options for obtaining the needed data.

Three major data collection tasks are included:
a. Waste form performance data and tools,
b. Geotechnical data and tools, and
c. Other data.

Because these data collection tasks are so different, they are described in separate sections in this report (see Sections 3.1,3.2, and 3.3). Only the task to issue a complete report is described in this section.

ii. List of Deliverable

Table 3.0-1a List of Deliverables for Create 2001 PA Data Packages

\begin{tabular}{|l|l|c|l|}
\hline Description & $\begin{array}{l}\text { Due } \\
\text { Date }\end{array}$ & Level & $\begin{array}{l}\text { 1999 } \\
\text { MYWP } \\
\text { Identifiers }\end{array}$ \\
\hline $\begin{array}{l}\text { Issue a report documenting the current state of knowledge } \\
\text { needed for the 2001 performance assessment. }\end{array}$ & done & 5 & $\begin{array}{l}46155 \mathrm{AOB} \\
\text { [46155A01] }\end{array}$ \\
\hline $\begin{array}{l}\text { Issue a revised report documenting the current state of } \\
\text { knowledge needed for the 2001 performance assessment. }\end{array}$ & $9 / 30 / 00$ & 5 & $\begin{array}{l}46155 \mathrm{A0C} \\
\text { [46155A01] }\end{array}$ \\
\hline
\end{tabular}

iii. $\quad$ Cost Summary $\quad$ WBS: $1.1 .1 .3 .4 .1 .3 .1 \quad$ TPCN: D4DM1

Table 3.0-1b Cost Summary for Create 2001 PA Data Packages

\begin{tabular}{||l|l|l||}
\hline Fiscal Year & Organization & Amount (1000\$) \\
\hline \hline 2000 & Fluor Federal Services (FFS) & \\
\hline
\end{tabular}

iv. Interfaces

This subactivity will use the reports created by the 2001 performance assessment data collection subactivities (Sections 3.1,3.2, and 3.3) as the basis for the main body of the data packages document and will use the reports themselves as the document appendices.

The data package document will provide all the data needed for the calculations and writing of the 2001 performance assessment. 
RPP-6702, Rev. 0

Formerly HNF-SD-WM-PAP-062 Rev. 4

Table 3.0-1c Interfaces for Create 2001 PA Data Packages

\begin{tabular}{|c|c|c|c|}
\hline $\begin{array}{l}1999 \text { MYWP } \\
\text { Identifiers }\end{array}$ & Interface & Description & Date \\
\hline \multicolumn{3}{|l|}{ Input } & Finish \\
\hline 46145GA & (3.1.i) & Waste Form Release Data Package & $12 / 31 / 99$ \\
\hline $46145 \mathrm{~J} 0 \mathrm{~A}$ & (3.2.b) & Geology Data Package & $12 / 31 / 99$ \\
\hline 46145K7A & (3.2.c) & Recharge Data Package & $12 / 31 / 99$ \\
\hline 46145M3A & (3.2.d) & Near-Field Hydraulic Package & $12 / 31 / 99$ \\
\hline 46145L5A & (3.2.e) & Far-Field Hydraulic Package & $12 / 31 / 99$ \\
\hline $4614502 \mathrm{~A}$ & $(3.2 . f)$ & Near-Field Chemical Package & $12 / 31 / 99$ \\
\hline 46145N5A & (3.2.g) & Far-Field Chemical Package & $12 / 31 / 99$ \\
\hline 46145P1A & (3.2.h) & Vadose Zone Simulation Code Package & $12 / 31 / 99$ \\
\hline \multicolumn{3}{|l|}{ Output } & Start \\
\hline 46155A11 & $(4.0)$ & Create 2001 Performance Assessment & $1 / 1 / 00$ \\
\hline
\end{tabular}

v. Detailed Description

A document defining the contents, format, and methods to be used for the preparing the 2001 version of the Hanford Low-Activity Tank Waste Performance Assessment will be issued (done, Mann/Puigh 2000). The document also will contain the data to be used in the supporting calculations along with justification for the selection of that data. The information will be summarized in the main text. The appendices will contain the documents used as primary references.

The contents and format to be used in the 2001 performance assessment will follow the then current guidance. This guidance will be summarized in the document.

The methods to be used include the standards against which the effect of the disposal action will be judged (performance objectives), the various scenarios and pathways that will be analyzed, and the tools with which the analyses will be done. The document will contain information conceming code selection, verification, and (where possible) validation.

The data to be used in the 2001 performance assessment will be summarized in the main text. Areas to be covered include

a. Inventory to be expected in the waste form,

b. Location(s) of the disposal facility,

c. Disposal facility design,

d. Waste form package description (including processing),

e. Behavior of disposal facility over time,

f. Behavior of waste form over time,

g. Moisture recharge rate,

h. Geology of disposal facility location,

i. Hydrologic parameters (both near- and far-field),

j. Geochemical parameters (both near- and far-field), 
RPP-6702, Rev. 0

Formerly HNF-SD-WM-PAP-062 Rev. 4

k. Performance objectives,

l. Scenarios to be studied, and

m. Dosimetry parameters.

Because the performance assessment depends so heavily on waste form performance and since the knowledge of how BNFL, Inc.-type glasses perform is increasing so rapidly, it is likely that a second waste form data package will be issued in FY00. If these new data are used in the 2001 ILAW PA, the 2001 ILAW PA data package document will be revised. 
RPP-6702, Rev. 0

Formerly HNF-SD-WM-PAP-062 Rev. 4

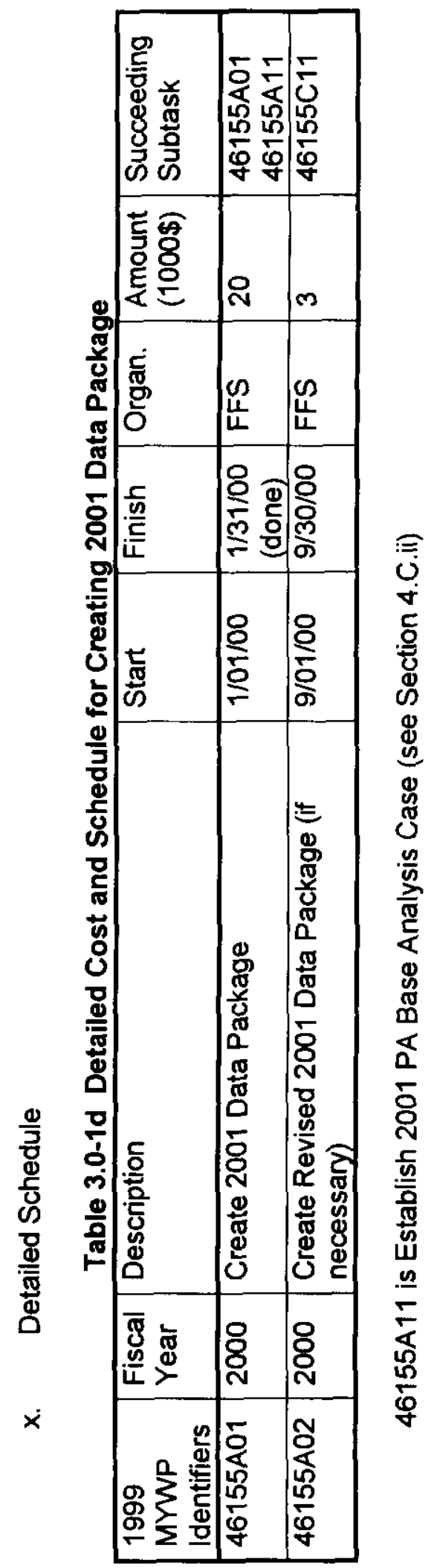


RPP-6702, Rev. 0

Formerly HNF-SD-WM-PAP-062 Rev. 4

\subsection{WASTE FORM PERFORMANCE DATA AND TOOLS}

\section{A. SUMMARY}

Provide data and calculational tools for the calculation of the release of contaminants from the waste form for the 2001 performance assessment. The documentation should provide the current state of knowledge for the waste form being supplied by the private vendors under the conditions expected in the disposal facility. The data collected should be directed toward supplying information needed for the calculation of the release of contaminants from the waste form and the transport of those contaminants in the near field over 10,000 years. The strategy for this effort is contained in McGrail 1999.

\section{B. GENERAL}

i. Background

The Hanford Low-Activity Tank Waste Performance Assessment (Mann 1999) has shown that the release rate from the waste form is one of the key parameters in the analysis and is probably the most uncertain. Because the release rate is important for thousands of years in a changing chemical and physical environment, the release rate must be estimated using computer models based on as much experimental data as possible obtained over a variety of conditions

Not only is the release rate needed from a regulatory requirement, but also from a return on investment view. One of the most significant costs to the Department of Energy (DOE) is the procurement cost of immobilizing the low-activity waste. If DOE can relax the release rate specifications, then this procurement cost can be significantly reduced.

The current models of release rate from a vitrified waste form deal with the physical and chemical interface between the glass and water. Glass undergoes a chemical reaction with water, the rate of which depends mainly on the glass formulation, temperature, $\mathrm{pH}$, and the amount of silicic acid in the water. An important secondary reaction (at the temperatures and $\mathrm{pH}$ of the disposal site) is the ion exchange reaction of $\mathrm{H}$ (in water) and $\mathrm{Na}$ (in the glass) because it increases the $\mathrm{pH}$ of the environment.

The reaction rate for releasing element $i$ via the first chemical reaction is given by

$$
R_{i}=v_{i} \vec{k} a^{-\eta} e^{-\frac{E_{a}}{R T}}\left[1-(Q / K)^{\sigma}\right]
$$

where

$\begin{array}{lll}\mathrm{R}_{\mathrm{i}} & = & \text { the flux of element } i\left(\mathrm{~g} \mathrm{~m}^{-2} \mathrm{~s}^{-1}\right) \\ v_{\mathrm{i}} & = & \text { the stoichiometric coefficient of element } i \text { in glass } \\ \vec{k} & = & \text { the intrinsic rate constant }\left(\mathrm{g} \mathrm{m}^{-2} \mathrm{~s}^{-1}\right) \\ \mathrm{a} & = & \mathrm{H}^{+} \text {ion activity } \\ \eta & = & \mathrm{pH} \text { power law coefficient } \\ \mathrm{E}_{\mathrm{a}} & = & \text { activation energy }(\mathrm{J} / \mathrm{mol}) \\ \mathrm{R} & = & \text { gas constant }\left(\mathrm{J} / \mathrm{mol} \mathrm{K}^{-1}\right) \\ \mathrm{T} & = & \text { temperature }(\mathrm{K})\end{array}$


RPP-6702, Rev. 0

Formerly HNF-SD-WM-PAP-062 Rev. 4

$\begin{array}{lll}\mathrm{Q} & = & \text { ion-activity product of rate controlling phase } \\ \mathrm{K} & = & \text { equilibrium constant for rate controlling phase } \\ \sigma & = & \text { net reaction order. }\end{array}$

The equation for the second reaction (the ion-exchange reaction) is the classical chemical equilibrium reaction with a different activation energy. The discovery of the importance of this secondary ion-exchange reaction to contaminant release rates occurred only recently. Little is known about the reaction mechanism except that it appears to be a diffusion-controlled process that persists as long as tests have been performed (that is, more than two years). A detailed investigation of this process is being conducted under DOE's Environmental Management Science Program.

The chemical affinity term $(\mathrm{Q} / \mathrm{K})$ and the $\mathrm{H}^{+}$ion activity term (related to the $\mathrm{pH}$ ) are modeled by computer simulation as a function of time and space. The stoichiometric constants $\left(v_{i}\right)$ are determined by glass composition. The six remaining six parameters ( $k_{\text {glass }}, k_{\text {ion }}, E_{a}, E_{i o n}, \eta$ and $\sigma$ ) must be determined from laboratory experiments.

For the Interim and 1998 ILAW Performance Assessments, the experimental parameters were measured for a typical low-activity waste glass LD6-5142 (McGrail 1996). These parameters must also be measured for the glasses being proposed by the glass vendor.

Since it is not possible to experimentally measure all conditions expected in the disposal facility, contaminant releases will be simulated using computer modeling. The computer code chosen must be validated against a wide range of experimental data so that any problems in the simulation can be found. Upgrades will be made to the computer code to improve the accuracy of the simulations and/or to decrease the time spent in modeling. 
RPP-6702, Rev. 0

Formerly HNF-SD-WM-PAP-062 Rev. 4

b. List of Deliverables

Table 3.1-1a List of Major Deliverables for 2001 PA Waste Form Data Package

\begin{tabular}{|c|c|c|c|}
\hline Description & $\begin{array}{l}\text { Due } \\
\text { Date }\end{array}$ & Level & $\begin{array}{l}\text { MYWP } \\
\text { Identifier }\end{array}$ \\
\hline $\begin{array}{l}\text { Issue a report documenting the current status of knowledge } \\
\text { for waste form performance needed for the } 2001 \\
\text { performance assessment. }\end{array}$ & $8 / 30 / 00$ & 6 & $46145 \mathrm{G} 1 \mathrm{~A}$ \\
\hline $\begin{array}{l}\text { Receive a letter report for an external panel on the first } \\
\text { draft of a report of waste form performance. }\end{array}$ & $6 / 30 / 00$ & 7 & $46145 G 1 B$ \\
\hline $\begin{array}{l}\text { Write a report documenting the current status of knowledge } \\
\text { for waste performance needed for the } 2001 \text { performance } \\
\text { assessment. }\end{array}$ & done & 7 & $46145 \mathrm{GOC}$ \\
\hline $\begin{array}{l}\text { Issue letter documenting installation of X-ray } \\
\text { microtomography equipment }\end{array}$ & done & 7 & $46145 \mathrm{~F} 6 \mathrm{~T}$ \\
\hline $\begin{array}{l}\text { Issue letter report documenting unsaturated measurements } \\
\text { on vendor waste form }\end{array}$ & done & 6 & $46145 F 2 A$ \\
\hline $\begin{array}{l}\text { Issue letter report documenting PCT measurements on } \\
\text { vendor waste form. }\end{array}$ & done & 7 & 46145F3B \\
\hline $\begin{array}{l}\text { Issue status report documenting unsaturated } \\
\text { measurements on vendor waste form }\end{array}$ & done & 7 & 46145FOI \\
\hline $\begin{array}{l}\text { Issue status report documenting PCT measurements on } \\
\text { vendor waste form. }\end{array}$ & done & 7 & $46145 \mathrm{~F} 1 \mathrm{G}$ \\
\hline Issue report on characterization of fully radioactive glass & done & 7 & 46145FOJ \\
\hline Issue report on Tc-doped glass testing & done & 7 & $45145 \mathrm{~F} 1 \mathrm{~L}$ \\
\hline Issue report on waste form screening & done & 6 & 46145E0A \\
\hline Issue report on PUF validation simulations & done & 7 & $46145 \mathrm{COB}$ \\
\hline Issue report on expected chemical range in near-field & done & 7 & $46145 \mathrm{COC}$ \\
\hline Issue V\&V report on waste form simulation code & $\begin{array}{l}\text { done } \\
\text { done }\end{array}$ & 7 & 46145B2A \\
\hline Issue report on selection of waste form simulation code & done & 7 & 46145BOE \\
\hline $\begin{array}{l}\text { Issue status report documenting calculations of } \\
\text { radionuclide release with LAWABP1 (or equivalent) glass }\end{array}$ & done & 7 & \\
\hline Issue data package for 2001 performance assessment. & done & 7 & 46145G1 \\
\hline Issue Revised Waste Form Data Package for 2001 PA & $8 / 30 / 00$ & 6 & $46145 G 4$ \\
\hline $\begin{array}{l}\text { Issue letter report documenting base analysis and } \\
\text { sensitivity case calculation results for the } 2001 \text { PA }\end{array}$ & $9 / 18 / 00$ & 6 & \\
\hline $\begin{array}{l}\text { Issue status report documenting FYOO testing on vendor } \\
\text { glasses. }\end{array}$ & $9 / 30 / 00$ & 7 & \\
\hline
\end{tabular}


RPP-6702, Rev. 0

Formerly HNF-SD-WM-PAP-062 Rev. 4

iii. Cost Summary

WBS: 1.1 .1 .3 .4 .1 .3 .2

TPCN: D4DM2

Table 3.1-1b Cost Summary for Waste Form Data for 2001 PA

\begin{tabular}{|c|c|c|}
\hline $\begin{array}{l}\text { Fiscal } \\
\text { Year }\end{array}$ & Organization & $\begin{array}{l}\text { Amount } \\
(\$ 1000)\end{array}$ \\
\hline \multirow[t]{3}{*}{1997} & Argonne National Laboratory (ANL) & 210 \\
\hline & Pacific Northwest National Laboratory (PNNL) & 110 \\
\hline & Total & 320 \\
\hline \multirow[t]{4}{*}{1998} & ANL & 355 \\
\hline & Lawrence Livermore National Laboratory (LLNL) & 41 \\
\hline & PNNL & 726 \\
\hline & Total & 1122 \\
\hline \multirow[t]{4}{*}{1999} & ANL & 125 \\
\hline & Lockheed Martin Hanford Company (LMH) & 25 \\
\hline & PNNL & 691 \\
\hline & Total & 841 \\
\hline \multirow{4}{*}{2000} & ANL & 0 \\
\hline & $\mathrm{LMH}$ & 13 \\
\hline & PNNL & 413 \\
\hline & Total & 426 \\
\hline \multicolumn{2}{|c|}{ Grand Total } & 2709 \\
\hline
\end{tabular}

iv. Interfaces

This subactivity builds heavily on the data collection methods and procedures used to collect data for the Interim and ILAW Performance Assessments. Beyond extending the conditions measured during that period, the major effort will be in measuring and understanding the long-term performance of the vendor-produced waste form.

The data collection activities (46145Ax through $46145 \mathrm{Fx}$ ) are used as the basis for preparing the waste form data package (46145G02). This document will be reviewed by an external panel (46145G03 AND 46145G04) and issued (46145G05) to form a basis for the 2001 performance assessment.

The waste form data package will contain all waste-form related data needed to perform calculations for the 2001 Performance Assessment. Such data shall include information to establish a best estimate case, uncertainty cases around that best estimate case, as well as a reasonably bounding case. The intent of the information is to allow a suite of cases to be calculated during the creation of the 2001 PA whose results would allow the reader of the 2001 PA to understand what is likely to occur if a disposal action were to occur and to realistically bound release rates should failure of one or more system components occur. 
RPP-6702, Rev. 0

Formerly HNF-SD-WM-PAP-062 Rev. 4

The output of this subactivity will mainly be used in creating the Data Packages for the 2001 Performance Assessment (see Section 3.0). The subsequent subactivity (Section 5.1 = Waste Form Data and Tools for the 2005 Performance Assessment) will build on the knowledge leamed in this subactivity.

v. Organization

The Applied Geology and Geochemistry Section of the Pacific Northwest National Laboratory (PNNL) will be responsible for this subactivity. Experiments will be conducted at both the Argonne (ANL) and Pacific Northwest National Laboratories.

PNNL is very experienced in determining the performance characteristics of vitrified waste forms. Not only have they had the lead for this task in the Hanford lowactivity tank waste performance assessment activity, but also they have been extremely active in the studying glasses for the high-level waste program and in the Pu-disposition program. They have developed both experimental and calculational techniques to understand how glasses (particularly those formulated for low-activity radioactive waste) decompose over time.

ANL also has been very active in studying glasses as the disposal medium for radioactive wastes. They have developed and used a series of tests to better understand how glasses decompose over time.

Scientists at the Lawrence Livermore National Laboratory are the authors and are responsible for the geochemical computer code EQ6.

As the funding source for the performance assessment, Lockheed Martin Hanford Company (LMH) is shown for the external waste form review board.

C. TASK DESCRIPTIONS

i. Summary List of Tasks

$\begin{array}{ll}\text { a. } & \text { Vendor Glass Screening } \\ \text { b. } & \text { Contaminant Release Modeling } \\ \text { c. } & \text { Source Term Simulations } \\ \text { d. Waste Form Data Packages for } 2001 \text { PA } \\ \text { e. Procure and Install High Performance Workstation } \\ \text { f. } \quad \text { Collect Waste Form Hydraulic Data } \\ \text { g. } \quad \text { Collect Waste Form Chemical Data }\end{array}$

ii. Vendor Glass Screening (Completed)

The objective of this task was to detect any possible long-term performance issues with the vendor glass before initiating a large and costly set of experiments to characterize its long-term behavior. The glass formulations under development by the private vendors are significantly different in composition as compared with LAW glasses previously tested. Before initiating a large and costly set of experiments to characterize the long-term behavior of one (or both) of these glass formulations, screening tests were 
RPP-6702, Rev. 0

Formerly HNF-SD-WM-PAP-062 Rev. 4

performed to identify any possible long-term performance issues. The screening tests consisted of high-temperature $\left(150^{\circ} \mathrm{C}\right)$ vapor hydration tests and PUF tests conducted at $90^{\circ} \mathrm{C}$. Test durations were limited to 3 months. Test results were documented in a letter report that was submitted to DOE and was made available to the private vendor(s).

\section{Table 3.1-2a List of Deliverables for Vendor Glass Screening Subtask}

\begin{tabular}{|l|l|c|l|}
\hline Description & $\begin{array}{l}\text { Due } \\
\text { Date }\end{array}$ & Level & $\begin{array}{l}\text { MWWP } \\
\text { Identifiers }\end{array}$ \\
\hline $\begin{array}{l}\text { Issue letter report on results of } \\
\text { screening tests }\end{array}$ & done & 6 & $46145 E 0 A$ \\
\hline
\end{tabular}

WBS: $1.1 .1 .3 .4 \cdot 1.3 .2 \quad T P C N$ : D4DM2

Table 3.1-2b Cost Summary for Vendor Glass Screening Subtask for 2001 PA

\begin{tabular}{||l|l|r|}
\hline $\begin{array}{c}\text { Fiscal } \\
\text { Year }\end{array}$ & Organization & Amount (1000\$) \\
\hline \hline \multirow{2}{*}{1998} & Argonne National Laboratory (ANL) & 15 \\
\cline { 2 - 4 } & Pacific Northwest National Laboratory (PNNL) & 41 \\
\hline \multicolumn{2}{|l|}{ Grand Total } & 56 \\
\hline
\end{tabular}


RPP-6702, Rev. 0

Formerly HNF-SD-WM-PAP-062 Rev. 4

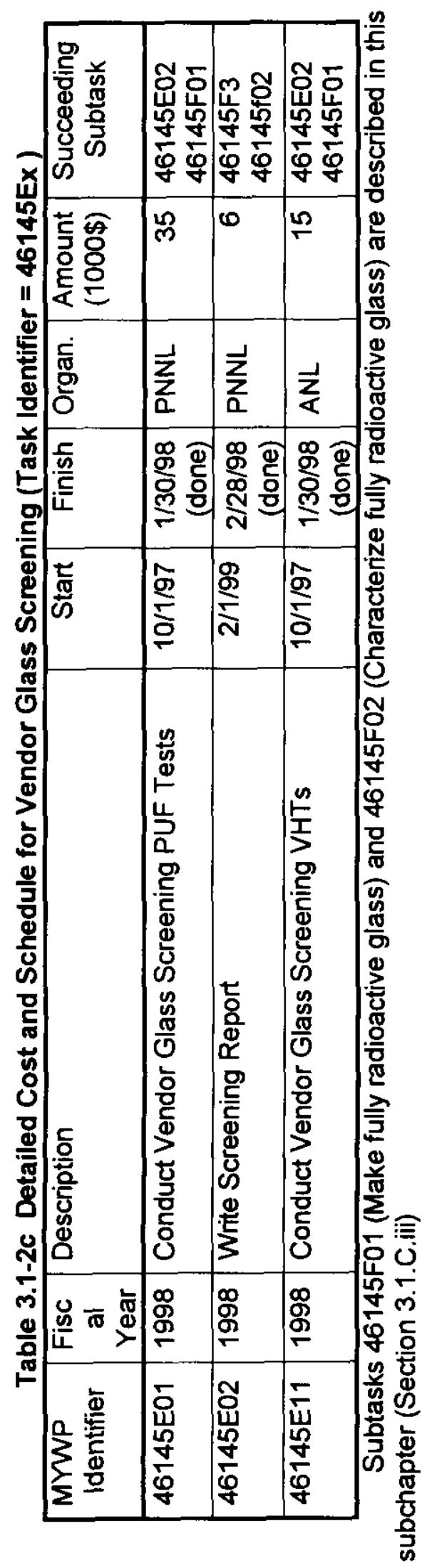


RPP-6702, Rev. 0

Formerly HNF-SD-WM-PAP-062 Rev. 4

iii. Vendor Glass Testing

a. Background

The Department of Energy (DOE) is procuring services to immobilize the lowactivity tank waste. The objective of this task is to collect the necessary data on the vendor waste glass form to support modeling of the long-term radionuclide release behavior of the glass under water unsaturated conditions. Contaminant release modeling is complex, requiring parameterization of the kinetic rate equation (1) as well as data on secondary phase formation (thermodynamic and kinetic), and unsaturated hydraulic properties, which can change as a result of waste form aging. This task supports specific sets of laboratory experiments that have been developed to obtain these critical data. This activity started in FY99.

b. List Of Deliverables

Table 3.1-3a List of Deliverables for Vendor Glass Testing Subtask

\begin{tabular}{|c|c|c|c|}
\hline Description & $\begin{array}{l}\text { Due } \\
\text { Date }\end{array}$ & Level & $\begin{array}{l}\text { MYWP } \\
\text { Identifier }\end{array}$ \\
\hline $\begin{array}{l}\text { Issue QA Level } 2 \text { Procedure for PUF } \\
\text { Testing }\end{array}$ & done & 8 & $\begin{array}{l}46145 \mathrm{FOF} \\
{[46145 \mathrm{~F} 7]}\end{array}$ \\
\hline $\begin{array}{l}\text { Make fully radioactive vendor glass } \\
\text { formulation }\end{array}$ & done & 8 & $\begin{array}{l}46145 \mathrm{FOK} \\
{[46145 \mathrm{~F} 2]}\end{array}$ \\
\hline $\begin{array}{l}\text { Issue test plan for PUF tests with vendor } \\
\text { glass }\end{array}$ & done & 7 & $\begin{array}{l}\text { 46145FOE } \\
\text { [46145F8] }\end{array}$ \\
\hline $\begin{array}{l}\text { Issue letter report on characterization of } \\
\text { vendor glass }\end{array}$ & done & 7 & $\begin{array}{l}46145 \mathrm{FOJ} \\
{[46145 \mathrm{~F} 3]}\end{array}$ \\
\hline $\begin{array}{l}\text { Issue test plan for PCT Measurements on } \\
\text { vendor glass }\end{array}$ & done & 7 & $\begin{array}{l}46145 \mathrm{~F} 1 \mathrm{H} \\
{[46145 \mathrm{~F} 5]}\end{array}$ \\
\hline Issue letter report on Tc-doped glass testing & done & 7 & $\begin{array}{l}46145 \mathrm{~F} 1 \mathrm{~L} \\
{[46145 \mathrm{~F} 1]}\end{array}$ \\
\hline $\begin{array}{l}\text { Issue letter report on initial results from } \\
\text { kinetic law measurements }\end{array}$ & done & 8 & $\begin{array}{l}\text { 46145FOI } \\
{[461454]}\end{array}$ \\
\hline $\begin{array}{l}\text { Issue letter report on initial results from } \\
\text { PCTs of vendor glass }\end{array}$ & done & 7 & $\begin{array}{l}46145 \mathrm{~F} 1 \mathrm{G} \\
{[46145 \mathrm{~F} 6]}\end{array}$ \\
\hline $\begin{array}{l}\text { Issue letter report on initial results from PUF } \\
\text { testing of vendor glass. }\end{array}$ & done & 7 & $\begin{array}{l}46145 \mathrm{FOD} \\
{[46145 \mathrm{Fg}]}\end{array}$ \\
\hline $\begin{array}{l}\text { Issue letter report on kinetic rate law } \\
\text { measurements on vendor glass }\end{array}$ & done & 7 & $\begin{array}{l}46145 \mathrm{~F} 2 \mathrm{C} \\
{[46145 \mathrm{~F} 11]}\end{array}$ \\
\hline $\begin{array}{l}\text { Issue letter report documenting PCT } \\
\text { measurements of vendor glass for } 2001 \text { PA. }\end{array}$ & done & 7 & $\begin{array}{l}46145 \mathrm{~F} 3 \mathrm{~B} \\
{[46145 \mathrm{~F} 12]}\end{array}$ \\
\hline $\begin{array}{l}\text { Issue letter report documenting PUF test } \\
\text { unsaturated rate data }\end{array}$ & done & 6 & $\begin{array}{l}\text { 46145F2A } \\
{[46145 \mathrm{~F} 13]}\end{array}$ \\
\hline $\begin{array}{l}\text { Issue draft ANL Report on Characterization } \\
\text { of Selected Vendor Glasses }\end{array}$ & done & 8 & \\
\hline $\begin{array}{l}\text { Issue final PNNL report on Characterization } \\
\text { of Selected Vendor Glasses }\end{array}$ & done & 8 & \\
\hline
\end{tabular}


RPP-6702, Rev. 0

Formerly HNF-SD-WM-PAP-062 Rev. 4

c. Cost Summary

WBS: $1.1 .1 .3 \cdot 4 \cdot 1 \cdot 3.2$

TPCN: D4DM2

Table 3.1-3b Cost Summary for Vendor Glass Testing for 2001 PA

\begin{tabular}{||l|r|r|}
\hline $\begin{array}{c}\text { Fiscal } \\
\text { Year }\end{array}$ & \multicolumn{1}{|c|}{ Organization } & $\begin{array}{r}\text { Amount } \\
(1000 \$)\end{array}$ \\
\hline \multirow{3}{*}{1997} & Argonne National Laboratory (ANL) & 210 \\
\cline { 2 - 3 } & Pacific Northwest National Laboratory (PNNL) & 25 \\
\cline { 2 - 3 } & Total & 235 \\
\hline \multirow{3}{*}{1998} & ANL & 340 \\
\cline { 2 - 3 } & PNNL & 440 \\
\cline { 2 - 3 } & Total & 780 \\
\hline \multirow{3}{*}{1999} & ANL & 125 \\
\cline { 2 - 3 } & PNNL & 265 \\
\cline { 2 - 3 } & Total & 390 \\
\hline \multirow{2}{*}{2000} & ANL & 0 \\
\cline { 2 - 3 } & PNNL & 333 \\
\cline { 2 - 3 } & Total & 333 \\
\hline \multirow{2}{*}{ Grand Total } & 1738 \\
\hline
\end{tabular}

d. Detailed Description

The objective of this task is to collect the necessary data on the vendor waste glasses to support modeling of the long-term radionuclide release behavior of the glass under water unsaturated conditions. The data collection activities are organized into four subtasks that support specific types of experiments, 1) Product Consistency Tests, 2) Single-Pass Flow-Through (SPFT) Tests, and 3) Pressurized Unsaturated Flow (PUF) Tests, and 4) Vapor Hydration Tests (VHT) Each of these subtasks are described in more detail in the following sections.

\section{i. Product Consistency Testing}

The specific objective of these tests is to provide sufficient data to determine the pseudoequlibrium constant $\mathrm{K}$ in Equation (1) and to identify critical alteration phases that either impact long-term corrosion rates of the glasses or trap the key radionuclides of interest. The PCT results will also be cross-correlated with results obtained from PUF testing.

In FY99, a statistically-designed matrix of $\mathbf{4 8}$ glasses was developed and subjected to VHT and PCTs. This work was funded under a separate EM-50 program. A subset of those glasses showing the best performance in these short-term tests will be subjected to more extensive short and long-term PCT testing under this task. The short to intermediate term PCT data will be included as part of the Waste Form data package for the 2001 ILAW PA.

A series of long-term PCTs started in 1996 with the selected "high-temperature" glass formulations remain in progress. These tests will be continued in FYOO and selected tests terminated to update the reaction progress with these glasses. 
RPP-6702, Rev. 0

Formerly HNF-SD-WM-PAP-062 Rev. 4

\section{ii. Single-Pass Flow-Through Testing}

Single-Pass Flow-Through (SPFT) tests will be performed to obtain the kinetic rate law parameters, $k, \eta, E_{a}$, and $\sigma$ in Equation (1) for a selected vendor glass formulation. Tests will be performed at 4 temperatures and 6 different $\mathrm{pH}$ values to provide a sufficient range of conditions to support a statistical analysis of the data set. In FY00, SPFT experiments will be performed where the concentrations of Si and Al are varied in the influent buffer solution. The purpose of these tests is to determine the reaction order parameter $\sigma$, and to determine whether Al needs to be explicitly included in kinetic rate law for glass dissolution. Scoping experiments with a simulated BNFL $\mathrm{HLW}$ waste glass have indicated that dissolved Al does have a significant impact on the dissolution rate and so will need to included in the rate law.

\section{iii. Pressurized Unsaturated Flow Tests}

The unique aspects of the Pressurized Unsaturated Flow (PUF) test design allow it to be utilized for multiple purposes including, 1) to obtain data on contaminant release rates from the selected glass formulations under conditions of low moisture content, 2) determine unsaturated hydraulic properties of aged glass waste forms, and 3) provide critical data for the validation of the selected waste form release computer code.

In FY97, significant improvements to the PUF test method were developed, including a computer data acquisition and control system and a electrically-operated pressure valve system that permits periodic venting and recharge of the gas phase in the column. These design modifications were incorporated into 4 new PUF systems that are now fully operational. However, because development of these new PUF systems was funded by another DOE program that is expected to support further work in FY99, additional PUF systems will be assembled to support FYOO and future work on this program. The new PUF systems will also be designed to incorporate the $x$-ray source and detector of a X-ray computed microtomography system.

In FY99, a third generation PUF system design was developed and two systems, capable of running 4 columns simultaneously, were assembled. Because of the need to test more glass compositions than originally expected, additional systems need to be built so that sufficient capacity exists to support planned testing on a timely basis. Consequently, two additional quad PUF systems will be built according to specifications completed in FY99.

Assembly of the new PUF systems will occur concurrently with the startup of testing in early October on the 6 selected glasses from the EM-50 study. Several of these experiments will be terminated prior to $12 / 99$ so that a full suite of solids analyses (SEM, TEM, and XRD) can be performed on the reacted solids. These analyses, along with the elemental release rates determined from ICP-MS analysis of effluent samples, will form a critical set of data to be included in the Waste Form Data Package for the 2001 ILAW PA. Longer-term PUF tests will continue throughout FYOO and into FY01 to support the 2005 PA (see Section 5.1).

\section{iv. Vapor Hydration Tests}

The Vapor Hydration Tests (VHT) is a static test in which a monolithic sample is exposed to water vapor in a sealed vessel. At relative humidity $(\mathrm{RH})$ above about $80 \%$, 


\section{RPP-6702, Rev. 0 \\ Formerly HNF-SD-WM-PAP-062 Rev. 4}

a thin film of water condenses on the sample. The thickness of the film increases with the $\mathrm{RH}$, and it is in this film that the glass corrodes. At the completion of a test, the sample is removed from the vessel, and the reacted surface is analyzed with highresolution electron microscopy. Discrete precipitated crystalline phases usually form when the sample corrodes.

To extract kinetic information, VHTs will be run over a minimum of four temperatures, all at $100 \% \mathrm{RH}$. -Tests with all six selected vendor glasses will be performed. Short and intermediate term VHTs will be terminated to provide input for the Waste Form Data Package for the 2001 ILAW PA.

e. Interfaces

This task builds on a substantial history of testing of ILAW glasses beginning in 1995. It also builds on testing on 48 BNFL, Inc-type glasses under EM-50 sponsorship, from which six glasses will be selected for testing under this task. This task will exchange information with the other waste form data collection tasks (3.1.C.iii, 3.1.C.iv) and with the waste form analysis tasks (3.1.C.vii, 3.1.C.viii, and 3.1.C.ix). The output of this task will form the major part of the data needed for 3.1.C.vii (Document Waste Form Data for the 2001 Performance Assessment).

f. Organization

Experiments will be conducted at both the Argonne (ANL) and Pacific Northwest National Laboratories (PNNL).

ANL also has been very active in studying glasses as the disposal medium for radioactive wastes. For this performance assessment activity they have performed longterm corrosion tests on LD6-5412 glass (both with and without Tc) and on other low-level glass waste types as well.

The PNNL Applied Geology and Geochemistry Section is very experienced in determining the performance characteristics of vitrified waste forms. This group has performed many forward rate measurements and unsaturated flow experiments for this performance assessment activity and is continuing to perform a multiyear experiments on experiments on a variety of low-level waste glass formulations. 
RPP-6702, Rev. 0

Formerly HNF-SD-WM-PAP-062 Rev. 4

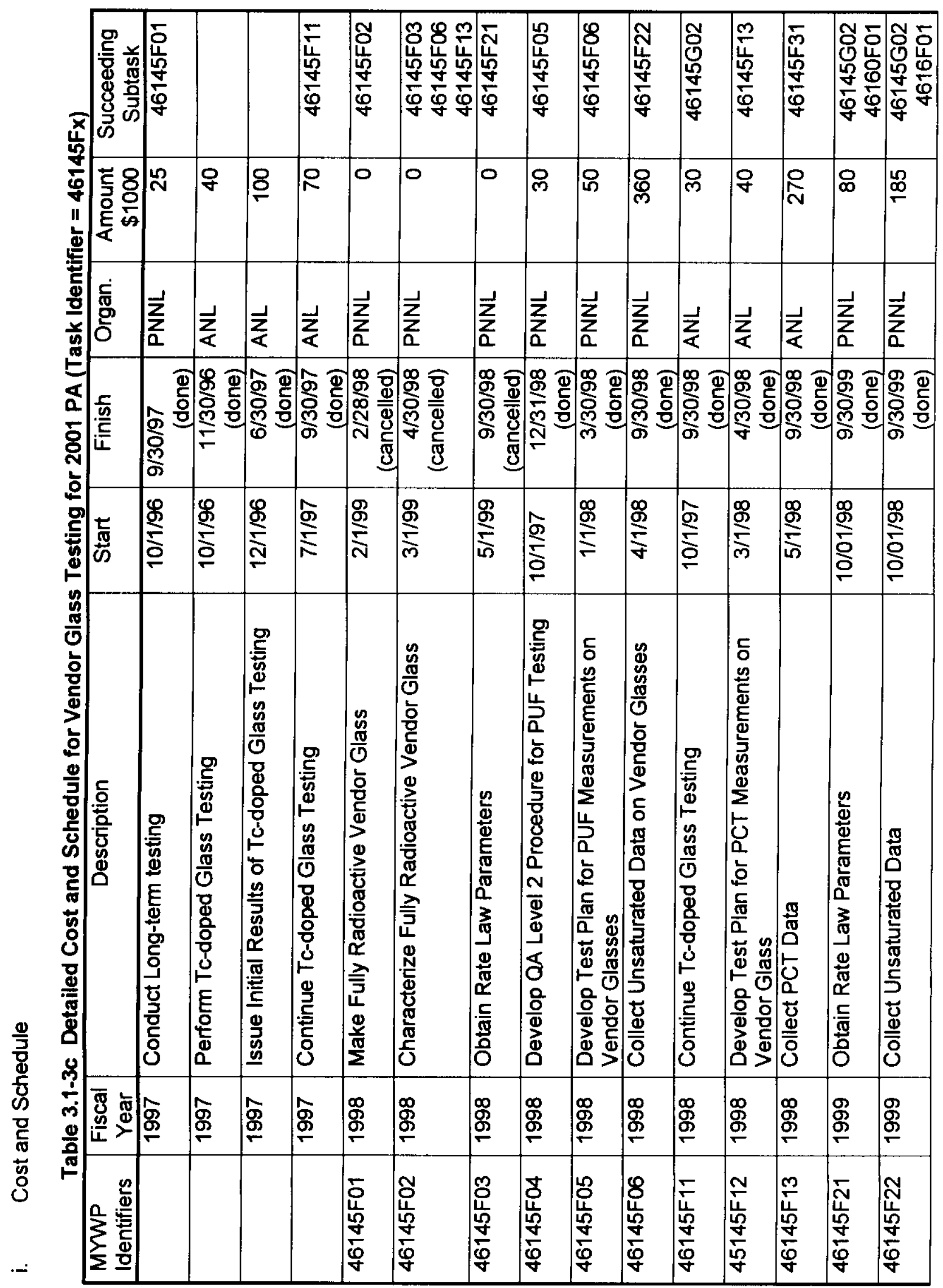


RPP-6702, Rev. 0

Formerly HNF-SD-WM-PAP-062 Rev. 4

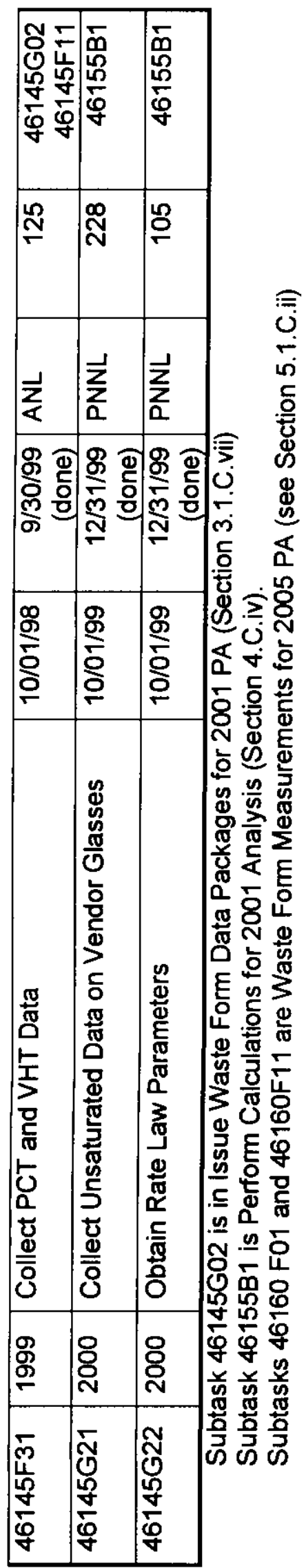


RPP-6702, Rev. 0

Formerly HNF-SD-WM-PAP-062 Rev. 4

iv. Contaminant Release Model

a. Background

Contaminant release from the waste form must be calculated for thousands of years. During this time, the chemical environment will change as the waste form releases contaminants into the water surrounding the waste form. Thus, it is not possible to rely on experiments or simple extrapolations of experimental results. Rather, a complex computer simulation is needed that models the physical and chemical evolution of the waste form-water system. The purpose of this subtask is to modify the code (STORM, the successor to AREST-CT, was selected in FY99 for contaminant release modeling) and to develop physical and/or chemical process submodels, where necessary, to support source-term simulations for the 2001 PA.

b. List Of Deliverables

Table 3.1-4a List of Deliverables for Waste Form Simulation Code

\begin{tabular}{|l|c|c|c|}
\hline Description & $\begin{array}{c}\text { Due } \\
\text { Date }\end{array}$ & Level & $\begin{array}{l}\text { MWWP } \\
\text { Identifier }\end{array}$ \\
\hline \hline $\begin{array}{l}\text { Issue letter report documenting implementation } \\
\text { of unsaturated flow module into AREST-CT. }\end{array}$ & done & 7 & FY97 \\
\hline $\begin{array}{l}\text { Issue letter report documenting the selection of } \\
\text { the code to be used in simulation of waste form } \\
\text { performance. }\end{array}$ & done & 7 & $\begin{array}{l}46145 \mathrm{BOE} \\
\text { [46145B01] }\end{array}$ \\
\hline $\begin{array}{l}\text { Issue letter report documenting updates to } \\
\text { selected waste form simulation and related } \\
\text { codes. }\end{array}$ & done & 8 & $\begin{array}{l}46145 \mathrm{BOD} \\
{[46145 \mathrm{~B} 04,} \\
46145 \mathrm{~B} 03]\end{array}$ \\
\hline $\begin{array}{l}\text { Issue user's manual for updated EQ6 module. } \\
\text { Issue user's manual for waste form simulation } \\
\text { code. }\end{array}$ & done & 8 & $\begin{array}{l}46145 \mathrm{~B} 1 \mathrm{C} \\
{[46145 \mathrm{~B} 11]}\end{array}$ \\
\hline $\begin{array}{l}\text { Issue report documenting the verification and } \\
\text { validation of the computer code to be used in } \\
\text { waste form performance simulations. }\end{array}$ & 8 & $\begin{array}{l}46145 \mathrm{~B} 2 \mathrm{~B} \\
{[46145 \mathrm{~B} 21]}\end{array}$ \\
\hline
\end{tabular}


RPP-6702, Rev. 0

Formerly HNF-SD-WM-PAP-062 Rev. 4

c. Cost Summary

WBS: 1.1 .1 .3 .4 .1 .3 .2

TPCN: D4DM2

Table 3.1-4bCost Summary for Waste Form Computer Simulation Code (2001 PA)

\begin{tabular}{|c|l|r|}
\hline $\begin{array}{c}\text { Fiscal } \\
\text { Year }\end{array}$ & \multicolumn{1}{|c|}{ Organ. } & $\begin{array}{c}\text { Amount } \\
(\$ 1000)\end{array}$ \\
\hline 1997 & Pacific Northwest National Laboratory (PNNL) & 85 \\
\hline 1998 & PNNL & 170 \\
\cline { 2 - 3 } & Lawrence Livermore National Lab (LLNL) & 41 \\
\cline { 2 - 3 } & Total & 211 \\
\hline 1999 & PNNL & 161 \\
\cline { 2 - 4 } & LLNL & 0 \\
\cline { 2 - 4 } & Total & 161 \\
\hline
\end{tabular}

d. Detailed Description

Radionuclide release from the low-level waste glass is the essential first step that is required for any subsequent transport to the accessible environment. The release rate from the glass may dominate the overall performance of the disposal site in the long-term so it is essential that a credible method be used to calculate releases from the glass waste form. Because release rates must be projected far into the future and over a range of environmental conditions that cannot be completely investigated in the laboratory, a model must be developed that is a reasonable and defensible representation of the system. Experience has shown that models based on fundamental principles of physics, chemistry, and thermodynamics (mechanistic models) are best suited for this application. Consequently, this task will develop and test a suitable model describing radionuclide release from low-level waste glass.

In FY97, two computer codes developed at PNNL (AREST-CT and STOMP) were merged into a single coupled code called STORM (Subsurface Transport Over Reactive Multiphases). Based on code selection criteria, STORM ranked highest among the various reactive-transport codes available, finishing ahead of two codes recently developed for Yucca Mountain analyses (McGrail 1999b).

In FY99, STORM was improved in two areas. The first allows StORM to calculate the dissolution of not only the main glass matrix but also of the glass matrix that has been modified by the $\mathrm{Na}-\mathrm{H}$ ion exchange reaction. Experimental evidence from this program has shown that at the temperatures and $\mathrm{Na}$ content of interest that the exchange of $\mathrm{Na}$ ions in the glass with $\mathrm{H}$ ions in the water is significant, thus causing the glass matrix to change. This modification to the STORM now allows the dissolution of both glass matrices to be calculated at the same time. Secondly, the engineered system under study is an open system, which means that oxygen and carbon dioxide participating in the chemical reactions can enter and leave the system. Different results from early experiments at ANL and PNNL showed the importance of this effect. STORM has now been modified to include the ability to calculate gas phase transport. In 


\section{RPP-6702, Rev. 0 \\ Formerly HNF-SD-WM-PAP-062 Rev. 4}

addition, the Lawrence Livermore National Laboratory has modified their EQ3/6 code to allow a more efficient solver to be used for the specialized equations of interest to this program.

In FY99, STORM was improved by implementing a second, alternative numerical strategy for solving the system of partial differential equations that make up the reactive transport model. STORM originally solved the reactive transport equations in one step using a global implicit technique. This technique has proven itself in being able to successfully conduct 2-D simulations out to times of 20,000 years when executed on a modem high-speed UNIX'workstation. However, the method utilizes a mathematical transformation of the original PDE's. These transformations restrict several aspects of model. For example, aqueous species must be assigned constant diffusion coefficients. More problematic is that the kinetic rate laws for glass and mineral dissolution must conform to classical mass action expressions. Recent experimental data is providing evidence that for glass dissolution, these conventional rate laws may not be adequate.

To allow more flexibility in solving nonconventional problems, an operator splitting/sequential iteration (OS/SI) numerical method was evaluated and implemented. The OS/SI approach solves the transport and chemical reaction equations separately, and so eliminates the need for mathematical transformations, as is required using the global implicit method. The OS/SI method thus allows more flexibility in the implementation of rate laws in the model.

A comprehensive suite of test problems was developed for a recent Reactive Transport Modeling Workshop held at PNNL. These problems involve both equilibrium and kinetic aqueous chemical reactions. A revision to the AREST-CT software verification and benchmarking document (PNL-10692) will be issued for the STORM code. The revision will include results from the STORM simulator on the test problems as compared with those of other geochemical reactive transport codes.

e. Interfaces

This task builds on the FY99 modifications of the STORM computer simulation code. This task will exchange information with the waste form data collection tasks (3.1.C.ii, 3.1.C.iii, and 3.1.C.iv) and with the other waste form analysis tasks (3.1.C.viii and 3.1.C.ix). The output of this task will form part of the data needed for 3.1.C.vii (Document Waste Form Data for the 2001 Performance Assessment). This task will also form the basis for continued code simulation efforts to support the 2005 performance assessment (Section 5.1.C.vii)

f. Organization

The PNNL Applied Geology and Geochemistry Section is responsible for the STORM simulation code.

g. Quality Assurance

All activities will be conducted in accordance with 10 CFR 830.120.

UNIX is a trademark of UNIX System Laboratories, Inc. 
RPP-6702, Rev. 0

Formerly HNF-SD-WM-PAP-062 Rev. 4

h. Effect of Not Performing Task

The contaminant release rate from the waste form is the major uncertainty in the performance assessment. Because the release will occur only thousands of years in a changing chemical environment, experiments are not adequate for the estimation of the release rate. Both experiments and the ILAW Performance Assessment pointed out areas needed for improvement. Given the state of research into low-level waste forms, it is expected that new findings will have to be incorporated into the computer code. 
RPP-6702, Rev. 0

Formerly HNF-SD-WM-PAP-062 Rev. 4

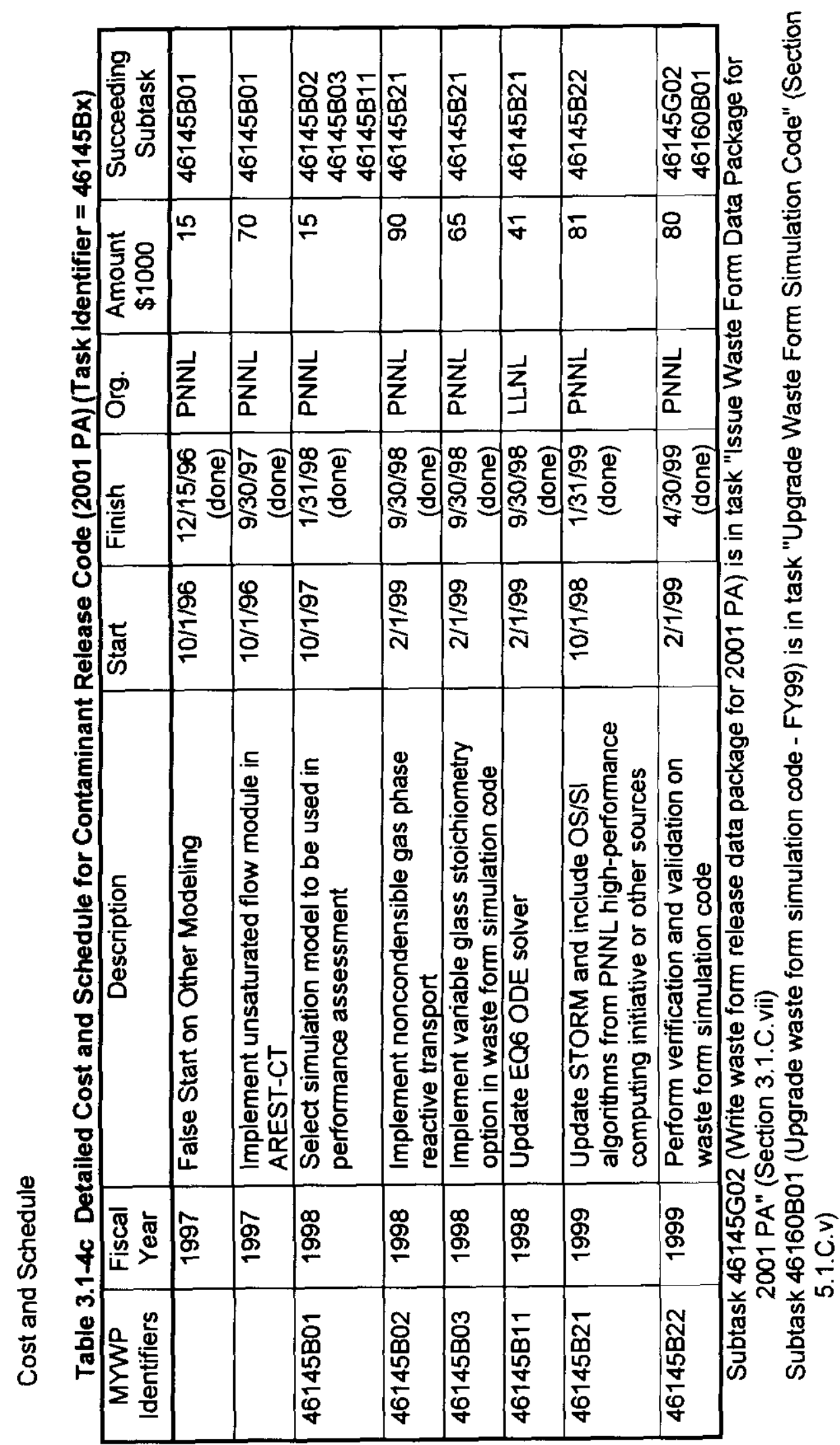




\section{RPP-6702, Rev. 0 \\ Formerly HNF-SD-WM-PAP-062 Rev. 4}

v. Source-Term Simulations

a. Background

Contaminant release from the waste form must be calculated for thousands of years. During this time, the chemical environment will change as the waste form releases contaminants into the water surrounding the waste form. Thus, it is not possible to rely on experiments or simple extrapolations of experimental results. Rather a complex computer simulation is needed that models the physical and chemical evolution of the waste form-water system.

The purposes of this subtask are

1) to conduct the required simulations to verify and validate the selected simulation tool and to conduct and document source-term calculations for the $2001 \mathrm{PA}$ and

2) to provide guidance to other tasks dealing with the near-field considering the expected chemical conditions.

The ILAW Performance Assessment (Mann 1999) showed the importance of the long-term release rate in estimating dose. Since simulations rather than measurements will be used to estimate such long-term releases, the simulation code must be compared with measurements. Such measurements are being performed under the Vendor Glass Testing task (Section 3.1.C.iii). This task performs the simulations.

Many experiments are being performed and much other data are being gathered to support near-field modeling. To limit the range of chemical environments over which experiments must be performed and the literature to be searched, calculations are needed to determine the $\mathrm{pH}$ and redox values that are expected at the waste form water interface.

These calculations will use the STORM code, which was selected for the 2001 performance assessment and the current best estimate of inventory and other data.

b. List Of Deliverables

Table 3.1-5a List of Deliverables for Source-Term Simulations

\begin{tabular}{|l|c|c|l|}
\hline Description & $\begin{array}{l}\text { Due } \\
\text { Date }\end{array}$ & Level & $\begin{array}{l}\text { MYWP } \\
\text { Identifier }\end{array}$ \\
\hline $\begin{array}{l}\text { Issue letter report documenting expected } \\
\text { chemical range that the waste form will be } \\
\text { expected to experience. }\end{array}$ & $\begin{array}{l}9 / 30 / 99 \\
\text { done }\end{array}$ & 7 & $\begin{array}{l}46145 \mathrm{COC} \\
{[46145 \mathrm{CO} 1]}\end{array}$ \\
\hline Issue letter report on PUF validation simulations & $\begin{array}{l}9 / 30 / 99 \\
\text { done }\end{array}$ & 8 & $\begin{array}{l}46145 \mathrm{COB} \\
{[46145 \mathrm{CO} 2]}\end{array}$ \\
\hline $\begin{array}{l}\text { Issue letter reports documenting expected } \\
\text { chemical range that the waste form will be } \\
\text { expected to experience. }\end{array}$ & $\begin{array}{l}4 / 30 / 99 \\
\text { done }\end{array}$ & 8 & $\begin{array}{l}46145 \mathrm{C} 1 \mathrm{~A} \\
{[46145 \mathrm{C} 11]}\end{array}$ \\
\hline $\begin{array}{l}\text { Issue letter reports documenting the effect of } \\
\text { design options as specified by the design staff. }\end{array}$ & $9 / 30 / 99$ & 8 & $\begin{array}{l}46145 \mathrm{CD} \\
{[46145 \mathrm{C} 13]}\end{array}$ \\
\hline
\end{tabular}


RPP-6702, Rev. 0

Formerly HNF-SD-WM-PAP-062 Rev. 4

\begin{tabular}{|l|c|c|c|}
\hline Issue Draft User's Manual for STORM Code & $\begin{array}{c}4 / 30 / 99 \\
\text { done }\end{array}$ & 8 & $46145 \mathrm{C} 1$ \\
\hline Issue Final User's Manual for STORM Code & done & 8 & $46145 \mathrm{C} 1$ \\
\hline $\begin{array}{l}\text { Issue Draft Letter Report Describing Effects of } \\
\text { Design Changes on Waste Form Performance }\end{array}$ & done & 8 & $46145 \mathrm{C} 1$ \\
\hline $\begin{array}{l}\text { Issue Final Letter Report Describing Effects of } \\
\text { Design Changes on Waste Form Performance }\end{array}$ & done & 8 & $46145 \mathrm{C1}$ \\
\hline $\begin{array}{l}\text { Issue status report documenting calculations of } \\
\text { radionuclide release with LAWABP1 (or } \\
\text { equivalent) glass }\end{array}$ & done & 7 & $46155 \mathrm{~B} 0$ \\
\hline
\end{tabular}

c. Cost Summary

WBS: 1.1 .1 .3 .4 .1 .3 .2

TPCN: D4DM2

Table 3.1-5b Cost Summary for Source-Term Simulations (2001 PA)

\begin{tabular}{|l|l|r|}
\hline $\begin{array}{c}\text { Fiscal } \\
\text { Year }\end{array}$ & \multicolumn{1}{|c|}{ Organization } & $\begin{array}{c}\text { Amount } \\
(\$ 1000)\end{array}$ \\
\hline 1998 & Pacific Northwest National Laboratory (PNNL) & 75 \\
\hline 1999 & PNNL & 80 \\
\hline \hline Grand Total & 155 \\
\hline
\end{tabular}

d. Detailed Description

This task provides for conducting and documenting source-term simulations for the purposes of verifying and validating the selected near-field release code, providing information to other data collection tasks on the range of chemical environments expected in the near-field, and for conducting and documenting near-field release calculations for the 2001 PA. The STORM code will be used for these simulations. This task will also calculate the chemical environment $(\mathrm{pH}$, reducing condition, concentrations of important species) for use by other tasks to guide their efforts so that their measurements and data gathering collection activities will be for the proper chemical environment.

In FYOO, a major calculational effort will be undertaken to support DOE-RL in making contractual decisions with BNFL, Inc. and to provide radionuclide release simulations to support the 2001 PA. Per DOE-RL directive, a preliminary set of release calculations were performed and documented by December 31, 1999 using the PNNL developed ILAW glass, LAWABP1 (or equivalent). Base analysis case calculations for the 2001 PA were performed with a representative BNFL, Inc. glass formulation, supported by the laboratory testing data generated under the waste form data collection task , 3.1.C.ii. 
RPP-6702, Rev. 0

Formerly HNF-SD-WM-PAP-062 Rev. 4

e. Interfaces

This task builds on the FY96, FY97, and FY99 calculations performed in support of the creation of the interim and ILAW performance assessments as well as the FY97 and FY99 modifications of the AREST computer simulation code that produced the STORM code. This task will exchange information with the waste form data collection tasks (3.1.C.ii, 3.1.C.iii, and 3.1.C.iv) and with the other waste form analysis tasks (3.1.C.viii and 3.1.C.ix). The output of this task will form part of the data needed for 3.1.C.vii (Document Waste Form Data for the 2001 Performance Assessment). This task will also form the basis for continued code simulation efforts to support the 2005 performance assessment (Section 5.1.C.vii)

f. Organization

The PNNL Applied Geology and Geochemistry Section is responsible for the STORM simulation code. 
RPP-6702, Rev. 0

Formerly HNF-SD-WM-PAP-062 Rev. 4

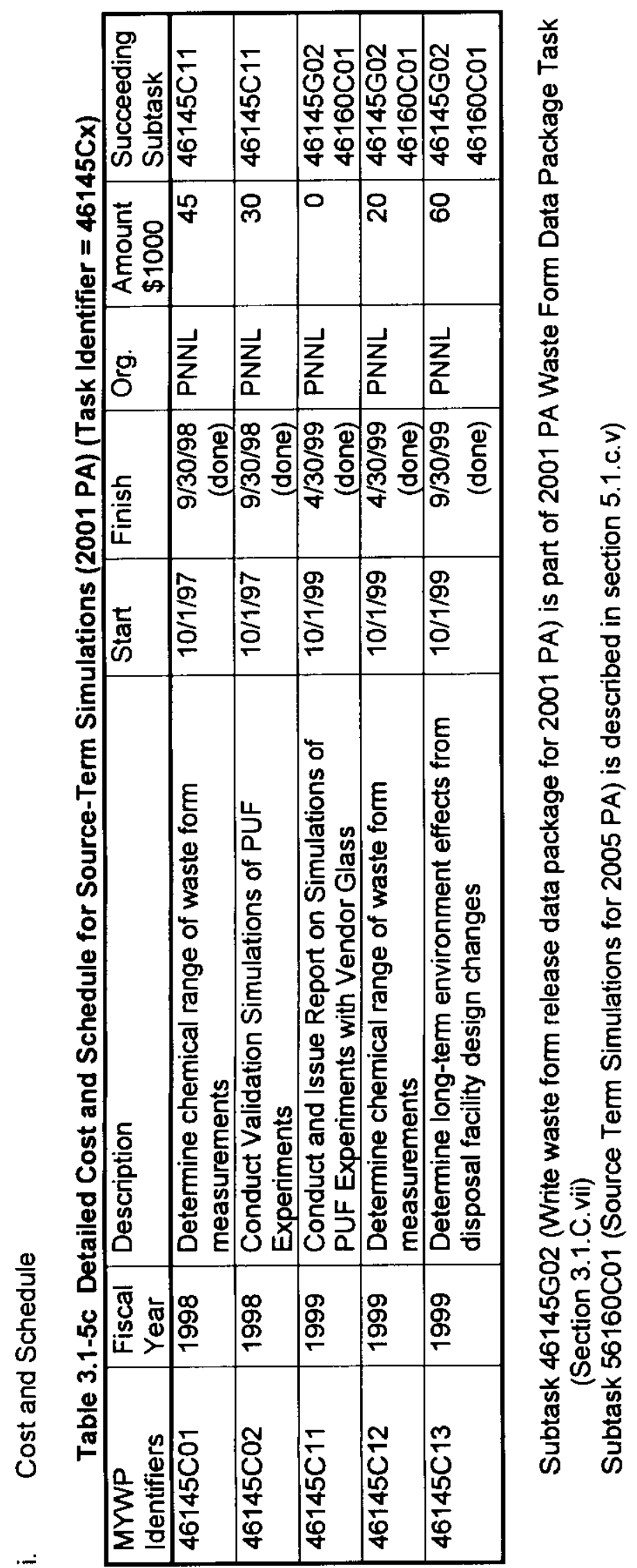


RPP-6702, Rev. 0

Formerly HNF-SD-WM-PAP-062 Rev. 4

vi. Waste Form Data Package for 2001 Performance Assessment

a. Background

The effective contaminant release rate from the waste form is one of the most important parameters in the performance assessment. All of the data (experimental, calculational, computer-code specific) needed for the calculation of this effective release rate for the 2001 performance assessment will be documented and justified.

b. List Of Deliverables

Table 3.1-6a List of Deliverables for 2001 PA Waste Form Data Package

\begin{tabular}{|l|c|c|c|}
\hline Description & Due Date & Level & $\begin{array}{l}\text { MYWP } \\
\text { Identifier }\end{array}$ \\
\hline $\begin{array}{l}\text { Write a review plan for the document } \\
\text { containing the current status of knowledge for } \\
\text { waste performance needed for the 2001 } \\
\text { performance assessment }\end{array}$ & $\begin{array}{r}4 / 30 / 99 \\
\text { done }\end{array}$ & 8 & $\begin{array}{l}46145 \mathrm{GOD} \\
\text { [46145G01] }\end{array}$ \\
\hline $\begin{array}{l}\text { Write a report documenting the current status } \\
\text { of knowledge for waste performance needed } \\
\text { for the 2001 performance assessment }\end{array}$ & done & 7 & $\begin{array}{l}46145 \mathrm{GOC} \\
{[46145 \mathrm{GO} 2]}\end{array}$ \\
\hline $\begin{array}{l}\text { Receive review comments on the first draft of } \\
\text { waste form performance data package }\end{array}$ & done & 7 & $\begin{array}{l}46145 \mathrm{G} 1 \mathrm{~B} \\
{[46145 \mathrm{G} 11]}\end{array}$ \\
\hline $\begin{array}{l}\text { Issue data package for 2001 performance } \\
\text { assessment. }\end{array}$ & done & 7 & $46145 \mathrm{G} 1$ \\
\hline $\begin{array}{l}\text { Receive a letter report from Hanford reviewers } \\
\text { on Waste Form Data Package }\end{array}$ & done & 7 & $46145 \mathrm{G} 1$ \\
\hline $\begin{array}{l}\text { Issue Waste Form Data Package for external } \\
\text { review }\end{array}$ & done & 7 & $46145 \mathrm{G1}$ \\
\hline $\begin{array}{l}\text { Receive letter report from external reviewers } \\
\text { containing comments on Waste Form Data } \\
\text { Package }\end{array}$ & $7 / 31 / 00$ & 7 & $46145 \mathrm{G} 1$ \\
\hline $\begin{array}{l}\text { Issue Final Waste Form Data Package for } \\
\text { 2001 PA }\end{array}$ & $8 / 30 / 00$ & 6 & $46145 \mathrm{G} 1 \mathrm{~A}$ \\
\hline
\end{tabular}


RPP-6702, Rev. 0

Formerly HNF-SD-WM-PAP-062 Rev. 4

c. Cost Summary

WBS: $1.1 \cdot 1 \cdot 3 \cdot 4 \cdot 1 \cdot 3 \cdot 2$

TPCN: D4DM2

Table 3.1-6b Cost Summary for 2001 PA Waste Form Data Package

\begin{tabular}{||l|l|r|}
\hline $\begin{array}{c}\text { Fiscal } \\
\text { Year }\end{array}$ & \multicolumn{1}{|c|}{ Organization } & $\begin{array}{r}\text { Amount } \\
(\$ 1000)\end{array}$ \\
\hline \multirow{3}{*}{1999} & Lockheed Martin Hanford Company (LMH) & 25 \\
\cline { 2 - 3 } & Pacific Northwest National Laboratory (PNNL) & 50 \\
\cline { 2 - 3 } & Total & 75 \\
\hline 2000 & LMH & 13 \\
\cline { 2 - 3 } & PNNL & 35 \\
\cline { 2 - 3 } & Total & 48 \\
\hline \multicolumn{2}{|l|}{ Grand Total } & 123 \\
\hline
\end{tabular}

d. Detailed Description

There are four subtasks in this task:

i. Write the draft version of the waste form data package,

ii. Review the draft version,

iii Review the comments and issue the waste from data package, and

iv. Determine if $12 / 99$ data package needs revision, and revise if necessary.

The draft version of the waste form data package shall contain all of the data needed for the contaminant release rate calculations in the 2001 performance assessment. Such data shall include information to establish a best estimate case, uncertainty cases around that best estimate case, as well as a reasonably bounding case. The intent of the information is to allow a suite of cases to be calculated during the creation of the 2001 PA whose results would allow the reader of the 2001 PA to understand what is likely to occur if a disposal action were to occur and how bad things would have to get in order for the disposal action to fail. The authors shall review the documents published in the other subtasks of this task (as well as documents produced by the performance assessment team and others). The authors will justify selection of data and methods.

Because the contaminant release rate is one of the most important parameters and one of the most uncertain, an external panel will review the draft version. The panel shall be selected by the performance assessment team leader after consultation with the waste form subteam leader. The draft version shall also be available to others for review.

Comments on the draft version of the waste form data packages shall be reviewed and incorporated into the document as appropriate. Some comments may be better included in a revised work effort than in the document itself. The final version of the waste form data package will be used in creating the full 2001 performance assessment data package and will appear in that document as an appendix. 
RPP-6702, Rev. 0

Formerly HNF-SD-WM-PAP-062 Rev. 4

Because the performance of the waste form is so important to the estimates of long-term environmental impacts and because our knowledge of the waste form performance for BNFL, Inc.-type glasses is increasing so rapidly, it may be necessary to revise the waste form data package in FYOO. Based on the FYOO glass experiments for the 2005 PA described in Chapter 5 and based on comments on the review of waste form data package, the ILAW PA team leader will decide whether a revision of the data package is necessary. If found to be necessary, a revise data package will be published.

e. Interfaces

This subtask will use the reports created by the other subtasks of the waste form data collection task to generate a report documenting all of the waste form data to be used in the 2001 performance assessment. An important part of the report is the justification for the values and methods chosen.

f. Organization

The writing of the draft and final version of the waste form data package will be lead by the leader of the performance assessment waste form subteam leader (currently Pete McGrail of the Pacific Northwest National Laboratory [PNNL]). He will also take an active part in meeting and communicating with the waste form review panel.

As the funding source for the performance assessment activity, Lockheed Martin Hanford Company (LMH) is shown as the organization responsible for the waste form review board.

g. Quality Assurance

All activities will be conducted in accordance with 10 CFR 830.120.

h. Effect of Not Performing Task

Without this document, there would be no central source for data needed for the calculation of contaminant release rate from the waste form, which is one of the most important and uncertain parameters in the performance assessment. Because these data are the most likely of all data supporting the performance assessment to change, configuration control of these data are crucial. 
RPP-6702, Rev. 0

Formerly HNF-SD-WM-PAP-062 Rev. 4

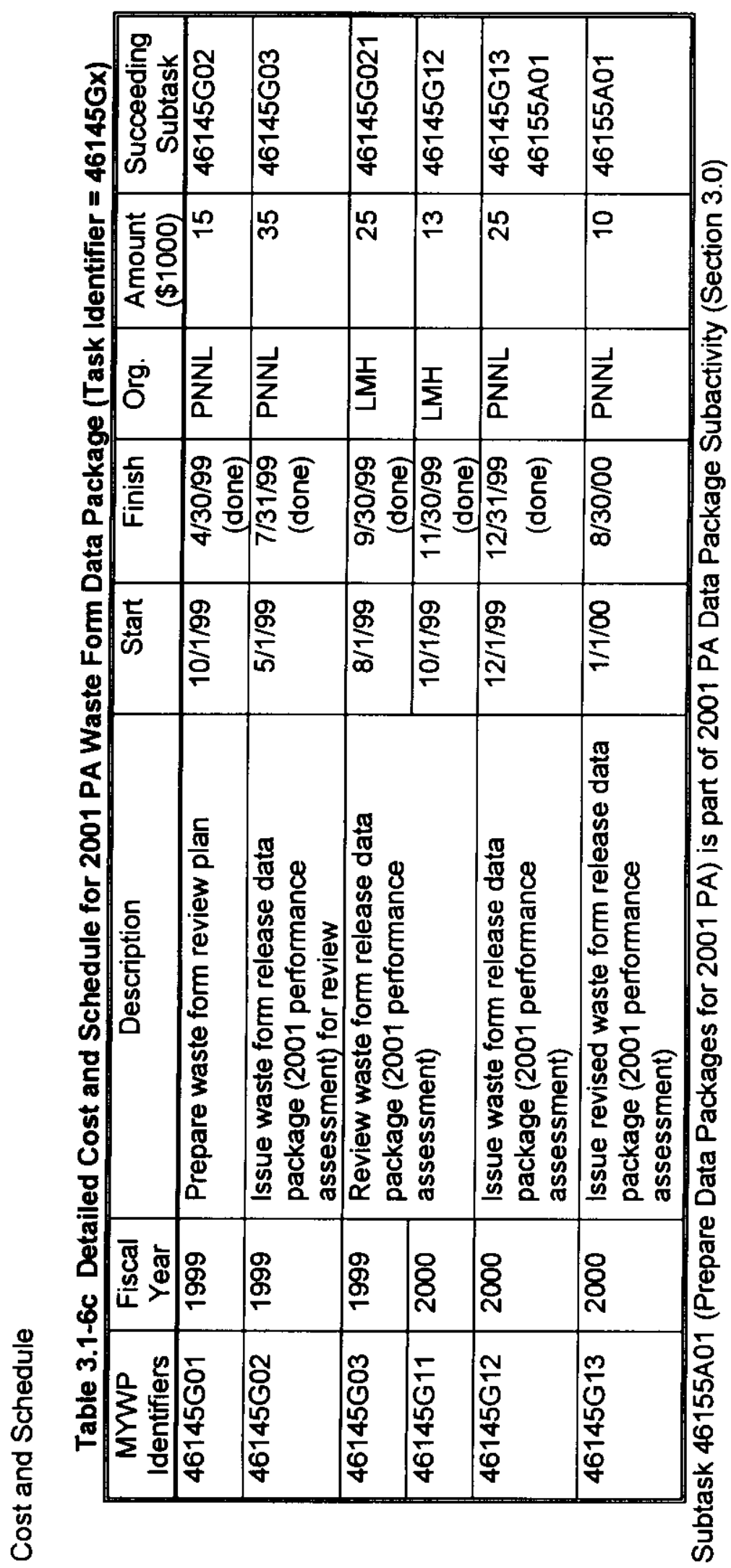


RPP-6702, Rev. 0

Formerly HNF-SD-WM-PAP-062 Rev. 4

vii. Procure and Install X-ray Microtomography Equipment (done)

a. Background

Measurements of contaminant release rates under unsaturated conditions are being performed with a new device called the pressurized unsaturated flow (PUF) system. Data from these experiments is also being used to validate the contaminant release simulation tool. Key pieces of data that are needed from this experiment are the distribution of moisture in the column and variations in the pore/fracture structure that occur over time from precipitation of secondary phases. Currently, total water content during a PUF experiment is measured but the moisture distribution is unknown. Variations in the pore/fracture structure are also unknown. Disassembly of the column and examination of the solids at selected depths is not a suitable option for obtaining these data as the pore structure and moisture distribution are destroyed upon test termination and disassembly. An in situ measurement technique is needed to obtain these critical data.

In FY97, two PUF columns were sent to a commercial laboratory to investigate the viability of $x$-ray microtomography as means to image the interior of a PUF column. Finely detailed image slices were obtained that clearly showed individual glass granules. Quantitative moisture distributions were obtainable by spiking the influent with a strong $\mathrm{x}$-ray absorber (Nal).

The purpose of this task is to procure and install a x-ray microtomography instrument. Approximately $50 \%$ of the capital cost of this instrument is to be shared with another program making use of the PUF system. It should also be noted that the instrument will be available for use in characterizing borehole core samples and for planned tests to study the hydraulic properties of near-field materials, including fractured glass monoliths.

b. List Of Deliverables

Table 3.1-7a List of Deliverables for X-ray Microtomography Equipment (CENRTC)

\begin{tabular}{|l|c|c|l|}
\hline Description & $\begin{array}{l}\text { Due } \\
\text { Date }\end{array}$ & Level & $\begin{array}{l}\text { MYWP } \\
\text { Identifier }\end{array}$ \\
\hline $\begin{array}{l}\text { Identify preferred commercial vendor of x-ray } \\
\text { microtomography equipment and initiate } \\
\text { purchase }\end{array}$ & Done & 8 & $\begin{array}{l}46145 F 5 \mathrm{~F} \\
\text { [46145F51] }\end{array}$ \\
\hline $\begin{array}{l}\text { Complete installation of x-ray microtomography } \\
\text { equipment }\end{array}$ & Done & 7 & $\begin{array}{l}46145 F 5 T \\
\text { [46145F52] }\end{array}$ \\
\hline
\end{tabular}


RPP-6702, Rev. 0

Formerly HNF-SD-WM-PAP-062 Rev. 4

c. Cost Summary

WBS: 1.1.1.3.4.1.3.2

TPCN: D4DM2

Table 3.1-7b Cost Summary for X-ray Microtomography Equipment (CENRTC)

\begin{tabular}{|l|l|r||}
\hline $\begin{array}{c}\text { Fiscal } \\
\text { Year }\end{array}$ & Organization & $\begin{array}{r}\text { Amount } \\
(\$ 1000)\end{array}$ \\
\hline 1999 & Pacific Northwest National Laboratory (PNNL) & 135 \\
\hline Grand Total & 135 \\
\hline
\end{tabular}

d. Detailed Description

Specifications for the $X$-ray microtomography equipment will be determined as will a preferred commercial vendor. Coordination with purchasing will occur to place the order. The equipment will then be installed and tested.

e. Interfaces

The equipment will primarily be used in the waste form measurement tasks (3.1.C.iii and 5.1.C.ii).

f. Organization

Procurement and installation of the $x$-ray microtomography equipment will be done under the direction of the waste form subteam leader (Pete McGrail of the Pacific Northwest National Laboratory [PNNL]). 
RPP-6702, Rev. 0

Formerly HNF-SD-WM-PAP-062 Rev. 4

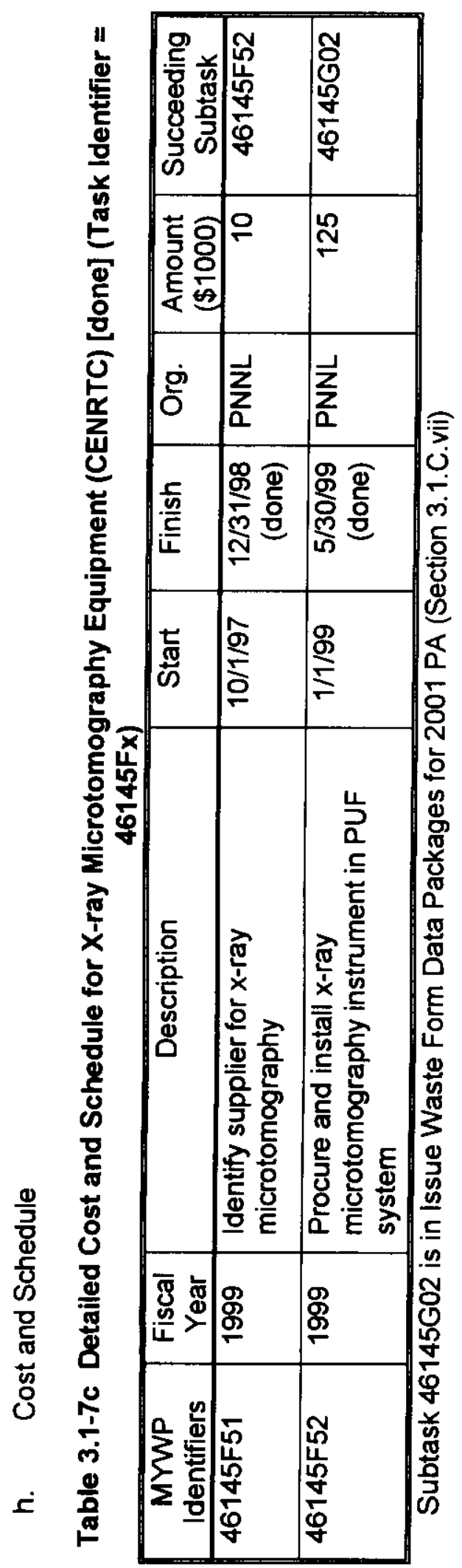


RPP-6702, Rev. 0

Formerly HNF-SD-WM-PAP-062 Rev. 4

viii. Procure and Install High Performance Workstation

a. Background

Modeling simulations using the STORM code will be performed as part of the 2001 PA. Because the selected vendor glass is more compositionally complex than previous LAW glasses, a significant number of additional solid and solution species will need to be considered in the model. Consequently, the computational requirements will increase significantly. A cutting edge computational workstation with large main memory core is needed to successfully complete the required simulations within reasonable run times.

b. List Of Deliverables

Table 3.1-8a List of Deliverables for High-Performance Workstation (CENRTC)

\begin{tabular}{|l|l|c|l|}
\hline Description & $\begin{array}{l}\text { Due } \\
\text { Date }\end{array}$ & Level & $\begin{array}{l}\text { MYWP } \\
\text { Identifier }\end{array}$ \\
\hline $\begin{array}{l}\text { Identify preferred commercial vendor of } \\
\text { workstation and initiate purchase }\end{array}$ & done & 8 & $\begin{array}{l}46145 \mathrm{~F} 6 \mathrm{~V} \\
\text { [46145F61] }\end{array}$ \\
\hline Receive and Install Workstation & done & 7 & $\begin{array}{l}46145 \mathrm{~F} 6 \mathrm{~W} \\
{[46145 \mathrm{~F} 62}\end{array}$ \\
\hline
\end{tabular}

c. Cost Summary

WBS: $1.1 .1 .3 .4 \cdot 1.3 .2$

TPCN: D4DM2

Table 3.1-8b Cost Summary for High-Performance Workstation (CENRTC)

\begin{tabular}{|l|c|r|}
\hline $\begin{array}{c}\text { Fiscal } \\
\text { Year }\end{array}$ & Organization & $\begin{array}{r}\text { Amount } \\
(\$ 1000)\end{array}$ \\
\hline 2000 & Pacific Northwest National Laboratory (PNNL) & 45 \\
\hline \hline Grand Total & 45 \\
\hline
\end{tabular}

d. Detailed Description

Specifications for the high-performance workstation were determined as was a preferred commercial vendor. The equipment was installed and tested.

e. Interfaces

The equipment will primarily be used in the waste form modeling tasks (3.1.C.V and 3.1.C.vi).

f. Organization

Procurement and installation of the workstation will be done under the direction of the waste form subteam leader (Pete McGrail of the Pacific Northwest National Laboratory [PNNL]). 
RPP-6702, Rev. 0

Formerly HNF-SD-WM-PAP-062 Rev. 4

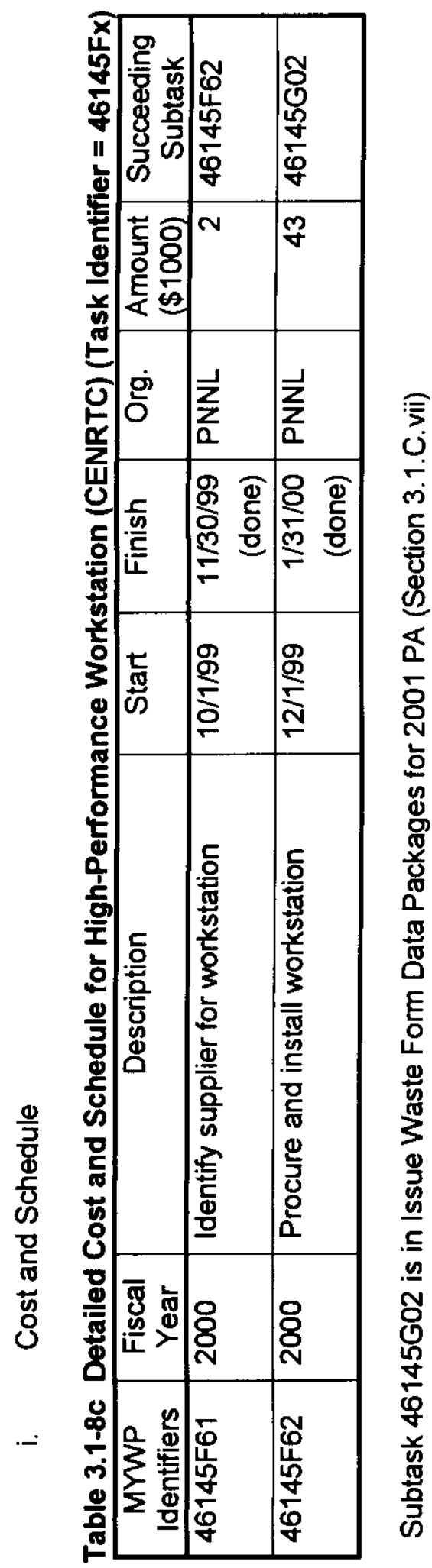


RPP-6702, Rev. 0

Formerly HNF-SD-WM-PAP-062 Rev. 4

ix. Collect Waste Form Hydraulics Data (See Section 3.2.C.v)

Although hydraulics data will play an important role in how contaminants move in the waste form region, the methods and procedures are more closely aligned with the geotechnical subactivity. Therefore this subactivity is described in Section 3.2.C.v. However, hydraulics data related specifically to the test materials used in PUF

experiments are being obtained as part of the vendor glass testing task (3.1.C.iii).

x. Collect Other Near-Field Chemical Data (See Section 3.2.C.vii)

Although chemical data not associated with the waste form (for example, the properties of getters) may play an important role in how contaminants move in the waste form region, the methods and procedures are more closely aligned with the geotechnical subactivity. Therefore this subactivity is described in Section 3.2.C.vii. 
RPP-6702, Rev. 0

Formerly HNF-SD-WM-PAP-062 Rev. 4

\subsection{GEOTECHNICAL DATA}

\section{A. SUMMARY (Done)}

Provide the data and calculational tools necessary to estimate the transport of contaminants from the waste form to the location for compliance for the 2001 performance assessment. The documentation should provide the current state of knowledge for the materials being considered for facility design and for the locations selected for waste disposal. The data collected should be directed toward supplying information needed for the calculation of contaminants over 10,000 years. Although probabilistic simulation codes are not expected to be used, uncertainty distributions and important data correlations must be determined to adequately represent the data.

With the publications of the data packages for the 2001 ILAW PA (Reidel 1999, Fayer 1999, Meyer 1999, Khaleel 1999, and Kaplan 1999), this activity is complete.

\section{B. GENERAL}

i. Background

The Hanford Low-Activity Tank Waste Performance Assessment (Mann 1998) has shown that geotechnical data determine the time at which contaminants enter the groundwater and that some of that data are also important in determining the peak impact. This contrasts with the results from most other performance assessments where geotechnical data determine both the time of travel and the peak impact.

Geotechnical data include those data that determine the transport of contaminants from the waste site to the compliance location. Over most of this distance, moving water transports contaminants; therefore, data concerning water movement plays a major role. The major components of geotechnical data of interest to the performance assessment are

a. Geologic layering information (stratigraphy),

b. Rate at which water enters the soil below the evapotranspiration zone (recharge),

c. Rate at which water moves through the disposal facility,

d. Rate at which water moves through the undisturbed soil,

e. Rate at which contaminants are retarded by the disposal facility, and

f. Rate at which contaminants are retarded by the soil.

Computer codes are used to estimate the flow of water and the movement of contaminants both through the dry zone (known as the vadose zone) and through the groundwater. Because of the complex geometry of the disposal facility, the depth of the vadose zone, and the size of the Hanford Site, such calculations strain the capacities of even the largest scientific computers.

Much of this information is obtained by analyzing samples that come from boreholes drilled at the disposal locations. A borehole was drilled in April 1998 southwest of the Project W-520 disposal facility (which is southwest of the PUREX 
RPP-6702, Rev. 0

Formerly HNF-SD-WM-PAP-062 Rev. 4

facility). Additional boreholes will be drilled during the production of the FY2005 Data Packages.

Hydraulic and chemical data are grouped by geologic layer. Also the geologic task will determine the presence of special geologic features such as clastic dikes. In addition, geologic information includes seismic event probability (which is needed for estimation of the degradation of the disposal facility).

Water is the driving force for the release of contaminants from the waste form and the transport of those contaminants down to groundwater. The rate at which water leaves the plant root zone and enters the facility will be estimated using three techniques, short-term measurements, long-term analysis using tracers, and computer simulation.

Hydraulic properties (hydraulic conductivity and moisture retention) in the disposal facility and in the vadose zone determine the rate at which water (and hence the most mobile contaminants) move. Also important are contaminant transport parameters (such as diffusion and dispersion coefficients).

Finally, geochemical parameters describe the retardation many elements experience as they proceed through the vadose zone. Special materials (getters) placed in the disposal facility can also greatly increase travel time. For example, uranium is highly retarded by concrete.

ii. List of Deliverables

Table 3.2-1a List of Major Deliverables for 2001 PA Geotechnical Subactivity

\begin{tabular}{|l|c|c|c|}
\hline Description & $\begin{array}{l}\text { Due } \\
\text { Date }\end{array}$ & $\begin{array}{l}\text { Level } \\
\text { Identifier }\end{array}$ \\
\hline $\begin{array}{l}\text { Issue summary report documenting the drilling of } \\
\text { borehole \#1 as well as the collection, distribution, } \\
\text { and preservation of samples from the borehole. }\end{array}$ & $\begin{array}{r}6 / 30 / 98 \\
\text { done }\end{array}$ & 5 & $46145 \mathrm{HOD}$ \\
\hline $\begin{array}{l}\text { Issue summary report documenting the drilling of } \\
\text { borehole \#1 as well as the collection, distribution, } \\
\text { and preservation of samples from the borehole. }\end{array}$ & $\begin{array}{r}7 / 31 / 98 \\
\text { done }\end{array}$ & 6 & $46145 \mathrm{HOA}$ \\
\hline $\begin{array}{l}\text { Issue a report documenting the stratigraphy at the } \\
\text { disposal sites based on new borehole } \\
\text { measurements as well as literature searches of } \\
\text { existing Hanford information. }\end{array}$ & done & 7 & $46145 \mathrm{JOA}$ \\
\hline $\begin{array}{l}\text { Issue a report documenting the recharge rate at the } \\
\text { disposal locations and the effect of the proposed } \\
\text { surface barrier on that rate. }\end{array}$ & done & 6 & $46145 \mathrm{~K} 7 \mathrm{~A}$ \\
\hline $\begin{array}{l}\text { Issue a report documenting the hydraulic properties } \\
\text { of materials expected to be in the disposal facility, } \\
\text { including those properties of degraded materials. }\end{array}$ & done & 6 & $46145 \mathrm{M} 3 \mathrm{~A}$ \\
\hline $\begin{array}{l}\text { Issue a report documenting the hydraulic properties } \\
\text { of the vadose zone at the disposal site locations. }\end{array}$ & done & 7 & $46145 \mathrm{~L} \mathrm{~A}$ \\
\hline $\begin{array}{l}\text { Issue a report documenting the geochemical } \\
\text { properties of materials expected to be in the } \\
\text { disposal facility. }\end{array}$ & done & 7 & $46145 \mathrm{O} 2 \mathrm{~A}$ \\
\hline
\end{tabular}


RPP-6702, Rev. 0

Formerly HNF-SD-WM-PAP-062 Rev. 4

\begin{tabular}{|l|l|l|l|}
\hline Description & $\begin{array}{l}\text { Due } \\
\text { Date }\end{array}$ & Level & $\begin{array}{l}\text { MWYP } \\
\text { Identifier }\end{array}$ \\
\hline $\begin{array}{l}\text { Issue a report documenting the geochemical } \\
\text { properties of the vadose zone at the disposal site } \\
\text { locations. }\end{array}$ & done & 6 & $46145 \mathrm{~N} 5 \mathrm{~A}$ \\
\hline $\begin{array}{l}\text { Issue a report documenting the verification and } \\
\text { (where appropriate) validation of the computer code } \\
\text { selected to calculation moisture flow and } \\
\text { contaminant transport in the vadose zone and in the } \\
\text { disposal facility. }\end{array}$ & done & 6 & $46145 \mathrm{P} 1 \mathrm{~A}$ \\
\hline
\end{tabular}

iii. $\quad$ Cost Summary

BS: 1.01.09.01.01.31.02.02 ACN: 1D9DM3, 2D9DM3

Table 3.2-1b Cost Summary for Creating 2001 PA Geotechnical Data Packages

\begin{tabular}{|l|l|r|}
\hline $\begin{array}{l}\text { Fiscal } \\
\text { Year }\end{array}$ & Organization & $\begin{array}{r}\text { Amount } \\
(1000 \$)\end{array}$ \\
\hline 1997 & Fluor Federal Services (FFS) & 127 \\
\cline { 2 - 3 } & Lockheed Martin Services Inc. (LMSI) & 30 \\
\cline { 2 - 3 } & Pacific Northwest National Laboratory (PNNL) & 317 \\
\cline { 2 - 3 } & Total & 474 \\
\hline 1998 & FFS & 218 \\
\cline { 2 - 3 } & Bechtel Hanford Incorporated (BHI) & $132^{*}$ \\
\cline { 2 - 3 } & LMSI & 8 \\
\cline { 2 - 3 } & PNNL & 1047 \\
\cline { 2 - 3 } & Waste Management Northwest (WMNW) & 90 \\
\cline { 2 - 3 } & Total & 1495 \\
\hline \multirow{5}{*}{1999} & FFS & 276 \\
\cline { 2 - 3 } & LHMC & 20 \\
\cline { 2 - 3 } & PNNL & 1089 \\
\cline { 2 - 3 } & Total & 1385 \\
\hline \multirow{3}{*}{2000} & FFS & 37 \\
\cline { 2 - 3 } & PNNL & 120 \\
\cline { 2 - 3 } & Total & $3511^{*}$ \\
\hline
\end{tabular}

Includes CENTRC funds $(\$ 132,000)$ for drilling

iv. Interfaces

This subactivity builds on FY98 data collection efforts for geotechnical data collection for the 2001 Performance Assessment as well as other Hanford data collection efforts, particularly those for the creation of other performance assessments (Kincaid 1995a, Wood 1994, Wood 1995, and Wood 1996). This work will focus on obtaining information for the disposal locations.

Close cooperation is maintained with the Tank Farm Vadose Zone Program (which deals with the vadose zone under tanks farms) as well as the Hanford 
RPP-6702, Rev. 0

Formerly HNF-SD-WM-PAP-062 Rev. 4

Groundwater / Vadose Zone Integration Program (which is chartered to develop and implement an overall program to understand the properties and effects of the vadose zone and groundwater underlying the Hanford Site).

The data collection activities (46145Hx through 46145Px) are used as the primary basis for preparing a series of data packages (activities 46145JA, 46145KA, 46145LA, 46145MA, 46145NA, 46145OA, and 46145PA) for the geotechnical activity. A series of data packages will be issued because of the many subdisciplines covered by this subactivity.

These data packages will be used in creating the Data Packages for the 2001 Performance Assessment (see Section 3.0). The subsequent Subactivity (Section $5.2=$ Geotechnical Data and Tools for the 2005 Performance Assessment) will build on the knowledge learned in this Subactivity.

v. Organization

A number of organizations will work on this activity because of the breadth of subdisciplines needed. Because of this breadth, there will not be a single point of contact for the Subactivity but will be managed by the overall activity leader.

The Environmental and Nuclear Initiatives Section of Fluor Federal Services (FFS) has played major parts in each of the previous Hanford performance assessments. They will take the lead in determining hydraulic parameters for the vadose zone.

The Pacific Northwest National Laboratory (PNNL) has many sections experienced with Hanford geotechnical activities. The Hydrology section led the production of the Grout Performance Assessment (Kincaid 1995a) and has performed most of the recharge measurements and analyses on the Hanford Site. The Hydrology section will lead the effort on the determination of near-field hydraulic parameters and of recharge. This section also has the lead for the Hanford Groundwater Project. The Interfacial Geochemistry section has extensive experience in using tracer techniques to estimate recharge at the Hanford Site and will use those techniques for this performance assessment. Finally, the Applied Geology and Geochemistry Section has the Hanford Site's expertise in geology, geochemistry, and in identifying, locating, and analyzing natural analogues in the Columbia Basin. They have worked on the previous Hanford Site performance assessments as well as most of the other environmental assessment reports dealing with the site.

\section{TASK DESCRIPTIONS}

i. Summary List of Tasks

a. Obtain and Document Borehole Samples

b. Determine Geologic Layer at Disposal Sites

c. Determine Recharge at Disposal Sites

d. Determine Hydraulic Parameters for Disposal Facility Materials

e. Determine Hydraulic Parameters for Soils at Disposal Sites

f. Determine Geochemical Parameters for Disposal Facility Materials

g. Determine Geochemical Parameters for Soils at Disposal Sites 
RPP-6702, Rev. 0

Formerly HNF-SD-WM-PAP-062 Rev. 4

h. Select and Upgrade Vadose Zone Moisture Flow and Contaminant Transport Simulation Code

i. Interact with Hanford Groundwater Project Concerning Hanford Site Groundwater Simulation Code Package

ii. Obtain and Document Borehole Samples (Complete)

a. Background

This activity was completed in FY98. Additional boreholes will be drilled as part of the Data Packages for the 2005 Performance Assessment (see Section 5.2.C.ii).

Last year's Statement of Work had the second borehole in this task. However, because the purpose of the second borehole is to provide samples which will be analyzed as part of the data collection effort for the 2005 performance assessment, the activities to drill the second borehole and obtain samples from that hole have moved to that data collection activity (See Section 5.2.C.ii for the 2005 PA).

b. List Of Deliverables

Table 3.2-2a List of Deliverables for 2001 PA Borehole Subtasks

\begin{tabular}{|c|c|c|c|}
\hline Description & \begin{tabular}{|l|} 
Due \\
Date \\
\end{tabular} & Level & $\begin{array}{l}\text { MYWP } \\
\text { Identifier }\end{array}$ \\
\hline Issue borehole \#1 characterization plan & done & 7 & $\begin{array}{l}46145 \mathrm{HOH} \\
{[46145 \mathrm{H01]}}\end{array}$ \\
\hline Drill $1^{\text {st }}$ borehole & done & 8 & $\begin{array}{l}46145 \mathrm{H} 05 \mathrm{~F} \\
{[46145 \mathrm{H} 01} \\
46145 \mathrm{H} 11]\end{array}$ \\
\hline $\begin{array}{l}\text { Document measured in-situ moisture contents at } 1^{\text {st }} \\
\text { borehole site }\end{array}$ & done & 7 & $\begin{array}{l}46145 \mathrm{HOE} \\
{[46145 \mathrm{HO3]}}\end{array}$ \\
\hline Document archived samples from $1^{\text {st }}$ borehole & done & 7 & $\begin{array}{l}46145 \mathrm{HOD} \\
{[46145 \mathrm{HO4]}}\end{array}$ \\
\hline $\begin{array}{l}\text { Document measured physical properties of samples } \\
\text { from } 1^{\text {st }} \text { borehole }\end{array}$ & done & 8 & $\begin{array}{l}46145 \mathrm{HOC} \\
{[46145 \mathrm{HOS}]}\end{array}$ \\
\hline Issue Summary Report for $1^{\text {st }}$ Borehole & done & 5 & $\begin{array}{l}46145 \mathrm{HOA} \\
{[46145 \mathrm{HOS}} \\
{[46145 \mathrm{H} 11]}\end{array}$ \\
\hline
\end{tabular}


RPP-6702, Rev. 0

Formerly HNF-SD-WM-PAP-062 Rev. 4

c. Cost Summary

Table 3.2-2b Cost Summary for 2001 PA Borehole Tasks

\begin{tabular}{|l|l|r|}
\hline $\begin{array}{l}\text { Fiscal } \\
\text { Year }\end{array}$ & Organ. & $\begin{array}{l}\text { Amount } \\
(\$ 1000)\end{array}$ \\
\hline 1997 & Fluor Federal Services (FFS) & 5 \\
\cline { 2 - 3 } & Pacific Northwest National Laboratory (PNNL) & 5 \\
\cline { 2 - 3 } & Total & 10 \\
\hline 1998 & Bechtel Hanford Incorporated (BHI) & $132^{*}$ \\
\cline { 2 - 3 } & PNNL & 70 \\
\cline { 2 - 3 } & Waste Management Northwest (WMNW) & 90 \\
\cline { 2 - 3 } & Total & $302^{*}$ \\
\hline
\end{tabular}

Includes $\$ 132,000$ of CENTRC funds for drilling for FY98.

d. Detailed Description

See section 5.2.C.iii for details on the measurements performed and location for the first borehole.

e. Interfaces

The location of the 1998 borehole was determined based on discussions with the Hanford Groundwater / Vadose Zone Integration Program, RCRA Operations and Monitoring Program, the DOE/RL Waste Integration Team, and the permitting team of the Immobilized Waste Program

Borehole samples and information from the borehole drilling was used by the geology task (3.2.C.iii), by the recharge task (3.2.C.iv), by the soil hydraulics task (3.2.C.vi), and by the soil geochemical task (3.2.C.viii).

f. Organization

Bechtel Hanford Incorporated $(\mathrm{BHI})$ has been designated by the Manager of DOE Richland Operations as responsible for drilling all boreholes at the Hanford Site which are not in tank farms. BHI is the environmental restoration contractor for the Hanford Site.

The Applied Geology and Geochemistry Section of the Pacific Northwest National Laboratory (PNNL) oversaw the borehole activity. Members of this section have overseen borehole drilling numerous times in the Hanford 200 Area. The section also supplied the drilling geologist.

Waste Management Northwest (WMNW) provided various waste management services to the Hanford Site. WMNW provided the field team leader for the PHMC interaction with $\mathrm{BHI}$ for the FY98 borehole. 
RPP.6702, Rev. 0

Formerly HNF-SD-WM-PAP-062 Rev. 4

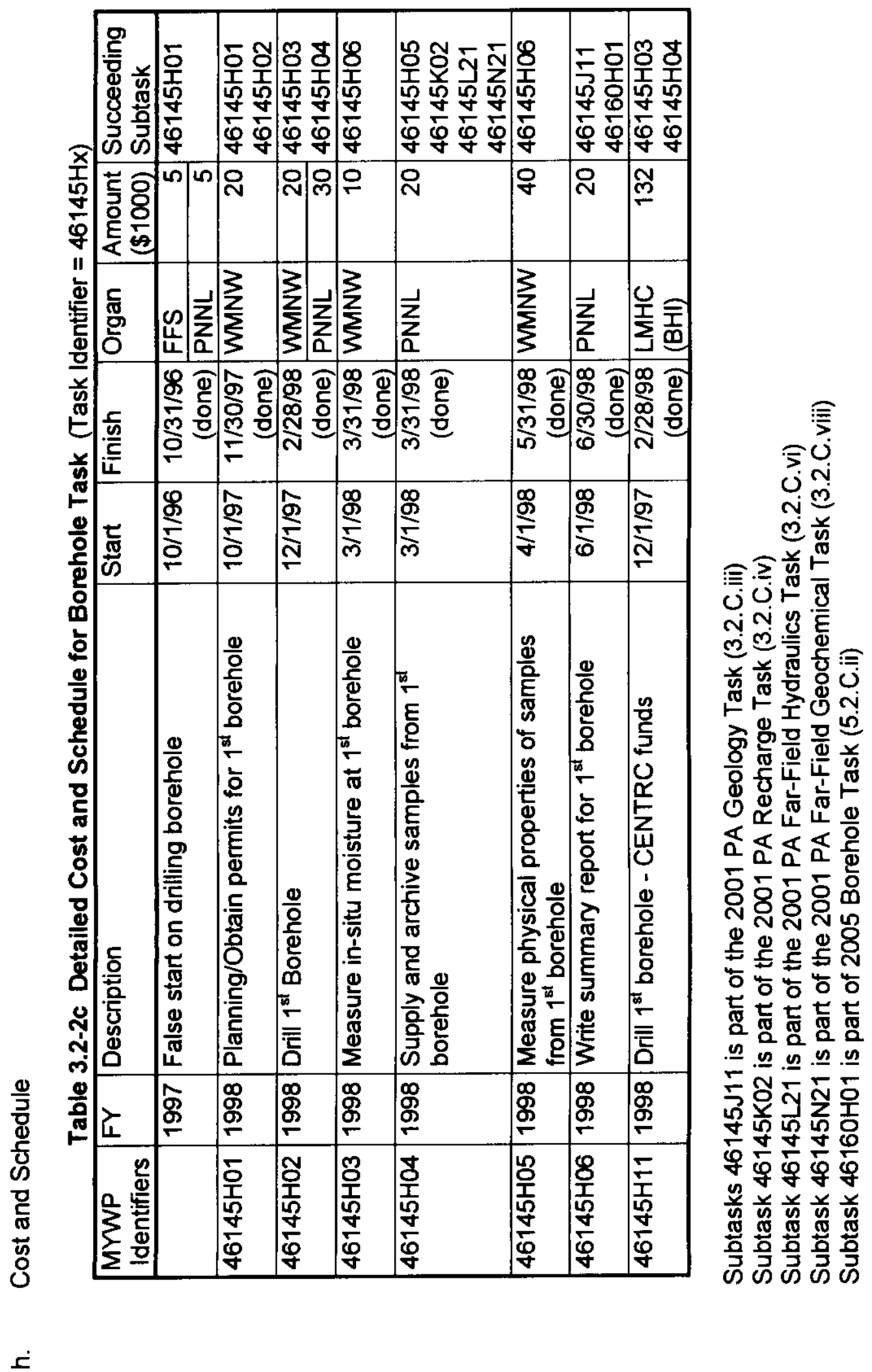


RPP-6702, Rev. 0

Formerly HNF-SD-WM-PAP-062 Rev. 4

iii.

Determine Geologic Layers at Disposal Sites (Complete)

a. Background

Geologic layers are the basic unit in the computer simulation of moisture flow and contaminant transport in a natural system. Each layer in the computer simulation (corresponding to the natural system) is assumed to have a unique set of properties, which describes it and makes it different from other layers.

This task will combine the data obtained from the boreholes drilled for this activity (see Section 3.2.C.ii) and from other relevant Hanford information to obtain the thickness of various layers (four are expected in the Hanford 200 East Area: upper Hanford gravel, Hanford sand, lower Hanford gravel, and Upper Ringold) and how this thickness varies over the disposal site.

With the publication of the geology data package for the 2001 ILAW PA (Reidel 1999), this activity is complete.

b. List Of Deliverables

Table 3.2-3a List of Deliverables for 2001 PA Geology Data Package

\begin{tabular}{|l|r|r|l|}
\hline Description & Due Date & Level & $\begin{array}{l}\text { MYWP } \\
\text { Identifier }\end{array}$ \\
\hline Plan clastic dikes tasks & done & 7 & $\begin{array}{l}\text { 46145J0E } \\
{[46145 \mathrm{JO1}]}\end{array}$ \\
\hline $\begin{array}{l}\text { Issue Review Plan for Geology Data } \\
\text { Package }\end{array}$ & done & 8 & $\begin{array}{l}\text { 46145J0F } \\
{[46145 \mathrm{~J} 13]}\end{array}$ \\
\hline Write draft geology document for 2001 PA & done & 8 & $\begin{array}{l}\text { 46145J0B } \\
{[46145 \mathrm{JO4}]}\end{array}$ \\
\hline $\begin{array}{l}\text { Issue revised geology document for 2001 } \\
\text { PA }\end{array}$ & done & 7 & $\begin{array}{l}\text { 46145J0A } \\
{[46145 \mathrm{~J} 06]}\end{array}$ \\
\hline
\end{tabular}

c. Cost Summary WBS: 1.01 .09 .01 .01 .31 .02 .02 .02

CACN: 1D9DM3

Table 3.2-3b Cost Summary for 2001 PA Geology Task

\begin{tabular}{|l|l|r|}
\hline $\begin{array}{l}\text { Fiscal } \\
\text { Year }\end{array}$ & Organization & $\begin{array}{l}\text { Amount } \\
(\$ 1000)\end{array}$ \\
\hline 1998 & Pacific Northwest National Laboratory (PNNL) & 40 \\
\hline 1999 & PNNL & 105 \\
\hline 2000 & PNNL & 24 \\
\hline Total & & 169 \\
\hline
\end{tabular}

d. Detailed Description

Geologic Layer Analysis.

This task will develop the geohydrologic model used for the PA modeling efforts. All borehole data obtained from the borehole task will be evaluated and integrated with 


\section{RPP.6702, Rev. 0 \\ Formerly HNF-SD-WM-PAP-062 Rev. 4}

existing subsurface information from the Hanford Site. The quality of subsurface data from the Hanford Site varies and an important aspect of this task will be to insure that only the superior, highest quality data will be used.

The principal product of this task will be a geohydrologic model for each site that describes the number of stratigraphic layers, their physical and hydraulic properties, and variability. Because of the limited number of boreholes at the disposal site, the greatest uncertainties will be in the lateral extent and uniformity of the layers. To reduce these uncertainties, comparison of the borehole data obtained here will be compared to boreholes from the surrounding area. The report will not only contain the best estimate of the geology in the area (including extent and tip angles) but also estimates of the uncertainty of such information.

\section{Clastic Dikes.}

Clastic dikes are a common geologic feature of the Pleistocene flood deposits of the Hanford formation and have been observed throughout much of the Hanford Site (e.g. the 241-SY Tank Farm, the 216-S-17 pond, the Environmental Restoration Disposal Facility (ERDF), and the U.S. Ecology Site). These vertical sedimentary structures cut across the normal horizontal bedding planes of the hydrogeologic units and have been found to extend up to $120 \mathrm{ft}$ in depth. Their potential effects on subsurface transport has long been recognized, but has not been well studied. Plans for obtaining clastic dike information have been developed and will be carried out in support of the 2005 PA (see section 5.2.C.iii).

Borehole samples and information obtained during the borehole drilling (3.2.C.ii) will provide the input to this activity as will the Far-Field Activity for the clastic dike study. The geologic information documented in this task will be used as part of the Data Packages for the 2001 Performance Assessment (Section 3.0). Since geotechnical data are assumed to be dependent on the stratigraphic layers identified in this task, information from this task will be used in the soil hydraulics (3.2.C.vi) and geochemical (3.2.C.viii) tasks.

f. Organization

The Applied Geology and Geochemistry Section of the Pacific Northwest National Laboratory will performed this task. This section has performed much of the geology for the Hanford Site and is expert in the Site's geology. 
RPP-6702, Rev. 0

Formerly HNF-SD-WM-PAP-062 Rev. 4

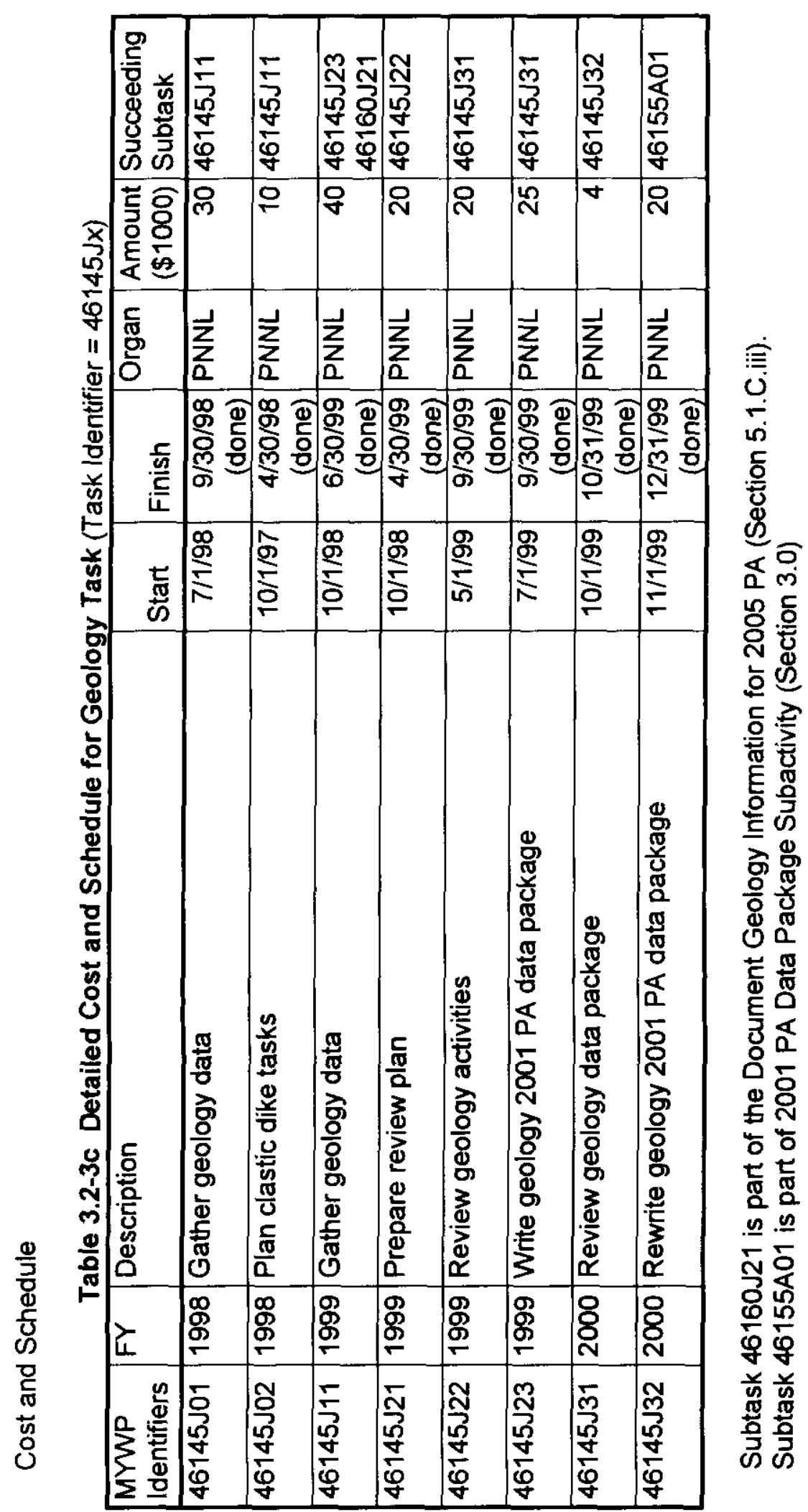




\author{
RPP-6702, Rev. 0 \\ Formerly HNF-SD-WM-PAP-062 Rev. 4
}

iv. Determine Recharge at Disposal Sites (Complete)

a. Background

Natural ground water recharge is the quantity of meteoric water that drains through the unsaturated zone to the water table. Quantifying natural ground water recharge rates is important because recharge water can leach contaminants from buried wastes and transport them to the unconfined aquifer. Recharge rates serve as the upper boundary conditions for analytical and numerical flow and transport models used to assess the performance of LLW disposal facilities, to evaluate the risks of such facilities, and ultimately, to help guide decisions related to public health and the safety of these facilities. Therefore, accurate and defensible estimates of natural ground water recharge rates are essential.

The objective of the Recharge Task is to provide defensible estimates of recharge rates for current and future conditions in and around the disposal facility. The scope of this task includes the disposal facility, the natural ecosystem that surrounds the facility, the Hanford Site, and any changes that might occur to these features while the disposed wastes still pose a threat to public health and safety.

Recharge rates in dry environments can be very small. At the Hanford Site, the average annual rate nominally ranges from $0.01 \mathrm{~mm} / \mathrm{yr}$ in silt loam soils covered by sagebrush to $75 \mathrm{~mm} / \mathrm{yr}$ in gravel-covered soils without vegetation. To effectively cover this range, three complementary methods are used to estimate recharge rates: lysimetry, the tracer technique, and computer simulations.

The goal of lysimetry is to provide both performance data and model testing data for specific combinations of soil, vegetation, and precipitation. Lysimetry at the Hanford Site has provided some of the best data in the world to understand the practical drivers of recharge under semi-arid and arid conditions. A series of lysimeters (that are basically experimental systems that collect water that has flowed through the root zone) have been constructed on-site and monitored for a number of years. Each lysimeter investigates a unique combination of soil, plants, and precipitation rates. In FY97 and FY98, this subtask continued the ongoing testing at the Field Lysimeter Test Facility (FLTF) to collect performance and model testing data.

The goal of the tracer method is to estimate historical recharge rates for durations of tens to thousands of years using measurements of tracer distributions in the soil. Chloride and stable isotopes of water are deposited naturally from the atmosphere. A large worldwide atmospheric spike of ${ }^{36} \mathrm{Cl}$ from Pacific nuclear bomb testing in the 1950 's is commonly identified in the vadose zone. The vertical distribution of these tracers represents the integration of many recharge events and can be used to estimate the mean recharge rate for the time scale of interest for a performance assessment. The tracer method offers a linkage between its long-term estimates of recharge, computer simulations, and short-term measurements such as lysimetry. A few measurements of tracer profiles have been performed at the Hanford Site (Murphy et al., 1996). There was no tracer method activity under this task in FY97; however, the effort was resumed in FY98.

The goal of simulation modeling is to leverage the existing short-term data into estimates of short-term performance when there are little or no data, and estimates of 
RPP-6702, Rev. 0

Formerly HNF-SD-WM-PAP-062 Rev. 4

long-term performance. Computer simulations of recharge at Hanford have been successful at highlighting the important factors that affect recharge and at predicting recharge rate for specific cases. The simulations also allow the results of the other two methods of recharge estimation (i.e., lysimetry and tracers) to be merged on a consistent basis. There was minimal model maintenance activity under this task in FY97. The effort increased in FY98.

With the publication of the recharge data package for the 2001 ILAW PA (Fayer 1999), this activity is complete.

b. List Of Deliverables

Table 3.2-4a List of Deliverables for 2001 PA Recharge Task

\begin{tabular}{|c|c|c|c|}
\hline Description & $\begin{array}{l}\text { Due } \\
\text { Date }\end{array}$ & Level & $\begin{array}{l}\text { MYWP } \\
\text { Identifier }\end{array}$ \\
\hline Issue letter report on recharge at the Grout Site & done & $\overline{7}$ & FY97 task \\
\hline $\begin{array}{l}\text { Issue letter reports documenting tracer } \\
\text { measurements on archived samples }\end{array}$ & done & 8 & $\begin{array}{l}46145 \mathrm{KOO} \\
{[46145 \mathrm{KO} 1]}\end{array}$ \\
\hline Document FY98 Lysimetry Measurements & done & 8 & $\begin{array}{l}46145 \mathrm{~K} 1 \mathrm{I} \\
{[46145 \mathrm{~K} 21]} \\
{[46145 \mathrm{~K} 22]}\end{array}$ \\
\hline Issue FY98 Vegetation Information & done & 8 & $\begin{array}{l}46145 \mathrm{~K} 2 \mathrm{H} \\
{[46145 \mathrm{~K} 25]}\end{array}$ \\
\hline $\begin{array}{l}\text { Issue report on tracer measurements for hole \#1 } \\
\text { and borehole \#1 }\end{array}$ & done & 7 & $\begin{array}{l}\text { 46145KOL } \\
\text { [46145KO2] }\end{array}$ \\
\hline Issue QA Report of Version 3.0 of UNSAT-H & done & 8 & $\begin{array}{l}\text { 46145K4E } \\
{[46145 \mathrm{~K} 41]}\end{array}$ \\
\hline $\begin{array}{l}\text { Issue letter report on comparison of simulations } \\
\text { to lysimetry data }\end{array}$ & done & 8 & $\begin{array}{l}46145 K 5 D \\
{[46145 K 51]}\end{array}$ \\
\hline Issue tracer report & done & 7 & $\begin{array}{l}\text { 46145K1J } \\
{[46145 \mathrm{~K} 14]}\end{array}$ \\
\hline Document lysimetry measurements & done & 8 & $\begin{array}{l}46145 \mathrm{~K} 3 \mathrm{G} \\
{[46145 \mathrm{~K} 31]}\end{array}$ \\
\hline Issue plant information & done & 8 & $\begin{array}{l}\text { 46145K3F } \\
{[46145 \mathrm{~K} 34]}\end{array}$ \\
\hline $\begin{array}{l}\text { Issue report on simulations of expected recharge } \\
\text { for sites of interest }\end{array}$ & done & 8 & $\begin{array}{l}46145 \mathrm{~K} 5 \mathrm{C} \\
{[46145 \mathrm{~K} 52]}\end{array}$ \\
\hline Issue review plan for recharge data package & done & 8 & $\begin{array}{l}46145 K 6 D \\
{[46145 K 61]}\end{array}$ \\
\hline Issue report on estimation of recharge rates & done & 8 & $\begin{array}{l}46145 \mathrm{~K} 6 \mathrm{~B} \\
{[46145 \mathrm{~K} 64]}\end{array}$ \\
\hline $\begin{array}{l}\text { Issue revised report on estimation of recharge } \\
\text { rates }\end{array}$ & done & 6 & $\begin{array}{l}\text { 46145K7A } \\
{[46145 \mathrm{~K} 72]}\end{array}$ \\
\hline
\end{tabular}


RPP-6702, Rev. 0

Formerly HNF-SD-WM-PAP-062 Rev. 4

c. Cost Summary

WBS: 1.01 .09 .01 .01 .31 .02 .02 .03

CACN: 1D9DM3

Table 3.2-4b Cost Summary for 2001 PA Recharge Task

\begin{tabular}{|l|l|l|r|}
\hline $\begin{array}{c}\text { Fiscal } \\
\text { Year }\end{array}$ & \multicolumn{1}{|c|}{ Task } & Organ. & \multicolumn{1}{|c|}{$\begin{array}{c}\text { Amount } \\
(\$ 1000)\end{array}$} \\
\hline 1997 & Recharge rate investigations & PNNL & 70 \\
\hline 1998 & Tracer Measurements & PNNL & 228 \\
\cline { 2 - 4 } & $\begin{array}{l}\text { Lysimetry and Vegetation } \\
\text { Measurements }\end{array}$ & PNNL & 135 \\
\cline { 2 - 4 } & Computer Simulations & PNNL & 45 \\
\cline { 2 - 4 } & Total & PNNL & 408 \\
\hline 1999 & Tracer Measurements & PNNL & 44 \\
\cline { 2 - 4 } & Lysimetry \& Vegetation & PNNL & 150 \\
& Measurements & & 75 \\
\cline { 2 - 4 } & Computer Simulations & PNNL & 70 \\
\cline { 2 - 4 } & Merging Data & PNNL & 339 \\
\cline { 2 - 4 } & Total & PNNL & 24 \\
\hline \multirow{2}{*}{2000} & Preparing Documentation & PNNL & 841 \\
\hline \hline Grand Total & & \\
\hline
\end{tabular}

d. Detailed Description

The objective of the Recharge Task is to provide defensible estimates of recharge rates for current and future conditions in and around the disposal facility for both the best estimate case and for identified alternatives. Based on the conceptual facility design in Burbank (1997), the best estimate case and alternatives are as follows:

i) Best Estimate Case

a) Surface Barrier. A surface barrier will be emplaced. Two important specifications are the design life and the infiltration limit of $0.5 \mathrm{~mm} / \mathrm{yr}$. Performance data from lysimeters shows promise that the barrier will be capable of meeting a 1,000-year specification. Continued collection of these data will ensure the longest record possible. After 1,000 years, the potential exists for barrier performance to be degraded, either covered by windblown sand, eroded to a thinner layer, or punctured by localized human excavation.

b) Sideslope. Surface barriers that are elevated above the surrounding terrain will need sideslopes to blend the cover with its surroundings without destablilzing the cover. Sideslope blending is typically accomplished with armoring such as a basalt riprap layer. Although it achieves the goal of cover stability, armoring increases water infiltration. 
RPP-6702, Rev. 0

Formerly HNF-SD-WM-PAP-062 Rev. 4

Rockhold et al. (1995) proposed assigning a recharge rate of $75 \mathrm{~mm} / \mathrm{yr}$ to the sideslope area.

c) Disturbed Adjacent Land. The disturbed area immediately around the disposal facility could potentially have a recharge rate higher than through the surface barrier. In that situation, water could move laterally under the cover and impact the waste. As proposed by Rockhold et al. (1995), recharge in this area is assumed to be $5.0 \mathrm{~mm} / \mathrm{yr}$, but this value assumed a natural condition. The best estimate of recharge in this area will depend on whether, after the disposal activity is completed, the disturbed area is engineered to resemble the natural system (e.g., same soil type and depth).

d) Undisturbed Adjacent Land. The undisturbed area immediately around the disposal facility could potentially have a recharge rate higher than through the surface barrier. In that situation, water could move laterally under the cover and impact the waste. As proposed by Rockhold et al. (1995), recharge in this area is assumed to be $5.0 \mathrm{~mm} / \mathrm{yr}$. Continued testing has the potential to reduce this rate considerably. For example, preliminary numerical modeling has indicated the annual recharge rate may be as low as 0.2 to $0.5 \mathrm{~mm} / \mathrm{yr}$. Tracer measurements in 1995 indicate the rate may even be as low as $0.015 \mathrm{~mm} / \mathrm{yr}$.

c) Climate. Weather patterns will continue to be similar to weather observations at the Hanford Meteorological Station (HMS) from 1957 to 1999.

ii) Alternative Conceptual Models

a) Modified Barrier. The potential exists for modifications to the barrier design if suitable materials are unavailable or the costs are excessive.

b) Changed Climate. The potential exists for changes in weather (which determines evapotranspiration) and changes in precipitation amount and seasonality. These changes may occur in response to natural variations in earth's orbit, variations in solar activity, and anthropogenic effects.

c) Changed Vegetation. The potential exists for a change from shrub to either grassland or cheatgrass.

The technical work outlined below is designed to provide the information necessary to estimate recharge rates for both the best estimate case and the altemative conceptual models identified above.

\section{Performance and Testing Data for Protective Barriers}

The existing configurations in the FLTF are focused on protective barriers. The length of record is nearly 10 years. Data will continue to be collected from some of these lysimeters until the final data package delivery date in 2001 . The rationale is to have the longest record of performance data possible for the protective barrier, which is vital to the performance of the disposal system. These data will also be used to verify 


\section{RPP-6702, Rev. 0 \\ Formerly HNF-SD-WM-PAP-062 Rev. 4}

the capability of the simulation model to predict long-term barrier performance under various climates. The Environmental Restoration Contractor is also collecting barrier performance data in the 200 East Area at the Hanford Prototype Barrier. Although data generated from the prototype barrier will be used as much as possible, that effort is in its third and final year. In contrast, the lysimeter performance data will eventually span 14 years (by the year 2001), providing a much longer and more valuable data set for verifying barrier performance and testing model predictions.

FY98 - (\$40K) Collect performance data for the protective barrier lysimeters. This effort extends the length of record to 11 years. The budget request is based on 1995 and 1996 costs. Oct 97 to Sep 98.

FY99 - (\$30K) Collect performance data for the protective barrier lysimeters. This effort extends the length of record to 12 years. The budget request is based on 1995 and 1996 costs. Oct 98 to May 99.

Performance and Testing Data for Degraded Barriers and Alternative Conceptual Models.

The original focus of the FLTF was to collect data to describe barrier performance. That focus was expanded to include the performance of degraded or modified barriers, and recharge in the adjacent land following a change in vegetation, all under both ambient and enhanced precipitation. In FY 1998, seven of the FLTF lysimeters were modified with configurations designed to provide performance data for the barrier degradation mechanisms of erosion and sand deposition, and for deep dune sand in the adjacent land. All seven modified lysimeters were vegetated with cheatgrass, which was identified as a possible future plant community. The modified lysimeters will provide performance data through the year 2001 for configurations that are significantly different from those currently being tested in the FLTF. In addition, data from these lysimeters will be used to test the capability of the simulation model for predicting recharge for these specific configurations.

Discussions with the disposal facility design team revealed that the surface cover is likely to be a modified RCRA Subtitle C cover (DOE 1996). This design differs from the Hanford Prototype Barrier in that 1) it uses only half of the silt loam, 2) the lower half of the silt loam is compacted, and 3) the design does not use the expensive basalt layer. In FY 1999, two additional lysimeters were modified to contain configurations that match that of the modified RCRA Subtitle $C$ barrier. One of the lysimeters received ambient precipitation; the other received irrigation to bring the total water addition to three times the long-term average precipitation rate. The results from these lysimeters will be directly applicable to other Hanford Site projects that envision using a similar surface barrier.

FY98 - $(\$ 30 \mathrm{~K})$ Collect performance data for the protective barrier lysimeters. This effort extends the length of record to 11 years. The budget request is based on 1995 and 1996 costs. Oct 97 to Sep 98.

FY99 - (\$30K) Modify two FLTF lysimeters in October and November 1998 and begin to collect performance and testing data. The budget request is based on experience modifying seven lysimeters for this project in FY 1998. The request includes enough funds to collect water content and vegetation data that are not 


\section{RPP-6702, Rev. 0 \\ Formerly HNF-SD-WM-PAP-062 Rev. 4}

being collected regularly from the barrier lysimeters. The increased data collection is needed because the length of record will be short (four years or less) and there is no preliminary data set on which to rely. Data collection will also continue for the seven lysimeters modified in FY 1998. Oct 98 to May 99.

\section{Historical Recharge in Adjacent Land.}

The application of environmental tracers generally yields a site-specific, longterm recharge estimate, and is one of the simplest, least expensive, and most successful techniques for determining recharge in arid climates (Allison, 1988; Allison et al., 1994). Tracer estimates of recharge have been previously applied at numerous sites including the Nevada Test Site (Tyler et al., 1996) and Ward Valley (National Research Council, 1995) and are becoming a standard method in performance assessment.

Tracers are not perfect indicators of water movement because water can move by convective liquid transport and/or vapor transport in the unsaturated zone. For example, chloride ions move by convective liquid transport, but are not subject to vapor transport. Multiple tracers are often needed to investigate the two transport processes. The three tracer methods used in FY 1998 will be used in FY 1999: 1) chloride mass balance (CMB) for transient paleorecharge over the Holocene, 2) bomb-pulse ${ }^{36} \mathrm{Cl}$ for a 50 -year average recharge rate, and 3) stable isotopes of water (deuterium- ${ }^{18} \mathrm{O}$ ) to evaluate the importance of vapor transport processes.

FY99 - (\$14K) Estimate recharge rates using tracer measurements. By December 31, 1998 , issue a final letter report that documents the estimation of recharge rates through tracer measurements and provides recommendations to guide future tracer activities.

FY99 - (\$30K) Collect soil samples at and around the disposal site to determine whether emissions from nearby facilities have been deposited to the extent that they could interfere with tracer studies. By October 30,1998 , issue a test plan for these measurements and their interpretation. By March 31, 1999, notify the technical representative that the analyses are completed. By May 31, 1999, issue a letter report summarizing the results.

Simulation Model.

Computer simulations will be used to quantify the impact on recharge from modifications to the barrier design, degradation of the barrier, and changes in climate and vegetation. Simulation activities under this subtask include modifications and maintenance of the recharge model UNSAT-H (Fayer and Jones 1990), testing of the recharge model with data sets from both the lysimetry and tracer subtasks, and application of the model to predict recharge rates. The recharge model will be applicable directly to other projects, including HTI, RPP, and the Hanford Site Integrated Vadose Zone/Groundwater Project.

In FY 1998, several processes and features were added to the code, including the mixed-method solution technique to improve mass balance calculations, hysteresis, water retention models that address vapor adsorption behavior, and the ability to conduct multi-year simulations. In FY 1999, the code was tested using data from the 


\section{RPP-6702, Rev. 0 \\ Formerly HNF-SD-WM-PAP-062 Rev. 4}

FLTF. Code outputs will be compared to measured drainage, water contents, matric potentials, and temperatures. A concurrent effort will address quality assurance documentation for UNSAT-H version 3.0. This effort involved documentation of the verification testing, peer review, and configuration management. The tested model was then used to simulate the impacts to recharge from changes in climate using estimates of precipitation and temperature changes from the Protective Barrier Program (Peterson et al. 1995). The impacts were compared with the simulation results using the current climate.

FY99 - (\$30K) Test the recharge model using performance data from the FLTF. Oct 98 to Mar 99.

FY99 - (\$10K) Update the quality assurance documentation and maintain UNSAT-H version 3.0. This effort involves documentation of the verification testing, peer review, and configuration management. Jan 99 to Mar 99.

FY99 - (\$20K) Simulate the impacts to recharge from changes in climate using estimates of precipitation and temperature changes from the Protective Barrier Program (Peterson et al. 1995). Compare the impacts with the simulation results using the current climate. Apr 99 to May 99.

Vegetation.

Plants have a direct and major impact on recharge rates (Allison et al. 1994). Depending on plant rooting depth, phenology, form, water use efficiency, and density, plants can effectively reduce or eliminate drainage and subsequent recharge (Gee et al. 1992, 1994). Understanding and predicting recharge under vegetated conditions requires knowledge of the plant community composition and behavior. Vegetation data will be collected at the new disposal site to provide model parameters with which to estimate recharge in the adjacent land and better understand the existing community relative to the soil and tracer data.

In FY 1998, existing data were compiled from programs not related to performance assessment and waste isolation (e.g., Ecosystem Monitoring; watershed studies). Field tests were then started to collect the data not found in the other programs. The first phase involved a survey of the new disposal site and the area around the Grout Site to document plant community composition and structure, phenology, density, and distribution. This survey built on the limited-area survey conducted in FY95.

In FY 1999, the main activities involved measurements of root distributions and plant water status. Excavations were used to characterize root distributions and densities relative to shrub locations. In particular, there is interest in knowing how much of the inter-shrub space is permeated with plant roots. The second activity is to collect plant water status information throughout all four seasons. Of particular interest is whether plants transpire during cold weather. Until now, the assumption has been that plants do not transpire much if any water during the late fall to early spring seasons. Both sets of data will be used in model simulations of plant behavior.

FY99 - (\$15K) excavate at the new disposal site to measure root distributions and densities relative to shrub and inter-shrub locations. Mar 99 to May 99. 
RPP-6702, Rev. 0

Formerly HNF-SD-WM-PAP-062 Rev. 4

FY99 - (\$30K) collect plant water status data throughout the year (including late fall, winter, and early spring). The budget request is based on prior experience with such measurements elsewhere at Hanford. Oct 98 to Apr 99.

FY99 - (\$20K) summarize plant information in a letter report. May 99.

\section{Estimation of Recharge Rates}

Information collected by the various recharge subtasks will be merged, synthesized, and integrated to provide a clear and consistent view of past, present, and future recharge rates at the proposed disposal site. The issued report will support the 2001 Performance Assessment. The recharge data package shall contain all of the data needed to specify the upper water flux boundary as a function of surface features and time for the calculations to be performed in the 2001 performance assessment. Such data shall include information to establish a best estimate case, uncertainty cases around that best estimate case, as well as a reasonable bounding case. The results will allow the reader of the 2001 PA to understand the likely impacts of the disposal action as well as the impacts if the disposal facility failed to perform as planned. The authors shall review the documents published in the other subtasks of this task (as well as documents produced by the performance assessment team and others). The authors will justify selection of data and methods.

A review plan was developed for the recharge activity to be reviewed. The review effort consisted of both the subtasks as well as the document on the estimation of the recharge and will begin only after the review plan is approved by the performance assessment activity leader.

Based on these comments as well as any others, the document on the estimation of recharge shall be modified and republished.

FY98 - No activity.

FY99 - (\$10K) Issue review plan

FY99 - (\$15K) Review of activities

FY99 - (\$30K) merge recharge data

FY99 - (\$35K) write recharge 2001 PA data package

FY0O - $(\$ 22 \mathrm{~K})$ review data package, address comments, and issue final recharge data package.

e. Interfaces

The lysimetry and computer simulation activities build on FY97 and FY98 efforts (maintenance of the Field Lysimetry Test Facility and determination of recharge at the Grout Site), while the tracer activities build on FY95 work. Multiple activities of the recharge task will use samples from the borehole drilling (3.2.C.ii) for determining physical and hydraulic properties and tracer distributions. The simulation task will also use field data collected by the near-field task (3.2.C.v).

The output of this task will form part of the Data Packages for the 2001 Performance Assessment (Section 3.0). In addition, the products and knowledge gained 


\section{RPP-6702, Rev. 0 \\ Formerly HNF-SD-WM-PAP-062 Rev. 4}

under this task are applicable directly to other projects, including HTI, RPP, and the Hanford Site Integrated Vadose Zone/Groundwater Project. These include the decade of performance data for multiple surface barrier designs, the recharge model, and the successful applications of the tracer technique for estimating historical recharge rates.

f. Organization

The Pacific Northwest National Laboratory (PNNL) has three sections experienced with recharge. The Hydrology Group performed the recharge analysis for the Interim and ILAW Performance Assessments as well as for other Hanford projects. The section designed and has operated the Field Lysimetry Test Facility since its construction. The Ecology Group has performed ecological surveys for the Site-Wide Surveillance Project and has conducted numerous ecological studies to support that and other projects. The Interfacial Geochemistry Group has extensive experience in using tracer techniques to estimate recharge at the Hanford Site. 
RPP-6702, Rev. 0

Formerly HNF-SD-WM-PAP-062 Rev. 4

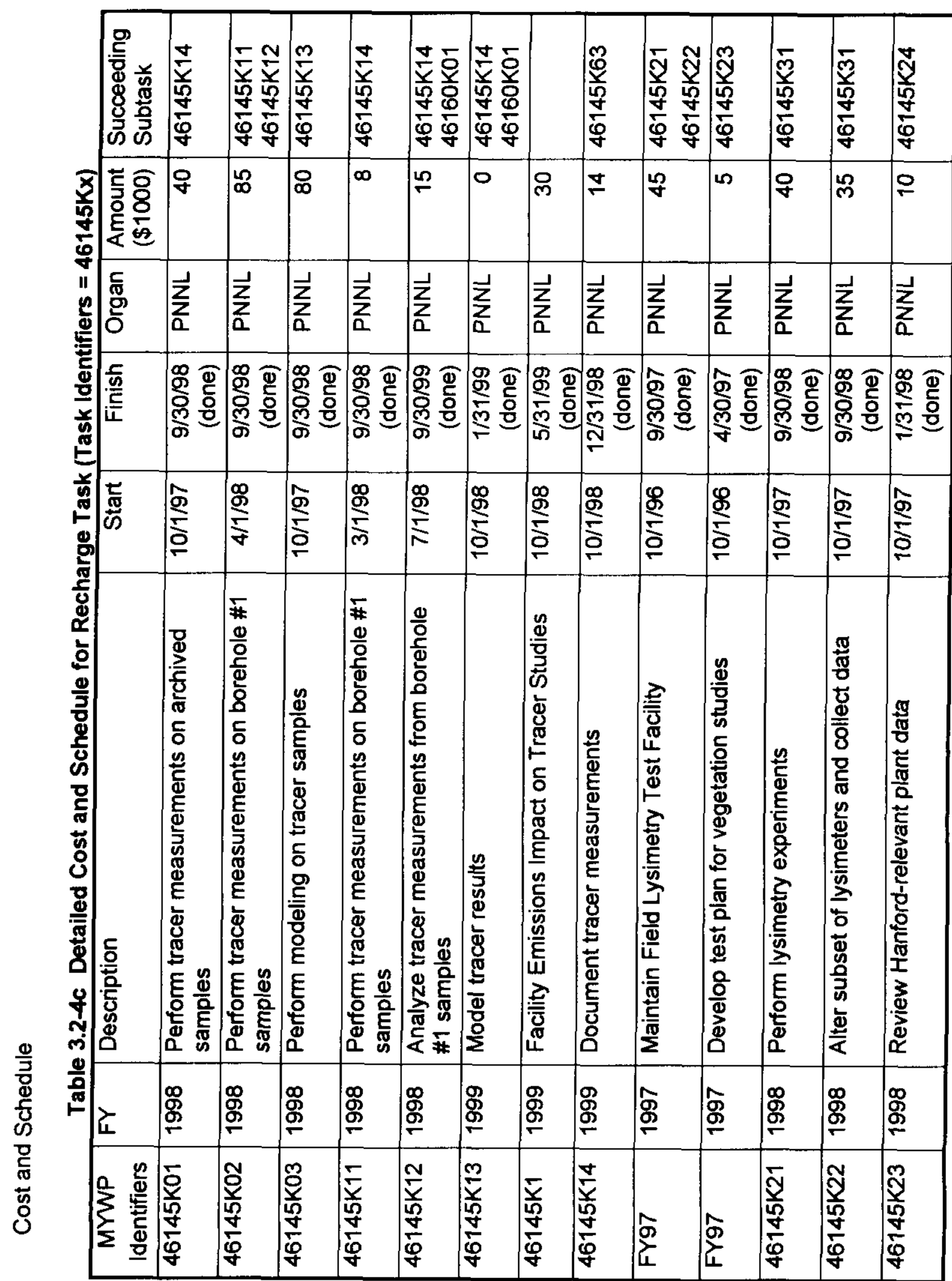


RPP-6702, Rev. 0

Formerly HNF-SD-WM-PAP-062 Rev. 4

\begin{tabular}{|c|c|c|c|c|c|c|c|c|c|c|c|c|c|}
\hline 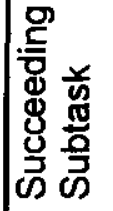 & 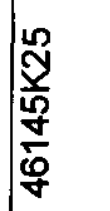 & 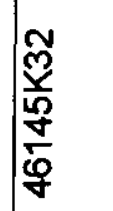 & 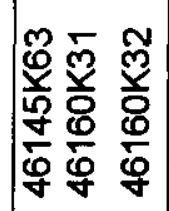 & 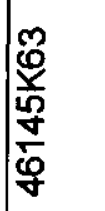 & 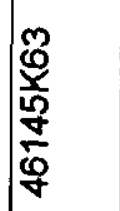 & 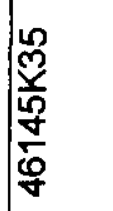 & 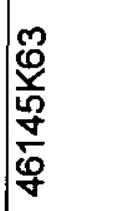 & 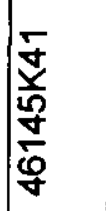 & 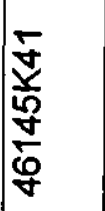 & $\frac{\sqrt{n}}{\frac{5}{0}}$ & 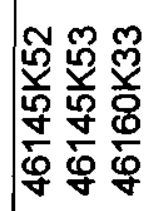 & 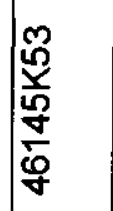 & 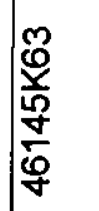 \\
\hline 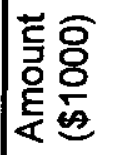 & \& & 으 & \& & 足 & \& & $\stackrel{n}{\infty}$ & 옹 & 음 & 은 & $\mathscr{H}$ & 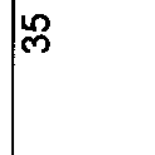 & $\stackrel{2}{2}$ & $\stackrel{\sim}{N}$ \\
\hline 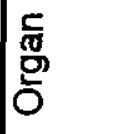 & $\sum_{\alpha}$ & $\sum_{\alpha} \sum_{\alpha}$ & $\sum_{\mathbf{\alpha}}$ & $\underset{\alpha}{\stackrel{2}{z}}$ & $\underset{\alpha}{\sum}$ & $\frac{\sum}{z}$ & $\underset{\alpha}{z}$ & $\sum_{n} \sum_{n}$ & $\sum_{n}^{1}$ & $\mid \begin{array}{l}\sum_{\alpha} \\
z\end{array}$ & $\sum_{a}$ & $\sum_{\alpha}$ & $\sum_{a}$ \\
\hline 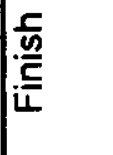 & 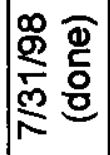 & 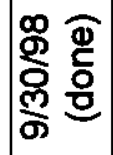 & 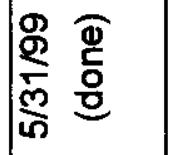 & 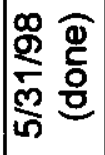 & 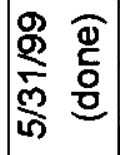 & 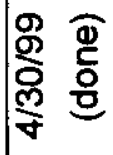 & 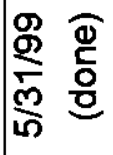 & 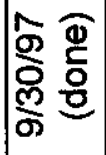 & 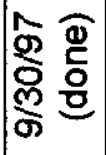 & 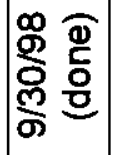 & $\frac{g}{20}$ & 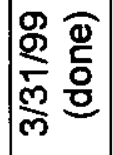 & 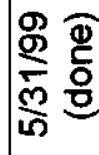 \\
\hline 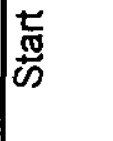 & $\underset{\text { o }}{\stackrel{\text { o }}{\boldsymbol{N}}}$ & $\underset{\infty}{\stackrel{\infty}{\infty}}$ & $\frac{\infty}{\mathscr{g}}$ & 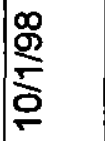 & $\frac{g}{\stackrel{\rho}{m}}$ & 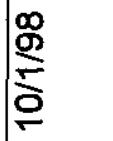 & $\frac{\operatorname{s}}{\stackrel{9}{2}}$ & $\stackrel{\mathscr{S}}{\stackrel{5}{0}}$ & $\frac{8}{2}$ & $\frac{\hat{2}}{\frac{1}{O}}$ & $\underset{\infty}{\infty}$ & $\stackrel{g}{\stackrel{g}{F}}$ & $\underset{\frac{g}{F}}{\frac{g}{f}}$ \\
\hline 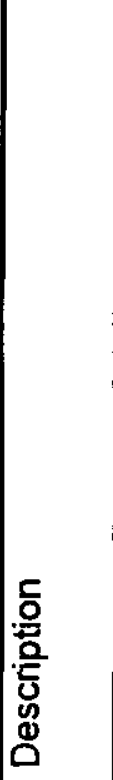 & 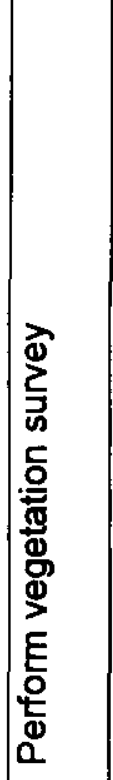 & 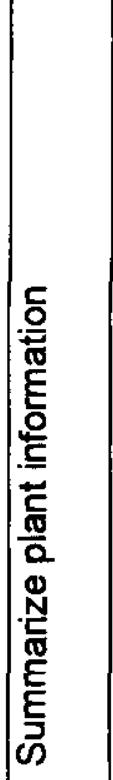 & 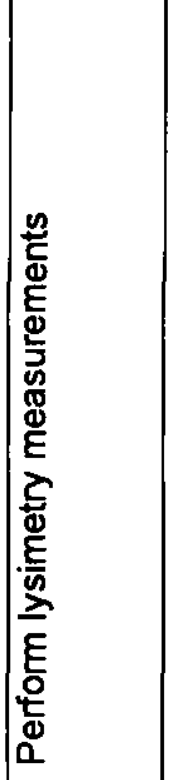 & 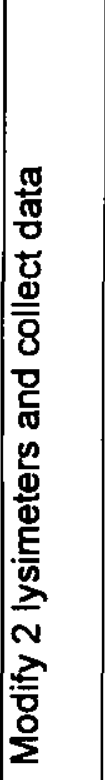 & 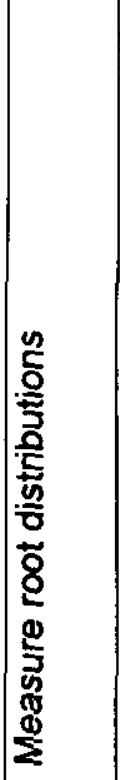 & 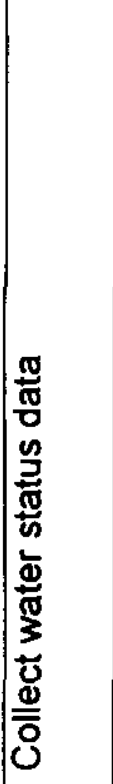 & 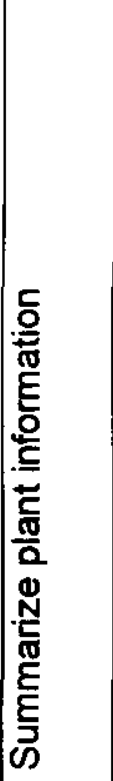 & 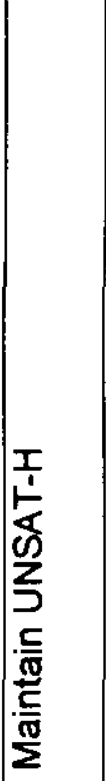 & 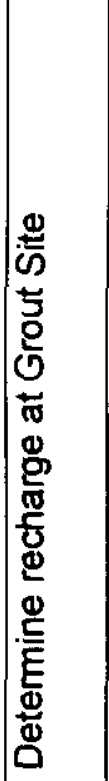 & 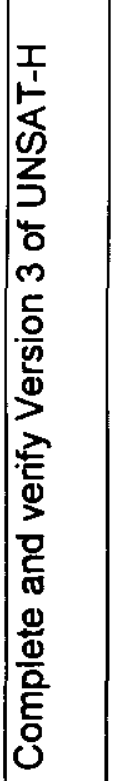 & 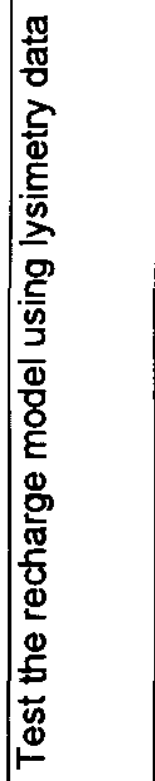 & 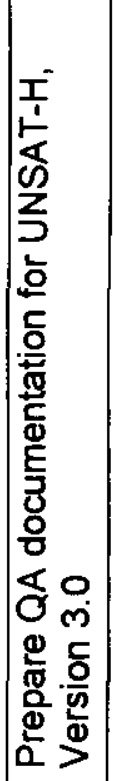 & 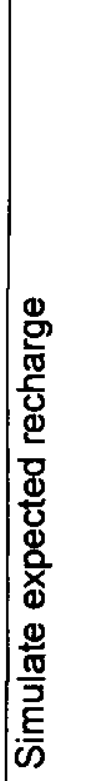 \\
\hline 立 & 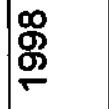 & $\begin{array}{l}\boldsymbol{\infty} \\
\stackrel{8}{\boldsymbol{g}} \\
\end{array}$ & 名 & 兽 & 多 & \% & \% & $\widehat{\sigma}$ & $\stackrel{s}{\sigma}$ & 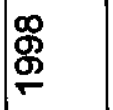 & 息 & 名 & 孚 \\
\hline 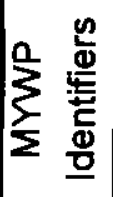 & 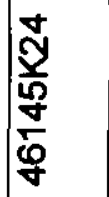 & 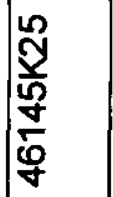 & 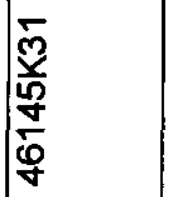 & 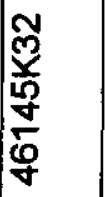 & 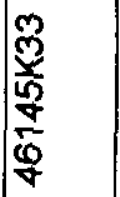 & 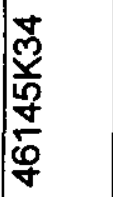 & 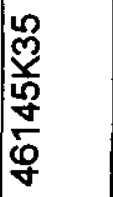 & के & 穴 & 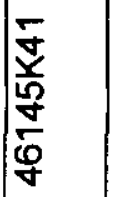 & 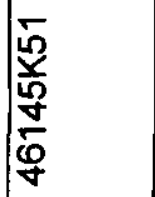 & 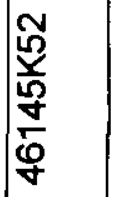 & 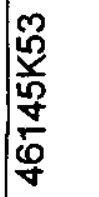 \\
\hline
\end{tabular}


RPP-6702, Rev. 0

Formerly HNF-SD-WM-PAP-062 Rev. 4

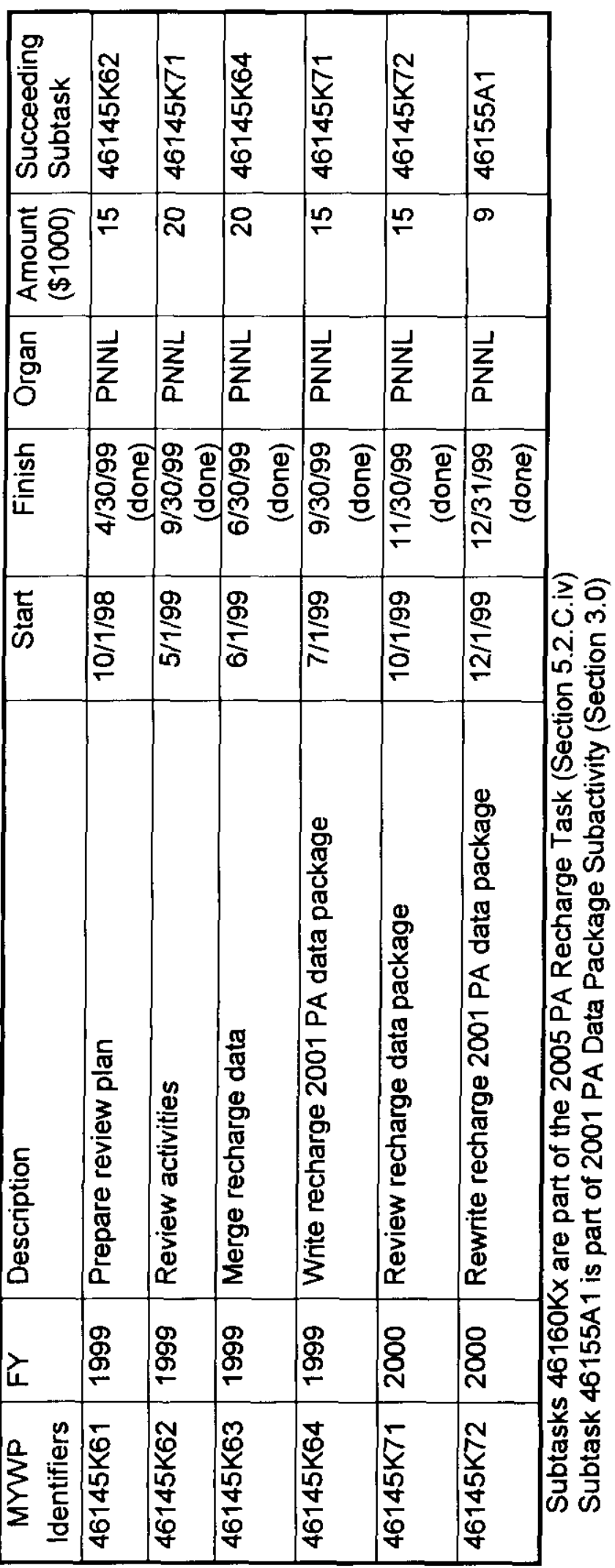




\section{RPP-6702, Rev. 0 \\ Formerly HNF-SD-WM-PAP-062 Rev. 4}

v. Determine Hydraulic Parameters for Disposal Facility Materials (Complete)

a. Background

The availability of water is a key factor in the dissolution of glass waste forms and the subsequent transport of dissolved contaminants out of the disposal facility and into the natural environment. Therefore, the disposal facility should be designed to minimize the amount of water in contact with the waste form. In addition, earlier studies (Kincaid 1995b) showed that for the conditions expected in the disposal facility, the transport of contaminants would either be advection-driven or diffusion-driven depending on a small change in parameters. Thus, knowledge of the water movement rates within the disposal facility will greatly enhance the confidence in estimates of the waste dissolution rate and subsequent contaminant transport rate.

Information is needed both for "original" fresh and "aged" materials to support simulations of the disposal facility for thousands of years. The required information will be obtained by interacting with other programs (both at Hanford and elsewhere) to obtain any relevant data and measuring the properties of expected materials when such data are unavailable.

For the conditions expected, water may move in both the liquid and vapor phases. Multiphase calculations performed by PNNL in FY97 indicated the range of parameters that might be important to measure when glass is disposed directly to the vadose zone without a facility structure or materials. Late in FY97, hydraulic properties (e.g., saturated hydraulic conductivity, hydraulic conductivity as a function of water content, matric potential as a function of water content) for materials likely to be part of the disposal facility began. Efforts in FY98 and later will focus on materials being considered in the disposal facility design and on the proposed waste form to be supplied by the vendors.

Hydraulic properties for disposal facility materials were not independently investigated for the interim and ILAW performance assessments, as no official conceptual design had yet been created. Instead, values for common construction materials were taken from the Grout Performance Assessment (Kincaid 1995a).

With the publication of the near-field hydrology data package for the 2001 ILAW PA (Meyer 1999), this activity is complete.

b. List Of Deliverables

Table 3.2-5a List of Deliverables for 2001 PA Near-Field Hydraulics Data Package

\begin{tabular}{|l|c|c|c|}
\hline Description & $\begin{array}{r}\text { Due } \\
\text { Date }\end{array}$ & Level & $\begin{array}{c}\text { MYWP } \\
\text { Identifier }\end{array}$ \\
\hline Issue Findings on Multiphase Calculations & $\begin{array}{r}3 / 28 / 97 \\
\text { done }\end{array}$ & 7 & FY97 \\
\hline Issue Test Plan for Samples/Measurements & $\begin{array}{r}7 / 25 / 97 \\
\text { done }\end{array}$ & 7 & FY97 \\
\hline Document Near-Field Sensitivity Studies & $\begin{array}{r}9 / 30 / 98 \\
\text { done }\end{array}$ & 8 & $\begin{array}{r}46145 \mathrm{MOF} \\
\text { [46145M06] }\end{array}$ \\
\hline
\end{tabular}


RPP-6702, Rev. 0

Formerly HNF-SD-WM-PAP-062 Rev. 4

\begin{tabular}{|l|c|c|c|}
\hline Description & $\begin{array}{r}\text { Due } \\
\text { Date }\end{array}$ & Level & $\begin{array}{c}\text { MYWP } \\
\text { Identifier }\end{array}$ \\
\hline Issue Report on IP Testing of Surface Soil & $\begin{array}{r}9 / 30 / 98 \\
\text { done }\end{array}$ & 8 & $\begin{array}{r}46145 \mathrm{M} 11 \\
{[46145 \mathrm{M} 03]}\end{array}$ \\
\hline Issue Report on IP Testing of Upper Hanford Formation & $\begin{array}{r}11 / 30 / 98 \\
\text { done }\end{array}$ & 8 & $\begin{array}{r}46145 \mathrm{M} 1 \mathrm{H} \\
{[46145 \mathrm{M} 11]}\end{array}$ \\
\hline Document Measured Near-Field Hydraulic Data & $\begin{array}{r}11 / 30 / 98 \\
\text { done }\end{array}$ & 8 & $\begin{array}{c}46145 \mathrm{M} 0 \mathrm{G} \\
{[46145 \mathrm{M} 12]}\end{array}$ \\
\hline Document Hydraulic Parameters of Aged Near-field & $6 / 30 / 99$ & 8 & $\begin{array}{c}46145 \mathrm{M} 1 \mathrm{E} \\
{[46145 \mathrm{M} 15]}\end{array}$ \\
\hline Materials & & & $\begin{array}{c}46145 \mathrm{M} 1 \mathrm{D} \\
{[46145 \mathrm{M} 16]}\end{array}$ \\
\hline Document Hydraulic Properties of pH and lonic Strength & $9 / 30 / 99$ & 8 & $\begin{array}{c}46145 \mathrm{M} 1 \mathrm{C} \\
{[46145 \mathrm{M} 17]}\end{array}$ \\
\hline Document Diffusion Coefficients of Near-Field Materials & $7 / 30 / 99$ & 8 & $\begin{array}{c}46145 \mathrm{M} 2 \mathrm{~F} \\
{[46145 \mathrm{M} 21]}\end{array}$ \\
\hline Issue Review Plan for Near-Field Hydraulics Data & $4 / 30 / 99$ \\
Package & 8 & $\begin{array}{c}46145 \mathrm{M} 2 \mathrm{~B} \\
{[46145 \mathrm{M} 24]}\end{array}$ \\
\hline Write Near-Field Hydraulic 2001 PA Data Package & done & 8 & $\begin{array}{c}46145 \mathrm{M} 3 \mathrm{~A} \\
{[46145 \mathrm{M} 32]}\end{array}$ \\
\hline Issue Near-Field Hydraulic 2001 PA Data Package & done & 6 & \\
\hline
\end{tabular}

c. Cost Summary WBS: 1.01.09.01.01.31.02.02.05 CACN: 1D9DM3

Table 3.2-5b Cost Summary for 2001 PA Near-Field Hydraulics Data Package

\begin{tabular}{|l|l|r|}
\hline $\begin{array}{l}\text { Fiscal } \\
\text { Year }\end{array}$ & Organ. & $\begin{array}{r}\text { Amount } \\
(\$ 1000)\end{array}$ \\
\hline 1997 & Pacific Northwest National Laboratory (PNNL) & 141 \\
\hline 1998 & PNNL & 156 \\
\hline 1999 & PNNL & 320 \\
\hline 2000 & PNNL & 24 \\
\hline Grand total & & 641 \\
\hline
\end{tabular}

d. Detailed Description

The objective of the near-field task is to identify the important conceptual models of processes and hydraulic relationships and obtain the data necessary to simulate those processes and relationships. The task will identify and use available information when appropriate and measure the important properties directly when information is unavailable or inadequate. Testing will be conducted in the laboratory using standard techniques and in the field using the instantaneous profile (IP) test. Testing methods will typically come from either Klute (1986c) or published ASTM procedures. Any special test procedures developed by this task will be documented and approved.

A unique challenge for this task is characterizing the hydraulic properties of the near-field and facility materials prior to completion of the facility design and specification of facility materials. The strategy will be to establish and maintain close contact with the design task so that materials under study are consistent with the design as it evolves. Currently, the generic materials being considered include the adjacent Hanford formation, backfill sediments, facility concrete, filler material (between the glass 


\section{RPP-6702, Rev. 0 \\ Formerly HNF-SD-WM-PAP-062 Rev. 4}

monoliths), and the glass waste form (monoliths). The hydraulic properties of the glass waste form are being measured by task 3.1.C.v.; those measurements will be coordinated with this task to ensure sufficient characterization to meet simulation modeling needs.

Based on the conceptual facility designs in Mann et al. (1996), the best estimate case is described as follows:

\section{Best Estimate Case}

a) Hanford Formation Sediments. The upper vadose zone of the disposal sites consists of Hanford formation sands. The excavation surface will create an interface that can affect near-field flow.

b) Backfill. Once the facility is constructed, sediments will be backfilled and compacted. The sediment source will likely be the excavated Hanford formation sands.

c) Water Diverter. A sloped capillary break will be emplaced above the facility to divert unsaturated liquid water flow laterally to a location where it can move downward without affecting the facility. This engineered feature can degrade if the facility experiences any settlement.

d) Concrete. The facility structure will consist of steel-reinforced concrete. The concrete will eventually begin to degrade, which will change the hydraulic properties considerably.

e) Filler Material. One or more porous media will be used to fill the gaps between the glass waste-form monoliths. The filler may or may not be compacted to reduce its settlement potential. The hydraulic properties could be altered in response to chemical changes (e.g., dissolution, precipitation)

f) Getter Material. One or more materials may be added to act as a sorbent for specific contaminants. The term "getter" refers to the fact that the material sorbs, or "gets", the contaminant(s) of interest. This getter material may be mixed with portions of the filler material or it may be added as a separate media. In either case, the hydraulic properties could be altered in response to chemical changes

(e.g., dissolution, precipitation)

\section{Alternative Conceptual Models.}

The only major altemative conceptual model at this time is that the concrete and glass monolith behaves as dual porosity or fractured media rather than as porous media.

\section{Collect Existing and Emerging Hydraulic Parameters for 2001 PA}

This subtask is designed to identify the near-field materials that control facility performance, obtain any existing physical and hydraulic data for those materials, and propose the laboratory and field tests needed to provide the data where none exists. This subtask is also designed to collate existing information, interact with other tasks collecting hydraulic properties, and integrate the results with the current design to 


\section{RPP-6702, Rev. 0 \\ Formerly HNF-SD-WM-PAP-062 Rev. 4}

determine where this task should focus. Concrete is a good example of a material for which there is existing information. Being a manufactured product, concrete has a legacy of testing data that could be used. The waste form release task will collect hydraulic data on glass samples. It is preferable for that task to perform the measurements because the testing is intimately linked with the geochemical tests. The role of this task is to ensure that sufficient and appropriate data are collected. Interactions must also occur with the geochemistry task, which will test and recommend possible getter materials. Likely getter candidates will have to be characterized for hydraulic properties by this task. Finally, there is a need to maintain contact with the disposal facility design team to identify important materials and design features that require hydraulic property testing.

FY98 - (\$20K) identify literature and disposal program sources of hydraulic property parameters for pertinent materials. Specifically look for tests conducted to demonstrate long-term performance and for degradation effects on that performance. Interact with the geochemistry and waste form task to ensure that sufficient and appropriate data are collected to describe hydraulic properties in computer simulations of disposal system performance. Level of effort.

FY99 - (\$10K) continue literature review and interaction with the geochemistry and waste form task and with the design team to ensure that sufficient and appropriate data are collected to describe hydraulic properties in computer simulations of disposal system performance. Level of effort.

\section{Determine In Situ Hydraulic Parameters - Surface Sediments}

An IP test of the surface sediment at the new disposal site was to be conducted in FY98 to obtain in situ hydraulic properties. The test was conducted with a slightly saline solution to enable calculation of dispersivity, which is a transport parameter. repeating a similar but incomplete test conducted in 1996. Equipment problems in 1996 were fixed in FY97. The results of the FY98 IP test will be used to confirm the correct functioning of the equipment and calculate hydraulic properties for the surface sediment. The test will be conducted with a slightly saline solution. The presence of the salt will enable calculation of dispersivity, which is a transport parameter. Following the test, core samples will be collected and taken to the laboratory for physical and hydraulic testing. (The results were used to compare hydraulic properties will be measured calculated with the different laboratory methods and at different scales. These results will be available in FY1999 for comparison to the field-scale measured values.)

FY98 - (\$37K) conduct IP test of surface soil. Process data and calculate hydraulic parameters. Costs based on FY96 activity. March 98 to April 98.

FY99 -(\$8K) summarize in situ hydraulic parameters for the surface sediment in a letter report. June 98 to September 98.

FY99 - no activity (completed)

Determine In Situ Hydraulic Parameters - Upper Hanford Formation. 


$$
\begin{gathered}
\text { RPP-6702, Rev. } 0 \\
\text { Formerly HNF-SD-WM-PAP-062 Rev. } 4
\end{gathered}
$$

After completion of the IP test on the surface sediment in FY98, the roughly 1.2$m$ sandy surface sediment was excavated to expose the underlying Hanford formation. An IP test was conducted on the upper Hanford formation to determine in situ hydraulic properties and dispersivity. The test will be conducted with a slightly saline solution. The presence of the salt will enable calculation of dispersivity, which is a transport parameter. (As for the previous IP test, cores samples were will be collected and archived at taken to the laboratory for future analyses and comparison to the field-scale properties.)

FY98 - $(\$ 21 \mathrm{~K})$ conduct IP test of upper Hanford formation. Process data and calculate hydraulic parameters. Costs based on FY96 activity. May 98 to September 98.

FY99 - (\$8K) summarize in situ hydraulic parameters

FY99 - (\$18K) summarize in situ hydraulic parameters for the upper Hanford Formation in a letter report. October 98 to June 98.

Determine Hydraulic Parameters - Initial and Aged Near-Field Materials

A variety of materials will be tested for physical and hydraulic properties. These materials include core samples from the in situ tests, samples from stockpiles, materials being considered for filler and getters, and structural elements like concrete.

FY98 - (\$38K) Core samples will be collected by hand from the IP field test sites in 1998. Separate samples from the Hanford formation will be composited and tested as possible backfill material. One or two likely getter materials will be identified. All of these samples and materials will be analyzed for a suite of physical and hydraulic properties, including bulk density, particle density, water retention, saturated hydraulic conductivity, and unsaturated hydraulic conductivity. April 98 to September 98 .

\section{Determine Hydraulic Properties of Aged Materials}

FY99 - (\$46K) Samples of intact and aged concrete and diverter, filler, and getter material will be considered for hydraulic property testing. Sample choices will be based on the data review in 1998, the near-field sensitivity simulations conducted in FY98, and close coordination with the geochemistry task. Once samples are identified and obtained, conduct the necessary hydraulic property tests. October 98 to June 99.

Measure Hydraulic Properties as a Function of $\mathrm{pH}$ and lonic Strength

FY99 - $\quad(\$ 55 \mathrm{~K})$ Measure hydraulic property changes in near-field materials using column experiments involving the ionic strength and $\mathrm{pH}$ changes expected in the disposal facility. These tests will repeat those conditions in the fiscal year 1998 because experimental artifacts compromised the FY98 tests. The results will enable the calculation of the rate that soil properties change during extended periods appropriate to the disposal facility evaluation. October 98 to June 99 . 


\author{
RPP-6702, Rev. 0 \\ Formerly HNF-SD-WM-PAP-062 Rev. 4
}

\title{
Measure Diffusion Coefficients of Near-Field Materials
}

FY99 - (\$45K) Measure diffusion coefficients of high ionic strength, high pH solution. The study of diffusion coefficients will be conducted in conjunction with a similar study being performed for the Solid Waste Burial Grounds. Methods of measuring the release of uranium, technetium, and iodine from high strength concrete are being developed for that program. These and similar methods will be used to determine release of technetium, uranium, and either selenium or iodine from concrete representative of the existing and new vaults, and typical filler material (a screened sample of typical backfill sediments). Long-term (15-month) tests will be run at ambient temperatures with some data gathered after a shorter period, e.g. 3 months. These 15-month tests would be conducted over an 18month research period. Non-isothermal tests will be run could be run at three temperatures for 90 to 100 days. A brief literature survey reporting on unsaturated concrete and sediment or soil measurements of diffusion will accompany the first year measurements in the fiscal year 1999 report and support the FY01 PA data package. October 98 to August 99.

\section{Perform Near-Field Sensitivity Simulations}

To guide the measurements of near-field hydraulic parameters, a detailed conceptual model of the disposal facility will be assembled in fiscal year 1998. Actual dimensions of features such as the glass monoliths and their spacing, concrete walls, and liquid water diverter will be included. Computer simulations will then be used to highlight the controlling parameters within the facility and identify the most important parameters and features. Of particular interest is the interaction of the various components with the evolving chemical status (i.e., $\mathrm{pH}$ and associated dissolution and precipitation) of the facility as it ages. The results will be compared and contrasted with the conclusions of the FY97 simulations, which did not consider facility materials or features.

FY98 - $(\$ 32 K)$ conduct near-field sensitivity simulations that incorporate facility features and materials. Costs are based on FY97 simulation costs. October 97 to March 98.

FY98 - (\$8K) summarize near-field sensitivity simulations in a letter report. April 98 to May 98.

FY99 - (\$30K) Once the conceptual model is developed and data begin to be generated on the hydraulic and transport properties, there will be a need to test hypotheses developed in the sensitivity tests using the measured hydraulic and transport properties. The results of these simulations will yield observations on physical and hydraulic properties to be reported in the 01PA data package.

\section{Document Hydraulic Parameters for 2001 PA}

Information collected by the various subtasks will be merged, synthesized, and integrated to provide a clear and consistent view of hydraulic properties for the near field 
RPP-6702, Rev. 0

Formerly HNF-SD-WM-PAP-062 Rev. 4

environment of the disposal facility. The issued report will support the 2001 Performance Assessment.

The near-field hydraulics data package shall contain all of the data needed for water flux calculations in the near-field to be performed in the 2001 performance assessment. The data package shall contain data needed for contaminant transport calculations normally supplied as part of a hydraulic data package, (e.g., porosity, water retention, relative permeability, saturated hydraulic conductivity, and unsaturated hydraulic conductivity), and the transport property of dispersion or dispersivity derived from field scale tests. Such data shall include information to establish a best estimate case, uncertainty cases around that best estimate case, as well as a reasonably bounding case. The intent of the information is to allow a suite of cases to be calculated during the creation of the 2001 PA. The results would allow the reader of the 2001 PA to understand what is likely to occur if a disposal action were to occur and how bad things would have to get in order for the disposal action to fail. The authors shall review the documents published in the other subtasks of this task (as well as documents produced by the performance assessment team and others). The authors will justify selection of data and methods.

A draft of the Near-Field Hydraulics Data Package will be completed in FY99. The data package contains data needed for contaminant transport calculations normally supplied as part of a hydraulic data package, (e.g., porosity, water retention, relative permeability, saturated hydraulic conductivity, and unsaturated hydraulic conductivity), and the transport property of dispersion or dispersivity derived from field scale tests. For the required transport parameters, the data package includes best estimate cases, uncertainty information, and reasonable bounds. The information in the data package will be used in the water flux and contaminant transport calculations of the near-field to be conducted as part of the 2001 performance assessment. The results will allow the reader of the 2001 PA to understand what is likely to occur if a disposal action were to occur and how bad things would have to get in order for the disposal action to fail.

FY99 - (\$30K) merge near-field hydraulic data. July 99.

FY99 - (\$35K) write near-field hydraulic data package. Aug 99 to Sep 99.

FY00 (\$17K) Address External Reviewers' Comments and Publish Data Package (start: 10/1/99; finish: 12/31/99)

This level of additional funding is being sought for these reporting efforts because a considerable effort will be required to assemble information on unsaturated media dispersivities and diffusion coefficients which are proving intractable to measure in time to support the FY01 PA. The funding is also needed to produce the thorough document required for extemal peer review.

\section{Perform Internal Quality Assurance Assessment}

The laboratory and field measurements being made by PNNL for the RPP ILAW 2001 PA data package are being collected under QA protocols provided in test plans. These protocols are designed to provide data sufficiently traceable and robust for regulatory purposes. Periodic review of staff adherence to the protocols is essential. An annual internal assessment will be conducted by staff of the Process Quality group. 


\section{RPP-6702, Rev. 0 \\ Formerly HNF-SD-WM-PAP-062 Rev. 4}

Their review will address the protocols, the data gathered, the records and databases, and staff adherence to the protocols.

FY99 (\$15K) Perform the assessment and provide the project with a brief letter report on findings.

\section{Perform External Review}

During FY99, a review plan was produced and two external technical reviewers were selected. These reviewers will conduct reviews of both the Recharge Data Package and the Near-Field Hydraulics Data Package. A single contract for review of the Near-Field Data Package will be established in FYOO in accordance with the schedule of the review plan. The reviewers have been notified to expect the data package in October, 1999 and will be given 30 to 45 calendar days to complete their reviews, with all comments returned by November 30,1999 . The extemal reviewers' comments will be addressed and the final data package published by December 31, 1999.

FY99 (5K) Develop Review Plan and Select Reviewers

FY99 (15K) Review Task activities and start review of Draft Data Package

FY00 (\$14K) Establish Contract and Complete Extemal Review (start: 10/1/99; finish: 11/30/99)

e. Interfaces

Continued interaction with the waste form, recharge, and geochemistry groups will take place during completion of the external review and incorporation of the reviewers' comments. The output of this task is the documentation of near-field hydraulic properties for the Data Packages of the 2001 Performance Assessment (Section 3.0).

f. Organization

The Hydrology Technical Group Section of the Pacific Northwest National Laboratory (PNNL) has the lead for this task. They were responsible for completion of the Near-Field Hydraulics Data Package. 
RPP-6702, Rev. 0

Formerly HNF-SD-WM-PAP-062 Rev. 4

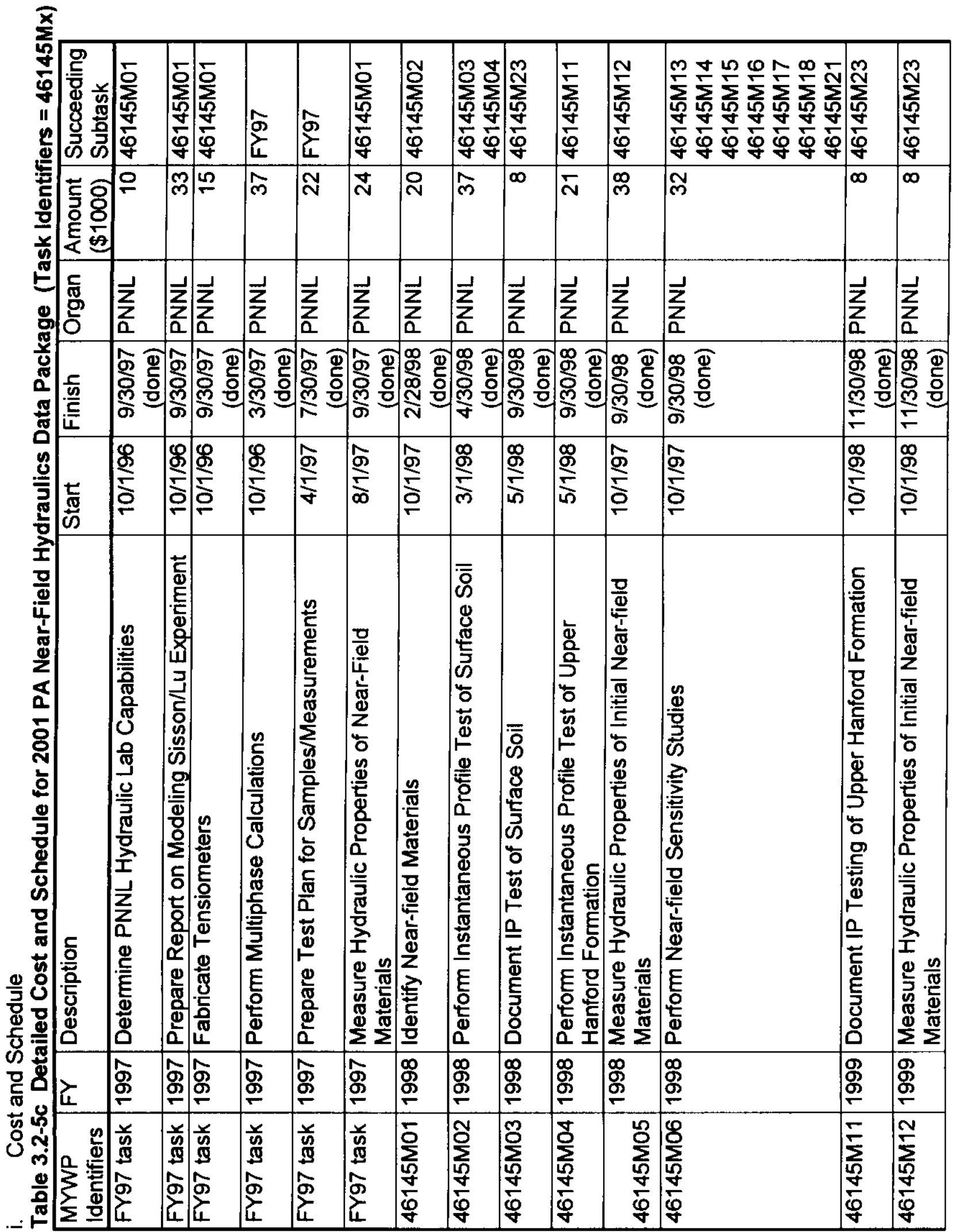


RPP-6702, Rev. 0

Formerly HNF-SD-WM-PAP-062 Rev. 4

\begin{tabular}{|c|c|c|c|c|c|c|c|c|c|c|c|c|c|}
\hline 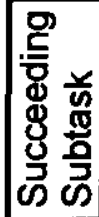 & 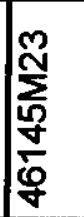 & 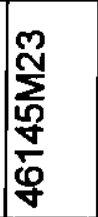 & 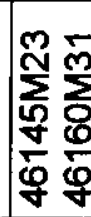 & 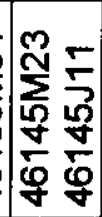 & 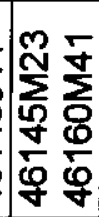 & 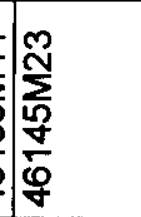 & 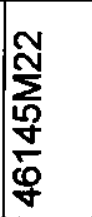 & $\sum_{\substack{n \\
\frac{m}{5}}}^{\frac{5}{0}}$ & 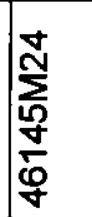 & 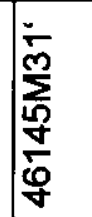 & 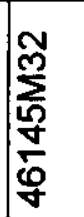 & 它 & 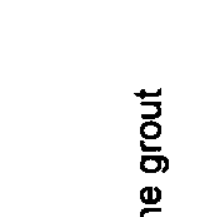 \\
\hline $\begin{array}{l}\text { 든 } \\
\text { 용 } \\
\text { 둔 } \\
\end{array}$ & 으 & $\infty$ & $\varphi$ & 员 & $\frac{8}{4}$ & 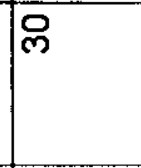 & 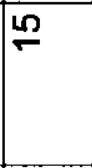 & 오 & Iי & m & 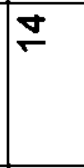 & 음 & $\frac{5}{2}$ \\
\hline $\begin{array}{l}\text { 동 } \\
\text { 잉 } \\
\end{array}$ & $\sum_{\alpha}$ & $\sum_{n}$ & $\sum_{a}$ & $\sum_{\alpha}$ & $\sum_{\alpha}$ & $\mid \begin{array}{l}\sum_{n} \\
z\end{array}$ & $\sum_{\alpha}$ & $\sum_{\alpha}$ & $\sum_{\alpha}$ & $\sum_{\text {L }}$ & $\sum_{\alpha}$ & $\sum_{\alpha}$ & $\begin{array}{r}\stackrel{\Phi}{5} \\
-5\end{array}$ \\
\hline 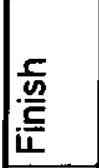 & 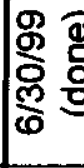 & 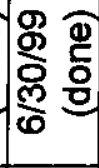 & 量 & 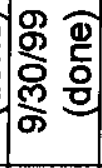 & 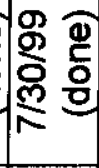 & 息 & 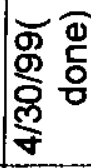 & 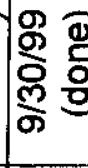 & 恋 & 量 & 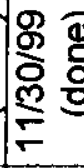 & 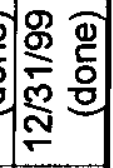 & 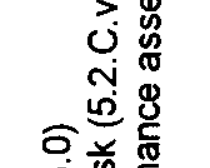 \\
\hline 旨 & $\stackrel{\infty}{\stackrel{\infty}{2}}$ & $\frac{\infty}{2}$ & $\frac{\infty}{\stackrel{0}{2}}$ & $\frac{\infty}{\stackrel{0}{2}}$ & 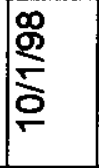 & 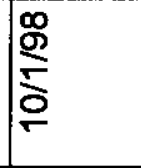 & $\frac{\infty}{\stackrel{\infty}{2}}$ & $\frac{g}{\operatorname{g}}$ & $\stackrel{g}{\stackrel{g}{5}}$ & $\frac{\mathscr{g}}{\underset{\infty}{\frac{\infty}{\infty}}}$ & $\frac{g}{g}$ & 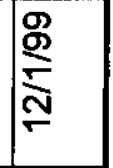 & 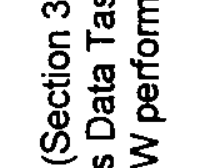 \\
\hline 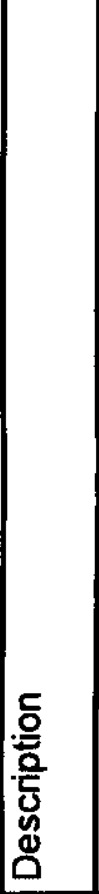 & 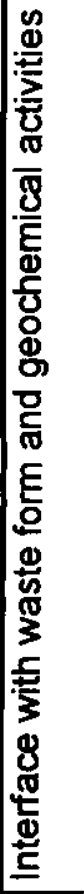 & 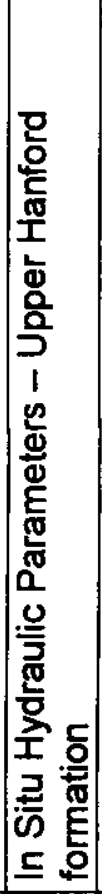 & 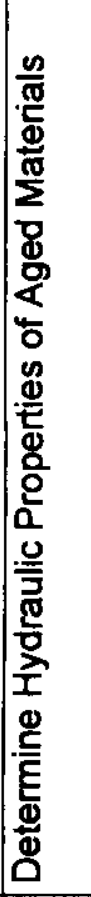 & 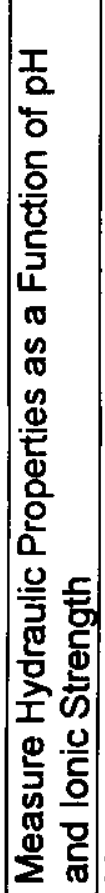 & 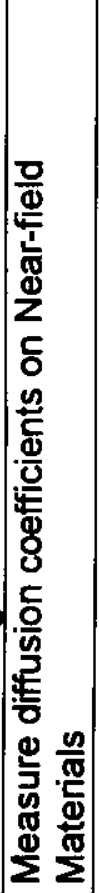 & 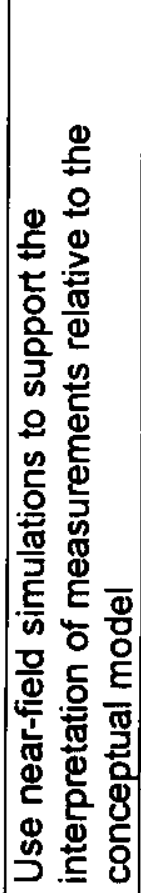 & 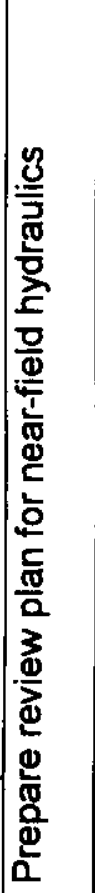 & 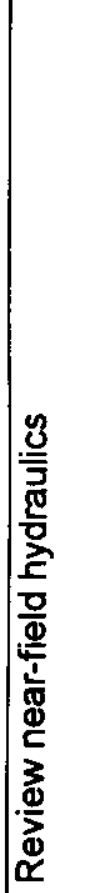 & 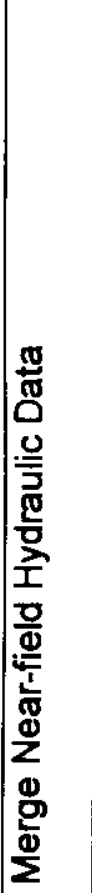 & 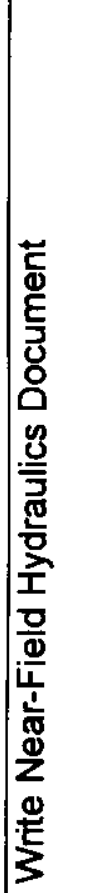 & 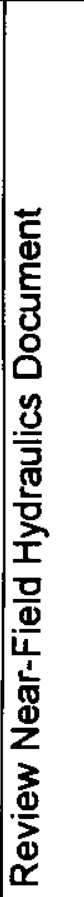 & 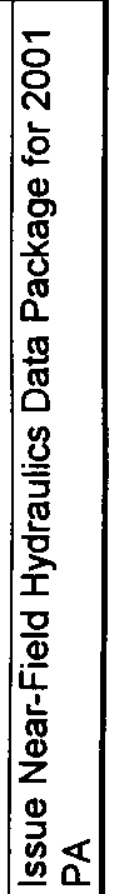 & 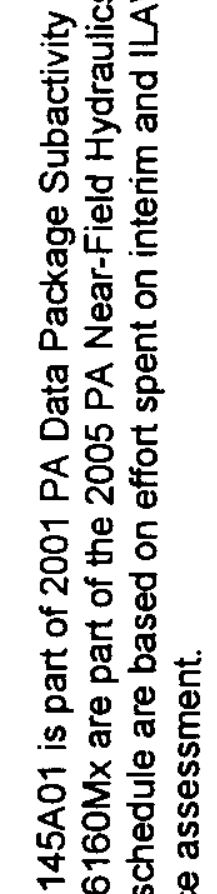 \\
\hline L & \% & \% & \% & क्ष & g & / & \% & \begin{tabular}{|}
$\boldsymbol{g}$ \\
\\
\end{tabular} & क् & \begin{tabular}{|l}
$\mathbf{g}$ \\
\\
\end{tabular} & 용 & ষ্ণ & 窇窇完 \\
\hline 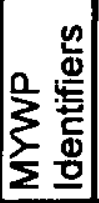 & 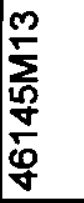 & $\sum_{\frac{\pi}{8}}^{\frac{N}{8}}$ & 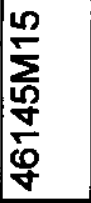 & 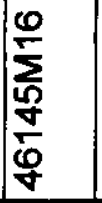 & $\sum_{\frac{\pi}{5}}^{N}$ & $\sum_{\frac{1}{\infty}}^{\infty}$ & $\bar{\pi}$ & 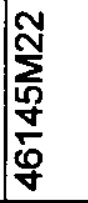 & 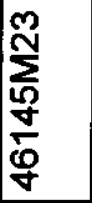 & 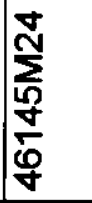 & $\sum_{\substack{n \\
\frac{m}{n}}}^{n}$ & 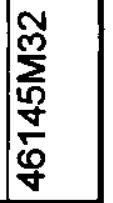 & ڤెं \\
\hline
\end{tabular}


RPP-6702, Rev. 0

Formerly HNF-SD-WM-PAP-062 Rev. 4

vi. Determine Hydraulic Parameters for Soils at Disposal Sites (Complete)

a. Background

Once the contaminants are released from the disposal facility, they are carried to the groundwater by the slowly moving downward moisture plume. The moisture content is determined by various hydraulic properties (saturated hydraulic conductivity, hydraulic conductivity as a function of moisture content, matric potential as a function of moisture content, liquid and vapor diffusion parameters) and by the recharge rate.

Knowledge of hydraulic properties for Hanford Site soils is limited to just a few locations. The variability of the parameters at a given location as a function of depth and at various locations is poorly known. In particular, preferential pathways (from previous boreholes or from natural features known as clastic dikes) are thought by some to be important.

For the interim and ILAW performance assessments, measurements of Hanford formation hydraulic properties for a variety of locations in the 200 Areas were combined to form a recommended set. The procedure and values obtained were documented in $\underline{A}$ Compilation of Hydrologic Properties for Low-activity Tank Waste Disposal Facility Performance Assessment (Khaleel 1995a).

With the publication of the far-field hydrology data package for the 2001 ILAW PA (Khaleel 1999), this activity is complete.

b. List Of Deliverables

Table 3.2-6a List of Deliverables for 2001 PA Far-Field Hydraulics Data Package

\begin{tabular}{|c|c|c|c|}
\hline Description & $\begin{array}{l}\text { Due } \\
\text { Date }\end{array}$ & Level & $\begin{array}{l}\text { MYWP } \\
\text { Identifier }\end{array}$ \\
\hline Document FY97 Aquifer Testing & done & 7 & FY97 task \\
\hline Document FY97 Vadose Zone Testing & done & 7 & FY97 task \\
\hline Document Modeling of Sisson/Lu Experiment & done & 7 & FY97 task \\
\hline Document clastic dyke data for $2001 \mathrm{PA}$ & done & 8 & $\begin{array}{l}\text { 46145L0J } \\
\text { [46145L01] }\end{array}$ \\
\hline Document tension dependent anisotropy & done & 8 & $\begin{array}{l}\text { 46145LOI } \\
\text { [46145LO2] }\end{array}$ \\
\hline $\begin{array}{l}\text { Issue status report on hydrological upscaling } \\
\text { relationships }\end{array}$ & done & 8 & $\begin{array}{l}46145 \mathrm{LOH} \\
\text { [46145LO3] }\end{array}$ \\
\hline $\begin{array}{l}\text { Issue status report on sorption-enhanced } \\
\text { dispersivity }\end{array}$ & done & 8 & $\begin{array}{l}\text { 46145LOG } \\
\text { [46145LO4] }\end{array}$ \\
\hline $\begin{array}{l}\text { Issue status report on Borehole \#1 Hydraulic } \\
\text { Data }\end{array}$ & done & 8 & $\begin{array}{l}\text { 46145L1D } \\
\text { [46145L21] }\end{array}$ \\
\hline $\begin{array}{l}\text { Issue review plan for far-field hydraulics data } \\
\text { package }\end{array}$ & done & 8 & $\begin{array}{l}\text { 46145L4D } \\
\text { [46145L41] }\end{array}$ \\
\hline $\begin{array}{l}\text { Issue report on hydrological upscaling } \\
\text { relationships }\end{array}$ & done & 7 & $\begin{array}{l}\text { 46145L1F } \\
{[46145 L 11]}\end{array}$ \\
\hline $\begin{array}{l}\text { Issue report on sorption-enhanced } \\
\text { dispersivity }\end{array}$ & done & 8 & $\begin{array}{l}46145 \mathrm{~L} 1 \mathrm{E} \\
{[46145 \mathrm{~L} 12]}\end{array}$ \\
\hline
\end{tabular}


RPP-6702, Rev. 0

Formerly HNF-SD-WM-PAP-062 Rev. 4

\begin{tabular}{|l|c|c|l|}
\hline Description & $\begin{array}{l}\text { Due } \\
\text { Date }\end{array}$ & Level & $\begin{array}{l}\text { MYWP } \\
\text { Identifier }\end{array}$ \\
\hline Document Borehole \#1 Hydraulic Data & done & 7 & $\begin{array}{l}46145 \mathrm{~L} 3 \mathrm{C} \\
{[46145 \mathrm{~L} 31]}\end{array}$ \\
\hline Document Far-Field Hydraulic Data & done & 8 & $\begin{array}{l}46145 \mathrm{~L} 4 \mathrm{~B} \\
{[46145 \mathrm{~L} 44]}\end{array}$ \\
\hline $\begin{array}{l}\text { Issue Far-Field Hydraulic Data Package for } \\
2001 \text { PA }\end{array}$ & done & 7 & $\begin{array}{l}46145 \mathrm{~L} 5 \mathrm{~A} \\
{[46145 \mathrm{~L} 52]}\end{array}$ \\
\hline
\end{tabular}

c. Cost Summary

WBS: $1.01 .09 .01 .01 .31 .02 .02 .04 \quad \mathrm{CACN}$ : 1D9DM3

Table 3.2-6b Cost Summary for 2001 PA Far-Field Hydraulics Data Package

\begin{tabular}{|l|l|r|}
\hline $\begin{array}{l}\text { Fiscal } \\
\text { Year }\end{array}$ & Organization & $\begin{array}{l}\text { Amount } \\
(\$ 1000)\end{array}$ \\
\hline \multirow{3}{*}{1997} & Fluor Federal Services (FFS) & 120 \\
\cline { 2 - 3 } & Pacific Northwest National Laboratory (PNNL) & 35 \\
\cline { 2 - 3 } & Total & 155 \\
\hline 1998 & FFS & 190 \\
\cline { 2 - 3 } & PNNL & 90 \\
\cline { 2 - 3 } & Total & 280 \\
\hline 1999 & FFS & 201 \\
\hline 2000 & FFS & 23 \\
\hline Grand total & & 659 \\
\hline
\end{tabular}

d. Detailed Description

Measurement and Hydraulic Parameter Estimation for Boreholes \# 1 Samples.

An accurate prediction of the water flow and contaminant transport in the vadose zone requires a detailed characterization of the hydrologic properties and their variability. In particular, data that are essential in quantifying the water storage and flow properties of unsaturated soils include a characterization of soil heterogeneities, and the soil hydraulic functions (i.e., moisture content versus pressure head and unsaturated hydraulic conductivity versus pressure head relationships) of various layers.

As part of site characterization activities for the Low-activity Tank Waste Disposal Facility, soil samples will be obtained in fiscal years 1998 and 1999 via borehole drilling and sampling program. The primary objective of this task is to provide, for the 2001 and 2005 PAs, the measured data and the derived hydraulic parameters for various geologic formations and soil types at the disposal sites.

For the borehole samples, particle-size distribution, bulk density, particle density, diffusivity, moisture retention (main drainage curve), unsaturated hydraulic conductivity, and saturated hydraulic conductivity $\left(\mathrm{K}_{8}\right)$ data will be obtained in the laboratory. The laboratory procedures that will be followed to obtain soil moisture characteristic data are described in detail elsewhere (e.g., Klute 1986a; Klute 1986b; Khaleel 1995b). If needed, the moisture retention data and $K_{s}$ values will be corrected for gravel content (> 


\section{RPP-6702, Rev. 0 \\ Formerly HNF-SD-WM-PAP-062 Rev. 4}

$2 \mathrm{~mm}$ size fraction) (Khaleel 1997; Gardner 1986; Bouwer 1984). When expressed as a function of moisture content, the unsaturated conductivities for gravelly soils are different from those for fine soils ( $<2 \mathrm{~mm}$ size). However, unlike moisture retention data for bulk (gravel and fine) soils, bulk unsaturated conductivities do not require correction for the gravel fraction when expressed as a function of matric potential (Mehuys 1975).

After the data are corrected and cataloged, hydraulic parameters will be determined by fitting the van Genuchten soil-moisture retention model (van Genuchten $1980)$ to the laboratory-measured main drainage data. The laboratory-based moisture retention data will be analyzed using RETC (van Genuchten 1991), a computer program that uses a nonlinear, least squares curve fitting procedure to match the measured moisture retention data to van Genuchten model. The database comprised of various soil categories will be used as the basis for describing the distribution for five hydraulic parameters (i.e., $\alpha, n, \Theta_{r}, \Theta_{s}$, and $K_{s}$ ).

In the absence of unsaturated hydraulic conductivity measurements, the Mualem predictive model (Mualem 1976), along with the fitted van Genuchten parameters, and saturated hydraulic conductivity estimate, is frequently used to predict unsaturated hydraulic conductivity over the desired range of moisture regime. Estimates based on the Mualem predictive model could be off by orders of magnitude especially at the dry end of the curves (Khaleel 1995b). Therefore, to avoid inaccurate unsaturated conductivity predictions at the dry end (moisture regime of primary interest for the PA), a simultaneous fit of both moisture retention and unsaturated conductivity data will be performed to derive the hydraulic parameters.

The preceeding analysis and parameter estimation of hydraulic parameters have been performed for samples from borehole \#1. As of $4 / 98$, the PNNL has been selected, among four candidate laboratories, for performing the laboratory measurements. $A$ detailed work plan has been developed on measurement and analysis of hydraulic properties for borehole samples, and a report issued. Borehole \#1 has been drilled and sediment samples have been obtained. Work has been completedat PNNL on the measurements. A report on the FY98 work wasissued on 9/30/98.

\section{Collect Other Far-field Hydraulic Data.}

Field-scale flow and transport processes within the vadose zone exercise major controls on contaminant transport from a waste disposal site. The recent (4/97) External Board peer review for the Interim Performance Assessment (IPA) for Low-activity Tank Waste Disposal identified several important field-scale processes which have not been considered in the IPA. It is important to include these processes in order to have a technically defensible PA and to be able to take additional credit in retardation of contaminant migration. The purpose of this task is to review, interpret, and incorporate vadose zone field scale processes in order to make them usable for the low-activity performance assessment modeling activities for the 2001 PA and 2005 PA.

Upscaling. For the 2001 performance assessment modeling, data on hydraulic properties will be based on different sources. These will comprise data obtained from laboratory tests on core samples (scales of a few $\mathrm{cm}$ ) obtained via boreholes and measurements from in-situ aquifer testing (scales of tens of meters). Numerical models of fluid flow and contaminant transport in the unsaturated zone require specifying hydraulic conductivity-matric potential relationships for each grid block discretizing the 


\section{RPP-6702, Rev. 0 \\ Formerly HNF-SD-WM-PAP-062 Rev. 4}

medium. However, the scale of the grid blocks is usually much larger than the scale at which the unsaturated properties are measured. This work is concerned with identifying useful approximations to the deterministic averaging laws by which measurement-scale conductivities are converted into block-scale values. A series of unsaturated flow numerical experiments will be conducted to calculate the equivalent unsaturated conductivity of heterogeneous block-shaped domains under steady, uniform mean gradient conditions. The block-scale conductivities thus obtained will then be compared to spatial averages of measurement-scale quantities in order to identify appropriate upscaling relationships.

A work plan detailing the approach and numerical modeling for upscaling has been developed and a report issued. In addition, work has been completed on development of a random number generator and assignment of material properties randomly in a two-dimensional modeling domain. A status report on the ongoing FY98 work was issued $9 / 30 / 98$.

Heterogeneous Sorption Enhanced Dispersivity. A parameter of importance in modeling contaminant transport is the distribution coefficient, $K_{d}$, which characterizes reversible, linear sorption. This contaminant-dependent and soil-dependent quantity describes the partitioning of the contaminant between the soil and the water. The net effect of sorption is to retard the velocity of the contaminant in the soil. Because sorption for specific contaminants may be a function of soil properties, as the soil properties experience spatial variability, the sorption also varies (Talbott and Gelhar 1994). The variation directly affects the velocity of the contaminant, which, in turn, enhances the spreading of the plume. The enhanced spreading is defined by a larger reactive longitudinal macrodispersivity, different from the non-reactive longitudinal macrodispersivity. The increased plume spreading due to heterogeneous sorption (over and above the result for no sorption) is defined as the macrodispersivity enhancement. Stochastic theory suggests that the effect of macrodispersivity enhancement only occurs in the longitudinal direction. The transverse macrodispersivity is unaffected by sorption variability (Garabedian et al. 1988).

Existing stochastic theories relative to macrodispersivity enhancement will be reviewed and the effects of heterogeneous sorption on plume spreading will be incorporated into existing performance assessment codes. An enhancement of macrodispersivity can have significant effects on the expected contaminant predictions for numerical models. A possible outcome of this task is the use of species-dependent enhanced longitudinal macrodispersivities in the 2001 PA modeling.

A work plan detailing the overall approach to evaluate sorption-enhanced macrodispersivity has been developed and a report issued. Work has also been completed on a review of stochastic theories on upscaling of effective porosity. A status report on the ongoing FY98 work was issued on 9/30/98.

Development of a systematic approach to address uncertainty in hydrologic variables.

For ILAW PA, the high degree of heterogeneity in Hanford soils, the difficulty in obtaining measurements of large-scale behavior, and the long time scales over which this behavior occurs contribute to a complication of the analysis. Small-scale samples on soil hydraulic properties and sorption coefficients are being obtained as part of site characterization efforts. Since a true discrete characterization of the subsurface 


\section{RPP-6702, Rev. 0 \\ Formerly HNF-SD-WM-PAP-062 Rev. 4}

conditions is not possible, a stochastic approach appears to be ideally suited to address the uncertainty and spatial variability in parameters. The stochastic theory is well developed in the field of subsurface hydrology and has been supported by the U.S. Nuclear Regulatory Commission for licensing low-level radioactive waste disposal facilities (Talbott and Gelhar 1994). This task will consider the applicability of stochastic approach in evaluating uncertainty in model predictions

The results of the stochastic parameterization process produce mean or effective parameters, based on small-scale parameters. The effective parameters will be used in numerical models of flow and transport to obtain mean concentration predictions. Sensitivities to effective input parameters and to model configurations will contribute to uncertainty in model predictions. Also, since the effective concentration predictions represent a mean solution, fluctuations about this mean are another source of uncertainty. The effect of the uncertainty in the concentration predictions is that they will represent a band of estimates about the mean expected values. Attempts will be made to integrate the results from this task with the overall strategy for evaluating uncertainty for the ILAW PA.

\section{Produce Far-Field Hydraulics Data Package}

Information collected by the various subtasks will be merged, synthesized, and integrated to provide a clear and consistent view of hydraulic properties for the far-field environment of the disposal facility. The issued report will support the 2001 Performance Assessment.

A review plan will be produced. Following the approval by the performance assessment activity leader, review of the methods and documentation shall occur.

The far-field hydraulics data package shall contain all of the data needed for moisture flow calculations in the far-field to be performed in the $\mathbf{2 0 0 1}$ performance assessment. The data package shall contain data needed for contaminant transport calculations (such as dispersion) normally supplied as part of a hydraulic data package. Such data shall include information to establish a best estimate case, uncertainty cases around that best estimate case, as well as a reasonably bounding case. The intent of the information is to allow a suite of cases to be calculated during the creation of the 2001 PA whose results would allow the reader of the 2001 PA to understand what is likely to occur if a disposal action were to occur and how bad things would have to get in order for the disposal action to fail. The authors shall review the documents published in the other subtasks of this task (as well as documents produced by the performance assessment team and others). The authors will justify selection of data and methods.

By the end of FY99, information collected by the various subtasks on far-field hydrology will be merged, synthesized, and integrated to provide a clear and consistent view of hydraulic properties for the far-field environment of the disposal facility. During FYO0, contracts will be placed for the technical peer review of the data package, provide consultant's time for the review, and issuing of the final document. The peer-reviewed report will support the 2001 Performance Assessment.

The far-field hydraulics data package shall contain all of the data needed for vadose zone flow calculations in the far-field to be performed in the 2001 performance assessment. The data package shall contain data needed for contaminant transport 
RPP-6702, Rev. 0

Formerly HNF-SD-WM-PAP-062 Rev. 4

calculations (such as dispersion) normally supplied as part of a hydraulic data package. Such data shall include information to establish a best estimate case, uncertainty cases around that best estimate case, as well as a reasonably bounding case. The intent of the information is to allow a suite of cases to be calculated during the creation of the 2001 PA whose results would allow the reader of the 2001 PA to understand what is likely to occur if a disposal action were to occur and how bad things would have to get in order for the disposal action to fail. Adequate justification will be provided on selection of data and methods.

e. Interfaces

This task builds on FY97 and FY98 tasks that identified important hydraulic parameters to be studied in the far-field. Site-specific samples were obtained from the borehole drilling (Section 3.2.C.ii). Stratigraphic information was obtained from the geology task (Section 3.2.C.iii). The output of this task forms part of the basis for the Data Packages of the 2001 Performance Assessment (Section 3.0).

f. Organization

The Environmental and Nuclear Initiatives Section of Fluor Federal Services (FFS) generated the hydraulic parameter database for the interim and ILAW performance assessment and for the Hanford solid waste performance assessments, and compiled the vadose zone database (Khaleel 1995c) for the Hanford Site composite performance assessment. The database was also the base for Hanford Site Composite Analysis (Kincaid 1998). After contacting four laboratories, FFS selected PNNL as the laboratory for the measurement of the hydraulic properties. 
RPP-6702, Rev. 0

Formerly HNF-SD-WM-PAP-062 Rev. 4

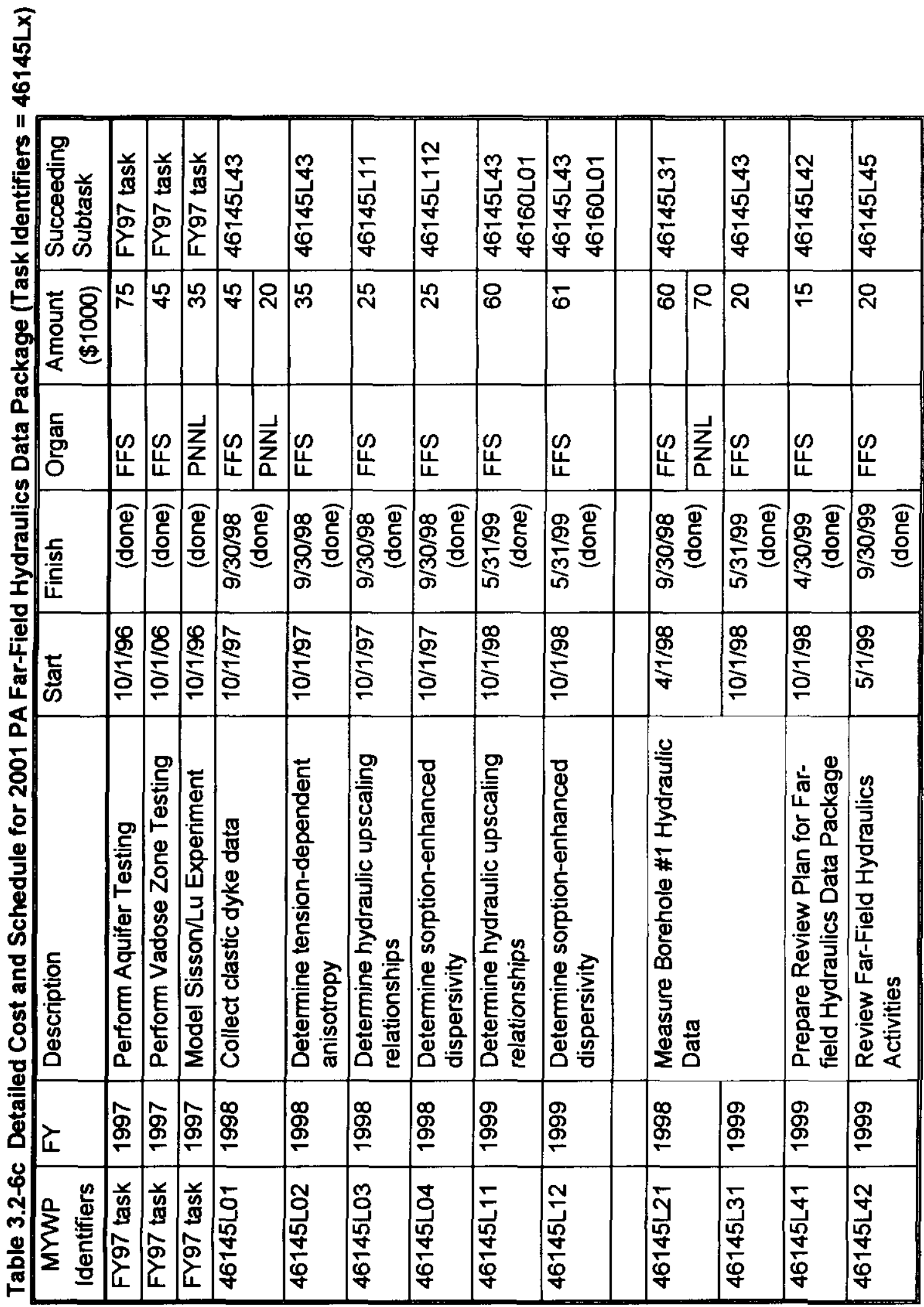


RPP-6702, Rev. 0

Formerly HNF-SD-WM-PAP-062 Rev. 4

\begin{tabular}{|c|c|c|c|c|}
\hline 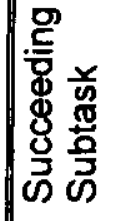 & 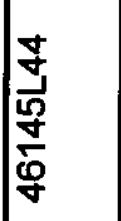 & 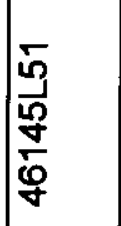 & 跑 & 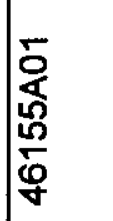 \\
\hline 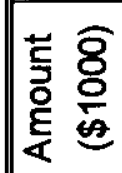 & 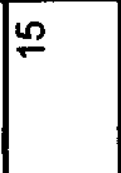 & 은 & $\not \infty$ & 10 \\
\hline $\begin{array}{l}\text { ॠ్ } \\
\text { o్ }\end{array}$ & 崩 & 帒 & $\mid \frac{\infty}{u}$ & $\frac{w}{4}$ \\
\hline 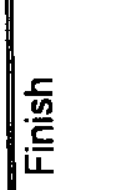 & 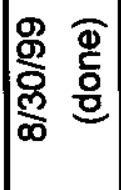 & 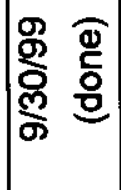 & 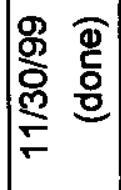 & 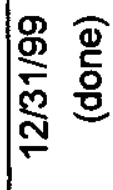 \\
\hline 泀 & $\frac{\mathscr{P}}{\stackrel{\rho}{6}}$ & $\frac{\mathscr{g}}{\stackrel{\rho}{\circ}}$ & 总 & 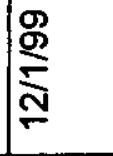 \\
\hline 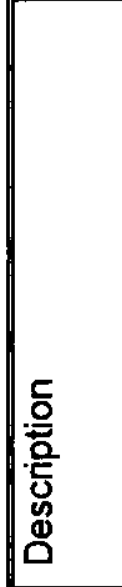 & 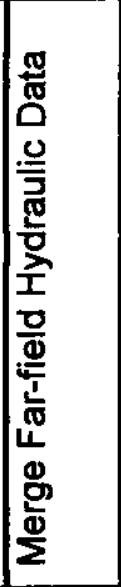 & 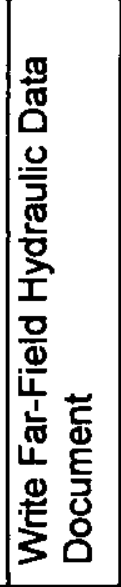 & 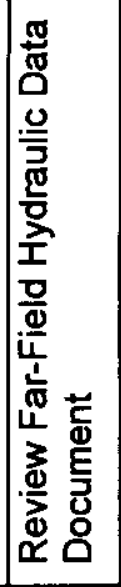 & 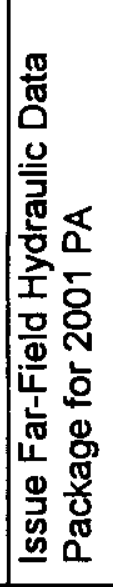 \\
\hline ז & 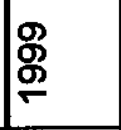 & 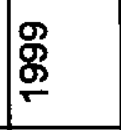 & ষ্ণ & ৪্ন \\
\hline 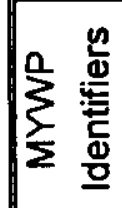 & 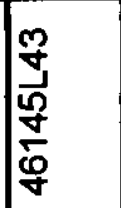 & 寺 & 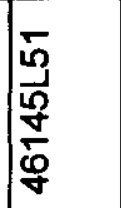 & 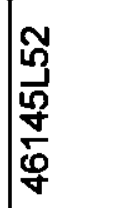 \\
\hline
\end{tabular}


RPP-6702, Rev. 0

Formerly HNF-SD-WM-PAP-062 Rev. 4

vii. Determine Geochemical Parameters for Disposal Facility Materials (Complete)

a. Background

The waste form provides the main trapping mechanism for the containment of contaminants. However, other features of the disposal facility can hinder transport of the released contaminants or can chemically reduce the rate at which the waste form dissolves.

Portland cement is a tremendous getter for uranium and actinide elements (Serne 1993). That is, the Portland cement chemically combines with these elements so that a very small amount of contaminants are left to move from the disposal facility. The Savannah River Saltstone Facility (the disposal facility for the Savannah River tank waste) relies on FeS as a getter for technetium (WSRC 1992).

Materials can also be used to chemically condition the water to reduce the rate at which the waste form dissolves.

Because of the lack of an official conceptual design, no credit for engineered chemical barriers was taken in the base analysis case of the interim or ILAW performance assessments.

With the publication of the geochemical data package for the 2001 ILAW PA (Kaplan 1999), this activity is complete.

b. List Of Deliverables

Table 3.2-7a List of Deliverables for 2001 PA Near-Field Geochemical Data Package

\begin{tabular}{|l|c|c|l|}
\hline Description & $\begin{array}{l}\text { Due } \\
\text { Date }\end{array}$ & Level & $\begin{array}{l}\text { MYWP } \\
\text { Identifier }\end{array}$ \\
\hline $\begin{array}{l}\text { Document effect of Silicate Water } \\
\text { onditioners on Glass Dissolution }\end{array}$ & done & 8 & $\begin{array}{l}4614501 \mathrm{H} \\
{[46145001]}\end{array}$ \\
\hline $\begin{array}{l}\text { Document Results of Studies Concerning } \\
\text { Secondary Zeolite Phases as Retardants to } \\
\text { Pertechnetate Mobility in the Near Field }\end{array}$ & done & 8 & $\begin{array}{l}4614501 \mathrm{~F} \\
{[46145002]}\end{array}$ \\
\hline $\begin{array}{l}\text { Issue Review Plan for Near-Field } \\
\text { Geochemical Data Packages }\end{array}$ & done & 8 & $\begin{array}{l}4614502 \mathrm{~F} \\
{[46145021]}\end{array}$ \\
\hline Write Geochemical 2001 PA Document & done & 8 & $\begin{array}{l}4614502 \mathrm{~B} \\
{[46145024]}\end{array}$ \\
\hline $\begin{array}{l}\text { Issue Geochemical Data Package for 2001 } \\
\text { PA }\end{array}$ & done & 7 & $\begin{array}{l}4614502 \mathrm{~A} \\
{[46145032]}\end{array}$ \\
\hline
\end{tabular}


RPP-6702, Rev. 0

Formerly HNF-SD-WM-PAP-062 Rev. 4

c. Cost Summary WBS: 1.01 .09 .01 .01 .31 .02 .02 .07

CACN: 1D9DM3

Table 3.2-7b Cost Summary for 2001 PA Near-Field Geochemical Data Package

\begin{tabular}{|l|l|r|}
\hline $\begin{array}{l}\text { Fiscal } \\
\text { Year }\end{array}$ & Organization & $\begin{array}{r}\text { Amount } \\
(\mathbf{\$ 1 0 0 0})\end{array}$ \\
\hline 1997 & Pacific Northwest National Laboratory (PNNL) & 5 \\
\hline 1998 & PNNL & 90 \\
\hline 1999 & PNNL & 190 \\
\hline 2000 & PNNL & 37 \\
\hline Grand Total & 322 \\
\hline
\end{tabular}

d. Detailed Description

1998

Effects of Near Field Chemistry on Radionuclide $\mathrm{K}_{\mathrm{d}} \mathrm{V}_{\mathrm{V}} \mathrm{lues-1998}$

$\mathrm{K}_{\mathrm{d}}$ values of several radionuclides change as a function of aqueous chemistry. The aqueous chemistry in the near and far fields is expected to be markedly different. It is not known if the chemistry of the glass plume will affect the magnitude of the $K_{d}$ values of Tc, I, Se, and U. However, previous experiments conducted for the LLW-PA (Kaplan et al. 1996) suggest that some rather dramatic changes in $U K_{d}$ values can occur as groundwater conditions vary. For example, when the $\mathrm{pH}$ of a Hanford sediment/water system was elevated from $\mathrm{pH} 8$ to 11 , the $U K_{d}$ value increased from about 1 to $>400$ $\mathrm{mL} / \mathrm{g}$. Documentation and understanding of such an immobilizing reaction can provide the PA with valuable defensible credit.

The objective of this subtask is to identify whether or not the $K_{d}$ values previously identified for the far field can be used in the near field. To do this a series of batch experiments will be conducted in which Hanford sediments and groundwater will be equilibrated with varying amounts of $\mathrm{NaOH}$ (a surrogate for the glass plume). The solubility and the sorption capacity of $\mathrm{Tc}, \mathrm{I}, \mathrm{Se}$, and $\mathrm{U}$ will be determined as a function of the $\mathrm{NaOH}$ added. Should the results indicate that no difference in solubility or sorption occurs over the entire $\mathrm{pH}$ range, then only one set of $\mathrm{K}_{d}$ values needs to be used in the near and far fields. If the $K_{d}$ values are found to change, then it may be desirable to use different $K_{d}$ values (or the lowest possible value) in the near and far fields. This work is especially important for the PA because the $K_{d}$ values of several radionuclides decrease as the ionic strength increases (as occurs within a contaminant plume). Thus, the farfield $K_{d}$ values previously measured may overestimate, i.e., not be conservative, values for near-field conditions.

Secondary Zeolite Phases as Retardants to Pertechnetate Mobility -1998

Studies conducted in association with the LLTW-PA have shown that zeolites form as secondary phases following glass dissolution (Mann et al. 1996). Zeolites have the ability to have a number of different ions substitute into their structure. Among the ions that can substitute into zeolite's structures are U, Tc, Se, and I. Should these ions be present during zeolite formation, it is possible (perhaps likely) that they will become incorporated within the zeolite structure. As such, their mobility will be essentially 


\section{RPP-6702, Rev. 0 \\ Formerly HNF-SD-WM-PAP-062 Rev. 4}

stopped. A series of simple batch-type experiments will be conducted to determine the likelihood that these ions will enter the structure of zeolites formed after glass dissolution. Formation of the zeolites in a glass/aqueous system will be promoted using the pressure/temperature conditions reported by McGrail. The aqueous phase will include the radionuclides of interest. After the zeolites have formed, the amount of radionuclide in the aqueous phase will be remeasured and compared to the concentration originally placed in the aqueous phase. If the final radionuclide concentration is less than the original concentration, then it can be assumed that the radionuclide is associated with the zeolite. To determine if the radionuclides simply adsorb to the exterior of already formed zeolite phases, the zeolites will be leached with a strong exchanging agent. Should the leachate contain radionuclides, it will be concluded that the radionuclides adsorbed onto the zeolites.

$\mathrm{pH}$ - and Silica-Water Conditioners -1998

Long-term Si-water conditioner experiments were conducted in FY1998. Additionally, formulations of the best performing materials will be optimized for chemical and hydraulic properties. (The hydraulic properties will be determined under the NearField Hydraulics Activity (see section 3.2.C.v). The optimization work will largely be conducted as column leaching experiments using McGrail's Single Pass Flow-Through System. With this experimental setup, pressure and temperature can be adjusted to increase the rate of kinetics. This task did not perform as planned and was dropped from the program.

Secondary Zeolite Phases as Retardants to Pertechnetate Mobility -1999

Continuation of FY1998 effort. The FY1998 effort found that zeolites may act as a getter for Se, Tc, I, and U. Preliminary indications show $86 \%$ of the Tc may be removed. The major questions is whether this removal is temporary or permanent.

\section{PA Near-Field Geochemical Data Package -1999}

A plan was prepared for the review of the near and far-field geochemical data activity and for the data package produced by the activity. Review started once the plan was approved by the performance assessment activity leader.

All the near-field data was tabulated and statistically analyzed. Selection of conservative and best estimates $K_{d}$ values were made and justified. Variability of the values was assigned to each estimate. Conceptual models used to describe radionuclide geochemistry were justified based on experimental data or through the use of the literature.

The 2001 near-field geochemical data package contains all of the geochemistry data needed for near-field calculations to be performed in the 2001 performance assessment. Such data includes information to establish a best estimate case, uncertainty cases around that best estimate case, as well as a reasonably bounding case. The intent of the information is to allow a suite of cases to be calculated during the creation of the 2001 PA whose results would allow the reader of the 2001 PA to understand what is likely to occur if a disposal action were to occur and how bad things would have to get in order for the disposal action to fail. 
RPP-6702, Rev. 0

Formerly HNF-SD-WM-PAP-062 Rev. 4

2001 PA Near Field Geochemical Data Package -2000

In the first quarter of FY2000 the external technical peer review and data package final publication occurred. The 2001 near field geochemical data package contains all the $\mathrm{Kd}$ and solubility data and the justification for the chosen values. The intent of the information is to allow a suite of performance calculations to be performed for the $2001 \mathrm{PA}$.

e. Interfaces

Both organizations continue to build on earlier Hanford tank performance assessment near-field work: Sandia National Laboratory (SNL) work in FY96 and Pacific Northwest National Laboratory work in FY97-99. Both organizations interact with the design interface (Section 3.3.C.iii) to ensure that their work is consistent with current designs.

One of the investigators of the ILAW team, Jeff Serne (PNNL) worked on both PA projects. Additionally, the investigators on this task will interface and share samples with the Hydrology investigators looking at diffusion through cement.

The major output of this task was to write reports that will form the basis of the Data Packages of the 2001 Performance Assessment (Section 3.0).

f. Organization

The Applied Geology and Geochemical Section of the Pacific Northwest National Laboratory has a long history of supplying geochemical data for near-field materials (especially for Nuclear Regulatory Commission (NRC) studies). The section has been supplied geochemical data for all of the Hanford performance assessments. 
RPP-6702, Rev. 0

Formerly, HNF-SD-WM-PAP-062 Rev. 4

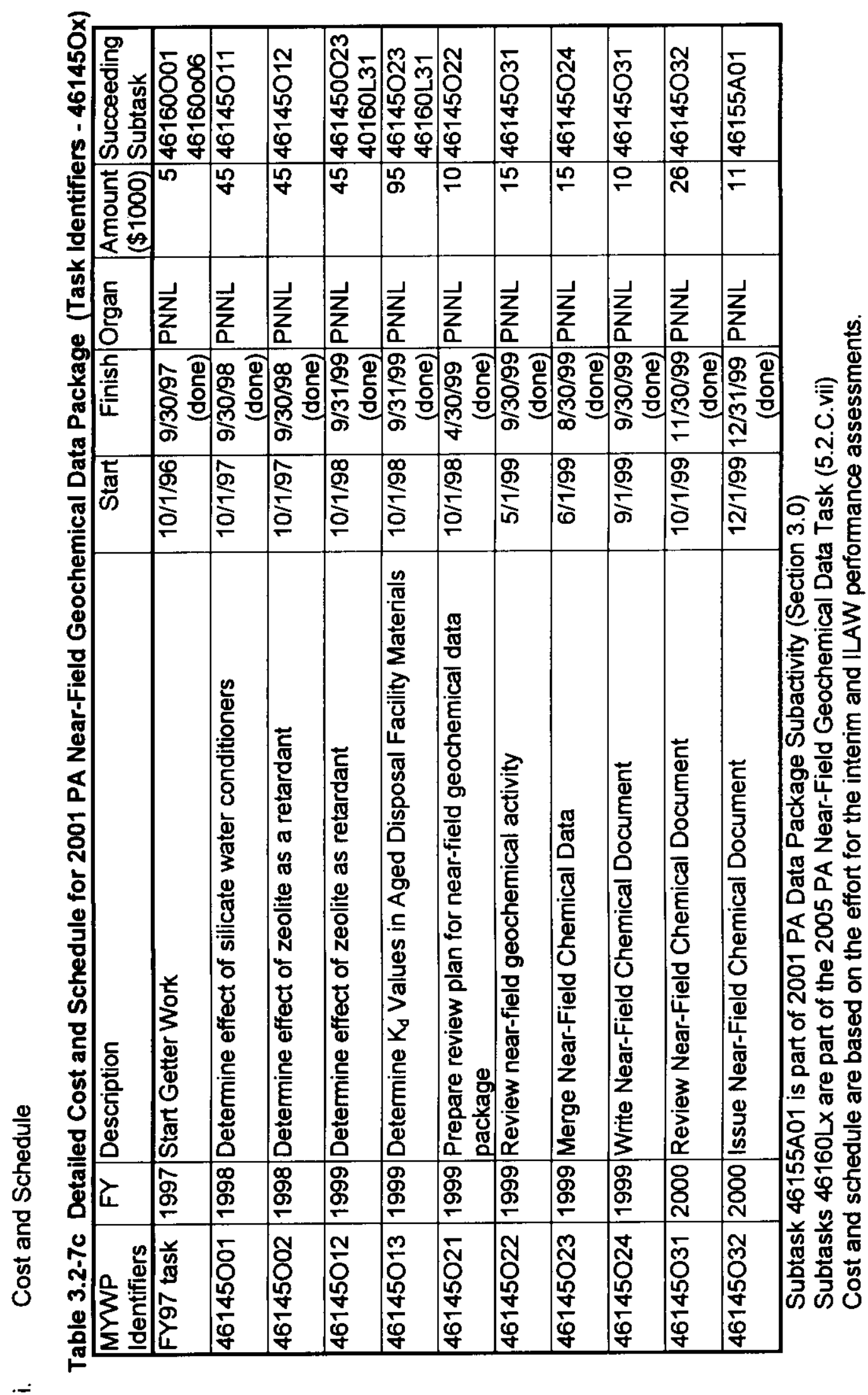


RPP-6702, Rev. 0

Formerly HNF-SD-WM-PAP-062 Rev. 4

viii. Determine Geochemical Parameters for Soils at Disposal Sites (Complete)

a. Background

The most mobile contaminants transport at the same velocity as the slowly moving moisture flow. However, most elements are chemically retarded by the soils in the vadose zone with the effect of greatly reducing their concentration. This reduction $\left(R_{f}=1+K_{d} \rho / \theta\right)$ depends on the bulk density of the soil $(\rho)$, on the moisture content of the soil $(\theta)$, and on a parameter describing the amount of retardation $\left(K_{d}\right)$.

Although a fairly large amount of data is available for Hanford soils for many of the elements, the data base is still sparse. In fiscal year 1996, the parameter describing retardation $\left(K_{d}\right)$ was found for uranium to depend on moisture, and this dependency depended on the Hanford soil type (Kaplan 1996).

For the interim and ILAW performance assessments, geochemical parameters were determined from Geochemical Factors Affecting Radionuclide Transport Through Near and Far-Fields at a Low-Level Waste Disposal Site (Kaplan 1995a) and for the five most important elements from Distribution Coefficient Values Describing lodine, Neptunium, Selenium, Technetium, and Uranium Sorption to Hanford Sediments (Kaplan 1995b).

With the publication of the geochemical data package for the 2001 ILAW PA (Kaplan 1999), this activity is complete.

\section{b. List Of Deliverables}

Table 3.2-8a List of Deliverables for 2001 PA Far-Field Geochemical Data Package

\begin{tabular}{|c|c|c|c|}
\hline Description & $\begin{array}{l}\text { Due } \\
\text { Date }\end{array}$ & Level & $\begin{array}{l}\text { MYWP } \\
\text { Identifier }\end{array}$ \\
\hline Issue Report on Colloid Movement & done & $\overline{7}$ & FY97 Task \\
\hline Write Test Plan for Determining $\mathrm{K}_{d}$ Parameters & done & 7 & FY97 Task \\
\hline $\begin{array}{l}\text { Issue Progress Report on Geochemical } \\
\text { Parameters }\end{array}$ & done & 7 & FY97 Task \\
\hline $\begin{array}{l}\text { Issue status report on measuring chemical data } \\
\text { from borehole \#1 }\end{array}$ & done & 8 & $\begin{array}{l}46145 \mathrm{~N} 2 \mathrm{I} \\
{[46145 \mathrm{~N} 21]}\end{array}$ \\
\hline $\begin{array}{l}\text { Issue status report on effect of near-field on vadose } \\
\text { zone } \mathrm{K}_{d} \mathrm{~s}\end{array}$ & done & 8 & $\begin{array}{l}46145 \mathrm{NOH} \\
{[46145 \mathrm{NO} 1]}\end{array}$ \\
\hline Issue report on effect of moisture on $\mathrm{K}_{d}$ & done & 7 & $\begin{array}{l}\text { 46145NOG } \\
{[46145 N 02]}\end{array}$ \\
\hline $\begin{array}{l}\text { Issue report on effect of near-field on vadose zone } \\
\mathrm{K}_{d} \mathrm{~s}\end{array}$ & done & 7 & $\begin{array}{l}46145 \mathrm{~N} 1 \mathrm{D} \\
46145 \mathrm{~N} 11]\end{array}$ \\
\hline $\begin{array}{l}\text { Issue report on measuring chemical data from } \\
\text { borehole \#1 }\end{array}$ & done & & $\begin{array}{l}46145 N 3 B \\
{[46145 N 31]}\end{array}$ \\
\hline $\begin{array}{l}\text { Issue review plan for far-field geochemical data } \\
\text { package }\end{array}$ & done & 8 & $\begin{array}{l}46145 N 4 F \\
{[46145 N 41]}\end{array}$ \\
\hline Issue status report on saturation effects on $\mathrm{K}_{d} \mathrm{~s}$ & done & 8 & $\begin{array}{l}46145 N 4 E \\
{[46145 N 11]}\end{array}$ \\
\hline
\end{tabular}


RPP-6702, Rev. 0

Formerly HNF-SD-WM-PAP-062 Rev. 4

\begin{tabular}{|l|r|c|l|}
\hline Description & $\begin{array}{r}\text { Due } \\
\text { Date }\end{array}$ & Level & $\begin{array}{l}\text { MYWP } \\
\text { Identifier }\end{array}$ \\
\hline Write Far-field Geochemical Document & done & 8 & $\begin{array}{l}\text { 46145N4C } \\
{[46145 N 44]}\end{array}$ \\
\hline $\begin{array}{l}\text { Issue 2001 PA Far-Field Geochemical Data } \\
\text { Package }\end{array}$ & done & 7 & $\begin{array}{l}\text { 46145N5A } \\
\text { [46145N52] }\end{array}$ \\
\hline
\end{tabular}

c. Cost Summary WBS: 1.01 .09 .01 .01 .31 .02 .02 .06

CACN: 1D9DM3

Table 3.2-8b Cost Summary for 2001 PA Far-Field Geochemical Data Package

\begin{tabular}{|l|l|r|}
\hline Fiscal Year & Organization & Amount (\$1000) \\
\hline 1997 & Pacific Northwest National Laboratory (PNNL) & 60 \\
\hline 1998 & PNNL & 185 \\
\hline 1999 & PNNL & 135 \\
\hline 2000 & PNNL & 11 \\
\hline Grand total & 391 \\
\hline
\end{tabular}

d. Detailed Description

1998

Determine Geochemical Parameters of Borehole Samples-1998

$\underline{\mathrm{K}}_{\mathrm{d}}$ measurements of borehole samples-1998: The types of experiments that were conducted in this task were greatly limited due to sample size limitations. Thus, borehole samples were not be used to develop our understanding of the geochemical processes affecting radionuclide interactions with Hanford sediments. Instead, the borehole samples were used exclusively for generating site-specific $K_{d}$ values. The nonborehole sediments continue to be used to improve our conceptual understanding of radionuclide geochemistry in the vadose zone.

This task provided site-specific $K_{d}$ values for $\mathrm{Cs}, \mathrm{Sr}, \mathrm{U}, \mathrm{Se}, \mathrm{Tc}$, and I. The $\mathrm{K}_{\mathrm{d}}$ values were measured using two types of groundwater: one to simulate far-field conditions and the other to simulate near-field conditions. The cost of doing this work increased by approximately $25 \%$ due to the higher QA requirement for this task.

Determine Geochemical Parameters of Non-Borehole Samples-1998-2000: Moisture Saturation on $\mathrm{K}_{d}$ Values-1998.

It is very important to understand the geochemical processes affecting radionuclide chemistry in the study site. Improving this understanding provides technical defensibility for selecting the correct conceptual models.

Experiments were conducted in FY96 indicating that $U-K_{d}$ values have a moisture dependency (Kaplan et al. 1996). The results indicated that the $K_{d}$ value in fine-grain sediments tended to increase upon desaturation. In coarse-grained sediment, the $K_{d}$ values tended to decrease upon desaturation. These results require confirmation since 
RPP-6702, Rev. 0

Formerly HNF-SD-WM-PAP-062 Rev. 4

they are novel and perhaps more importantly, may require that $K_{d}$ values lower than those measured by traditional batch methods, be used for the PA. As the results presently stand, not enough information is available to quantitatively predict the effect of moisture content on $\mathrm{K}_{d}$ values. Additional moisture dependency experiments will be conducted with two additional sediments, a coarse-textured and a fine-textured sediment.

1999

Geochemical Parameters for Borehole Samples-1999

This task is a continuation of the 1998 task and provides site-specific $K_{d}$ values for $\mathrm{Cs}, \mathrm{Sr}, \mathrm{U}, \mathrm{Se}, \mathrm{Tc}$, and I. The $\mathrm{K}_{\mathrm{d}}$ values are measured using two types of groundwater: one to simulate far-field conditions and the other to simulate near-field conditions. It is anticipated that the cost of doing this work will increase by approximately $25 \%$ due to the higher QA requirement for this task: QA Level II.

\section{Geochemical Parameters for Non-borehole Samples-1999}

1. Unsaturated Effects on $K_{d}$ Values: To date, experiments conducted for the ILAW-PA project has shown that $U-K_{d}$ values vary as a function of moisture saturation (Kaplan 1996). This trend varies with sediment texture. For fine textured sediments, as moisture increases, $U-K_{d}$ values increase. For coarse textured sediments, as moisture increases, $U-K_{d}$ values decrease. Experiments have been initiated in FY98 to confirm these trends with three additional sediments.

A hypothesis was proposed by Kaplan (1996) to explain these trends. Briefly, in coarser textured sediments, as the saturation decreases, the water associated with the hydraulically isolated fines becomes largely immobile and most of the water flows, via film flow, along the sides of larger pores. These larger pores are lined by larger particles, mainly quartz and feldspar. These minerals tend to have low sorption potentials for $U$. In the finer textured sediments, as the saturation decreases, the larger pores drain first. This results in the water flowing mostly in the smaller pores, which are lined by smaller particles. But unlike in the coarser sediment, the fines form hydraulically continuous pores through out the length of the column. Consequently, the water and the $U$ in the water come into contact more with the fine particles as desaturation of the sediment increases. Again, these fines have a greater sorption capacity than the larger particles for $U$.

The objective of this task is to create columns of sediments by arranging coarse and fine particles in various special arrangements to test the above hypothesis. This work will directly test the above hypothesis and will provide a conceptual model of how to treat $K_{d}$ moisture dependency. The previous unsaturated $K_{d}$ work will provide the actual values to use in the conceptual model identified by these experiments.

\section{PA Far-Field Geochemical Data Package-1999}

A plan was prepared for the review of the far-field geochemical data activity and for the data package produced by the activity. Review started once the performance assessment activity leader approved the plan. 


\section{RPP.6702, Rev. 0 \\ Formerly HNF-SD-WM-PAP-062 Rev. 4}

All the far-field data was tabulated and statistically analyzed. Selection of conservative and best estimates was made and justified. Variability of the values was assigned to each estimate. No significant difference was found to exist between ILAW borehole-specific and non-borehole samples, thus all available Hanford formation $K_{d}$ data were combined.

\section{PA Far Field Geochemical Data Package-2000}

In the first half of FY2000 the external technical peer review and data package final publication occurred. The 2001 far field geochemical data package contains all the $\mathrm{K}_{\mathrm{d}}$ data and the justification for the chosen values. The intent of the information is to allow a suite of performance calculations to be performed for the $2001 \mathrm{PA}$.

e. Interfaces

This task builds on FY97 effort (development of a test plan, the start of data collection using Hanford soils). This task received borehole samples from 299 E17-21 (see 3.2.C.ii) to develop site-specific data. The task produced a report [Kaplan et al. 1998] that forms part of the data packages of the 2001 Performance Assessment (3.0). The task builds on FY 98 and FY 99 tasks that identified particle scale hydraulic heterogeneity arising from regions of mobile-immobile water as a contributor to variability in contaminant sorption during transport in unsaturated sediments. Hydraulic heterogeneity will be established under the hydraulic parameters task (section $3.2 \mathrm{C}$. vi.) which is the underlying basis for assessing sorption heterogeneity.

f. Organization

The Applied Geology and Geochemistry section of the Pacific Northwest National Laboratory (PNNL) has supplied the far-field geochemical data for all the performance assessments concerning Hanford waste. The Applied Geology and Geochemistry group has been addressing the issue of sorption heterogeneity (Kaplan et al., 1996; Gamerdinger et al., 1998) and recently coupled this with hydraulic heterogeneity at the column scale. 
RPP-6702, Rev. 0

Formerly HNF-SD-WM-PAP-062 Rev.4

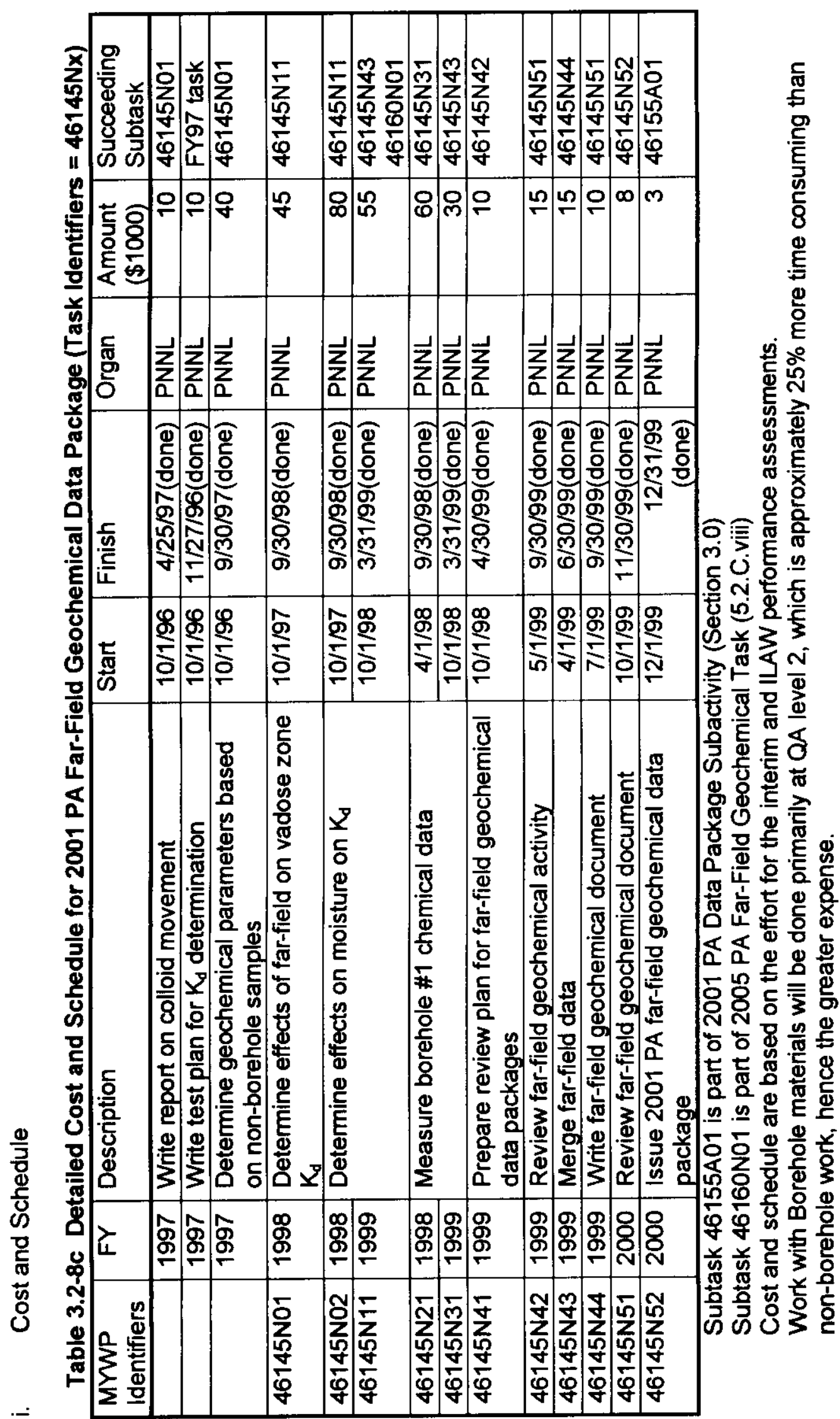


RPP-6702, Rev. 0

Formerly HNF-SD-WM-PAP-062 Rev. 4

ix. Select and Upgrade Vadose Zone Moisture Flow and Contaminant Transport Simulation Code(Complete)

a. Background

Even the most mobile contaminants will take thousands of years to move from the disposal facility to the groundwater under the expected conditions. Given the relatively complex geometry and long-time frames, computer simulation of the movement of the contaminants through the vadose zone is necessary.

For the interim and ILAW performance assessments, general computer code selection criteria were established in Computer Code Selection Criteria and Considerations for the Hanford Low-Level Waste Interim Performance Assessment (Mann 1995g). The selection of the code for use in the flow and transport calculation was documented in Selection of Flow and Transport Code for the Hanford Low-Level Tank Waste Interim Performance Assessment (Piepho 1995).

The same version of the PORFLOW moisture flow and contaminant transport code was used in both the Grout Performance Assessment (Kincaid 1995a) as well as the Interim and ILAW Performance Assessments (Mann 1997a and Mann 1998). Many thousands of hours of computing time were used for each assessment. Given the improvements in modeling and computer hardware, a new version of the modeling code will be cost beneficial.

With the publication of the vadose zone computer code selection document (Voogd 1999) and of the verification and validation document (Finfrock 2000), this activity is complete.

b. List Of Deliverables

Table 3.2-9a List of Deliverables for 2001 PA Vadose Zone Simulation Code Data Package

\begin{tabular}{|l|r|c|l|}
\hline Description & Due & Level & $\begin{array}{l}\text { MYWP } \\
\text { Identifier }\end{array}$ \\
\hline $\begin{array}{l}\text { Obtain License for new version of } \\
\text { PORFLOW }\end{array}$ & done & 7 & FY97 \\
\hline $\begin{array}{l}\text { Issue PORFLOW Quality Assurance } \\
\text { documentation }\end{array}$ & done & 7 & FY97 \\
\hline Issue Vadose Zone Code Selection Criteria & done & 8 & $\begin{array}{l}46145 P O F \\
{[46145 P 03]}\end{array}$ \\
\hline $\begin{array}{l}\text { Select Code to be Used in Vadose Zone } \\
\text { Calculations }\end{array}$ & done & 7 & $\begin{array}{l}46145 \mathrm{POE} \\
{[46145 \mathrm{P} 08]}\end{array}$ \\
\hline Issue Plan to Upgrade Code & done & 7 & $\begin{array}{l}\text { 46145POD } \\
{[46145 \mathrm{P} 11]}\end{array}$ \\
\hline $\begin{array}{l}\text { Issue User's Manual for Upgraded Vadose } \\
\text { Zone Code }\end{array}$ & done & 8 & $\begin{array}{l}46145 \mathrm{P} 1 \mathrm{~B} \\
{[46145 \mathrm{P} 12]}\end{array}$ \\
\hline $\begin{array}{l}\text { Issue V\&V Report on Upgraded Vadose } \\
\text { Zone Code }\end{array}$ & done & 7 & $\begin{array}{l}46145 \mathrm{P} 1 \mathrm{~A} \\
{[46145 \mathrm{P} 13]}\end{array}$ \\
\hline
\end{tabular}


RPP-6702, Rev. 0

Formerly HNF-SD-WM-PAP-062 Rev. 4

c. Cost Summary WBS: 1.01 .09 .01 .01 .31 .02 .02 .08 CACN: 1D9DM3, 2D9DM3

Table 3.2-9b Cost Summary for 2001 PA Vadose Zone Simulation Code Data Package

\begin{tabular}{|l|l|r|}
\hline Fiscal Year & Organization & Amount (\$1000) \\
\hline 1997 & Fluor Federal Services (FFS) & 2 \\
\cline { 2 - 3 } & Lockheed Martin Services, Inc. (LMSI) & 30 \\
\cline { 2 - 3 } & Pacific Northwest National Laboratory (PNNL) & 1 \\
\cline { 2 - 3 } & Total & 33 \\
\hline 1998 & FFS & 28 \\
\cline { 2 - 3 } & LMSI & 8 \\
\cline { 2 - 3 } & PNNL & 8 \\
\cline { 2 - 3 } & Total & 44 \\
\hline 1999 & FFS & 75 \\
\cline { 2 - 3 } & Lockheed Martin Hanford Company (LMHC) & $20^{\star}$ \\
\cline { 2 - 3 } & Total & $95^{\star}$ \\
\hline 2000 & FFS & 14 \\
\hline Grand total & & 186 \\
\hline
\end{tabular}

Includes $\$ 20 \mathrm{~K}$ of CENTRC funds.

d. Detailed Description

A set of code selection criteria were developed (Mann 1998b). In FY98, the Program Activity Manager selected a code to be used for modeling of moisture flow and contaminant transport in the unsaturated (vadose) zone.

During FY99, the code was updated to improve the applicability of the selected code to ILAW vadose zone modeling. Such improvements was identified as part of the code selection process. Any changes were documented. During the latter part of FY99 and during the early part of FYOO, verification and validation studies were performed on the modified code and documented.

e. Interfaces

This task will build on the experiences gained from calculations performed for the Interim and ILAW performance assessments as well as other Hanford performance and risk assessments. The output of this task was a verified code to be used in the calculations for the 2001 and 2005 performance assessments.

f. Organization

The Environmental and Nuclear Initiatives Section of Fluor Federal Services (FFS) have responsible during the code selection phase.

FFS has performed calculations for various Hanford performance and risk assessments including the ILAW Performance Assessment.

The Scientific Systems and Program Support Section of Lockheed Martin Services, Inc. (LMSI) have also performed many of the calculations for Hanford 


\section{RPP-6702, Rev. 0}

Formerly HNF-SD-WM-PAP-062 Rev. 4

performance and risk assessments, including the interim and ILAW performance assessment.

The Hydrology Section of the Pacific Northwest National Laboratory (PNNL) has provided the calculations for various Hanford risk assessments including the composite analysis. 
RPP-6702, Rev. 0

Formerly HNF-SD-WM-PAP-062 Rev. 4

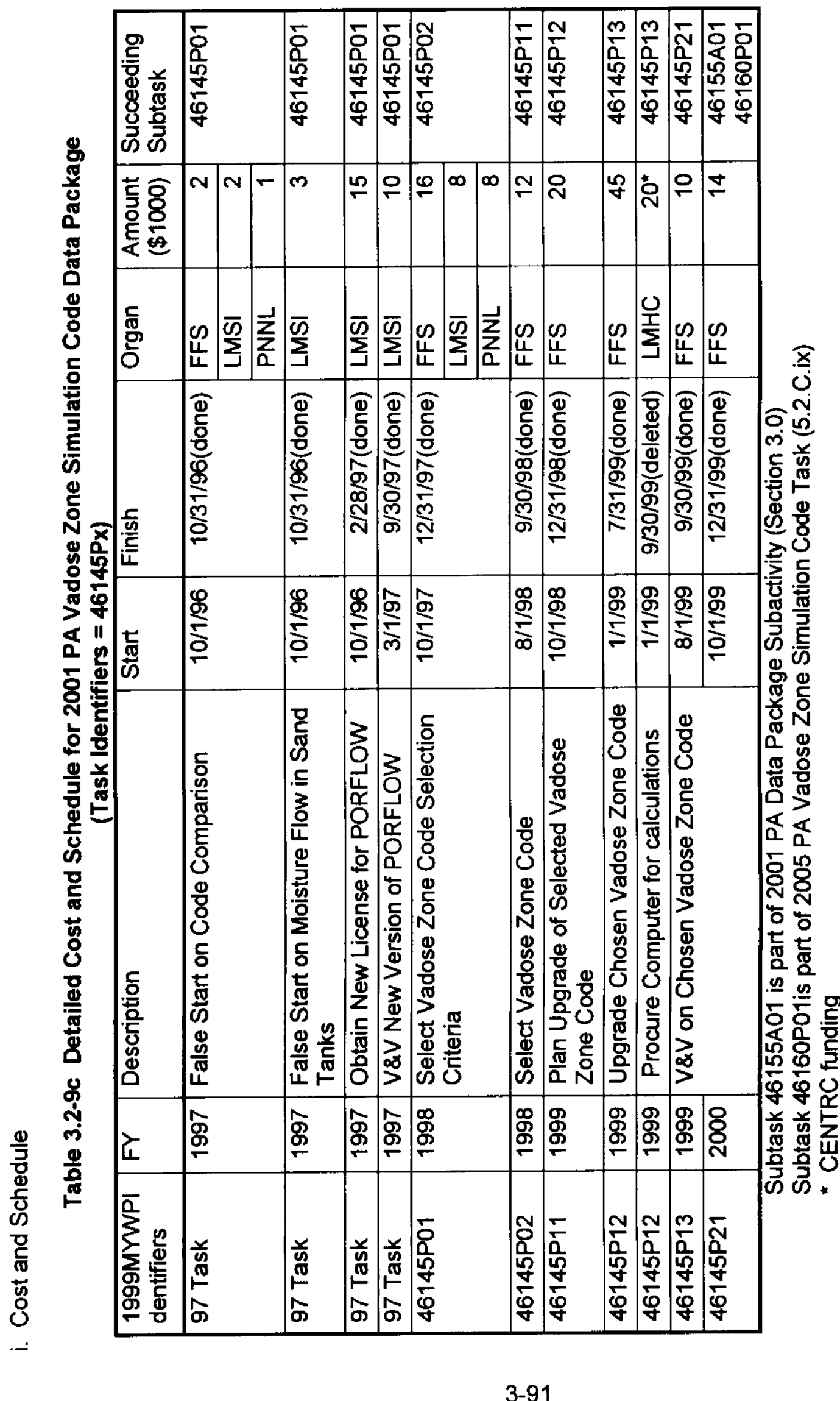


RPP-6702, Rev. 0

Formerly HNF-SD-WM-PAP-062 Rev. 4

x. Interact with Hanford Groundwater Project Concerning Hanford Site Groundwater Simulation Code Package

This section now in "Interact with Hanford Site Integrated Vadose Zone/Groundwater/Columbia River Project" (see section 9.C.viii). 


\subsection{OTHER DATA COLLECTION}

\section{A. SUMMARY (Complete)}

Issue reports documenting other data (inventory in waste form, disposal facility conceptual model, dosimetry, performance objectives, and scenarios) to be used in the 2001 performance assessment. These data are determined (or largely influenced) by others. Thus these tasks are largely interfacial and documentary.

With the issuance of the applicable data packages for the 2001 ILAW PA (Mann 199a, Mann 199b, Wootan, 1999, Puigh 1999b, Rittmann 1999, and Evans 2000), this activity is complete.

\section{B. GENERAL}

i. Background

Unlike the waste form (Section 3.1) and geotechnical (Section 3.2) data collection subactivities where the performance assessment data activity performs most of the work in gathering the data, other data are needed for the performance assessment that mainly is gathered or controlled by others. These data include

a. Inventory in the waste form,

b. Conceptual model of the disposal facility,

c. Dosimetry data,

d. Performance objectives, and

e Scenarios.

The inventory in the disposed waste form depends on the amount of materials in the Hanford tanks and on the separations performed by the private vendors. By using historical records and computer modeling, the Standard RPP Inventory effort will provide estimates of radionuclides in the tanks. The private vendors will separate the tank waste into a high-activity component and a low-activity component and information about their processes and specifications will determine the estimate of the amount of material in the immobilized low-activity waste form.

By the time of the 2001 performance activity, a conceptual design of the disposal facility will be ready. This conceptual design will be translated into a model suitable for computer generation. In addition, this task will provide the lessons learned from the performance assessment activity to those responsible for facility design.

The dosimetry data translate the radionuclide concentrations into dose rates. In addition, some scenario parameter data that have been standardized for the Hanford Site are documented.

The performance objectives for the performance assessment are becoming more standardized as the Department of Energy gains experience in performing performance assessments. However, there are still objectives that must be established locally. 
RPP-6702, Rev. 0

Formerly HNF-SD-WM-PAP-062 Rev. 4

The scenarios and pathways needed to be investigated are also becoming standardized, especially at the Hanford Site. However, because of the some of the unique features of tank waste disposal, some documentation is required.

\section{ii. List of Deliverables}

Table 3.3-1a List of Major Deliverables for 2002 PA Other Data Collection Subactivity

\begin{tabular}{|c|c|c|c|}
\hline Description & Due Date & Level & $\begin{array}{c}\text { MYWP } \\
\text { Identifier }\end{array}$ \\
\hline Issue 2001 PA Inventory Data Package & done & 6 & $46145 \mathrm{QAA}$ \\
\hline $\begin{array}{c}\text { Issue 2001 PA Conceptual Model Data } \\
\text { Package }\end{array}$ & done & 7 & $46145 \mathrm{R} 2 \mathrm{~A}$ \\
\hline $\begin{array}{c}\text { Issue 2001 PA Dosimetry Data Package } \\
\text { Issue 2001 PA Performance Objectives } \\
\text { Data Packages }\end{array}$ & done & 7 & $46145 S 2 \mathrm{~A}$ \\
\hline Issue 2001 PA Scenarios Data Package & done & 7 & $46145 T 1 \mathrm{~A}$ \\
\hline
\end{tabular}

iii. Cost Summary WBS: $1.1 .3 .4 .1 .3 .4 \quad$ TPCN: D4DM4

Table 3.3-1b Cost Summary for 2001 PA Other Data Collection

\begin{tabular}{|l|l|r|}
\hline Fiscal Year & Organization & $\begin{array}{c}\text { Amount } \\
(\$ 1000)\end{array}$ \\
\hline 1997 & Fluor Federal Services (FFS) & 40 \\
\hline 1998 & FFS & 86 \\
& PNNL & 60 \\
\hline 1999 & FFS & 118 \\
& PNNL & 46 \\
\hline 2000 & FFS & 41 \\
\cline { 2 - 3 } & Pacific Northest National Laboratory & 19 \\
\cline { 2 - 3 } & Total & 60 \\
\hline \hline
\end{tabular}

iv. Interfaces

Because of the many interfaces involved in this subactivity, they will be discussed under each task.

v. Organization

The Environmental and Nuclear Initiative Section of Fluor Federal Services (FFS) is responsible for leading the Hanford Low-activity Tank Waste Performance Assessment activity. Its staff have developed the contacts with the various 
RPP-6702, Rev. 0

Formerly HNF-SD-WM-PAP-062 Rev. 4

organizations to provide the proper interfaces for the activity. One of its members is on the Hanford Environmental Dose Oversight Panel.

\section{TASK DESCRIPTIONS}

i. Summary List of Tasks
a. Determine Waste Form Inventory
b. Determine Disposal Facility Conceptual Model
c. Determine Dosimetry Data
d. Determine Performance Objectives
e. Determine Scenarios and Pathways to be Analyzed

ii. Determine Waste Form Inventory (Complete)

a. Background

The environmental and human health impact of disposal of Hanford's tank waste is proportional to the amount of ${ }^{99} \mathrm{Tc}$ (and to other key nuclides for longer times). The amount of the key isotopes $\left({ }^{99} \mathrm{Tc},{ }^{79} \mathrm{Se},{ }^{237} \mathrm{~Np}\right.$, and the uranium isotopes) depends both on the amount of the isotopes in the tanks and the degree of separations performed by the private vendor.

Currently only that immobilized low-activity tank waste provided by the vendor will be placed in the disposal facility being analyzed by the performance assessment activity. Other low-level waste produced by the vendor (for example, chemical resins, melter components, and off-gas filters) will, by contract, go to other disposal sites. Although other types of waste have been proposed for disposal in the facility, so far more suitable disposal sites have been identified for such waste.

The Standard RPP Inventory effort is chartered to provide the official estimates of tank inventories of important radionuclides and chemical starting at the end of FY97. The estimates will be updated roughly twice a year thereafter. The estimates are based on production records, transfer records, and computer simulations. Members of the performance assessment team have played a major role in the determination of the radionuclide inventory.

The private vendors will separate the tank waste into a low-activity and a highactivity component before immobilizing the waste. The intent is to maximize the amount of radionuclides in the high-activity waste, while maximizing the volume of tank waste in the low-activity fraction.

This task will interface with both groups, attempting to obtain the best estimates from each so that a good estimate of the tank waste inventory to be disposed on the Hanford Site will be obtained.

The effort for the interim and ILAW performance assessments was based on the estimate of tank contents based on reactor production calculations and research on Hanford process knowledge preformed by the performance assessment team. Knowledge of separations chemistry and likely immobilization strategies was taken from 
RPP-6702, Rev. 0

Formerly HNF-SD-WM-PAP-062 Rev. 4

RPP Engineering. The generation of the inventory data for the interim and ILAW performance assessments and the inventory data used were documented in Inventories for Low-Level Tank Waste (Schmittroth 1995).

With the publication of the inventory data package for the 2001 ILAW PA (Wootan 1999), this activity is complete.

b. List Of Deliverables

Table 3.3-2a List of Deliverables for 2001 PA Inventory Data Package

\begin{tabular}{||c|r|r|r|}
\hline Description & Due Date & Level & $\begin{array}{c}\text { MYWP } \\
\text { Identifier }\end{array}$ \\
\hline Write 2001 PA Inventory Document & done & 8 & $\begin{array}{r}46145 Q 1 B \\
{[46145 Q 13]}\end{array}$ \\
\hline Issue 2001 PA Inventory Document & done & 6 & $\begin{array}{r}46145 Q 2 A \\
{[46145 Q 22]}\end{array}$ \\
\hline
\end{tabular}

c. Cost Summary WBS: 1.1.1.3.4.1.3.3 TPCN:D4DM3

Table 3.3-2b Cost Summary for 2001 PA Inventory Data Package

\begin{tabular}{|l|l|r|}
\hline \multicolumn{1}{|c|}{ Fiscal Year } & \multicolumn{1}{|c|}{ Organization } & \multicolumn{1}{c|}{ Amount (\$1000) } \\
\hline 1997 & Fluor Federal Services (FFS) & 20 \\
\hline 1998 & FFS & 36 \\
\hline 1999 & FFS & 30 \\
\hline 2000 & FFS & 8 \\
\hline \hline Grand Total & 94 \\
\hline
\end{tabular}

d. Detailed Description

Determine the inventory to be used for the 2001 performance assessment by interacting with the RPP Standard Inventory Project and with the private vendors. The inventory estimates will not only include best estimates but also uncertainty values. To the extent possible (limited by tank by tank estimates and by changing vendor procedures), estimates will be provided for the maximum amounts of key isotopes as a function of waste production history.

e. Interfaces

The RPP Standard Inventory function is responsible for providing the radionuclide estimates by tank. The private vendors are responsible for developing the separations processes and treatment processes that will produced the immobilized lowactivity waste. 
RPP-6702, Rev. 0

Formerly HNF-SD-WM-PAP-062 Rev. 4

f. Organization

The Environmental and Nuclear Initiatives Section of Fluor Federal Services (FFS) produced the inventory estimates for the interim and ILAW performance assessments. The members of the section are in close contact both with the Standard RPP Inventory function and with the DOE contracting officers for the private vendors. 
RPP-6702, Rev. 0

Formerly HNF-SD-WM-PAP-062 Rev. 4

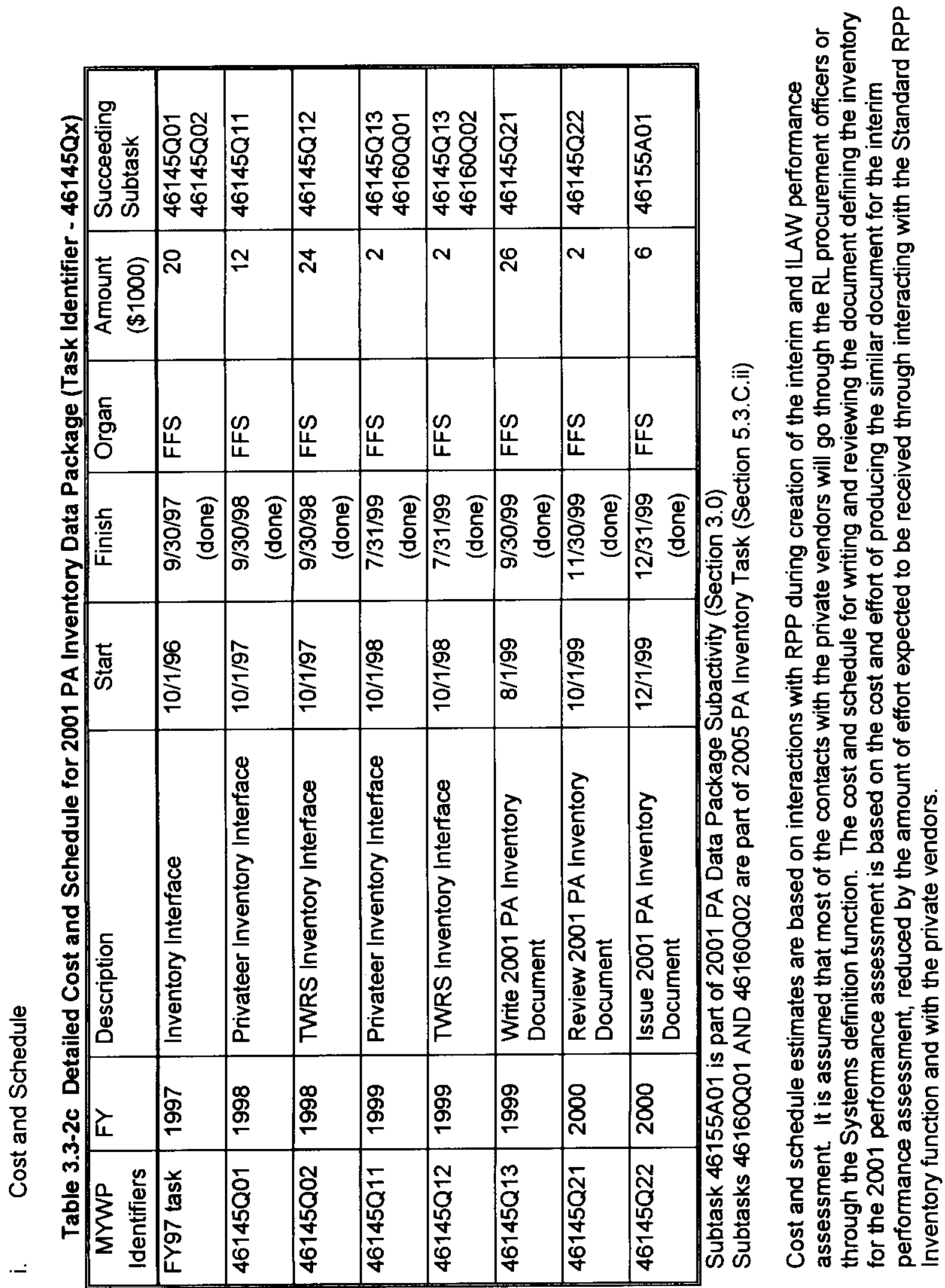


RPP-6702, Rev. 0

Formerly HNF-SD-WM-PAP-062 Rev. 4

iii. Determine Disposal Facility Conceptual Model (Complete)

a. Background

The Design and Construction Activity of the RPP Immobilized Waste Program is responsible for the design of the disposal facility. The performance assessment will interface with this activity to pass along the understanding achieved from the performance assessment analyses and to receive from them the current thinking on the design.

The performance assessment activity had most of the responsibility for choosing a design to be conceptualized for the interim and ILAW performance assessments. This effort was documented in Disposal Facility Data for the Interim Performance Assessment (Eiholzer 1955). The current design philosophy is documented in Burbank 1997, which was produced by the Design and Construction Activity.

With publication of the disposal facility data package for the 2001 ILAW PA (Puigh 1999b), this activity is complete.

b. List Of Deliverables

Table 3.3-3a List of Deliverables for 2001 PA Conceptual Model Data Package

\begin{tabular}{|l|l|c|l|}
\hline Description & $\begin{array}{l}\text { Due } \\
\text { Date }\end{array}$ & Level & $\begin{array}{l}\text { MYWP } \\
\text { Identifier }\end{array}$ \\
\hline $\begin{array}{l}\text { Write 2001 PA Conceptual Model Data } \\
\text { Package }\end{array}$ & done & 8 & $\begin{array}{l}46145 R 2 B \\
{[46145 R 21]}\end{array}$ \\
\hline $\begin{array}{l}\text { Issue 2001 PA Conceptual Model Data } \\
\text { Package }\end{array}$ & done & 7 & $\begin{array}{l}46145 R 2 A \\
{[46145 R 23]}\end{array}$ \\
\hline
\end{tabular}

c. Cost Summary WBS: $1.1 .1 .3 .4 .1 .3 .3 \quad$ TPCN:D4DM3

Table 3.3-3b Cost Summary for 2001 PA Conceptual Model Data Package

\begin{tabular}{|l|l|r|}
\hline \multicolumn{1}{|c|}{ Fiscal Year } & \multicolumn{1}{|c|}{ Organization } & $\begin{array}{c}\text { Amount } \\
(\$ 1000)\end{array}$ \\
\hline 1997 & Fluor Federal Services (FFS) & 20 \\
\hline 1998 & FFS & 30 \\
\hline 1999 & FFS & 20 \\
\hline 2000 & FFS & 15 \\
\hline \hline Grand Total & 85 \\
\hline
\end{tabular}

d. Detailed Description

Determine and document a conceptual model of the disposal facility for use in the 2001 performance assessment. Interactions with the System Definition Activity and with the Design Activity (including the architect-engineers) of the RPP Immobilized 
RPP-6702, Rev. 0

Formerly HNF-SD-WM-PAP-062 Rev. 4

Waste Project will include the communication of the long-term impacts of various design features and needs of the performance assessment activity. Interactions with the computer modelers of the performance assessment activity will ensure that the conceptual model is suitable for translation into a computer model.

This activity will also determine the likely degradation of the disposal facility. To the extent possible (given the stage of the design of the facility), parameters for the degradation shall be documented and justified.

e. Interfaces

The design effort is under the design activity of the RPP Immobilized Waste Project. An architect-engineer will be selected by the design activity to perform conceptual, preliminary, and detailed design. The output of this performance assessment task is to develop a model of the design of the architect-engineer's conceptual design suitable for computer analysis of the long-term environmental impacts. Those members of the performance assessment team responsible for modeling (3.1.C.vii) and (3.2.C.ix) will be engaged in determining the appropriate computer model.

f. Organization

The Environmental and Nuclear Initiatives Sections of Fluor Federal Services (FFS) will be responsible for the interface with the architect engineer and with the design activity. Members of the modeling effort (organizations to be determined base on code selection) will also be involved. 
RPP-6702, Rev. 0

Formerly HNF-SD-WM-PAP-062 Rev. 4

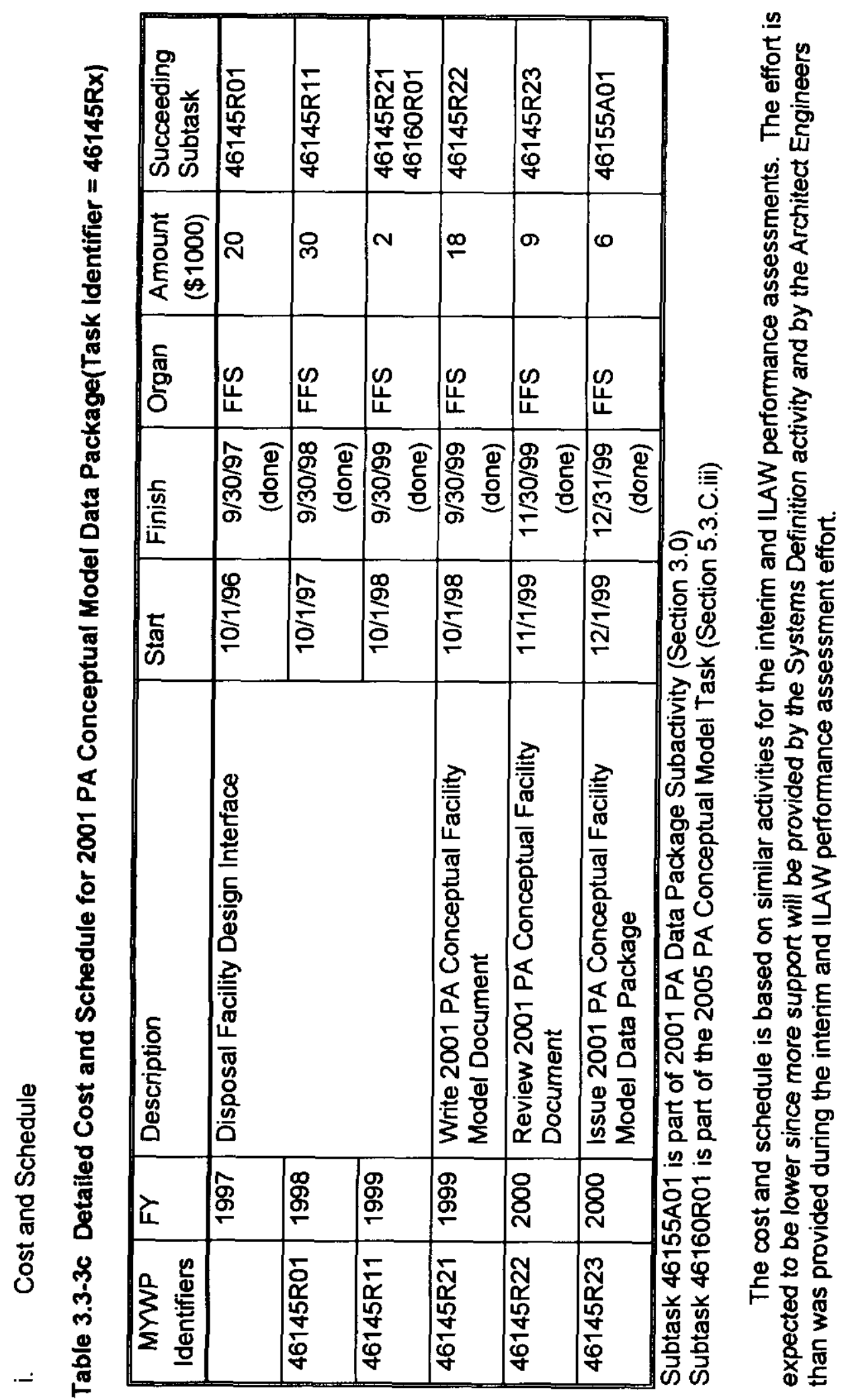


RPP-6702, Rev. 0

Formerly HNF-SD-WM-PAP-062 Rev. 4

iv. Determine Dosimetry Data (Complete)

a. Background

Dosimetry data are factors used to convert radionuclide concentrations in soil, air, and water into dose rates. They often depend on site-specific scenarios. The Hanford Environmental Dose Oversight Panel sets the standard methods and data for use in Hanford environmental dose assessments.

With the publication of the dosimetry data package for the 2001 ILAW PA (Rittmann 1999), this activity is complete.

b. List Of Deliverables

Table 3.3-4a List of Deliverables for 2001 PA Dosimetry Data Package

\begin{tabular}{|l|l|c|l||}
\hline Description & Due Date & Level & $\begin{array}{l}\text { MYWP } \\
\text { Identifier }\end{array}$ \\
\hline $\begin{array}{l}\text { Write 2001 PA Dosimetry Data } \\
\text { Report }\end{array}$ & done & 8 & $\begin{array}{l}46145 S 1 B \\
{[46145 S 12]}\end{array}$ \\
\hline $\begin{array}{l}\text { Issue 2001 PA Dosimetry Data } \\
\text { Report }\end{array}$ & done & 7 & $\begin{array}{l}46145 S 2 A \\
{[46145 S 22]}\end{array}$ \\
\hline
\end{tabular}

c. Cost Summary WBS: $1.1 .1 .3 .4 .1 .3 .3 \quad$ TPCN:D4DM3

Table 3.3-4b Cost Summary for 2001 PA Dosimetry Data Package

\begin{tabular}{|l|l|r|}
\hline Fiscal Year & \multicolumn{1}{|c|}{ Organization } & \multicolumn{1}{|c|}{$\begin{array}{c}\text { Amount } \\
(\$ 1000)\end{array}$} \\
\hline 1998 & Fluor Federal Services (FFS) & 20 \\
\cline { 2 - 3 } & $\begin{array}{l}\text { Pacific Northwest National Laboratory } \\
\text { (PNNL) }\end{array}$ & 60 \\
\cline { 2 - 3 } & Total & 80 \\
\hline 1999 & FFS & 25 \\
\hline 2000 & FFS & 9 \\
\hline \hline Grand Total & 114 \\
\hline
\end{tabular}

d. Detailed Description

Determine and document dosimetry parameters to be used in the 2001 performance assessment. To the maximum extent possible, values will be taken from standard sources, particularly those blessed by the Hanford Environmental Dose Oversight Panel who will review the documentation.

Because of the large uncertainties in the half-lives of the key radionuclide ${ }^{126} \mathrm{Sn}$, its half-life was measured. 
RPP-6702, Rev. 0

Formerly HNF-SD-WM-PAP-062 Rev. 4

e. Interfaces

The measurement of the ${ }^{126} \mathrm{Sn}$ half life will feed into the general dosimetry effort.

The general dosimetry effort is based on interacting with the Hanford Environmental Dose Oversight Panel. This panel will also reviewed (as required by $R L$ direction) the dosimetry parameters and calculations used in the performance assessment. This effort will build on the effort for the ILAW performance assessment.

f. Organization

The Environmental and Nuclear Initiatives Section of Fluor Federal Services (FFS) has produced the dosimetry data for various Hanford risk and performance assessments, including the interim and ILAW performance assessments.

The Radiological and Chemical Sciences Group at the Pacific Northwest National Laboratory have long measured low-level radiations as part of environmental and national defense missions. 
RPP-6702, Rev. 0

Formerly HNF-SD-WM-PAP-062 Rev. 4

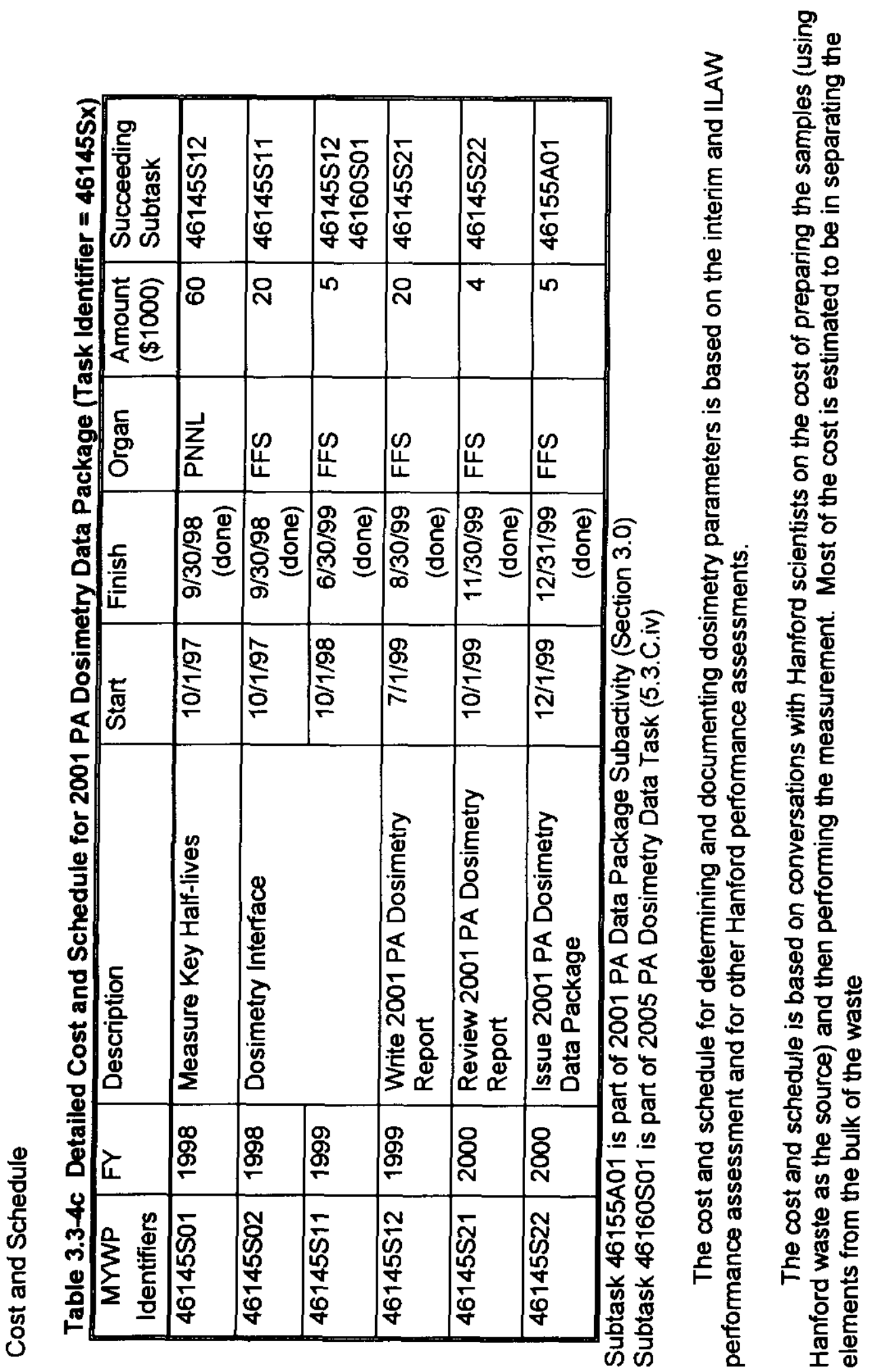


RPP-6702, Rev. 0

Formerly HNF-SD-WM-PAP-062 Rev. 4

v. Determine Performance Objectives (Complete)

a. Background

Performance objectives are the standards against which the environmental and health safety estimates from the performance assessment are compared. The performance objectives are becoming more standardized (Frei 1996) as DOE gains more experience with the performance assessment process. However, the requirements for performance assessments are expected to change as the underlying DOE Order (DOE 1988) is changed. In addition, there are still site-specific and disposalaction specific objectives (for example, groundwater protection, location of compliance) which must be determined locally. For the interim and ILAW performance assessments, scenarios were defined in Performance Objectives of the Tank Waste Remediation System Low-Level Disposal Program, (Mann 1995e).

With the publication of the performance objectives for the 2001 ILAW PA (Mann $1999 a)$, this activity is complete.

b. List Of Deliverables

Table 3.3-5a List of Deliverables for 2001 PA Performance Objectives Data Package

\begin{tabular}{||l|c|c|l||}
\hline Description & Due Date & Level & $\begin{array}{l}\text { MYWP } \\
\text { Identifier }\end{array}$ \\
\hline $\begin{array}{l}\text { Write 2001 PA Performance Objectives } \\
\text { Report }\end{array}$ & $\begin{array}{r}7 / 31 / 99 \\
\text { done }\end{array}$ & 8 & $\begin{array}{l}\text { 46145TOB } \\
\text { [46145T02] }\end{array}$ \\
\hline $\begin{array}{l}\text { Issue 2001 PA Performance } \\
\text { Objectives Data Package }\end{array}$ & done & 7 & $\begin{array}{l}46145 T 1 \mathrm{~A} \\
{[46145 T 12]}\end{array}$ \\
\hline
\end{tabular}

$\begin{array}{llll}\text { c. Cost Summary } & \text { BS: 1.1.3.4.1.3.3 TPCN:D4DM3 }\end{array}$

Table 3.3-5b Cost Summary for 2001 PA Performance Objectives Data Package

\begin{tabular}{|l|l|r|}
\hline \multicolumn{1}{|c|}{ Fiscal Year } & \multicolumn{1}{|c|}{ Organization } & \multicolumn{1}{|c|}{ Amount $(\$ 1000)$} \\
\hline 1999 & Fluor Federal Services (FFS) & 21 \\
\hline 2000 & FFS & 9 \\
\hline \hline Total & 30 \\
\hline
\end{tabular}

d. Detailed Description

Determine and document the performance objectives to be used in the 2001 performance assessment. The draft document was issued for public comment in February 1999. During the initial comment period, no comments were received. The comment period was extended for the State of Oregon. A revised document will be issued by the end of FY99. 
RPP-6702, Rev. 0

Formerly HNF-SD-WM-PAP-062 Rev. 4

e. Interfaces

This effort will build on the effort of the 2001 performance assessment and on guidance used by the DOE Office of Environmental Management. Because of the interest of Hanford stakeholders, review by the Hanford Advisory Board (or a subcommittee) is expected.

f. Organization

The Environmental and Nuclear Initiatives Section of Fluor Federal Services (FFS) produced the performance objectives for the interim and ILAW performance assessments. 
RPP-6702, Rev. 0

Formerly HNF-SD-WM-PAP-062 Rev. 4

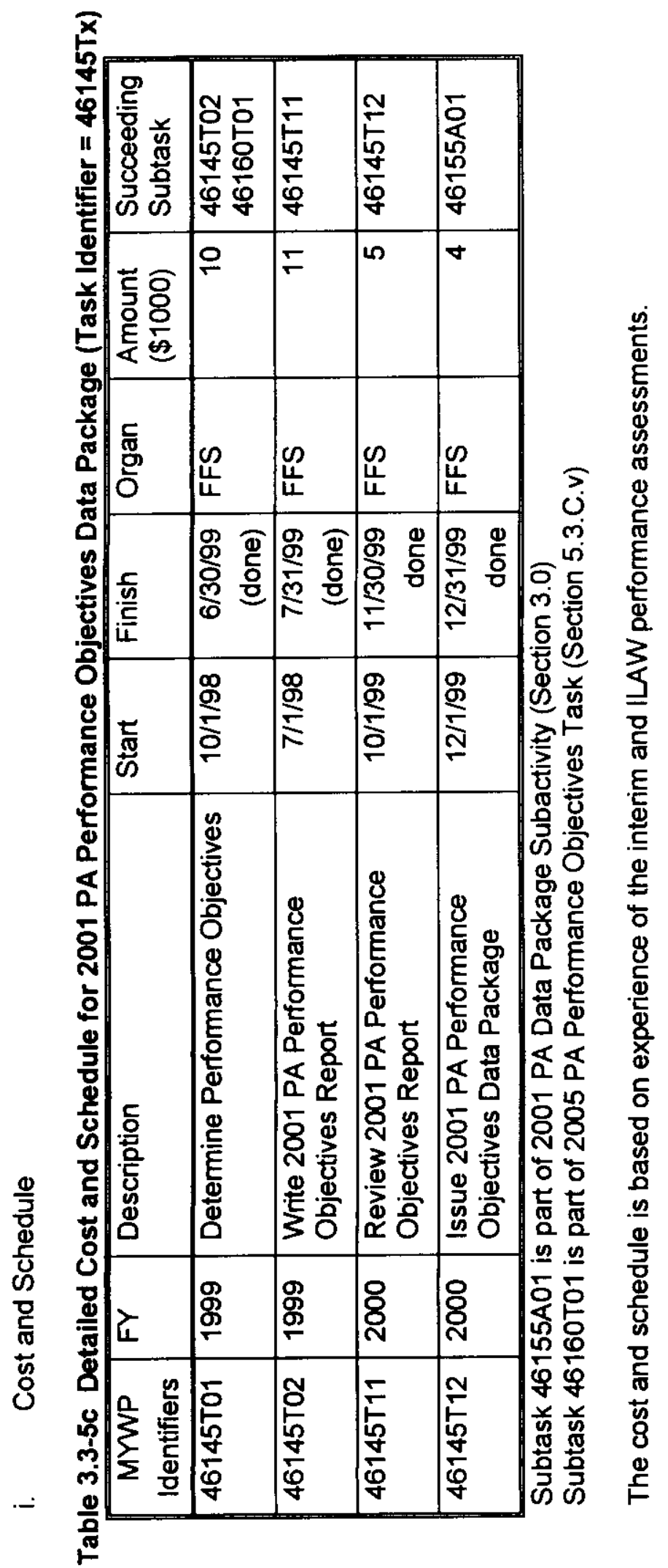


RPP-6702, Rev. 0

Formerly HNF-SD-WM-PAP-062 Rev. 4

vi. Determine Scenarios and Pathways to be Analyzed (Complete)

a. Background

Scenarios describe the pathways through which the contaminants move from the disposal facility to the place of compliance. Also included are the parameters associated with inadvertent intrusion into the facility. For the interim and ILAW performance assessments, scenarios were defined in Scenarios of the TWRS Low-Level Disposal Program, (Mann 1995f).

The 1998 Performance Assessment and the Hanford Site Composite Analysis (Kincaid 1998) both showed the need to better document various parameters of scenarios that are often taken for granted in Hanford Site analyses.

With the publication of the scenarios for the 2001 ILAW PA (Mann 1999b) and of document of potential future agricultural uses of the Hanford Site (Evans 2000), this activity is compleete.

b. List Of Deliverables

Table 3.3-6a List of Deliverables for 2001 PA Scenarios Data Package

\begin{tabular}{|l|l|c|l|}
\hline Description & $\begin{array}{l}\text { Due } \\
\text { Date }\end{array}$ & Level & $\begin{array}{l}\text { MYWP } \\
\text { Identifier }\end{array}$ \\
\hline $\begin{array}{l}\text { Document Future Agricultural } \\
\text { Scenarios }\end{array}$ & done & 8 & $\begin{array}{l}46145 \cup 0 C \\
{[46145 \cup 01]}\end{array}$ \\
\hline Write 2001 PA Scenario Report & done & 8 & $\begin{array}{l}46145 \cup 0 B \\
{[46145 \cup 03]}\end{array}$ \\
\hline $\begin{array}{l}\text { Issue 2001 PA Scenario Data } \\
\text { Package }\end{array}$ & done & 7 & $\begin{array}{l}46145 \cup 1 A \\
{[46145 U 12]}\end{array}$ \\
\hline
\end{tabular}

c. Cost Summary

WBS: $1.1 \cdot 1 \cdot 3 \cdot 4 \cdot 1 \cdot 3.3$

TPCN:D4DM3

Table 3.3-6b Cost Summary for 2001 PA Scenarios Data Package

\begin{tabular}{|l|l|r|}
\hline $\begin{array}{c}\text { Fiscal } \\
\text { Year }\end{array}$ & \multicolumn{1}{|c|}{ Organization } & Amount (\$1000) \\
\hline 1999 & Fluor Federal Services (FFS) & 22 \\
\cline { 2 - 3 } & Pacific Northwest National Laboratory & 46 \\
\cline { 2 - 3 } & Total & 68 \\
\hline 2000 & PNNL & 19 \\
\hline Grand total & 87 \\
\hline
\end{tabular}

d. Detailed Description

1. GENERAL

Determine and document the scenarios to be used in the 2001 performance assessment. 
RPP-6702, Rev. 0

Formerly HNF-SD-WM-PAP-062 Rev. 4

The draft document was issued for public comment. During the initial comment period, no comments were received. The comment period was extended for the State of Oregon. A revised document will be issued by the end of FY99.

\section{DEVELOPMENT OF HANFORD SITE AGRICULTURAL SCENARIOS}

Estimates of future exposure and dose depend directly on assumptions about future land use at the Hanford Site. Past analyses have shown the potential significance of excessive quantities of recharge attributed to current agricultural practices applied to regions of the site (Cearlock et al. 1966, DOE 1987, Kincaid et al 1995). Agricultural or family-farm scenarios generally yield the greatest dose from all-pathways exposure assessments. As part of the information compiled to support a composite analysis of radioactive wastes on the central plateau of the Hanford Site, an interview was conducted with regional agricultural experts at the Agricultural Experiment Station located at Prosser, Washington. The results of this dialogue formed the basis for some aspects of scenarios included and omitted from the composite analysis. However, the dialogue was not formalized in a report available for all programs at the Hanford Site. Under this activity, staff at the Experiment Station will work jointly with a PNNL staff member to develop a formal report documenting the likely future agriculture practices and applications at the Hanford Site.

With participation of PNNL staff, the staff of the Experiment Station will prepare a manuscript on all aspects of the future application of agriculture practices including 1) constraints on the availability of water at Hanford, 2) potential impacts of advanced methods of water and nutrient management, 3) potential risk and adverse U.S. public reaction to crops from Hanford soils, 4) potential for development of the East High region of the Columbia Basin Project, 5) likely crops related to favorable or unfavorable wind patterns, 6) the current ability of recharge to flush salts from the rooting depth, and 7) potential adverse intemational opinion to crops grown in Hanford soils making their way overseas.

The purpose of this activity is for the USDA Experiment Station at Prosser, expert in agriculture in the Columbia Basin, to provide a thorough and credible analysis of potential future agriculture at the present day Hanford Site. Clearly, a peer reviewed and accepted professional statement of the potential future agricultural practices applicable to the Hanford Site will significantly assist many programs in their efforts to quantify potential impacts on future generations.

A draft report entitled "Future Agricultural Practices and Applications at the Hanford Site" will be submitted on or before March 31, 1999. The final report will be revised to incorporate comments and will be published by June 30,1999 . Means and timing to produce this as a USDA Experiment Station publication will be explored with the Experiment Station staff. If this is not possible or intractable, a PNNL report will be issued.

The total budget requirement is $\$ 50 \mathrm{~K}$ in fiscal year 1999. PNNL will establish a subcontract with the Agricultural Experiment Station in Prosser, Washington, for the involvement of experts in soils, crops, water resources, nutrients requirements, salinity buildup, and agricultural resource management. The subcontract will be for $\$ 30 \mathrm{~K}$. 
RPP-6702, Rev. 0

Formerly HNF-SD-WM-PAP-062 Rev. 4

Costs within PNNL for participation in the work, administration of the subcontract, and publication of the report will be $\$ 20 \mathrm{~K}$. Because of existing work, the Agricultural Experiment Station started the work late and found that the scope should be somewhat extended. The work is expected to be completed in FY99. However, a task has been added for FYOO to ensure completion.

e. Interfaces

This effort builds on the effort of the 2001 performance assessment and on guidance used by the DOE Office of Environmental Management. Because of the interest of Hanford stakeholders, review by the Hanford Advisory Board (or a subcommittee) is expected.

f. Organization

The Environmental and Nuclear Initiatives Section of Fluor Federal Services (FFS) produced the scenarios for the 2001 ILAW performance assessments.

The Hydrology Technical Group of the Pacific Northwest National Laboratory will be responsible for the agricultural scenarios. This group was responsible for the Hanford Site Composite Analysis. 
RPP-6702, Rev. 0

Formerly HNF-SD-WM-PAP-062 Rev. 4

i. Cost and Schedule

Table 3.3-6c Detailed Cost and Schedule for 2001 PA Scenarios Data Package (Task (dentifier $=46145 \mathrm{Ux}$ )

\begin{tabular}{|c|c|c|c|c|c|c|c|}
\hline $\begin{array}{c}\text { MYWP } \\
\text { Identifiers }\end{array}$ & $\overline{F Y}$ & Description & Start & Finish & Organ & $\begin{array}{l}\text { Amount } \\
(\$ 1000)\end{array}$ & $\begin{array}{l}\text { Succeeding } \\
\text { Subtask }\end{array}$ \\
\hline $46145 \cup 01$ & 1999 & $\begin{array}{l}\text { Document Agricultural } \\
\text { Scenarios }\end{array}$ & $10 / 1 / 98$ & $\begin{array}{r}9 / 30 / 99 \\
\text { (done) }\end{array}$ & $\overline{P N N L}$ & 46 & $46145 \cup 03$ \\
\hline 46145U02 & $19 \overline{99}$ & $\begin{array}{l}\text { Determine } 2001 \mathrm{PA} \\
\text { Scenarios }\end{array}$ & $10 / 1 / 98$ & $\begin{array}{r}8 / 31 / 99 \\
\text { (done) }\end{array}$ & FFS & 10 & $\begin{array}{l}\text { 46145U03 } \\
\text { 46160R3 }\end{array}$ \\
\hline $46145 \cup 03$ & 1999 & $\begin{array}{l}\text { Write } 2001 \text { PA Scenarios } \\
\text { Report }\end{array}$ & $9 / 1 / 99$ & $\begin{array}{r}9 / 30 / 99 \\
\text { (done) }\end{array}$ & FFS & 12 & $46145 \cup 11$ \\
\hline $46145 \mathrm{U} 11$ & 2000 & $\begin{array}{l}\text { Review } 2001 \text { PA } \\
\text { Scenarios Report }\end{array}$ & $10 / 1 / 99$ & $\begin{array}{r}11 / 30 / 99 \\
\text { (done) }\end{array}$ & FFS & 0 & $46145 \cup 12$ \\
\hline $46145 \cup 12$ & 2000 & $\begin{array}{l}\text { Issue } 2001 \text { PA Scenarios } \\
\text { Data Package }\end{array}$ & $12 / 1 / 99$ & $\begin{array}{r}12 / 31 / 99 \\
\text { (done) }\end{array}$ & FFS & 0 & $46155 \mathrm{A01}$ \\
\hline $46145 \mathrm{U1}$ & 2000 & $\begin{array}{l}\text { Extend Agricultural } \\
\text { Scenario }\end{array}$ & $10 / 1 / 99$ & $\begin{array}{r}12 / 31 / 99 \\
\text { (done) }\end{array}$ & PNNL & 19 & $46155 \mathrm{~A} 01$ \\
\hline
\end{tabular}

Subtask 46155A01 is part of 2001 PA Data Package Subactivity (Section 3.0)

Subtask 46160R1 is part of 2005 PA Scenario Task (Section 5.3.c.vi) 


\section{RPP-6702, Rev. 0 \\ Formerly HNF-SD-WM-PAP-062 Rev. 4}

4.0 2001 PERFORMANCE ASSESSMENT

\section{A. SUMMARY}

Issue a report documenting the current state of knowledge of the long-term environmental and human-health impact from the disposal of the low-activity component of Hanford tank waste. The format and contents of the report shall follow as closely as possible the guidance provided by DOE .

Because the type of glass waste form to be disposed will have a significantly different composition and will be created at a significantly different temperature than the waste form (LD6-5412) used in the 98 ILAW PA, a formal performance assessment will be created for the 2001 Performance Assessment. This is a change from the assumption in last year's Statement of Work (Mann 1998c).

\section{B. GENERAL}

i. Background

The DOE order on radioactive waste management (DOE 1999) requires that when information affecting the estimation of the impacts from a disposal action is generated that the performance assessment be revised. Significant new data (glass composition, facility design, and site-specific geotechnical data) have been documented, necessitating a new performance assessment in 2001.

The Hanford Site has submitted five previous performance assessments (Kincaid 1995a, Wood 1994, Wood 1995, Wood 1996, and Mann 1998a). The information contained in these documents as well as the methods used by the activities that produced those documents will be used as much as possible in the generation of this 2001 performance assessment.

To support DOE's decision in August 2000 on how to proceed with the treatment contract, a white paper was issued in April 2000 describing the best estimate of how the waste packages and facility will impact long-term environmental health and safety. This white paper should form the core of the 2001 ILAW PA, however, further calculations may change the concussions of the white paper in minor ways. This white paper was issued (Mann 2000b). 
RPP-6702, Rev. 0

Formerly HNF-SD-WM-PAP-062 Rev. 4

ii. List of Deliverables

Table 4.0-1a List of Major Deliverables for Creating the 2001 PA

\begin{tabular}{|l|l|c|l||}
\hline Description & $\begin{array}{l}\text { Due } \\
\text { Date }\end{array}$ & Level & $\begin{array}{l}\text { MYWP } \\
\text { ldentifier }\end{array}$ \\
\hline $\begin{array}{l}\text { Issue 2001 PA base analysis case and } \\
\text { sensitivity cases definition }\end{array}$ & done & 6 & $46155 \mathrm{~A} 1 \mathrm{~A}$ \\
\hline $\begin{array}{l}\text { Issue White Paper on Waste Form and } \\
\text { Facility Performance }\end{array}$ & done & 5 & \\
\hline Write 2001 Performance Assessment & $2 / 28 / 01$ & 6 & $46155 \mathrm{C} 1 \mathrm{~B}$ \\
\hline Issue 2001 Performance Assessment & $3 / 31 / 01$ & 5 & $46155 \mathrm{C} 1 \mathrm{~A}$ \\
\hline $\begin{array}{l}\text { Receive Approval Comments from HQ on } \\
\text { 2001 PA }\end{array}$ & $3 / 31 / 02$ & 7 & $46155 \mathrm{D} 1 \mathrm{~A}$ \\
\hline
\end{tabular}

iii. Cost Summary

WBS: $1.1 .1 .3 .4 \cdot 1.3 .1$

TPCN: D4DM1

Table 4.0-1b Cost Summary for Creating 2001 PA

\begin{tabular}{|l|l|r||}
\hline Fiscal Year & Organization & Amount (\$1000) \\
\hline 2000 & Fluor Federal Services (FFS) & 268 \\
\cline { 2 - 3 } & Pacific Northwest National Laboratory (PNNL) & 152 \\
\cline { 2 - 3 } & Total & 420 \\
\hline 2001 & FFS & 122 \\
\hline 2002 & FFS & 5 \\
\hline \hline Grand Total & 547 \\
\hline
\end{tabular}

iv. Interfaces

All of the data and tools need for the $\mathbf{2 0 0 1}$ performance assessment are documented in the Data Packages for the Hanford Low-activity Tank Waste 2001 Performance Assessment, which is produced in Activity 46145A1 (See Chapter 3.0).

Information gained from this activity will feed into the data collection activities for the 2005 performance assessment (see Chapter 5.0) and will directly drive (particularly the comments from the headquarters review) the writing the 2005 performance assessment (see Chapter 6.0).

\section{v. Organization}

Fluor Federal Services (FFS) wrote the interim and the ILAW performance assessments and led their review. The organization that will calculate moisture flow and contaminant transport will be decided by selection process involving activities 46145P1 through 46145P8 (See Section 3.2.C.ix). For convenience, FFS is assumed to be the organization. 
RPP-6702, Rev. 0

Formerly HNF-SD-WM-PAP-062 Rev. 4

The Pacific Northwest National Laboratory (PNNL) has been assigned the task for developing a groundwater model for the Hanford Site. PNNL may also become responsible for actually running the model. For convenience, PNNL will run the model. PNNL performed the waste form calculations for the interim and ILAW performance assessments. PNNL was selected (Activity 46145B2, see Section 3.1.C.v) to calculate waste form performance for the 2001 PA.

\section{TASK DESCRIPTIONS}

i. Summary List of Tasks

a. Establish 2001 PA Base Analysis Case and Sensitivity Cases

b. Perform Calculations for the 2001 Performance Assessment

c. Issue the 2001 Performance Assessment for HQ Review

d. Receive Comments from Peer Review Panel on 2001 PA

ii. Establish 2001 PA Base Analysis Case and Sensitivity Cases (Complete)

a. Background

A lesson leamed during the review of the Grout Performance Assessment (Kincaid 1995a) was the careful creation and documentation of the basis analysis cases for the performance assessment. The creation of the Definition of the Base Analysis Case of the Interim Performance Assessment (Mann 1995c) greatly helped keep the analysts working to a defined set of data.

b. List Of Deliverables

Table 4.0-2a List of Deliverables for 2001 PA Base Analysis Case Definition

\begin{tabular}{|l|l|c|l|}
\hline Description & Due Date & Level & $\begin{array}{l}\text { MYWP } \\
\text { Identifier }\end{array}$ \\
\hline $\begin{array}{l}\text { Establish 2001 PA Base Analysis } \\
\text { Case and Sensitivity Cases }\end{array}$ & done & 6 & $\begin{array}{l}46155 \mathrm{~A} 1 \mathrm{~A} \\
\text { [46145A11] }\end{array}$ \\
\hline
\end{tabular}

c. Cost Summary

WBS: $1.1 \cdot 1 \cdot 3 \cdot 4 \cdot 1 \cdot 3.1$

TPCN:D4DM1

Table 4.0-2b Cost Summary for 2001 PA Base Analysis Case Definition

\begin{tabular}{|l|l|r|}
\hline Fiscal Year & Organization & Amount (\$1000) \\
\hline 2000 & Fluor Federal Services (FFS) & 27 \\
\hline
\end{tabular}

d. Detailed Description

Based on the information gathered during the data collection phase of the 2001 performance assessment, determine and justify the values of all parameters to be used in the base analysis case. The major sensitivity and uncertainty cases shall also be defined. 
RPP-6702, Rev. 0

e. Interfaces

The input to this task is the Data Packages for the 2001 Performance Assessment (Section 3.0). The output of this task will be used by those calculating responses for the 2001 performance assessment (Section 4.C.iii) and in the actual writing of the performance assessment (4.C.iv).

f. Organization

The Environment and Nuclear Initiatives Section of Fluor Federal Services (FFS) leads the performance assessment effort and hence is responsible for determining the base analysis case. 
RPP-6702, Rev. 0

Formerly HNF-SD-WM-PAP-062 Rev. 4

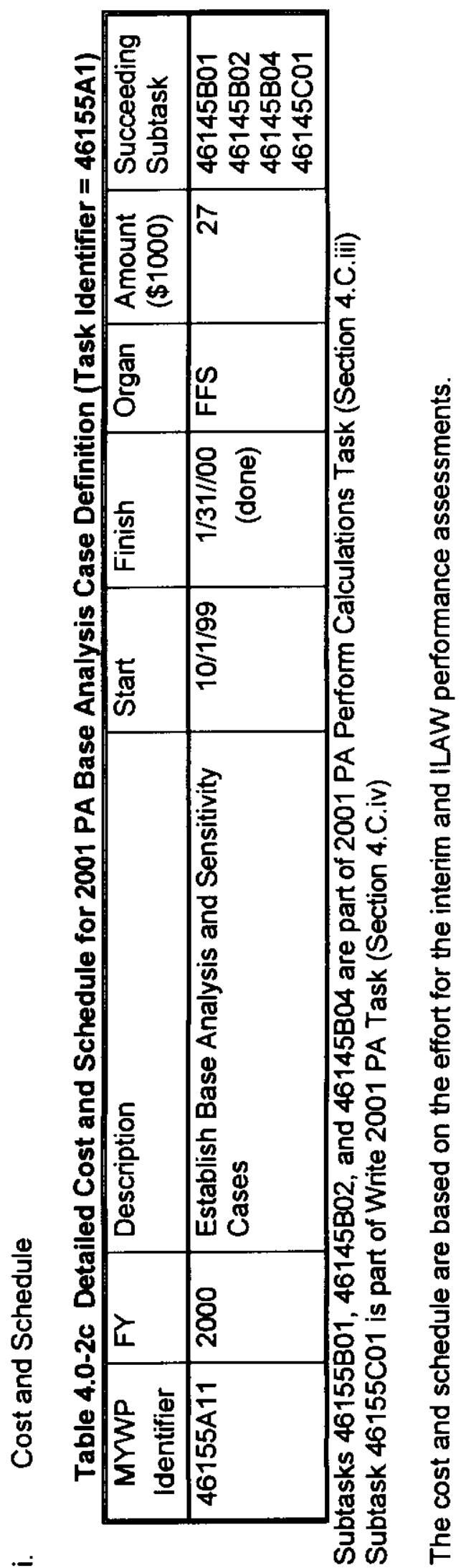


RPP-6702, Rev. 0

Formerly HNF-SD-WM-PAP-062 Rev. 4

iii. Perform Calculations for the 2001 Performance Assessment

a. Background

Estimations of long-term environmental and human health impacts must be performed for thousands of years into the future. Since extrapolations from experimental results are not sufficient, computer models must make these estimations. Because the complex geometry (waste form, disposal facility, vadose zone, and groundwater) involved, the calculations are complex and time consuming. Many hundreds of hours of computer time on scientific computers have been used on each of the Hanford performance assessments.

The major calculations involve

1) Calculation of the moisture flow in the disposal facility, providing a mechanism for the waste form to release its contaminants,

2) Calculation of the time and spatial dependent chemical environment surrounding the waste form and the resulting contaminant release rate from the waste form,

3) Calculation of the contaminant movement from the waste form (or disposal facility) through the vadose zone to the groundwater,

4) Calculation of the contaminant movement through the groundwater to the compliance point, and

5) Calculation of the long-term impact that combines the previous calculations with inventory and dosimetry values.

Because of the need to issue a white paper in April 2000 describing the results of the base analysis case, letter reports describing preliminary calculations was issued on March 30, 2000.

b. List Of Deliverables

Table 4.0-3a List of Deliverables for 2001 PA Perform Calculations

\begin{tabular}{||l|c|c|l||}
\hline Description & $\begin{array}{l}\text { Due } \\
\text { Date }\end{array}$ & Level & $\begin{array}{l}\text { MYWP } \\
\text { Identifier }\end{array}$ \\
\hline $\begin{array}{l}\text { Letter report on vault in flow calculations for } \\
\text { white paper }\end{array}$ & done & 8 & $946155 \mathrm{BO}$ \\
\hline $\begin{array}{l}\text { Letter report on waste form release calculations } \\
\text { for white paper }\end{array}$ & done & 8 & $946155 \mathrm{~B} 0$ \\
\hline $\begin{array}{l}\text { Letter report on vadose zone calculations for } \\
\text { white paper }\end{array}$ & done & 8 & $946155 \mathrm{~B} 0$ \\
\hline $\begin{array}{l}\text { Letter report on groundwater calculations for } \\
\text { white paper }\end{array}$ & done & 8 & $946155 \mathrm{BO}$ \\
\hline \begin{tabular}{l} 
Document flow calculations in the vault \\
\hline
\end{tabular}
\end{tabular}


RPP-6702, Rev. 0

Formerly HNF-SD-WM-PAP-062 Rev. 4

\begin{tabular}{|l|c|c|c|}
\hline $\begin{array}{l}\text { Document contaminant release rate from the } \\
\text { waste form/disposal facility }\end{array}$ & $9 / 30 / 00$ & 8 & $946155 \mathrm{BO}$ \\
\hline Document groundwater calculations & $9 / 30 / 00$ & 8 & $946155 \mathrm{~B} 0$ \\
\hline Document vadose zone contaminant transport & $11 / 30 / 00$ & 8 & $946155 \mathrm{~B} 1$ \\
\hline Calculate exposure impacts & $12 / 31 / 00$ & 8 & $946155 \mathrm{~B} 1$ \\
\hline
\end{tabular}

c. Cost Summary

WBS: $1.1 \cdot 1 \cdot 3 \cdot 4 \cdot 1 \cdot 3.1$

TPCN:D4DM1

Table 4.0-3b Cost Summary for 2001 PA Perform Calculations

\begin{tabular}{|l|l|r|}
\hline $\begin{array}{c}\text { Fiscal } \\
\text { Year }\end{array}$ & \multicolumn{1}{|c|}{ Organization } & $\begin{array}{r}\text { Amount } \\
(\$ 1000)\end{array}$ \\
\hline 2000 & $\begin{array}{l}\text { Fluor Federal ServicesFederal Services } \\
\text { (FFS) }\end{array}$ & 109 \\
\cline { 2 - 3 } & $\begin{array}{l}\text { Pacific Northwest National Laboratory } \\
\text { (PNNL) }\end{array}$ & 152 \\
\cline { 2 - 3 } & Total & 261 \\
\hline 2001 & FFS & 25 \\
\hline \hline Grand Total & 286 \\
\hline
\end{tabular}

d. Detailed Description

The calculations needed for the 2001 performance assessment shall be done and documented. The major tasks are

i. calculation of moisture flow into the disposal facility and then through the vadose zone,

ii. calculation of the contaminant release rate from the disposal facility as a function of time (given the moisture infiltration rate and changing chemical environment),

iii. calculation of the contaminant transport as a function of time from the disposal facility through the vadose zone,

iv calculation of contaminant transport through the groundwater, and

v. combining the results of the calculations with inventory and dosimetry data to determine exposure parameters.

For each of the categories, the cases to be run, the numerical codes to be used, and the data to be used are determined by earlier activities. For each category, an overview is presented describing the type of calculations to be performed. 
RPP-6702, Rev. 0

Formerly HNF-SD-WM-PAP-062 Rev. 4

i. Moisture Flow into Disposal Facility

As shown in the 98 ILAW PA, the rate of contaminant transport from the waste form through the disposal facility bottom depends on the amount of moisture entering the facility In addition, this calculation provides the amount of moisture that is diverted by the facility which is needed for vadose zone calculations. These calculations will determine the moisture flow from surface barrier and capillary barrier designs being considered by the Immobilized Waste Program. In addition, sensitivity studies will investigate the effect of early degradation and large man-made recharge scenarios.

\section{ii. Contaminant Release Rate from Facility}

Because BNFL, Inc. has not yet selected the waste form composition it will used, the release rates from a number of different compositions will be estimated. In addition, the sensitivity of release rates to various environmental conditions (e.g. infiltration rate, atmospheric gas mixing) and modeling assumptions (e.g., rate of ion exchange reaction rates, formation of secondary phases) will be determined. Based on the 1998 ILAW PA, these calculations will form the heart of the analysis as the release rate is the main controllable parameter that impacts the magnitude of long-term impact.

\section{iii. Contaminant Transport through Vadose Zone}

Once the contaminants are released from the waste form and leave the disposal facility, they are transported by moisture through the natural, unsaturated soils forming the vadose zone. This transport through the natural system determines the length of time before disposal action will impact humans or the surface environment. Because it is a natural system, our knowledge of its exact nature and its heterogeneities is limited. Sensitivity cases will be performed to determine the impact of this ignorance.

\section{iv. Contaminant Transport through Groundwater}

Once the contaminants leave the vadose zone and enter the groundwater, they begin to mix (and dilute) because of the much greater amount of water in the groundwater. In addition, their rate of transport increases, as does their amount of dispersion. Using the Hanford Site Groundwater Model, the sensitivity cases will be run to determine the impact of our lack of knowledge of groundwater flow.

\section{v. Combination of Results to Determine Exposure Parameters}

Each of the above calculations assume an unit inputs (e.g. $1 \mathrm{Ci}$ of inventory, 1 $\mathrm{Ci} / \mathrm{yr}$ of flux). The results of each of the calculations must be combined along with inventory and dosimetry conversion coefficients to determine impacts.

e. Interfaces

The inputs to this task are Data Packages for the 2001 Performance Assessment (Section 3.0), the definition of the base analysis case (Section 4.C.ii), and numerical code selections (3.1.C.iii for waste form and 3.2.C.ix for the vadose zone). By the decision of the Hanford Site Manager, the Hanford Groundwater Program is responsible for model and data selection for groundwater calculations. The output of this task will be results used in the writing of the 2001 performance assessment (Section 4.C.iv). 
RPP-6702, Rev. 0

Formerly HNF-SD-WM-PAP-062 Rev. 4

f. Organization

The groups whose codes were selected (waste form: 3.1.C.vii - PNNL, vadose zone: 3.2.C.ix - FFS, and groundwater: 3.2.C.X - PNNL) will be those performing the work.

g. Quality Assurance

All activities will be conducted in accordance with 10 CFR 830.120.

h. Effect of Not Performing Task

The performance assessment depends on the calculations of contaminant release and transport. Without such calculations, there can be no performance assessment. 
RPP-6702, Rev. 0

Formerly HNF-SD-WM-PAP-062 Rev. 4

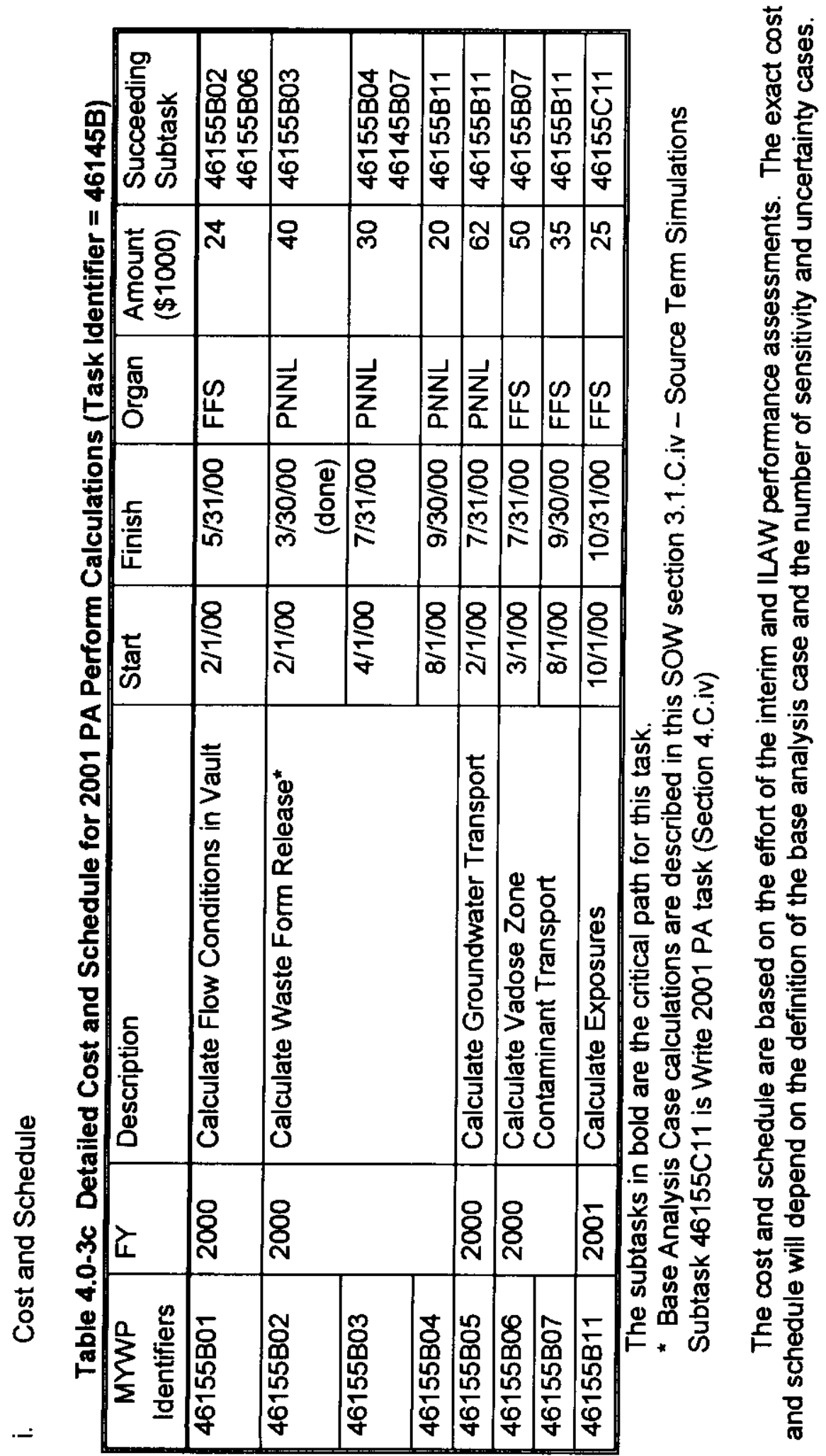


RPP-6702, Rev. 0

Formerly HNF-SD-WM-PAP-062 Rev. 4

iv. Write the 2001 Performance Assessment

a. Background

This task actually produces the 2001 performance assessment for the Department of Energy to review. The task will also produce the maintenance plan for future PAs as required by DOE policy and the new DOE Order on radioactive waste management (DOE O 435.1).

The 2001 ILAW PA will build on the experience of creating the interim and ILAW performance assessments (Mann 1997a and Mann 1998a) and the comments that were received on those documents. The maintenance plan will be based on the maintenance plan for the Hanford Site Solid Waste PAs.

b. List Of Deliverables

Table 4.0-4a List of Deliverables for Write 2001 PA

\begin{tabular}{|c|c|c|c|}
\hline Description & Due Date & Level & $\begin{array}{l}\text { MYWP } \\
\text { Identifier }\end{array}$ \\
\hline $\begin{array}{l}\text { Issue White Paper on Waste } \\
\text { Form and Facility Performance }\end{array}$ & done & 5 & $\begin{array}{l}46155 \mathrm{COA} \\
{[46155 \mathrm{CO}]}\end{array}$ \\
\hline Issue Maintenance Plan & done & 5 & [46155Co] \\
\hline $\begin{array}{l}\text { Write } 2001 \text { Performance } \\
\text { Assessment }\end{array}$ & $1 / 31 / 01$ & 6 & $\begin{array}{l}\text { 46155C1B } \\
{[46155 \mathrm{C} 11]}\end{array}$ \\
\hline $\begin{array}{l}\text { Issue } 2001 \text { Performance } \\
\text { Assessment }\end{array}$ & $3 / 31 / 01$ & 5 & $\begin{array}{l}46155 \mathrm{C} 1 \mathrm{~A} \\
{[46155 \mathrm{C} 13]}\end{array}$ \\
\hline
\end{tabular}

$\begin{array}{lll}\text { c. Cost Summary } \quad \text { WBS: } 1.1 .1 .3 .4 .1 .3 .1 & \text { TPCN:D4DM1 }\end{array}$

Table 4.0-4b Cost Summary for Write 2001 PA

\begin{tabular}{|l|l|r|}
\hline \multicolumn{1}{|c|}{ Fiscal Year } & \multicolumn{1}{|c|}{ Organization } & \multicolumn{1}{|c|}{ Amount (\$1000) } \\
\hline 2000 & Fluor Federal Services (FFS) & 132 \\
\hline 2001 & FFS & 87 \\
\hline \hline Grand Total & 219 \\
\hline
\end{tabular}

d. Detailed Description

Write the 2001 performance assessment document. This document will follow the guidelines currently in place for performance assessments. The current practice of an emphasis on justification is expected to continue. A white paper will be written to support the DOE decision on the extension of the contract with BNFL, Inc. This was completed by the issuance of Mann 2000b. 
RPP-6702, Rev. 0

Formerly HNF-SD-WM-PAP-062 Rev. 4

Write and issue maintenance plan for the ILAW performance assessments. This document is required by DOE policy and by the new DOE order on radioactive waste management (DOE O 435.1). The maintenance plan will be based on the maintenance plan for the Hanford Site Solid Waste PA as well as this statement of work. This was completed by issuance of Mann 2000a.

e. Interfaces

The inputs to this task are the Data Packages for the 2001 Performance Assessment (Section 3.0), the definition of the base analysis case (4.C.ii), and the calculations for the 2001 performance assessment (4.C.iii). The output of this task is the 2001 performance assessment that will be reviewed by the Department of Energy (Section 4.C.v) and by others. Conclusions of the 2001 performance assessment may affect the data collection effort for the 2005 performance assessment effort (Section 5.0). The 2005 performance assessment (Section 6.0) will be heavily based on the 2001 performance assessment.

f. Organization

The Environmental and Nuclear Initiatives Section of Fluor Federal Services (FFS) will write the 2001 performance assessment, just as they wrote the interim and ILAW performance assessments.

g. Quality Assurance

All activities will be conducted in accordance with 10 CFR 830.120.

h. Effect of Not Performing Task

The 2001 performance assessment is required by the Peer Review Panel before the submission of the 2005 performance assessment. 
RPP-6702, Rev. 0

Formerly HNF-SD-WM-PAP-062 Rev. 4

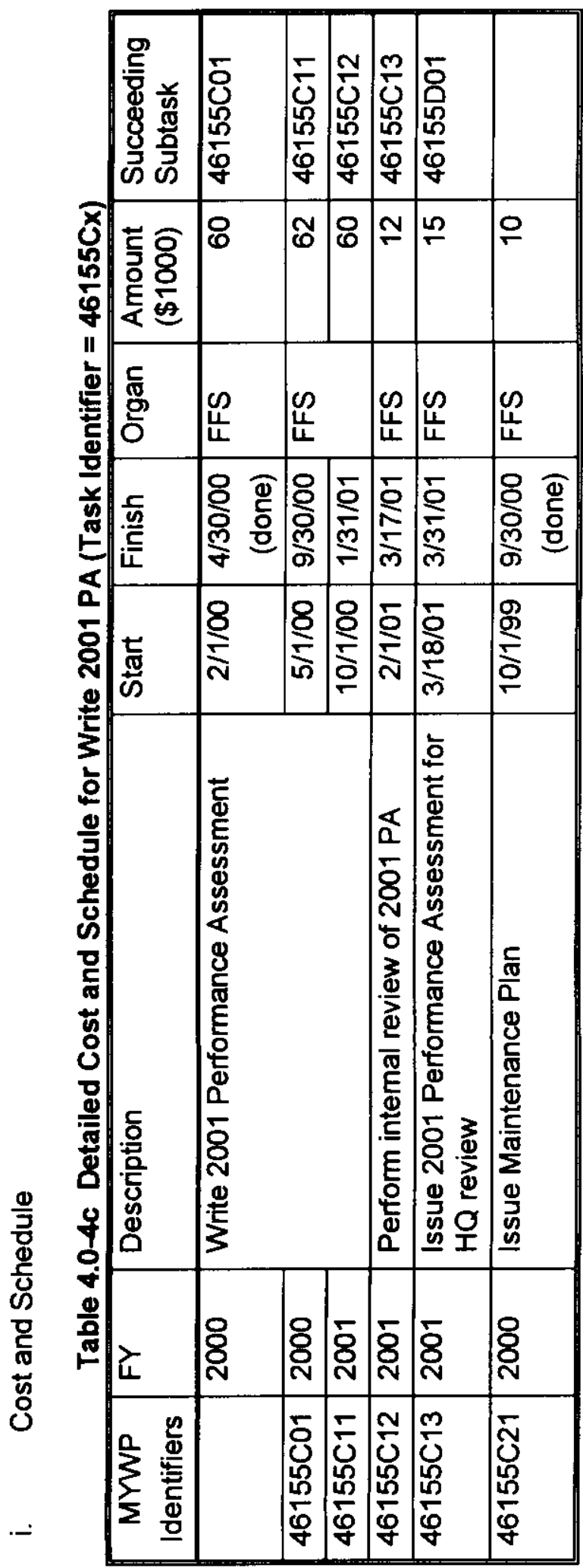

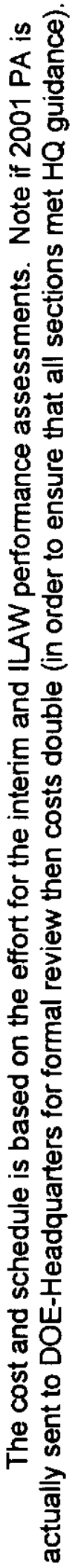


RPP-6702, Rev. 0

Formerly HNF-SD-WM-PAP-062 Rev. 4

v. $\quad$ HQ-2001 PA Interaction

a. Background

During the review of the performance assessment, DOE Headquarters staff and the review committees they appoint will raise questions conceming the performance assessment. This task funds the efforts to answer those questions.

b. List Of Deliverables

Table 4.0-5a List of Deliverables for 2001 PA-HQ Interaction

\begin{tabular}{|l|c|c|l||}
\hline Description & Due Date & Level & $\begin{array}{l}\text { MYWP } \\
\text { Identifier }\end{array}$ \\
\hline Receive Comments from HQ & $3 / 31 / 02$ & 7 & $\begin{array}{l}\text { 46155D1A } \\
{[46155 \mathrm{D} 11]}\end{array}$ \\
\hline
\end{tabular}

c. Cost Summary WBS: 1.1.1.3.4.1.3.1

Table 4.0-5b Cost Summary for 2001 PA-HQ Interaction

\begin{tabular}{|l|l|r|}
\hline \multicolumn{1}{|c|}{ Fiscal Year } & \multicolumn{1}{|c|}{ Organization } & \multicolumn{1}{|c|}{ Amount (\$1000) } \\
\hline 2001 & Fluor Federal Services (FFS) & 5 \\
\hline 2002 & FFS & 15 \\
\hline \hline Grand Total & & 5 \\
\hline
\end{tabular}

d. Detailed Description

Interact with the Department of Energy review boards during their review of the 2001 performance assessment. This effort covers the expense of the performance assessment team.

e. Interfaces

The 2001 performance assessment will be submitted to the Peer Review Panel. The Peer Review Panel is established by DOE Order 5820.2A to technically review performance assessments for the Department of Energy.

f. Organization

The Environmental and Nuclear Initiatives Sections of Fluor Federal Services (FFS) will interact with the Peer Review Panel, since they are responsible for the performance assessment activity.

g. Quality Assurance

All activities will be conducted in accordance with 10 CFR 830.120.

h. Effect of Not Performing Task

Required by DOE Order. 
RPP-6702, Rev. 0

Formerly HNF-SD-WM-PAP-062 Rev. 4

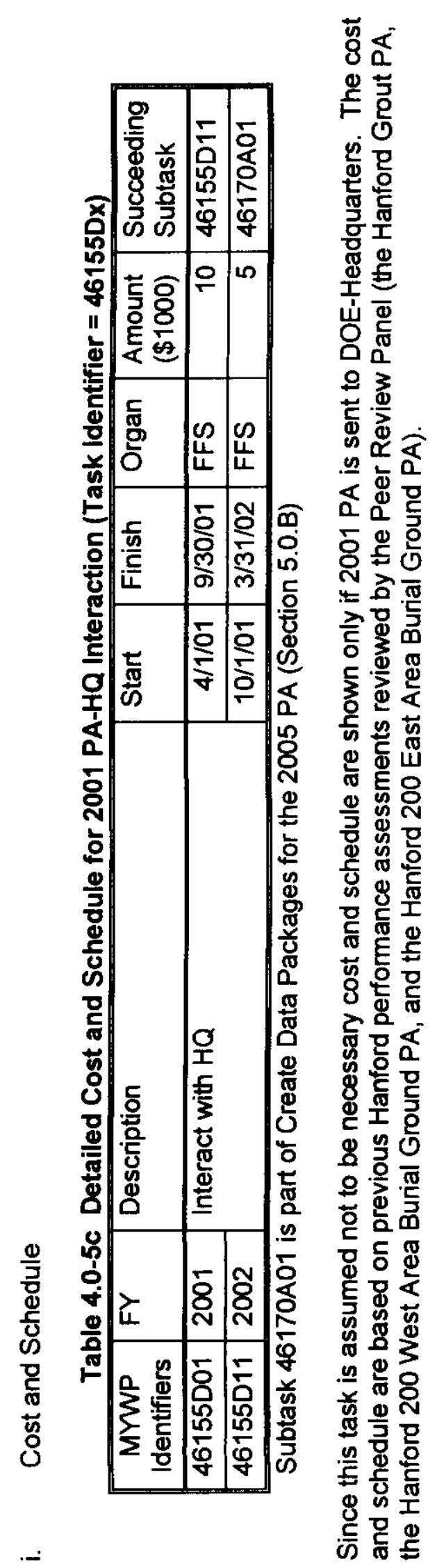


RPP-6702, Rev. 0

Formerly HNF-SD-WM-PAP-062 Rev. 4

\subsection{DATA PACKAGES FOR 2005 PERFORMANCE ASSESSMENT}

\section{A. SUMMARY}

Issue a report documenting the current state of knowledge needed for the 2005 performance assessment. The main body of the report shall summarize the data with appendices containing a detailed description of the data and the justification for the selected of the data. The report shall serve a similar function as the Data Packages for the Hanford LowLevel Tank Waste Interim Performance Assessment (Mann 1995b) and the Data Packages for the Hanford Low-activity Tank Waste 2001 Performance Assessment (described in Chapter 3.0). Data collection activities are described in Sections 5.1, 5.2, and 5.3.

In prior versions of this document, this performance assessment was to be due in 2003 . However, several items have now made 2005 a more appropriate date:

- $\quad$ DOE has approved the 1998 ILAW PA (DOE 1999b) and issued a disposal authorization statement (DOE 1999c).

- $\quad$ The date for receiving waste is now 2007.

- The 2001 ILAW PA will analyze for the effects of new disposal facility design (Taylor 1999) and for new glass composition.

B. ISSUE DATA PACKAGES FOR HANFORD LOW-ACTIVITY TANK WASTE 2005 PERFORMANCE ASSESSMENT

i. Background

The purpose and need for the generation of data packages for the 2005 performance assessment are the same as for the generation of packages for the 2001 performance assessment (see Chapter 3 ).

ii. List of Deliverable

Table 5.0-1a List of Deliverables for Create 2005 PA Data Packages

\begin{tabular}{|l|l|c|l|}
\hline Description & $\begin{array}{l}\text { Due } \\
\text { Date }\end{array}$ & Level & $\begin{array}{l}\text { MYWP } \\
\text { Identifier }\end{array}$ \\
\hline $\begin{array}{l}\text { Issue a report documenting the current state of } \\
\text { knowledge needed for the } 2005 \text { performance } \\
\text { assessment. }\end{array}$ & $1 / 31 / 04$ & 5 & $\begin{array}{l}46170 \mathrm{AB} \\
\text { [46170A1] }\end{array}$ \\
\hline
\end{tabular}


RPP-6702, Rev. 0

Formerly HNF-SD-WM-PAP-062 Rev. 4

iii. Cost Summary

WBS: 1.1 .1 .3 .4 .1 .3 .1

TPCN: D4DM1

Table 5.0-1bCost Summary for Create 2005 PA Data Packages

\begin{tabular}{|l|l|l|}
\hline $\begin{array}{l}\text { Fiscal } \\
\text { Year }\end{array}$ & Organization & Amount (1000\$) \\
\hline 2004 & Fluor Federal Services (FFS) & 27 \\
\hline
\end{tabular}

iv. Interfaces

This subactivity will use the reports created by the 2005 performance assessment data collection subactivities (Sections 5.1,5.2, and 5.3) as the basis for the main body of the data packages document and will use the reports themselves as the document appendices.

The data package document will provide all the data needed for the calculations and writing of the 2005 performance assessment.

Table 5.0-1c Interfaces for Create 2005 PA Data Packages

\begin{tabular}{|c|c|c|c|}
\hline Number & Interface & Description & Date \\
\hline \multicolumn{3}{|l|}{ Input } & Finish \\
\hline 46160G1A & (5.1.i) & $\begin{array}{l}\text { Waste Form Release Data } \\
\text { Package }\end{array}$ & $12 / 31 / 03$ \\
\hline $46160 \mathrm{~J} 4 \mathrm{~A}$ & (5.2.b) & Geology Data Package & $12 / 31 / 03$ \\
\hline 46160K7A & (5.2.c) & Recharge Data Package & $12 / 31 / 03$ \\
\hline 46160M7A & (5.2.d) & Near-Field Hydraulic Package & $12 / 31 / 03$ \\
\hline 46160L7A & (5.2.e) & Far-Field Hydraulic Package & $12 / 31 / 03$ \\
\hline $4616007 A$ & $(5.2 . f)$ & Near-Field Chemical Package & $12 / 31 / 03$ \\
\hline $46160 N 7 A$ & (5.2.g) & Far-Field Chemical Package & $12 / 31 / 03$ \\
\hline \multicolumn{3}{|l|}{ Output } & Start \\
\hline $46160 \mathrm{~A} 1$ & $(6.0)$ & $\begin{array}{l}\text { Establish } 2005 \text { PA Base Analysis } \\
\text { Case }\end{array}$ & $2 / 1 / 04$ \\
\hline
\end{tabular}

\section{v. Detailed Description}

A document defining the contents, format, and methods to be used for the preparing the 2005 version of the Hanford Low-activity Tank Waste Performance Assessment will be issued. The document also will contain the data to be used in the supporting calculations along with justification for the selection of that data. The information will be summarized in the main text. The appendices will contain the documents used as primary references.

The contents and format to be used in the 2005 performance assessment will follow the then current guidance. This guidance will be summarized in the document. 


\section{RPP-6702, Rev. 0 \\ Formerly HNF-SD-WM-PAP-062 Rev. 4}

The methods to be used include the standards against which the effect of the disposal action will be judged (performance objectives), the various scenarios and pathways which will be analyzed, and the tools with which the analyses will be done. The document will contain information concerning code selection, verification, and (where possible) validation.

The data to be used in the 2005 performance assessment will be summarized in the main text. Areas covered include

a. Inventory to be expected in the waste form,

b. Location(s) of the disposal facility,

c. Disposal facility design,

d. Waste form package description (including processing),

e. Behavior of disposal facility over time,

f. Behavior of waste form over time,

g. Moisture recharge rate,

h. Geology of disposal facility location,

i. Hydrologic parameters (both near- and far-field),

j. Geochemical parameters (both near- and far-field), and

k. Dosimetry parameters.

vi. Organization

The Environmental and Nuclear Initiatives Section of Fluor Federal Services will be responsible for producing the data packages document.

vii. Quality Assurance

All activities will be conducted in accordance with 10 CFR 830.120. The authors of the appendices upon which the main text will be based will review the main text. The review of the appendices will have occurred before their issuance.

viii. Cost and Schedule (Task Identifier $=46170 \mathrm{A01})$

The estimated cost $(\$ 23,000)$ and duration (30 days) is based on the cost of preparing Low-Level Tank Waste Interim Performance Assessment (Mann 1995b). The cost includes labor and duplication costs.

ix. Effect of Not Performing Task

Without this task, there is no central repository data for information to be used in the performance assessment and hence no configuration control for that information. This activity also encourages all members of the performance assessment team to review the work by others on the team. 
RPP-6702, Rev. 0

Formerly HNF-SD-WM-PAP-062 Rev. 4

\subsection{WASTE FORM PERFORMANCE DATA AND TOOLS}

\section{A. SUMMARY}

The objective of this task is to provide data and calculational tools for the calculation of the release of contaminants from the waste form for the 2005 performance assessment. The documentation should provide the current state of knowledge for the long-term release behavior of the waste form under the conditions expected in the disposal facility. The data collected should be directed toward supplying information needed for the calculation of the release of contaminants from the waste form and the transport of those contaminants in the near field over 10,000 years.

\section{B. GENERAL}

\section{i. Background}

The background section in Chapter 3.1 should be consulted. The emphasis during this phase of data collection is to extend long-term testing and to investigate areas of concem arising from the earlier testing.

FY99 and 00 have been a period of extraordinarily rapid change in the formulation of ILAW glasses. We expect this rapid change to continue through issuance of the 2005 PA while detailed flow sheets and vitrification plant operating regimes are being developed. Despite this rapid change, the general principles outlined in our strategic plan (McGrail 1999) remain robust in terms of generating the necessary data to conduct long-term performance calculations with reasonable confidence. These general principles were used to guide the proposed work outlined in tasks below.

ii. List of Deliverables

Table 5.1-1a List of Major Deliverables for 2005 PA Waste Form Data Package

\begin{tabular}{|l|l|l|l|}
\hline Description & Due Date & Level & $\begin{array}{l}\text { MYWP } \\
\text { Identifier }\end{array}$ \\
\hline $\begin{array}{l}\text { Issue a report documenting the current status of } \\
\text { knowledge for waste form performance needed for the } \\
2005 \text { performance assessment. }\end{array}$ & $12 / 31 / 04$ & 7 & $\begin{array}{l}46160 \mathrm{~EB} \\
{[46160 \mathrm{E} 1]}\end{array}$ \\
\hline $\begin{array}{l}\text { Write a report documenting the current status of } \\
\text { knowledge for waste performance needed for the 2005 } \\
\text { performance assessment. }\end{array}$ & $7 / 31 / 04$ & 6 & $\begin{array}{l}46160 \mathrm{EA} \\
{[46160 \mathrm{E}]}\end{array}$ \\
\hline
\end{tabular}

Additional deliverables will be expected as the tasks are better defined. 
RPP-6702, Rev. 0

Formerly HNF-SD-WM-PAP-062 Rev. 4

iii. Cost Summary

WBS: $1.1 \cdot 1 \cdot 3 \cdot 4 \cdot 1 \cdot 3.2$

TPCN: D4DM2

Table 5.1-1b Cost Summary for Waste Form Data for 2005 PA

\begin{tabular}{|l|l|l|}
\hline $\begin{array}{l}\text { Fiscal } \\
\text { Year }\end{array}$ & Organization & $\begin{array}{l}\text { Amount } \\
(\$ 1000)\end{array}$ \\
\hline \multirow{3}{*}{2999} & Argonne National Laboratory (ANL) & 0 \\
\cline { 2 - 3 } & Pacific Northwest National Laboratory (PNNL) & 174 \\
\cline { 2 - 3 } & Total & 174 \\
\hline \multirow{3}{*}{2000} & ANL & 140 \\
\cline { 2 - 3 } & PNNL & 552 \\
\cline { 2 - 3 } & Total & 692 \\
\cline { 2 - 3 } & ANL & 335 \\
\cline { 2 - 3 } & PNNL & 1890 \\
\cline { 2 - 3 } & Total & 2225 \\
\hline \multirow{3}{*}{2002} & ANL & 350 \\
\cline { 2 - 3 } & PNNL & 1965 \\
\cline { 2 - 3 } & Total & 2315 \\
\hline \multirow{3}{*}{2003} & ANL & 200 \\
\cline { 2 - 3 } & PNNL & 1873 \\
\cline { 2 - 3 } & Total & 2073 \\
\hline \multirow{2}{*}{2004} & CH2M Hill Hanford Group (CHG) & 30 \\
\cline { 2 - 3 } & PNNL & 72 \\
\cline { 2 - 3 } & Total & 7551 \\
\hline \multirow{2}{*}{ Grand Total } & \\
\hline
\end{tabular}

iv. Interfaces

This subactivity builds heavily on the data collection methods and procedures used to collect data for the 2001 performance assessment activity (Chapter 3.1). Beyond extending the conditions measured during that period, the major effort will be in measuring and understanding the long-term performance of the vendor-produced waste form.

The data collection activities (46160Ax through $46160 \mathrm{Dx}$ ) are used as the basis for preparing the waste form data package (46160E1). This document will be reviewed by an external panel (46160E2/3) and issued (46160E4) to form a basis for the 2005 performance assessment.

The output of this subactivity will mainly be used in creating the Data Packages for the 2005 Performance Assessment (see Section 5.0). The subsequent tasks (see Section 7. = Maintain Performance Assessments) will build on the knowledge learned in this subactivity. 


\section{RPP-6702, Rev. 0 \\ Formerly HNF-SD-WM-PAP-062 Rev. 4}

v. Organization

The Applied Geology and Geochemistry Section of the Pacific Northwest National Laboratory (PNNL) will be responsible for this subactivity. Experiments will be conducted at both the Argonne (ANL) and Pacific Northwest National Laboratories.

PNNL is very experienced in determining the performance characteristics of vitrified waste forms. Not only have they had the lead for this task in the Hanford lowactivity tank waste performance assessment activity, they have been extremely active in the studying glasses for the high-level waste program and in the Pu-disposition program. They have developed both experimental and calculational techniques to understand how glasses (particularly those formulated for low-activity radioactive waste) decompose over time.

ANL also has been very active in studying glasses as the disposal medium for radioactive wastes. They have developed and used a series of tests to better understand how glasses decompose over time.

As the funding source for the performance assessment, $\mathrm{CH} 2 \mathrm{M}$ Hill Hanford Group (CHG) is shown for the external waste form review board.

\section{TASK DESCRIPTIONS}

i. Summary List of Tasks
a. Perform Waste Form Measurements
b. Develop Kinetic Rate Law for Irreversible Reactions
c. Measurement of Solid-Water Interfacial Area
d. Perform Waste Form Simulations
e. Update Waste Form Simulation Code
f. Glass Analog Field Test Data Collection and Modeling
g. TFA Glass Formulation Studies
h. Water Penetration into Fractured Glass
i. Ion-exchange Processes and Mechanisms
j. Document Waste Form Data for 2005 Performance Assessment

ii. Perform Waste Form Measurements

a. Background

Measurements are needed to determine the value of parameters to be used in the computer codes that will be used to estimate contaminant release from the waste form and subsequent transport in the disposal facility. This effort will extend the effort for the 2001 PA by continuing long-term tests, by looking at different feed envelopes, conducting tests with natural analogs, and by using the latest waste form formulation and processing information from the private vendors. The testing effort to be executed in this task has been outlined in Strategy Plan by McGrail, Ebert and Strachan (1998) and in the specific implementing test plans developed in response to this strategy. 


\section{RPP-6702, Rev. 0 \\ Formerly HNF-SD-WM-PAP-062 Rev. 4}

The suite of tests to be performed under this task includes Vapor Hydration Tests, PCT tests, SPFT tests, and PUF experiments using both nonradioactive simulated waste glass and glass containing each of the key radionuclides of importance to the PA. Each of these tests provides different, but complementary, information on the long-term radionuclide release behavior of the glass that is needed to build a defensible predictive model (see Section 5.1.C.iii). Additional tests may be needed to support specific data needs for the radionuclide release model. For example, the accelerated testing program has shown that specific alteration phases significantly affect glass corrosion rates, but for which a solubility product or precipitation rate constants are not available. Consequently, a thermodynamic data development task will conduct separate experiments to obtain these parameters.

SPFT experiments in FY01 will focus on resolving remaining significant uncertainties in several aspects of ILAW glass dissolution. At present, we have investigated the effects of $\mathrm{Si}$ and $\mathrm{Al}$ on glass dissolution rates at only a single $\mathrm{pH}$. Experiments at several additional $\mathrm{pH}$ values will be performed to determine whether these effects change as a function of $\mathrm{pH}$. Measurements of $\mathrm{Na}$ ion-exchange rates have also only been performed at a single $\mathrm{pH}$ value. As a result, we have been making the implicit assumption that $\mathrm{Na}$ exchange rates are independent of $\mathrm{pH}$ in STORM modeling. In some of the simulations, the calculated pH in the disposal system differs by several units from the $\mathrm{pH}(9)$ where the exchange rates have been measured. We will check the veracity of this assumption by measuring $\mathrm{Na}$ ion-exchange rates over a range of $\mathrm{pH}$ values.

\section{b. List Of Deliverables}

Reports from ANL, and PNNL on experiments will be expected by May 31, 2003. The contents of these reports will be determined as results from tests performed under Section 3.1 and this Section are completed. However, progress letter reports will be created by September 30 of 2001 and 2002. 
RPP.6702, Rev. 0

Formerly HNF-SD-WM-PAP-062 Rev. 4

c. Cost Summary

WBS: 1.1.1.3.4.1.3.2

TPCN: D4DM2

Table 5.1-2a Cost Summary for Waste Form Measurements for 2005 PA

\begin{tabular}{|l|l|r|}
\hline $\begin{array}{c}\text { Fiscal } \\
\text { Year }\end{array}$ & \multicolumn{1}{|c|}{ Organization } & $\begin{array}{r}\text { Amount } \\
(1000 \$)\end{array}$ \\
\hline 1999 & Argonne National Laboratory (ANL) & 0 \\
\cline { 2 - 3 } & Pacific Northwest National Laboratory (PNNL) & 114 \\
\cline { 2 - 3 } & Total & 114 \\
\hline \multirow{3}{*}{2000} & ANL & 140 \\
\cline { 2 - 3 } & PNNL & 300 \\
\cline { 2 - 3 } & Total & 440 \\
\hline \multirow{3}{*}{2001} & ANL & 335 \\
\cline { 2 - 3 } & PNNL & 885 \\
\cline { 2 - 3 } & Total & 1220 \\
\hline \multirow{3}{*}{2002} & ANL & 350 \\
\cline { 2 - 3 } & PNNL & 900 \\
\cline { 2 - 3 } & Total & 1250 \\
\hline \multirow{3}{*}{2003} & ANL & 200 \\
\cline { 2 - 3 } & PNNL & 700 \\
\cline { 2 - 3 } & Total & 900 \\
\hline
\end{tabular}


RPP-6702, Rev. 0

Formerly HNF-SD-WM-PAP-062 Rev. 4

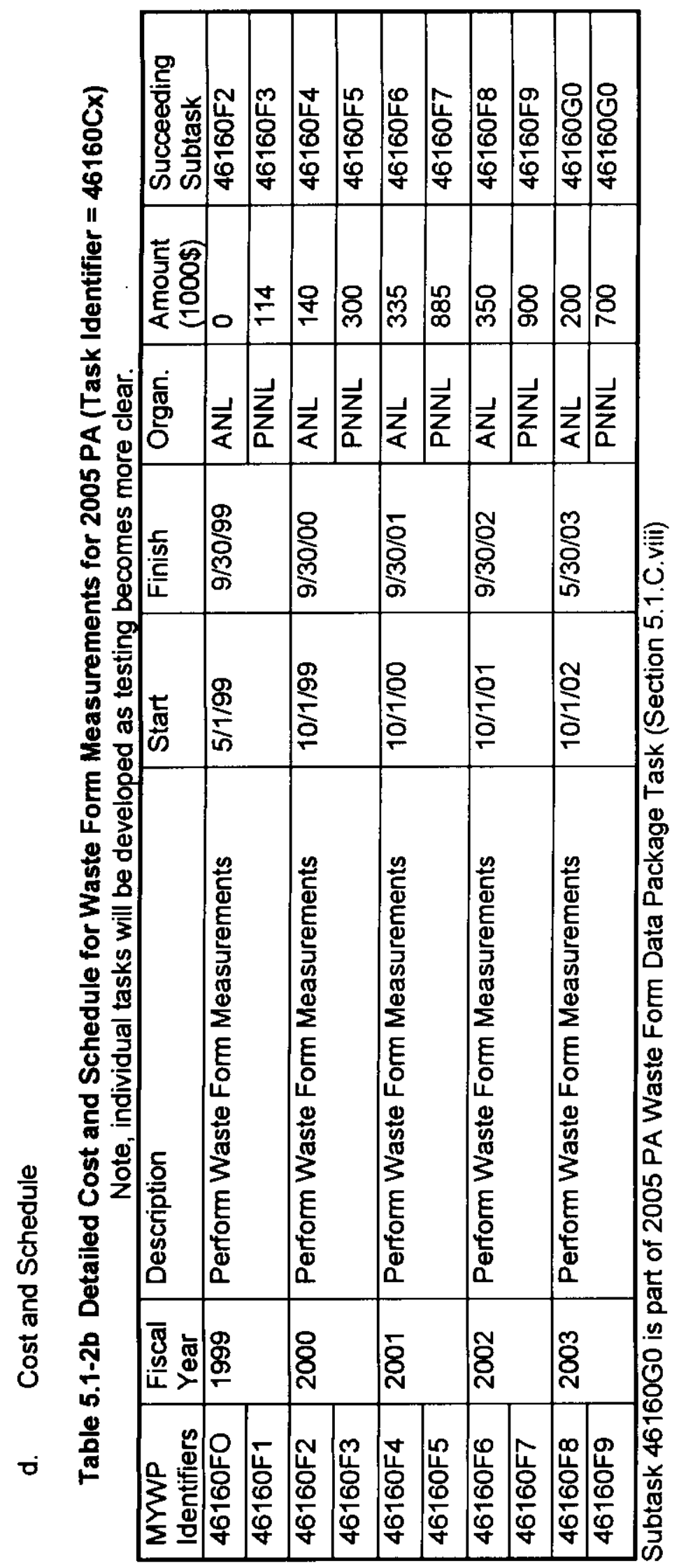


RPP-6702, Rev. 0

Formerly HNF-SD-WM-PAP-062 Rev. 4

iii. Develop Kinetic Rate Law for Irreversible Reactions

a. Background

The kinetic rate law that is currently being used to model glass dissolution was derived by Aagard and Helgeson for the dissolution of silicate minerals:

$$
R_{i}=v_{i} \vec{k} a^{-\eta} e^{-\frac{E_{a}}{\mathrm{R} T}}\left[1-(Q / K)^{\sigma}\right]
$$

where

$\begin{array}{lll}\mathrm{R}_{\mathrm{i}} & = & \text { the flux of element } i\left(\mathrm{~g} \mathrm{~m}^{-2} \mathrm{~s}^{-1}\right) \\ v_{\mathrm{i}} & = & \text { the stoichiometric coefficient of element } i \text { in glass } \\ \vec{k} & = & \text { the intrinsic rate constant }\left(\mathrm{g} \mathrm{m}^{-2} \mathrm{~s}^{-1}\right) \\ \mathrm{a} & = & \mathrm{H}^{+} \text {ion activity } \\ \eta & = & \mathrm{pH} \text { power law coefficient } \\ \mathrm{E}_{\mathrm{a}} & = & \text { activation energy }(\mathrm{J} / \mathrm{mol}) \\ \mathrm{R} & = & \text { gas constant }\left(\mathrm{J} / \mathrm{mol} \mathrm{K} \mathrm{K}^{-1}\right) \\ \mathrm{T} & = & \text { temperature }(\mathrm{K}) \\ \mathrm{Q} & = & \text { ion-activity product of rate controlling phase } \\ \mathrm{K} & = & \text { equilibrium constant for rate controlling phase } \\ \sigma & & =\quad \text { net reaction order (assumed }=1)\end{array}$

This equation is fundamentally only applicable to reversible reactions, i.e. reactions where the dissolving solid can precipitate from solution. That is impossible for silicate glasses. Also, the equilibrium constant $(K)$ is fundamentally defined as including all the components of the dissolving solid. For waste glasses, it has been observed that only a small number of components ( $\mathrm{Si}$ and $\mathrm{Al}$ ) have a significant effect on the dissolution kinetics. Consequently, the equilibrium constant has been redefined in this equation as a pseudoequilibrium constant corresponding to the activity product of $\mathrm{SiO}_{2}(\mathrm{aq})$ and possibly $\mathrm{AlO}_{2}^{-}$species.

Another problem is that Transition State Theory (Eyring, 1935), from which the rate law was derived, requires that the system of heterogeneous reactions is not constrained by the mass of water or the interfacial area between the reacting solid and the aqueous solution. As such, Equation 1 requires that the rate of reaction is directly proportional to the surface area of the solid and the mass of water in the system is not considered explicitly (Rimstidt and Bames, 1980). These are good assumptions for water saturated porous media. However, in unsaturated porous media, especially in variably saturated systems with temporal changes in water content due to sources, sinks, or dynamically changing hydraulic properties, the solid-liquid interfacial area is a function of the water content and the limited mass of water in the system may also limit the reaction kinetics. Thus, Eq. 1 as written is not strictly valid for unsaturated systems.

In FY00, STORM calculations were performed using the above kinetic rate law with the equilibrium constant given by $K_{g}=a\left[\mathrm{AlO}_{2}^{-}\right]^{u_{1}}\left[a\left[\mathrm{SiO}_{2}(\mathrm{aq})\right]^{u_{2}}\right.$, which provided the best fit to the available data for LAWABP1 glass. In several of the simulations, $\mathrm{AlO}_{2}{ }^{-}$ concentrations dropped to very low values $\left(<10^{-10} \mathrm{M}\right)$ because of $A$ l consumption into a nontronite clay alteration product. Even though the solutions were also computed as 
RPP.6702, Rev. 0

Formerly HNF-SD-WM-PAP-062 Rev. 4

being saturated with respect to $\mathrm{SiO}_{2}(\mathrm{am})$, the low aluminum concentrations produced small $Q$ values and the glass was predicted to be dissolving at near the forward rate of reaction. This calculational result is contrary to numerous experimental results that show silicate glasses dissolve at a very low rate in Si saturated solutions, even when Al concentrations are below detection levels.

In this task, a new kinetic rate law will be developed that is applicable to irreversible reactions, such as the glass-water reaction, for variably saturated porous media. The new rate law will provide for the observed catalytic and inhibitory affect that different cations/anions have on the dissolution kinetics. However, the new formulation will correct the current deficiencies in the rate law regarding the effect of $\mathrm{Al}$ (and other inhibitor species) and will prevent the rate from dropping to zero as is possible with the current rate equation. The influence of water saturation and solid-water interfacial area will be explicitly considered in the rate law formulation. Because of the general importance of the development of this rate law in geochemical modeling, the work will be submitted for publication in a journal of high intemational regard, such as Geochimica et Cosmochimica Acta. The new rate law will also be implemented and tested in the STORM code. This task is also linked to the experimental task that follows where techniques for measuring the solid-water interfacial area as a function of water saturation will be developed and tested.

b. List Of Deliverables

A journal article will be prepared and issued by $8 / 31 / 2001$ with the derivation of the kinetic rate law along with experimental evidence supporting its validity.

$\begin{array}{lll}\text { c. Cost Summary } \quad \text { WBS: } 1.1 .1 .3 .4 .1 .3 .2 & \text { TPCN: D4DM2 }\end{array}$

Table 5.1-3a Cost Summary for Kinetic Rate Law Development for 2005 PA

\begin{tabular}{|l|l|l|}
\hline $\begin{array}{l}\text { Fiscal } \\
\text { Year }\end{array}$ & Organization & $\begin{array}{l}\text { Amount } \\
(1000 \$)\end{array}$ \\
\hline 2001 & Pacific Northwest National Laboratory (PNNL) & 95 \\
\hline 2002 & PNNL & 35 \\
\hline 2003 & PNNL & 15 \\
\hline Grand Total & 145 \\
\hline
\end{tabular}


Formerly HNF-SD-WM-PAP-062 Rev. 4

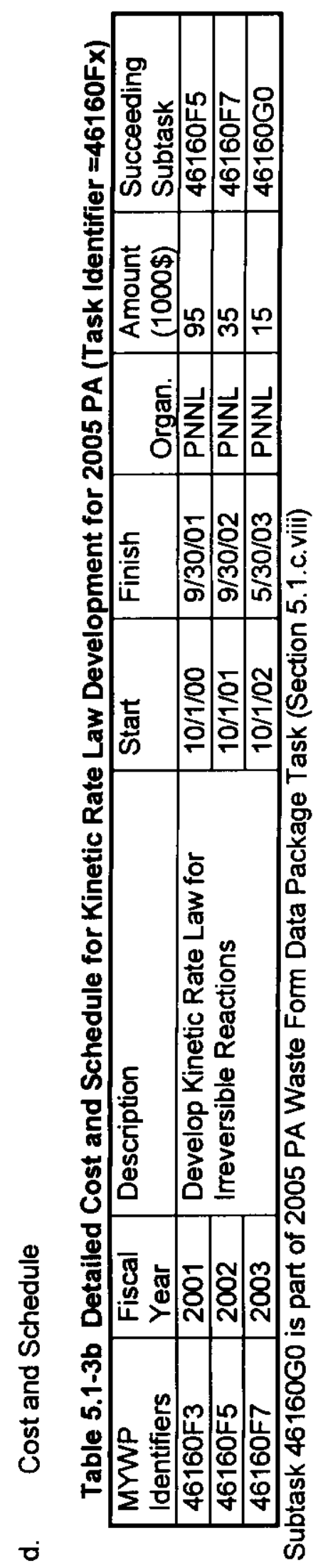


RPP-6702, Rev. 0

Formerly HNF-SD-WM-PAP-062 Rev. 4

iv. Measurement of Solid-Water Interfacial Area

a. Background

In FYO0, one of the key variables that impacted release rates from the disposal system was an assumption regarding the contact area between the water percolating through the disposal system and the ILAW glass. For the 2001 PA, a conservative assumption was made where the entire geometric surface area of the glass monolith was assumed to be contacted by water. To get a better understanding of what the actual solid-liquid contact area will be in an unsaturated disposal system, measurements of the glass-water interfacial area under unsaturated conditions are critically needed.

In this task, we will develop novel tracer methods to measure changes in the specific solid (ILAW glass) - water contact area $\left(a_{s w}, \mathrm{~cm}^{2} / \mathrm{cm}^{3}\right)$ as a function of the degree of water saturation: Currently, no methods or models exist that describe this relationship. Modified PUF experimental cells with a pressure plate and rubber O-ring gasket seals will be used to conduct the experiments. The modified PUF cell will allow variation of fluid saturations and interfacial areas by controlling the capillary pressure across the cell. The modified PUF cell incorporates a capillary barrier at the effluent end, which allows the wetting fluid to flow through while non-wetting fluid (air) is retained, provided capillary pressures are below the barrier entry pressure. The top of the modified PUF cell will be kept exposed to the atmosphere, except in the case of a fully water saturated experiment. The average capillary pressure experienced by the porous medium in the cell can be adjusted to the required value by adjusting the vertical position of a hanging column of water (i.e., the hanging effluent column) at the bottom of the cell. An increase in the length of hanging column causes a corresponding increase in the capillary pressure, causing a decrease in the water saturation. Thus, by altering the position of hanging column in a step-wise fashion, a step-wise change in water saturation is achieved.

An experiment will be conducted by initially saturating the cell $\left(S_{w}=100 \%\right)$. The system will be allowed to reach a steady flow condition and the system parameters such as flow, fluid saturation, and fluid pressures recorded. At each stage of capillary pressure, it may require several hours to days for the system to fully adjust to the new state of capillary equilibrium, which is indicated by static (non-fluctuating) water levels. The water saturation corresponding to each such stage within the cell will be uniform and constant. A suit of tracers (non-reactive, partitioning and interfacial tracers) will be used in tandem to characterize the solid-water and air-water interfacial areas at each stage of saturation. The tracer/solute concentration is monitored continuously at the effluent port. The retardation of the interfacial tracer breakthrough curves relative to non-reactive tracers will be used to calculate the interfacial areas. The proposed experiments will be limited to pore saturations of about $20 \%$. Pending successful outcome of these experiments, additional follow-on experiments will be proposed that extend the measurements to lower saturations (5 to $20 \%$ ).

b. List Of Deliverables

A journal article on the experiments and their interpretation will be prepared and issued by April 30, 2001. 
RPP-6702, Rev. 0

Formerly HNF-SD-WM-PAP-062 Rev. 4

c. Cost Summary WBS: 1.1.1.3.4.1.3.2 TPCN: D4DM2

Table 5.1-4a Cost Summary for Measurement of Solid-Water Interfacial Area for 2005 PA

\begin{tabular}{|l|l|r|}
\hline $\begin{array}{l}\text { Fiscal } \\
\text { Year }\end{array}$ & Organization & Amount (1000\$) \\
\hline 2001 & Pacific Northwest National Laboratory (PNNL) & 85 \\
\hline 2002 & PNNL & 105 \\
\hline 2003 & PNNL & 65 \\
\hline Grand Total & 255 \\
\hline
\end{tabular}


RPP-6702, Rev. 0

Formerly HNF-SD-WM-PAP-062 Rev. 4

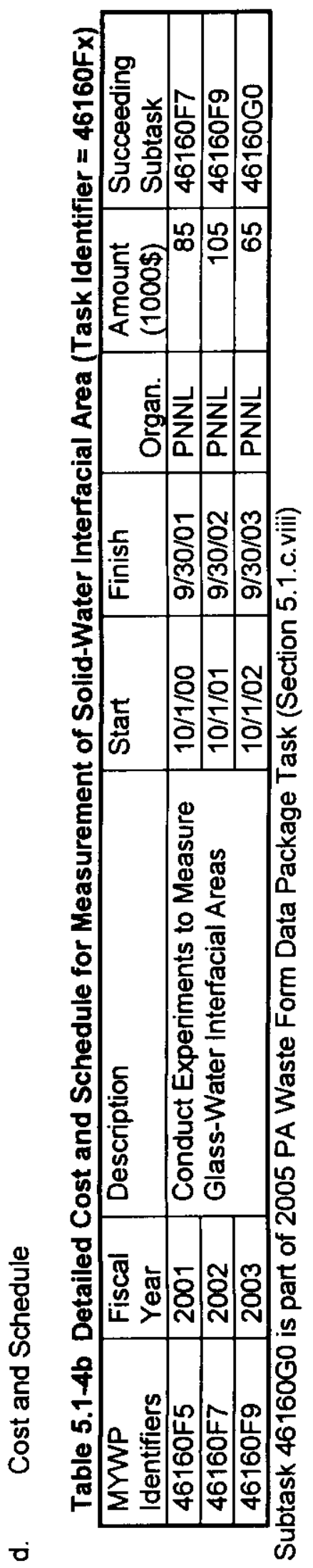


RPP-6702, Rev. 0

Formerly HNF-SD-WM-PAP-062 Rev. 4

v. Perform Waste Form Simulations

a. Background

The purposes of this subtask are

1) to conduct the required simulations to verify and validate the selected simulation tool and to conduct and document source-term calculations for the 2005 PA and

2) to provide guidance to other tasks dealing with the near-field considering the expected chemical conditions.

The conceptual design for the ILAW disposal facility evolved very rapidly in FYOO with the selection of a trench design for the base case analysis. Additional design changes and design options will need to be evaluated prior to the 2005 PA. This task will support these design efforts by conducting simulations to elucidate the impacts of design changes/options on glass performance and near-field release rates. Several difficulties were also encountered in applying the near-field simulation code to the trench design concept. Consequently, simulation exercises need to be conducted routinely so that computational issues can be identified and corrected well in advance of deadlines for the 2005 PA.

Many experiments are being performed and much other data are being gathered to support near-field modeling. To limit the range of chemical environments over which experiments must be performed and the literature to be searched, calculations are also needed to determine the $\mathrm{pH}$ and redox values that are expected at the waste form water interface. These calculations will use the STORM code (selected for the 2001 performance assessment) or its successor, along with the current best estimate of inventory and other data.

b. List Of Deliverables

Reports on simulations will be prepared through the period with the last expected by September 30,2004 . The contents of these reports will be determined as results from activities performed under Section 3.1 and this section are completed.

c. Cost Summary

WBS: $1.1 \cdot 1 \cdot 3 \cdot 4 \cdot 1.3 .2$

TPCN: D4DM2

Table 5.1-5a Cost Summary for Waste Form Simulations for 2005 PA

\begin{tabular}{|l|l|l|}
\hline $\begin{array}{l}\text { Fiscal } \\
\text { Year }\end{array}$ & Organization & $\begin{array}{l}\text { Amount } \\
(1000 \$)\end{array}$ \\
\hline 1999 & Pacific Northwest National Laboratory (PNNL) & 60 \\
\hline 2000 & PNNL & 157 \\
\hline 2001 & PNNL & 210 \\
\hline 2002 & PNNL & 250 \\
\hline 2003 & PNNL & 260 \\
\hline Grand Total & 937 \\
\hline
\end{tabular}


RPP-6702, Rev. 0

Formerly HNF-SD-WM-PAP-062 Rev. 4

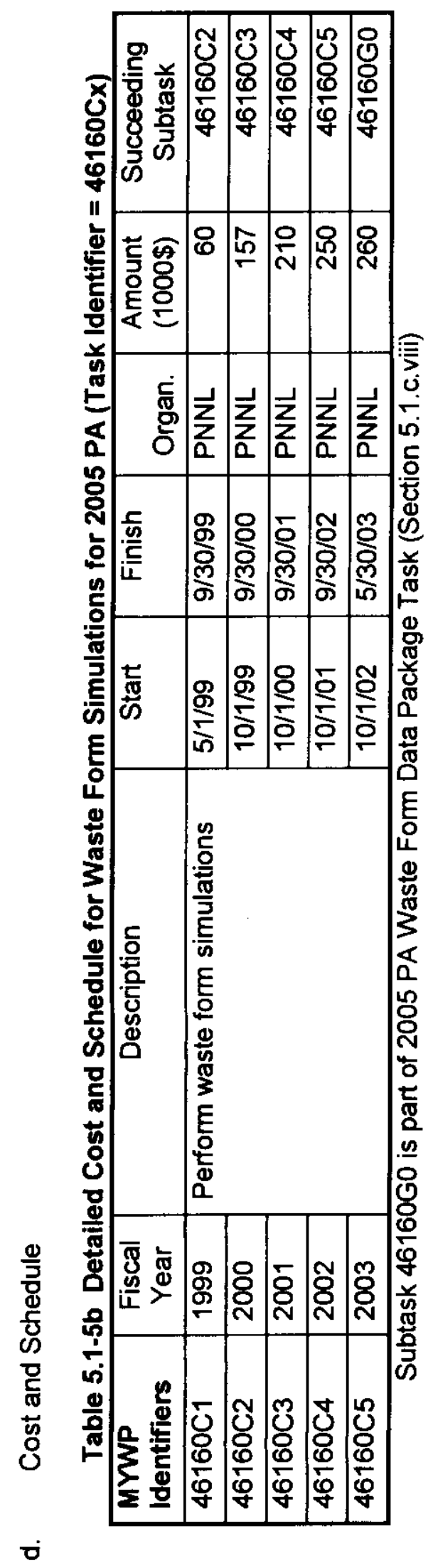


RPP-6702, Rev. 0

Formerly HNF-SD-WM-PAP-062 Rev. 4

vi. Upgrade Waste Form Simulation Code

a. Background

The waste form simulation code translates our knowledge of waste form behavior and contaminant transport into results that are used in the performance assessment. As the measurements conducted under this program and under other programs provide new understanding, the simulation code will have to be modified to include those important for this activity. Also, it is expected that computer technology will continue to evolve, making modifications of code cost effective in utilizing the new technology.

Currently, the STORM code is capable of modeling flow and transport properties in porous media systems only. Fractured media, such as the glass waste packages, must be treated as an equivalent porous medium and assigned approximate physical and hydraulic properties. In FYOO, we began studies of alternative numerical strategies for better simulating flow and transport in mixed porous and fractured media. A promising approach that was investigated is the lattice Boltzmann simulation method, which solves the Navier-Stokes equation for complex geometries. The Computational Fluid Dynamics group in PNNL has developed a multiphase flow and reactive transport simulator based on the lattice-Boltzmann technique. The code has been parallelized for operation on PNNL's massively parallel IBM computer. This is important because the code has demonstrated a linear reduction in run time with number of processors. Run times for STORM on SUN Workstations are taking days to weeks to complete.

Significant increases in computational speed are required to complete more than a handful of sensitivity and uncertainty cases with the code. Million node, 10 chemical component reactive transport problems have been run in a few hours with this simulator.

In FY01, the lattice-Boltzmann code will be modified so that it is capable of conducting fully coupled multiphase flow and reactive transport calculations, equivalent to what is currently possible with the STORM simulator. To do this, the existing chemistry module in the code will be replaced with the Kinetic-Equilibrium Module (KEMOD) code developed by Prof. George Yeh at the Penn State University. KEMOD provides for both kinetic and equilibrium controlled dissolution/precipitation reactions, ion-exchange, adsorption, and oxidation-reduction reduction reactions. Consequently, the full complement of chemical processes needed for waste form release simulations is available. After implementation of KEMOD, additional modifications necessary to model glass dissolution will be made to the code.

The lattice-Boltzmann model will be used to duplicate a 2-D calculation performed by the STORM simulator for the 2001 PA. Results from the lattice-Boltzmann model and STORM will be compared and contrasted. Additional simulations will performed that increase in complexity, including the number of grid nodes and chemical reactions being considered beyond those possible with the STORM simulator. This will be done to ascertain any computational problems with the code and to establish speed/complexity relationships for conducting sensitivity and uncertainty analyses for the 2005 PA.

In addition to the lattice-Boltzmann model development, several improvements will be made to STORM to make it run more efficiently. Currently, simulations are forced to use small time steps when aqueous concentrations of some species become very small, causing the the matrix solver to "blow up" due to an ill-conditioned matrix. An option to remove low concentration species from the reaction matrix will be added. Also, the current LU decomposition solver that STORM uses is not very robust and will be 
RPP-6702, Rev. 0

Formerly HNF-SD-WM-PAP-062 Rev. 4

replaced with NSPCG, a Non-Symmetric Preconditioned Conjugate Gradient method. NSPCG is a package of linear algebra routines developed by Rice University for iteratively solving large, sparse matrices. Finally, time steps are also kept small because the reactive transport routines are highly nonlinear. Many iterations are necessary to converge to the correct answer. A more efficient extrapolation scheme will be implemented to allow STORM to reduce the number of iterations required for convergence.

b. List Of Deliverables

The primary deliverable will be a journal article that will describe the results from the lattice-Boltzmann model development and testing. The article will be prepared and issued by $9 / 30 / 2001$.

Table 5.1-6a List of Deliverables for Update Waste Form Simulation Code for 2005 PA

\begin{tabular}{|c|c|c|c|}
\hline Description & $\begin{array}{l}\text { Due } \\
\text { Date }\end{array}$ & Level & $\begin{array}{l}\text { MYWP } \\
\text { Identifier }\end{array}$ \\
\hline $\begin{array}{l}\text { Issue electronic message that fractured glass } \\
\text { samples have been made for testing }\end{array}$ & $3 / 31 / 00$ & 8 & \\
\hline $\begin{array}{l}\text { Issue report documenting the lattice } \\
\text { Boltzmann simulation technique, } \\
\text { characterization of the glass monolith fracture } \\
\text { structure, a presentation of simulation results } \\
\text { and comparison of results with literature } \\
\text { values and experimental data. }\end{array}$ & $9 / 30 / 01$ & 7 & \\
\hline
\end{tabular}

c. Cost Summary

WBS: $1.1 .1 \cdot 3 \cdot 4 \cdot 1 \cdot 3.2$

TPCN: D4DM2

Table 5.1-6b Cost Summary for Update Waste Form Simulations Code for 2005 PA

\begin{tabular}{|l|l|r|}
\hline Fiscal Year & \multicolumn{1}{|c|}{ Organ. } & Amount (\$1000K) \\
\hline 1999 & Pacific Northwest National Laboratory (PNNL) & 0 \\
\hline 2000 & PNNL & 95 \\
\hline $2001^{\star}$ & PNNL & 335 \\
\hline 2002 & PNNL & 350 \\
\hline 2003 & PNNL & 350 \\
\hline Grand Total & 1130 \\
\hline
\end{tabular}

- Costs in FY01 include costs for issuing a subcontract to the Penn State University to modify KEMOD to support a kinetic rate for glass dissolution 
RPP-6702, Rev. 0

Formerly HNF-SD-WM-PAP-062 Rev. 4

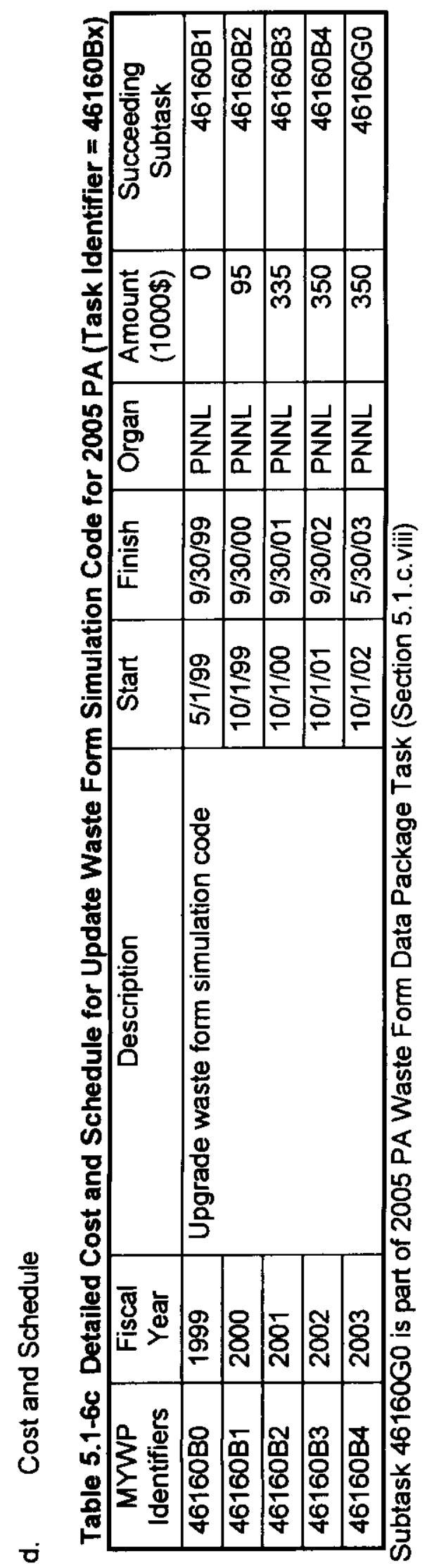


RPP-6702, Rev. 0

Formerly HNF-SD-WM-PAP-062 Rev. 4

vii. ILAW Glass Analog Field Test Data Collection and Modeling

At a workshop on the long-term performance of glass in its disposal environment (Bruges, Belgium, 4/10 to 4/14/2000), Dr. Michael Ojovan (Scientific and Industrial Association, Radon Institute, Moscow, Russia) gave a presentation on a field experiment that has been running for 12 years in the Russian Republic. A radioactive waste glass (K-26) made from actual intermediate-level waste from the Kursk (RBMK reactor) was manufactured and placed in a shallow trench. The waste stream from which the glass was made was $86 \mathrm{wt} \% \mathrm{NaNO}_{3}$, very similar to the salt content expected for Hanford LAW. The final glass composition had a $\mathrm{Na}_{2} \mathrm{O}$ content of 16.1 to $24.0 \mathrm{wt} \%$, making it very relevant to the glass formulations being considered at Hanford. Dr. Ojovan and his team have collected and analyzed fluid, soil, and reacted glass samples from the "repository" site over the last 12 years. As a result, a unique and important database has been developed that could be used to validate the models being used for glass corrosion and near-field release.

The objectives of this task are:

- Initiate a collaborative agreement with Dr. Ojovan to provide a detailed report on the available data from the field test site and to identify any archive samples that might be available for more detailed analysis than is available to Dr. Ojovan at the Radon Institute. This may include providing funding for Dr. Ojovan to travel to PNNL for an extended stay as a visiting scientist

- Obtain samples and conduct the necessary laboratory experiments with the K-26 waste glass so that STORM calculations can be conducted for the burial site,

- Conduct STORM calculations and compare the code outputs with the experimental data obtained at the field site, and

- If required, provide for travel to the field site to discuss the field tests with the operators and plan and/or collect additional samples to better characterize the release and transport behavior of the radionuclides at the site.

b. List Of Deliverables

Table 5.1-7a ILAW Glass Analog Field Test Data Collection and Modeling

\begin{tabular}{|l|l|l|l||}
\hline Description & Due Date & Level & $\begin{array}{l}\text { MYWP } \\
\text { Identifier }\end{array}$ \\
\hline $\begin{array}{l}\text { Issue subcontract to Radon Institute for Data } \\
\text { Report on Field Test }\end{array}$ & $12 / 31 / 00$ & & \\
\hline Receive Data Report from Radon Institute & $5 / 30 / 01$ & & \\
\hline Obtain K-26 Glass Samples & $6 / 31 / 01$ & & \\
\hline Initiate Laboratory Testing with K-26 Samples & $7 / 30 / 01$ & & \\
\hline Complete Laboratory Testing with K-26 Glass & $9 / 30 / 02$ & & \\
\hline Complete STORM Simulations of K-26 Burial Site & $12 / 31 / 02$ & & \\
\hline $\begin{array}{l}\text { Issue Report on K-26 Burial Site and Comparison } \\
\text { of Model Predictions with Site Data }\end{array}$ & $4 / 30 / 03$ & & \\
\hline
\end{tabular}


RPP-6702, Rev. 0

Formerly HNF-SD-WM-PAP-062 Rev. 4

c. Cost Summary

WBS:

TPCN: D4DM2

Table 5.1-7b Cost Summary for Glass Analog Field Test Data Collection and Modeling

\begin{tabular}{|l|l|l|}
\hline Fiscal Year & Organ. & Amount $(\$ 1000 \mathrm{~K})$ \\
\hline 2001 & Pacific Northwest National Laboratory (PNNL) & 175 \\
\hline 2002 & PNNL & 325 \\
\hline 2003 & PNNL & 450 \\
\hline \hline Grand Total & 950 \\
\hline
\end{tabular}

Costs in FY01 through FY03 include costs for a subcontract to the Radon Institute, Moscow, Russia. 
RPP-6702, Rev. 0

Formerly HNF-SD-WM-PAP-062 Rev. 4

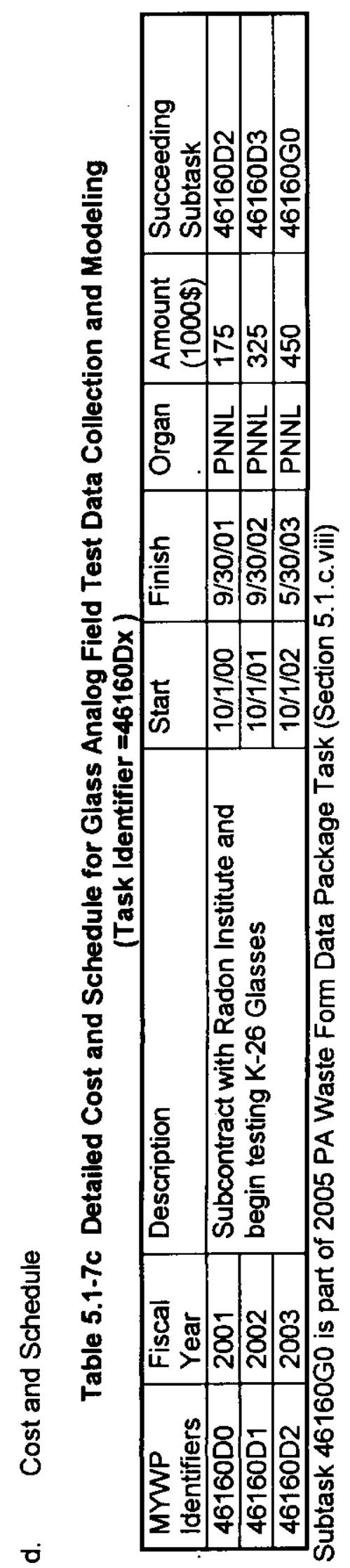


RPP-6702, Rev. 0

Formerly HNF-SD-WM-PAP-062 Rev. 4

viii. Document Waste Form Data for 2005 Performance Assessment

a. Background

The effective contaminant release rate from the waste form is one of the most important parameters in the performance assessment. All of the data (experimental, calculational, computer-code specific) needed for the calculation of this effective release rate for the 2005 performance assessment will be documented and justified.

b. List Of Deliverables

Table 5.1-8a List of Deliverables for 2005 PA Waste Form Data Package

\begin{tabular}{|l|c|c|l||}
\hline Description & Due Date & Level & $\begin{array}{l}\text { MYWP } \\
\text { Identifier }\end{array}$ \\
\hline $\begin{array}{l}\text { Write a report documenting the current status } \\
\text { of knowledge for waste performance needed } \\
\text { for the 2005 performance assessment. }\end{array}$ & $12 / 31 / 03$ & 7 & $\begin{array}{l}\text { 46160EC } \\
\text { [46160E1] }\end{array}$ \\
\hline $\begin{array}{l}\text { Receive a letter report from an external review } \\
\text { panel on the first draft of a report of waste } \\
\text { form performance. }\end{array}$ & $3 / 30 / 04$ & 7 & $\begin{array}{l}\text { 46160EB } \\
\text { [46160E3] }\end{array}$ \\
\hline $\begin{array}{l}\text { Issue a report documenting the current status } \\
\text { of knowledge for waste form performance } \\
\text { needed for the 2005 performance } \\
\text { assessment. }\end{array}$ & $7 / 31 / 04$ & 6 & $\begin{array}{l}\text { 46160EA } \\
\text { [46160E4] }\end{array}$ \\
\hline
\end{tabular}

c. Cost Summary

WBS: $1.1 .1 \cdot 3 \cdot 4 \cdot 1 \cdot 3.2$

TPCN: D4DM2

Table 5.1-8b Cost Summary for Documenting Waste Form Data for 2005 PA

\begin{tabular}{|l|l|r|}
\hline $\begin{array}{l}\text { Fiscal } \\
\text { Year }\end{array}$ & Organ. & $\begin{array}{l}\text { Amount } \\
(\$ 1000)\end{array}$ \\
\hline 2003 & Pacific Northwest national Laboratory (PNNL) & 33 \\
\hline 2004 & CH2M Hill Hanford Group (CHG) & 40 \\
\cline { 2 - 3 } & PNNL & 32 \\
\cline { 2 - 3 } & Total & 72 \\
\hline \hline
\end{tabular}

d. Detailed Description

There are three subtasks in this task:

i. Write the draft version of the waste form data package,

ii. Review the draft version, and

iii. Review the comments and issue the waste from data package.

The draft version of the waste form data package shall contain all of the data needed for the contaminant release rate calculations in the 2005 performance assessment. The authors shall review the documents published in the other subtasks of 
RPP-6702, Rev. 0

Formerly HNF-SD-WM-PAP-062 Rev. 4

this task (as well as documents produced by the performance assessment team and others). The authors will justify selection of data and methods.

Because the contaminant release rate is one of the most important parameters and one of the most uncertain, an external panel will review the draft version. The panel shall be selected by the performance assessment team leader after consultation with RPP, the waste form subteam leader, and the waste form expert on the Performance Assessment Review Board (see Section 7.C.iv). The draft version shall also be available to others for review.

Comments on the draft version of the waste form data packages shall be reviewed and incorporated into the document as appropriate. Some comments may be better included in a revised work effort than in the document itself. The final version of the waste form data package will be used in creating the full 2005 performance assessment data package and will appear in that document as an appendix. 
RPP-6702, Rev. 0

Formerly HNF-SD-WM-PAP-062 Rev. 4

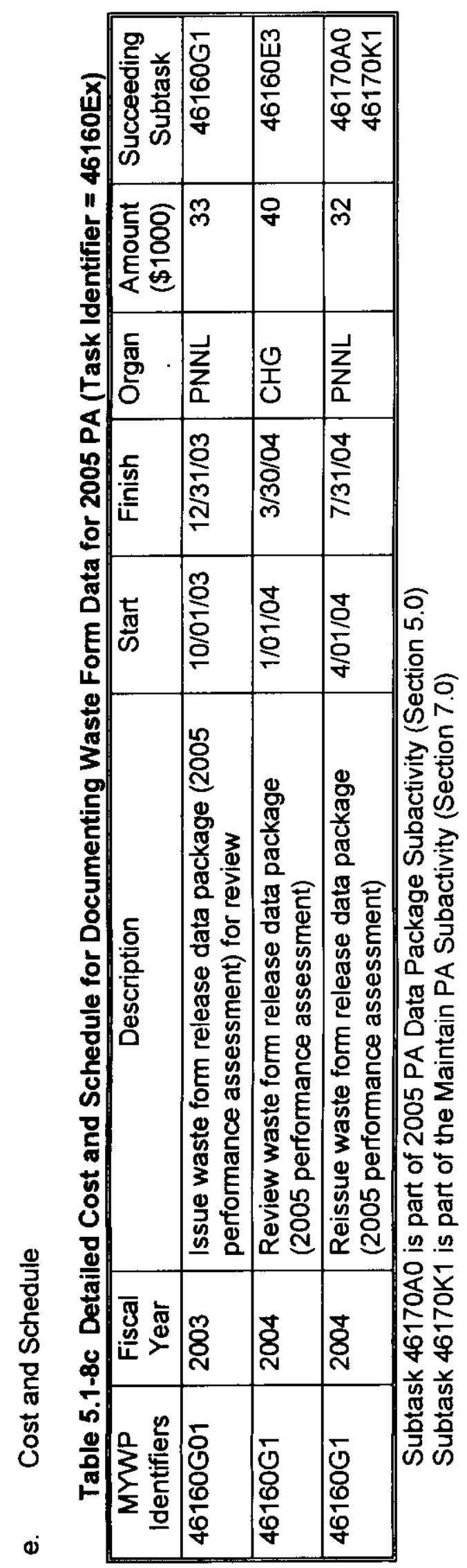


RPP-6702, Rev. 0

Formerly HNF-SD-WM-PAP-062 Rev. 4

ix Procure and Install Scanning Laser Raman System

a. Background

Currently, examination of the reaction products formed during long-term PUF experiments must be done destructively by stopping the experiment and removing the reacted solids. Because this is the only way that an understanding of the reaction processes can be developed, multiple PUF runs are necessary to permit data collection in a timely manner. Costs are incurred from the need to build multiple PUF systems and for labor and analytical costs involved in running additional experiments.

b. List Of Deliverables

The deliverable for this task would be an electronic message to the technical lead that the installation of the scanning laser Raman system is complete and the system is operational.

c. Cost Summary WBS:

Table 5.1-9a Cost Summary for Procure and Install Scanning Laser Raman System

\begin{tabular}{|l|l|l|}
\hline $\begin{array}{l}\text { Fiscal } \\
\text { Year }\end{array}$ & Organ. & $\begin{array}{l}\text { Amount } \\
(\$ 1000)\end{array}$ \\
\hline 2001 & Pacific Northwest national Laboratory (PNNL) & 105 \\
\hline \hline Grand Total & 105 \\
\hline
\end{tabular}

d. Detailed Description

To circumvent these difficulties, an in situ analytical technique is needed to help identify glass reaction products without terminating a PUF experiment. A scanning laser Raman spectroscopy system will be procured and interfaced with the PUF system. Raman spectra provide a means to chemically identify silicate minerals using the known characteristic absorption lines for these phases. Banning scanning the laser beam, a 2-D picture of the distribution of the mineral alteration phases can be obtained. Laser Raman spectra can be obtained using a back-scattering geometry with a Spex Triplemate Raman spectrometer equipped with a microprobe attachment capable of resolution down to the micron scale. The $514.5 \mathrm{~nm}$ line of a Spectra Physics $\mathrm{Ar}^{+}$laser has previously been used for sample excitation. The spectrometer is calibrated with respect to the characteristic Raman bands with a polycrystalline $\mathrm{TiO}_{2}$ standard. Data is collected using a CCD detector. The PUF cells will be modified to incorporate a sapphire window that has very low absorbance in the optical and infrared parts of the spectrum. 
RPP-6702, Rev. 0

Formerly HNF-SD-WM-PAP-062 Rev. 4

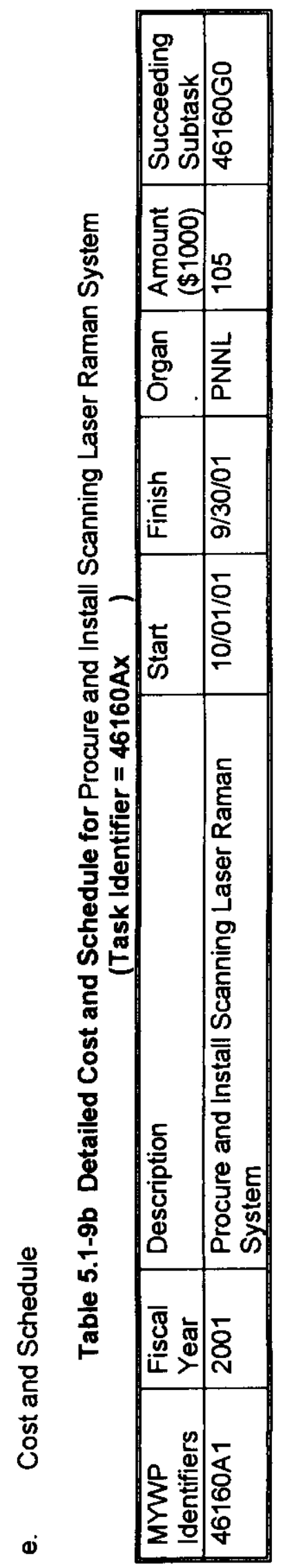


RPP-6702, Rev. 0

Formerly HNF-SD-WM-PAP-062 Rev. 4

\subsection{GEOTECHNICAL DATA}

\section{A. SUMMARY}

Provide data and the calculational tools necessary to calculate the transport of contaminants from the waste form to the location for compliance for the 2005 performance assessment. The documentation should provide the current state of knowledge for the materials being considered for facility design and for the locations selected for waste disposal. The data collected should be directed toward supplying information needed for the calculation of contaminants over 10,000 years.

\section{B. GENERAL}

i. Background

The purpose and need for the generation of data packages for the 2005 performance assessment are the same as for the generation of packages for the 2001 performance assessment (see Chapter 3.2).

ii. List of Deliverables

Table5.2-1a List of Major Deliverables for 2005 PA Geotechnical Subactivity

\begin{tabular}{|l|l|c|c|}
\hline Description & $\begin{array}{l}\text { Due } \\
\text { Date }\end{array}$ & Level & $\begin{array}{l}\text { MYWP } \\
\text { Identifier }\end{array}$ \\
\hline $\begin{array}{l}\text { Issue summary report documenting the drilling of } \\
\text { 2nd borehole as well as the collection, distribution, } \\
\text { and preservation of samples from the borehole. }\end{array}$ & $9 / 30 / 01$ & 6 & $46160 \mathrm{FA}$ \\
\hline $\begin{array}{l}\text { Issue summary report documenting the drilling of } \\
\text { 3rd borehole as well as the collection, distribution, } \\
\text { and preservation of samples from the borehole. }\end{array}$ & $9 / 30 / 02$ & 6 & $46160 \mathrm{FA}$ \\
\hline $\begin{array}{l}\text { Issue a report documenting the stratigraphy at the } \\
\text { disposal sites based on new borehole } \\
\text { measurements as well as literature searches of } \\
\text { existing Hanford information. }\end{array}$ & $12 / 31 / 03$ & 7 & $46160 \mathrm{GA}$ \\
\hline $\begin{array}{l}\text { Issue a report documenting the recharge rate at the } \\
\text { disposal locations and the effect of the proposed } \\
\text { surface barrier on that rate. }\end{array}$ & $12 / 31 / 03$ & 6 & $46160 \mathrm{HA}$ \\
\hline $\begin{array}{l}\text { Issue a report documenting the hydraulic properties } \\
\text { of the vadose zone at the disposal site locations. }\end{array}$ & $12 / 31 / 03$ & 6 & $46160 \mathrm{~A}$ \\
\hline $\begin{array}{l}\text { Issue a report documenting the hydraulic properties } \\
\text { of materials expected to be in the disposal facility, } \\
\text { including those properties of degraded materials. }\end{array}$ & $12 / 31 / 03$ & 6 & $46160 \mathrm{JA}$ \\
\hline $\begin{array}{l}\text { Issue a report documenting the geochemical } \\
\text { properties of the vadose zone at the disposal site } \\
\text { locations. }\end{array}$ & $12 / 31 / 03$ & 6 & $46160 \mathrm{KA}$ \\
\hline $\begin{array}{l}\text { Issue a report documenting the geochemical } \\
\text { properties of materials expected to be in the }\end{array}$ & $12 / 31 / 03$ & 6 & $46160 \mathrm{LA}$ \\
\hline
\end{tabular}


RPP-6702, Rev. 0

Formerly HNF-SD-WM-PAP-062 Rev. 4

\begin{tabular}{|l|l|c|c|}
\hline Description & $\begin{array}{l}\text { Due } \\
\text { Date }\end{array}$ & Level & $\begin{array}{l}\text { MYWP } \\
\text { Identifier }\end{array}$ \\
\hline disposal facility. & & & \\
\hline $\begin{array}{l}\text { Issue a report documenting the verification and } \\
\text { (where appropriate) validation of the computer code } \\
\text { selected to calculation moisture flow and } \\
\text { contaminant transport in the vadose zone and in the } \\
\text { disposal facility. }\end{array}$ & $12 / 31 / 03$ & 6 & $\mathbf{4 6 1 6 0 \mathrm { MA }}$ \\
\hline
\end{tabular}

iii. Cost Summary

WBS: $1.1 \cdot 3 \cdot 4 \cdot 1 \cdot 3.3$

TPCN: D4DM3

Table 5.2-1b Cost Summary for Creating 2005 PA Geotechnical Data Packages

\begin{tabular}{|l|l|r|}
\hline $\begin{array}{l}\text { Fiscal } \\
\text { Year }\end{array}$ & Organization & $\begin{array}{r}\text { Amount } \\
(1000 \$)\end{array}$ \\
\hline 1999 & Pacific Northwest National Laboratory (PNNL) & 35 \\
\hline 2000 & Fluor Federal Services (FFS) & 220 \\
\cline { 2 - 3 } & Bechtel Hanford Incorporated (BHI) & 0 \\
\cline { 2 - 3 } & Pacific Northwest National Laboratory (PNNL) & 962 \\
\cline { 2 - 3 } & Sandia National Laboratory (SNL) & 0 \\
\cline { 2 - 3 } & Waste Management Northwest WMNW) & 0 \\
\cline { 2 - 3 } & Savannah River Site (SRS) & 1217 \\
\hline \multirow{3}{*}{2001} & Total & 396 \\
\cline { 2 - 3 } & FFS & 250 \\
\cline { 2 - 3 } & BHI & 2254 \\
\cline { 2 - 3 } & PNNL & 80 \\
\cline { 2 - 3 } & SNL & 45 \\
\cline { 2 - 3 } & SRS & 20 \\
\cline { 2 - 3 } & WMNW & 3045 \\
\hline \multirow{5}{*}{2003} & Total & 80 \\
\hline \multirow{5}{*}{2002} & SNL & 115 \\
\cline { 2 - 3 } & SRS & 20 \\
\cline { 2 - 3 } & WMNW & 296 \\
\cline { 2 - 3 } & FFS & 250 \\
\cline { 2 - 3 } & BHI & 1848 \\
\cline { 2 - 3 } & PNNL & 120 \\
\cline { 2 - 3 } & SRS & 100 \\
\cline { 2 - 3 } & SNL & 80 \\
\hline
\end{tabular}


RPP-6702, Rev. 0

Formerly HNF-SD-WM-PAP-062 Rev. 4

\begin{tabular}{|l|l|r|}
\hline \multirow{3}{*}{2004} & Total & 2148 \\
\cline { 2 - 3 } & PNNL & 464 \\
\cline { 2 - 3 } & FFS & 25 \\
\cline { 2 - 3 } & SRS & 20 \\
\hline & Total & 509 \\
\hline \multirow{2}{*}{2005} & PNNL & 130 \\
\cline { 2 - 3 } & Total & 130 \\
\hline \multirow{2}{*}{ Grand Total } & 10534 \\
\hline
\end{tabular}

Includes $\$ 530,000$ of CENTRC funds for drilling in FY01 and FY02.

iv. Interfaces

This Subactivity builds on previous data collection efforts at Hanford, particularly those for the creation of other performance assessments (Kincaid 1995a, Mann 1998a, Wood 1994, Wood 1995, and Wood 1996). This work will focus on obtaining information for the disposal locations.

The data collection activities (46160Fx through $46160 \mathrm{Mx}$ ) are used as the primary basis for preparing a series of data packages (milestones 46160FA, 46160GA, $46160 \mathrm{HA}, 46160 \mathrm{~A}, 46160 \mathrm{JA}, 46160 \mathrm{KA}, 46160 \mathrm{LA}$, and $46160 \mathrm{MA}$ ) for the geotechnical activity. A series of data packages will be issued because of the many subdisciplines covered by this Subactivity.

These data packages will be used in creating the Data Packages for the 2005 Performance Assessment (see Section 5.0). The subsequent Subactivity (Chapter $7.0=$ Maintenance Performance Assessment) will build on the knowledge learned in this Subactivity.

v. Organization

A number of organizations will work on this activity because of the breadth of subdisciplines needed. Because of this breath, there will not be a single point of contact for the Subactivity but will be managed by the overall activity leader.

The Environmental and Nuclear Initiatives Section of Fluor Federal Services (FFS) has played major parts in each of the previous Hanford performance assessments. They will take the lead in determining hydraulic parameters for the vadose zone and for the groundwater modeling activity.

The Pacific Northwest National Laboratory (PNNL) has many sections experienced with Hanford geotechnical activities. The Hydrology section led the production of the Grout Performance Assessment (Kincaid 1995a) and has performed most of the recharge measurements and analyses on the Hanford Site. The Hydrology section will lead the effort on the determination of near-field hydraulic parameters and of recharge. This section also has the lead for the Hanford Groundwater Project. The Interfacial Geochemistry section has extensive experience in using tracer techniques to estimate recharge at the Hanford Site and will use those techniques for this performance assessment. Finally, the Applied Geology and Geochemistry Section has the Hanford 


\section{RPP-6702, Rev. 0 \\ Formerly HNF-SD-WM-PAP-062 Rev. 4}

Site's expertise in geology and geochemistry. They have worked on the previous Hanford performance assessments as well as most of the other environmental assessment reports dealing with the site.

The Sandia National Laboratory (SNL) has extensive experience with identifying and providing data for materials that can chemically sorb contaminants.

C. TASK DESCRIPTIONS

i. Summary List of Tasks

a. Obtain and Document Borehole Samples

b. Determine Geologic Layer at Disposal Sites

c. Determine Recharge at Disposal Sites

d. Determine Hydraulic Parameters for Disposal Facility Materials

e. Determine Hydraulic Parameters for Soils at Disposal Sites

f. Determine Geochemical Parameters for Disposal Facility Materials

g. Determine Geochemical Parameters for Soils at Disposal Sites

h. Upgrade Vadose Zone Moisture Flow and Contaminant Transport Simulation Code

ii. Obtain and Document Borehole Samples

a. Background

In order to estimate the travel of contaminants from the disposal facility through the vadose zone to the groundwater, parameters describing the natural system must be determined. To determine the parameters, measurements of the natural system and of samples from that natural system must be made. Boreholes dug at the disposal sites provide the means to make the field measurements and to obtain samples for laboratory measurements.

Under the Geotechnical Data Collection activity for the 2001 Performance Assessment, one borehole was drilled (FY98). This activity will bore a second and a third (both down-gradient of the new disposal site, one near the north end and one near the south end). Both boreholes will be converted into RCRA groundwater monitoring holes.

Field measurements include the determination of geologic layering (stratigraphy) (See Section 5.2.C.iii) and of in-situ moisture content and potential. Geologic layers are important because they are the basic unit for modeling (Section 5.2.C.ix). In each layer, parameters for each property are assumed to have one distribution function. In-situ moisture properties not only provide initial conditions for the modeling but provide a test for the computer models and associated hydraulic parameters.

Borehole samples are used in the determination of recharge (Section 5.2.C.iv), of hydraulic properties of the vadose zone (Section 5.2.C.v), and of geochemical properties of the vadose zone (Section 5.2.C.vii). Because backfill materials are also likely to be used in the disposal facility, hydraulic and geochemical properties (Sections 5.2.C.vi and 5.2.C.viii, respectively) of these materials. 
RPP-6702, Rev. 0

Formerly HNF-SD-WM-PAP-062 Rev. 4

The subsurface characterization documented in the Characterization Plan for the Proposed TWRS Treatment Complex (Reidel et al. 1995) was based on the needs of the Hanford low-activity tank waste performance assessment activity. This document, using a data quality objectives approach, provides justification for the number of wells and samples in each well. This plan was updated (Reidel and Reynolds, 1997) reflecting new needs-and providing detail data on the boreholes drilled in FY98.

\section{b. List Of Deliverables}

Table 5.2-2a List of Deliverables for 2005 PA Borehole Subtasks

\begin{tabular}{|c|c|c|c|}
\hline Description & Due Date & Level & $\begin{array}{l}\text { MYWP } \\
\text { Identifier }\end{array}$ \\
\hline Obtain permits for drilling $2^{\text {nd }}$ borehole & $12 / 31 / 00$ & $\overline{8}$ & 46160FK \\
\hline Start drilling 2nd borehole & $3 / 01 / 01$ & 8 & $46160 \mathrm{FI}$ \\
\hline Drill $2^{\text {nd }}$ borehole, supply samples & $4 / 01 / 01$ & 8 & 46160FG \\
\hline Document archived samples from $2^{\text {nd }}$ borehole & $6 / 01 / 01$ & 7 & 46160FE \\
\hline $\begin{array}{l}\text { Document measured physical properties of } \\
\text { samples from } 2^{\text {nd }} \text { borehole }\end{array}$ & $7 / 01 / 01$ & 8 & 46160FC \\
\hline Issue Summary Report for $2^{\text {nd }}$ Borehole & $9 / 30 / 01$ & 6 & 46160FA \\
\hline Issue Slug Test Report & $9 / 30 / 01$ & (new) & (new) \\
\hline Obtain permits for drilling 3rd borehole & $12 / 31 / 01$ & 8 & 46160FK \\
\hline Start drilling 3rd borehole & $2 / 01 / 02$ & 8 & $46160 \mathrm{FI}$ \\
\hline Drill $3^{\text {rd }}$ borehole, supply sample & $3 / 31 / 02$ & 8 & 46160FG \\
\hline Document archived samples from $3^{\text {rd }}$ borehole & $6 / 01 / 02$ & 7 & 46160FE \\
\hline $\begin{array}{l}\text { Document measured physical properties of } \\
\text { samples from } 3^{\text {rd }} \text { borehole }\end{array}$ & $7 / 01 / 02$ & 8 & 46160FC \\
\hline Issue Summary Report for 3rd Borehole & $9 / 30 / 02$ & 6 & 46160FA \\
\hline Issue Slug Test Report & $9 / 30 / 02$ & (new) & (new) \\
\hline
\end{tabular}

c. Cost Summary

WBS: $1.1 \cdot 1 \cdot 3 \cdot 4 \cdot 1 \cdot 3.3$

TPCN: D4DM3

Table 5.2-2b Cost Summary for 2005 PA Borehole Tasks

\begin{tabular}{|l|l|r|}
\hline $\begin{array}{c}\text { Fiscal } \\
\text { Year }\end{array}$ & \multicolumn{1}{|c|}{ Organ. } & $\begin{array}{r}\text { Amount } \\
(\$ 1000)\end{array}$ \\
\hline 2000 & Pacific Northwest national Laboratory (PNNL) & 65 \\
\hline \multirow{2}{*}{$\begin{array}{l}\text { Bore- } \\
\text { hole \#2 }\end{array}$} & Bechtel Hanford Incorporated (BHI)* & 250 \\
\cline { 2 - 3 } & Pacific Northwest National Laboratory (PNNL) & 140 \\
\cline { 2 - 3 } & Waste Management Northwest (WMNW) & 20 \\
\cline { 2 - 3 } & Total & 410 \\
\hline \multirow{2}{*}{$\begin{array}{l}2002 \\
\text { Bore- } \\
\text { hole \#3 }\end{array}$} & Bechtel Hanford Incorporated (BHI) & 250 \\
\cline { 2 - 3 } & Pacific Northwest National Laboratory (PNNL) & 205 \\
\end{tabular}


RPP-6702, Rev. 0

Formerly HNF-SD-WM-PAP-062 Rev. 4

\begin{tabular}{|c|c|c|}
\hline & Waste Management Northwest (WMNW) & 20 \\
\hline & Total & 475 \\
\hline Grand tota & & 950 \\
\hline
\end{tabular}

* The CENTRC funds have been used in FY1999; therefore, program costs include cost for drilling wells

\section{d. Detailed Description}

The geologic and hydrologic properties of the vadose zone control the flow of water and the transport of contaminants through the vadose sediments to the unconfined aquifer. Two boreholes will be drilled to determine and characterize the physical and geochemical properties of the vadose zone and saturated zone underlying the proposed new disposal facility for the immobilized low-activity tank waste. These boreholes will be completed as groundwater monitoring wells to obtain groundwater data and for aquifer testing.

In addition, the boreholes will be used to determine the presence of radiological and chemical contaminants throughout the borehole section and help establish the preoperational baseline. Borehole data will provide a preliminary chemical and radiological assessment of the borehole sediments of the two sites. The results will be used to evaluate the existence of potential health hazards on the sites so that any necessary actions for protection can be implemented prior to, and during, construction. These data also will provide a preliminary database that can be used to develop a baseline for the Site prior to RPP operations.

Geologic Sample Analysis of Vadose Zone Samples. This task will determine the geologic, hydrologic, and geochemical properties of vadose zone samples from the boreholes at the sites. These properties provide parameters for a quantitative conceptual model that will be used in the PA of the Site to predict flow and transport in the vadose zone. Samples collected in this study will also be used to determine the $K_{d}$ values of the vadose zone sediments and to investigate infiltration rates.

Of special interest are the buried soil horizons (paleosols) found during the drilling of the first ILAW holes. Work during FY99 has shown that at least one of the paleosols at a depth of about 70 feet may be is present over the whole ILAW site. This paleosol may be an important contaminant-spreading horizon near the 216-A-10 cribs east of the ILAW site. If this is true, then the paleosols could greatly increase the amount of time before contaminants reach groundwater. An additional borehole on the east side of the ILAW site is needed to confirm this.

The following vadose zone data will be obtained from the borehole samples:

1. Stratigraphy and textural properties

2. Physical properties including bulk density and porosity

3. Mineralogical/petrological composition

4. Selected ion measurements

5. Radiological and chemical contamination

6. Geochemistry and $K_{d}$ determinations 


\section{RPP-6702, Rev. 0 \\ Formerly HNF-SD-WM-PAP-062 Rev. 4}

7. Moisture content and moisture potential

8. Infiltration/recharge rates.

Aquifer Characterization. Saturated zone geohydrologic characterization data will be used to determine the conditions and properties that control groundwater flow directions and rates within the aquifer. Data collection and interpretation are focused on geology, geochemistry, hydrogeology, hydrochemistry, and groundwater modeling. These boreholes will provide the following:

1. Geochemical/radiological baseline

2. Stratigraphic data and physical properties

3. Hydrologic parameters

4. Monitoring and aquifer testing boreholes

5. Hydrostratigraphy information about the bottom of the aquifer.

Geochemical and hydrochemical measurements will be used to evaluate the chemical behavior of key constituents in the aquifer. Mineralogic composition and sorptive properties of the aquifer solids combined with geochemical characteristics of the pore fluid (groundwater) and geochemical modeling will be used to evaluate factors that influence contaminant migration rate (e.g., redox status, sorption, solubility, chemical precipitation, and/or isotope exchange reactions). Sampling and analysis for appropriate regulatory constituents will also provide background or baseline data to meet the groundwater component of environmental monitoring requirements (see Section 8.2).

Location of Boreholes. The number and placement of the deep boreholes is based on (1) processes controlling deposition of vadose zone sediments and post depositional processes such as soil development, (2) the size and layout of the area, and (3) usefulness for establishing a groundwater baseline and for operational and postclosure monitoring. These are discussed in detail in Reidel et al. 1995.

Two different locations are needed. The new borehole will be drilled during FY01 but at the west end of the B-Pond complex. Although that borehole is too far east to provide direct characterization of the grout vaults, the data obtained from this will be useful to determining the lateral extent of stratigraphic units, lithologic properties and paleosols The second location is along the eastern boundary of the ILAW site. This location will provide valuable information on the lateral extent of the paleosols and lithologies. The second ILAW borehole will also serve as a downgradient groundwater monitoring well.

Borehole Data Collection. All boreholes will be drilled through the vadose zone and saturated zone to the top of the basalt. As continuous a record of the sediments at the sites will be obtained from the drilling. The sampling will be done with thin-walled splittube samplers. If the thin-walled samplers prove to be inadequate another technique will be chosen to maximize sample return and minimize disruption of the samples. Water or other drilling fluids will not be used in the vadose zone. Samples will be described by the well site geologist and quickly sealed in plastic for characterization measurements and archiving for future studies.

Geologic Data. Samples will be geologically logged and analyzed for physical properties and chemical compositions. Selected samples will be analyzed for potential chemical and radiological contamination. The number of samples, locations, and 


\section{RPP-6702, Rev. 0 \\ Formerly HNF-SD-WM-PAP-062 Rev. 4}

analyses are discussed in Reidel et al. 1995. A new characterization plan (similar to that provided for the FY98 Borehole (Reidel and Reynolds, 1997) will be prepared for each borehole and all data will be documented in a report similar to FY98 (Reidel, Reynolds and Horton, 1998).

Geologic descriptions will include, but not be limited to, detailed field lithologic descriptions, including color, texture, sorting, bulk mineralogy, roundness, relative calcium carbonate reactivity, consolidation, and cementation. All drilling and well construction data will be documented.

Laboratory analyses include selected chemical characteristics, grain size distribution, physical and hydraulic properties, and mineralogy.

Geophysical Logging. All boreholes will be geophysically logged. Geophysical logging provides data comparison with core derived data for stratigraphic interpretation, density (porosity) estimation, and relative moisture content of the sediments drilled.

Neutron/moisture, gamma, and radionuclide logs will be run to measure moisture, infer stratigraphy, and gamma density, and high-resolution spectral gamma to measure radionuclides. Geophysical tools will be used to help define hydrostratigraphic units and to correlate these units among adjacent boreholes.

Groundwater Samples. It is anticipated that a minimum of two water samples will be collected during drilling; final decision will be made when drilling has progressed to the saturated zone. In addition, groundwater samples will be taken every 20 feet through the aquifer for compositional screening if the borehole is drilled deeper than the upper portion of the aquifer.

Aquifer Testing. When all groundwater monitoring wells are installed, a multiple well aquifer test will be used to obtain in situ hydraulic conductivities and to refine estimates of groundwater travel time. In situ flow direction and velocity measurements will also be made in each of the three boreholes to confirm inferred flow and direction velocity based on water table elevations (gradient) and Darcy's law. Hydraulic testing will consist of instantaneous slug tests and constant rate discharge tests at one well. The other two wells and/or the nearest existing monitoring wells will be used as observation wells during the constant rate discharge tests. The multi-borehole aquifer test will be described in a test plan. A separate test plan will be written for this aquifer testing after installation of the proposed borehole(s).

e. Interfaces

The location of the boreholes will be determined based on discussions with the Hanford Site Integrated Vadose Zone/Groundwater Program, RCRA Operations and Monitoring Program, the DOE/RL Waste Integration Team, and the permitting team of the Immobilized Waste Program. A separate groundwater-monitoring plan will be written to define the groundwater monitoring program at the site and to meet ECOLOGY requirements. 


\section{RPP-6702, Rev. 0 \\ Formerly HNF-SD-WM-PAP-062 Rev. 4}

Borehole samples and information from the borehole drilling will be used by the geology task (5.2.C.iii), by the recharge task (5.2.C.iv), by the soil hydraulics task (5.2.C.vi), and by the soil geochemical task (5.2.C.viii).

f. Organization

Bechtel Hanford Incorporated (BHI) has been designated by the Manager of DOE Richland Operations as responsible for drilling all boreholes at the Hanford Site which are not in tank farms. BHI is the environmental restoration contractor for the Hanford Site.

The Applied Geology and Geochemistry Section of the Pacific Northwest National Laboratory (PNNL) will oversee the borehole activity. Members of this section have overseen borehole drilling numerous times in the Hanford 200 Area. The section will also supply the drilling geologist. services.

Waste Management Northwest (WMNW) will provide geophysical logging

g. Quality Assurance

All activities will be conducted in accordance with 10 CFR 830.120 and the Hanford Analytical Services Quality Assurance Requirements Document. Data collection efforts will be performed at PNNL QA impact level 2. Supporting analysis will be performed at impact level 3. Contractor QA levels will be at similar levels.

h. Effect of Not Performing Task

Boreholes and borehole samples are needed to provide site-specific geotechnical data as required by the Peer Review Panel. Without such site-specific data, it is highly unlikely that the performance assessment will be found "technically adequate." Without such a finding, DOE will not approve the performance assessment and hence will not be able to be dispose of the waste. 
RPP-6702, Rev. 0

Formerly HNF-SD-WM-PAP-062 Rev. 4

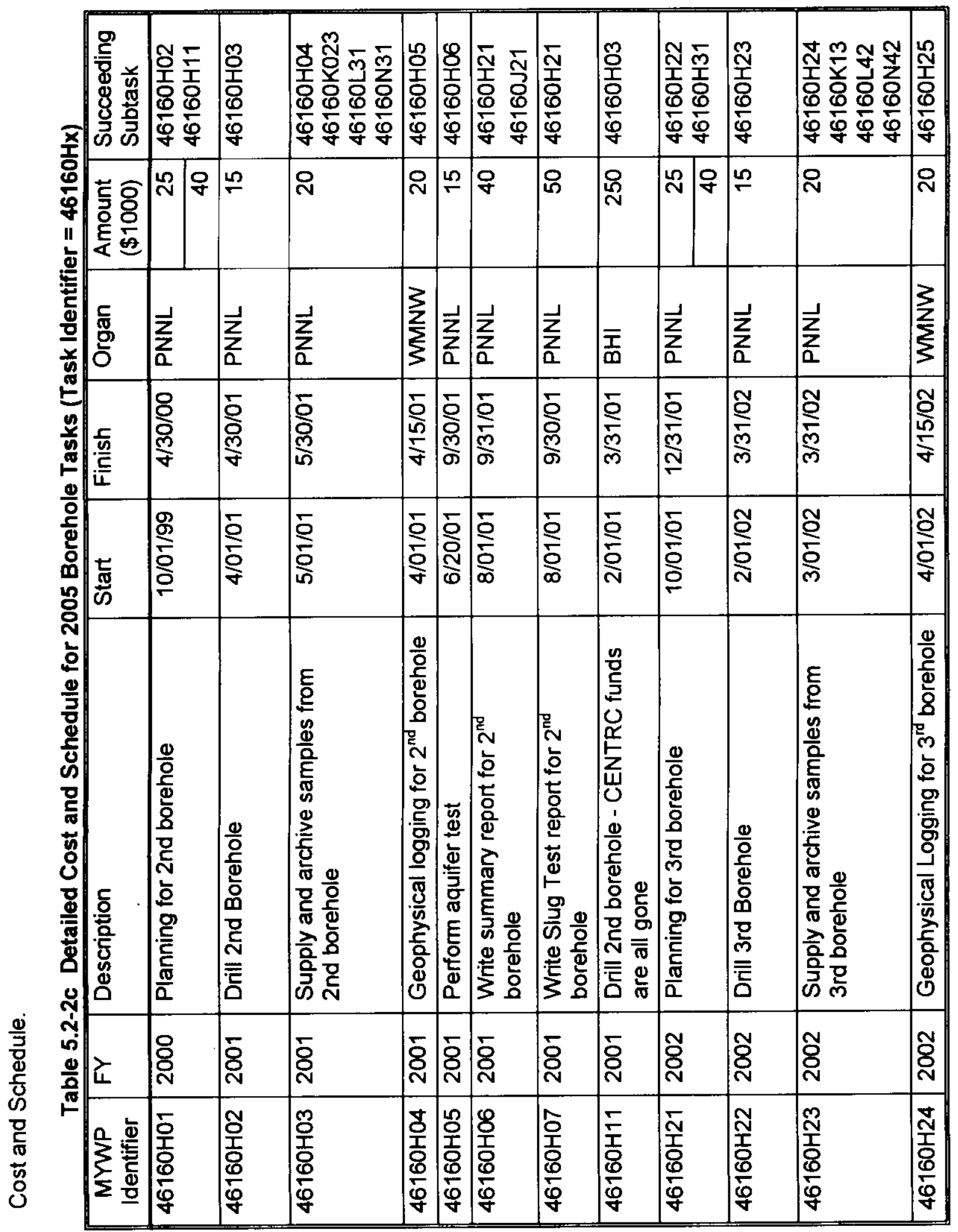


RPP-6702, Rev. 0

Formerly HNF-SD-WM-PAP-062 Rev. 4

\begin{tabular}{|c|c|c|c|c|}
\hline 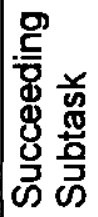 & 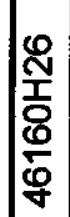 & 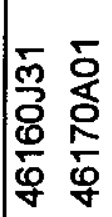 & 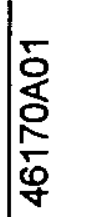 & 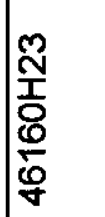 \\
\hline 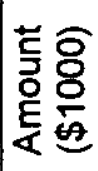 & 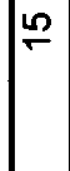 & P & 요 & 怘 \\
\hline $\begin{array}{l}\text { 동 } \\
\text { ơ } \\
\text { Oे }\end{array}$ & $\frac{z}{z}$ & $\sum_{2}^{1}$ & $\frac{\sum}{z}$ & $\mid \overline{\mathbf{I}}$ \\
\hline 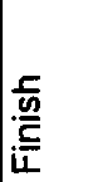 & 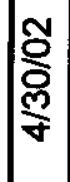 & $\frac{\mathscr{N}}{\frac{\mathscr{m}}{\sigma}}$ & 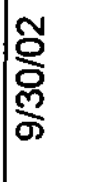 & $\frac{N}{\grave{m}}$ \\
\hline 党 & 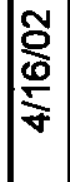 & $\frac{\Upsilon}{8}$ & $\frac{y}{\frac{Y}{6}}$ & 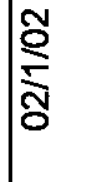 \\
\hline 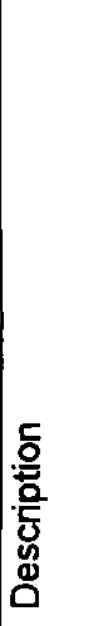 & 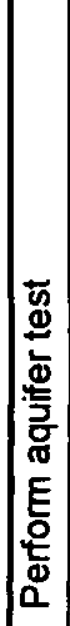 & 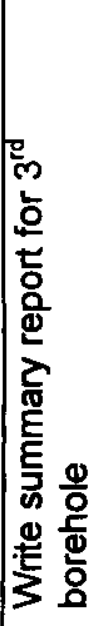 & 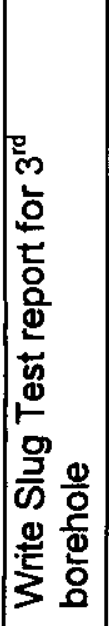 & 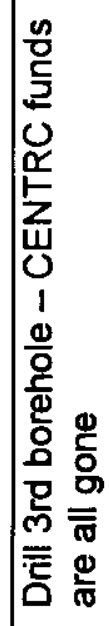 \\
\hline 左 & 尺্ & ণ్లి & ণ্ণ & 尺్ల \\
\hline 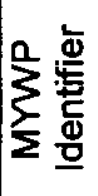 & 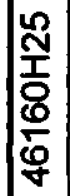 & 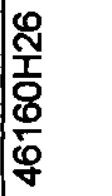 & $\frac{\hat{N}}{\frac{1}{\delta}}$ & 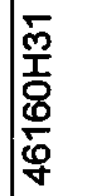 \\
\hline
\end{tabular}

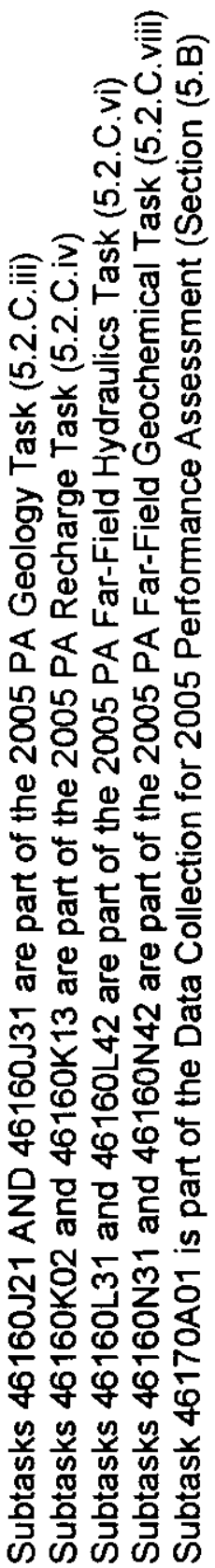


RPP-6702, Rev. 0

Formerly HNF-SD-WM-PAP-062 Rev. 4

Costs are based on the costs for the ILAW borehole drilled in FY98.Cost breakouts for $\mathrm{BHI}$ costs for borehole drilling are given in Table 5.2-2d.

PNNL costs are for writing drilling plan, coordinating with $\mathrm{BHI}$, supplying and archiving samples, perform testing of aquifer, and document borehole activities in a summary report.

WMNW costs are for planning the drilling, performing the geophysical logging, and for providing the sampling team and well site support for construction, drilling, and aquifer sampling. Geophysical logging will include neutron/neutron (to determine moisture), spectral gamma, and gross gamma (to determine geologic layers and possible contamination) for the deep borehole as well as the two shallow holes.

Table 5.2-2d Drilling Capital Costs (BHI)

\begin{tabular}{|c|c|c|}
\hline BOREHOLE ACTIVITY & & COSTS \\
\hline PAD CONSTRUCTION & & $\$ 20 \mathrm{~K}$ \\
\hline DRILLING $(\mathrm{BHI})$ & $\begin{array}{l}\text { Assumes same technique as the continuous } \\
\text { coring done last fall at } S-S X \text { but to greater } \\
\text { depth. }\end{array}$ & \multirow[t]{3}{*}{$\begin{array}{l}\text { \$200K (safe- } \\
\text { side estimate) }\end{array}$} \\
\hline $\begin{array}{l}\text { Mobilization, drilling, and } \\
\text { demobilization }\end{array}$ & $\begin{array}{l}0-360 \mathrm{ft}(\$ 400 / \mathrm{ft}) \text { Water table at approx. } 300 \\
\text { feet }\end{array}$ & \\
\hline $\begin{array}{l}\text { SAMPLING (continuous) } \\
30 \text { split spoons - } 10 \mathrm{ft} \text { each } \\
\text { in vadose zone }(0-300 \mathrm{ft})\end{array}$ & $\begin{array}{l}\text { About another } 50 \mathrm{~K} \text {. ORP paid } 35 \mathrm{~K} \text { for standby } \\
\text { time, extra time to drill continuous split spoons } \\
\text { to drill } 175 \text { feet continuous split spoon. }\end{array}$ & \\
\hline \multirow[t]{2}{*}{ DRILLING SUPPORT } & $\mathrm{BHI} / \mathrm{PNNL}$ & \multirow[t]{2}{*}{$\$ 65 \mathrm{~K}$} \\
\hline & $\begin{array}{l}\text { Well site support for drilling, sampling team } \\
\text { (Dynacorp-union), well site construction } \\
\text { support, support for aquifer testing }\end{array}$ & \\
\hline BHI MANAGEMENT & $\begin{array}{l}\text { Procurement, management, safety coverage, } \\
\text { health physics etc. }\end{array}$ & $\$ 30 \mathrm{~K}$ \\
\hline $\begin{array}{l}\text { PNNL PROJECT } \\
\text { MANAGEMENT }\end{array}$ & Costs during drilling & $\$ 15 \mathrm{~K}$ \\
\hline AQUIFER TESTING & PNNL & $\$ 15 K$ \\
\hline GEOPHYSICAL LOGGING & $\begin{array}{l}\text { Neutron/neutron (moisture measurement); } \\
\text { Spectral Gamma; Gross Gamma. (deep } \\
\text { borehole and two shallow boreholes) }\end{array}$ & $\$ 20 K$ \\
\hline $\begin{array}{l}\text { TOTAL DRILLING COST } \\
\text { (for one borehole) }\end{array}$ & & Total: $\$ 365 \mathrm{~K}$ \\
\hline $\begin{array}{l}\text { Logging, description and } \\
\text { report }\end{array}$ & PNNL & $90 \mathrm{~K}$ \\
\hline Grand Total & & $\$ 455 \mathrm{~K}$ \\
\hline
\end{tabular}


RPP-6702, Rev. 0

Formerly HNF-SD-WM-PAP-062 Rev. 4

iii. Determine Geologic Information at Disposal Sites

a. Background

A variety of geologic information is needed by the performance assessment: geologic layering, natural waste form analogs, clastic dyke properties, and natural background. More information is presented in Section 3.2.C.iii.

Geologic layers are the basic unit in the computer simulation of moisture flow and contaminant transport in a natural system. Each layer has a unique set of properties which describes it and makes it different from other layers.

This task will combine the data obtained from the borehole drilled for this activity (see Section 5.2.C.ii) and from other relevant Hanford information to obtain the thickness of various layers (four are known from the ILAW site: 3 are layers of the Hanford formation defined by palesols, and upper Ringold) and how this thickness varies over the disposal site. This task will build on the database prepared for FYOO.

This task will also be part of a multidisciplinary effort (including material scientists, hydrologists, and geochemists) to determine whether natural analogues in the Columbia Basin can provide information on the long-term dissolution rates under arid natural conditions of the waste form. The task will identify likely geologic analogs and make measurements of the dissolution rates of those analogues.

b. List Of Deliverables

Table 5.2-3a List of Deliverables for 2005 PA Geology Data Package

\begin{tabular}{|c|c|c|c|}
\hline Description & Due Date & Level & $\begin{array}{l}\text { MYWP } \\
\text { Identifier }\end{array}$ \\
\hline Plan natural background task. & $12 / 31 / 00$ & 7 & $\begin{array}{l}46145 \mathrm{~J} 00 \mathrm{D} \\
{[46145 \mathrm{~J} 02]}\end{array}$ \\
\hline Issue report on natural background studies & $9 / 30 / 01$ & 8 & $\begin{array}{l}46160 \mathrm{~J} 3 \mathrm{C} \\
{[46160 \mathrm{~J} 3]}\end{array}$ \\
\hline Issue report on clastic dike studies & $9 / 30 / 02$ & 8 & $\begin{array}{l}\text { 46160J2D } \\
\text { [46160J2] }\end{array}$ \\
\hline $\begin{array}{l}\text { Issue report on mineralogy/petrology composition } \\
\text { of vadose zone }\end{array}$ & $9 / 30 / 01$ & 18 & \\
\hline $\begin{array}{l}\text { Issue report on glass dust created by intruder } \\
\text { drilling }\end{array}$ & $9 / 30 / 01$ & 18 & \\
\hline Issue report on analog study & $9 / 30 / 01$ & 18 & \\
\hline Write draft geology document for 2005 PA & $9 / 30 / 03$ & 8 & $\begin{array}{l}46160 \mathrm{~J} 4 \mathrm{~B} \\
{[46160 \mathrm{~J} 4]}\end{array}$ \\
\hline Issue revised geology data package for $2005 \mathrm{PA}$ & $12 / 31 / 03$ & 6 & $\begin{array}{l}46160 \mathrm{~J} 6 \mathrm{~A} \\
{[46160 \mathrm{~J} 6]}\end{array}$ \\
\hline
\end{tabular}


RPP-6702, Rev. 0

Formerly HNF-SD-WM-PAP-062 Rev. 4

c. Cost Summary

WBS: 1.1 .1 .3 .4 .1 .3 .3

TPCN:D4DM3

Table 5.2-3b Cost Summary for 2005 PA Geology Task

\begin{tabular}{|c|l|r|}
\hline $\begin{array}{c}\text { Fiscal } \\
\text { Year }\end{array}$ & Organ. & \multicolumn{1}{|c|}{$\begin{array}{c}\text { Amount } \\
(\$ 1000)\end{array}$} \\
\hline 2000 & PNNL & 0 \\
\hline 2001 & PNNL & 280 \\
\hline 2002 & PNNL & 260 \\
\hline 2003 & PNNL & 175 \\
\hline 2004 & PNNL & 40 \\
\hline \hline Total & 755 \\
\hline
\end{tabular}

d. Detailed Description

\section{Geologic Layer Analysis.}

This task will develop the geohydrologic model used for the PA modeling efforts. All borehole data obtained from the borehole task will be evaluated and integrated with existing subsurface information from the Hanford Site. The quality of subsurface data from the Hanford Site varies and an important aspect of this task will be to insure that only the superior, highest quality data will be used.

The principal product of this task will be a geohydrologic model for each site that describes the number of stratigraphic layers, their physical and hydraulic properties, and variability. Because of the limited number of boreholes at the ILAW site, the greatest uncertainties will be in the lateral extent and uniformity of the layers. To reduce these uncertainties, comparison of the borehole data obtained here will be compared to the first ILAW borehole and boreholes from the surrounding area. The report will not only contain the best estimate of the geology in the area (including extent and tip angles) but also estimates of the uncertainty of such information.

\section{Analog Studies.}

Because of the conditions of the site or the nature of a test, neither of the disposal sites provide an adequate environment to determine some important physical properties in situ. The subtasks covered in this section are for planning. The actual effort is covered in Section 5.1.C.iii.

\section{Clastic Dikes. (Suitable for Integration Project Funding)}

Clastic Dikes are a common geologic feature of the Pleistocene flood deposits of the Hanford formation and have been observed throughout much of the Hanford Site, including the 241-SY Tank Farm, the 216-S-17 pond, the Environmental Restoration Disposal Facility (ERDF), and the U.S. Ecology Site. These vertical sedimentary structures cut across the normal horizontal bedding planes of the hydrogeologic units and have been found to extend up to $120 \mathrm{ft}$ in depth. Their potential effects on subsurface transport has long been recognized, but has not been well studied. 
RPP-6702, Rev. 0

Formerly HNF-SD-WM-PAP-062 Rev. 4

Anisotropic flow within the normally bedded Hanford formation sediments has been estimated at approximately 10:1 (horizontal flow to vertical flow). However, flow within these clastic dikes is likely to be just the reverse of this (i.e., 1:10) and perhaps with even greater anisotropy due to the presence of clay skins along the walls of the dikes, and the preferential effects of gravity on vertical flow. Thus, these features could represent a 100 fold increase in the vertical transport pathway over normal sedimentary conditions.

The presence or absence of clastic dikes will be determined at the sites (Reidel et al. 1995) but, because they are narrow, vertical to subvertical, subsurface features, their physical properties cannot be directly determined at these sites.

Task Description: The purpose of this task is to evaluate the presence and extensiveness of clastic dikes within the proposed disposal area(s) for RPP Low-activity Tank Waste, and to measure the hydrologic properties of a representative number of these dikes. This information will be incorporated into the PA and the geohydrologic model of the sites. This task will integrate with the clastic dike "Far-Field" activity to provide a combined approach to locating clastic dikes at the ILAW site and determining their hydraulic properties in situ and with laboratory analyses. This task will be integrated with FFS' Ground Penetrating Radar study of the ILAW site.

The activity will include the following:

- a review of literature and historical air photos to evaluate the presence and extensiveness of these clastic dike systems

- Ground penetrating radar survey over selected areas of the ILAW to locate several areas of clastic dikes (This task is integrated with task defined under section 5.2.c.vi.) (PNNL support to this task $\$ 10 \mathrm{~K}$ )

- Trench up to four sites where clastic dikes occur and map and sample them in the trench walls (about \$60K -PNNL). This will follow task defined under section 5.2.c.vi.

Natural (Geologic) Glass Dissolution Rates.

The use of analog sites to how well glass resists the environment and how it breaks down will provide preliminary information for PA modeling. Analysis of natural (i.e., geologic) deposits that are analogous to engineered systems provides a measure for the interpretation/validation of the long-term (100's to 1000's of years) performance of these systems. Long-term performance data of similar materials/design under similar environmental conditions can not otherwise be obtained. Without these long-term data from natural analogs, validation of computer simulations of system performance would be limited to the extrapolation of data acquired over just a few months or years and/or under radically different environmental conditions selected to advance the long-term effects.

\section{Task Description:}

The purpose of this task is to locate geologic glass (i.e. obsidian) deposits that are analogous to the proposed TWRS Low-activity Tank Waste glass, and that have been 


\section{RPP-6702, Rev. 0 \\ Formerly HNF-SD-WM-PAP-062 Rev. 4}

subjected to similar environmental conditions predicted for this glass waste form.

Obsidian flows at Newberry Crater, Oregon (25 miles south of Bend, Oregon) range in age from 1,200 to about 6,700 yr. B.P. This area has an arid environment similar to that of the Hanford Site, and potentially provides similar analogs at different ages within a short distance of each other.

Of primary concern to the long-term performance of the Immobilized Low-activity Waste Storage site is the rate of dissolution of the glass waste form, and leaching of the long-lived radioactive elements. Microscopic and microprobe analysis of carefully selected analog samples will provide a measure of the weathering/dissolution effects of these natural glass deposits. The leaching of trace metals from the weathering rinds of multiple samples and from different ages will provide a statistical correlation with which to derive the dissolution rates. Trace element analysis of soil samples juxtaposed to the natural glass samples will provide a second measure of the leaching and migration of trace metals out of the glass and into the soils.

This task includes the following activities:

perform literature review and select target analog sites

prepare detailed sampling and analysis plan, including the analog sample

selection criteria and data quality objectives for this study

It is expected that the sampling and analysis plan would include:

perform field reconnaissance and initial sampling

perform microscopic thin section analysis and microprobe analysis of the samples perform statistical analysis of the analytical data

if necessary perform a second round of sampling and analyses

prepare formal report summarizing the results of the laboratory analysis and statistical interpretation of the dissolution rates

\section{Mineralogy/Petrology Composition of Vadose Zone Layers, ILAW Site.}

Geology studies for the ILAW PA have shown that the Hanford formation vadose zone consists of three ages of Missoula flood deposits. The youngest is approximately 10,000 year old and the oldest is over 770,000 years old. The surface of each deposit in the southwest corner of the site is marked by a paleosol and the lowest layer has a reversed polarity. The sediments that form these layers were derived from rock in and surrounding the Columbia Basin.

The sediments comprising each of the three layers consist of a heterogeneous collection of many rocks and minerals having all size fractions including gravel, sand, silt, and clay with minor calcium carbonate cementation. Gravels are rock fragments lacking induration and usually consisting of many different types of minerals. At Hanford, gravels can be composed of pure quartzites, basalt or one of many different types of metamorphic rocks derived from the wide range of rocks surrounding the Columbia Basin. Sands and silts generally are single mineral grains derived from one of the many gravel types at Hanford or one of the many rocks surrounding the Columbia Basin. Clays are usually alteration products from gravels, sand and silt. 


\section{RPP-6702, Rev. 0 \\ Formerly HNF-SD-WM-PAP-062 Rev. 4}

Selected samples from the first ILAW borehole were analyzed by XRD in FYOO for detailed mineral phases and approximate percentages. In addition, samples from boreholes drilled in and near the ILAW site prior to the ILAW project were analyzed for particle size distribution. These data provide important information on the mineralogy and grain size of the three Missoula flood layers at the ILAW site. However, no other characterization data are available on minerals, rocks and percentages from the ILAW site other than the southwest corner.

Optical microscope and hand specimen identification methods are a rapid means to determine mineral phases, rock types comprising the gravels and rock and mineral abundances on many samples. The percentage of different rock types is typically determined by doing "pebble counts" in which the size, shape and composition of representative samples are tabulated. Optical microscope examination of sand and some silts allow similar data to be collected.

Boreholes in and around the ILAW site that were drilled prior to the ILAW project can be utilized to get mineral phases other than clays and most silts, rock types and mineral and rock abundances without drilling additional boreholes. Samples were collected from these boreholes at 5 feet intervals and archived in the Hanford Geotechnical Sample Library along with core from the first ILAW borehole.

Samples from the three flood-deposit layers in the first ILAW borehole will first be examined for differences in mineral content, gravel composition and, mineral and rock percentages using optical microscope and hand identification techniques. These results will be compared to XRD results and evaluated to determine what differences, if any, can be used to distinguish between the three Missoula layers and what properties can be used to define these deposits. Archived sediments from other boreholes near the ILAW site will be examined for mineralogical and petrologic differences in layers to extend the properties defined for the three layers and provide a methodology for extending defining the three layers in older, non-cored boreholes.

\section{Task: Utilize and Integrate Geologic Data from other Hanford Projects.}

The principal means of obtaining geologic information at Hanford is from boreholes. Vadose zone investigations for Tank Farms and Groundwater Monitoring Project wells will be drilling perhaps as many as 25 boreholes per year over the next several years. Boreholes drilled in the 200 East Area will provide additional information for characterizing the ILAW site.

This task will integrate other geologic activities that are near the ILAW site and could provide valuable information for the ILAW PA. There are two parts to this task.

\section{TASK A: Utilize other borehole data.}

The first part of this task is to utilize data applicable to the ILAW from other geologic studies. As new boreholes are drilled around the 200 East Area such as the BBY-BX Tank Farms, the data collected from those projects will be evaluated and incorperated into the ILAW Project where applicable. 
RPP-6702, Rev. 0

Formerly HNF-SD-WM-PAP-062 Rev. 4

TASK B. Obtain Continuous core from other project boreholes that would be valuable to the ILAWPA.

The second task is to provide funds to collect continuous core from RCRA boreholes drilled close to the ILAW site. If another project is planning on drilling a borehole close by the ILAW site in an area where data from the borehole would benefit the ILAW PA, this task would provide the means and funding to obtain continuous core from that borehole.

Determine Natural Background at ILAW Site.

The US Department of Energy provided background values for nonradioactive analytes in 1992 (DOE-RL, 1992b), for radioactive analytes in 1996 (DOE-RL, 1996), and for groundwater (DOE-RL-1992a; 1997). These reports were intended to provide an estimate of natural background values as a basis for distinguishing the presence and significance of contamination at Hanford and for use in environmental restoration at Hanford. The background study used analytical results for a wide range of soil types collected from various locations across the entire Hanford Site. The objective of the natural background study was to establish the "maximum" (upper 95 percentile) of background concentrations. Whereas the focus for the ILAW PA is on the mean, range and variance of soil background in the vicinity of the disposal site.

Task Description.

The DOE natural background reports attempted to provide an estimate of the overall background for the Hanford Site but did not attempt to determine site specific variability. Although most of the Site's geologic features formed during the Pleistocene, the sediment type and grain size is variable. The samples collected for the natural background studies attempted to sample this variability but in doing so lost natural background for individual areas.

Because the natural background reports focused on the upper range of background concentrations across the entire Hanford Site, samples that were collected included a wide range of sediment/soil types and grain size distributions. Changes in mineralogy with grain size can significantly affect the concentrations of chemical constituents of interest. Thus, the more uniform depositional conditions in more restricted areas could result in a significantly lower variability than for the entire data set used for the background study.

The approach to update the soil and groundwater background for the ILAW site will be to first determine the location of samples used in the DOE reports and which are representative of the ILAW site. If there are enough representative samples, then the appropriate statistical analyses will be preformed on them and compared to the DOE Site-wide values.

\section{TASK: Evaluate Dust Created by Intruder Drilling into ILAW Glass.}

If an "intruder" should attempt to drill a water well through the ILAW site, they are assumed to penetrate the waste package and trenches. One potential source of ILAW release is as the drill penetrates the glass and the drill crew inhales fine ILAW glass dust. At present, this scenario is the most restrictive in the PA analyses (Mann 1999). By 


\section{RPP-6702, Rev. 0 \\ Formerly HNF-SD-WM-PAP-062 Rev. 4}

documenting the amiount of dust created during drilling, significant in-tank characterization costs for ${ }^{126} \mathrm{Sn}$ can be avoided.

In order to evaluate how much glass dust could be inhaled, an estimate of how much dust will be created during drilling is necessary. This will be done by reviewing records of the amount of dust created by a typical water-well borehole. Because the glass is a coherent, solid mass and not loosely bound particles as in sediment, a good analog would be volcanic rocks that are glassy. Basalt rock can range from 50 to $80 \%$ glass and thyolite rock can be as much as $95 \%$ glass. Drilling records on the amount of dust created by such a drilling operation through these rock types will be reviewed and compiled for estimating dust released from drilling glass waste logs. This will be documented in a report.

TASK: Compile Final ILAW Geologic Data Package.

e. Interfaces

Borehole samples and information obtained during the borehole drilling (5.2.C.ii) will provide the input to this activity and the Far-Field Activity for the clastic dike study. The geologic information documented in this task will be used as part of the Data Packages for the 2005 Performance Assessment (Section 5.0). Since geotechnical data are assumed to be dependent on the stratigraphic layers identified in this task, information from this task will be used in the soil hydraulics (5.2.C.vi) and geochemical (5.2.C.viii) tasks.

f. Organization

The Applied Geology and Geochemistry Section of the Pacific Northwest National Laboratory will performed this task. This section has performed much of the geology for the Hanford Site and is expert in the Site's geology.

g. Quality Assurance

All activities will be conducted in accordance with 10 CFR 830.120. The Hanford Analytical Services Quality Assurance Requirements Document will apply to field sampling and analysis of field samples. Data collection efforts will be performed at PNNL QA impact level 2. Supporting analysis, including modeling, will be performed at impact level 3.

h. Effect of Not Performing Task

The stratigraphic layers (as determined by the geologic investigations) form the basic logical structure for the determination of geotechnical data. Other determinations (physical and chemical) depend upon the geologic investigations being performed. Without such geologic data, the other data lose their value and the performance assessment will not be built on site-specific data as is required. Without such data, it is unlikely that the performance assessment would be approved and hence authorization for waste disposal would not be received.

Without collecting natural analog data, there will be no very long term validation efforts for waste form dissolution. Validation efforts will rely on few year-long tests. 
RPP-6702, Rev. 0

Formerly HNF-SD-WM-PAP-062 Rev. 4

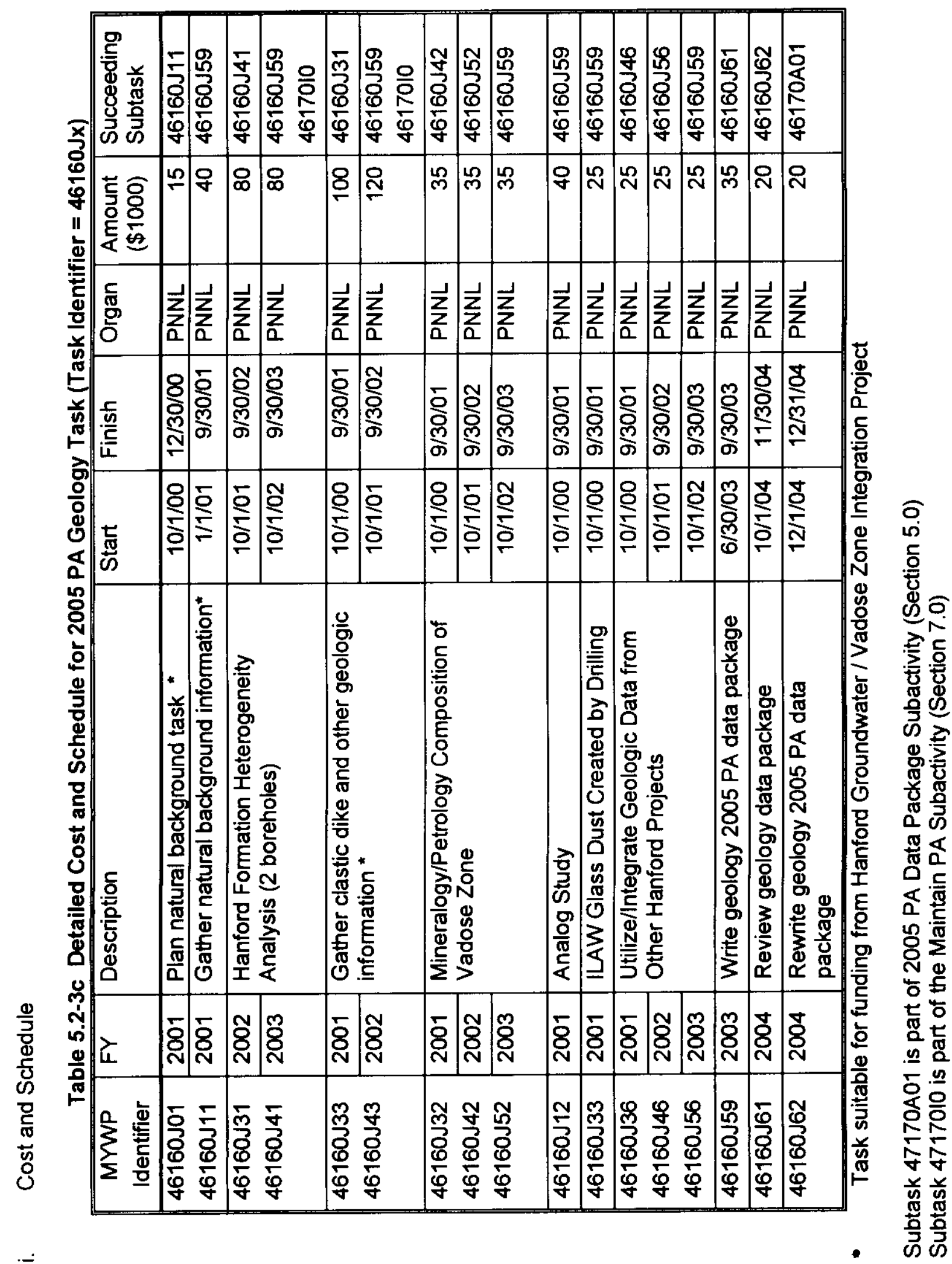


RPP-6702, Rev. 0

Formerly HNF-SD-WM-PAP-062 Rev. 4

iv. Determine Recharge at Disposal Sites

a. Background

See background of Section 3.2.C.iv (2001 PA Recharge Task).

b. List Of Deliverables

Table 5.2-4a List of Deliverables for 2005 PA Recharge Task

\begin{tabular}{|l|c|c|l||}
\hline Description & Due Date & Level & $\begin{array}{l}\text { MYWP } \\
\text { Identifier }\end{array}$ \\
\hline $\begin{array}{l}\text { Document tracer } \\
\text { measurements }\end{array}$ & $5 / 30 / 03$ & 7 & $\begin{array}{l}46160 \mathrm{HD} \\
{[46160 \mathrm{H} 7]}\end{array}$ \\
\hline $\begin{array}{l}\text { Document lysimetery } \\
\text { measurements }\end{array}$ & $6 / 30 / 03$ & 8 & $\begin{array}{l}46160 \mathrm{HC} \\
{[46160 \mathrm{H} 13]}\end{array}$ \\
\hline Write Recharge Document & $9 / 30 / 03$ & 8 & $\begin{array}{l}46160 \mathrm{HB} \\
{[46160 \mathrm{H} 32]}\end{array}$ \\
\hline $\begin{array}{l}\text { Issue Recharge Estimates } \\
\text { for 2005 PA }\end{array}$ & $12 / 31 / 03$ & 6 & $\begin{array}{l}46160 \mathrm{KA} 7 \\
{[46160 \mathrm{~K} 72]}\end{array}$ \\
\hline
\end{tabular}

c. Cost Summary

WBS: $1.1 \cdot 1 \cdot 3 \cdot 4 \cdot 1 \cdot 3 \cdot 3$

TPCN: D4DM3

Table 5.2-4b Cost Summary for 2005 PA Recharge Task

\begin{tabular}{|l|l|r|}
\hline Fiscal Year & Organ. & $\begin{array}{l}\text { Amount } \\
(\$ 1000)\end{array}$ \\
\hline 1999 & $\begin{array}{l}\text { Pacific Northwest National Laboratory } \\
\text { (PNNL) }\end{array}$ & 35 \\
\hline 2000 & PNNL & 182 \\
\hline 2001 & PNNL & 242 \\
\hline 2002 & PNNL & 398 \\
\hline 2003 & PNNL & 338 \\
\hline 2004 & PNNL & 36 \\
\hline \hline Grand Total & 1231 \\
\hline
\end{tabular}

d. Detailed Description

The objective of the Recharge Task is to provide defensible estimates of recharge rates for current and future conditions in and around the disposal facility for both the best estimate case and for identified alternatives. Based on the conceptual facility design in Burbank and Klem (1997) and the recharge estimates in Fayer et al. (1999), the best estimate case and alternatives are as follows:

i) Best Estimate Case

a) Surface Barrier. A surface barrier will be emplaced that meets the design specifications of the modified RCRA Subtitle C barrier (DOE/RL 1996; Burbank and 


\section{RPP-6702, Rev. 0 \\ Formerly HNF-SD-WM-PAP-062 Rev. 4}

Klem 1997). Two important specifications include a design life of 500 years and an infiltration limit of $0.5 \mathrm{~mm} / \mathrm{yr}$. Performance data from lysimeters show promise that the barrier will be capable of meeting the design specification (Fayer et al. 1999). Continued collection of these data will ensure the longest record possible. After 500 years, the potential exists for barrier performance to be degraded, either by deposition of windblown sand, erosion to a thinner silt loam layer, or punctures by localized human excavation.

b) Adjacent Land. The area immediately around the disposal facility could potentially have a recharge rate higher than through the surface barrier. In that situation, water could move laterally under the cover and impact the waste. As proposed by Fayer et al. (1999), recharge in this area is assumed to be 0.9 to $4.2 \mathrm{~mm} /$ year, depending on the soil type. Continued testing has the potential to reduce this rate considerably.

c) Climate. Weather patterns will continue to be similar to weather observations at the Hanford Meteorological Station (HMS) from 1957 to 1999.

ii) Alternative Conceptual Models

a) Modified Barrier. The potential exists for modifications to the barrier design if suitable materials are unavailable or the costs are excessive.

b) Changed Climate. The potential exists for changes in weather (which determines evapotranspiration) and changes in precipitation amount and seasonality.

c) Changed Vegetation. The potential exists for a change from shrub to either grassland or cheaters.

The technical work outlined below is designed to provide the information necessary to estimate recharge rates for both the best estimate case and the altemative conceptual models identified above.

\section{Performance and Testing Data for Protective Barriers.}

Thirteen of the 24 lysimeters in the Field Lysimeter Test Facility (FLTF) are focused on protective barriers. As of 30 September 2000 , the length of record will be nearly 13 years. Data will continue to be collected from some of these lysimeters until March 2003. The rationale is to have the longest record of performance data possible for the protective barrier, which is vital to the performance of the disposal system. These data will also be used to verify the capability of the simulation model to predict long-term barrier performance under various climates. The FLTF performance data will eventually span 15.5 years (by March 2003), providing a valuable data set for verifying barrier performance and testing model predictions.

FY00 - (\$28K) Collect performance data for the protective barrier lysimeters. This effort extends the length of record to 13 years. Oct 1999 to Sep 2000.

FY01 - $(\$ 36 \mathrm{~K})$ Collect performance data for the protective barrier lysimeters. This effort extends the length of record to 14 years. Oct 2000 to Sep 2001.

FY02 - $(\$ 36 \mathrm{~K})$ Collect performance data for the protective barrier lysimeters. This effort extends the length of record to 15 years. Oct 2001 to Sep 2002. 


\author{
RPP-6702, Rev. 0 \\ Formerly HNF-SD-WM-PAP-062 Rev. 4
}

FY03 - (\$28K) Collect performance data for the protective barrier lysimeters. This effort extends the length of record to 15.5 years. Oct 2002 to Mar 2003.

\title{
Performance and Testing Data for Degraded Barriers and Alternative Conceptual
} Models.

A subset of the lysimeters at the FLTF are being used to collect performance data for degraded or modified barriers, and for recharge in the adjacent land following a change in vegetation, all under both ambient and enhanced precipitation. These tests were initiated in FY 1998 and FY 1999 to test the impact of the barrier degradation mechanisms of erosion and sand deposition. The modified lysimeters will provide performance data through March 2003 for configurations that are significantly different from those currently being tested in the FLTF. In addition, data from these lysimeters will be used to test the capability of the simulation model for predicting recharge for these specific configurations. Because the length of record for these modified lysimeters will be shorter than five years, the frequency of data collection will be increased at certain times to provide a larger range of performance data.

FY00 - (\$28K) Collect detailed performance and testing data from the modified lysimeters. Oct 1999 to Sep 2000.

FY01 - $(\$ 28 \mathrm{~K})$ Collect detailed performance and testing data from the modified lysimeters. Oct 2000 to Sep 2001.

FY02 - $(\$ 28 \mathrm{~K})$ Collect detailed performance and testing data from the modified lysimeters. Oct 2001 to Sep 2002.

FY03 - (\$24K) Collect detailed performance and testing data from the modified lysimeters. Oct 2002 to Mar 2003.

\section{Historical Recharge in Adjacent Land.}

The analysis of environmental soil tracers generally yields a site-specific, longterm recharge estimate. Tracer estimates of recharge have been previously applied at numerous sites including the Nevada Test Site (Tyler et al., 1996) and Ward Valley (National Research Council, 1995) and are becoming a standard method in performance assessment. Tracers are not perfect indicators of water movement because water can move by convective liquid transport and/or vapor transport in the unsaturated zone. For example, chloride ions move by convective liquid transport, but are not subject to vapor transport. Multiple tracers are often needed to investigate the two transport processes. Two tracer methods have been used at the ILAW site: 1) chloride mass balance (CMB) for transient paleorecharge over the Holocene, 2) bomb-pulse ${ }^{36} \mathrm{Cl}$ for a 50 -year average recharge rate. Although not used previously, the stable isotopes of water (deuterium${ }^{18} \mathrm{O}$ ) could be used to evaluate the importance of vapor transport processes.

An ILAW borehole will be drilled in FY 2001, similar to the borehole drilled FY 1998. The sediments will be analyzed using procedures similar to those used for the FY 1998 borehole tracer activities. The results will be used to estimate of site-specific longterm recharge rates. Fayer et al. (1999) presented evidence to suggest that emissions from the coal plant could have deposited chloride at the ILAW Disposal Site. In FY 2001, a specialist at Stanford University will be engaged to determine whether sulfur isotopes in the sediments at the ILAW site could be used to establish a deposition "fingerprint." Fayer et al. (1999) also indicated that recharge rates may range from $4.2 \mathrm{~mm} /$ year to as low as $0.1 \mathrm{~mm} / \mathrm{yr}$. At the lower rates, plant uptake could be significant factor in the 


\section{RPP-6702, Rev. 0 \\ Formerly HNF-SD-WM-PAP-062 Rev. 4}

cycling of elements such as chloride and bromine (used in conjunction with chloride to interpret chloride sources). In FY 2001, a plant physiologist will be engaged to review the plant literature for measurements or calculations of halocarbon emissions from desert species.

In FY 2002, a third ILAW borehole will be drilled and analyzed using procedures similar to those used for the FY 1998 borehole tracer activities. In addition, four locations at the ILAW Disposal Site will be selected and trenched to obtain samples for detailed tracer analyses. The objective will be to collect sufficient data to resolve the tracerrelated issues identified by Fayer et al. (1999). The locations for the trenches will be chosen based on the data reported by Fayer et al. (1999), the data from the second ILAW borehole, and the results of the sulfur isotope and plant emission work in FY 2001. Trenching allows us to obtain high-quality samples of sufficient size to measure multiple tracers, including chloride, bromide, sulfur, ${ }^{36} \mathrm{Cl},{ }^{2} \mathrm{H},{ }^{3} \mathrm{H},{ }^{18} \mathrm{O}$, and possibly sulfur isotopes (depending on FY 2001 work) as well as soil particle size distribution. Samples will also be collected to provide sufficient depth resolution.

FY00 - (\$12K)Prepare strategy for interpreting tracer data and estimating recharge rates at the ILAW Disposal Site.

FY01 - (\$48K)Participate in the analysis of samples from ILAW Borehole No. 2, specifically to measure chloride, bromide, and sulfate as functions of depth. Contract with a Stanford specialist to determine whether sulfur isotopes can be used at the ILAW site to identify deposition of coal plant emissions. Contract with a WSU specialist to estimate plant emissions of halocarbons at the ILAW site to identify possible chloride fluxes.

FY02 - (\$48K)Participate in the analysis of samples from ILAW Borehole No. 3 , specifically to measure chloride, bromide, and sulfate as functions of depth.

FY02 - (\$140K) Dig four widely dispersed trenches at the ILAW site to obtain samples of sufficient size to measure multiple tracers, including chloride, bromide, sulfur, ${ }^{36} \mathrm{Cl},{ }^{2} \mathrm{H},{ }^{3} \mathrm{H},{ }^{18} \mathrm{O}$, and possibly sulfur isotopes (depending on FY 2001 work) as well as soil particle size distribution. Samples will also be collected to provide sufficient depth resolution (Oct 2001 to Sep 2002)

FY03 - (\$24K)Complete measurements on the samples from the FY 2002 trenches. Synthesize the tracer results to support recharge estimates for the ILAW 2005 PA (Oct 2002 to Mar 2003)

\section{Simulation Model.}

Computer simulations will be used to quantify the impact on recharge from modifications to the barrier design, degradation of the barrier, and changes in climate and vegetation. Simulation activities under this subtask include modifications and maintenance of the recharge model UNSAT-H (Fayer 2000), testing of the recharge model with data sets from both the lysimetry and tracer subtasks, and application of the model to predict recharge rates. In FY 2000, a theory/user manual for UNSAT-H Version 3.0 was prepared and published. Version 3.0 includes new features such as hysteresis, better mass balance control, and an option to conduct multiple year simulations.

In FY 2001, we will develop the conceptual and mathematical models to address multiple plant species (utilizing all of the knowledge gained on the Vegetation task), snow, and snowmelt. These additional capabilities will address comments received during a 1995 peer review workshop (Honeyman 1995). 
RPP-6702, Rev. 0

Formerly HNF-SD-WM-PAP-062 Rev. 4

In FY 2002 and FY 2003, the capabilities identified in FY 2001 will be added to UNSAT-H. Once completed, the modified code will be tested using data from the lysimeters and the vegetation subtask. The modified version of the code will be formally documented and the user manual will be published. A series of simulations with the modified code will be conducted to provide recharges estimates for the ILAW 2005 PA.

Throughout FY 2000 to 2003 , the UNSAT-H code will be maintained using configuration control and it will continue to be tested using the latest observations from the lysimeters and the field studies. The modified UNSAT-H code will be available to all Hanford Site projects.

FY0O - (\$32K) Update and publish the user manual for UNSAT-H Version 3.0. New capabilities include hysteresis, better mass balance control, and an option to conduct multiple year simulations (Oct 1999 to Mar 2000)

FY01 - (\$32K) Develop the conceptual and mathematical model s to address multiple plant species (utilizing all of the knowledge gained on the Vegetation task), snow, and snowmelt (Mar 2001 to Sep 2001)

FY01 - (\$2OK) Continue to test the UNSAT-H code with the latest observations and maintain configuration control of the code (Oct 2000 to Sep 2001)

FY02 - (\$48K) Implement within the recharge model the conceptual and mathematical models developed in FY 2001 under this task. This version of UNSAT-H will be able to simulate multiple plant species simultaneously and simulate snow and snowmelt effects (Oct 2001 to Jun 2002)

FY02 - (\$2OK) Continue to test the UNSAT-H code with the latest observations and maintain configuration control of the code (Oct 2001 to Sep 2002)

FY03 - (\$36K) Update and publish the user manual for UNSAT-H Version 4.0. Update the verification testing, peer review, and configuration management (Oct 2002 to Feb 2003)

FY03 - (\$24K) Simulate the impacts to recharge from changes in climate using estimates of precipitation and temperature changes from the Protective Barrier Program (Peterson et al. 1995). Compare the impacts with the simulation results using the current climate (Apr 2003 to Jun 2003)

\section{Vegetation.}

Plants have a direct and major impact on recharge rates (Allison et al. 1994). Depending on plant rooting depth, phenology, form, water use efficiency, and density, plants can effectively reduce or eliminate drainage and subsequent recharge (Gee et al. 1992, 1994). Understanding and predicting recharge under vegetated conditions requires knowledge of the plant community composition and behavior.

In prior years, root data were collected at the ILAW Disposal Site. The data were collected along a transect starting at a shrub and crossing a sizable inter-shrub space. Sampling depth was $1.0 \mathrm{~m}$. The objective was to document how much of the inter-shrub space was permeated with roots. Early indications are that there is a quantifiable difference between shrub and inter-shrub spaces with respect to rooting behavior. Based on these and earlier data, a hypothesis will be proposed for describing such rooting behavior. The results will be used to support development of the recharge model UNSAT-H as well as provide data to support estimates of recharge using UNSAT-H. 


\section{RPP-6702, Rev. 0 \\ Formerly HNF-SD-WM-PAP-062 Rev. 4}

Since FY 1999, plant water status data have been collected throughout all seasons. The objective has been to determine whether transpiration is significant in seasons during which plants are typically thought to be dormant. The data are indicating that grasses are dormant for a significant portion of the winter but that shrubs remain active. So far, the two winters were very warm and easily could be anomalous. In subsequent years, plant water status will continue to be sampled throughout the year so that the relationship of plant behavior to weather will be clearer and more quantifiable. These measurements will be coordinated with the Field Recharge Test so that correlations can be made between soil water status and plant water status. Based on these and earlier data, a hypotheses will be proposed for describing transpiration during these times. The results will be used to support development of the recharge model UNSAT-H as well as provide data to support estimates of recharge using UNSAT-H.

FY00 - (\$42K) Collect plant water status data throughout the year (including late fall, winter, and early spring) and measure root distributions. Oct 1999 to Sep 2000.

FY01 - (\$42K) Collect plant water status data throughout the year (including late fall, winter, and early spring). Work with the modeling task to develop mathematical relationships to describe the observations. Oct 2000 to Sep 2001.

FY02 - (\$42K) Collect plant water status data throughout the year (including late fall, winter, and early spring). Work with the modeling task to complete and test the mathematical relationships. Oct 2001 to Sep 2002.

FY03 - (\$36K) Collect plant water status data throughout the year (including late fall, winter, and early spring). Oct 2002 to Mar 2003.

\section{Field Recharge Study.}

Acceptance of the ILAW PA will depend, in part, on demonstrating a good understanding of the processes that affect the natural recharge rate at the ILAW site. Although lysimeter, modeling, and tracer studies are being conducted and will be useful, some direct field testing at the ILAW site is necessary. The objectives of the field recharge study are to observe of field water behavior during several winters, document the variability of such behavior, provide soil water status information for the vegetation task (i.e. the study of plant water status), and provide a set of field data for model testing.

In FY 2000, two locations at the ILAW site were instrumented with neutron probe access wells and time-domain-reflectometry (TDR) probes to measure water content, and heat dissipation units (HDUs) and thermocouple psychrometers (TCPs) to measure matric potential and temperature.

From FY 2001 through March FY 2003, the installed sensors will be monitored to provide a database of seasonal values at multiple soil depths. These measurements will be coordinated with the Vegetation Task so that correlations can be made between soil water status and plant water status. These measurements will also be used to provide annual ranges of matric potential and temperature as a function of depth for the task that will design a Field-Scale Engineering Test Pad. Finally, the results will be used to support recharge estimation.

FYOO - $(\$ 32 \mathrm{~K})$ Identify locations at the ILAW site to conduct field recharge study. Purchase, calibrate, and install instrumentation (Oct 1999 to Sep 2000) 
RPP-6702, Rev. 0

\author{
Formerly HNF-SD-WM-PAP-062 Rev. 4
}

FY01 - $(\$ 36 \mathrm{~K})$ Collect field water status data at the ILAW recharge study sites (Oct 2000 to Sep 2001)

FY02 - (\$36K)Collect field water status data at the ILAW recharge study sites (Oct 2001 to Sep 2002)

FY03 - (\$28K)Collect field water status data at the ILAW recharge study sites (Oct 2002 to Mar 2003)

\title{
Recharge Data Packages.
}

Information collected by the various recharge subtasks will be merged, synthesized, and integrated to provide a clear and consistent view of past, present, and future recharge rates at the proposed disposal site. The issued report will support the 2005 Performance Assessment.

The recharge data package shall contain all of the data needed to specify the upper water flux boundary as a function of surface features and time for the calculations to be performed in the 2005 performance assessment. Such data shall include information to establish a best estimate case, uncertainty cases around that best estimate case, as well as reasonable bounding cases. The results will allow the reader to understand the likely impacts of the disposal action as well as the impacts if the disposal facility failed to perform as planned. The authors shall review the documents published in the other subtasks of this task (as well as documents produced by the performance assessment team and others). The authors will justify selection of data and methods.

FY03 - (\$48K) Merge recharge data. Jun 2003.

FY03 - (\$42K) Write recharge data package for the 2005 PA. Sep 2003.

FY04 - (\$36K) Review data package, address comments, and issue final recharge data package for 2005 PA. Oct 2003 to Dec 2003.

e. Interfaces

The activities of the recharge task build on earlier work for the 2001 PA (e.g., maintenance of the Field Lysimetry Test Facility, determination of recharge at the Grout Site, measurement of tracer distributions for recharge estimation. Multiple activities of the recharge task will use samples from the borehole drilling (5.2.C.ii) for determining physical and hydraulic properties and tracer distributions. The simulation task will also use field data collected by the near-field task (5.2.C.v).

The output of this task will form part of the Data Packages for the 2005 Performance Assessment (Section 5.0). In addition, the products and knowledge gained under this task are applicable directly to other projects, including HTI, RPP, and the Hanford Site Integrated Vadose Zone/Groundwater Project. These include the decade of performance data for multiple surface barrier designs, the recharge model, and the successful applications of the tracer technique for estimating historical recharge rates.

f. Organization

The Pacific Northwest National Laboratory (PNNL) has four groups experienced with recharge. The Hydrology Group performed the recharge analysis for the Interim and ILAW Performance Assessments as well as for other Hanford projects. The Group 
RPP-6702, Rev. 0

Formerly HNF-SD-WM-PAP-062 Rev. 4

designed and has operated the Field Lysimetry Test Facility since its construction. The Ecology Group has performed ecological surveys for the Site-Wide Surveillance Project and has conducted numerous ecological studies to support that and other projects. The Interfacial Geochemistry Group has extensive experience in using tracer techniques to estimate recharge at the Hanford Site. The Applied Geology and Geophysics Group also has experience in using tracer techniques.

g. Quality Assurance

All activities will be conducted in accordance with 10 CFR 830.120. The Hanford Analytical Services Quality Assurance Requirements Document will apply to the analysis of field samples. In addition, all laboratory and field experiments will be conducted per the applicable PNNL quality assurance (QA) requirements described in PNNL's Standards Based Management System (SBMS), unless specified otherwise by project management.

h. Effect of Not Performing Task

Water infiltration is the main driver for waste release and waste transport. Without a strongly justifiable estimate of the rate, estimates of the contaminant release rate from the waste form and the subsequent travel to the groundwater must be quite conservative. A major advantage of the central plateau of the Hanford Site is the long travel time for contaminant travel. Without adequately justifiable values of recharge, one of Hanford's main assets cannot be used in the analysis. 
RPP-6702, Rev. 0

Formerly HNF-SD-WM-PAP-062 Rev. 4

\begin{tabular}{|c|c|c|c|c|c|c|c|c|c|c|c|c|c|c|c|c|c|c|c|}
\hline & 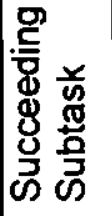 & 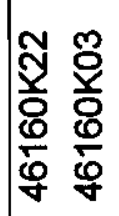 & 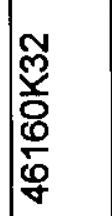 & 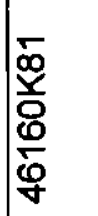 & $\begin{array}{l}\frac{m}{\bar{x}} \\
0 \\
0 \\
0 \\
\mathscr{\varphi}\end{array}$ & 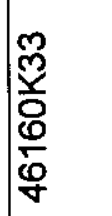 & 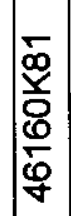 & 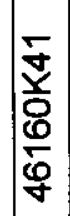 & 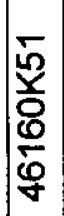 & 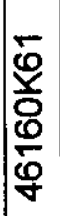 & 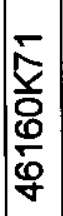 & 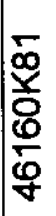 & 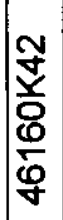 & 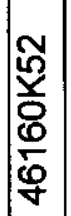 & 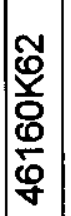 & 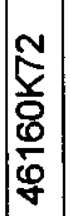 & 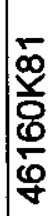 & 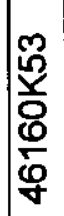 & 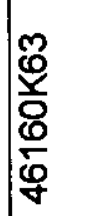 \\
\hline 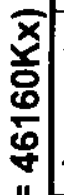 & 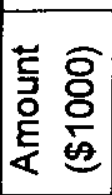 & $\stackrel{\sim}{\sim}$ & 守 & ন & 乎 & $\mathscr{q}$ & $\stackrel{\infty}{q}$ & $\stackrel{20}{\sigma}$ & 足 & $\mathscr{m}$ & $\ddot{m}$ & $\stackrel{\infty}{\sim}$ & 只 & 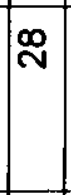 & $\stackrel{\infty}{\sim}$ & 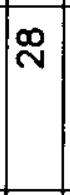 & 离 & $\widetilde{్}$ & กั \\
\hline 竧 & 点 & $\frac{1}{z}$ & $\sum_{a}^{2}$ & $\sum_{\alpha}$ & $\frac{\vec{z}}{z}$ & $\frac{\bar{z}}{z}$ & $\underset{n}{\sum}$ & $\underset{z}{z}$ & $\sum_{\alpha}$ & $\sum_{\alpha}$ & $\sum_{a}$ & $\frac{1}{\sum_{n}}$ & $\sum_{n}$ & $\frac{\sum}{z}$ & $\frac{1}{z}$ & $\frac{1}{z}$ & $\sum_{\alpha}$ & $\sum_{a}$ & $\sum_{a}$ \\
\hline 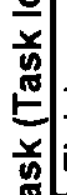 & 而 & \% & 总 & & 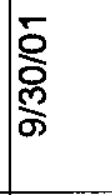 & §ָ & 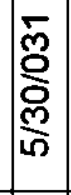 & 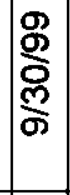 & 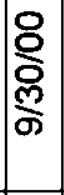 & 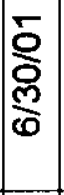 & 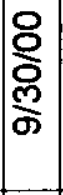 & $\frac{m}{\rho}$ & 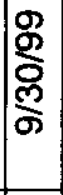 & 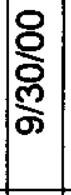 & 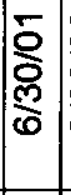 & 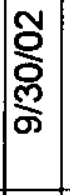 & 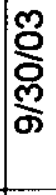 & 옹 & $\frac{5}{\stackrel{m}{m}}$ \\
\hline 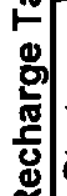 & $\frac{t}{\frac{t}{\sigma}}$ & $\frac{\text { g }}{\stackrel{9}{\circ}}$ & 옹 & 옹 & $\underset{\frac{5}{\sigma}}{\frac{\gamma}{\sigma}}$ & 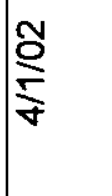 & $\frac{m}{\mathfrak{n}}$ & $\frac{\mathscr{g}}{\stackrel{g}{F}}$ & $\frac{g}{\frac{g}{2}}$ & $\frac{8}{9}$ & $\frac{\overline{9}}{\frac{5}{0}}$ & $\frac{\mathfrak{N}}{\frac{\mathcal{O}}{2}}$ & $\stackrel{g}{g}$ & 总 & $\frac{\text { 용 }}{\frac{8}{8}}$ & $\frac{5}{\frac{5}{2}}$ & $\frac{\Upsilon}{2}$ & $\stackrel{\text { g }}{\stackrel{\text { }}{2}}$ & $\frac{8}{\stackrel{8}{\circ}}$ \\
\hline 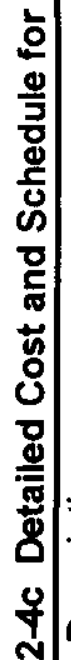 & 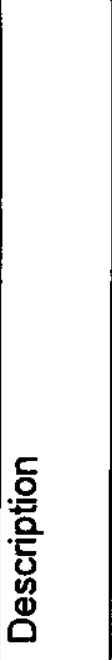 & 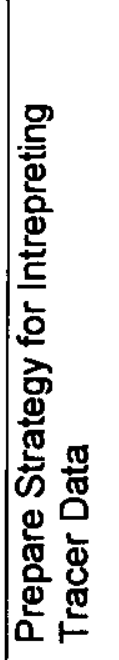 & 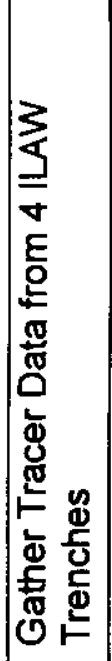 & 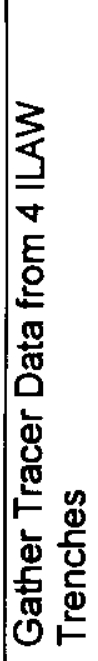 & 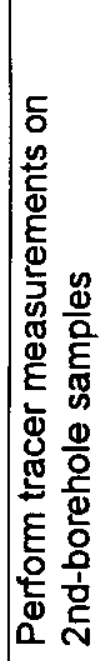 & 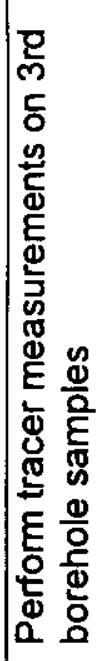 & 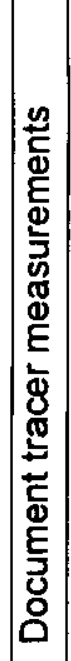 & 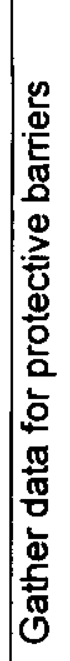 & & & & & 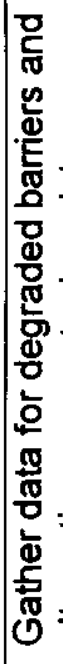 & 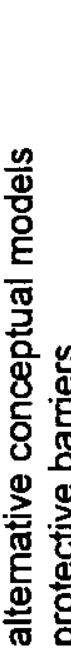 & & & & 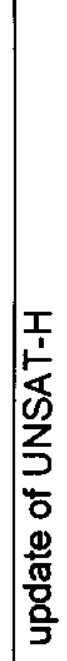 & 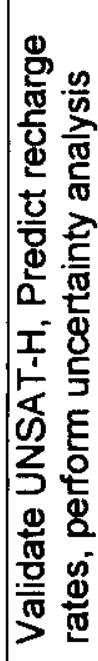 \\
\hline $\begin{array}{l}\frac{\Phi}{0} \\
\frac{0}{\pi}\end{array}$ & ז & ষ্ণ & §్ & স্ণ & ్ㅠ & ণ్ర్ల & স্ণ & 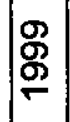 & স্ট্ণ & 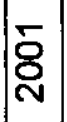 & ণ্ণ & স্ণ & $\stackrel{\mathscr{g}}{\mathscr{\mathscr { g }}}$ & প্ণ & ర্ঠ & 尺 & প্ণ & 유 & চ্ঠি \\
\hline & 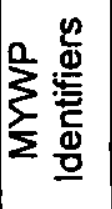 & 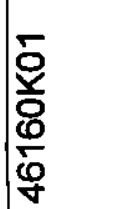 & $\frac{y}{y}$ & 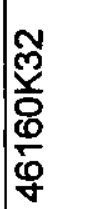 & 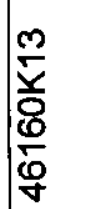 & 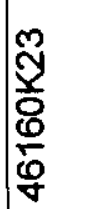 & 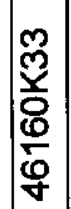 & 官 & 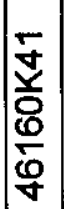 & 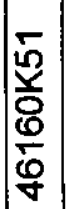 & 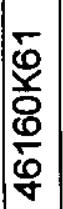 & $\begin{array}{l}\frac{1}{\hat{\alpha}} \\
\frac{8}{0} \\
\frac{0}{0} \\
\frac{9}{y}\end{array}$ & $\frac{8}{\frac{8}{2}}$ & 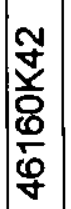 & 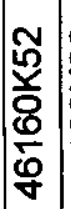 & 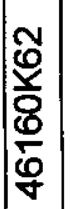 & 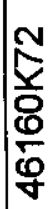 & 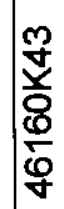 & 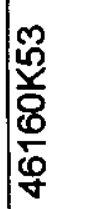 \\
\hline
\end{tabular}


RPP-6702, Rev. 0

Formerly HNF-SD-WM-PAP-062 Rev. 4

\begin{tabular}{|c|c|c|c|c|c|c|c|c|c|c|c|}
\hline 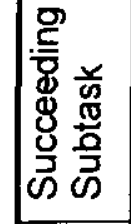 & 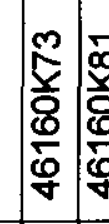 & & 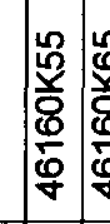 & 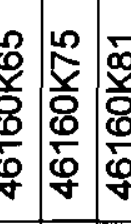 & 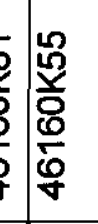 & 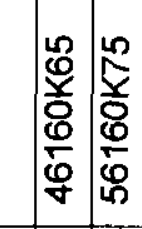 & 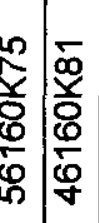 & 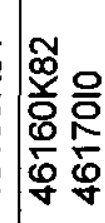 & 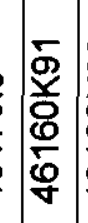 & $\mid$\begin{tabular}{c}
$\mathbb{2}$ \\
\hdashline \\
\hdashline
\end{tabular} & \\
\hline 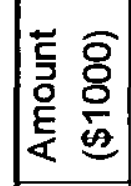 & $\stackrel{\infty}{\infty}$ & & ₹ & $y)$ & 3 ल & $\mathscr{ল}$ & $\begin{array}{c}\stackrel{\infty}{\infty}) \\
\sim\end{array}$ & $\underset{\sim}{\infty}$ & ₹ & a & \\
\hline 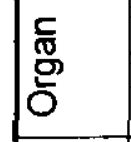 & $\sum_{a}^{1}$ & & 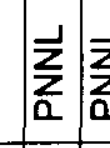 & 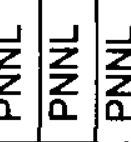 & 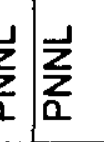 & & $\frac{1}{a} \frac{1}{\vec{z}}$ & $\frac{1}{z}$ & $\frac{1}{a}$ & $\sum_{a}$ & \\
\hline$\underline{5}$ & 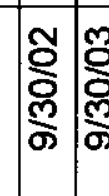 & & 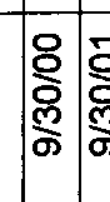 & 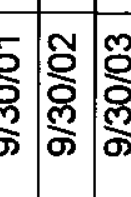 & 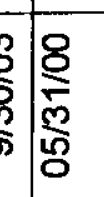 & 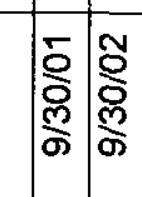 & 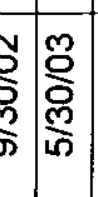 & 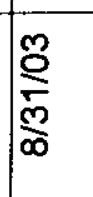 & 怘 & 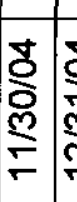 & \\
\hline 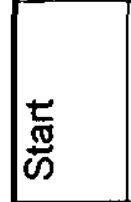 & 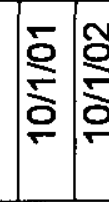 & & : & 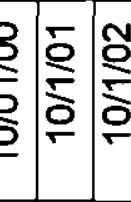 & : & 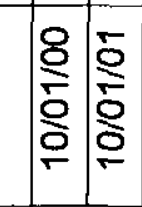 & 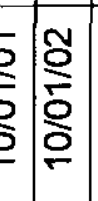 & 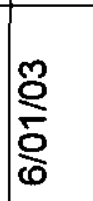 & & 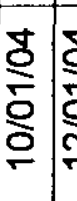 & \\
\hline 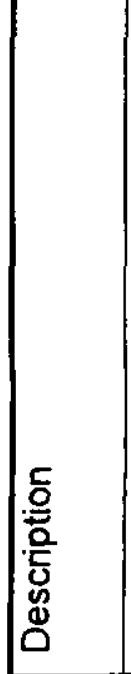 & 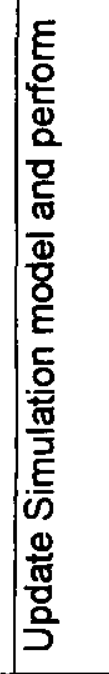 & $\begin{array}{l}\frac{\mathscr{2}}{0} \\
\frac{0}{0} \\
\frac{0}{5} \\
\frac{5}{5}\end{array}$ & 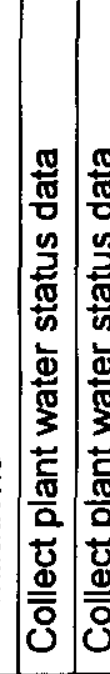 & 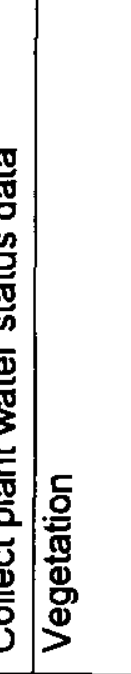 & 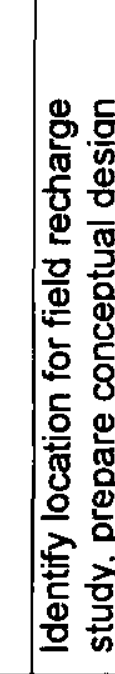 & 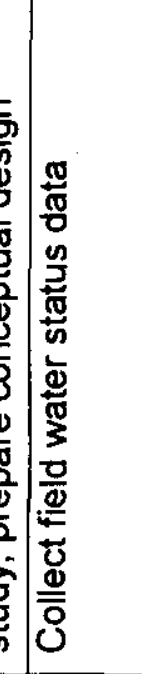 & & 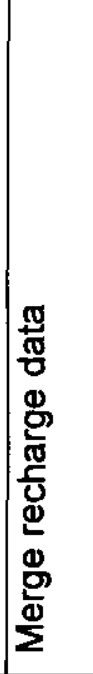 & 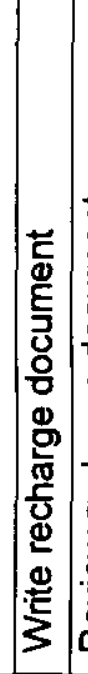 & 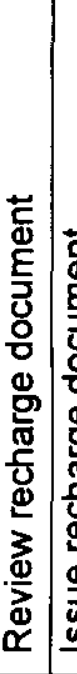 & \\
\hline 4 & 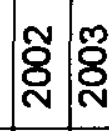 & & ఫ্নి & s) & 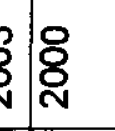 & 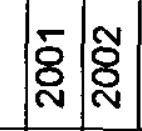 & : & ్ֶֻ & & ষ্ণ & \\
\hline $\mid$ & 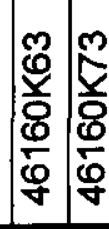 & & 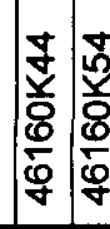 & 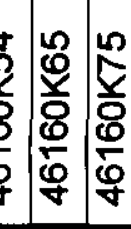 & 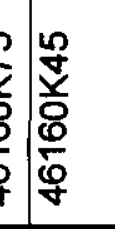 & 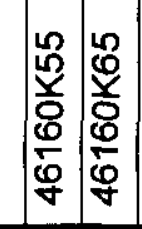 & 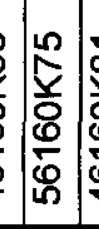 & & 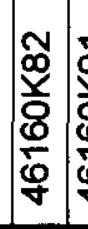 & 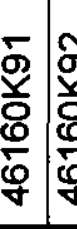 & \\
\hline
\end{tabular}


RPP-6702, Rev. 0

Formerly HNF-SD-WM-PAP-062 Rev. 4

v. Determine Hydraulic Parameters for Disposal Facility Materials

a. Background

Water is the key variable in the dissolution of waste forms, and the process models and parameters determining how water flows and transports contaminants in and beyond the engineered facility are essential to the prediction of radionuclide release, migration and fate. The data package containing best-estimates of the physical, hydraulic, and transport properties of near-field materials was prepared for the fiscal year 2001 performance assessment. The data package also contained information on the properties of aged materials and an assessment of the uncertainty in the parameter estimates. Information in the data package was constrained by uncertainty in the materials to be specified in the design of the facility, and by uncertainty in the waste form itself. The data package was further constrained by the time and budget resources available once the materials became defined well enough to study in detail. As a result, parameters for some of the materials are more uncertain than is desirable. In particular, the hydraulic and transport parameters (diffusion coefficients) for the glass waste form need to be refined. In addition, the effect on hydraulic parameters of chemical changes induced by glass corrosion over time remains ill-defined.

As efforts begin to gather data to support the fiscal year 2005 performance assessment, the construction materials and design configuration of the new disposal vaults and the waste form are still not completely known, although they are becoming better defined. Additional time has allowed the degradation of samples formed in prior fiscal years and the evaluation of altered physical, hydraulic, and transport (diffusion) properties. As materials and the design become well-defined, the study and analysis of well specified materials and the analysis of their degradation enables the data package for the fiscal year 2005 performance assessment to be of significant value to the program.

b. List Of Deliverables

Table 5.2-5a List of Deliverables for 2005 PA Near-Field Hydraulics Data Package

\begin{tabular}{|l|l|l|l|}
\hline Description & $\begin{array}{l}\text { Due } \\
\text { Date }\end{array}$ & Level & $\begin{array}{l}\text { MYWP } \\
\text { Identifier }\end{array}$ \\
\hline $\begin{array}{l}\text { PNNL progress report on measurements of } \\
\text { hydraulic properties as a function of } \mathrm{pH} \text { and } \\
\text { ionic strength (quartz sand and backfill } \\
\text { sediments) }\end{array}$ & $9 / 30 / 00$ & & \\
\hline $\begin{array}{l}\text { Letter report on measurements of changes in } \\
\text { hydraulic properties of glass as a result of } \\
\text { secondary mineral precipitation }\end{array}$ & $9 / 30 / 00$ & & \\
\hline $\begin{array}{l}\text { Letter report update on measured } \\
\text { unsaturated hydraulic properties of near-field } \\
\text { materials }\end{array}$ & $9 / 30 / 00$ & & \\
\hline $\begin{array}{l}\text { Electronic message confirming } \\
\text { implementation of constitutive model in } \\
\text { STORM for calculating changes in properties }\end{array}$ & $9 / 30 / 00$ & & \\
\hline
\end{tabular}


RPP-6702, Rev. 0

Formerly HNF-SD-WM-PAP-062 Rev. 4

\begin{tabular}{|c|c|c|c|}
\hline as a function of mineral precipitation & & & \\
\hline $\begin{array}{l}\text { Issue test plan for measurement of changes } \\
\text { in glass and backfill properties as a function } \\
\text { of mineral precipitation }\end{array}$ & $11 / 30 / 00$ & & \\
\hline $\begin{array}{l}\text { Issue test plan for measurements of near- } \\
\text { field material physical, hydraulic, and } \\
\text { transport properties }\end{array}$ & $11 / 30 / 00$ & & \\
\hline $\begin{array}{l}\text { Letter report update on measured physical, } \\
\text { hydraulic, and transport properties for near- } \\
\text { field materials }\end{array}$ & $9 / 30 / 01$ & & \\
\hline $\begin{array}{l}\text { Letter report update on measurements of } \\
\text { changes in hydraulic properties of glass and } \\
\text { backfill materials as a function of secondary } \\
\text { mineral precipitation }\end{array}$ & $0 / 30 / 01$ & & \\
\hline $\begin{array}{l}\text { PNNL progress report on measurements of } \\
\text { hydraulic properties as a function of } \mathrm{pH} \text { and } \\
\text { ionic strength }\end{array}$ & $9 / 30 / 01$ & & \\
\hline $\begin{array}{l}\text { Letter report on results of simulations to } \\
\text { support facility design }\end{array}$ & $6 / 30 / 01$ & & \\
\hline $\begin{array}{l}\text { Report describing formal design and } \\
\text { construction plan for field experimental facility }\end{array}$ & $7 / 31 / 01$ & & \\
\hline $\begin{array}{l}\text { Letter report on the implementation in } \\
\text { STORM of a method for upscaling flow } \\
\text { properties }\end{array}$ & $9 / 30 / 01$ & & \\
\hline $\begin{array}{l}\text { Letter report describing the results of the } \\
\text { measurement on gravel and gravel- } \\
\text { dominated materials }\end{array}$ & $9 / 30 / 01$ & & \\
\hline $\begin{array}{l}\text { Letter report documenting the model relating } \\
\text { fracture characteristics to the glass hydraulic } \\
\text { properties }\end{array}$ & $9 / 30 / 01$ & & \\
\hline $\begin{array}{l}\text { Issue Report on Characterization Of The } \\
\text { Unsaturated Hydraulic Conductivities Of llaw } \\
\text { Near-Field Materials (Glass, Gravel And } \\
\text { Rock) }\end{array}$ & $9 / 30 / 02$ & & \\
\hline Issue data package review plan & $3 / 31 / 03$ & & \\
\hline $\begin{array}{l}\text { Electronic message confirming that near-field } \\
\text { hydraulic data for the } 2005 \text { PA has been } \\
\text { merged }\end{array}$ & $6 / 30 / 03$ & & \\
\hline $\begin{array}{l}\text { Write Near-Field Hydraulic } 2005 \text { PA Data } \\
\text { Package }\end{array}$ & $9 / 30 / 03$ & 8 & $\begin{array}{l}\text { 46160M6B } \\
{[46160 \mathrm{M} 62]}\end{array}$ \\
\hline $\begin{array}{l}\text { Issue Near-Field Hydraulic } 2005 \text { PA Data } \\
\text { Package }\end{array}$ & $12 / 31 / 03$ & 6 & $\begin{array}{l}\text { 46160M7A } \\
{[46160 \mathrm{M} 72]}\end{array}$ \\
\hline
\end{tabular}


RPP-6702, Rev. 0

Formerly HNF-SD-WM-PAP-062 Rev. 4

c. Cost Summary

WBS: 1.1 .1 .3 .4 .1 .3 .3

TPCN: D4DM3

Table 5.2-5b Cost Summary for 2005 PA Near-Field Hydraulics Data Package

\begin{tabular}{|l|l|r|}
\hline $\begin{array}{c}\text { Fiscal } \\
\text { Year }\end{array}$ & Organ. & $\begin{array}{r}\text { Amount } \\
(\$ 1000)\end{array}$ \\
\hline 2000 & PNNL & 405 \\
\hline 2001 & PNNL & 777 \\
& FFS & 16 \\
\hline 2002 & PNNL & 941 \\
& FFS & 16 \\
\hline 2003 & PNNL & 760 \\
\hline 2004 & PNNL & 163 \\
\hline 2005 & PNNL & 130 \\
\hline \hline Grand total & & 3208 \\
\hline
\end{tabular}

d. Detailed Description:

The ILAW PA relies on direct measurement of physical, hydraulic, and transport properties of the near-field materials wherever possible. For those materials that do not significantly affect performance, literature values may be used to estimate parameters. Uncertainty estimates generally rely more heavily on literature-based values, but multiple direct measurements are preferred for those materials critical to facility performance.

\section{Changes In Near-Field Hydraulic Properties Due To Precipitation/Dissolution} Reactions.

Simulations of the disposal facility conducted by the waste form group indicate that the degradation of the glass waste form will induce significant chemical changes within and around the disposal facility. Simulations of the waste form group indicate that these chemical changes may induce significant mineral precipitation within the waste form itself, the backfill materials, and potentially the gravel component of the diversion layer. These chemical changes will modify the pore structure of the associated materials, potentially affecting the performance of the facility. Although it is known that changes in the pore size distribution due to mineral precipitation will alter the hydraulic properties of the near-field materials, the manner in which this occurs is currently unknown. A quantitative model describing changes in hydraulic properties as a function of precipitation/dissolution is needed to reliably predict the effect of glass waste degradation on facility performance.

A variety of activities are underway in fiscal year 2000 to address the issue of changes in hydraulic properties of the near-field materials as a result of glass waste degradation. A comprehensive review of the available literature on modeling changes in hydraulic properties due to chemical reactions has been completed. This review confirmed that there is currently no comprehensive model available to represent the processes anticipated within the ILAW disposal facility. The review did identify a simplified, largely empirical approach that is a logical first step. This approach is 
RPP-6702, Rev. 0

Formerly HNF-SD-WM-PAP-062 Rev. 4

currently being implemented in STORM. Laboratory experiments are also underway to provide a set of data that will be used to investigate the nature of the hydraulic property changes in response to glass degradation and also to validate (or invalidate) the simplified model and any more process-based models developed to represent the changes in material properties. The initial experiments are concerned with changes in the hydraulic properties of the glass waste itself. These experiments are being conducted using the PUF system with simulated waste glass samples.

The literature review on modeling changes in hydraulic properties due to chemical reactions contained a series of recommendations for follow-on work to the activities underway in FYOO. These recommendations include additional modeling studies as well as experimental work. In FY01 reaction path modeling will be used to arrive at a quantitative assessment of the changes in the solid (precipitate) mass in the pore networks of either porous or fractured media. The conceptual models and geochemical data necessary for this analysis has been derived/collected by the waste form group. The information on changes in solid mass can be used in tum to model the changes in porosity and permeability of ILAW near-field materials, using simplified approaches to relate the two. The modifications to the STORM code necessary to do this are being completed in FYOO. This approach idealizes the pore networks as batch reactors.

A better, but more complex, approach will also be undertaken using reactive transport modeling (with the STORM code) to extract the mass balance information related to the changes in the solid (precipitate) mass. The resulting changes in the porosity and permeability will be compared with the same from the batch reactor approach to evaluate how such changes differ between a saturated batch process and an unsaturated reactive transport field. The modifications to STORM being completed in FYOO implement a relatively simple approach, addressing changes in porosity and permeability only. Additional model development will be undertaken in FY01 to address changes in water retention, unsaturated hydraulic conductivity, and capillary pressureinterfacial area relationships. The models developed will be implemented in STORM. Development of appropriate models for changes in these fundamental relationships as a function of chemical reactions will make use of the experimental data collected in FYOO and experiments planned for FY01-03. The results from the $\mathrm{pH} /$ ionic strength experiments on backfill and quartz sand materials (described below) will also be used in the model development.

Flow experiments to provide additional characterization of changes in the hydraulic properties of the glass waste form in its initial and degraded states will be conducted. Efforts will be focused on developing representative (fractured) samples that can be used with the PUF apparatus. Results from other tasks will be needed to scale up from the small size of these samples to the larger scale of the actual waste packages. Established characterization techniques for water retention and unsaturated hydraulic conductivity will be coupled with innovative tracer methods to measure interfacial area. The effect of chemical reactions on the properties and relationships will be investigated by using these methods sequentially on a given material in pristine and reacted (i.e., degraded) states.

In outyears, the fractured glass materials will be further aged to develop samples representing advanced weathering of glass waste. Measurements of hydraulic properties and interfacial areas will be repeated and model development updated. 
RPP-6702, Rev. 0

Formerly HNF-SD-WM-PAP-062 Rev. 4

FY01 (\$100K) Develop representative fractured glass samples for use in the PUF system. Measure hydraulic properties and interfacial area. Progressively age the samples and repeat the measurements. Assumes four samples and includes money for reporting.

\section{Measure Hydraulic Properties As A Function Of Ph And lonic Strength.}

Measure hydraulic property changes in near-field materials using column experiments involving the ionic strength and $\mathrm{pH}$ changes expected in the disposal facility. The results will enable the calculation of the rate that soil properties change during extended periods in contact with caustic solutions appropriate to the leachates expected to percolate out of the disposal facility.

Two long-term column experiments were completed in fiscal year 2000 to reveal the alteration of unsaturated hydraulic properties. These examined the potential for quartz sand and a fine-grained backfill soil [Warden silt loam] to be impacted by continuous exposure to $\mathrm{NaOH}$ solution. These two experiments were an attempt to determine long-term degradation through short-term tests run at an elevated base concentration. The two materials were characterized for saturated hydraulic conductivity after several contact times, and particle size, mineralogy of the silt/clay fraction at the end of the tests.

The columns were scanned periodically by XMT to investigate whether preferred channels have developed during the interaction with the caustic solution. Also, the effluents from contact with sodium hydroxide solutions at several concentrations were characterized for alkali, alkaline earth, dissolved $\mathrm{Al}, \mathrm{Si}, \mathrm{Fe}$, and $\mathrm{Mn}$ throughout the duration of testing. At the end of the contact time (1/2 year) but prior to dissecting the columns for complete particle size and mineralogy, the columns were drained by centrifugation and hydraulic conductivity was determined under unsaturated conditions. The columns were also monitored by using X-ray tomography. Both $\mathrm{NaOH}$ treated and non- treated sediments were evaluated in order to determine if variations in predicted fluid flow could be observed.

In FY2001 we will start some new columns with purified quartz and the Warden silt loam and a composite sand consisting of mixtures of several depths from the 299E17-21 borehole. Similar treatments with $\mathrm{NaOH}$ and $\mathrm{NaOH}-\mathrm{NaAlO}$ 4 will be performed to study the dissolution and combined dissolution/Al precipitation, respectively that occurs. The most useful characterizations that were determined in the FYOO progress report will be continued on these new columns. Additionally, a few columns (without and after $\mathrm{NaOH}$ and $\mathrm{NaOH}-\mathrm{NaAlO}_{4}$ treatments) will be wetted with contrasting agents to assess mobile and immobile water phases by running groundwater through them and looking for areas within the pore structure where the contrasting agent remains (does not flush out readily with imbibing groundwater). During such a test, we should expect diffusion to occur and the $\mathrm{Nal}$ contrasting species should eventually be diluted into the flowing groundwater, and we should be able to observe this by changes in the measured X-Ray attenuation values. In FY2001 we request $\$ 70 \mathrm{~K}$ to perform these tests and to prepare a progress report.

In FY2002 through FY2003 we project needing \$80K per year; based on the costs associated with ongoing program and the maintenance of samples in a controlled 


\section{RPP-6702, Rev. 0 \\ Formerly HNF-SD-WM-PAP-062 Rev. 4}

environment for a long period to continue studying other engineered barriers. The FY2002 and 2003 studies will use other candidate backfill and getter materials that have been evaluated for their geochemical properties and chosen as final candidates in the disposal facility design. Complete dissection and full characterization of the long-term samples in fiscal year 2001-2003 and will support the FY05 PA data package.

Measurements Of Unsaturated Hydraulic And Transport Properties Of Original And Degraded Near-Field Materials.

The near-field hydrology data package completed for the 2001 ILAW PA contains the best-estimate hydraulic parameters and uncertainty information for the near-field materials of the ILAW disposal facility. The data package also identified limitations in the data on which the best-estimate parameter values were based. One of the comments of the external reviewers of the data package was their approval of the reliance on actual measurements of material properties to estimate parameters (as opposed to reliance on literature-based values or empirically-based estimates). Current and future efforts under this task are directed at further reducing the uncertainty in the parameter values by providing additional data for those materials whose parameters were based on limited or no actual measurements. These include materials that are identified by the facility design team to consider design alternatives or modifications. The primary emphasis is on improving the parameter estimates for those materials whose properties have the greatest potential effect on the performance of the facility, as determined from computer simulations of flow and transport and interactions with the facility design, geochemistry, and waste form groups.

Measurements are being carried out in fiscal year 2000 on the compacted silt loam component of the Modified RCRA C surface barrier, the backfill material, and the glass waste form. Measurement of the silt loam material supports the estimate of recharge. Backfill soil samples were obtained from the grout site excavation and from cores obtained southwest of the ILAW site in FY98 and used by the recharge group for chloride measurements. These materials are from the near surface and represent soils resulting from the eventual excavation of the facility. The glass being measured is simulated waste glass and is being mechanically fractured to represent the initial waste form.

Based on the results of the near-field hydrology data package, the conceptual design of the remote-handled trench, and the measurements currently being taken, additional measurements will be required in preparation for the 2005 PA. The glass waste form presents the greatest measurement difficulty because, although it has been treated as a porous medium, flow and transport are initially anticipated to occur through a network of fractures. Standard measurement techniques are not necessarily applicable to the glass waste form because of the presence of fractures and the scale of the fractures in the actual waste packages relative to the scale of typical lab samples. As the glass degrades, its structure will begin to look more and more like a porous medium. The initial measurements being conducted in FYOO will establish the ability to produce a small-scale, representative sample of fractured glass and will obtain initial measurements of water retention on this fractured sample. Additional measurements will be required to obtain hydraulic conductivity relationships and diffusion properties for the fractured samples. Additional measurements will also be used to develop a model to relate measurable fracture characteristics (fracture density, distribution of fracture apertures, etc.) to standard hydraulic parameters for use in the PA simulations. 


\author{
RPP-6702, Rev. 0 \\ Formerly HNF-SD-WM-PAP-062 Rev. 4
}

Additional measurements in FY01 will be conducted to measure diffusion in the backfill material as a function of water content. These measurements will be made using the procedure described in Conca and Wright Water Resour. Res., 26(5):1055-1066, 1990). Several potential backfill materials will be examined to provide some input to the facility design. Funds are also provided for measurement of diffusion through the RCRA liner materials:

Outyear funds are included to provide measurements for additional materials (or modified matierals) that become specified as the facility design proceeds. As described in the near-field hydrology data package for the $2001 \mathrm{PA}$, the measurements will include physical properties, unsaturated hydraulic properties, and transport properties. Diffusion is the primary transport parameter of interest, although dispersion measurements may also be made should this be indicated through simulations or other means. As stated in the data package, however, lab-scale dispersion measurements are of relatively little use in this application. For those materials whose properties are expected to change over time, measurements will be made to determine property values at the time of placement and in a degraded state. Currently, material property changes due to aging over time are being investigated under other tasks described elsewhere in this section.

As was done for the near-field hydrology data package for the $2001 \mathrm{PA}$, the literature will be reviewed for applicable measurements or estimation methods for nearfield materials. This information may be used to provide best-estimate parameter values for those near-field materials found to be adequately characterized by published data. For other materials on which direct measurements are required, the literature information will be used to estimate parameter uncertainties.

The internal quality assurance assessment of the data gathering and interpretation efforts for the Geotechnical Data task will be repeated in fiscal years 20012003. All activities under the Geotechnical Data task will be reviewed and a brief letter report issued.

\title{
Interface With Facility Design Team.
}

This task provides funds for interaction with the facility design group to provide hydrologic and geochemical input to the design as components of that design are being considered. The goal of this task is to fully utilize the resources and expertise of the near-field hydraulics, recharge, geochemistry, and waste form groups in supporting the design of the ILAW facility. Funding is provided to involve staff from the near-field hydraulics group in the activities of the design group throughout the design process and for interaction between the near-field hydraulics group and the recharge, near-field geochemistry, and waste form groups. (Direct involvement of these groups with the design group will also be utilized when necessary or beneficial.) Application of hydrologic, geochemistry, and waste form expertise throughout the design process will result in a more efficient design process and potentially a more cost-effective design. It will also result in a more rapid and complete specification of design altematives, which will facilitate the measurements being made by the near-field hydraulics, geochemistry, and waste form groups.

Funds are provided for two activities. The first activity is the direct interation between near-field hydraulics group staff and facility design group staff through 
RPP-6702, Rev. 0

Formerly HNF-SD-WM-PAP-062 Rev. 4

attendance at meetings, phone calls, and e-mail. This activity includes interactions between the near-field hydraulics group and the other groups responsible for estimation of near-field material properties. The activity will also include reviews of the open literature and discussions with other research groups (as appropriate) as well as assessment of the data requirements arising from altemative designs and altemative conceptual models of particular design components.

The second activity provides funding for simulations of the facility to provide assistance to the design group. It has been our experience that questions regarding the performance of design altematives and their specific components arise during the design process. This task provides funding to address these questions using the simulation models currently used by the near-field hydraulics and waste form groups. This relatively rapid feedback to the design group will make the design process more effective since hydrologic and geochemical information can be continuously incorporated in the design. Preliminary simulation of facility performance also supports the near-field hydraulics measurement task by determining which materials or parameters are the most important to be measured.

Outyear costs are expected to be less as the conceptual design of the facility is to be completed in FY01. Funds are provided, however, to provide continued interaction and support during the final facility design process.

\section{Field Experimental Facility.}

Current estimates of near-field hydraulic and transport parameters are based primarily on measurements made on small-scale laboratory samples. (The situation is similar for near-field geochemical and waste form parameters.) There is great value in having field-scale measurements of near-field material properties and in situ measurements that are representative of overall disposal facility performance.

The initial conceptual design of and requirements for an ILAW field experimental facility are being being completed in FYOO. This task use the conceptual design and requirements report as the basis for completing the formal facility design. This field experimental facility will be a small-scale mock-up of the ILAW disposal facility that will provide the ability to evaluate the longterm performance of the ILAW facility with in situ field measurements. Measurements made on the facility will allow us to determine whether the laboratory measurements made in support of the 2001 and 2005 performance assessments can be extrapolated to the field scale. In addition, we will be able to assess the degree of uncertainty introduced in the parameter values and facility performance estimates by that extrapolation. The field experimental facility will also provide additional confidence in the as-built performance of disposal facilitiy components such as the surface cover and diversion layer. We will also be able to evaluate, under field conditions, our ability to monitor and detect contaminant transport from the facility. Finally, the field data from the experimental facility will be useful in validating the waste form release and contaminant transport models being used in the 2001 and 2005 performance assessments.

Completion of this task will require the full participation of a number of staff. Funds are included in FY01 for participation by staff from the facility design group, the waste form group, the recharge group, and the near-field geochemistry group. It is anticipated that additional groups will also need to be involved to obtain approval of the 
RPP-6702, Rev. 0

Formerly HNF-SD-WM-PAP-062 Rev. 4

final design. Funds are also included in FY01 for computer simulation of the experimental facility to support its design and for the preparation of reports documenting the final design, and the plan for construction.

\section{Upscaling Of Near-Field Material Properties.}

The current conceptual design of the disposal facility includes a number of distinct materials in close proximity to each other; i.e., glass waste, steel containers (which will corrode to a porous material), and filler material. The steel containers and the filler material occupy a relatively small fraction of the disposal facility volume, but may have a significant effect on the water flow and contaminant transport within the facility and ultimately on the release rate from the facility. For large-scale simulations of the facility, it may not be possible to represent the small-scale detail of the filler and corroded steel materials (e.g., it may not be possible to accurately represent the cylindrical shape of each waste package). In this case, effective hydraulic and geochemical materials will be needed in the numerical models used to determine release rates. These effective properties will be used in those numerical model grid cells that, due to computational constraints, contain more than one type of material. The effective properties will be a function of the properties of the individual materials and the volume percentage of each material within a model grid cell.

A review of upscaling strategies applicable for modeling flow and transport in the near-field materials of the ILAW disposal facility is being conducted in fiscal year 2000 . Future activities related to upscaling will be based on the results of this review and follow a phased approach. During FY01, the upscaling method recommended in the review will be implemented and tested with respect to the unsaturated flow within the near field. The upscaling method will be implemented within the reactive transport code used in the near-field simulations for the 2001 PA (STORM). Detailed computer simulations will be carried out to verify the appropriateness of the upscaling method implemented and to examine the errors in transport that arise from upscaling with respect to flow only and not with respect to both flow and transport. Additional activities in outyears will be carried out to implement an upscaling method for the reactive transport should this appear necessary based on the results of the FY01 activity. This task will be conducted with the waste form and near-field geochemistry groups and with input from the far-field hydraulics group.

Hydraulic Properties Of Clean Gravel And Gravel-Dominated Sediments.

Gravel is prevalent throughout the vadose zone at the ILAW Disposal Site. The presence of gravel within the sediments can have a major impact on their hydraulic properties. Near-field materials affected by gravel include backfill materials around the vaults, which may have a significant fraction of gravel if composed of excavated Hanford formation sediments. In addition, clean gravel is a component of a capillary barrier diversion layer used to enhance the hydraulic isolation of the ILAW disposal vaults. Performance of this diversion layer will depend on the hydraulic properties of the clean gravel. Recent laboratory results reported by Walter et al. [Water Resour. Res., $36(4): 841-849,2000$ ] demonstrate that the predicted diversion layer performance can be easily overestimated without good estimates of the hydraulic properties of the diversion layer components. 
RPP-6702, Rev. 0

Formerly HNF-SD-WM-PAP-062 Rev. 4

The hydraulic properties of gravel-dominated materials are usually estimated by scaling from measurements on the sediment fraction that is less than $2 \mathrm{~mm}$ in diameter. The potential error introduced in water content estimates by the use of this scaling procedure has been investigated by Khaleel and Relyea [Water Resour. Res., $33(8): 1875-1978,1997]$. The potential errors of the scaling procedure typically used for saturated conductivity (Bouwer and Rice, Proc.Char. and Monit. of the Vadose Zone, pp. 77-93, Dec. 8-10, 1983) has not been verified for Hanford Site sediments, however, particularly those with gravel contents greater than $50 \%$. The properties of clean gravel have generally been estimated at Hanford, with only a few direct measurements reported. Because of the difficulty in these measurements and the presence of gravel materials in the near-field of the ILAW disposal facility, a need exists to develop and formalize an accurate method to measure the hydraulic properties of gravel directly.

The objective of this task will be to measure the hydraulic properties of clean gravel and gravel-dominated sediments. We will do this using a controlled flux apparatus to achieve unit gradient conditions in the samples. Funds are included in FY01 for purchase of the necessary equipment. It is anticipated that water content measurements will be made with an available dual gamma system.

\section{Fractured Material Model Development And Validation.}

The glass waste will initially exist in a fractured form. As the glass corrodes over time, it is anticipated that the surfaces of the fractures and the density and aperture of the fractures will change. The current assumption is that there will be a sufficient number of fractures that the glass can be treated in simulation models as a porous medium, like the backfill material surrounding it. Other tasks, described above, are measuring the properties of the glass material in its initial and aged state. These tasks will parameterize flow in the glass as a porous material, but will also measure the fracture characteristics of the samples. This task will develop a model to relate the fracture characteristics to the hydraulic parameters. This model will be available to be used when the actual glass waste form becomes available and its fracture properties can be measured. The model will be used at that time to estimate the hydraulic properties of the large-scale, actual glass waste on which it will be impractical to directly measure the hydraulic properties.

Characterization of The Unsaturated Hydraulic Conductivities Of llaw Near-Field Materials (Glass, Gravel And Rock).

The ILAW near-field environment consists of significant fractions of coarse materials, such as fractured and rubbelized waste glass, gravel and rock. A quantitative characterization of the unsaturated hydraulic conductivity $(K=f(\theta, \Psi))$ of these media, and its dependence on water content is crucial for ILAW near-field modeling and risk assessment. Earlier work on Hanford coarse materials such as gravel showed considerable disagreement between the measured data and the existing predictive models such as the van Genuchten-Mualem relationships (Khaleel and Relyea, 1995). Recently, we proposed a new Interfacial Area Ratio (IAR) model, based on a new definition of tortuosity factor, as the real to ideal interfacial area ratio (Saripalli et al., $2000)$. We define the tortuosity factor for saturated porous media $\left(1 / \tau_{s}\right)$ as the ratio $S / S_{o}$ (specific surface of real porous medium to that of an idealized capillary bundle). For unsaturated media, tortuosity factor $\left(1 / \tau_{a}\right)$ is defined as $a_{m w} / a_{m, o}$ (ratio of the specific airwater interfacial area of real and the corresponding idealized porous medium). This tortuosity factor is suitably measured using sorptive tracers (BET method) for saturated 
RPP-6702, Rev. 0

Formerly HNF-SD-WM-PAP-062 Rev. 4

media and interfacial tracers for unsaturated media. Diffusion coefficients and diffusive resistances measured in a number of saturated and unsaturated porous media (Conca et al., 1996) agreed well with the predictions of the IAR model. The model needs to be developed further and validated using the available measured data sets (Khaleel et al., 1995, 1997).

Air-water interfacial area (rather than water saturation alone) is a more realistic, representative characteristic of film flow that predominates unsaturated flow in coarse materials. As such, the proposed interfacial area ratio based (IAR) models are expected to be particularly useful in unconventional media, such as fractured, coarse and rubbelized geological materials, which are important components of the ILAW near-field environment.

In the present work, we propose to (i) develop improved predictive models for the unsaturated conductivities of water and air as a function of saturation based on the IAR tortuosity concept, and (ii) validate the models so developed using the extensive laboratory measured $K(=f(\theta, \Psi))$ data of Khaleel et al. $(1995,1997)$. The resulting concepts and models would be valuable towards understanding and modeling the ILAW vadose zone flow and transport in the near-field and far-field media.

\section{Write And Finalize Near-Field Hydraulics Data Package.}

Under this activity the near-field data will be merged, and the data package drafted, reviewed, and a final draft prepared according to a negotiated schedule. The format of the data package to support the 2001 PA will be followed. The near-field hydraulics data package will contain best-estimates and uncertainty information (including reasonable bounding values) for the hydraulic properties of the near-field materials. A technical review of the data package involving at least two extemal peer reviewers will be conducted.

e. Interfaces:

The near-field hydraulics task will establish and maintain strong ties to the design engineering, the PA waste-form group, the near-field geochemistry group, and the recharge group. These interactions will ensure early and accurate identification of nearfield materials as well as the integration of waste-form and near-field geochemistry knowledge.

f. Organization:

The PNNL Hydrology Technical Group leads these tasks with substantial support from staff in the PNNL Applied Geology and Geochemistry Group.

g. Quality Assurance:

Sample analysis activities will be conducted in accordance with 10 CFR 830.120 and the Hanford Analytical Services Quality Assurance Requirements Document. Other activites will be conducted in accordance with 10 CFR 830.120. 
h. Effect of Not Performing Task:

Production of the hydraulic property data package (including physical and transport properties) in support of the 2005 PA is essential. The near-field materials and waste form are continually becoming better specified as the facility design evolves. Additional materials are now in the facility design that were not included in the 2001 PA data package. Also, the data was limited for several critical materials, including the glass waste form, which is the most difficult material to characterize. Thus, the 2005 PA data package will be the first opportunity to publish in a complete and concise form the literature-based estimates and measurements of the physical, hydraulic, and transport properties of the near-field materials including the waste form. Failure to complete this activity would result is a loss of credibility within the regulatory, tribal, and stakeholder communities. 
RPP-6702, Rev. 0

Formerly HNF-SD-WM-PAP-062 Rev. 4

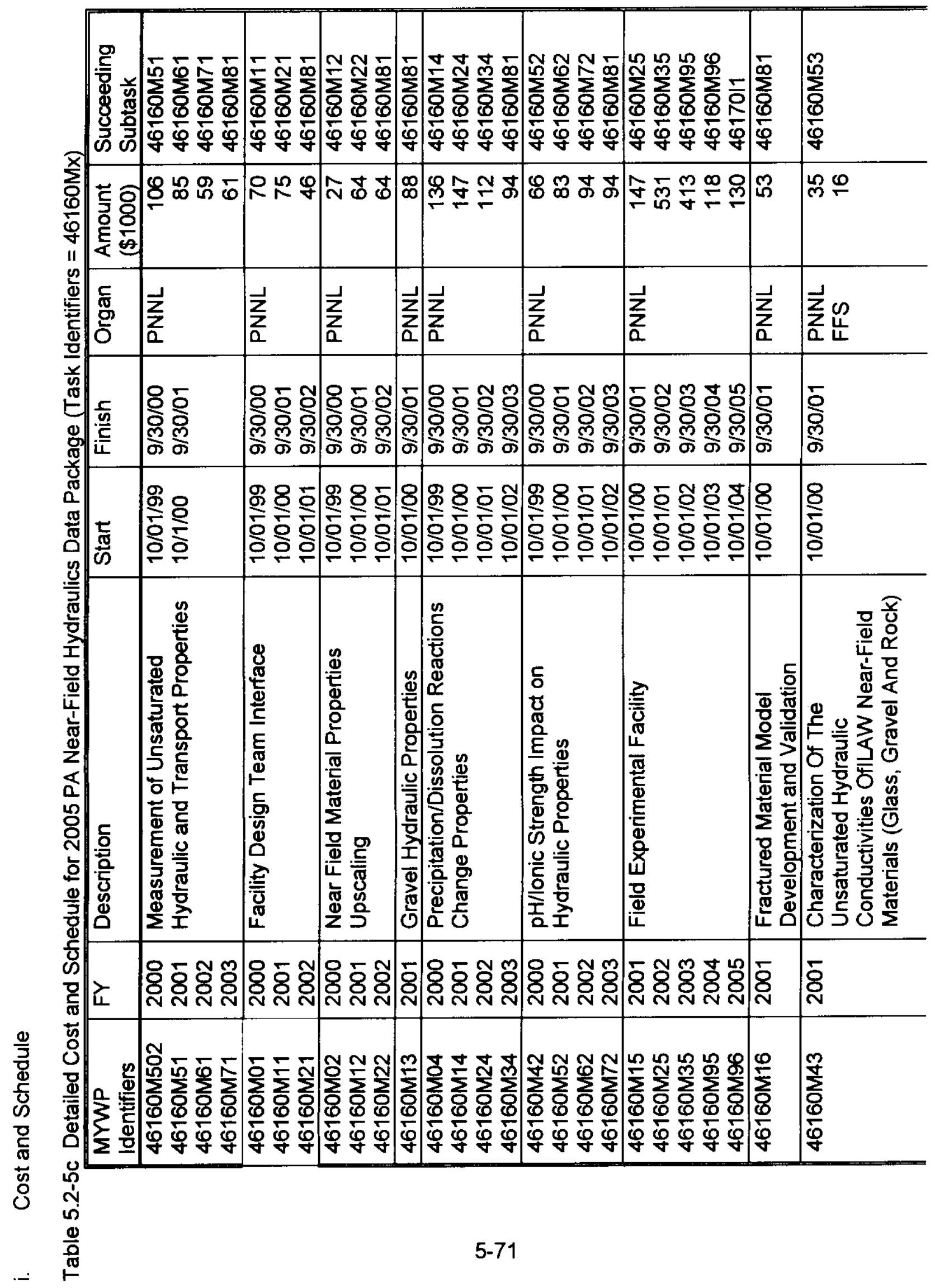


RPP-6702, Rev. 0

Formerly HNF-SD-WM-PAP-062 Rev. 4

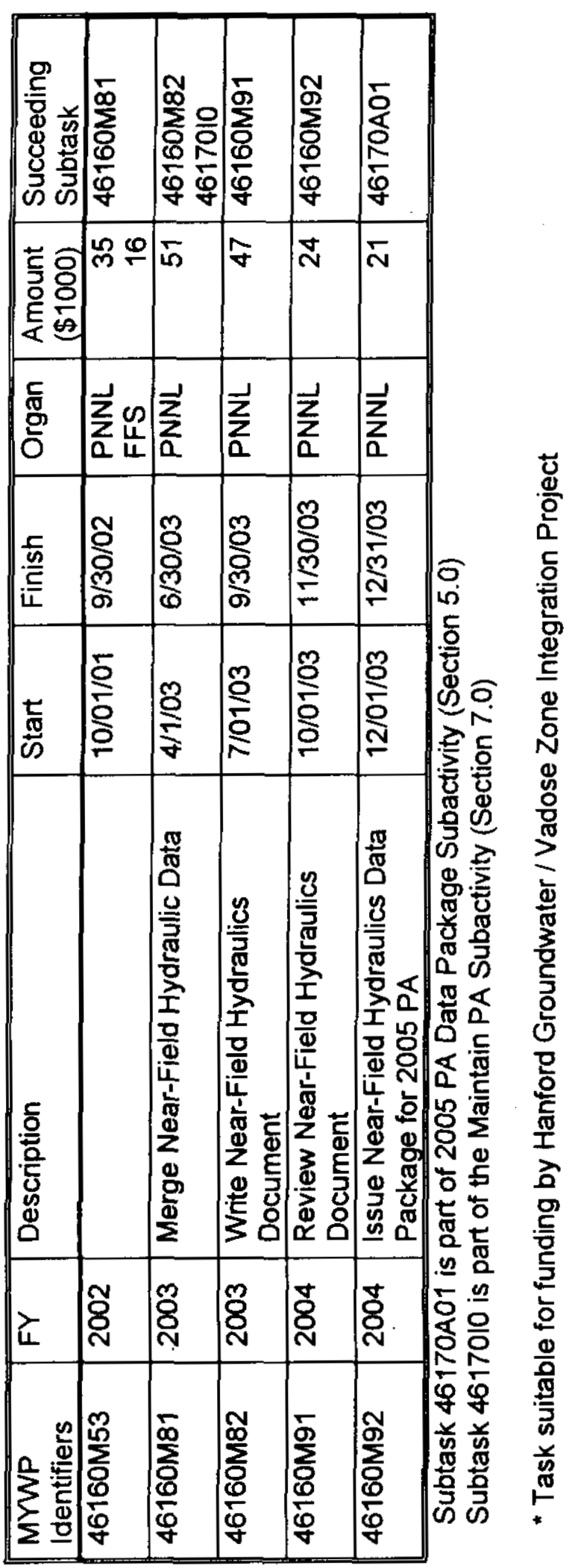


RPP-6702, Rev. 0

Formerly HNF-SD-WM-PAP-062 Rev. 4

vi. Determine Hydraulic Parameters for Soils at Disposal Sites

a. Background

Once the contaminants are released from the disposal facility, they are carried to the groundwater by the slowly moving downward moisture flow. The rate at which the moisture moves $(v)$ is determined by the recharge rate $(r)$ and the moisture content of the soil $(\theta)[v=r / \theta]$. The moisture content is determined by various hydraulic properties (saturated hydraulic conductivity, hydraulic conductivity as a function of moisture contention, hydraulic potential as a function of moisture content, liquid and vapor diffusion parameters) and by the recharge rate.

Within a geologic layer, particle scale heterogeneities affect water and contaminant movement. Regions of mobile and immobile water (fast flow paths) and particle surface reactivity vary with particle size. The mobile flow regime also determines the accessibility of contaminants to reactive mineral surfaces and therefore contaminant retardation. Interactions between these physical and chemical heterogeneities will be determined in order to account for variations in geochemical parameters with decreasing water content in unsaturated sediments.

b. List Of Deliverables

Table 5.2-6a List of Deliverables for 2005 PA Far-Field Hydraulics Data Package

\begin{tabular}{|l|l|l|l|}
\hline Description & Due Date & Level & $\begin{array}{l}\text { MYWP } \\
\text { Identifier }\end{array}$ \\
\hline $\begin{array}{l}\text { Issue Report on Upscaling and } \\
\text { Sorption-enhanced } \\
\text { Macrodispersivity }\end{array}$ & $9 / 30 / 02$ & & \\
\hline $\begin{array}{l}\text { Issue Updated Soil Hydraulic } \\
\text { Properties Database }\end{array}$ & $9 / 30 / 02$ & & \\
\hline $\begin{array}{l}\text { Issue Gravelly Formation Hydraulic } \\
\text { Properties Report for Borehole \#2 }\end{array}$ & $9 / 30 / 01$ & & \\
\hline $\begin{array}{l}\text { Issue Gravelly Formation Hydraulic } \\
\text { Properties Report for Borehole \#3 }\end{array}$ & $9 / 30 / 02$ & & \\
\hline Issue Report on Preferential Flow & $9 / 30 / 01$ & & \\
\hline $\begin{array}{l}\text { Issue Report on Particle Scale } \\
\text { Hydraulic Heterogeeity }\end{array}$ & $9 / 30 / 02$ & & \\
\hline Issue GRP Report & $12 / 31 / 00$ & & \\
\hline $\begin{array}{l}\text { Issue Report on Vadose Zone } \\
\text { Measurements Using Remote } \\
\text { Techniques }\end{array}$ & $9 / 30 / 01$ & & \\
\hline $\begin{array}{l}\text { Document Other Far-Field Hydraulic } \\
\text { Data }\end{array}$ & $9 / 30 / 02$ & 8 & $\begin{array}{l}46160 \mathrm{~L} 2 \mathrm{E} \\
{[46160 \mathrm{~L} 21]}\end{array}$ \\
\hline $\begin{array}{l}\text { Document 2nd Borehole Hydraulic } \\
\text { Data }\end{array}$ & $9 / 30 / 01$ & 7 & $\begin{array}{l}46160 \mathrm{~L} 4 \mathrm{D} \\
{[46160 \mathrm{~L} 41]}\end{array}$ \\
\hline $\begin{array}{l}\text { Document 3rd Borehole Hydraulic } \\
\text { Data }\end{array}$ & $9 / 30 / 02$ & 7 & $461600 \mathrm{~L} 5 \mathrm{D}$ \\
\hline
\end{tabular}


RPP-6702, Rev. 0

Formerly HNF-SD-WM-PAP-062 Rev. 4

\begin{tabular}{|l|l|l|l|}
\hline & & & {$[46160$ L51] } \\
\hline Document Far-Field Hydraulic Data & $9 / 30 / 03$ & 8 & $\begin{array}{l}\text { 46160L6B } \\
{[46160 L 62]}\end{array}$ \\
\hline $\begin{array}{l}\text { Issue Far-Field Hydraulic Data } \\
\text { Package for 2005 PA }\end{array}$ & $12 / 31 / 03$ & 6 & $\begin{array}{l}46160 L 7 A \\
{[46160 L 72]}\end{array}$ \\
\hline
\end{tabular}

c. Cost Summary

WBS: $1.1 \cdot 1 \cdot 3 \cdot 4 \cdot 1 \cdot 3 \cdot 3$

TPCN: D4DM3

Table 5.2-6b Cost Summary for 2005 PA Far-Field Hydraulics Data Package

\begin{tabular}{|l|l|r|}
\hline Fiscal Year & \multicolumn{1}{|c|}{ Organization } & Amount (\$1000) \\
\hline 2000 & Fluor Federal Services (FFS) & 170 \\
\hline 2001 & FFS & 330 \\
& Pacific Northwest National Laboratory (PNNL) & 140 \\
\hline 2002 & FFS & 280 \\
& PNNL & 150 \\
\hline 2003 & FFS & 120 \\
\hline 2004 & FFS & 0 \\
\hline \hline Grand Total & 1190 \\
\hline
\end{tabular}

d. Detailed Description

Measurement and Hydraulic Parameter Estimation for Boreholes \#2 and \#3.

An accurate prediction of the water flow and contaminant transport in the vadose zone requires a detailed characterization of the hydrologic properties and their variability. In particular, data that are essential in quantifying the water storage and flow properties of unsaturated soils include a characterization of soil heterogeneities, and the soil hydraulic functions (i.e., moisture content versus pressure head and unsaturated hydraulic conductivity versus pressure head relationships) of various layers.

As part of site characterization activities for the Low-activity Tank Waste Disposal Facility, soil samples will be obtained in fiscal years 1998 and 1999 via borehole drilling and sampling program. The primary objective of this task is to provide, for the 2005 PA, the measured data and the derived hydraulic parameters for various geologic formations and soil types at the disposal sites.

For the borehole samples, particle-size distribution, bulk density, particle density, diffusivity, moisture retention (main drainage curve), unsaturated hydraulic conductivity, and saturated hydraulic conductivity $\left(\mathrm{K}_{8}\right)$ data will be obtained in the laboratory. The laboratory procedures that will be followed to obtain soil moisture characteristic data are described in detail elsewhere (e.g., Klute 1986a; Klute 1986b; Khaleel 1995b). If needed, the moisture retention data and $\mathrm{K}_{\mathrm{s}}$ values will be corrected for gravel content (> $2 \mathrm{~mm}$ size fraction) (Khaleel 1997; Gardner 1986; Bouwer 1984). When expressed as a function of moisture content, the unsaturated conductivities for gravelly soils are different 


\section{RPP-6702, Rev. 0 \\ Formerly HNF-SD-WM-PAP-062 Rev. 4}

from those for fine soils ( $<2 \mathrm{~mm}$ size). However, unlike moisture retention data for bulk (gravel and fine) soils, bulk unsaturated conductivities do not require correction for the gravel fraction when expressed as a function of matric potential (Mehuys 1975).

After the data are corrected and cataloged, hydraulic parameters will be determined by fitting the van Genuchten soil-moisture retention model (van Genuchten 1980 ) to the laboratory-measured main drainage data. The laboratory-based moisture retention data will be analyzed using RETC (van Genuchten 1991), a computer program that uses a nonlinear, least squares curve fitting procedure to match the measured moisture retention data to van Genuchten model. The database comprised of various soil categories will be used as the basis for describing the distribution for five hydraulic parameters (i.e., $\alpha, n, \theta_{\mathrm{r}}, \theta_{\mathrm{s}}$, and $\mathrm{K}_{\mathrm{s}}$ ).

In the absence of unsaturated hydraulic conductivity measurements, the Mualem predictive model (Mualem 1976), along with the fitted van Genuchten parameters, and saturated hydraulic conductivity estimate, is frequently used to predict unsaturated hydraulic conductivity over the desired range of moisture regime. Estimates based on the Mualem predictive model could be off by orders of magnitude especially at the dry end of the curves (Khaleel 1995b). Therefore, to avoid inaccurate unsaturated conductivity predictions at the dry end (moisture regime of primary interest for the PA), a simultaneous fit of both moisture retention and unsaturated conductivity data will be performed to derive the hydraulic parameters.

The preceding analysis and parameter estimation of hydraulic parameters will be performed for samples from boreholes \#2 and \#3.

See section on "Measurement and Hydraulic Parameter estimation for Borehole \#1 Samples" in Section 3.2.C.vi.

\section{Collect Other Far-Field Hydraulic Data.}

Field-scale flow and transport processes within the vadose zone exercise major controls on contaminant transport from a waste disposal site. The FY97 external peer review for the Interim Performance Assessment (IPA) for Low-activity Tank Waste Disposal identified several important field-scale processes which have not been considered in the IPA. Many of the important issues raised by the FY97 panel and the FY99 extemal review of the far-field hydrology data package have been addressed. The purpose of this task is to review, interpret, and incorporate new data from boreholes \#2 and \#3 samples, and make them useable for the 2005 ILAW PA.

\section{Upscaling and sorption-enhanced macrodispersivity}

Numerical models of fluid flow and contaminant transport in the unsaturated zone require specifying hydraulic conductivity-matric potential relationships for each grid block discretizing the medium. However, the scale of the grid blocks is usually much larger than the scale at which the unsaturated properties are measured. Another aspect is the sorption-enhanced macrodispersivity. The increased plume spreading due to heterogeneous sorption (over and above the result for no sorption) is defined as the macrodispersivity enhancement. Stochastic theory suggests that the effect of macrodispersivity enhancement only occurs in the longitudinal direction. Both upscaling and sorption-enhanced macrodispersivity concepts were evaluated during FY1999, 
RPP-6702, Rev. 0

Formerly HNF-SD-WM-PAP-062 Rev. 4

based on borehole \#1 samples. A particular concem of the FY99 far-field hydrology external review was that the linear sorption isotherm $\mathrm{Kd}$ experiments and unsaturated hydraulic conductivity experiments were not run on identical samples. This limitation will be corrected for laboratory analysis of borebole \#2 and \#3 samples, and appropriate relationships will be investigated between $\mathrm{Kd}$ and unsaturated conductivity, using stochastic theory. The grid-scale values required for the 2005 ILAW PA modeling of vadose zone flow and transport will be based on laboratory-measured soil hydraulic properties for samples from the ILAW borehole \#2 and \#3, combined with results of upscaling and enhanced macrodispersivity work.

\section{Updating Soil Hydraulic Properties' Database}

Over the years, data have been obtained on soil properties in the 200 Areas. Much of these data have been gathered as part of recent site characterization activities for the Environmental Restoration Program. Khaleel and Freeman (1995) compiled available data for the principal formations and soil types in the 200 Areas plateau. Information on particle-size distribution, moisture retention, and saturated hydraulic conductivity $\left(\mathrm{K}_{\mathrm{s}}\right)$ is available for 183 samples from 12 sites in the 200 Areas. Data on moisture retention and $\mathrm{K}_{\mathrm{s}}$ were corrected for gravel content (Khaleel and Relyea 1997). After the data were corrected and cataloged, hydraulic parameters were determined by fitting the van Genuchten (1980) soil-moisture retention model to the data. Provided unsaturated conductivity measurements are available, the moisture retention curve-fitting parameters, Mualem's model, and a single unsaturated conductivity measurement can be used to predict unsaturated conductivities for the desired range-offield-moisture regime (Khaleel et al. 1995).

A scaling technique for similar media with linearly variable hydraulic properties was applied to simplify the description of the spatial variability of 200 Area soils. Comparisons made between the best fit van Genuchten curves for the unscaled data and those for the scaled data showed that scaling reduced the sums of squares by amounts varying from 63 to 89 percent (Khaleel and Freeman 1995). Results suggest that, for the soil types considered, scaling can be used successfully to describe the variability of soil hydraulic properties in the 200 Areas plateau.

Both unscaled and scaled data parameter statistics (Khaleel and Freeman 1995) can play an important role in characterizing the spatial variability of hydraulic properties for a given soil horizon and between soil horizons at the ILAW facility. Therefore, this task will involve updating the database on soil and gravel properties using the recently available information. The additional data will be based on laboratory analysis of samples from boreholes 1,2, and 3. Other more recent sources of data include those from boreholes in the northern portion of 200 East and the 100 Areas.

During the years 1992 through 1996, the WHC Geotechnical Engineering Laboratory analyzed over 100 samples from 100 Areas for particle-size distribution, bulk density, moisture retention, saturated and unsaturated hydraulic conductivity. This is an extremely rich database - the database is significant in particular because bulk of the samples are highly gravelly (gravel content as high as 75 percent) and unsaturated hydraulic conductivity data are available for these gravelly samples. The data currently exist mostly as raw data in project report files and have not been analyzed to develop any closed-form expressions for moisture retention and unsaturated conductivity. The goal of this task is to present the data in a form that will allow analysts use of the data 


\section{RPP-6702, Rev. 0 \\ Formerly HNF-SD-WM-PAP-062 Rev. 4}

and the derived closed-form expressions for the highly gravelly soils. A report will be produced documenting the database and the derived physical and hydraulic parameters.

\section{Determine Hydraulic Properties for Gravelly Formation}

The Borehole No. 1 that was drilled near the ILAW disposal facility encountered a 50-70 ft thick gravelly formation. The formation could potentially be much like an open framework gravel, since the air pressures applied through the borehole essentially dissipated within the formation. No direct laboratory measurements for hydraulic properties can be done for large, cobble-sized (cobble diameters of 10" and more noted for borehole \#1) open framework gravels. But for PA calculations, defensible hydraulic parameters are very much needed for such an extensive, thick vadose zone. In lieu of laboratory measurements, a variety of alternate approaches, as indicated below, will be used to develop the parameter estimates.

During the drilling of borehole \#2 and \#3, conduct a planned in-situ air permeability test by air pressure buildup via borehole, measuring air flux, and other parameters. The Darcy's Law for the gas phase can then be applied to obtain the gas phase permeability. This will help provide, as a surrogate, estimates of in-situ saturated hydraulic conductivity for the liquid phase with the formation.

Develop a numerical simulation procedure to perform a series of steady, unit gradient numerical experiments to obtain unsaturated hydraulic conductivity estimates for open framework gravels. The numerical procedure will also be extended, via a particle-tracking routine, to provide for a tracer breakthrough curve and dispersivity estimates; another important parameter for the PA calculations.

Review existing data on measured hydraulic properties for 100 Area sediments, estimates of hydraulic properties for clean gravels, and other data available in the soil physics literature to provide for defensible estimates of particle sizes and its distribution, bulk density, moisture retention, saturated and unsaturated conductivities, and dispersivity for gravelly soils.

Another important consideration (but not part of this work scope) is the estimate for sorption coefficients for open framework gravels.

\section{Evaluate Preferential Flow for ILAW PA}

During the FY1997 external peer review of the interim ILAW PA, issues were raised regarding potential occurrence of preferential flow at the disposal facility. The purpose of this task is to do a literature review of preferential flow at arid, "dry" sites, consult with recognized experts in the area of preferential flow, and provide a rationale on the potential (or non-occurrence) at the ILAW site.

In general, two types of moisture movement can occur in vadose zones; piston flow and preferential flow. Piston flow refers to uniform moisture movement through the soil matrix whereby infiltrated water displaces initial water. Under piston-like flow conditions most, if not all, preexisting ("old") water is displaced and moved ahead of the "new" infiltration water added from above. Under natural recharge conditions, the medium to coarse-grained sands at tank farm sites are expected to be quite conducive to piston flow. 
RPP-6702, Rev. 0

Formerly HNF-SD-WM-PAP-062 Rev. 4

Preferential flow refers to nonuniform moisture movement along preferred pathways. During preferential flow, local wetting fronts may propagate to considerable depths in a soil profile, essentially bypassing the matrix pore space. While preferential flow has been recognized and widely studied under saturated or near-saturated flow conditions (e.g., Nkedi-Kizza et al. 1983; De Smedt and Wierenga 1984), arid and semiarid climates or areas under low-water fluxes, particularly where soils are coarse grained, such as under the proposed ILAW facility, show little evidence of it. Thus, under natural recharge conditions, precipitation at arid sites usually is too low to invoke preferential flow; much of the water in the dry soils is simply adsorbed onto the grain surfaces and cannot move along preferred pathways. This is, of course, quite different from tank leak conditions; Caggiano et al. (1996) presented several hypothetical sources and migration pathways for contaminant movement within the vadose zone.

Although, clastic dikes can potentially increase flow rate, they are unlikely to intersect large segments of ILAW wastes and, when they do, the cross sectional area of the intersection is small (DOE 1997). Therefore, the presence of clastic dikes in unsaturated media appears unlikely to contribute much to transporting the bulk quantity of leaked wastes to groundwater. This said, the chances of encountering a clastic dike are high, and contaminants could move along this preferential pathway. Many clastic dikes are present at the U.S. Ecology site southwest of the 200 East Area and in the vicinity of the ILAW facility.

Other potential preferential pathways include "fingering" flow and "funneled" flow (DOE 1997). Fingering flow results when media instabilities cause uniform flows to split into fingers. Funneled flow results when media heterogeneities cause the flow area to shrink (Kung 1990). A simulated tank leak study in the 200 East Area (Narbutovskih et al. 1996) provided some evidence of preferential flow; electrical resistivity tomography data indicate that relatively small volumes $(<50,000 \mathrm{~L})$ of liquid waste can reach depths of $>30 \mathrm{~m}$ within the vadose zone in tens of days.

For the 2005 ILAW PA, the importance of preferential flow (i.e., clastic dikes, fingering, funneling) will be evaluated for both the far-field system and the near-field engineered facility. Data collected via various field experiments at the Hanford Site and other arid sites will be reviewed. Work will proceed in collaboration with experts at national laboratories (PNNL and SNL). Dr. Robert Glass at Sandia has devoted nearly 25 years to the study of preferential flow under low infiltration fluxes. Based on the review of data and the unique conditions of the ILAW disposal facility, a test plan will be developed providing details on any necessary laboratory and field experiments to evaluate the importance of preferential flow for the ILAW facility.

\section{Determination of Particle Scale Hydraulic Heterogeneity}

At low moisture contents in unsaturated sediments, particle scale heterogeneities result in regions of mobile-immobile water within a geologic layer. This can lead to fast flow paths and also determines the accessibility of contaminants to reactive mineral surfaces, and therefore contaminant retardation. Comments on the 1998 draft ILAW PA noted the importance of considering heterogeneities and fast flow paths in the vadose zone. 


\section{RPP-6702, Rev. 0 \\ Formerly HNF-SD-WM-PAP-062 Rev. 4}

In unsaturated sediments, the pathway for water flow becomes more tortuous, and water held in films and small pores can be "disconnected" with respect to the mobile flow regime. In reviewing water flow and transport in the vadose zone, Nielsen et al. (1986) note that in addition to water held within aggregates, immobile water may exist in thin liquid films around soil particles, in dead-end pores, or as relatively isolated regions associated with unsaturated flow.

Hydraulic heterogeneity due to regions of mobile-immobile water (dual porosity) in unsaturated sediments has long been established (Nielsen and Biggar, 1961; Biggar and Nielsen, 1962; Gaudet et al., 1977). Within a geologic layer, the fraction of immobile water increases as moisture content is decreased; regions of immobile water develop to a greater extent in coarse-textured media (gravel, sand, fine sand) than in fine-textured sediments (silt, clay) (Gamerdinger and Kaplan, 1999). The unsaturated flow regime (particles in contact with mobile water) is thought to differ depending upon the dominant sediment texture within a geologic layer, e.g., film flow along the particle surface of coarse-textured media and matrix flow through small, water-filled pores of fine-textured media.

Hydraulic conductivity is a master variable for water flow and contaminant transport and also varies with sediment texture and water content. In unsaturated sediments, hydraulic conductivity may provide a single parameter for relating the combined effects of texture and water content on the development of particle scale hydraulic heterogeneity arising from mobile-immobile water domains in unsaturated sediments. Controlled laboratory investigations for a range of sediment textures and unsaturated moisture conditions are necessary for establishing this relationship. Such relationships form the basis for incorporating heterogeneity into computer codes for transport models (Gelhar and Axness, 1983; Dagan 1984; Thompson and Gelhar, 1990).

Several complementary methods will be used to characterize hydraulic heterogeneity and water distribution in unsaturated sediments. Column methods provide a means for understanding average properties of the media and the effect on transport while imaging methods provide detailed information at the particle scale. Unsaturated column experiments with conservative, non-sorptive tracers $\left({ }^{3} \mathrm{H}_{2} \mathrm{O}\right.$, pentafluorobenzoic acid, PFBA) will provide a measure of the proportion of water in the mobile versus stagnant domains $\left(\phi_{m}\right)$, mass transfer between mobile and stagnant domains $\left(\alpha, \mathrm{hr}^{-1}\right)$, and hydrodynamic dispersion $\left(D, \mathrm{~cm}^{2} / \mathrm{hr}\right)$. The dependence of the mass transfer rate on the pore-water velocity will be evaluated. An interfacial tracer (sodium dodecylbenzene sulfonate, SDBS), will be used to determine the effective, specific air-water interfacial area $\left(a_{1} \mathrm{~cm}^{2} \mathrm{~cm}^{-3}\right)$ in progressively unsaturated columns (Saripalli et al., 1997; Kim et al., 1997). Values are bounded by zero for the saturated case and the specific surface area of the sediment as a maximum (thin film of water at surface). When normalized to the specific volume of the fluid phase (air, $a$, or water, $w, \mathrm{~cm}^{3}$ ), the ratio is defined as the "morphology" or heterogeneity index, $H$. Analysis of $a_{l}, H_{a}$, and $H_{w}$ with varying water content and sediment texture will indicate changes in phase connectivity and water distribution.

Recent improvements in imaging technologies have increased our ability to directly distinguish the distribution of water (i.e., films at the particle surface, pendular water at the intersection of two particles, or water held in small pores). X-ray microtomography combined with computer image reconstruction will provide $2 D$ and $3 D$ images of unsaturated columns with $20-50 \mu \mathrm{m}$ resolution. Experiments with high atomic 
RPP-6702, Rev. 0

Formerly HNF-SD-WM-PAP-062 Rev. 4

number tracers in the solution phase (e.g., sodium iodide, Nal) will be used as a probe to image the water distribution in unsaturated sediments. Imaging solute mass transfer from regions of mobile to immobile water will be attempted. Unsaturated hydraulic conductivity, $K_{h}$, is a master variable for transport in unsaturated sediments and will be determined for all sediments over a range of unsaturated water contents. The combined results of the transport experiments with non-sorptive and interfacial tracers, hydraulic conductivity determination, and computer-enhanced microtomography imaging will provide complementary measures to assess changes in hydrodynamic properties that develop as the soil water content is decreased.

These experiments at the bench scale (unsaturated column) are necessary for determining correlations among sediment properties (particle size, specific surface area, water content), hydraulic conductivity, and hydraulic heterogeneity parameters. Upon establishing these relationships, further evaluation is needed at the intermediate (meter) scale to determine the importance of these phenomena in gravel layers, which cannot be considered in laboratory columns. Ultimately, the techniques developed for assessing hydraulic heterogeneity within geologic layers will be evaluated for contaminant movement between geologic layers at the field scale.

In the PA, hydraulic and chemical data are grouped by geologic layer. An understanding of mechanisms by which hydraulic heterogeneity is linked to hydraulic conductivity (and geochemical parameters, section X.2.C. viii.) will improve computer codes for estimating water and contaminant movement. Although fast flow paths develop in unsaturated sediments, improved understanding of solute distribution and mass transfer between regions of mobile and immobile water will allow credit for solutes in stagnant water domains. This task will provide the basis for assessing contaminant distribution in the immobile water domain, eliminating the need for a conservative assumption that all soluble species are present in the mobile flow regime.

\section{Vadose Zone Measurements Using Remote Techniques}

Sediment heterogenities are suspected to cause preferential flow of contaminant streams. Ground-Penetrating Radar (GPR) will be used to locate heterogeneous structures and characterize moisture content distribution. The GPR method has the advantage of being non-intrusive, does not produce any waste, is cheap to operate, provides real-time output, and provides a continuous profile coverage. The proposed work is to be performed in conjunction with the clastic dike study proposed by Reidel (1998). Reidel proposed using GPR to identify the occurrence, location and orientation of clastic dikes. This additional work is intended to use the information from the GPR surveys to assign hydraulic properties, delineate stratigraphic features, and quantify heterogeneity necessary for development of a realistic conceptual model of the flow paths and transport distribution. Specific objectives include (1) identification of horizontal layering and identification of layer composition, (2) identification of vertical clastic dikes, (3) evaluation of water content distribution in the dykes and in the layered sediments. Well logs from existing wells at the Hanford site will be used to condition the GPR measurements. Geostatistical analysis of the data will be performed to assist in quantifying heterogeneity and to improve resolution by cross-correlation of properties from GPR and borehole data.

Initial measurements using the GRP were completed in FY00. During FY01 a report documenting the GPR measurements will be issued. Also, a feasibility study will 
RPP-6702, Rev. 0

Formerly HNF-SD-WM-PAP-062 Rev. 4

be initiated fo the application of other remote sensing technologies to provide cost effective vadose zone information.

Produce Far-Field Hydraulics Data Package.

See section on "Produce Far-Field Hydraulics Data Package" in Section 3.2.C.vi. 
RPP-6702, Rev. 0

Formerly HNF-SD-WM-PAP-062 Rev. 4

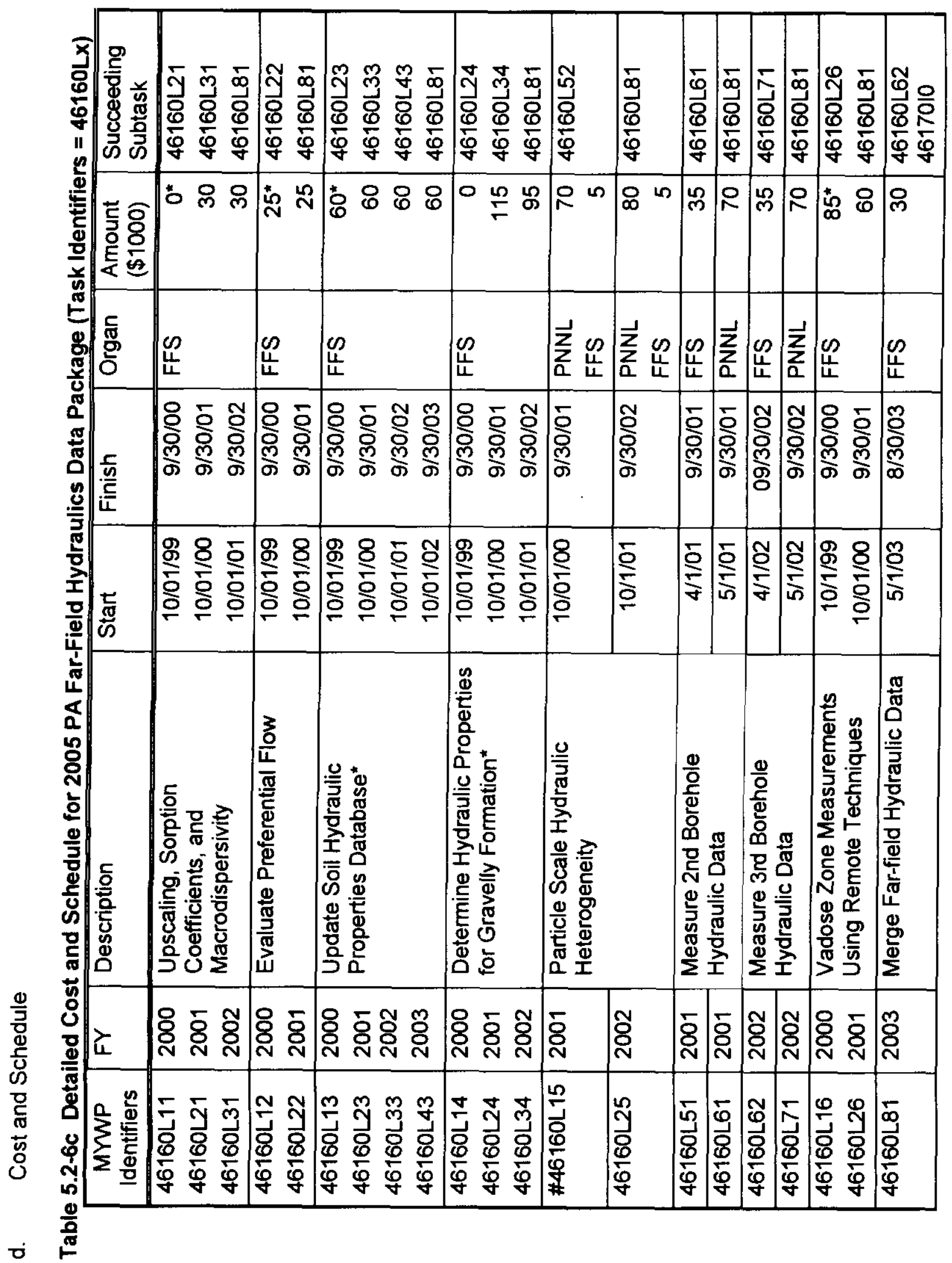


RPP-6702, Rev. 0

Formerly HNF-SD-WM-PAP-062 Rev. 4

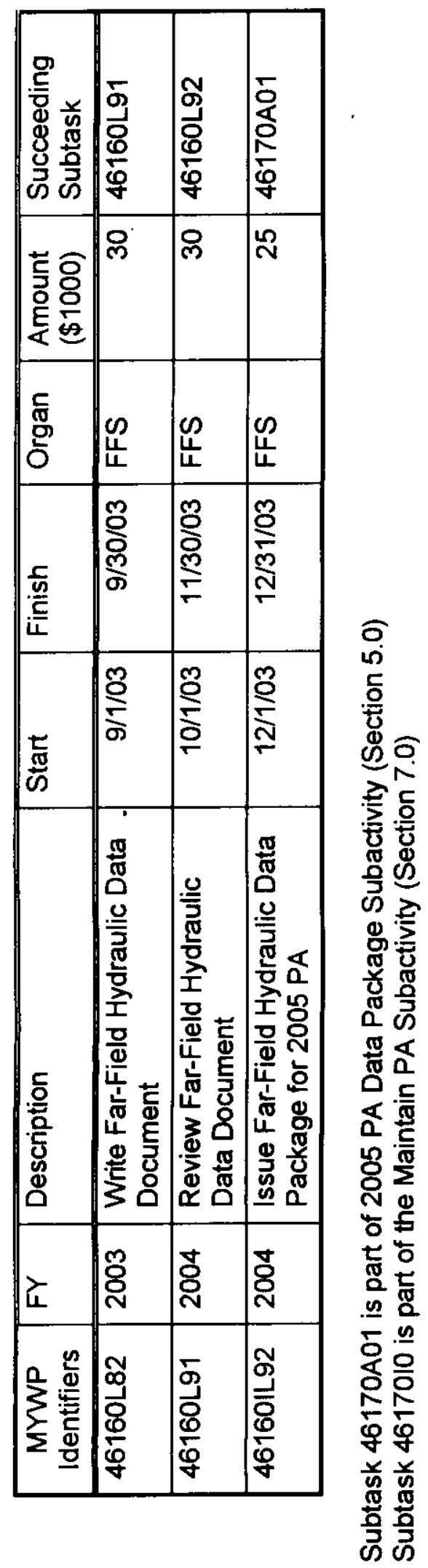


RPP-6702, Rev. 0

Formerly HNF-SD-WM-PAP-062 Rev. 4

vii. Determine Geochemical Parameters for Disposal Facility Materials

a. Background

The waste form provides the main trapping mechanisms for the containment of contaminants. However, other features of the disposal facility can hinder transport of the release contaminants or can chemically reduce the rate at which the waste form dissolves. The major output of this task will be to write reports that will form the basis of the Data Packages of the 2005 Performance Assessment (Section 5.0).

b. List Of Deliverables

Table 5.2-7a List of Deliverables for 2005 PA Near-Field Geochemical Data Package

\begin{tabular}{|l|l|l|l|}
\hline Description & $\begin{array}{l}\text { Due } \\
\text { Date }\end{array}$ & Level & $\begin{array}{l}\text { MYWP } \\
\text { Identifier }\end{array}$ \\
\hline $\begin{array}{l}\text { Write Test Plan for Intermediate Scale } \\
\text { Experimental System }\end{array}$ & $\begin{array}{r}3 / 31 / 00 \\
\text { done }\end{array}$ & & \\
\hline Kd vs. Solubility Progress Report (SRL) & $5 / 31 / 02$ & & \\
\hline Kd vs. Solubility Final Report (SRL) & $9 / 30 / 03$ & & \\
\hline Zeolite Sequestration Progress Report & $3 / 31 / 02$ & & \\
\hline Zeolite Sequestration Final Report & $9 / 30 / 03$ & & \\
\hline $\begin{array}{l}\text { Caustic Effects on Near Field Hanford } \\
\text { Formation Sediments-Progress Report }\end{array}$ & $12 / 31 / 01$ & & \\
\hline $\begin{array}{l}\text { Caustic Effects on Hanford Sediments- } \\
\text { Final Report }\end{array}$ & $7 / 31 / 03$ & & \\
\hline Getter Progress Report \#1 & $12 / 31 / 01$ & & \\
\hline Getter Progress Report \#2 & $9 / 30 / 02$ & & \\
\hline $\begin{array}{l}\text { Document Measuring Geochemical } \\
\text { Data for Potential Getters }\end{array}$ & $7 / 31 / 03$ & 8 & $4616002 \mathrm{C}$ \\
\hline Rubblelized Glass Final Report & $8 / 01 / 02$ & & \\
\hline $\begin{array}{l}\text { Intermediate Scale Test System } \\
\text { Progress Report \#1 }\end{array}$ & $3 / 31 / 02$ & & \\
\hline $\begin{array}{l}\text { Intermediate Scale Test System } \\
\text { Progress Report \#2 }\end{array}$ & $12 / 15 / 02$ & & \\
\hline $\begin{array}{l}\text { Final Intermediate Scale Test System } \\
\text { Report }\end{array}$ & $9 / 30 / 03$ & & \\
\hline $\begin{array}{l}\text { Write Geochemical 2005 PA } \\
\text { Geochemical Data Package Review } \\
\text { Plan }\end{array}$ & $9 / 30 / 04$ & 8 & $4616006 \mathrm{~B}$ \\
\hline $\begin{array}{l}\text { Issue Geochemical Data Package for } \\
\text { 2005 PA }\end{array}$ & $12 / 31 / 04$ & 6 & $4616007 \mathrm{~A}$ \\
{$[46160072]$} \\
\hline
\end{tabular}


RPP-6702, Rev. 0

Formerly HNF-SD-WM-PAP-062 Rev. 4

c. Cost Summary

WBS: $1.1 \cdot 1 \cdot 3 \cdot 4 \cdot 1 \cdot 3 \cdot 3$

TPCN: D4DM3

Table 5.2-7b Cost Summary for 2005 PA Near-Field Geochemical Data Package

\begin{tabular}{|c|c|c|}
\hline $\begin{array}{l}\text { Fiscal } \\
\text { Year }\end{array}$ & Organization & $\begin{array}{l}\text { Amount } \\
(\$ 1000)\end{array}$ \\
\hline 2000 & Pacific Northwest National Lab (PNNL) & 160 \\
\hline \multirow[t]{4}{*}{2001} & PNNL & 460 \\
\hline & SNL (Sandia National Lab) & 80 \\
\hline & SRS (Savannah River Site) & 30 \\
\hline & Total & 570 \\
\hline \multirow[t]{4}{*}{2002} & PNNL & 520 \\
\hline & SNL & 80 \\
\hline & SRS & 75 \\
\hline & Total & 675 \\
\hline \multirow[t]{4}{*}{2003} & PNNL & 465 \\
\hline & SNL & 80 \\
\hline & SRS & 75 \\
\hline & Total & 620 \\
\hline \multirow[t]{3}{*}{2004} & PNNL & 135 \\
\hline & SRS & 0 \\
\hline & Total & 135 \\
\hline \multicolumn{2}{|c|}{ Grand Total } & 2160 \\
\hline
\end{tabular}

d. Detailed Description

Effects of Near Field Chemistry on Radionuclide Kd and Solubility Values.

The objective of this subtask is to identify whether or not the distribution coefficient, $K_{d}$, values previously identified for the far field can be used in the near-field. To do this a series of batch experiments will be conducted in which Hanford sediments and engineered barrier materials are equilibrated with solutions with varying amounts of $\mathrm{NaOH}-\mathrm{NaClO}_{4}$ (surrogate solution for glass leachate). The $\mathrm{K}_{d}$ and/or solubility limit for $\mathrm{Tc}, \mathrm{I}, \mathrm{Se}, \mathrm{Sn}, \mathrm{Sr}, \mathrm{Cs}$, and $\mathrm{U}$ will be determined as a function of $\mathrm{NaOH}$ concentration and time of contact. The results will be used to generate look-up tables for these two parameters for the near-field geochemical data package. It is expected that the higher $\mathrm{pH}$ leachate will cause the $\mathrm{K}_{\mathrm{d}}$ values to be larger and will cause the solubility of some of the contaminants to be lower than those for ambient background groundwater. Thus the near field may retard the migration of some of these key mobile contaminants to a higher degree than predictions using far-field values that were used as default values on earlier PA's.

During experiments performed in FY98-99, attention was directed at the identification of the chemical mechanisms controlling the sorption processes to provide technical defensibility for the selection of the distribution coefficients $\left(K_{d}\right)$ to be used in 


\section{RPP-6702, Rev. 0 \\ Formerly HNF-SD-WM-PAP-062 Rev. 4}

future performance assessments. It was found, during the conduct of the experiments, that selenium and technetium $\mathrm{K}_{d} \mathrm{~s}$ increased as ionic strength increased. The cause for this is most likely to be that the higher ionic strength caused the double layer around the particles to decrease, thereby permitting greater interaction with the mineral surfaces. Further, the $\mathrm{pH}$ level had an effect on the sorption of these anions.

These are the first-ever experiments conducted with Hanford Site sediment in which the $\mathrm{K}_{\mathrm{d}} \mathrm{s}$ were measured as a function of ionic strength and $\mathrm{pH}$. Overall, the observed trends were consistent with more generalized geochemical principles. One of the most important contributions of these experiments was that they quantified the $K_{d}$ changes induced by variations in ionic strength and $\mathrm{pH}$ that are expected to exist in the near field.

These results have some important implications for the ILAW performance assessment. They include the following:

- A suite of $\mathrm{K}_{\mathrm{d}}$ values for $\mathrm{I}^{-}, \mathrm{SeO}_{4}{ }^{2-}$, and $\mathrm{TCO}_{4}{ }^{-}$were measured. These values can be used to technically defend the choice of $K_{d}$ values to be used in the near-field ILAW environment. These results support the use of unique $K_{d}$ values for specific $\mathrm{pH}$ and ionic-strength conditions likely to exist in the near field.

- The $\mathrm{TCO}_{4}{ }^{-} \mathrm{K}_{\mathrm{d}}$ values in the near field are likely to be $>0 \mathrm{~mL}$, perhaps conservatively set at 0.2 to $0.6 \mathrm{~mL} / \mathrm{g}$. For conditions in which the $\mathrm{pH}$ is $>10$ and the ionic strength is $>0.5 \mathrm{M}, \mathrm{K}_{\mathrm{d}}$ values as high as $3.9 \mathrm{~mL} / \mathrm{g}$ were measured. The cause for the greater degree of adsorption under near-field conditions is not clearly understood, but is likely the result of compression of the electrical double layer around the sediments leading to less anionic repulsion and more $\mathrm{TCO}_{4} /$ sediment interaction.

- The $\mathrm{I}^{-}$and $\mathrm{SeO}_{4}{ }^{2-} \mathrm{K}_{\mathrm{d}}$ values followed consistent but not simple trends with $\mathrm{pH}$ and ionic strength. $\mathrm{K}_{d}$ values of these radionuclides decrease when $\mathrm{pH}$ is $>10$. Conservative $\mathrm{K}_{d}$ values for $\mathrm{I}^{-}$and $\mathrm{SeO}_{4}{ }^{-}$in $\mathrm{pH}-10$ systems should be 0.2 and $0 \mathrm{~mL} / \mathrm{g}$, respectively. In $\mathrm{pH}-11$ systems, conservative $K_{d}$ values should be set to $0 \mathrm{~mL} / \mathrm{g}$. However, under conditions in which the $\mathrm{pH}$ remains $\sim 8.0$ (i.e., background level) and the ionic strength increases above $80 \mathrm{mM}$ (perhaps only 2 times background), conservative estimates of $\mathrm{I}^{-}$and $\mathrm{SeO}_{4}{ }^{2-}$ $K_{d}$ values would be 0.5 and $4 \mathrm{~mL} / \mathrm{g}$, respectively.

In FY2000 tests with contact times as long as 1 year will be completed for two Hanford sediments. The composite sediment that has been in use since FY98 has been found to be contaminated with microbes so we have started using a different sediment but continue the other tests to investigate the effects of living organisms on Kd values.

\section{Secondary Zeolite Phases as Retardants to Tc, I, Se, and U Mobility.}

Past ILAW studies have shown that zeolites form as secondary phases following the glass waste form dissolution (Mann et al. 1996 and Mattigod et al. 1998). Zeolites have the ability to sequester many different ions within their crystalline structure. Preliminary tests (Mattigod et al. 1998) have shown that these four potentially mobile contaminants are partially incorporated into the structures of the weathering products of 
RPP-6702, Rev. 0

Formerly HNF-SD-WM-PAP-062 Rev. 4

two glass types. The diffraction data from weathered LD6 glass matched the standard diffraction data for phillipsite, a zeolite mineral. Phillipsite is an aluminosilicate mineral with a doubly connected 4-ring framework structure and is known to form from weathering of alkali glasses and gels (Breck 1974, Barrer 1982, Gottardi and Galli 1985). The framework consists of tetrahedrally coordinated $\mathrm{Si}$ and $\mathrm{Al}$ that form 8-ringed channels in both $a$ and $b$ crystallographic directions (Breck 1974). These open channels, with dimensions of $4.2 \times 4.8 \AA$ and $2.8 \times 4.8 \AA$, contain hydrated exchangeable cations that are coordinated with framework oxygen. These exchangeable cations compensate the positive charge deficiency in the structure arising from the lower valence ion, $\mathrm{Al}(\mathrm{III})$ substituting for the higher valence ion, Si(IV).

The presence of phillipsite, a secondary mineral in fresh glass, indicated that the glass surfaces were highly reactive and that some of these particles during storage at room temperature appeared to have reacted with ambient moisture, resulting in clusters of phillipsite. Such formation of phillipsite under ambient conditions is in accordance with observations of this mineral's formation under earth-surface conditions (Gottardi and Galli 1985).

For a second glass type (SRL202), XRD data indicated that at the end of the first week a crystalline secondary mineral had formed from weathering the glass.

Subsequent analysis showed no significant changes in diffraction intensities, indicating that a major fraction of glass alteration reactions had taken place during the first week of weathering. Also, the broad, diffuse nature of the diffraction peaks indicated that the weathering product was a microcrystalline (submicron-size crystals) mineral. The diffraction data from weathered glass matched the standard diffraction data for nontronite, an iron-rich phyllosilicate mineral. Nontronite has a sheet-like structure with two sheets of silica tetrahedra sandwiching an octahedrally coordinated layer containing mainly iron. These structural units range from 9.5 to $10 \AA$ in thickness, and the interlayer space between adjacent structural units is occupied by exchangeable cations. A smaller fraction of exchangeable cations in this structure occupy ionized hydroxyl sites along the sheet edges.

SEM examination of glass particles weathered for 4 weeks revealed roseate clusters of thin, sheet-like crystals of nontronite growing on matrices of highly weathered (corroded) glass. The crystals are very thin $(\sim 0.05-\mu \mathrm{m})$ sheets and completely covered the glass surfaces. The morphology of these crystals reflect the sheet-like structure of a typical phyllosilicate mineral. The nontronite is silica and iron rich, which reflects the composition of the parent glass.

Results of the weathering of a third glass sample (LAWA33) conducted during FY99, showed that the weathering products consisted of mainly herschelite, a zeolite mineral with minor amounts of other zeolite minerals such as analcime and phillipsite. Continued weathering of this glass resulted in increasing amounts of analcime with concomitant decrease in the amount of herschelite. The sequestration experiments with LAWA33 glass showed that the degree of incorporation of radionuclides in these zeolite minerals increased with increasing concentration of these elements in the spike solution.

The incorporation of the aforementioned mobile contaminants will be studied in more detail in FY00-01 using LAWBP1, a more stable reformulated glass. A series of batch experiments are being conducted to determine the quantity of mobile contaminants that are incorporated into the weathering products during aging at elevated 
RPP-6702, Rev. 0

Formerly HNF-SD-WM-PAP-062 Rev. 4

temperatures. To determine whether the contaminants simply adsorb onto the outer surfaces of the zeolites/clays or whether they are more strongly bound in crystal lattice sites, the contaminant laden zeolites will be leached with a strong exchange solution. Should the exchange leachate remove substantial amounts of contaminants, one can conclude that they are adsorbed to exchange sites. Kd values will be generated from the data. If the contaminants remain fixed in the weathering products, long-term solubility tests will be performed to generate empirical solubility data for the near field geochemical data package.

Effects of Near Field Chemistry - Chemical Behavior of Radionuclides during Vadose Zone Sediment Interactions with Highly Alkaline Glass Leachate.

The objective of this subtask is identify the fate of the radionuclide during the interaction between highly alkaline glass leachates and the near-field vadose zone sediments. To examine the nature of these reactions, a series of batch experiments will be conducted in which Hanford formation sediments will be reacted with $\mathrm{NaOH}$ solutions (surrogate solution for glass leachate) containing radionuclides of interest. The parameters to be examined will include, the molarity of $\mathrm{NaOH}$, the contact time and reaction temperature. The reacted sediments will be analyzed for radionuclide activity, mineralogy and any changes in $\mathrm{Kd}$. The desorption $\mathrm{Kd}$ of the reacted sediments will also be tested for selected radionuclides. These data will provide valuable information about any changes in the properties of near-field sediments that may retard the migration of some of the key mobile contaminants to a noticeably higher degree than surface adsorption reactions.

These experiments are a follow up to understanding better the chemical mechanisms controlling the radionuclide reaction processes to provide technical defensibility for the selection of the distribution coefficients $\left(K_{d}\right)$ to be used in future performance assessments. Previous experiments have shown that selenium and technetium $K_{d} s$ increased as ionic strength increased. The cause for this is most likely to be that the higher ionic strength caused the double layer around the particles to decrease, thereby permitting greater interaction with the mineral surfaces. Furthermore, the $\mathrm{pH}$ level had an effect on the sorption of these anions. However, kinetics of sediment-solution interaction can be better investigated by conducting these experiments at several elevated temperatures, contact times and hydroxyl molarities.

These results have some important implications for the ILAW performance assessment. They include the following:

- Understand the reaction mechanism (adsorption or solubility) of radionuclide interaction with sediments.

- Calculate the kinetics of sediment-solution interaction at ambient temperatures

- Potential rate of desorption or solubility of contaminant radionuclide from the reacted near-field sediment.

\section{Chemical Getters to Retard Contaminant Migration Out of Near-Field.}

The objective of this subtask is evaluate some recent identified getter materials for Tc, Se, I, and U. Five broad classes of materials will be evaluated: Fe-bearing reducing materials, silver-amended minerals, soft-metal containing minerals, phospate 


\section{RPP-6702, Rev. 0 \\ Formerly HNF-SD-WM-PAP-062 Rev. 4}

minerals, and functionalized and metal-capped SAMMS (Self Assembled Monolayers on Mesoporous Silica) materials.

The general approach that will be taken in these experiments will be to conduct laboratory batch experiments in which Se, I, Tc, and/or $U$ will be put in contact with the getters under a range of environmental conditions expected to exist in the near field (varying ionic strength and $\mathrm{pH}$ ). Then the amount of $\mathrm{Se}, \mathrm{l}, \mathrm{Tc}$, and/or $\mathrm{U}$ remaining in solutions will be determined. From this data $\mathrm{K}_{d}$ values or conditional solubility constants will be calculated.

Tc, Se, I, and $U$ will exist as anions in the near field environment, which will have a high ionic strength and high $\mathrm{pH}$. Anion exchange is very ineffective under these environmental conditions. Thus, successful getter materials must remove these anions by mechanisms other than anion exchange or pH-dependent surface complexation. Precipitation is a removal process that has been evaluated by a number of researchers. Based on a recent literature, a number of minerals containing soft metals and sulfides have been found to be particularly effective for this purpose. The most promising of these minerals will be evaluated in this study; they include chalcopyrite ( $\mathrm{FeCuS}_{2}$ ), stibnite $\left(\mathrm{Sb}_{2} \mathrm{~S}_{2}\right)$, chalcocite $\left(\mathrm{Cu}_{2} \mathrm{~S}\right)$ and antimony sulfide $\left(\mathrm{Sb}_{2} \mathrm{~S}_{3}\right)$. Another material which does not contain a soft metal that will be evaluated is calcium monosulfate aluminate. This latter material appears to immobilize the anions by forming a yet unidentified precipitate.

One set of getter experiments will be directed primarily at immobilizing iodine, and is likely to work also with technetium. These getters are silver-amended minerals. This is a very well established method used in recover iodine from gas stacks throughout the DOE complex. It has also been shown to be an effective material for recovering iodide and iodide-organic complexes out of solution (Babad and Strachan, 1980, US Patent $4,229,317$ ). The silver can be plated or exchanged onto zeolite, activated carbon, or smectitic minerals (Puppe et al. 1990, US Patent 4,913,850; Ho and Kraus, 1981 , J. Inorg. Nucl. Chem. 43:583). The silver in these minerals form sparingly soluble complexes with iodine and is likely capable of recovering Se and Tc. Also, preliminary testing of another class of getters known as metal-capped SAMMS (Self Assembled Monolayers on Mesoporous Silica) have shown that these materials can adsorb with high specificity, iodine and technicium from a groundwater matrix. Detailed testing of these materials will be conducted to evaluate their capacity and specificity for iodine and technicium adsorption from groundwater and glass leachate matrices. Additionally, iodine and technicium desorption tests will also be conducted on a selected set of getters which exhibit specific adsorption characteristics for radionuclides of interest.

Uranium and Tc are much more mobile in the oxidized state [U(VI) and Tc(VII)] than in the reduced state [U(IV) and Tc(IV)]. Once reduced, these radionuclides form sparingly soluble precipitates that are not inclined (not kinetically favored) to reoxidize, especially for Tc. Engineers and scientists have exploited the removal of the oxidized forms of these radionuclides via reductive precipitation for years. FeS and basalt will be evaluated as getter materials under a range of environmental conditions likely to exist in the near field. FeS has been accepted as a suitable getter material at the Savannah River Site and basalt is inexpensive and relatively effective at removing $T c$ and $U$ (and possibly Se) from solution. 
RPP-6702, Rev. 0

Formerly HNF-SD-WM-PAP-062 Rev. 4

Apatite, a phosphate mineral, can be inexpensively mined from the earth. It has the formula of $\mathrm{Ca}_{2} \mathrm{Ca}_{3}\left[\mathrm{PO}_{4}\right]_{3}(\mathrm{OH}, \mathrm{F})$. Calcium is written twice in this formulation because it exists in two different sites in the structure of apatite. From structural and composition studies of natural materials, it has been shown that many elements can substitute into the structure of these minerals. For example $\mathrm{TcO}_{4}, \mathrm{CO}_{3}, \mathrm{SiO}_{4}, \mathrm{SO}_{4}, \mathrm{AsO}_{4}, \mathrm{VO}_{4}, \mathrm{CrO}_{4}$, $\mathrm{BeO}_{4}, \mathrm{BO}_{4}$, and possibly $\mathrm{FeO}_{4}$ and $\mathrm{AlO}_{4}$ have been found in natural systems to be substituted for $\mathrm{PO}_{4}$ in apatite. Similarly, $\mathrm{Sr}, \mathrm{Ce}, \mathrm{Pb}, \mathrm{Cs}, \mathrm{Th}, \mathrm{U}, \mathrm{Cr}, \mathrm{Am}, \mathrm{Ac}$, and $\mathrm{Hg}$ have been found to substitute into $\mathrm{Ca}$ sites of apatite. Finally, $\mathrm{Cr}, \mathrm{Cl}, \mathrm{F}$, and I have been found to naturally substitute into the $\mathrm{OH}$ and $\mathrm{F}$ site of apatite. Among these substitutions is $\mathrm{Tc}$, which as $\mathrm{TCO}_{4}^{-}$, has a crystal radius of $0.268-\mathrm{nm}$, making it highly compatible for substitution with the phosphate that has a crystal radius of $0.255-\mathrm{nm}$. Similarly, $U^{6+}$, $(0.0081-\mathrm{nm})$ has been shown to easily substitute for $\mathrm{Ca}(0.0106-\mathrm{nm})$ in apatite.

(However, it must be kept in mind that there are many other materials that can adsorb uranyl more effectively than apatite, e.g., many cements.)

\section{Determine Geochemical Parameters Governing Rubbelized ILAW Waste Glass Behavior under Unsaturated Conditions.}

The critical geochemical parameters necessary for understanding the long-term leaching behavior of ILAW waste glasses buried in the Hanford waste repository, and modeling the same can be categorized below:

\section{Geochemical (Transport) Parameters}

Effective Diffusion coefficient $\left(D_{e}\right)$, Tortuosity factor $(\square)$, Constrictivity factor $(\square)$, Retardation factor $(R)$, Dispersion $(D)$, Partitioning (sorption) coefficient $(K)$, and Rates of reactions $(k)$ such as glass dissolution, sorption and ion exchange.

\section{Hydrologic (Flow) Parameters}

Water content $\left(S_{w}\right)$, Air content $\left(S_{a}\right)$, Hydraulic conductivity $(K)$, relative permeability $\left(k_{r, l}\right)$, Air-water interfacial area $\left(a_{a w}\right)$, solid-water interfacial area (specific surface) $\left(a_{s w}\right)$, solid-air interfacial area $\left(a_{s e}\right)$, Air morphology index $\left(l=S_{g} / a_{a w}\right)$. Particle size (d) distribution, Pore size $\left(d_{p}\right)$ distribution, Fracture size $\left(L_{f}\right)$, roughness and aperture (b).

In addition, all of the above flow and transport parameters vary as a function of the degree of saturation (and hence capillary pressure, $P_{c}$ ). At Hanford the effect of saturation is of interest because highly unsaturated conditions prevail. From earlier work at PNNL and reports from elsewhere, there is a reasonable body of knowledge to ascertain many of these key parameters necessary for modeling and understanding ILAW waste glass behavior in saturated and unsaturated porous media (Meyer and Serne, 1999; and McGrail et al., 1999 [ILAW data packages]). In addition, the variation of all of the above flow and transport parameters is related to the degree of saturation (and hence capillary pressure, $P_{c}$ ) at the Hanford site, where highly unsaturated conditions prevail.

However, such data and knowledge are lacking for modeling the flow, transport and leaching from ILAW glass when it is in fractured and rubbelized states. In general, reports on flow and transport through rubbelized and fractured materials, let alone glass, are scarce in the literature. There is a need for the measurement of the key geochemical properties in rubbelized and fractured state ILAW glass under unsaturated conditions, and elucidation of the relevant flow and transport mechanisms (phase advection, 
RPP-6702, Rev. 0

Formerly HNF-SD-WM-PAP-062 Rev. 4

diffusion, dispersion, sorption, dissolution). In this context, rubbelized glass and rock are to be defined to fall in the size range of ASTM coarse aggregates (i.e. average particle size of $5 \mathrm{~mm}$ to $50 \mathrm{~mm}$ ). Accordingly, we propose to investigate the measurement of the following geochemical parameters in rubbelized glass and the impact of variability in hydraulic properties on these parameters:

Geochemical (Flow) Parameters to be measured in the experiments

Effective Diffusion coefficient $\left(D_{e}\right)$, Tortuosity factor $(\square)$, Constrictivity factor $(\square)$, Dispersion coefficient $(D)$, Partitioning (sorption) coefficient $(K)$.

Hydrologic (Flow) Parameters to be varied in the experiments

Water content $\left(S_{w}\right)$, Air content $\left(S_{a}\right)$, Hydraulic conductivity $(K)$, Relative permeability $\left(k_{r, l}\right)$, Air-water interfacial area $\left(a_{a w}\right)$, solid-water interfacial area (specific surface) $\left(a_{s w}\right)$, solid-air interfacial area $\left(a_{s a}\right)$, Air morphology index $\left(I=S_{d} / a_{a w}\right)$, Particle size (d) distribution, Pore size $\left(d_{p}\right)$ distribution.

Methods: Intermediate scale modified capillary cells with a pressure plate and rubber Oring gasket seals will be used to conduct the flow and transport experiments through rubbelized glass. Experiments will be conducted using such cells to investigate unsaturated phase characterization using nonreactive tracers (for $K, k_{n}, D$ ) partitioning tracers (for $S_{w}, S_{a}$ ) and interfacial tracers (for $a_{a w}, a_{s w}, a_{s s}$ and $I$ ). Following table illustrates the proposed matrix of experiments:

Advective Flow (Tracer) Experiments

\begin{tabular}{|l|l|l|l|l|}
\hline Material & Experiment & Solute/Tracer & eps & Stages of saturation \\
\hline Rubbelized Glass & Advection/Tarcers & $\begin{array}{l}\text { Nonreactive } \\
\text { Partitioning } \\
\text { Interfacial }\end{array}$ & 5 \\
\hline
\end{tabular}

Total number of experiments

$3 \times 2 \times 5=30$

By using these innovative tracer methods in tandem, we will seek to measure the listed geochemical parameters through rubbelized glass at various saturations.

Data/Results Analysis

We will use the traditional tracer and diffusion data analysis techniques for the analysis and interpretation of results, and determination of the stated geochemical and hydrologic parameters for rubbelized glass. In the recent past, we have developed new theoretical modeling techniques to determine the geochemical transport parameters such as tortuosity and diffusion coefficient as a function of water unsaturation (manuscript enclosed; Saripalli et al, 2000), which is particularly suitable for the analysis and modeling of flow and transport through rubbelized and fractured materials. We will use the present results to further corroborate and extend the new theoretical modeling efforts.

\section{Related Work}

Transport experiments through rubbelized sandstone (rock) will be conducted in the near field hydrology task, analogous to the rubbelized glass research proposed above. The contrast between the nonporous glass and porous rock will help elucidate the role of matrix porosity in transport processes. 
Diffusion experiments in rubbelized glass and rock are necessary for the elucidation of this important transport process at the Hanford site, where advective fluxes over long storage times may be secondary to diffusion, in the highly unsaturated arid environment. Diffusion experiments are not amenable to established (half-cell) methods of diffusion measurements. We have designed a new apparatus specifically for this purpose, by suppressing the advective flux in a capillary cell flow experiment and conducting the diffusive flux in a direction perpendicular to the gravitational unit gradient, we seek to conduct diffusion measurements in rubbelized media. This new method will be tested as a part of the future experimental work, as an extension of the present proposal.

\section{Intermediate Scale Experimental System.}

The FYOO near-field geochemistry subtask $1 \mathrm{~b}$ designed an intermediate scale unsaturated advective flow apparatus and diffusive flow apparatus. Their intended use is to characterize the geochemical and hydrologic properties of various near-field and far-field materials. The current baseline design calls for disposal of the waste packages in a lined trench.

Studying the movement of water, air, tracers and the key risk driver contaminants $\left({ }^{129} \mathrm{l},{ }^{237} \mathrm{~Np},{ }^{79} \mathrm{Se},{ }^{99} \mathrm{Tc}\right.$ and $\left.{ }^{233,235,238} \mathrm{U}\right)$ is an integral part of the PA assessment. The geomedia that are encountered during the transport of such contaminants and fluids in the ILAW environment are predicted to include near-field media (fractured and rubbelized glass) and far-field media (granular soil and sediments). The near-field materials are those within the disturbed region of the ILAW disposal facility, comprising both natural materials (such as the backfill) and man-made materials (such as the glass waste). Depending upon the final design, they may include silt loam - gravel admix and compacted silt loam, sand and gravel filters and gravel drainage material, asphaltic concrete, asphalt base and grading fill, diversion layer, water conditioning layer, crushed glass material, concrete, filler backfill, glass waste, backfill, cement/soil mixture, geosynthetic liners, and admix liners (Meyer, 1999). The far-field materials include Hanford sediments, gravel and rock.

In the near-field environment, the availability of water is a key factor in the dissolution of glass waste forms and the subsequent transport of dissolved contaminants out of the disposal facility and into the natural environment. Therefore, the disposal facility should be designed to minimize the amount of water in contact with the waste form. In addition, earlier studies (Kincaid, 1995b) showed that for the conditions expected in the disposal facility, the transport of contaminants would either be advectiondriven or diffusion-driven depending on a small change in parameters. Thus, knowledge of the water movement rates within the near-field and far-field environments will greatly enhance the confidence in estimates of the waste dissolution rate and subsequent contaminant transport rate. Information is needed both for "original" fresh and "aged" materials to support simulations of the disposal facility for thousands of years. The intermediate scale test system will be used to study the movement of immiscible fluids and contaminants over a range of water saturation important for the ILAW disposal environments in near-field materials, obtain spatial and temporal distributions of the critical hydrologic/geochemical parameters that govern contaminant transport, which is necessary input for modeling, characterize the constitutive relationships among these parameters at the intermediate scale. 
RPP-6702, Rev. 0

Formerly HNF-SD-WM-PAP-062 Rev. 4

Intermediate-scale flow and transport experiments allow the simulation of important flow and transport processes at a scale closer to the real-world ILAW repository environment, with detailed spatial and temporal resolution, in a well controlled manner. They also allow one to investigate the effect of spatial heterogeneity of the media and their hydrologic properties on fluid flow and contaminant transport. Further, the intermediate scale cells accommodate larger solid particle sizes (such as gravel, rubbelized glass and rock), that are important to the ILAW repository environment. Furthermore, the intermediate scale cell can be designed to obtain visual information on the fluid front movement and phenomena such as fingering.

We have considered two alternative designs for the intermediate scale unsaturated experimental cell: (i) an unconfined cell with its contents open to the atmosphere and (ii) a closed capillary cell with its contents closed to the atmosphere. Between the two designs, the closed capillary cell is recommended as the most suitable design for the ILAW PA experimental purposes, because the closed cell design ensures a uniform degree of water saturation that will remain undisturbed at each stage of capillary equilibrium. Further, it will also allow step-wise increments in the air phase saturation $\left(S_{a}\right)$ by manipulating the hanging column of water in the effluent tubes and hence the capillary head. The open (unconfined) aquifer design does not allow such control. Height of the unsaturated medium is known with more certainty and controlled well in the former cell. The open aquifer design also results in a non-uniform water saturation in the capillary fringe created near the top of the cell, which has a tendency to collapse during tracer experiments (Jawitz et al., 1997). The height of the capillary fringe is a direct function of the air-water surface tension. If the surface tension significantly decreases due to chemical addition in transport experiments, it may result in a reduction in the height of the capillary fringe (i.e., collapse).

\section{Experimental Methods}

The primary objective of constructing an Intermediate Scale Experimental Cell is to conduct saturated and unsaturated flow and transport experiments at a scale larger than typical laboratory columns, and to study the movement of immiscible fluids and contaminants over a range of water saturations important for the ILAW disposal environments in both near-field and far-field materials. In addition to the scale-up, visualization of flow and transport phenomena of interest and ability to create media heterogeneities are additional features offered by the intermediate scale cell. Many of the geochemical and hydrologic properties of interest can be readily characterized using tracer methods, as described in the following sections. Described here is the procedure to conduct a tracer experiment in the Intermediate Scale Experimental Cell, using a stepwise variation in water saturation.

The intermediate scale cell allows variation of fluid saturations and interfacial areas by controlling the capillary pressure across the cell. The intermediate cell incorporates a capillary barrier at the effluent end, which allows the wetting fluid to flow through while non-wetting fluid (air) is retained, provided capillary pressures are below the barrier entry pressure. Top of the intermediate scale cell is always kept exposed to the atmosphere, except in the case of a fully water saturated experiment. The average capillary pressure experienced by the geomedia in the cell can be adjusted to the required value by adjusting the vertical position of the hanging columns of water (i.e., the hanging effluent tubes) at the bottom of the cell. An increase in the length of hanging column causes a corresponding increase in the capillary pressure, causing a decrease in the water saturation. Thus, by altering the position of the tips of the hanging columns 
simultaneously in a step-wise fashion, one would achieve a corresponding reduction in the water saturation. Water is delivered by a set of syringe pumps at a very low flow rate so as not to disturb the capillary equilibrium (and hence the water saturation) at a given capillary pressure. The fluid pressures required for steady state flow are reached given sufficient equilibration time. The tracer/solute concentration is monitored at several spatial locations on the faces of the cell, through the sampling ports installed on the cell faces.

An experiment is conducted by initially saturating the soil within the cell to complete water saturation $\left(S_{w}=100 \%\right)$. The system will be allowed to reach a steady flow condition and the system parameters such as flow, fluid saturation, and fluid pressures recorded. The fluid pressures in the cell will be known by observing the fluid elevations in the piezometers installed along the height of the cell, and the pressure drop across the cell by pressure transducers. Pressure at the outflow end of the column is fixed by the position of the effluent ports grid (held at atmospheric pressure). Therefore at any water saturation corresponding to a state of capillary equilibrium, the system is completely defined. At each stage of capillary pressure, it may require several hours to days for the system to fully adjust to the new state of capillary equilibrium, which is indicated by static (non-fluctuating) water levels. The water saturation corresponding to each such stage within the cell will be uniform and constant. At each stage of unsaturation, non-reactive, partitioning and interfacial tracer tests will be transported through the intermediate cell, by injecting the tracers through the influent grid at a very slow flow rate, and collecting the same at the effluent ports of the effluent grid. The tracer breakthrough curves at each of the effluent port contains information on the hydrologic and geochemical properties of the medium volume swept by the tracer between the influent and corresponding effluent ports. The resulting data sets will be useful for the characterization of the hydrologic and geochemical properties of various ILAW materials at various scales of spatial resolution, and for the verification and validation of the models describing flow and transport in ILAW environment.

Diffusion experiments in rubbelized glass, gravel or rock are not amenable to established (half-cell) methods of diffusion measurements. We have designed a new apparatus specifically for this purpose. By suppressing the advective flux in a capillary cell flow experiment and conducting the diffusive flux in a direction perpendicular to the gravitational unit gradient, we seek to conduct diffusion measurements in rubbelized media. Since the tracer experiments are conducted in the diffusion cell at a very low advective flux, the resulting information can be used to define the parameters that characterize diffusive transport, especially the unsaturated medium tortuosity. In a recent paper (Saripalli et al., 2000) we have reported on the characterization of tortuosity as a function of water saturation based on interfacial areas, which are measured using interfacial tracer tests. This new method will be tested as a part of the present experimental work.

\section{Data/Results Analysis}

We will use the traditional tracer and diffusion data analysis techniques for the advective flow analysis and interpretation of results, and the determination of the stated geochemical and hydrologic parameters for rubbelized glass, gravel and rock. In the recent past, we have developed new theoretical modeling techniques to determine the geochemical transport parameters such as tortuosity and diffusion coefficient as a function of water unsaturation (Saripalli et al., 2000), which is particularly suitable for the analysis and modeling of flow and transport through rubbelized and fractured materials. 
RPP-6702, Rev. 0

Formerly HNF-SD-WM-PAP-062 Rev. 4

We will use the results to further corroborate and extend the new theoretical modeling efforts.

\section{Geochemical Data Packages for 2005 PA: 2001-2005.}

Calculation of Near Field Solubility Constants - 2003.

Radionuclide geochemistry is being described in the Geochemistry Data

Package using $K_{d}$ and the solubility values. The solubility construct will be invoked when the radionuclide concentrations are high, more specifically, when they exceed the solubility limit of the concentration-defining solid phase. The Geochemistry Data Package will assign unique geochemistry parameters to six modeling zones: 1) Near Field, 2) Degraded Concrete Vault, 3) Far Field \#1(impacted zone), 4) Far Field \#2(gravel impacted zone), 5) Far Field \#5 (natural; gravel impacted), and 6) Far Field \#6 (natural). Of these zones, only the first two zones will likely require solubility data. Zone 1 will contain high radionuclide concentrations in high ionic strength, glass leachate.

Zone 2 will contain somewhat lower radionuclide concentrations in high ionic strength, concrete leachate.

The objective of this subtask is to: 1) identify the appropriate solubility-limiting phases for each radionuclide, and 2) calculate the solubility limit of the radionuclides under the chemical conditions expected in each zone. The first objective will be accomplished by a critical literature review. The second objective will be met by conducting chemical speciation and solubility calculations using the solid phases identified in the literature review. The OLI model (OLI Software Systems, New Brunswick, NJ) will be used in these calculations. We have extensive experience with this model (Kaplan et al., 1999, BNF-003-98-0098, WSRC, Aiken, SC). It has an extensive database containing $>3000$ inorganic and organic species, and perhaps more importantly, it offers technical support that will conduct literature reviews and calculate needed constants. The aqueous model is predictive over the general range of 0 to 300 ${ }^{\circ} \mathrm{C}, 0$ to 1500 bars, and 0 to 30 (molal) ionic strength. This broad range capability is particularly relevant to the needs of ILAW because speciation calculations in high ionic strength solutions ( $>0.5$ molar) are especially difficult. Finally, OLI is used throughout the RPP program and has a thermodynamic data set already especially designed to address Hanford High-Level Waste issues.

This task will provide important technical defensibility to the selection of solubility values used in Zones 1 and 2 of the Geochemistry Data Package.

e. Interfaces

The three organizations will build on earlier Hanford tank performance assessment near-field work: Sandia National Laboratory (SNL) work in FY96 and Pacific Northwest National Laboratory work in FY97. In FY99 one of the key ILAW contributors, Dan Kaplan, left PNNL and is now at Savannah River (SRS). Dr. Kaplan has remained a key contributor in FY99 under subcontract. All three organizations will interact with the design interface (Section 3.3.C.iii) to ensure that their work is consistent with current designs. 
RPP-6702, Rev. 0

Formerly HNF-SD-WM-PAP-062 Rev. 4

f. Organization

The Applied Geology and Geochemical Section of the Pacific Northwest National Laboratory has a long history of supplying geochemical data for near-field materials (especially for Nuclear Regulatory Commission (NRC) studies). The section has been supplied geochemical data for all of the Hanford performance assessments.

g. Quality Assurance

All activities will be conducted in accordance with 10 CFR 830.120. The Hanford Analytical Services Quality Assurance Requirements Document will apply to the analysis of field samples.

h. Effect of Not Performing Task

Near-field chemical effects could greatly the transport of contaminants once they have left the waste form. For example, under NRC-sponsored research, PNNL has shown that the transport of uranium is very highly retarded through concrete. Without this research, possible credit for the retardation of technetium could not be taken. 
RPP-6702, Rev. 0

Formerly HNF-SD-WM-PAP-062 Rev. 4

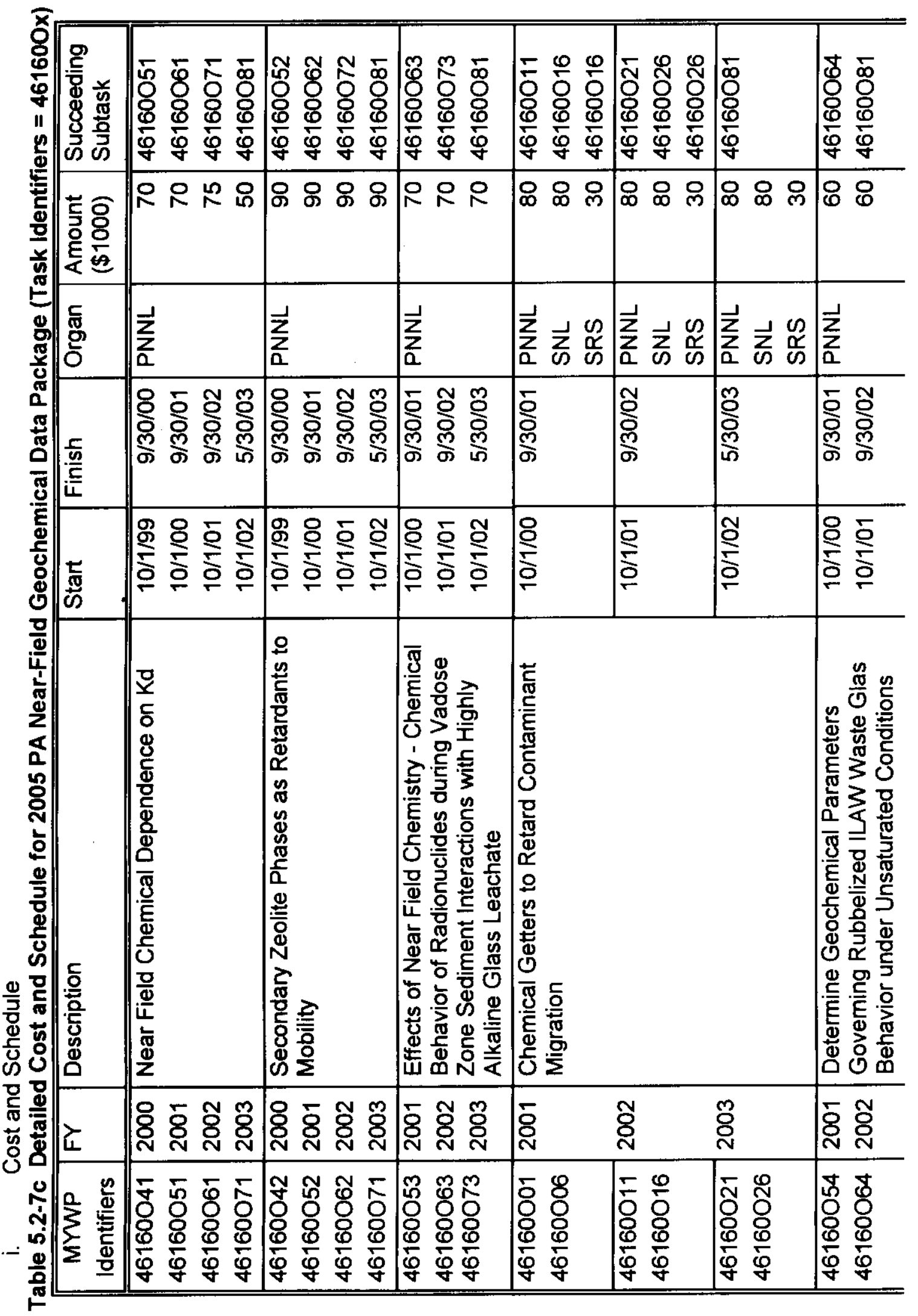


RPP-6702, Rev. 0

Formerly HNF-SD-WM-PAP-062 Rev. 4

\begin{tabular}{|c|c|c|c|c|c|c|}
\hline 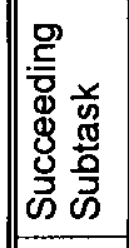 & 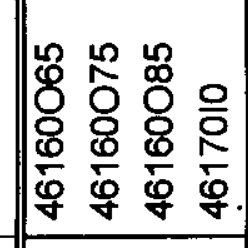 & 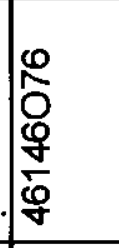 & 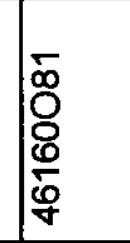 & 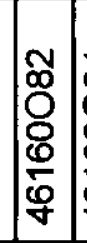 & & 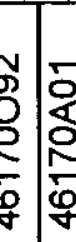 \\
\hline 官 & ৪ 웅 & If ? & 98 & হি: & ? & \begin{tabular}{|l|l} 
\\
\end{tabular} \\
\hline & $\mid \frac{3}{z}$ & 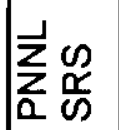 & 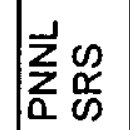 & $\mid \frac{1}{2}$ & $\sum_{a}^{1} \mid \frac{1}{a}$ & $\sum_{2}^{n}$ \\
\hline & | & 恿 & 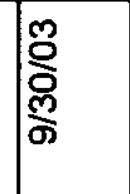 & 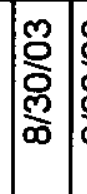 & 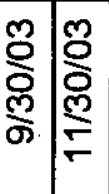 & 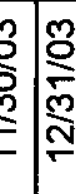 \\
\hline t్ț & 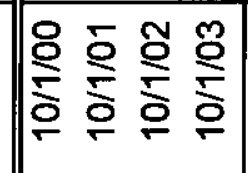 & 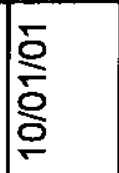 & 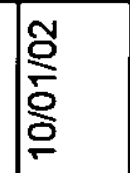 & $\frac{9}{0}$ & & $=$ \\
\hline 흘 & 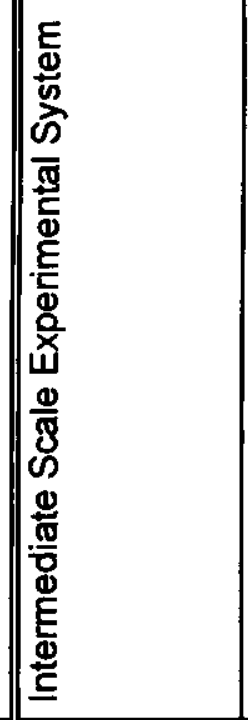 & 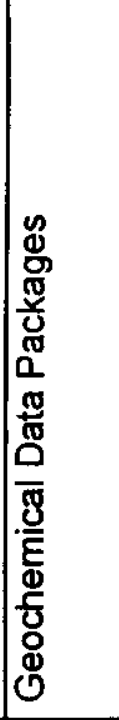 & & 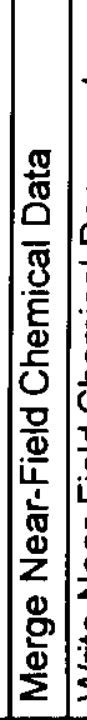 & 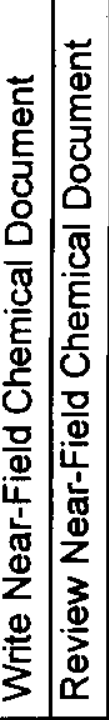 & 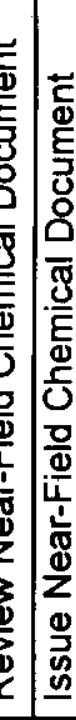 \\
\hline$\underline{L}$ & $\mid \begin{array}{ccc} & 0 \\
\end{array}$ & ర్సి & ర్లి & & 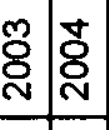 & 空 \\
\hline 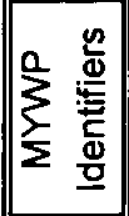 & $\begin{array}{|ccc|}0 \\
0\end{array}$ & & $\begin{array}{l}0 \\
0 \\
0 \\
\frac{0}{0} \\
0\end{array}$ & 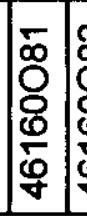 & 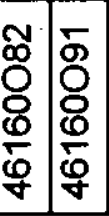 & 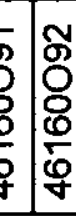 \\
\hline
\end{tabular}

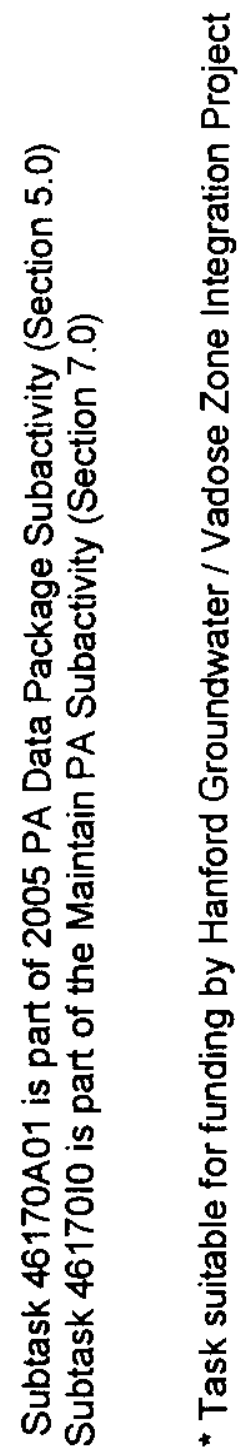


RPP-6702, Rev. 0

Formerly HNF-SD-WM-PAP-062 Rev. 4

viii. Determine Geochemical Parameters for Soils at Disposal Sites

a. Background

The most mobile contaminants flow with the slowly moving moisture stream. However, most elements are chemically retarded by the soils in the vadose zone with the effect of greatly reducing their concentration in the transporting pore fluid. This reduction $\left(R_{f}=1+K_{d} \rho / \theta\right)$ depends on the bulk density of the soil $(\rho)$, on the moisture content of the soil $(\theta)$, and on a parameter describing the amount of retardation $\left(K_{d}\right)$.

b. List Of Deliverables

Table 5.2-8a List of Deliverables for 2005 PA Far-Field Geochemical Data Package

\begin{tabular}{|c|c|c|c|}
\hline Description & $\begin{array}{l}\text { Due } \\
\text { Date }\end{array}$ & Level & $\begin{array}{l}\text { MYWP } \\
\text { Identifier }\end{array}$ \\
\hline $\begin{array}{l}\text { Technical Report on Mineralogy of } \\
\text { Borehole } 299 \text { E-17-21 }\end{array}$ & $6 / 30 / 00$ & & \\
\hline $\begin{array}{l}\text { Document Geochemical/Mineralogic } \\
\text { Data from Borehole \#2 Samples }\end{array}$ & $7 / 31 / 01$ & 7 & $\begin{array}{l}\text { 46160N4D[ } \\
46160 \mathrm{~N} 41]\end{array}$ \\
\hline $\begin{array}{l}\text { Document Geochemical/Mineralogic } \\
\text { Data from Borehole \#3 Samples }\end{array}$ & $7 / 31 / 02$ & 7 & $\begin{array}{l}\text { 46160N5C } \\
{[46160 \mathrm{~N} 51]}\end{array}$ \\
\hline Borehole \#2 Specific Kd Report & $9 / 30 / 02$ & & \\
\hline Borehole \#3 Specific Kd Report & $9 / 03 / 03$ & & \\
\hline $\begin{array}{l}\text { Write Test Plan for Determining Particle } \\
\text { Scale Sorption Heterogeneity (column } \\
\text { scale) }\end{array}$ & $\begin{array}{r}11 / 30 / 99 \\
\text { done }\end{array}$ & & \\
\hline $\begin{array}{l}\text { Issue Final Report on Particle Scale } \\
\text { Sorption Heterogeneity }\end{array}$ & $9 / 30 / 01$ & & \\
\hline Issue Final Report on Gravel Effects & $8 / 30 / 02$ & & \\
\hline $\begin{array}{l}\text { Issue Status Report on Increased Credit } \\
\text { for Long-term Reactions }\end{array}$ & $3 / 31 / 03$ & & \\
\hline $\begin{array}{l}\text { Issue Final Report on Increased Credit } \\
\text { for Long-Term Reactions }\end{array}$ & $7 / 31 / 04$ & 8 & $\begin{array}{l}\text { 46160N2E } \\
{[46160 \mathrm{~N} 21]}\end{array}$ \\
\hline $\begin{array}{l}\text { Write Far-field Geochemical Data } \\
\text { Package Review Plan }\end{array}$ & $3 / 30 / 04$ & 8 & $\begin{array}{l}46160 \mathrm{~K} 6 \mathrm{~B} \\
{[46160 \mathrm{~K} 62]}\end{array}$ \\
\hline $\begin{array}{l}\text { Draft Far-field Geochemical Data } \\
\text { Package for Hanford Review }\end{array}$ & $8 / 15 / 04$ & & \\
\hline $\begin{array}{l}\text { Issue } 2005 \text { PA Far-Field Geochemical } \\
\text { Data Package }\end{array}$ & $12 / 31 / 04$ & 6 & $\begin{array}{l}46160 \mathrm{~K} 7 \mathrm{~A} \\
{[46160 \mathrm{~K} 72]}\end{array}$ \\
\hline
\end{tabular}


RPP-6702, Rev. 0

Formerly HNF-SD-WM-PAP-062 Rev. 4

c. Cost Summary

WBS: $1.1 .1 .3 .4 \cdot 1 \cdot 3.3$

TPCN: D4DM3

Table 5.2-8b Cost Summary for 2005 PA Far-Field Geochemical Data Package

\begin{tabular}{|l|l|r|}
\hline Fiscal Year & Organization & $\begin{array}{l}\text { Amount } \\
(\$ 1000)\end{array}$ \\
\hline \hline 2000 & Pacific Northwest National Laboratory (PNNL) & 150 \\
\hline 2001 & PNNL & 215 \\
\cline { 2 - 3 } & Savannah River Site (SRS) & 15 \\
\hline \multirow{2}{*}{2002} & PNNL & 215 \\
\cline { 2 - 3 } & SRS & 40 \\
\hline 2003 & PNNL & 110 \\
\cline { 2 - 3 } & SRS & 25 \\
\hline 2004 & PNNL & 90 \\
\cline { 2 - 3 } & SRS & 20 \\
\hline Grand Total & & 880 \\
\hline
\end{tabular}

d. Detailed Description

Borehole Specific

Determine Geochemical Parameters of First Borehole Samples-2000.

We have not finished the mineralogic characterization of the first ILAW borehole [299-E17-21]. Semi-quantitative bulk mineralogy and quantitative mineralogy of the silt and clay fractions of the 10 samples used in past Kd work would be useful to better understand the Kd results presented in Kaplan et al. (1998). If we know the mineralogy, we can better defend Kd selection, e.g., Cs sorption to illites, Sr sorption to high-CEC smectites. Coatings will tell us how much pH dependent charge we need to take into consideration. Quantification of carbonate phases will tell us likelihood that solid solutions will form with multivalent radionuclides.

Determine Geochemical Parameters of Second and Third Borehole Samples.

As described in the Geology subtask sections a second ILAW specific borehole is planned for late FY00 or early FY01. As performed on the first ILAW specific borehole sediments geochemical characterization is needed. Semi-quantitative bulk and quantitative mineralogy of the sand and silt and clay fractions, respectively are needed to better understand the proposed $\mathrm{Kd}$ results. Besides mineralogy and particle size (determined in Hydrology subtasks), we will determine cation-exchange capacity, amorphous hydrous oxide, carbonate and organic contents on sediments from the second borehole. We will use the geology stratigraphy picks and identification of paleosols to determine how many distinct samples to characterize. If a third borehole is drilled near the old grout vaults similar geochemical/mineralogic characterization would be performed.

Determine Kd Values for Key Contaminants Using Borehole Specific Sediments. 


\section{RPP-6702, Rev. 0 \\ Formerly HNF-SD-WM-PAP-062 Rev. 4}

If the second new borehole (on the east edge of the ILAW site are drilled in FYOO, the following work would be done to augment the existing site-specific $\mathrm{Kd}$ data set. Site-specific Kd values for Hanford Formation sediments for Cs, Sr, U, Se, Tc, I, $\mathrm{Np}$, and Sn will be measured using two solutions: a groundwater representative of the upper unconfined aquifer and a water with the attributes of glass/engineered barrier effected leachate. It is anticipated that the cost of doing this work will be $125 \%$ of the non site-specific work because of the higher $Q A$ requirement. If the third borehole near the Grout vault were also drilled the same scope would be considered provided the funding was augmented. If the $\mathrm{Kd}$ values for the second borehole Hanford formation sediments are quite similar to the results available in Kaplan et al. (1998) and the 2001 Geochemical Data Package (Kaplan and Seme 2000), then it might be more cost effective to study samples from the Ringold and Lower Mud layer; assuming they are available and representative (not compromised by driling). That is, it may be unnecessary to continue studies on Hanford formation sediment from ILAW specific boreholes after the second borehole because the Kd's for key radionuckides may not vary enough to warrant more work.

\section{Non-Borehole Specific}

\section{Determination of Particle Scale Sorption Heterogeneity.}

Experiments in FY96 and FY98 indicated that $U(V I)$ sorption was dependent upon the moisture content in unsaturated sediments (Kaplan et al., 1996; Gamerdinger et al., 1998). The results indicated that the $K_{d}$ value in fine-grain sediments tended to increase at lower moisture contents. In coarse-grained sediments, the $K_{d}$ values tended to decrease at lower moisture saturations.

FY99 work has resulted in a more focused conceptual model which relates changes in the unsaturated flow regime that occur with decreasing water content to reactive site accessibility and particle scale chemical heterogeneity. It is currently thought that hydraulic and chemical heterogeneity are linked at the particle scale through variation in particle surface reactivity with particle size. Hydraulic heterogeneity due to immobile water increases with lower moisture saturation and modifies the accessibility of sorptive solutes to reactive surfaces. The association of the mobile flow regime with large (fine sand, sand, gravel) and small (silt and clay) particles is thought to depend on the dominant sediment texture within a geologic layer. The change in contaminant sorption (in response to a change in moisture saturation) will depend on the association of the mobile flow regime with large versus small particles. Additional explanations of hydraulic heterogeneity are discussed in section $5.2 \mathrm{C}$. vi.

As the results presently stand, there is insufficient information to link the anticipated change in sorption ( $\mathrm{K}_{\mathrm{d}}$ value) to sediment and hydraulic properties that are included in transport models. Experiments at the bench scale (unsaturated column) are necessary for determining correlations among sediment properties, hydraulic, and sorption parameters. Upon establishing these relationships, further evaluation is needed at the intermediate (meter) scale to determine the importance of these phenomena in gravel layers, which cannot be considered in laboratory columns. Ultimately, the techniques developed for assessing coupled hydraulic and sorption heterogeneity will be evaluated for contaminant movement between geologic layers at the field scale. 
RPP-6702, Rev. 0

Formerly HNF-SD-WM-PAP-062 Rev. 4

In the PA, hydraulic and chemical data are grouped by geologic layer. An understanding of mechanisms by which hydraulic and geochemical parameters are linked will improve computer codes for estimating water and contaminant movement. Specifically, $\mathrm{K}_{d}$ values can be programmed to change in accordance with hydraulic properties (i.e., with lower water content or decreased hydraulic conductivity).

Rather than using a single, conservative $K_{d}$ value for all moisture conditions within a layer, this task will allow credit for increased sorption or retardation in silty sediments and less conservative estimates of sorption in sandy sediments where hydraulic heterogeneities have not developed.

This task will end in FY2001 and any new work will be incorporated into the Intermediate Scale Experimental System subtask in the Near-Field Geochemistry section (see 5.2.C. vii).

\section{Gravel Effects on Far-field Geochemical Parameters.}

Standard batch- $K_{d}$ measurements use only the $<2-\mathrm{mm}$ fraction of a sediment. This sediment size fraction is used by researchers to 1) standardize the method and 2) ease experimental protocol whereby large containers/tests don't have to be used to accommodate gravel (>2-mm particles). One problem in using only the $<2-\mathrm{mm}$ fraction in these tests is that it is not truly representative of the sorptive potential of the sediments in the coarser zones of the Hanford and Ringold formations. As the field sediments contain an increasing amount of gravel, the magnitude of the $<2-\mathrm{mm} \mathrm{K}_{\mathrm{d}}$ values become increasingly incorrect.

The objective of this study will be to:

1) determine how the presence of gravel effects $K_{d}$ values, and

2) determine how best to correct laboratory $K_{d}$ values determined from $<2-\mathrm{mm}$ size fraction to reflect the $K_{d}$ value of the total sediment, that is, establish how to determine a "gravel-corrected $\mathrm{K}_{d}$ value."

Six subsurface sediment samples from the 200 Area on the Hanford Site will be collected. These sediment will have similar geological origins (will be collected from the same trench), exhibit a large gravel fraction, and a wide range of particle size distributions. Three size fractions of each sediment will be created: total sediment, $>2$ $\mathrm{mm}$, and $<2-\mathrm{mm}$. The total sediment fractions will be characterized for $\mathrm{pH}$, cation exchange capacity, particle size distribution: gravel, sand, silt, and clay (dry sieve: Gee and Bauder, 1986). ). Finally, the mineralogy of the silt/clay fraction of the bulk sediments will be determined.

$\mathrm{U}-, \mathrm{Sr}-$, and $\mathrm{Cs}-\mathrm{K}_{\mathrm{d}}$ values will be determined on all three size fractions using a representative Hanford groundwater. The sediment fractions will be pre-equilibrated with Hanford Groundwater prior to contact with the radionuclide spiked solutions. There will be three replicates of each batch $K_{d}$ test. The data from these tests will be used to evaluate the following approaches to "gravel corrected $K_{d}$ values."

$$
\begin{aligned}
& \mathrm{K}_{\mathrm{d}-\mathrm{GC}}=\mathrm{K}_{\mathrm{d}<2-\mathrm{mm}}{ }^{*}(1-\gamma)+\mathrm{K}_{\mathrm{dg}} * \gamma \\
& \mathrm{K}_{\mathrm{d}-\mathrm{GC}}=\mathrm{K}_{\mathrm{d}<2-\mathrm{mm}}{ }^{*}(1-\gamma)
\end{aligned}
$$


RPP-6702, Rev. 0

Formerly HNF-SD-WM-PAP-062 Rev. 4

where $K_{d-G c}$ is the $K d$ corrected for gravel, $K d<2-m m$ is the $K d$ of the $<2-m m$

fraction, $K_{d g}$ is the $K_{d}$ of the gravel fraction, and $\gamma$ is the mass fraction of the gravel. Corelations between extract $\mathrm{pH}$, silt/clay fraction mineralogy, $\mathrm{CEC}$ and $\mathrm{Kd}$ will be determined to see if there are differences between the 6 samples that can help explain any observed differences. This task would be completed in one year.

Increased $K_{d}$ Credit for Long-Term Association of Radionuclides to Sediments.

Since the Chernobyl incident, there have been a number of studies showing that the greater the contact time of a radionuclide with a sediment, the more tenacious the radionuclide is held by the sediment. This process is likely occurring with some radionuclides in Hanford sediments. Experiments that identify and quantify this process in Hanford sediments would provide the ILAW PA additional Kd credit.

A number of mechanisms have been proposed to explain this observation. One mechanism is that, with time, the sorbed radionuclides migrate (driven by solid-phase diffusion) from the surface exchange sites into the interior pores or interior structure of the mineral (Salbu et al., 1994, Health Physics, 67:518). A second mechanism, is that naturally occurring coatings, such as Fe-oxides and carbonates, coat the sorbed radionuclide, thereby covering the radionuclide and distancing it from the mobile aqueous phase. With time this coating mechanism is leads to the radionuclides forming a solid solution with the carbonate and Fe-oxide phases. This process has been observed with transition metals and carbonate phases in desert sediments (Davis et al., 1987, Geochimica Cosmochimca Acta, 51:1477; Golberg and Glaubig, 1988, Soil Sci.

Soc. Am. J., 52:954). A third mechanism, is that the bond between the radionuclide and the surfaces changes its character from electrostatic to covalent, becoming increasingly stronger. (Related to this mechanism, its been proposed that the radionuclide initially sorbed as an outer-sphere surface complex and then with time, move to an inner-sphere complex.) Of these processes, the solid solution mechanism is the mostly likely one that we will be able to take credit for in long term PA predictions.

The way that we will evaluate this issue is by conducting sequential extraction experiments of contaminated Hanford sediments. Sequential extractions are a series of increasingly stronger extractants that recover radionuclides from operationally defined phases. It provides an index to the relative tenacity that a sorbed species is held by sediment. We will compare the "difficulty" of desorbing a radionuclide that has been aged with a sediment to the "difficulty" of desorbing a different isotope of the same radionuclide that has been in contact with the sediment for only two weeks. Should it be more difficult to recover the radionuclide in the aged sediment, then these experiments will provide technical defensibility to the notion that the PA should take credit for higher $\mathrm{Kd}$ values for the long-term contact between radionuclides and sediments. One sequential extraction series that will be evaluated is the Tessier method (Tessier et al. 1979. Anal. Chem. 51:844.) In this sequence, the first extract recovers the "exchangeable fraction" with a $1 \mathrm{M} \mathrm{NaOAC}, \mathrm{pH} 8.2$ solution. The second extract recovers the "carbonate fraction" with a $1 \mathrm{M} \mathrm{NaOAc}, \mathrm{pH} 5$ solution. The third extract recovers the "Fe-Mn oxide fraction" with a dithionite, citrate, carbonate solution. The fourth extract recovers the "organic fraction" with an acidified hydrogen peroxide solution. The final extract is the "structure fraction" recovered by totally digesting the remaining solid phase with a strong acid. 
RPP-6702, Rev. 0

Formerly HNF-SD-WM-PAP-062 Rev. 4

We presently have Hanford sediments that have been contaminated for extended periods (tens of years) with $\mathrm{U}, \mathrm{Cs}, \mathrm{Sr}, \mathrm{Tc}, \mathrm{Eu}, \mathrm{Co}$, and various metals that can be used as analogues for radionuclides of interest. Additional contaminated sediments from Hanford will be made available during ERC and ORP characterization activities during FY01 and beyond. We will obtain these contaminated sediments and incorporate them into our test matrix for this three-year proposed ILAW study.

\section{Far-Field Geochemical Data Package.}

All efforts in FY01 through FY02 will be devoted to date generation. In FY03 we will start updating the FY01 Geochemical Data Package. In FY 04 we will continue the updating and prepare the Data Package Review Plan, prepare the draft Data Package, and get the Hanford reviews completed. In FYO4 we will finish the external review and finalize the Data Package. 
RPP-6702, Rev. 0

Formerly HNF-SD-WM-PAP-062 Rev. 4

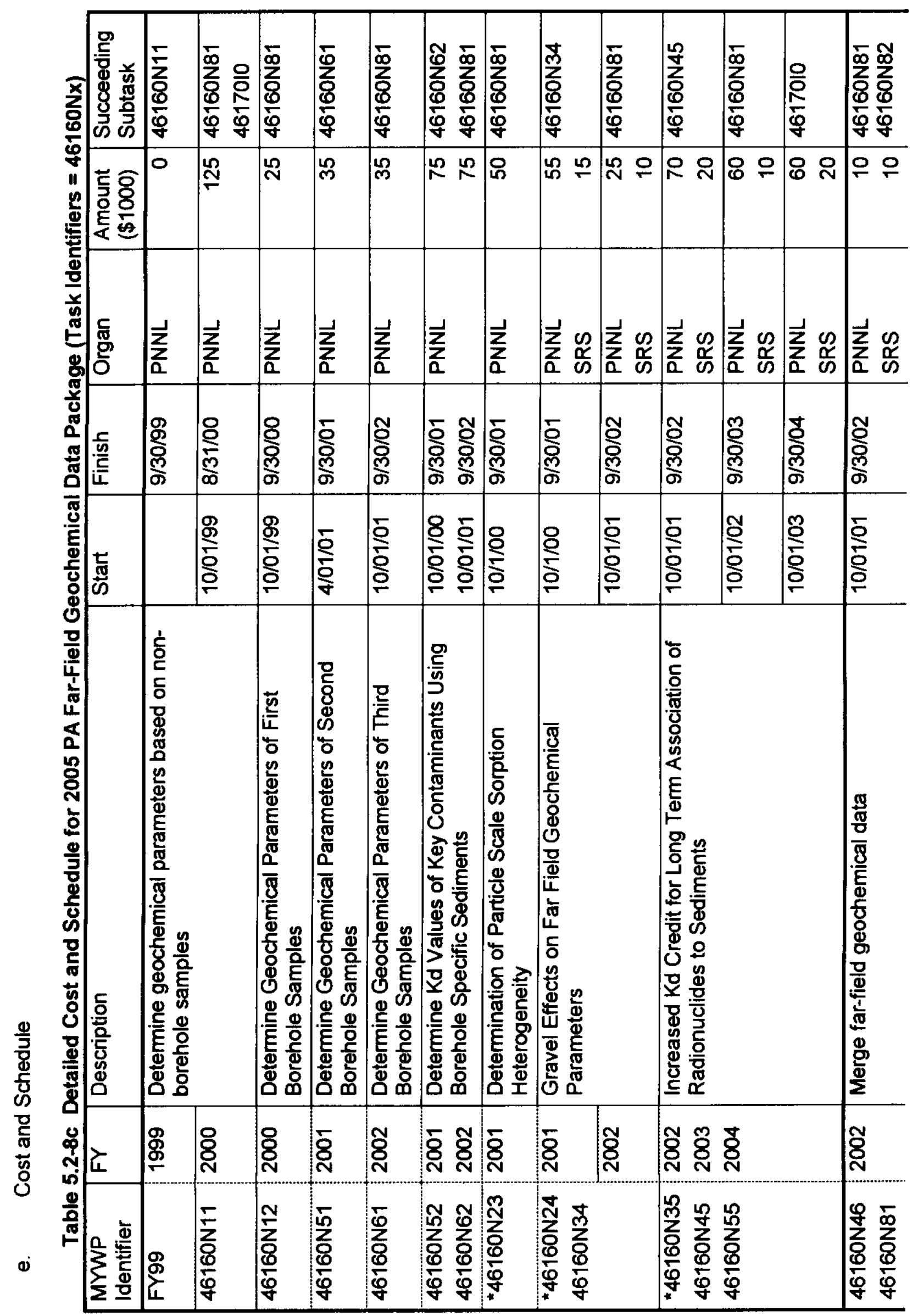


Formerly HNF-SD-WM-PAP-062 Rev. 4

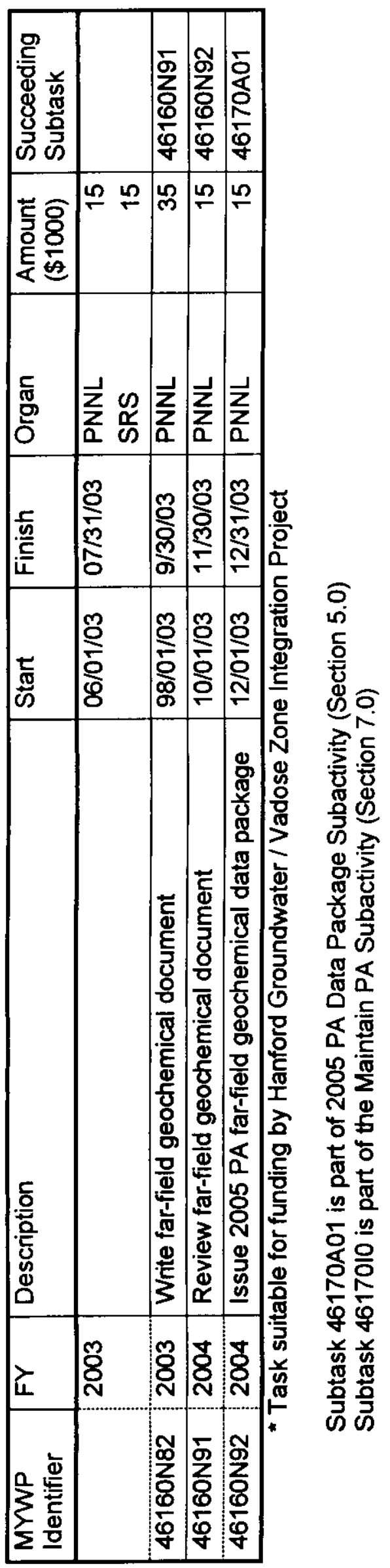


RPP-6702, Rev. 0

Formerly HNF-SD-WM-PAP-062 Rev. 4

ix. Upgrade Vadose Zone Moisture Flow and Contaminant Transport Simulation Code

a. Background

Even the most mobile contaminants will take thousands of years to move from the disposal facility to the groundwater under the expected conditions. Given the relatively complex geometry and long-time frames, computer simulation of the movement of the contaminants through the vadose zone is necessary.

Unless a major problem occurs, the same simulation code used in the 2001 performance assessment will be used in the 2005 performance assessment.

b. List Of Deliverables

Table 5.2-9a List of Deliverables for 2005 PA Vadose Zone Simulation Code Data Package

\begin{tabular}{|l|c|c|l|}
\hline Description & Due Date & Level & $\begin{array}{l}\text { MYWP } \\
\text { Identifier }\end{array}$ \\
\hline $\begin{array}{l}\text { Issue User's Manual for Upgraded Vadose } \\
\text { Zone Code }\end{array}$ & $9 / 30 / 01$ & 8 & $\begin{array}{l}46160 \mathrm{P} 1 \mathrm{~B} \\
{[46160 \mathrm{P} 11]}\end{array}$ \\
\hline Issue V\&V Report on Upgraded Code & $12 / 31 / 01$ & 6 & $\begin{array}{l}46160 \mathrm{P} 2 \mathrm{~A} \\
\text { [46160P21] }\end{array}$ \\
\hline
\end{tabular}

c. Cost Summary WBS: $1.1 .1 .3 .4 .1 .3 .3 \quad$ TPCN: D4DM3

Table 5.2-9b Cost Summary for 2005 PA Vadose Zone Simulation Code Data Package

\begin{tabular}{|l|l|r|}
\hline \multicolumn{1}{|c|}{ Fiscal Year } & \multicolumn{1}{|c|}{ Organization } & \multicolumn{1}{|c|}{ Amount (\$1000) } \\
\hline 2000 & Fluor Federal Services (FFS) & 50 \\
\hline 2001 & FFS & 0 \\
\hline 2002 & FFS & 0 \\
\hline 2003 & FFS & 25 \\
\hline 2004 & FFS & 125 \\
\hline \hline Grand Total & & 50 \\
\hline
\end{tabular}

d. Detailed Description

This is a placeholder awaiting work performed for 2001 Performance Assessmen 
RPP-6702, Rev. 0

Formerly HNF-SD-WM-PAP-062 Rev. 4

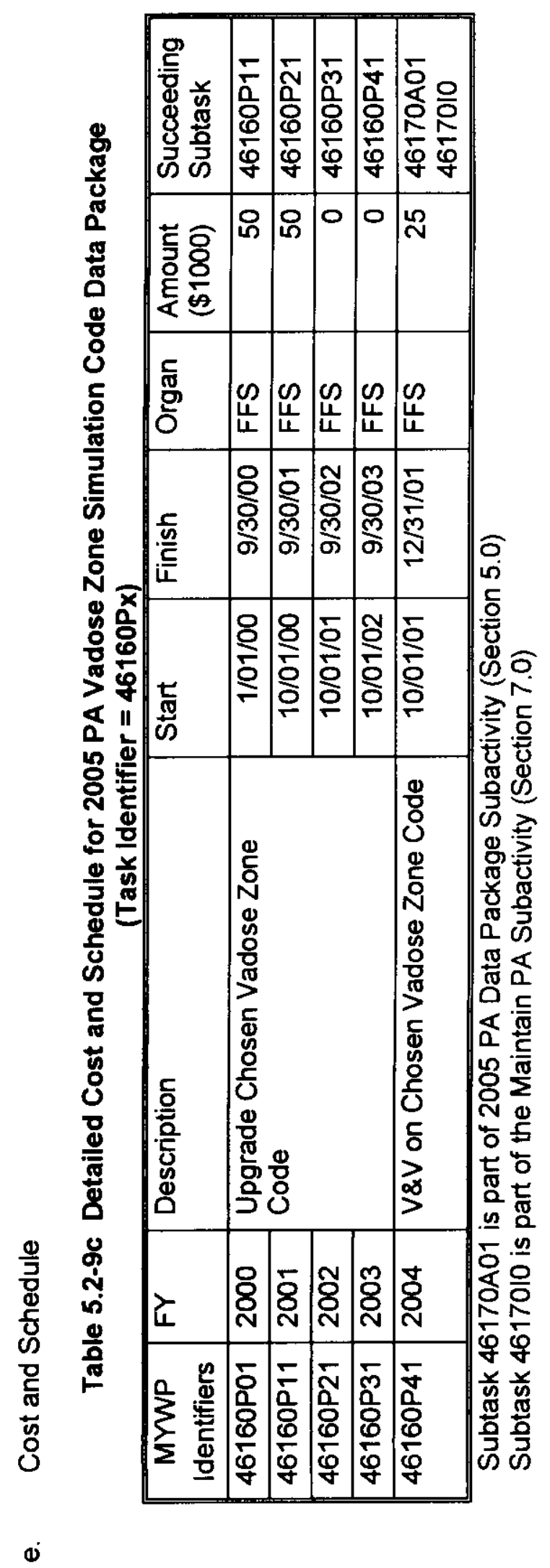


RPP-6702, Rev. 0

Formerly HNF-SD-WM-PAP-062 Rev. 4

\subsection{OTHER DATA COLLECTION}

\section{A. SUMMARY}

Issue reports documenting other data (inventory in waste form, disposal facility conceptual model, dosimetry, performance objectives, and scenarios) to be used in the 2005 performance assessment. These data are determined (or largely influenced) by others. Thus these tasks are largely interfacial and documentary.

\section{B. GENERAL}

i. Background

Unlike the waste form (Section 5.1) and geotechnical (Section 5.2) data collection subactivities where the performance assessment data activity performs most of the work in gathering the data, other data are needed for the performance assessment that mainly is gathered or controlled by others. These data include

Inventory in the waste form,

Conceptual model of the disposal facility,

Dosimetry data,

Performance objectives, and

Scenarios.

More background information is given in Chapter 3.3 .

ii. List of Deliverables

Table 5.3-1a List of Major Deliverables for 2005 PA Other Data Collection Subactivity

\begin{tabular}{|l|c|c|l||}
\hline Description & Due Date & Level & $\begin{array}{l}\text { 99 MYWP } \\
\text { Identifier }\end{array}$ \\
\hline Issue 2005 PA Inventory Data Package & $12 / 31 / 03$ & 6 & $46160 \mathrm{AA}$ \\
\hline $\begin{array}{l}\text { Issue 2005 PA Conceptual Model Data } \\
\text { Package }\end{array}$ & $12 / 31 / 03$ & 6 & $46160 \mathrm{RA}$ \\
\hline Issue 2005 PA Dosimetry Data Package & $12 / 31 / 03$ & 6 & $46160 \mathrm{SA}$ \\
\hline $\begin{array}{l}\text { Issue 2005 PA Performance Objectives } \\
\text { Data Packages }\end{array}$ & $12 / 31 / 03$ & 6 & $46160 \mathrm{TA}$ \\
\hline Issue 2005 PA Scenarios Data Package & $12 / 31 / 03$ & 6 & 46160UA \\
\hline
\end{tabular}

iii. Cost Summary

WBS: 1.1 .3 .4 .1 .3 .4

TPCN: D4DM4

Table 5.3-1b Cost Summary for 2005 PA Other Data Collection

\begin{tabular}{|l|l|r|}
\hline Fiscal Year & Organization & Amount (\$1000) \\
\hline 2000 & Fluor Federal Services (FFS) & 46 \\
\hline 2001 & FFS & 86 \\
\hline
\end{tabular}


RPP-6702, Rev. 0

Formerly HNF-SD-WM-PAP-062 Rev. 4

\begin{tabular}{|l|l|r|}
\hline \hline 2002 & FFS & 76 \\
\hline 2003 & FFS & 131 \\
\hline 2004 & FFS & 85 \\
\hline \hline Grand Total & 424 \\
\hline
\end{tabular}

iv. Interfaces

Because of the many interfaces involved in this subactivity, they will be discussed under each task.

v. Organization

The Environmental and Nuclear Initiative Section of Fluor Federal Services (FFS) is responsible for leading the Hanford Low-activity Tank Waste Performance Assessment activity. Its staff have developed the contacts with the various organizations to provide the proper interfaces for the activity. One of its members is on the Hanford Environmental Dose Oversight Panel.

\section{TASK DESCRIPTIONS}

i. Summary List of Tasks

a. Determine Waste Form Inventory

b. Determine Disposal Facility Conceptual Model

c. Determine Dosimetry Data

d. Determine Performance Objectives

e. Determine Scenarios and Pathways to be Analyzed

ii. Determine Waste Form Inventory

a. Background

The environmental and human health impact of disposal of Hanfords tank waste is proportional to the amount of ${ }^{99} \mathrm{Tc}$ (and to other key nuclides for longer times). The amount of the key isotopes $\left({ }^{99} \mathrm{Tc},{ }^{79} \mathrm{Se},{ }^{237} \mathrm{~Np}\right.$, and the uranium isotopes) depends both on the amount of the isotopes in the tanks and the degree of separations performed by the private vendor.

The Standard RPP Inventory effort is chartered to provide the official estimates of tank inventories of important radionuclides and chemical starting at the end of FY97. The estimates will be updated roughly twice a year thereafter. The estimates are based on production records, transfer records, and computer simulations. Members of the performance assessment team have played a major role in the determination of the radionuclide inventory.

The treatment vendors will separate the tank waste into a low-activity and a highactivity component before immobilizing the waste. The intent is to maximize the amount 
RPP-6702, Rev. 0

Formerly HNF-SD-WM-PAP-062 Rev. 4

of radionuclides in the high-activity waste, while maximizing the volume of tank waste in the low-activity fraction.

This task will interface with both groups, attempting to obtain the best estimates from each so that a good estimate of the tank waste inventory to be disposed on the Hanford Site will be obtained.

b. List Of Deliverables

Table 5.3-2a List of Deliverables for 2005 PA Inventory Data Package

\begin{tabular}{|l|c|c|l||}
\hline Description & Due Date & Level & $\begin{array}{l}\text { MYWP } \\
\text { Identifier }\end{array}$ \\
\hline $\begin{array}{l}\text { Write 2005 PA Inventory } \\
\text { Document }\end{array}$ & $9 / 30 / 03$ & 8 & $\begin{array}{l}46160 Q 3 B \\
{[46160 Q 33]}\end{array}$ \\
\hline $\begin{array}{l}\text { Issue 2005 PA Inventory } \\
\text { Document }\end{array}$ & $12 / 31 / 03$ & 6 & $\begin{array}{l}46160 Q 4 B \\
{[46160 Q 42}\end{array}$ \\
\hline
\end{tabular}

c. Cost Summary

WBS: $1 \cdot 1 \cdot 1 \cdot 3 \cdot 4 \cdot 1 \cdot 3 \cdot 3$

TPCN: D4DM3

Table 5.3-2b Cost Summary for 2005 PA Inventory Data Package

\begin{tabular}{|l|l|r|}
\hline \multicolumn{1}{|c|}{ Fiscal Year } & \multicolumn{1}{|c|}{ Organization } & $\begin{array}{c}\text { Amount } \\
(\$ 1000)\end{array}$ \\
\hline 2000 & $\begin{array}{l}\text { Fluor Federal Services } \\
\text { (FFS) }\end{array}$ & 12 \\
\hline 2001 & FFS & 12 \\
\hline 2002 & FFS & 12 \\
\hline 2003 & FFS & 37 \\
\hline 2004 & FFS & 25 \\
\hline \hline Grand Total & 98 \\
\hline
\end{tabular}

d. Detailed Description

Document and justify the inventory data to be used in the 2005 performance assessment. The activity is similar to that for the 2001 performance assessment (3.3.C.ii). 


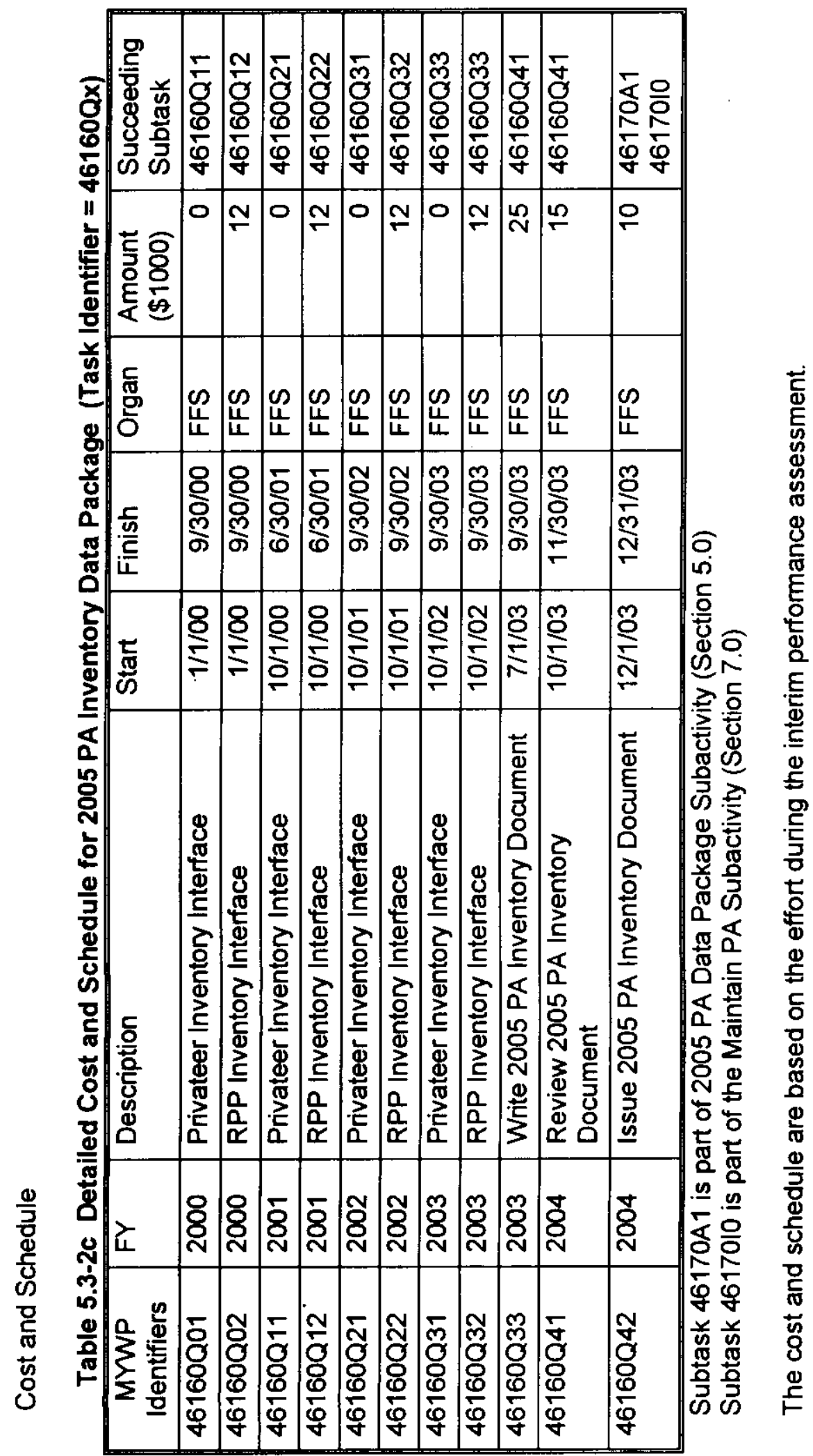


RPP-6702, Rev. 0

Formerly HNF-SD-WM-PAP-062 Rev. 4

iii. Determine Disposal Facility Conceptual Model

a. Background

The Design and Construction Activity of the RPP Immobilized Waste Program is responsible for the design of the disposal facility. The performance assessment will interface with this activity to pass along the understanding achieved from the performance assessment analyses and to receive from them the current thinking on the design. Table 0.0-2 (Section 0.) displays the design, operation, and closure schedule for the disposal facilities.

b. List Of Deliverables

Table 5.3-3a List of Deliverables for 2005 PA Conceptual Model Data Package

\begin{tabular}{||l|c|c|l||}
\hline Description & Due Date & Level & $\begin{array}{l}\text { MYWP } \\
\text { Identifier }\end{array}$ \\
\hline $\begin{array}{l}\text { Write 2005 PA Conceptual Model } \\
\text { Data Package }\end{array}$ & $9 / 30 / 03$ & 8 & $\begin{array}{l}461600 R 3 B \\
\text { [46160R32] }\end{array}$ \\
\hline $\begin{array}{l}\text { Issue 2005 PA Conceptual Model } \\
\text { Data Package }\end{array}$ & $12 / 31 / 03$ & 6 & $\begin{array}{l}\text { 46160R4A } \\
\text { [46160R42] }\end{array}$ \\
\hline
\end{tabular}

c. Cost Summary

WBS: $1.1 .1 .3 .4 \cdot 1 \cdot 3.3$

TPCN: D4DM3

Table 5.3-3b Cost Summary for 2005 PA Conceptual Model Data Package

\begin{tabular}{|l|l|r|}
\hline \multicolumn{1}{|c|}{ Fiscal Year } & \multicolumn{1}{|c|}{ Organization } & Amount (\$1000) \\
\hline 2000 & Fluor Federal Services (FFS) & 12 \\
\hline 2001 & FFS & 52 \\
\hline 2002 & FFS & 42 \\
\hline 2003 & FFS & 37 \\
\hline 2004 & FFS & 25 \\
\hline \hline Grand Total & 168 \\
\hline
\end{tabular}

d. Detailed Description

Determine and document the conceptual model of the disposal facility to be used in the $\mathbf{2 0 0 5}$ performance assessment. The activities are similar to those for the 2001 performance assessment (3.2.C.iii), except that a detailed design of the new facilities should be available near the end of the task.

\section{Barrier Design Support.}

Near field models have ben developed to assess tne perfromance of the disposal facility for the 2001 ILAW PA. These models include design options such as capillary barriers, and different material ooptions that permit the investigation of the sensitivity of the various design ptions to selected design options and material selections. The design authority for the ILAW disposal facility will define the scope of the caclulations to be 
RPP-6702, Rev. 0

Formerly HNF-SD-WM-PAP-062 Rev. 4

perfromed. Selected design options would then be modeled and the relative effects on facility performance estimated. This information would be recorded in a report and would serve to guide the selection of final disposal facility design. 
RPP-6702, Rev. 0

Formerly HNF-SD-WM-PAP-062 Rev. 4

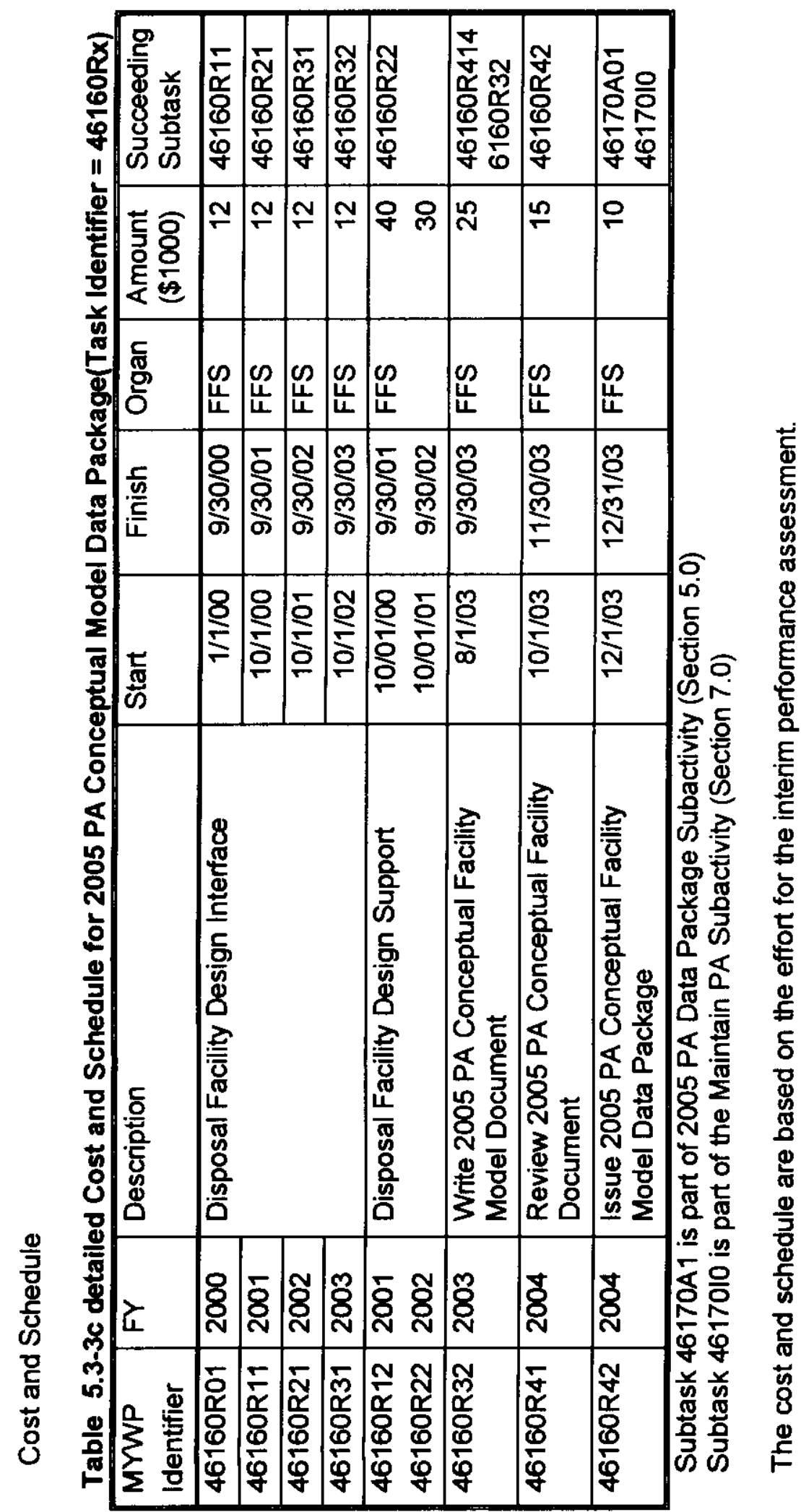

๑ 
RPP-6702, Rev. 0

Formerly HNF-SD-WM-PAP-062 Rev. 4

iv. Determine Dosimetry Data

a. Background

Dosimetry data are factors used to convert radionuclide concentrations in soil, air, and water into dose rates. They often depend on site-specific scenarios. The Hanford Environmental Dose Oversight Panel sets the standard methods and data for use in Hanford environmental dose assessments.

b. List Of Deliverables

Table 5.3-4a List of Deliverables for 2005 PA Dosimetry Data Package

\begin{tabular}{||l|c|c|l||}
\hline \hline Description & Due Date & Level & $\begin{array}{l}\text { MYWP } \\
\text { Identifier }\end{array}$ \\
\hline Write 2005 PA Dosimetry Data Report & $9 / 30 / 03$ & 8 & $\begin{array}{l}46160 S 3 \mathrm{~B} \\
{[46160 \mathrm{S32}]}\end{array}$ \\
\hline Issue 2005 PA Dosimetry Data Report & $12 / 31 / 03$ & 6 & $\begin{array}{l}\text { 46160S4A } \\
{[46160 S 42]}\end{array}$ \\
\hline
\end{tabular}

Analytical results for environmental samples submitted for AMS measurement. Data packages will report selenium concentration, selenium-79: total selenium atom ratio, calculated selenium-79 concentration, and estimate of analytical errors. Due $7 / 31 / 2000$.

Letter report consisting of draft journal article on analytical methodology and summary of results and significance. Due 9/30/2000.

c. Cost Summary

WBS: $1.1 \cdot 1 \cdot 3 \cdot 4 \cdot 1 \cdot 3.3$

TPCN: D4DM3

Table 5.3-4b Cost Summary for 2005 PA Dosimetry Code Data Package

\begin{tabular}{|l|l|r|}
\hline Fiscal Year & \multicolumn{1}{|c|}{ Organization } & Amount (\$1000) \\
\hline 2000 & Fluor Federal Services (FFS) & 12 \\
\hline 2001 & FFS & 12 \\
\hline 2002 & FFS & 12 \\
\hline 2003 & FFS & 37 \\
\hline 2004 & FFS & 25 \\
\hline \hline Grand Total & 98 \\
\hline
\end{tabular}

d. Detailed Description

Determine and document the dosimetry data to be used in the 2005 performance assessment. The effort is similar to that for the 2001 performance assessment (Section 3.3.C.iv). 
RPP-6702, Rev. 0

Formerly HNF-SD-WM-PAP-062 Rev. 4

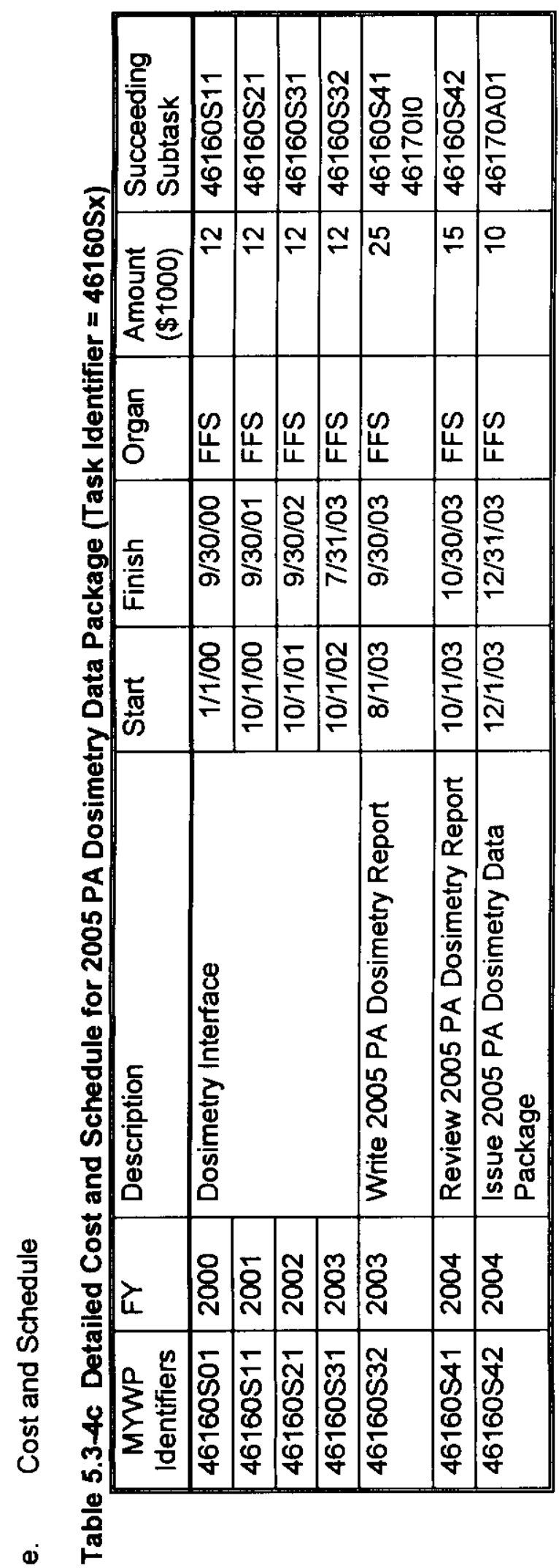

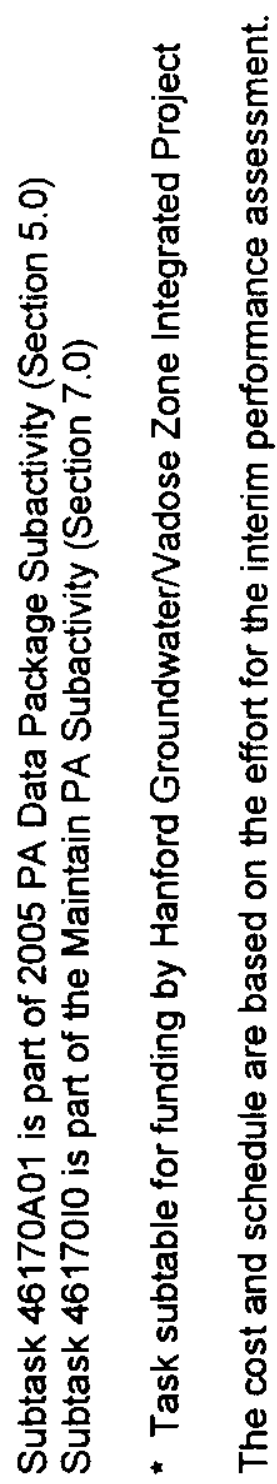


RPP-6702, Rev. 0

Formerly HNF-SD-WM-PAP-062 Rev. 4

f. Organization

The Environmental and Nuclear Initatives Section of Fluor Federal Services (FFS) will be responsible for preparing the data packages. The person performing this task is a member of the Hanford Environmental Dose Oversight Panel and has prepared the dosimetry data package for previous ILAW PAs.

g. Quality Assurance

All activities will be conducted in accordance with 10 CFR 830.120 . The Hanford Analytical Services Quality Assurance Requirements Document will apply to the analysis of field samples.

h. Effect of Not Performing Task

Because of its long half-life, high environmental mobility, and potential to concentrate in specific waste streams, the lack of ability to measure selenium-79 and to integrate site data into performance assessments and remedial investigations represents a significant gap in the decision making process. DOE thus becomes more vulnerable to allegations that the interpretations are not sufficiently based on "reality."

v. Determine Performance Objectives

a. Background

Performance objectives are the standards against which the environmental and health safety estimates from the performance assessment are compared. The performance objectives are becoming more standardized (Frei 1996) as DOE gains more experience with the performance assessment process. However, there are still site-specific and disposal-action specific objectives (for example, groundwater protection, location of compliance) which must be determined. The performance objectives used in the 2001 performance assessment (3.3.C.v) are expected to undergo little change.

b. List Of Deliverables

Table 5.3-5a List of Deliverables for 2005 PA Performance Objectives Data Package

\begin{tabular}{|l|l|c|l|}
\hline Description & $\begin{array}{l}\text { Due } \\
\text { Date }\end{array}$ & Level & $\begin{array}{l}\text { MWWP } \\
\text { Identifier }\end{array}$ \\
\hline $\begin{array}{l}\text { Write 2005 PA Performance } \\
\text { Objectives Report }\end{array}$ & $7 / 31 / 03$ & 8 & $\begin{array}{l}\text { 46160T3C } \\
\text { [46160T32] }\end{array}$ \\
\hline $\begin{array}{l}\text { Issue 2005 PA Performance } \\
\text { Objectives Data Package }\end{array}$ & $12 / 31 / 03$ & 6 & $\begin{array}{l}\text { 46160T4A } \\
\text { [46160T42] }\end{array}$ \\
\hline
\end{tabular}


RPP-6702, Rev. 0

Formerly HNF-SD-WM-PAP-062 Rev. 4

c. Cost Summary

WBS: 1.1.1.3.4.1.3.3

TPCN: D4DM3

Table 5.3-5b Cost Summary for 2005 PA Performance Objectives Data Package

\begin{tabular}{|l|l|r|}
\hline \multicolumn{1}{|c|}{ Fiscal Year } & \multicolumn{1}{|c|}{ Organization } & \multicolumn{1}{|c|}{$\begin{array}{c}\text { Amount } \\
(\$ 1000)\end{array}$} \\
\hline 2000 & Fluor Federal Services (FFS) & 5 \\
\hline 2001 & FFS & 5 \\
\hline 2002 & FFS & 5 \\
\hline 2003 & FFS & 10 \\
\hline 2004 & FFS & 5 \\
\hline \hline Grand Total & 30 \\
\hline
\end{tabular}

d. Detailed Description

Determine and document performance objectives to be used in the 2005 performance assessment. It is expected that the one determined for the 2001 performance assessment (3.3.C.V) will be used.4 
RPP-6702, Rev. 0

Formerly HNF-SD-WM-PAP-062 Rev. 4

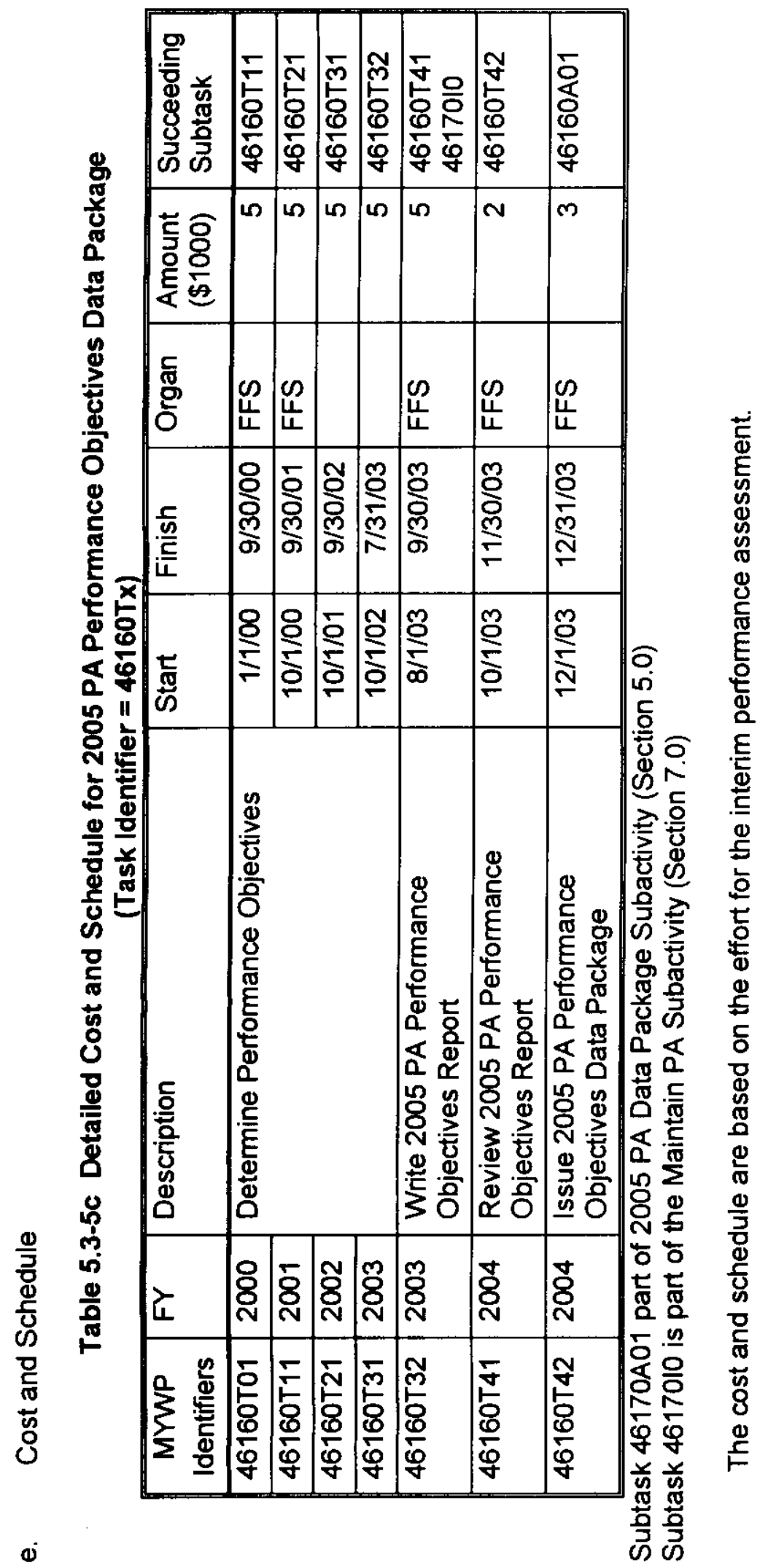


RPP-6702, Rev. 0

Formerly HNF-SD-WM-PAP-062 Rev. 4

vi. Determine Scenarios and Pathways to be Analyzed

a. Background

Scenarios describe the pathways through which the contaminants move from the disposal facility to the place of compliance. Also included are the parameters associated with inadvertent intrusion into the facility.

Hanford stakeholders (for example, members of the Hanford Advisory Board) have expressed strong interest in this area. Hence the review period is extended.

b. List Of Deliverables

Table 5.3-6a List of Deliverables for 2005 PA Scenarios Data Package

\begin{tabular}{|l|c|c|l||}
\hline Description & Due Date & Level & $\begin{array}{l}\text { MYWP } \\
\text { Identifier }\end{array}$ \\
\hline Write 2005 PA Scenario Report & $7 / 31 / 03$ & 8 & $\begin{array}{l}46160 \text { U3C } \\
{[46160 \text { U32] }}\end{array}$ \\
\hline $\begin{array}{l}\text { Issue 2005 PA Scenario Data } \\
\text { Package }\end{array}$ & $12 / 31 / 03$ & 6 & $\begin{array}{l}46160 \text { U4A } \\
46140 U 42]\end{array}$ \\
\hline
\end{tabular}

c. Cost Summary

WBS: $1.1 \cdot 1 \cdot 3 \cdot 4 \cdot 1 \cdot 3.3$

TPCN: D4DM3

Table 5.3-6b Cost Summary for 2005 PA Scenarios Data Package

\begin{tabular}{|l|l|r|}
\hline \multicolumn{1}{|c|}{ Fiscal Year } & \multicolumn{1}{|c|}{ Organization } & $\begin{array}{r}\text { Amount } \\
(\$ 1000)\end{array}$ \\
\hline 2000 & Fluor Federal Services (FFS) & 5 \\
\hline 2001 & FFS & 5 \\
\hline 2002 & FFS & 5 \\
\hline 2003 & FFS & 10 \\
\hline 2004 & FFS & 5 \\
\hline \hline Grand Total & 30 \\
\hline
\end{tabular}

d. Detailed Description

Determine and document scenarios to be used in the 2005 performance assessment. It is expected that the one determined for the 2001 performance assessment (3.3.C.vi) will be used. 
RPP-6702, Rev .0

Formerly HNF-SD-WM-PAP-062 Rev. 4

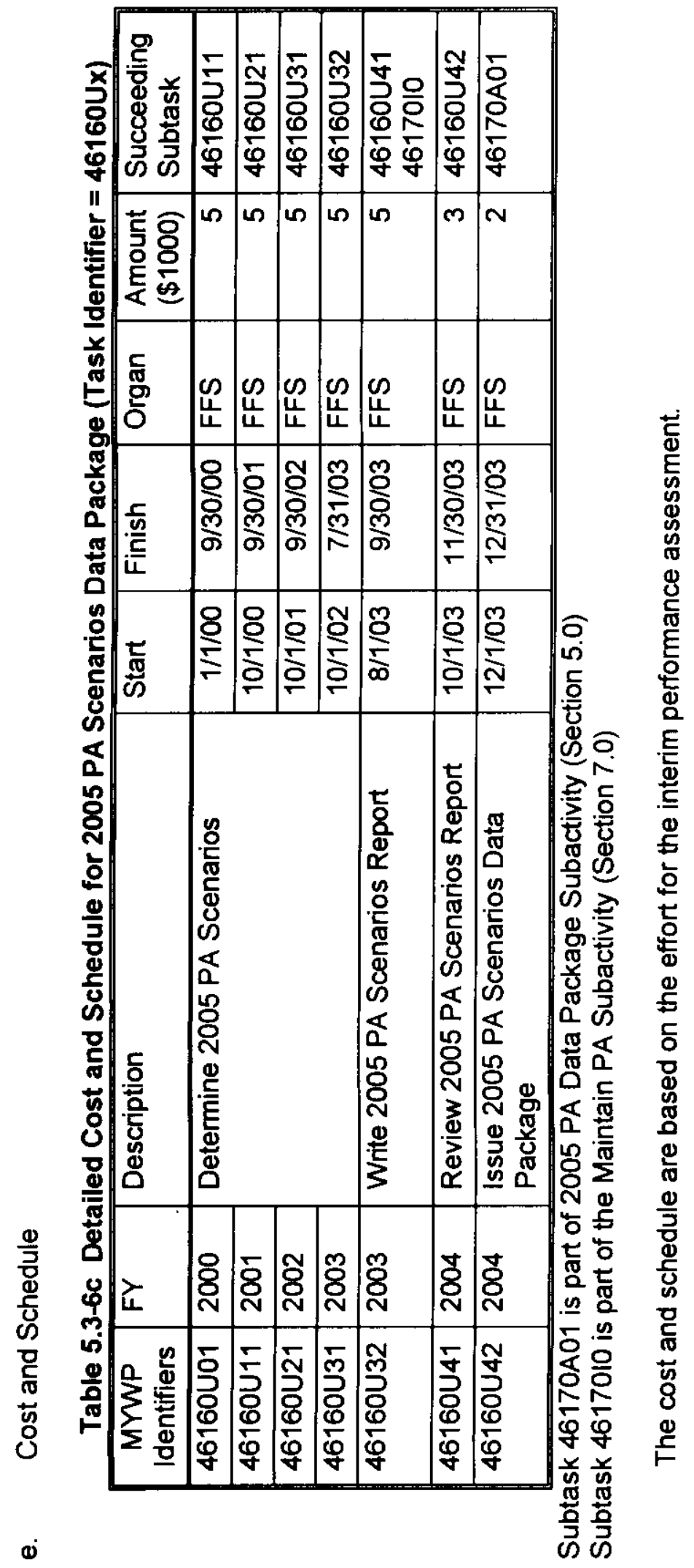


RPP-6702, Rev. 0

Formerly HNF-SD-WM-PAP-062 Rev. 4

\subsection{PERFORMANCE ASSESSMENT}

\section{A. SUMMARY}

Issue a report documenting the current state of knowledge of the long-term environmental and human-health impact from the disposal of the low-activity component of Hanford tank waste. The format and contents of the report shall follow as closely as possible the guidance provided by DOE.

In prior versions of this document, this performance assessment was to be due in 2003. However, several items have now made 2005 a more appropriate date:

- $\quad$ DOE has approved the 1998 ILAW PA (DOE 1999b) and issued a disposal authorization statement (DOE 1999c).

- $\quad$ The date for receiving waste is now 2007.

- The 2001 ILAW PA will analyze for the effects of new disposal facility design (Taylor 1999) and for new glass composition.

\section{B. GENERAL}

i. Background

The current procedure for fulfilling the requirements of Chapter III, Section 3 of the DOE Order on Radioactive Waste Management (DOE 1999) is to submit a 2005 performance assessment (2005 PA) for DOE Headquarters approval. As part of this approval, the Low Level Waste Disposal Facility Federal Review Group judges the technical adequacy of the performance assessment. By the DOE order, waste disposal cannot occur unless a performance assessment is maintained.

Five previous performance assessments (Kincaid 1995a, Wood 1994, Wood 1995, and Wood 1996, Mann 1998a) have been submitted by the Hanford Site. By the time of this activity, comments on the 2001 performance assessment (Chapter 4.0) by the review panel established by DOE will have been received. The information contained in these documents as well as the methods used by the activities that produced those documents will be used as much as possible in the generation of the 2005 performance assessment.

ii. List of Deliverables

Table 6.0-1a List of Major Deliverables for Creating the 2005 PA

\begin{tabular}{|l|l|c|l||}
\hline Description & $\begin{array}{l}\text { Due } \\
\text { Date }\end{array}$ & Level & $\begin{array}{l}\text { MYWP } \\
\text { Identifier }\end{array}$ \\
\hline $\begin{array}{l}\text { Issue 2005 PA base analysis case and } \\
\text { sensitivity cases definition }\end{array}$ & $3 / 31 / 04$ & 6 & $46170 \mathrm{~A} 1 \mathrm{~A}$ \\
\hline Write 2005 Performance Assessment & $11 / 30 / 04$ & 6 & $46170 \mathrm{C} 1 \mathrm{~B}$ \\
\hline $\begin{array}{l}\text { Issue 2005 Performance Assessment for } \\
\text { HQ Review }\end{array}$ & $1 / 31 / 05$ & 3 & $46170 \mathrm{C} 1 \mathrm{~A}$ \\
\hline
\end{tabular}


RPP-6702, Rev. 0

Formerly HNF-SD-WM-PAP-062 Rev. 4

\begin{tabular}{|l|l|l|l|}
\hline $\begin{array}{l}\text { Receive Approval of 2005 PA and } \\
\text { Issuance of Waste Disposal Authorization }\end{array}$ & $1 / 31 / 05$ & 6 & $4617000 A$ \\
\hline
\end{tabular}

iii. $\quad$ Cost Summary

WBS: $1.1 \cdot 1 \cdot 3 \cdot 4 \cdot 1 \cdot 3.1$

TPCN: D4DM1

Table 6.0-1b Cost Summary for Creating 2005 PA

\begin{tabular}{|l|l|r|}
\hline $\begin{array}{l}\text { Fiscal } \\
\text { Year }\end{array}$ & Organization & $\begin{array}{r}\text { Amount } \\
(\$ 1000)\end{array}$ \\
\hline 2004 & Fluor Federal Services (FFS) & 240 \\
\cline { 2 - 3 } & $\begin{array}{l}\text { Pacific Northwest National Laboratory } \\
\text { (PNNL) }\end{array}$ & 140 \\
\cline { 2 - 3 } & Total & 380 \\
\hline 2005 & FFS & 70 \\
\hline 2006 & FFS & 10 \\
\hline \hline Grand Total & 460 \\
\hline
\end{tabular}

iv. Interfaces

All of the data and tools need for the 2005 performance assessment should be documented in the Data Packages for the Hanford Low-activity Tank Waste 2005 Performance Assessment, which is produced in Activity S1W03888 (See Chapter 5.0).

After approval of the 2005 performance assessment, the performance assessment greatly reduces in scope. The main follow-on activities deal with maintaining the performance assessment for the life of the disposal facility.

\section{v. Organization}

Fluor Federal Services (FFS) wrote the interim performance assessment and led its review. It is assumed to supply those functions for the $\mathbf{2 0 0 5}$ performance assessment as well. The organization that will calculate moisture flow and contaminant transport will be decided by selection process involving activities 36145Px (See Section 3.2.C.ix). For convenience, FFS is assumed to be the organization.

The Pacific Northwest National Laboratory (PNNL) has been assigned the task for developing a groundwater model for the Hanford Site. PNNL may also become responsible for actually running the model. For convenience, PNNL is assumed to be running the model. PNNL was selected to perform the calculations on waste form performance for the 2001 PA (activity 46145B2 - Section 3.1.C.v). PNNL is assumed to continue in that role.

\section{TASK DESCRIPTIONS}

i. Summary List of Tasks

a. Establish 2005 PA Base Analysis Case and Sensitivity Cases

b. Perform Calculations for the 2005 Performance Assessment

c. Issue the 2005 Performance Assessment for DOE Approval 
RPP-6702, Rev. 0

Formerly HNF-SD-WM-PAP-062 Rev. 4

d. Receive Waste Disposal Authorization from DOE

ii. Establish 2005 PA Base Analysis Case and Sensitivity Cases

a. Background

A lesson leamed during the review of the Grout Performance Assessment (Kincaid 1995a) was the careful creation and documentation of the basis analysis cases for the performance assessment. The creation of the Definition of the Base Analysis Case of the Interim Performance Assessment (Mann 1995c) greatly helped keep the analysts working to a defined set of data.

b. List Of Deliverables

Table 6.0-2a List of Deliverables for 2005 PA Base Analysis Case Definition

\begin{tabular}{|l|l|c|l||}
\hline Description & $\begin{array}{l}\text { Due } \\
\text { Date }\end{array}$ & Level & $\begin{array}{l}\text { MYWP } \\
\text { Identifier }\end{array}$ \\
\hline $\begin{array}{l}\text { Establish 2005 PA Base Analysis } \\
\text { Case and Sensitivity Cases }\end{array}$ & $3 / 31 / 04$ & 6 & $46170 \mathrm{A1A}$ \\
\hline
\end{tabular}

c. Cost Summary

WBS: $1 \cdot 1 \cdot 1 \cdot 3 \cdot 4 \cdot 1 \cdot 3 \cdot 1$

TPCN: D4DM1

Table 6.0-2b Cost Summary for 2005 PA Base Analysis Case Definition

\begin{tabular}{|l|l|r|}
\hline \multicolumn{1}{|c|}{ Fiscal Year } & \multicolumn{1}{|c|}{ Organization } & \multicolumn{1}{|c|}{$\begin{array}{l}\text { Amount } \\
(\$ 1000)\end{array}$} \\
\hline 2004 & $\begin{array}{l}\text { Fluor Federal Services } \\
\text { (FFS) }\end{array}$ & 30 \\
\hline
\end{tabular}

d. Detailed Description

Determine and document all the parameters to be used in the base analysis case. Major sensitivity and uncertainty cases will also be determined. The effort is similar to that performed for the 2001 performance assessment (6.0.C.ii). 
RPP-6702, Rev. 0

Formerly HNF-SD-WM-PAP-062 Rev. 4

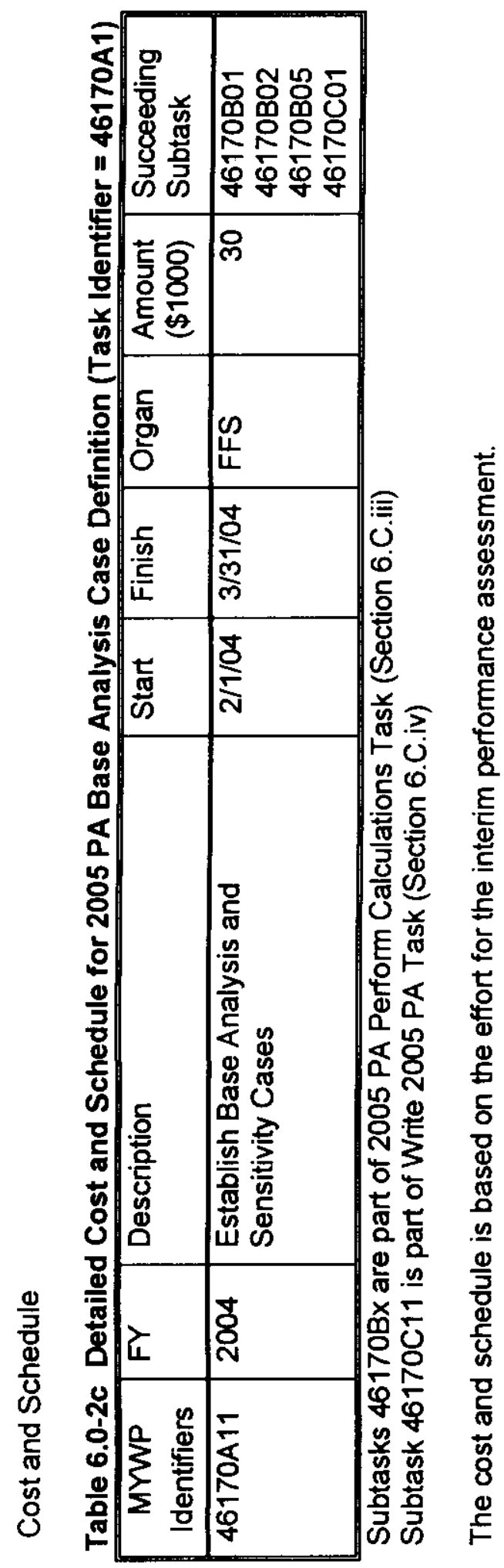

(1) 
RPP-6702, Rev. 0

Formerly HNF-SD-WM-PAP-062 Rev. 4

iii. Perform Calculations for the 2005 Performance Assessment

a. Background

Estimations of long-term environmental and human health impacts must be performed for thousands of years into the future. Since extrapolations from experimental results are not sufficient, computer models must make these estimations. Because the complex geometry (waste form, disposal facility, vadose zone, and groundwater) involved, the calculations are complex and time consuming. Many hundreds of hours of computer time on scientific computers have been used on each of the Hanford performance assessments.

The major calculations involve

1) Calculation of the moisture flow in the disposal facility, providing a mechanism for the waste form to release its contaminants,

2) Calculation of the time and spatial dependent chemical environment surrounding the waste form and the resulting contaminant release rate from the waste form,

3) Calculation of the contaminant movement from the waste form (or disposal facility) through the vadose zone to the groundwater,

4) Calculation of the contaminant movement through the groundwater to the compliance point, and

5) Calculation of the long-term impact that combines the previous calculations with inventory and dosimetry values.

b. List Of Deliverables

Table 6.0-3a List of Deliverables for 2005 PA Perform Calculations

\begin{tabular}{|l|c|c|l||}
\hline Description & $\begin{array}{l}\text { Due } \\
\text { Date }\end{array}$ & Level & $\begin{array}{l}\text { MYWP } \\
\text { ldentifier }\end{array}$ \\
\hline Document flow calculations in the vault & $4 / 30 / 04$ & 8 & $\begin{array}{l}46170 \mathrm{BOE} \\
\text { [46170B01] }\end{array}$ \\
\hline $\begin{array}{l}\text { Document contaminant release rate from the } \\
\text { waste form/disposal facility }\end{array}$ & $6 / 30 / 04$ & 8 & $\begin{array}{l}46170 \mathrm{BOD} \\
{[46170 \mathrm{~B} 04]}\end{array}$ \\
\hline Document groundwater calculations & $8 / 31 / 04$ & 8 & $\begin{array}{l}\text { 46170B0C } \\
\text { [46170B05] }\end{array}$ \\
\hline Document vadose zone contaminant transport & $8 / 31 / 04$ & 8 & $\begin{array}{l}\text { 46170B0B } \\
\text { [46170B07] }\end{array}$ \\
\hline Calculate exposure impacts & $9 / 30 / 04$ & 8 & $\begin{array}{l}46170 \mathrm{BOA} \\
\text { [46170B08] }\end{array}$ \\
\hline
\end{tabular}


RPP-6702, Rev. 0

Formerly HNF-SD-WM-PAP-062 Rev. 4

c. Cost Summary

WBS: $1.1 \cdot 1 \cdot 3 \cdot 4 \cdot 1 \cdot 3.1$

TPCN: D4DM1

Table 6.0-3b Cost Summary for 2005 PA Perform Calculations

\begin{tabular}{|l|l|r|}
\hline $\begin{array}{c}\text { Fiscal } \\
\text { Year }\end{array}$ & \multicolumn{1}{|c|}{ Organization } & $\begin{array}{r}\text { Amount } \\
(\$ 1000)\end{array}$ \\
\hline 2004 & Fluor Federal Services (FFS) & 140 \\
\cline { 2 - 3 } & Pacific Northwest National Laboratory (PNNL) & 140 \\
\hline \hline Grand Total & 280 \\
\hline
\end{tabular}

d. Detailed Description

Perform the calculations necessary for the 2005 performance assessment. The tasks are the same as for the 2001 performance assessment (6.0.C.iii). 
RPP-6702, Rev. 0

Formerly HNF-SD-WM-PAP-062 Rev. 4

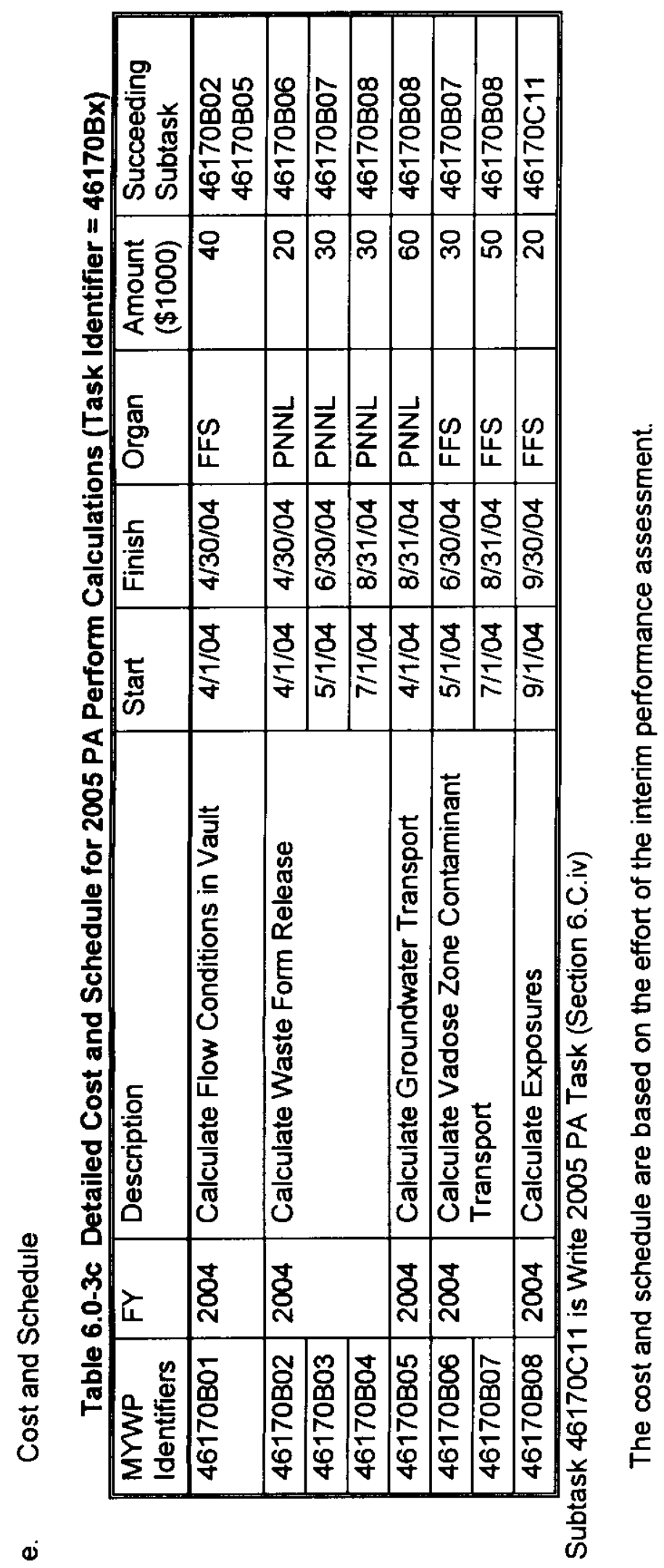


RPP-6702, Rev. 0

Formerly HNF-SD-WM-PAP-062 Rev. 4

iv. Write the 2005 Performance Assessment

a. Background

This task actually produces the 2005 performance assessment for submittal to DOE Headquarters for approval.

It will build on the experience of creating the 2001 performance assessment and the comments that were received on that document.

b. List Of Deliverables

Table 6.0-4a List of Deliverables for Write 2005 PA

\begin{tabular}{|l|l|c|l||}
\hline Description & $\begin{array}{l}\text { Due } \\
\text { Date }\end{array}$ & Level & $\begin{array}{l}\text { MYWP } \\
\text { Identifier }\end{array}$ \\
\hline $\begin{array}{l}\text { Write 2005 Performance } \\
\text { Assessment }\end{array}$ & $11 / 30 / 04$ & 6 & $\begin{array}{l}46170 \mathrm{C} 1 \mathrm{C} \\
\text { [46170C11] }\end{array}$ \\
\hline $\begin{array}{l}\text { Issue 2005 Performance } \\
\text { Assessment }\end{array}$ & $1 / 31 / 05$ & 3 & $\begin{array}{l}46170 \mathrm{C} 1 \mathrm{~A} \\
\text { [46170C13] }\end{array}$ \\
\hline
\end{tabular}

c. Cost Summary WBS: $1.1 .1 .3 .4 .1 .3 .1 \quad$ TPCN: D4DM1

Table 6.0-4b Cost Summary for Write 2005 PA

\begin{tabular}{|l|l|r|}
\hline \multicolumn{1}{|c|}{ Fiscal Year } & \multicolumn{1}{|c|}{ Organization } & \multicolumn{1}{|c|}{$\begin{array}{c}\text { Amount } \\
(\$ 1000)\end{array}$} \\
\hline 2004 & $\begin{array}{l}\text { Fluor Federal Services } \\
\text { (FFS) }\end{array}$ & 70 \\
\hline 2005 & FFS & 50 \\
\hline \hline Total & 120 \\
\hline
\end{tabular}

d. Detailed Description

Write the 2005 performance assessment document. Most of the 2001 performance assessment (2.0.C.iv) should be useable for the 2005 performance assessment. 


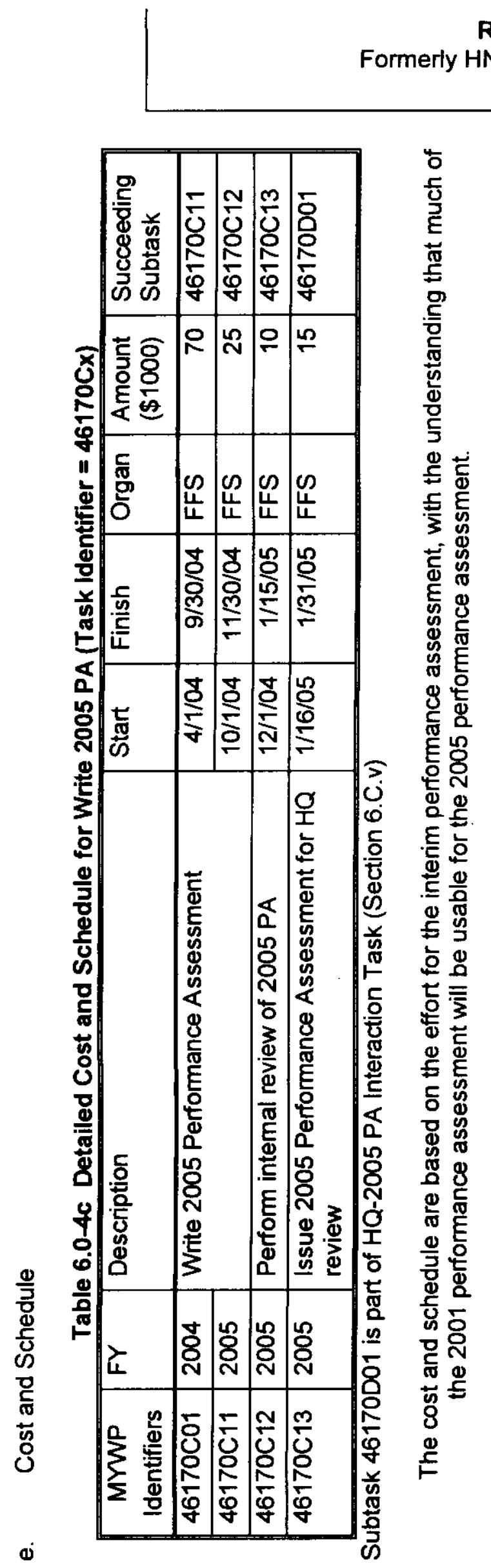

RPP-6702, Rev. 0

Formerly HNF-SD-WM-PAP-062 Rev. 4 
RPP-6702, Rev. 0

Formerly HNF-SD-WM-PAP-062 Rev. 4

v. HQ-2005 PA Interaction

a. Background

During the review of a performance assessment, DOE Headquarters staff and the committees will raise questions concerning the performance assessment. This task funds efforts to answer those questions.

b. List Of Deliverables

Table 6.0-5a List of Deliverables for HQ-2005 PA Interaction

\begin{tabular}{||l|l|c|l|}
\hline Description & $\begin{array}{l}\text { Due } \\
\text { Date }\end{array}$ & Level & $\begin{array}{l}\text { MYWP } \\
\text { Identifier }\end{array}$ \\
\hline $\begin{array}{l}\text { Receive Waste Disposal } \\
\text { Authorization }\end{array}$ & $1 / 31 / 06$ & 6 & $\begin{array}{l}\text { 46170D0A } \\
\text { [46170AD02] }\end{array}$ \\
\hline
\end{tabular}

c. Cost Summary

WBS: 1.1.1.3.4.1.1 TPCN: D4DM1

Table 6.0-5b Cost Summary for HQ-2005 PA Interaction

\begin{tabular}{|l|l|r|}
\hline \multicolumn{1}{|c|}{ Fiscal Year } & \multicolumn{1}{|c|}{ Organization } & \multicolumn{1}{|c|}{$\begin{array}{c}\text { Amount } \\
(\$ 1000)\end{array}$} \\
\hline 2005 & $\begin{array}{l}\text { Fluor Federal Services } \\
\text { (FFS) }\end{array}$ & 20 \\
\hline 2006 & FFS & 10 \\
\hline \hline Grand Total & 30 \\
\hline
\end{tabular}

d. Detailed Description

Interact with the Peer Review Panel and with DOE Headquarters on the review and approval of the 2005 performance assessment. 
RPP-6702, Rev. 0

Formerly HNF-SD-WM-PAP-062 Rev. 4

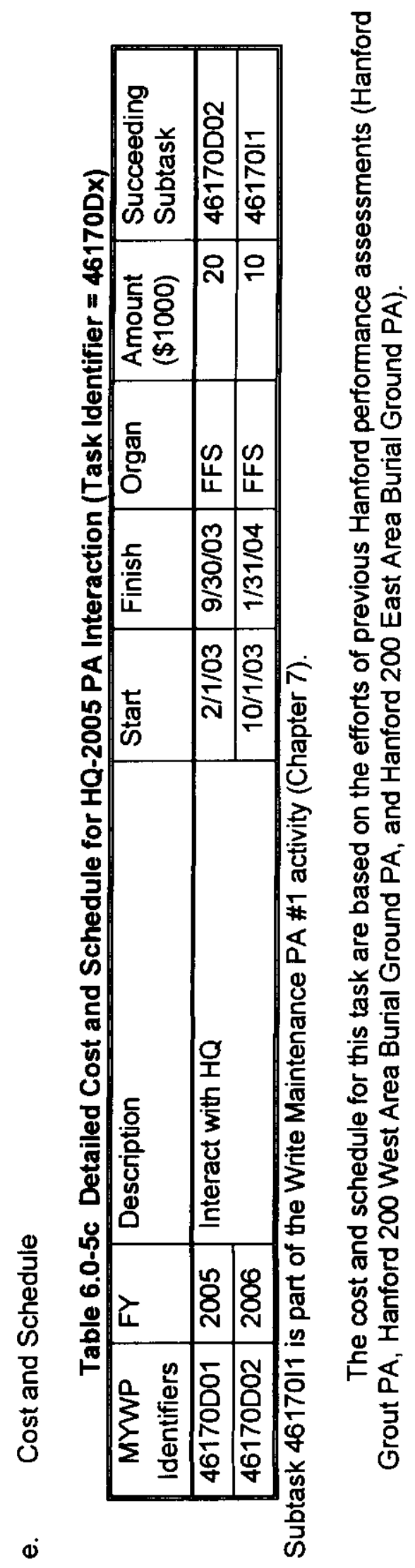


RPP-6702, Rev. 0

Formerly HNF-SD-WM-PAP-062 Rev. 4

\subsection{MAINTENANCE PERFORMANCE ASSESSMENTS}

\section{A. SUMMARY}

Issue reports documenting the current knowledge of long-term environmental and human health impact from the disposal of the low-activity component of Hanford tank waste. The format and content of such reports shall follow the guidance provided by DOE.

\section{B. GENERAL}

i. Background

The DOE order on radioactive waste management (DOE 1999) mandates that performance assessments be maintained until the disposal facility is closed. The reports are to document new information (whether arising from policy changes, operations changes, or from new knowledge of the natural or man-made system) and how this information affects the estimates made in the 2005 performance assessment.

Because of the newness of the policy and of the guidance and because only recently have performance assessments been approved, no practical experience exists (particularly at the Hanford Site).

It is expected that data collection activities will quickly decline as phase II of waste treatment is entered.

ii. List of Deliverables

Table 7.0a List of Deliverables for Maintenance PAs

\begin{tabular}{||l|c|c|l||}
\hline Description & $\begin{array}{l}\text { Due } \\
\text { Date }\end{array}$ & Level & $\begin{array}{l}\text { MYWP } \\
\text { Identifier }\end{array}$ \\
\hline Document Database For MPA \#1 & $9 / 30 / 09$ & 6 & $46170 \mathrm{AA}$ \\
\hline Write Maintenance PA \#1 & $9 / 30 / 10$ & 5 & $46170 \mathrm{JA}$ \\
\hline Document Database For MPA \#2 & $9 / 30 / 14$ & 6 & $46170 \mathrm{KA}$ \\
\hline Write Maintenance PA \#2 & $9 / 30 / 15$ & 5 & $64040 \mathrm{DA}$ \\
\hline Document Database For MPA \#3 & $9 / 30 / 19$ & 6 & $64040 \mathrm{FA}$ \\
\hline Write Maintenance PA \#3 & $9 / 30 / 20$ & 5 & $64040 \mathrm{HA}$ \\
\hline Document Database For MPA \#4 & $9 / 30 / 24$ & 6 & $64040 \mathrm{JA}$ \\
\hline Write Maintenance PA \#4 & $9 / 30 / 25$ & 5 & $64040 \mathrm{LA}$ \\
\hline
\end{tabular}


RPP-6702, Rev. 0

Formerly HNF-SD-WM-PAP-062 Rev. 4

iii. Cost Summary

WBS: $1.1 \cdot 1 \cdot 3 \cdot 4 \cdot 1 \cdot 3 \cdot 1$

TPCN: D4DM1

Table 7.0b Cost Summary for Maintenance PAs

\begin{tabular}{|l|l|r|}
\hline \multicolumn{1}{|c|}{$\begin{array}{c}\text { Fiscal } \\
\text { Year }\end{array}$} & \multicolumn{1}{|c|}{ Organization } & $\begin{array}{c}\text { Amount } \\
(\$ 1000)\end{array}$ \\
\hline 2004 & $\begin{array}{l}\text { Fluor Federal Services } \\
\text { (FFS) }\end{array}$ & 300 \\
\hline 2005 & FFS & 600 \\
\hline 2006 & FFS & 600 \\
\hline 2007 & FFS & 600 \\
\hline 2008 & FFS & 600 \\
\hline 2009 & FFS & 500 \\
\hline 2010 & FFS & 440 \\
\hline 2011 & FFS & 400 \\
\hline 2012 & FFS & 400 \\
\hline 2013 & FFS & 300 \\
\hline 2014 & FFS & 200 \\
\hline 2015 & FFS & 240 \\
\hline 2016 & FFS & 200 \\
\hline 2017 & FFS & 100 \\
\hline 2018 & FFS & 100 \\
\hline 2019 & FFS & 100 \\
\hline 2020 & FFS & 40 \\
\hline 2021 & FFS & 100 \\
\hline 2022 & FFS & 100 \\
\hline 2023 & FFS & 100 \\
\hline 2024 & FFS & 100 \\
\hline 2025 & FFS & 6260 \\
\hline \hline Grand Total & & \\
\hline
\end{tabular}

iv. Detailed Description

Create the data packages and maintenance performance assessments as required. The data collection for the first maintenance performance assessment will focus on the long-term performance of waste forms actually produced by the vendors in production quantities (which starts in 2004). The data collection for the second maintenance effort will decline with the focus on the requirements caused by the Phase II contract specifications and design and construction of new disposal facilities. Data collection for the succeeding maintenance performance assessments will be reduced to interface with the disposal facility operators and private product vendors to ensure that values in the performance assessments remain valid. 
RPP-6702, Rev. 0

Formerly HNF-SD-WM-PAP-062 Rev. 4

The schedule for a five-year cycle is based on guidance from DOE Headquarters that a maintenance performance assessment must be issued whenever conditions warrant, but on not more than a five year cycle.

Costs are based on data collection and writing costs of the interim performance assessment but noting that the greatly reduced data needs later in the program. See Section 5.C.iv for details.

Because no maintenance performance assessments have yet been done in the DOE complex and because it is uncertain how the Phase 1 waste form will be related to the Phase 2 waste form, the cost estimates lack a strong justification. The assumptions used were the following:

1) Waste Form Data Collection and Interfaces

From FY04 through FY10, there will be a large waste form data gathering activity ( $\$ 450,000$ per year) in order to determine firstly how phase 1 waste form as produced by the vendors will behave in the long-term and secondly how the proposed phase 2 waste form is likely to behave in the long-term. This cost estimate is based on the current plans for FY98 and FY99.

From FY11 to FY14, the waste form data collection activities are expected to be reduced (to $\$ 300,000$ per year) as many of the tests on proposed phase 2 waste form will be completed.

From FY14 to FY15, there will be limited waste form data testing as the actual phase 2 operations begin. Beyond FY16, only an interface activity (approximately $\$ 40,000$ per year) will be maintained to understand how waste form processing and waste form composition might affect conclusions reached in the performance assessment.

2) Other Data Collection and Interfaces

From FY04 through FY15, other activities are estimated at $\$ 150,000$ per year. These activities will include interfacing with disposal facility design and construction, with RPP characterization, retrieval, and private vendors to determine inventory. With the Hanford geotechnical community to determine if assumptions or data used in the performance assessments remain accurate. Also include are general administrative costs. The budgets for these early years are higher than later years because the new disposal facilities will be being built and it is expected that lessons learned during construction and early operation will need to be factored into later performance assessments.

Beyond FY16, operations are expected to become more routine and hence performance activities are expected to decrease (resulting in a budget of about $\$ 60,0000$ per year). Activities involving inventory, evolving disposal facility design, general geotechnical interface, and overall program supervision would continue.

3) Writing each Maintenance Performance Assessment 


\section{RPP-6702, Rev. 0 \\ Formerly HNF-SD-WM-PAP-062 Rev. 4}

The depth of analysis for a maintenance performance assessment is not known. The estimate is made that relatively little computation will be involved $(\$ 20,000)$ and that 6 man-weeks will be needed to write, edit, and review the document.

\section{v. Organization}

Fluor Federal Services (FFS) is shown as the organization performing the work only for convenience. 
RPP-6702, Rev. 0

Formerly HNF-SD-WM-PAP-062 Rev. 4

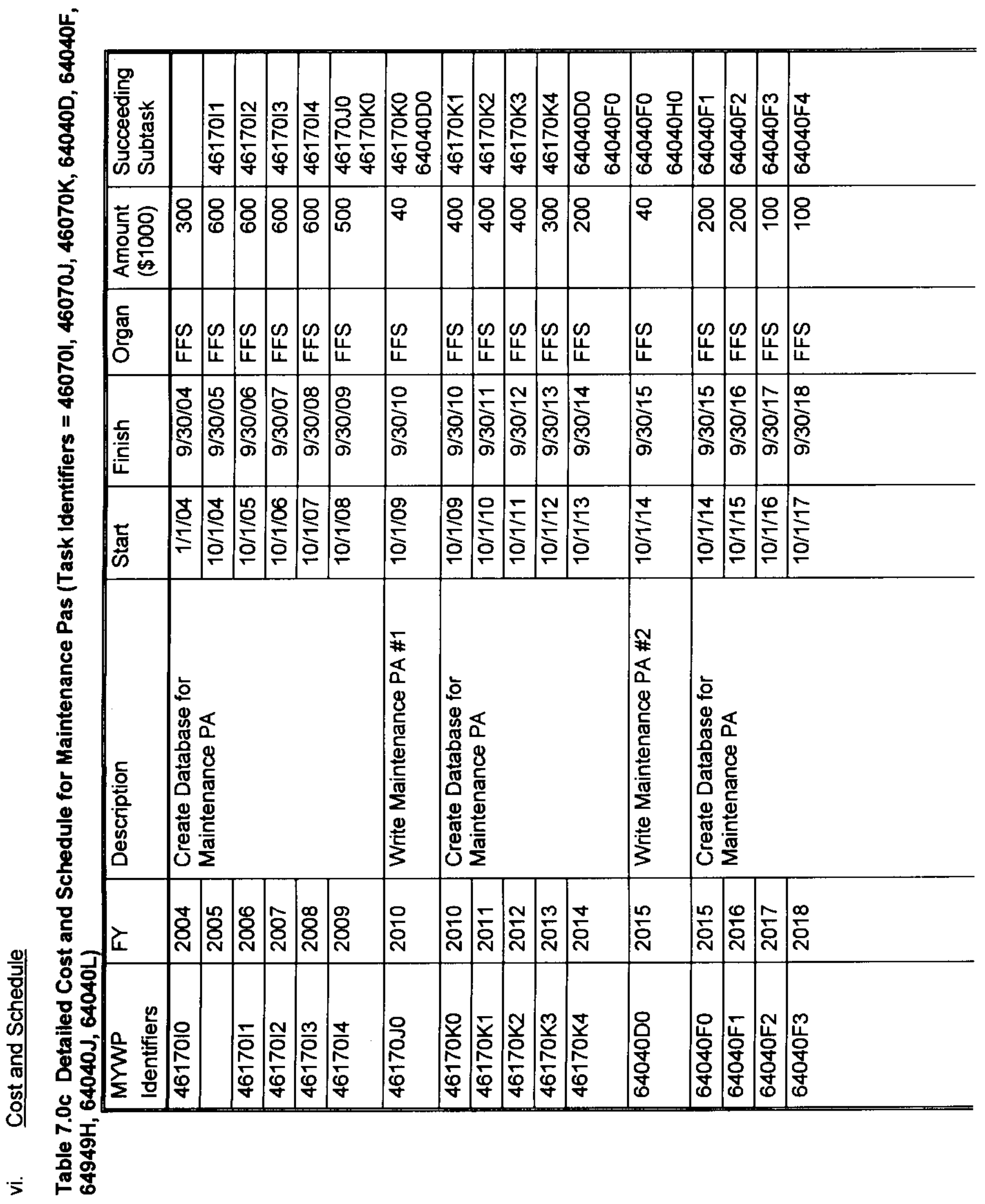


RPP-6702, Rev. 0

Formerly HNF-SD-WM-PAP-062 Rev. 4

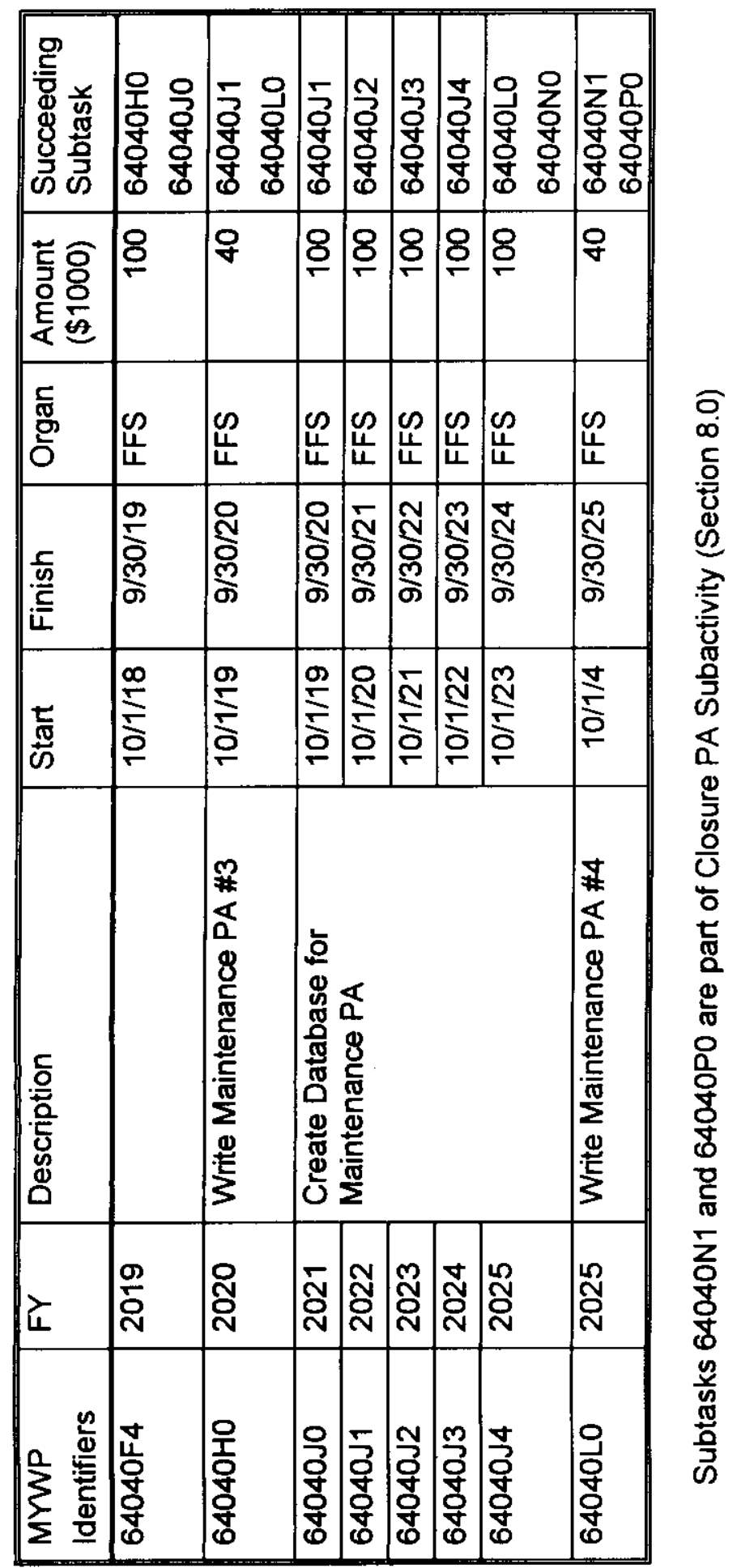


RPP-6702, Rev. 0

Formerly HNF-SD-WM-PAP-062 Rev. 4

\subsection{CLOSURE PERFORMANCE ASSESSMENT}

\section{A. SUMMARY}

Issue the report documenting the final state of knowledge of long-term environmental and human health impact from the disposal of the low-activity component of Hanford tank waste. The goal of this report is to receive permission from DOE to close all ILAW disposal facilities. The format and content of such reports shall follow the guidance provided by DOE .

\section{B. GENERAL}

i. Background

The DOE order on radioactive waste management (DOE 1999) mandates that before a disposal facility can be closed, a final maintenance performance assessment (known as a closure performance assessment) be approved. The purpose of this report is to give DOE reasonable assurance that after closure activities the long-term environmental and human health impact be acceptable.

Because of the newness of the policy and of the guidance and because only recently have performance assessments been approved, no practical experience exists (particularly at the Hanford Site).

ii. List of Deliverables

Table 8.0a List of Deliverables for Closure PA

\begin{tabular}{|l|l|c|l|}
\hline Description & $\begin{array}{l}\text { Due } \\
\text { Date }\end{array}$ & Level & $\begin{array}{l}\text { MWWP } \\
\text { Identifier }\end{array}$ \\
\hline Document Database For Closure PA & $3 / 31 / 27$ & 6 & $64040 N A$ \\
\hline Write Maintenance Closure PA & $9 / 30 / 27$ & 5 & $64040 \mathrm{~PB}$ \\
\hline $\begin{array}{l}\text { Receive Permission to Closure Disposal } \\
\text { Facility }\end{array}$ & $9 / 30 / 28$ & 6 & $64040 \mathrm{PA}$ \\
\hline
\end{tabular}


RPP-6702, Rev. 0

Formerly HNF-SD-WM-PAP-062 Rev. 4

iii. Cost Summary

WBS: $1 \cdot 1 \cdot 1 \cdot 3 \cdot 4 \cdot 1 \cdot 3.1$

TPCN: D4DM1

Table 8.0b Cost Summary for Closure PA

\begin{tabular}{|l|l|r|}
\hline \multicolumn{1}{|c|}{ Fiscal Year } & \multicolumn{1}{|c|}{ Organization } & \multicolumn{1}{|c|}{ Amount (\$1000) } \\
\hline 2025 & Fluor Federal Services (FFS) & 100 \\
\hline 2026 & FFS & 100 \\
\hline 2027 & FFS & 220 \\
\hline 2028 & FFS & 25 \\
\hline \hline Grand Total & 445 \\
\hline
\end{tabular}

iv. Detailed Description

Create the data base for and write the closure performance assessment. The level of effort for this activity is unknown as no DOE has even started to perform this activity. The data collection effort is assumed to on the level of the final maintenance performance assessment (Section 7.0) while the production of the document and interaction with the reviewers is at the level of the 1998, 2001, and 2005 performance assessments (Section 2.0, 4.0, and 6.0).

\section{v. Organization}

Fluor Federal Services (FFS) is shown as the organization performing the work only for convenience. 
RPP-6702, Rev. 0

Formerly HNF-SD-WM-PAP-062 Rev. 4

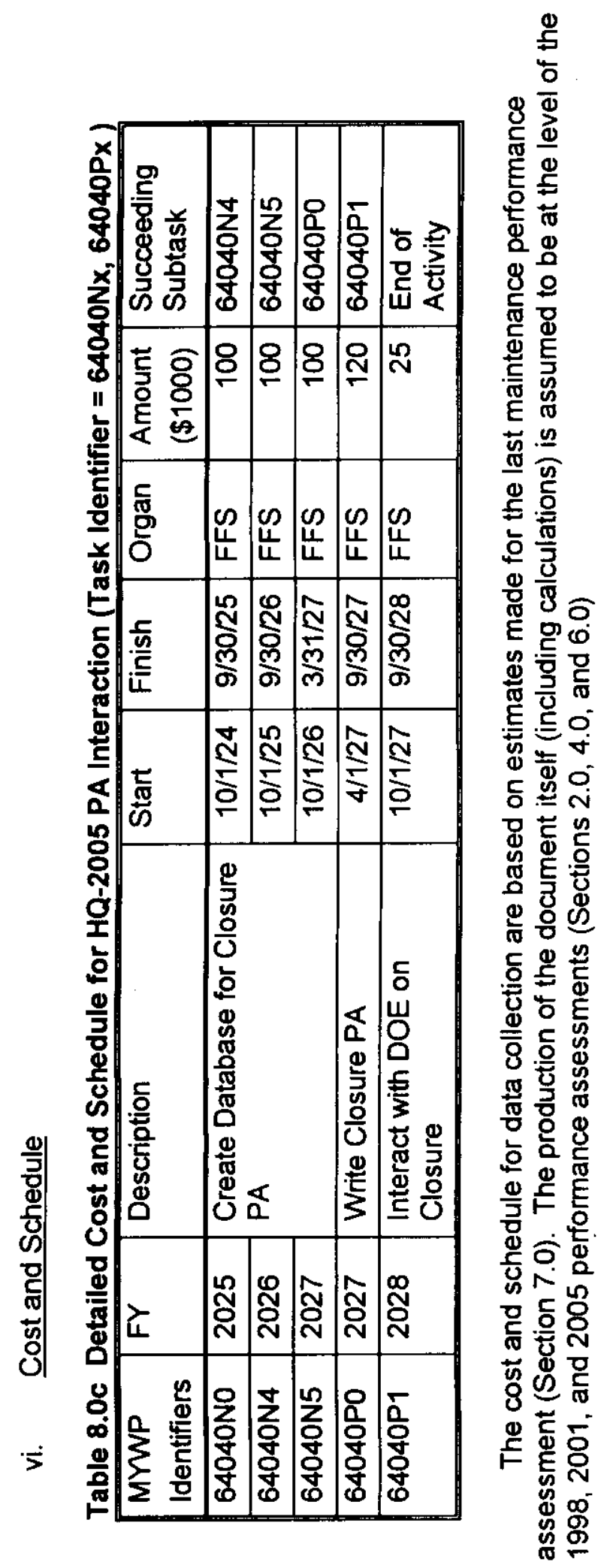


RPP-6702, Rev. 0

Formerly HNF-SD-WM-PAP-062 Rev. 4

\subsection{ACTIVITY SUPERVISION AND REVIEW}

\section{A. SUMMARY}

Provide program coordination and review as necessary to achieve maximum efficiency. Included in this subactivity are also interactions with the DOEs Peer Review Panel and with an extemal review board.

B. GENERAL

i. Background

Because of the many different activities in a variety of fields, program coordination and review are necessary to achieve maximum efficiency. Included in this subactivity are also interactions with the DOE's Peer Review Panel and with an external review board. These tasks are funded only for a limited time as such coordination and interaction will end as the major deliverables (the 2001 and 2005 performance assessments) are produced.

ii. List of Deliverables

Table 9.0-1a List of Deliverables for Activity Supervision

\begin{tabular}{|l|l|c|l||}
\hline Description & Due Date & $\begin{array}{c}\text { Leve } \\
\text { I }\end{array}$ & $\begin{array}{l}\text { MYWP } \\
\text { Identifier }\end{array}$ \\
\hline $\begin{array}{l}\text { Prepare Statement of Work (SOW) for } \\
\text { FY98 - 03 }\end{array}$ & done & 5 & FY97 \\
\hline Prepare SOW for FY99 - 04 & done & 5 & 46145 W0A \\
\hline Prepare SOW for FY 00 - 05 & done & 5 & 46145 W1A \\
\hline Prepare SOW for FY 01-06 & $\begin{array}{l}\text { this } \\
\text { document }\end{array}$ & 5 & 46145 W2C \\
\hline Prepare SOW for FY 02 - 07 & $6 / 15 / 01$ & 5 & $46160 \mathrm{~V} 1 \mathrm{~A}$ \\
\hline Prepare SOW for FY 03 - 08 & $6 / 15 / 02$ & 5 & $46160 \mathrm{~V} 2 \mathrm{~B}$ \\
\hline
\end{tabular}

iii. Cost Summary

WBS: $1.1 \cdot 1 \cdot 3 \cdot 4 \cdot 1 \cdot 3 \cdot 1$

TPCN: D4DM1

Table 9.0-1b Cost Summary for Supervision Task

\begin{tabular}{|l|l|r|}
\hline $\begin{array}{l}\text { Fiscal } \\
\text { Year }\end{array}$ & Organization & $\begin{array}{r}\text { Amount } \\
(\$ 1000)\end{array}$ \\
\hline \multirow{3}{*}{1997} & Fluor Federal Services (FFS) & 175.8 \\
\cline { 2 - 3 } & Lockheed Martin Hanford (LMH) & 65. \\
\cline { 2 - 3 } & Pacific Northwest National Laboratory (PNNL) & 40. \\
\cline { 2 - 3 } & Total & 280.8 \\
\hline 1998 & FFS & 292. \\
\cline { 2 - 3 } & LMH & 53.3
\end{tabular}


RPP-6702, Rev. 0

Formerly HNF-SD-WM-PAP-062 Rev. 4

\begin{tabular}{|c|c|c|}
\hline $\begin{array}{l}\text { Fiscal } \\
\text { Year }\end{array}$ & Organization & $\begin{array}{l}\text { Amount } \\
(\$ 1000)\end{array}$ \\
\hline & PNNL & 40. \\
\hline & Total & 385.3 \\
\hline \multirow[t]{4}{*}{1999} & FFS & 310 \\
\hline & $\mathrm{LMH}$ & 13.2 \\
\hline & PNNL & 40. \\
\hline & Total & 363.2 \\
\hline \multirow[t]{4}{*}{2000} & FFS & 310. \\
\hline & $\mathrm{CH} 2 \mathrm{M}$ Hill Hanford Group (CHG) & 12.9 \\
\hline & PNNL & 40. \\
\hline & Total & 362.9 \\
\hline \multirow[t]{4}{*}{2001} & FFS & 280. \\
\hline & $\mathrm{CHG}$ & 12.9 \\
\hline & PNNL & 40. \\
\hline & Total & 332.9 \\
\hline \multirow[t]{4}{*}{2002} & FFS & 280. \\
\hline & $\mathrm{CHG}$ & 12.9 \\
\hline & PNNL & 40. \\
\hline & Total & 332.9 \\
\hline \multirow[t]{4}{*}{2003} & FFS & 260. \\
\hline & CHG & 12.9 \\
\hline & PNNL & 40. \\
\hline & Total & 312.9 \\
\hline \multirow[t]{4}{*}{2004} & FFS & 260. \\
\hline & $\mathrm{CHG}$ & 12.9 \\
\hline & PNNL & 80. \\
\hline & Total & 352.9 \\
\hline \multirow[t]{4}{*}{2005} & FFS & 180. \\
\hline & PNNL & 40. \\
\hline & $\mathrm{CHG}$ & 12.8 \\
\hline & Total & 232.8 \\
\hline \multicolumn{2}{|c|}{ Grand Total } & 2956.6 \\
\hline
\end{tabular}

iv. Interfaces

These tasks interact with all activities as they involve the coordination and review of all the tasks of the performance assessment activity. In particular, the statements of work define the work that is planned for the performance assessment activity. 
RPP-6702, Rev. 0

Formerly HNF-SD-WM-PAP-062 Rev. 4

v. Organization

Fluor Federal Services (FFS) has the responsibility for coordinating the performance assessment activity. This role is assumed to continue for the life of the activity.

$\mathrm{CH} 2 \mathrm{M}$ Hill Hanford Group (CHG) is now the overall program manager for the RPP activity. Therefore the extemal contract for the advisory board is shown under that organization. Previous to 2000, it was Lockheed Martin Hanford Company (LMH)

The Pacific Northwest National Laboratory (PNNL) has supplied the technical representatives from the Hanford Site to DOE-headquarters for the review of performance assessments. PNNL is also leading the effort (the composite analysis) for determine the impact from the disposal of waste on the Hanford Site.

\section{TASK DESCRIPTIONS}

i. Summary List of Tasks
a. Provide Administration Support
b. Prepare Statements of Work
c. Provide Interaction with the Hanford Site Technical
Representative/Composite Analysis Team
d. Support External Advisory Board
e. Reissue IPA
f. Support Waste Integration Team
g. Interact with Hanford Groundwater / Vadose Zone Integration Project

ii. Provide Administration Support

\section{a. Background}

This task provides the general administrative support for the performance assessment activity. This task also funds all interactions with the RPP Program Office and general (i.e., non-task specific interactions) with DOE Headquarters and the Hanford Site Integrated Vadose Zone/Groundwater /Columbia River Project (HSIVZGWCRP). Specific task interactions, Interactions with DOE Headquarters on each performance assessment (4.C.v, 6.C.v, 7.0, 8.0) and interactions with the HSIVZGwCRP on groundwater model selection (3.2.c.x), are funded separately.

\section{b. List Of Deliverables}

Provide monthly cost and schedule reports.

Direct quarterly or semi-annual internal project review.

Provide multi-year work plan input (including activity planning forms, milestone description sheets, estimated worksheets, and basis of estimate documents).

Provide program planing and strategy information as needed by the program. 
RPP-6702, Rev. 0

Formerly HNF-SD-WM-PAP-062 Rev. 4

c. Cost Summary WBS: 1.1.1.3.4.1.3.1 TPCN: D4DM1

Table 9.0-2a Cost Summary for Provide Administrative Support

\begin{tabular}{|c|c|c|}
\hline Fiscal Year & Organization & $\begin{array}{l}\text { Amount } \\
(\$ 1000)\end{array}$ \\
\hline \multirow[t]{3}{*}{1997} & Fluor Federal Services (FFS) & 115.8 \\
\hline & Lockheed Martin Hanford (LMH) & 10. \\
\hline & Total & 125.8 \\
\hline \multirow[t]{3}{*}{1998} & FFS & 230. \\
\hline & LMH & 13.3 \\
\hline & Total & 243.3 \\
\hline \multirow[t]{3}{*}{1999} & FFS & 230. \\
\hline & LMH & 13.2 \\
\hline & Total & 243.2 \\
\hline \multirow[t]{3}{*}{2000} & FFS & 230. \\
\hline & CH2M Hill Hanford Group (CHG) & 12.9 \\
\hline & Total & 242.9 \\
\hline \multirow[t]{3}{*}{2001} & FFS & 200. \\
\hline & $\mathrm{CHG}$ & 12.9 \\
\hline & Total & 212.9 \\
\hline \multirow[t]{3}{*}{2002} & FFS & 200. \\
\hline & $\mathrm{CHG}$ & 12.9 \\
\hline & Total & 212.9 \\
\hline \multirow[t]{3}{*}{2003} & FFS & 200. \\
\hline & $\mathrm{CHG}$ & 12.9 \\
\hline & Total & 212.9 \\
\hline \multirow[t]{3}{*}{2004} & FFS & 200. \\
\hline & $\mathrm{CHG}$ & 12.9 \\
\hline & Total & 212.9 \\
\hline \multirow[t]{3}{*}{2005} & FFS & 150. \\
\hline & $\mathrm{CHG}$ & 12.8 \\
\hline & Total & 162.8 \\
\hline Beyond & & * \\
\hline \multicolumn{2}{|l|}{ Grand Total } & 1869.7 \\
\hline
\end{tabular}

- Funding for these types of activities is assumed to be small during the maintenance and closure phases and hence is included in Chapters 7 and 8. 
RPP-6702, Rev. 0

Formerly HNF-SD-WM-PAP-062 Rev. 4

d. Detailed Description

This task is responsible for all coordination of the performance assessment activity. It includes the management and financial interfaces with the RPP Program Office and with all those working on the performance assessment activity.

Continuing deliverables are monthly program status reports and financial variance reports. The program manager is kept informed of both progress and concerns.

e. Interfaces

This subtask interfaces with all performance assessment activities and with the RPP Program Office.

f. Organization

The Environmental and Nuclear Initiative Section of Fluor Federal Services (FFS) has had the lead responsibility for the performance assessment activity since the inception of the activity.

g. Quality Assurance

All activities will be conducted in accordance with 10 CFR 830.120.

h. Effect of Not Performing Task

With coordination, the many tasks contained in the performance assessment activity would quickly become disconnected and the necessary interfaces among tasks would disagree. Necessary reports (both managerial and financial) would not be submitted. 
RPP-6702, Rev. 0

Formerly HNF-SD-WM-PAP-062 Rev. 4
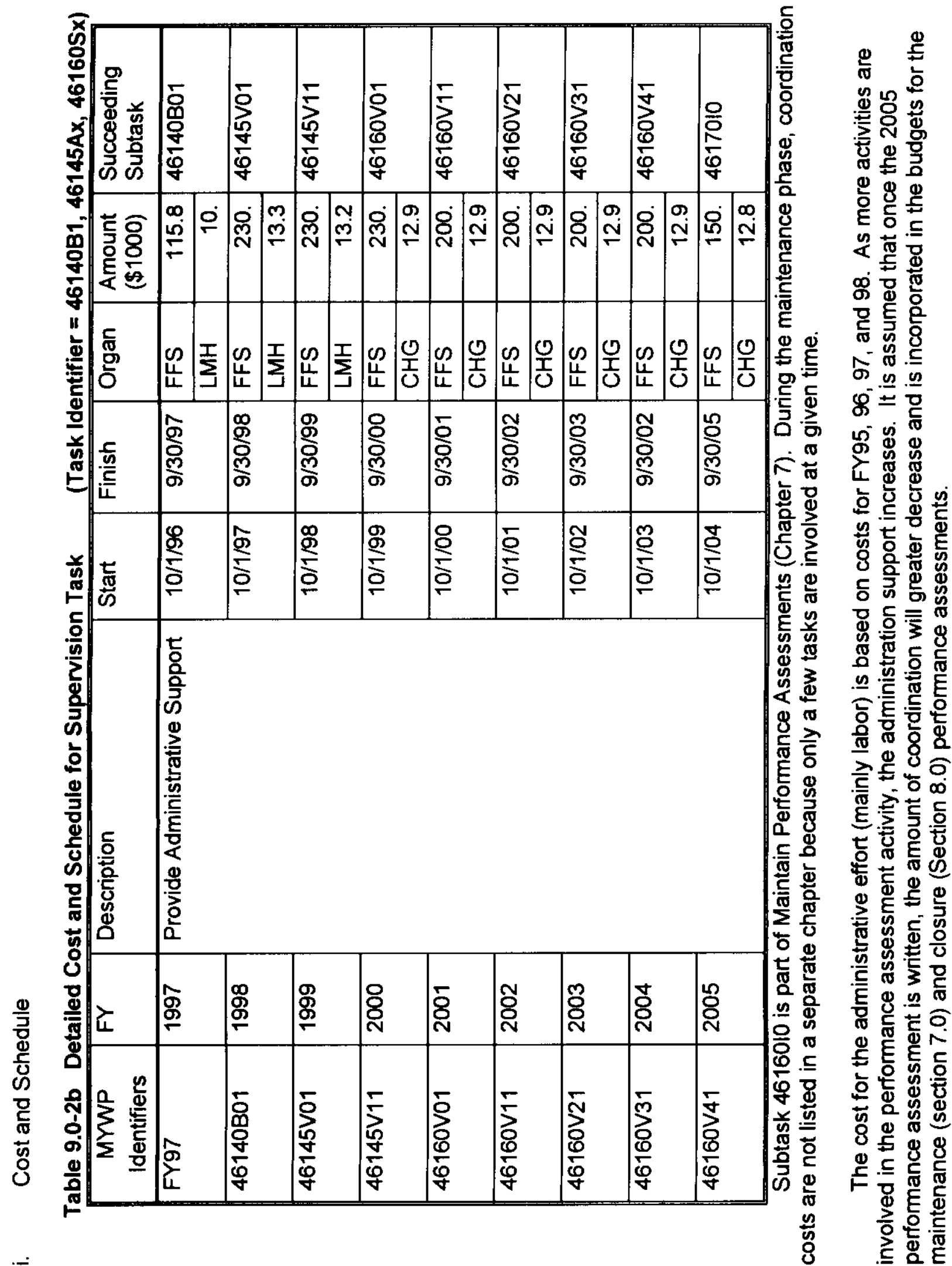
RPP-6702, Rev. 0

Formerly HNF-SD-WM-PAP-062 Rev. 4

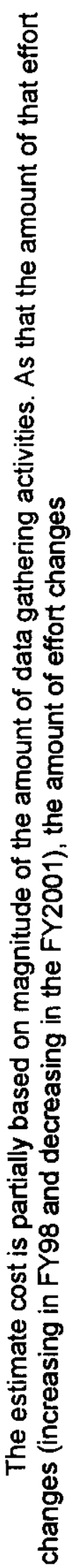


RPP-6702, Rev. 0

Formerly HNF-SD-WM-PAP-062 Rev. 4

iii. Prepare Statements of Work

a. Background

Many different tasks in many different disciplines are needed for the performance assessment. In order to ensure that only the needed subtasks are performed and that all of the subtasks are properly coordinated, a document describing the subtasks, tasks, and subactivity and describing the relationships among all this work is created.

Statements of work have been produced for the performance assessment activity in 1994 (Mann 1994), 1995 (Mann 1995d), 1997 (Mann 1997b), and in 1998 (the present document). Because of the sharply reduced budget in 1996, no statement of work was produced in that year, but instead the previous years effort was used.

The preparation of Statements of Work will not occur after Fiscal Year 2003 as the amount of effort in the performance assessment activity will greatly reduced, only approval of the 2005 performance assessment and maintenance activities will be performed. If the amount of effort again becomes significant, then statements of work will be created.

b. List Of Deliverables

Table 9.0-3a List of Deliverables for Prepare Statements of Work

\begin{tabular}{|l|l|c|l|}
\hline Description & Due Date & Level & $\begin{array}{l}\text { MYWP } \\
\text { Identifier }\end{array}$ \\
\hline $\begin{array}{l}\text { Prepare Statement of Work (SOW) for } \\
\text { FY98-03 }\end{array}$ & done & 5 & $\star$ \\
\hline Prepare SOW for FY99-04 & $\begin{array}{l}\text { this } \\
\text { document }\end{array}$ & 5 & $\begin{array}{l}46145 W 0 A \\
{[46140 W 01]}\end{array}$ \\
\hline Prepare SOW for FY00-05 & $6 / 15 / 99$ & 5 & $\begin{array}{l}46145 W 1 B \\
{[46145 W 11]}\end{array}$ \\
\hline Prepare SOW for FY01-06 & $6 / 15 / 00$ & 5 & $\begin{array}{l}4614 W 2 C \\
{[46145 W 21]}\end{array}$ \\
\hline Prepare SOW for FY02-07 & $6 / 15 / 01$ & 5 & $46160 \mathrm{~V} 1 \mathrm{~A}$ \\
\hline Prepare SOW for FY03-08 & $6 / 15 / 02$ & 5 & $46160 \mathrm{~V} 2 \mathrm{~B}$ \\
\hline
\end{tabular}

As the statements of work define all the effort in the succeeding years, all activities in those years are successors to the subtask.

c. Cost Summary

WBS: $1.1 \cdot 1 \cdot 3 \cdot 4 \cdot 1 \cdot 3 \cdot 1$

TPCN: D4DM1

Table 9.0-3b Cost Summary for Prepare SOWs

\begin{tabular}{|l|l|r|}
\hline \multicolumn{1}{|c|}{ Fiscal Year } & \multicolumn{1}{|c|}{ Organization } & Amount $(\$ 1000)$ \\
\hline 1997 & Fluor Federal Services (FFS) & 15 \\
\hline 1998 & FFS & 20 \\
\hline 1999 & FFS & 20 \\
\hline
\end{tabular}


RPP-6702, Rev. 0

Formerly HNF-SD-WM-PAP-062 Rev. 4

\begin{tabular}{|l|l|r|}
\hline 2000 & FFS & 20 \\
\hline 2001 & FFS & 20 \\
\hline 2002 & FFS & 20 \\
\hline \hline Grand Total & 115 \\
\hline
\end{tabular}

d. Detailed Description

This subtask prepares revisions to this document. Changes are expected due to budget guidance, changes in regulatory requirements, and changes in management direction.

e. Interfaces

This subtask interfaces with all performance assessment activities as it defines those activities.

f. Organization

The Environmental and Nuclear Initiatives Section of Fluor Federal Services (FFS) leads the performance assessment activity and has produced all statements of work for that activity.

g. Quality Assurance

Not applicable.

h. Effect of Not Performing Task

Without this subtask, the planning effort for the performance assessment activity would be greatly reduced. The DOE Headquarters (FM-50) Financial Review Team (Integrated Cost Evaluation) termed the previous edition, one of the best planning documents found in the complex. 
RPP-6702, Rev. 0

Formerly HNF-SD-WM-PAP-062 Rev. 4

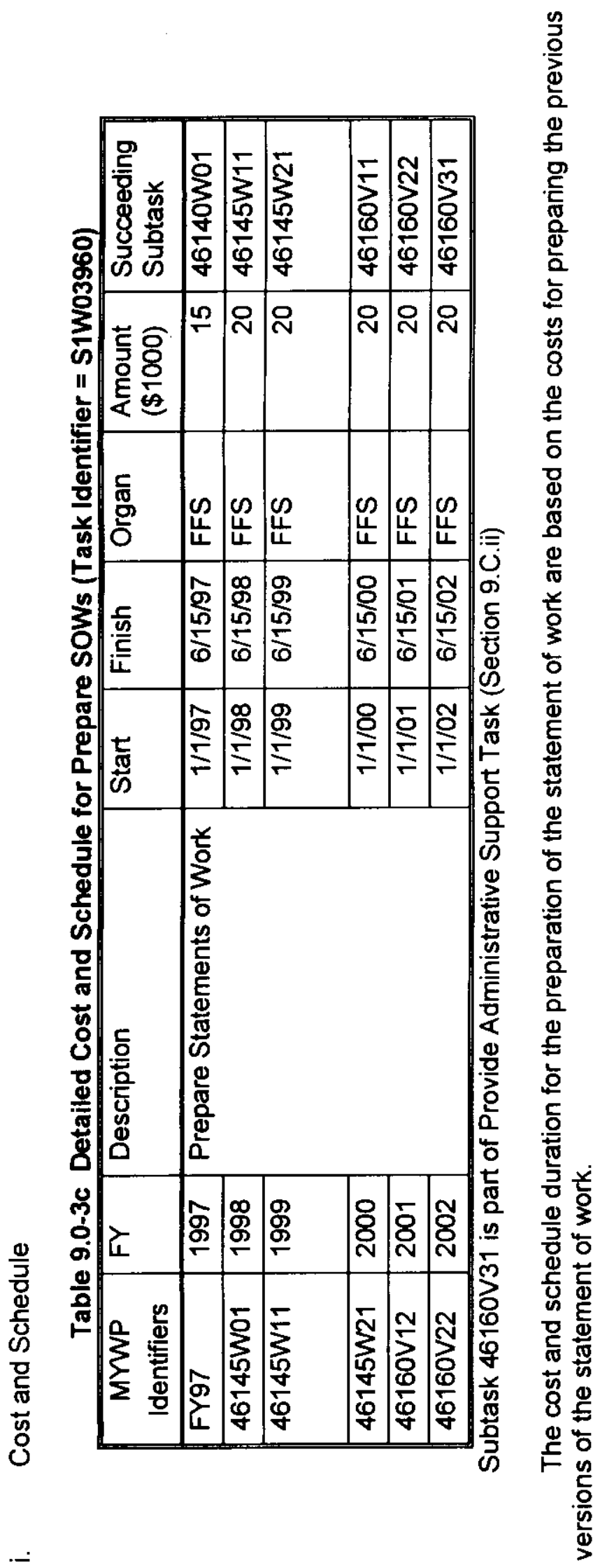


RPP-6702, Rev. 0

Formerly HNF-SD-WM-PAP-062 Rev. 4

iv. Provide Interaction with the Hanford Site Technical Representative/Composite Analysis Team

a. Background

DOE-headquarters established a Per Review Panel (PRP) to aid them in the review of performance assessments. More recently, the Richland Operations representative has chosen a technical representative to aid him in the technical review of performance assessments and composite analyses. This technical representative advises the performance assessment activity and recommends actions to increase the probability of the acceptance of the performance assessment by the headquarters groups. Funding for this task is included only through the approval of the 2005 performance assessment.

DOE now requires headquarters approval of both the performance assessment and the composite analysis before waste can be disposed. The composite analysis estimates the impact of all of the site's actions at the site fenceline. The composite analysis also uses different performance objectives for compliance. Since the performance assessment and the composite analysis used similar data and methods and since the composite analysis is also needed for waste disposal authorization, a close tie between the two documents is crucial.

With the creation of the Hanford Groundwater Vadose Zone Integration Project and with that project taking responsibility for the Composite Analysis, this task is being merged with the Interact with the Hanford Groundwater Vadose Zone Integration Project (see 9.C.viii).

b. List Of Deliverables

1. Reports on activities of the Peer Review Panel and its successor under DOE Order 435.1

2. Copies of the Composite Analysis as they are produced.

3. Guidance based on Headquarters and $R L$ interactions and in producing the Composite Analysis (particularly in regard to the level of technical justification needed for acceptance and to strategy for submittal).

c. Cost Summary

WBS: $1.1 \cdot 1 \cdot 3 \cdot 4 \cdot 1.3 .1$

TPCN: D4DM1

Table 9.0-4a Cost Summary for PRP/CA Interaction

\begin{tabular}{|l|l|r|}
\hline $\begin{array}{c}\text { Fiscal } \\
\text { Year }\end{array}$ & \multicolumn{1}{|c|}{ Organization } & $\begin{array}{r}\text { Amount } \\
(\$ 1000)\end{array}$ \\
\hline 1997 & Pacific Northwest National Laboratory (PNNL) & 40 \\
\hline 1998 & PNNL & 40 \\
\hline 1999 & PNNL & 40 \\
\hline 2000 & PNNL & 40 \\
\hline 2001 & PNNL & 40 \\
\hline 2002 & PNNL & 40 \\
\hline
\end{tabular}


RPP-6702, Rev. 0

Formerly HNF-SD-WM-PAP-062 Rev. 4

\begin{tabular}{|l|l|r|}
\hline 2003 & PNNL & 40 \\
\hline 2004 & PNNL & 40 \\
\hline 2005 & PNNL & 40 \\
\hline \hline Grand Total & 360 \\
\hline
\end{tabular}

d. Detailed Description

Provide recommendations based on technical review and interactions of performance assessments and composite analyses sent to Headquarters for review.

Coordinate with the composite analysis team and provide information learned from that team to the performance assessment activity.

e. Interfaces

As the Peer Review Panel decisions and recommendations can affect any element of the performance assessment, this task can interface with any task in the performance assessment activity. However, the greatest interface will be with the writing of the performance assessment documents (4.C.iv and 6.C.iv) and with their review (4.C.v and 6.C.V).

f. Organization

Charlie Kincaid of the Hydrology Section of the Pacific Northwest National Laboratory is the Hanford technical representative. He is also the technical lead of the Hanford Site Composite Analysis.

g. Quality Assurance

All activities will be conducted in accordance with 10 CFR 830.120.

h. Effect of Not Performing Task

Less coordination will greatly reduce the probability that the performance assessment will be approved. 
RPP-6702, Rev. 0

Formerly HNF-SD-WM-PAP-062 Rev. 4

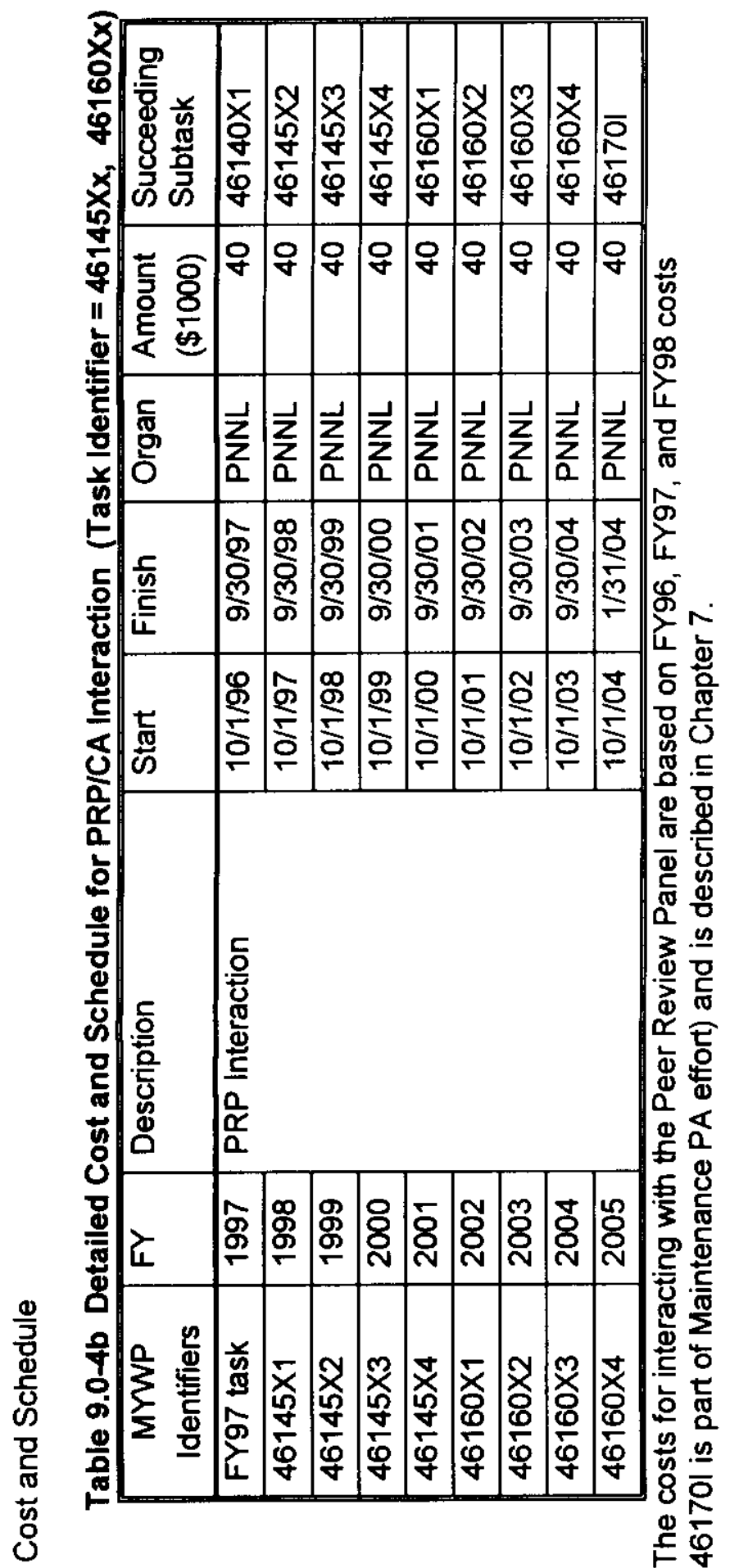


RPP-6702, Rev. 0

Formerly HNF-SD-WM-PAP-062 Rev. 4

v. Support External Advisory Board (Complete)

a. Background

The external advisory board was created to serve as the Peer Review Board (defined in DOE Order 5820.2A) for the interim performance assessment (Mann 1996) as the interim performance assessment was not formally reviewed by DOE Headquarters. With the change in strategy of submitting a performance assessment in 1998 (Mann 1998a), future activities of the review board will be to advise the program office of ways to cost effectively meet the requirements and recommendations of DOE Headquarters and other bodies.

b. List Of Deliverables

Table 9.0-5a List of Deliverables for Advisory Board

\begin{tabular}{|l|l|c|l|}
\hline Description & Due Date & Level & Identifier \\
\hline Place contract for services of the board & Done & 6 & FY97 \\
\hline Receive Comments from Board on IPA & Done & 7 & FY97 \\
\hline
\end{tabular}

Future efforts will be defined by activities funded for each year. Therefore more emphasis may be placed on geotechnical advice as brothels are drilled and samples are measured. Likewise, as DOE Order 435.1 is implemented, advice on how headquarters and other DOE sites are responding will take precedence. As activities with the Hanford Advisory Board increased, advice will be sought on public interactions. Finally as waste form data collection accelerates, comments on our testing will be sought.

c. Cost Summary

WBS: $1.1 \cdot 1 \cdot 3 \cdot 4 \cdot 1 \cdot 3 \cdot 1$

TPCN: D4DM1

Table 9.0-5b Cost Summary for Advisory Board

\begin{tabular}{|l|l|r|}
\hline $\begin{array}{c}\text { Fiscal } \\
\text { Year }\end{array}$ & \multicolumn{1}{|c|}{ Organization } & $\begin{array}{c}\text { Amount } \\
(\$ 1000)\end{array}$ \\
\hline 1997 & Fluor Federal Services (FFS) & 10 \\
\cline { 2 - 3 } & Lockheed Martin Hanford Company (LMH) & 55 \\
\cline { 2 - 3 } & Total & 65 \\
\hline 1998 & LMH & 40 \\
\hline \hline Grand total & 105 \\
\hline
\end{tabular}

d. Detailed Description

The review board will review the activities of the performance assessment activity as determined by the RPP Program manager and the RL Program Manager. See discussion under deliverables. 
RPP-6702, Rev. 0

Formerly HNF-SD-WM-PAP-062 Rev. 4

e. Interfaces

The review board will review all of the performance assessment tasks. Therefore all tasks may be impacted.

f. Organization

As the funding agent for the performance assessment activity, Lockheed Martin Hanford Company (LMH) is shown as the organization responsible for the effort. Members of the review board are all external to Hanford.

Fluor Federal Services as the leader of the performance assessment activity will maintain the closest contact with the group. 
Formerly HNF-SD-WM-PAP-062 Rev. 4

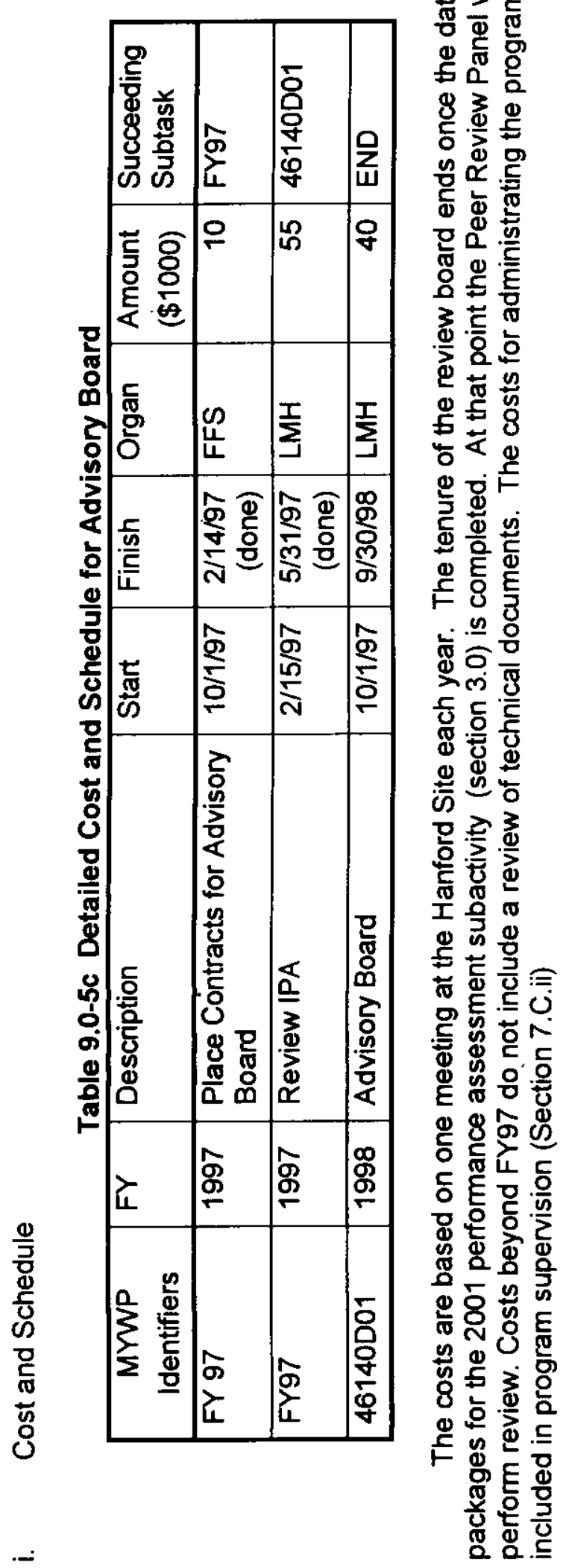


RPP-6702, Rev. 0

Formerly HNF-SD-WM-PAP-062 Rev. 4

vi. Reissue Interim Performance Assessment (Complete) (completed)

a. Background

The Interim Performance Assessment (Mann 1997a) analyzes the long-term environmental and human health risk from disposing the immobilized low-activity tank waste at the Hanford Site. This document used the methods and techniques used in performance assessments required by DOE Order on radioactive waste management (DOE 1988). However, because the document was created early in the life of the project, much of the data used in the document was not of the quality normally found in a performance assessment.

b. List Of Deliverables

Table 9.0-6a List of Deliverables for Reissue IPA

\begin{tabular}{|l|l|c|l|}
\hline Description & Due Date & Level & Identifier \\
\hline Reissue IPA & done & 5 & FY97 \\
\hline
\end{tabular}

c. Cost Summary

WBS: $1.1 \cdot 1 \cdot 3 \cdot 4 \cdot 1.3 .1$

TPCN: D4DM1

Table 9.0-6b Cost Summary for Reissue IPA

\begin{tabular}{|c|l|l|}
\hline Fiscal Year & \multicolumn{1}{|c|}{ Organization } & Amount $(\$ 1000)$ \\
\hline 1997 & Fluor Federal Services (FFS) & 35 \\
\hline
\end{tabular}

d. Detailed Description

Based on the comments from the external advisory board, Hanford stakeholders, and Hanford Site staff, the Hanford Low-Level Tank Waste Interim Performance Assessment (Mann 1996) will be revised and reissued. Rev. 1 was published in September 1997 (Mann 1997a)

e. Interfaces

Comments were received from the Advisory Board (see previous section).

f. Organization

The Environmental and Nuclear Initiative Section of Fluor Federal Services (FFS) wrote the Interim Performance Assessment. 
RPP-6702, Rev. 0

Formerly HNF-SD-WM-PAP-062 Rev. 4

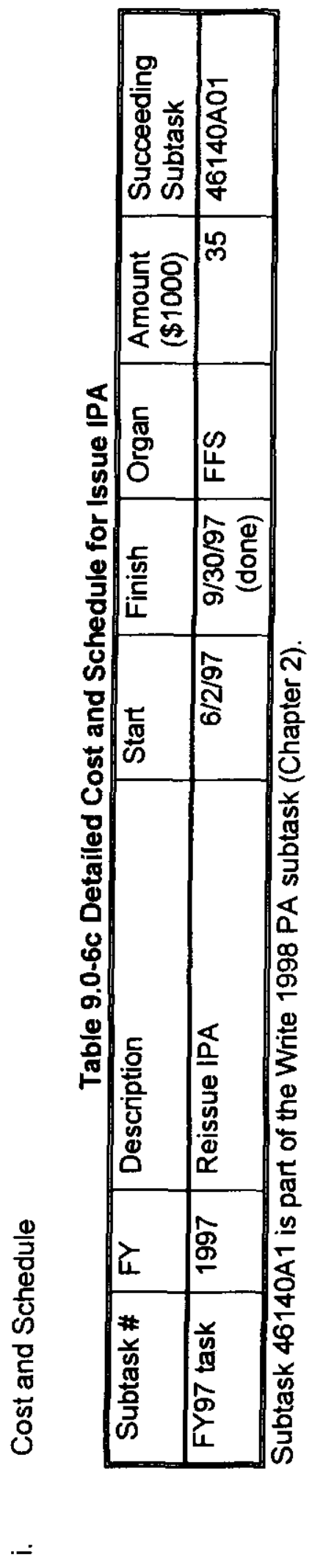


RPP-6702, Rev. 0

Formerly HNF-SD-WM-PAP-062 Rev. 4

vii. Provide Support to the Waste Integration Team

a. Background

The Waste Integration Team (WIT) is the group that DOE has set up to manage the contracts will the treatment vendors for the treatment and immobilization of the tank waste. Because the performance assessment activities is a major source of information for setting specifications for the vendors, members of the waste integration team interact with the performance assessment team.

b. Cost Summary

WBS: $1 \cdot 1 \cdot 1 \cdot 3 \cdot 4 \cdot 1 \cdot 3 \cdot 1$

TPCN: D4DM1

Table 9.0-7a Cost Summary for Support WIT

\begin{tabular}{|l|l|r|}
\hline \multicolumn{1}{|c|}{ Fiscal Year } & \multicolumn{1}{|c|}{ Organization } & Amount (\$1000) \\
\hline 1998 & Fluor Federal Services (FFS) & 30 \\
\hline 1999 & FFS & 30 \\
\hline 2000 & FFS & 30 \\
\hline 2001 & FFS & 30 \\
\hline 2002 & FFS & 30 \\
\hline 2003 & FFS & 30 \\
\hline 2004 & FFS & 30 \\
\hline 2005 & FFS & 30 \\
\hline \hline Total & & 240 \\
\hline
\end{tabular}

d. Detailed Description

Provide support to Waste Integration Team as requested.

e. Interfaces

Waste Integration Team. Others in performance assessment team as appropriate.

f. Organization

The Environmental and Nuclear Initiative Section of Fluor Federal Services (FFS) is presently leading the performance assessment effort.

g. Quality Assurance

All activities will be conducted in accordance with 10 CFR 830.120.

h. Effect of Not Performing Task manner.

Supporting of the waste integration team will be done in an informal, best-effort 
RPP-6702, Rev. 0

Formerly HNF-SD-WM-PAP-062 Rev. 4

i. Cost and Schedule

Table 9.0-7b Detailed Cost and Schedule for Support WIT (Task Identifier $=46145 \mathrm{Yx}$, 46160YX)

\begin{tabular}{|c|c|c|c|c|c|c|c|}
\hline $\begin{array}{c}\text { MYWP } \\
\text { Identifier }\end{array}$ & $F Y$ & Description & Start & Finish & Organ & $\begin{array}{l}\text { Amount } \\
(\$ 1000)\end{array}$ & $\begin{array}{l}\text { Succeeding } \\
\text { Subtask }\end{array}$ \\
\hline $46145 Y 0$ & 1998 & \multirow{8}{*}{$\begin{array}{l}\text { Support Waste } \\
\text { Integration Team }\end{array}$} & $10 / 1 / 97$ & $9 / 30 / 98$ & FFS & 30 & $46145 A 41$ \\
\hline $46145 Y 1$ & 1999 & & $10 / 1 / 98$ & $9 / 30 / 99$ & FFS & 30 & $46145 \mathrm{~A} 42$ \\
\hline $46145 Y 2$ & 2000 & & $10 / 1 / 99$ & $9 / 30 / 00$ & FFS & 30 & $46145 A 43$ \\
\hline $46145 Y 3$ & 2001 & & $10 / 1 / 00$ & $9 / 30 / 01$ & FFS & 30 & 46160521 \\
\hline $46160 Y 1$ & 2002 & & $10 / 1 / 01$ & $9 / 30 / 02$ & FFS & 30 & $46160 S 22$ \\
\hline $46160 Y 2$ & 2003 & & $10 / 1 / 02$ & $9 / 30 / 03$ & FFS & 30 & $46160 \$ 23$ \\
\hline $46160 Y 3$ & 2004 & & $10 / 1 / 03$ & $9 / 30 / 04$ & FFS & 30 & 46160524 \\
\hline $46160 Y 4$ & 2005 & & $10 / 1 / 04$ & $3 / 30 / 05$ & FFS & 30 & 461701 \\
\hline
\end{tabular}

Estimate based on effort expected. Effort is expected to significantly decreased once 2005 Performance Assessment has been approved and results incorporated into phase II Specifications.

Activity 46170 (Maintenance Pas) is described in Chapter 7. 
RPP-6702, Rev. 0

Formerly HNF-SD-WM-PAP-062 Rev. 4

viii. Provide Support to the Hanford Site Groundwater / Vadose Zone Integration Project

a. Background

DOE (Wagoner 1996) has mandated that a single groundwater model be established for the Hanford Site. The Pacific Northwest National Laboratory (PNNL) will lead the effort to standardize the model. The RPP low-activity tank waste performance assessment will work with PNNL in establishing the model and determining the rules for its use.

As a outgrowth of this groundwater integration and other efforts, DOE has established the Hanford Groundwater / Vadose Zone Integration Project to coordinate all Hanford Site activities that involve the vadose zone, groundwater, or the Columbia River and to act as a single point of contact for all such activities.

The Integration Project has taken over the responsibility of producing the Hanford Site Composite Analysis. Starting in FYOO, the task to interact with the Composite Analysis is merged into this effort.

b. List Of Deliverables

Table 9.0-8a List of Deliverables for Support Hanford Site Integration

\begin{tabular}{|l|c|c|l|}
\hline Description & Due Date & Level & $\begin{array}{l}\text { MWWP } \\
\text { Identifier }\end{array}$ \\
\hline $\begin{array}{l}\text { Select Model to be Used for } \\
\text { Aquifer Transport }\end{array}$ & $12 / 31 / 99$ & 8 & $\begin{array}{l}46145 \mathrm{PE} \\
{[46145 \mathrm{P} 22]}\end{array}$ \\
\hline
\end{tabular}

c. Cost Summary WBS: 1.1.1.3.4.1.3.3 TPCN: D4DM3

Table 9.0-8b Cost Summary for 2001 PA Groundwater Code Data Package

\begin{tabular}{|l|l|r|}
\hline Fiscal Year & Organization & Amount (\$1000) \\
\hline 1998 & Fluor Federal Services (FFS) & 12 \\
\hline 1999 & FFS & 30 \\
\hline 2000 & FFS & 30 \\
\hline 2001 & FFS & 30 \\
\hline 2002 & FFS & 30 \\
\hline 2003 & FFS & 30 \\
\hline 2004 & FFS & 30 \\
& Pacific Northwest National Laboratory (PNNL) & 40 \\
\hline Grand total & & 232 \\
\hline
\end{tabular}

d. Detailed Description

Interact with the Hydrology Section of the Pacific Northwest Laboratory (PNNL) which has been given responsibility by DOE for selecting the groundwater computer model and code to be used at the Hanford Site. The requirements and needs of the performance assessment activity shall be communicated to PNNL. Documentation on the computer code and model selection and verification process shall be reviewed. $A$ 
RPP-6702, Rev. 0

Formerly HNF-SD-WM-PAP-062 Rev. 4

document shall be prepared for the Data Packages for the 2001 Performance

Assessment.

Interact with the Hanford Site Vadose Zone / Groundwater / Columbia River Project. Such interaction shall include providing information from the ILAW performance assessment to the integration project, being part of the integration teams, and carrying out requirements from the integration project.

e. Organization

The Environmental and Nuclear Initiatives Section of Fluor Federal Services (FFS) has overall leadership of the performance assessment effort. This section produced the interim and ILAW performance assessments and has the best understanding of the groundwater modeling needs for the performance assessment effort.

f. Quality Assurance

All activities will be conducted in accordance with 10 CFR 830.120 .

g. Effect of Not Performing Task

The estimation of the groundwater flow underneath the disposal facility sites is one of the most important factors in determining the long-term impact of the disposal of waste. Without an adequate groundwater modeling code, conservative estimates of such flow would be necessary, introducing large conservatism into the analysis. 
RPP-6702, Rev. 0

Formerly HNF-SD-WM-PAP-062 Rev. 4

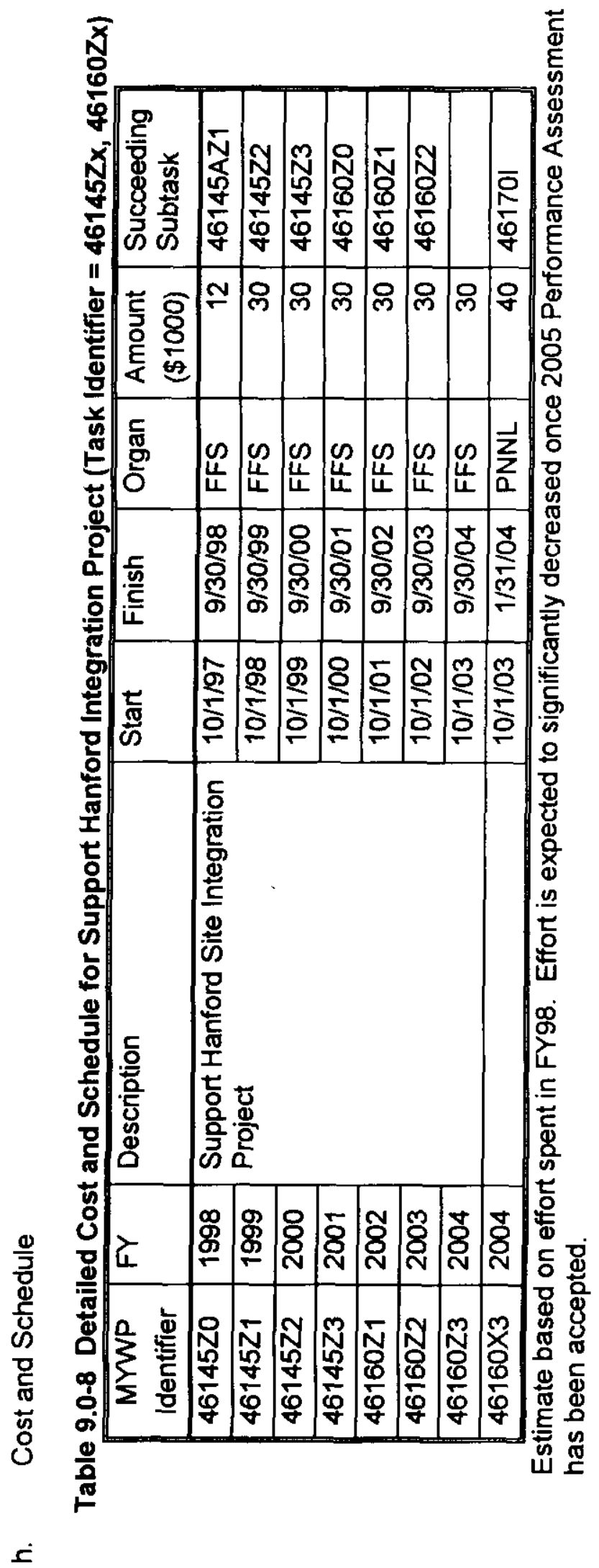


RPP-6702, Rev. 0

Formerly HNF-SD-WM-PAP-062 Rev. 4

\subsection{REFERENCES}

Allison 1988, G.B. Allison, A review of some of the physical, chemical, and isotopic techniques available for estimating groundwater recharge, NATO ASI Ser. Ser C, 222, 49-72, 1988.

Allison 1994, G.B. Allison, G.W. Gee, and S.W. Tyler, Vadose-zone techniques for estimating groundwater recharge in arid and semiarid regions, Soil Sci. Soc. Am. J., 58, 6-14, 1994.

Alm 1997, A.L. Alm (Assistant Secretary for Environmental Management), "Critical Assumptions for Department of Energy Low-Level Waste Disposal Facility Assessments", attachment to letter dated March 7, 1997 to John T. Conway (Chairman, Defense Nuclear Facilities Safety Board), Department of Energy, Washington, D.C.

Arya, L.M., and J.F. Paris, A physicoempirical model to predict the soil moisture characteristic from particle-size distribution and bulk density data, Soil Sci. Soc. Am. J., 45, 10231030, 1981.

Babad and Strachan, 1980, H. Babad, and D. M. Strachan, Method for immobilizing radioactive iodine, US Patent 4,229,317, Washington, DC, 1980.

Bacon 2000, D.H. Bacon, M.D. White, and B.P. McGrail, Subsurface Transport Over Reactive Multiphases (STORM): A General, Coupled Nonisothermal Multiphase Flow, Reactive Transport, and Porous Medium Alteration Simulator, Version2, User's Guide, PNNL13108, Pacific Northwest National Laboratory, February 2000.

Barrer 1982, R. M. Barrer, Hydrothermal Chemistry of Zeolites, Academic Press, New York, New York, 360 pg, 1982.

Bibler, N.E., Kinard, W.F., Boyce, W.T. and Coleman, C.J.(1998) Determination of long lived fission products and actinides in Savannah River Site HLW sludge and glass for waste acceptance. Jour. Rad. Nuc. Chem. vol. 234, pp. 159-163

Bouwer 1984, H. Bouwer and R.C. Rice, Hydraulic Properties of Stony Vadose Zones, Ground Water, vol. 22, pp. 696-705.

Breck 1974, D. W. Breck, Zeolite Molecular Sieves, Structure, Chemistry and Use, John Wiley and Sons, New York, New York, pg 771, 1974.

Burbank 1997, D.A. Burbank and M.J. Klem, Analysis Altematives for Immobilized Low-Activity Waste Disposal, HNF-SD-TWR-AGA-004, Rev. 0, SGN Eurisys Services Corporation, Richland, Washington, October 1997.

Caggiano, 1996, J. A. Caggiano, Assessment Groundwater Monitoring Plan for Single Shell Tank Waste Management Area S-SX. WHC-SD-EN-AP-191, Rev. 0, Westinghouse Hanford Company, Richland, WA.

Chunsheng, L., Jingru, G. and Daming, L. (1997) A procedure for the separation of ${ }^{79}$ Se from fission products and application to the determination of the ${ }^{79}$ Se halfife. Jour. Rad. Nuc. Chem. vol. 220, pp. 69-71. 
RPP-6702, Rev. 0

Formerly HNF-SD-WM-PAP-062 Rev. 4

Davis, et al. 1987. J. A. Davis, C. C. Fuller, and A. D. Cook, A model for trace metal sorption processes at the calcite surface: Adsorption of cadmium ion(2+) and subsequent solid solution formation, Geochim. Cosmochim. Acta, 51, 1477-1490,1987.

De Smedt 1984, F. De Smedt and P. J. Wierenga. Solute Transfer through Columns of Glass Beads. Water Resources Res. 20:225-232.

DOE 1996. Focused feasibility study of engineered barriers for Wastes Management Units in the 200 Areas, DOE/RL-93-33, Rev. 0, U.S. Department of Energy, Richland, Washington.

DOE. 1997. TWRS Vadose Zone Contamination /ssue Expert Pane/ Status Report, DOE/RL-9749 REV. 0, U.S. Department of Energy, Richland, Washington.

DOE 1988, Radioactive Waste Management, DOE Order 5820.2A, U.S. Department of Energy, Washington, D.C., September 26, 1988. Note that this order is being revised and will be published as DOE Order 435.1. The effective date for the new order is projected to be October 1, 1999.

[Chapter III, Section 3 describes the requirement and content of a performance assessment.]

DOE 1996. Focused feasibility study of engineered bamiers for Wastes Management Units in the 200 Areas, DOE/RL-93-33, Rev. 0, U.S. Department of Energy, Richland, Washington.

DOE 1997. TWRS Vadose Zone Contamination Issue Expert Panel Status Report, DOE/RL-9749 REV. 0, U.S. Department of Energy, Richland, Washington.

DOE 1999a, "Radioactive Waste Management", DOE O 435.1, U.S. Department of Energy, Washington, D.C., July 9, 1999. This order is implemented in Manual for DOE O 435.1", DOE M 435.1, U.S. Department of Energy, Washington, D.C., July 9, 1999.

DOE 1999b, "Conditional Acceptance of the Immobilized Low-Activity Tank Waste Disposal Facility Performance Assessment and the Hanford Site 200 Plateau Composite Analysis," Memorandum from James J. Fiore and Mark W. Frei to Richard French and Keith A. Klein, U.S. Department of Energy, Washington, D.C., October 20, 1999.

DOE 1999c, "Disposal Authorization for the Hanford Site Low-Level Waste Disposal Facilities," Memorandum from James J. Fiore and Mark W. Frei to Richard French and Keith A. Klein, U.S. Department of Energy, Washington, D.C., October 25, 1999.

DOE/RL 1998, F. M. Mann, R.J. Puigh II, C. R. Eiholzer, A. H. Lu, P. D. Rittmann, N. W. Kline, Y. Chen, and B. P. McGrail, Hanford Low-Activity Tank Waste Performance Assessment, DOE/RL-97-69, Rev. 0, Lockheed Martin Hanford Company, Richland, Washington, March 1998.

Eiholzer 1955, Disposal Facility Data for the Interim Performance Assessment, WHC-SD-WMRPT-159, Westinghouse Hanford Company, Richland, Washington, May 1995.

Evans 2000, R.G. Evans, M.J. Hattendorf, and C.T. Kincaid, Evaluation of the Potential for Agricultural Development at the Hanford Site, PNNL-13125, Pacific Northwest National 
RPP-6702, Rev. 0

Formerly HNF-SD-WM-PAP-062 Rev. 4

Laboratory, Richland, Washington, January 2000. This work was performed by the Washington State University.

Fayer 1990, M.J. Fayer and T.L. Jones,_UNSAT-H version 2.0: Unsaturated soil water and Heat Flow Model. PNL-6779, Pacific Northwest Laboratory, Richland, Washington, 1990.

Fayer 1995, M.J. Fayer,_Retrofitted Lysimeters for Recharge Studies - Test Plan, PVTD-C95-

04.02S Rev. 1., Pacific Northwest Laboratory, Richland, Washington, 1995.

Fayer 1999, M.J. Fayer, Recharge Data Package for the Immobilized Low-Activity Waste 2001 Performance Assessment, PNNL-13033, Pacific Northwest National Laboratory, Richland, Washington, December 1999. Also Appendix J of Mann/Puigh 2000.

Finfrock 2000, S.H. Finfrock, Verification and Validation for VAM3DF, Version 1.00 (FFS Version 1.00), HNF-5769, Rev. 0, Fluor Federal Services, Richland, Washington, January 2000.

Frei 1996, Interim Format and Content Guide and Standard Review Plan for U.S. Department of Energy Low-Level Waste Disposal Facility Performance Assessments, U.S. Department of Energy, Washington, D.C., October 31, 1996. Issued by memorandum ("Issuance of Low-Level Waste Performance Assessment Guidance") from Mark W. Frei (Acting Associate Deputy Assistant Secretary for Waste Management) dated November 1, 1996.

French 1999, R.T. French, "Disposal Authorization for the Hanford Site Low-Level Waste Disposal Activities", memorandum to Mark W. Frei, 99-DPD-071, Office of River Protection, U.S. Department of Energy, Richland, Washington, December 29, 1999

French 2000, R.T. French, "Initial Data Package from the Tank Focus Area on 55 Test Glasses for Hanford Immobilized Low-Activity Waste (ILAW) Studies," memorandum to Mark W. Frei, 00-DPD-018, Office of River Protection, U.S. Department of Energy, Richland, Washington, March 10, 2000.

Gamerdinger et al., 1998, A. P. Gamerdinger, D. I. Kaplan, and C. T. Resch, Uranium(VI) Sorption and Transport in Unsaturated, Subsurface hanford Site Sediments - Effect of Moisture Content and Sediment Texture, PNNL-11975, Pacific Northwest National Laboratory, Richland, Washington.

Garabedian 1988, S.P. Garabedian, L.W. Gelhar, and M.A. Celia, Large-scale dispersive transport in aquifers: field experiments and reactive transport theory, Ralph $\mathrm{M}$. Parsons Lab. Tech. Report 315, Massachusetts Institute of Technology, Cambridge, MA, 1988.

Gardner 1986, W.H. Gardner, "Water Content". In Methods of Soils Analysis, Part 1, A. Klute, ed., pp. 493-544, Am. Soc. Agron., Madison, WI.

Gee and Bauder 1986, Gee, G. W., and J. W. Bauder. 1986. "Particle-size Analysis." pp. 383411. In. Methods of Soil Analysis, Part 1. Physical and Mineralogy Methods. Klute, A. (Ed.). Soil Science Society of America, Madison, Wisconsin.

Gee 1992, G.W. Gee, M.J. Fayer, M.L. Rockhold, and M.D. Campbell, Variations in recharge at the Hanford Site, Northwest Science 66:237-250, 1992. 
RPP-6702, Rev. 0

Formerly HNF-SD-WM-PAP-062 Rev. 4

Gee 1994, G.W. Gee, P.J. Wierenga, B.J. Andraski, M.H. Young, M.J. Fayer, and M.L. Rockhold, Variations in water balance and recharge potential at three western desert sites. Soil Sci. Soc. Am. J. 58:63-72, 1994.

Gelhar 1993, L. W., Stochastic Subsurface Hydrology, Prentice Hall, New York, 1993.

Goldberg and Glaubig 1988, S. Goldberg, and R. A. Glaubig. Anion sorption on a calcareous, montmorillonitic soil - arsenic, Soil Sci. Soc. Am. J. ㄴ. 1297-300, 1988.

Gottardi and Galli 1985, G. Gottardi and E. Galli, Natural Zeolites, Springer-Verlag, New York, New York, pp. 409, 1985.

Guimond 1996, Revised Interim DOE Policy on Management, Direction, and Oversight of LowLevel Radioactive Waste Management and Disposal, Attachment to a memorandum from Richard J. Guimond (Assistant Surgeon General - USPHS, and Principal Deputy Assistant Secretary for Environmental Management) and Tara J. O'Toole, Assistant Secretary for Environment, Safety, and Health) to Distribution July 31, 1996.

Ho and Kraus 1981, P. C. Ho, and K. A. Kraus, Adsorption on inorganic materials - VIII Adsorption of iodide on AgCl-filled carbon, J. Inorg. Nucl. Chem., 43, 583, 1981.

Hoitnik 1994, D.J. Hoitnik and K.W. Bark, Climatological Data Summary 1993 with Historical Data. PNL-9809, Pacific Northwest Laboratory, Richland, Washington, 1994.

Honeyman, JO, 1995. Peer review comments on Hanford recharge workshop, Letter 9554648 , to Mr. L. Erickson, U.S. Department of Energy, Richland, Washington.

Ikeda, T., F. Izumi, T. Kodaira, and T. Kamiyama. 1998, Structural Study of Sodium-Type Zeolite LTA by Combination of Rietveld and Maximum-Entropy Methods, Chem. Mater. 8: $3996-4004$.

Kaplan 1995a, DI Kaplan, RJ Serne, and M.G. Piepho, Geochemical Factors Affecting Radionuclide Transport Through Near and Far Fields at a Low-Level Waste Disposal Site, PNL-10379, Pacific Northwest Laboratory, Richland, Washington, March 1995.

Kaplan 1995b, DI Kaplan and RJ Serne, Distribution Coefficient Values Describing lodine, Neptunium, Selenium, Technetium, and Uranium Sorption to Hanford Sediments, PNL10379, Sup. 1, Pacific Northwest Laboratory, Richland, Washington, March 1995.

Kaplan 1996, DI Kaplan, RJ Serne, AT Owen, J. Conca, T.W. Wietsma, and T.L. Gervais, Radionuclide Adsorption Coefficients Measured in Hanford Sediments for the Low-Level Waste Performance Assessment Project, PNNL-11385, Pacific Northwest National Laboratory, Richland, Washington, August 1996.

Kaplan et al. 1998, Kaplan, D. I., K. E. Parker, and I. V. Kutynakov. 1998c. Radionuclide Distribution Coefficients for Sediments Collected from Borehole 299-E17-21: Final Report for Subtask 1a. PNNL-11996. Pacific Northwest National Laboratory, Richland, Washington.

Kaplan 1999, D.L. Kaplan And R.J. Seme, Geochemical Data Package For The Immobilized Low-Activity Waste Performance Assessment, PNNL - 13037, Pacific Northwest 
RPP-6702, Rev. 0

Formerly HNF-SD-WM-PAP-062 Rev. 4

National Laboratory, Richland, Washington, December 1999. Also Appendix N of Mann/Puigh 2000.

Kaplan et al., 1999, D. I. Kaplan, D. McCabe, S. Serkiz, Phase / chemical speciation modeling of stream mixing in the LAW/HLW envelope A treatment process, BNF-003-98-0098, Westinghouse Savannah River Company, Aiken, SC, 1999.

Khaleel 1995a, R. Khaleel and E.J. Freeman, A Compilation of Hydrologic Properties for LowLevel Tank Waste Disposal Facility Performance Assessment, WHC-SD-WM-RPT-0165, Westinghouse Hanford Company, Richland, Washington, June 1995.

Khaleel 1995b, R. Khaleel, J.F. Relyea and J.L. Conca, Evaluation of van Genuchten-Mualem Relationships to Estimate Unsaturated Conductivity at Low Water Contents, Water Resour. Res. 31:2659-2668, 1995.

Khaleel 1995c, R. Khaleel and E.J. Freeman, Variability and Scaling of Hydraulic Properties for 200 Area Soils, Hanford Site. WHC-EP-0883. Westinghouse Hanford Company. Richland, Washington, 1995.

Khaleel 1997, R. Khaleel and J. F. Relyea, Correcting Laboratory-Measured Moisture Retention Data for Gravels, Water Resour. Res. 33:1875-1879, 1997.

Khaleel 1999, R. Khaleel, Far-Field Hydrology Data Package For The Immobilized Low-Activity Waste Performance Assessment, HNF-4769, Rev. 2, Fluor Federal Services, Richland, Washington, December 1999. Also Appendix M of Mann/Puigh 2000.

Kincaid 1998, C.T. Kincaid, M.P. Bergeron, C.R. Cole, M.D. Freshley, D.L. Strenge, P.D. Thorne, L.W. Vail, and S.K. Wumster, Composite Analysis for the Low-Level Waste Disposal in the 200 Area Plateau of the Hanford Site, PNL-11800, Pacific Northwest National Laboratory, Richland, Washington, March 1998.

Kincaid, C.T. et al. (1998) Composite Analysis for Low-Level Waste Disposal in the 200-Area Plateau of the Hanford Site. Pacific Northwest National Laboratory. PNNL-11800.

Kincaid 1995a, C.T. Kincaid, J.W. Shade, G.A. Whyatt, M.G. Piepho, K. Rhoads, J.A. Voogd, J.H. Westsik, Jr., K.A. Blanchard, and B.G. Lauzon, Performance Assessment of Grouted Double-Shell Tank Waste Disposal at Hanford, WHC-SD-WM-EE-004, Revision 1, Westinghouse Hanford Company, Richland, Washington, May 1995.

Kincaid 1995b, C.T. Kincaid, letter to J.L. Straalsund concerning Milestone 1.07.02.02.02.03A, Pacific Northwest Laboratory, Richland, Washington, July 12, 1995. [Discusses contaminant releases from glass waste form and travel in Hanford soils.]

Kinard, W.F., Bibler, N.E., Coleman, C.J., and Dewberry, R.A. (1997) Radiochemical analysis for the defense waste processing facility startup at the Savannah River Site. Jour. Rad. Nuc. Chem. vol. 219, pp. 197-201.

Klute 1986a, A. Klute and C. Dirksen, Hydraulic Conductivity and Diffusivity: Laboratory Methods, in Methods of Soil Analysis, Part I, edited by A. Klute, pp. 687-734, Am. Soc. Agron., Madison, WI., 1986. 
RPP-6702, Rev. 0

Formerly HNF-SD-WM-PAP-062 Rev. 4

Klute 1986b, A. Klute, Water Retention: Laboratory Methods, in Methods of Soil Analysis, Part I, edited by A. Klute, pp. 635-660, Am. Soc. Agron., Madison, WI., 1986.

Klute 1986c, A. Klute, Methods of soil analysis Part 1, No. 9, American Society of Agronomy, Inc., Madison, Wisconsin, 1986.

Kung, 1990, K-J. S. Kung. Preferential Flow in a Stony Vadose Zone: 2. Mechanism and Implications. Geoderma 46:59-71.

Kupfer, M.J. et al. (1997) Standard inventories of chemicals and radionuclides in Hanford Site tank wastes. Lockheed Martin Hanford Corporation, HNF-SD-WM-TI-740 Rev. 0.

Mann 1994, F.M. Mann, Statements of Work for FY 1995 to 2000 for the Hanford Low-Level Tank Waste Performance Assessment Project, WHC-SD-WM-PAP-062, Rev. 0 , Westinghouse Hanford Company, Richland Washington, June 1994.

Mann 1995a, F. M. Mann, C. R. Eiholzer, N. W. Kline, B. P. McGrail, and M. G. Piepho, Impacts of Disposal System Design Options on Low-Level Glass Waste Disposal System Performance, WHC-EP-0810, Revision 1, Westinghouse Hanford Company, Richland, Washington, September 1995.

Mann 1995b, F. M. Mann, Data Packages for the Hanford Low-Level Tank Waste Interim Performance Assessment, WHC-SD-WM-RPT-166, Rev. 0, Westinghouse Hanford Company, Richland, Washington, July 1995.

Mann 1995c, F. M. Mann, C. R. Eiholzer, R. Khaleel, N. W. Kline, A. H. Lu, B. P. McGrail, P. D. Rittmann, and F. Schmittroth, Definition of the Base Analysis Case of the Interim Performance Assessment, WHC-SD-WM-RPT-200, Rev. 0, Westinghouse Hanford Company, Richland, Washington, December 1995.

Mann 1995d, F.M. Mann, Statements of Work for FY 1996 to 2001 for the Hanford Low-Level Tank Waste Performance Assessment Project, WHC-SD-WM-PAP-062, Rev. 1, Westinghouse Hanford Company, Richland Washington, June 1995.

Mann 1995e, F.M. Mann, Performance Objectives of the Tank Waste Remediation System LowLevel Waste Disposal Program, WHC-EP-0826, Rev. 1, Westinghouse Hanford Company, Richland, Washington, January 1995.

Mann 1995f, F.M. Mann, Scenarios of the TWRS Low-Level Waste Disposal Program, WHCEP-0828, Rev. 1, Westinghouse Hanford Company, Richland, Washington, January 1995.

Mann 1995g, F.M. Mann, Computer Code Selection Criteria and Considerations for the Hanford Low-Level Waste Interim Performance Assessment, WHC-SD.-WM-CSWD-073, Westinghouse Hanford Company, Richland, Washington, March 1995.

Mann 1996, F. M. Mann, C. R. Eiholzer, A. H. Lu, P. D. Rittmann, N. W. Kline, Y. Chen, and B. P. McGrail, Hanford Low-Level Tank Waste Interim Performance Assessment, WHC-EP0884, Rev. 0, Westinghouse Hanford Company, Richland, Washington, September 1996. 
RPP-6702, Rev. 0

Formerly HNF-SD-WM-PAP-062 Rev. 4

Mann 1997a, F. M. Mann, C. R. Eiholzer, A. H. Lu, P. D. Rittmann, N. W. Kline, Y. Chen, and B. P. McGrail, Hanford Low-Level Tank Waste Interim Performance Assessment, HNF-EP0884, Rev. 1, Lockheed Martin Hanford Company, Richland, Washington, September 1997.

Mann 1997b, F.M. Mann, Statements of Work for FY 1998 to 2003 for the Hanford Low-Level Tank Waste Performance Assessment Project, HNF-SD-WM-PAP-062, Rev. 2, Lockheed Martin Hanford Company, Richland Washington, June 1997.

Mann 1998a, F. M. Mann, C. R. Eiholzer, A. H. Lu, P. D. Rittmann, N. W. Kline, Y. Chen, and B. P. McGrail, Hanford Low-Activity Tank Waste Performance Assessment,

DOE/RL-97-69, Rev. 0, Lockheed Martin Hanford Company, Richland, Washington, March 1998.

Mann 1998b, F.M. Mann and D.A. Myers, Computer Code Selection Criteria for Flow and Transport Code(s) to Be Used in Undisturbed Vadose Zone Calculations for TWRS Environmental Analyses, HNF-1839, Rev. 0, Lockheed Martin Hanford Company, Richland, Washington, January 1998.

Mann 1998c, F.M. Mann, Statements of Work for FY 1999 to 2004 for the Hanford Low-Level Tank Waste Performance Assessment Project, HNF-SD-WM-PAP-062, Rev. 3, Lockheed Martin Hanford Company, Richland Washington, August 1998.

Mann 1999a, F. M. Mann, Performance Objectives for the Hanford Immobilized Low-Activity Waste (ILAW) Performance Assessment, HNF-EP-0826, Revision 3, Fluor Daniel Northwest, Inc., Richland, Washington August 1999. Also Appendix A of Mann/Puigh 2000.

Mann 1999b, Scenarios for the Hanford Immobilized Low-Activity Waste (ILAW) Performance Assessment, HNF-EP-0828, Rev. 3, Lockheed Martin Hanford Company, Richland, Washington, August 1999. Also Appendix B of Mann/Puigh 2000.

Mann 2000a, F.M. Mann, S.H. Finfrock, E.J. Freeman, R.J. Puigh II, D.H. Bacon, M.P. Bergeron, B.P. McGrail, and S.K. Wurstner, White Paper Updating the Conclusions of 1998 ILAW Performance Assessment, DOE/ORP-2000-07, Office of River Protection, Department of Energy, Richland, Washington, April 2000.

Mann 2000b, F.M. Mann, Maintenance Plan for the Hanford Immobilized Low-Activity Tank Waste Performance Assessment, DOE/ORP-2000-01, Rev. 0, Department of Energy, Office of River Protection, Richland, Washington, February 2000. This plan was formally by the ORP Field Manager in a memorandum to Mark W. Frei (Deputy Assistant Secretary, Office of Projection Completion, Department of Energy) dated March 7, 2000, 00-DPD-015.

Mann/Puigh 2000, F. M. Mann and R. J. Puigh II, Data Packages for the Hanford Immobilized Low-Activity Tank Waste Performance Assessment: 2001 Version, HNF-5636, Fluor Federal Services, Richland, Washington, February 2000. 


\section{RPP-6702, Rev. 0 \\ Formerly HNF-SD-WM-PAP-062 Rev. 4}

Mattigod et al. 1998, S. V. Mattigod, D. I. Kaplan, V. LeGore, R. D. Orr, H. T. Schaef, J. S. Young, Radionuclide Incorporation in Secondary Crystalline Minerals Resulting from Chemical Weathering of Selected Waste Glasses: Progress Report for Subtask 3d, PNNL-12005, Pacific Northwest National Laboratory, Richland Washington.

McAninch, J.E., Bench, G.S., Freeman, S.P.H.T, Roberts, M.L, Southon, J.R., Vogel, J.S., and Proctor, I.D. (1995) PXAMS - projectile X-ray AMS: Xray yields and applications. Nucl. Instr. and Meth. B. vol. 99, pp. 541.

McCord 1991, J.T. McCord, D.B. Stephens, and J.L. Wilson, Hysteresis and State-dependent Anisotropy in Modeling Unsaturated Hillslope Hydrologic Processes, Water Resources Research, 27(7), 1501-1518, 1991.

McGrail 1994, B.P. McGrail and L.A. Mahoney, Selection of a Computer Code for Hanford LowLevel Waste Engineered-System Performance Assessment, PVTD-C95-04.01E, Rev. 1, Pacific Northwest Laboratory, Richland, Washington, December 1994.

McGrail 1996, B.P. McGrail, W. L. Ebert, A. J. Bakel, and D. K. Peeler, Measurement of Kinetic Rate Law Parameters on a Na-Cal-Al Borosilicate Glass for Low-Activity Waste, Pacific Northwest National Laboratory, Richland, Washington, October 1996. Submitted for publication in Joumal of Nuclear Materials.

McGrail 1998a, B.P. McGrail, W.L. Ebert, D.H. Bacon, and D.M. Strachen, A Strategy to Conduct an Analysis of the Long-term Performance of Low-Activity Waste Glass in a Shallow Subsurface Disposal System at Hanford, PNNL-11834, Pacific Northwest National Laboratory, March 1998.

[This document is also contained in Appendix G of DOE/RL 1998]

McGrail 1998b, B.P. McGrail and D.H. Bacon, Selection of a Computer Code for Hanford LowLevel Waste Engineered-System Performance Assessment, PNNL-10830, Rev. 1, Pacific Northwest National Laboratory, Richland, Washington, March 1998.

McGrail 1999, B. P. McGrail, D. H. Bacon, J. P. Icenhower, W. L. Ebert, P. F. Martin, H. T. Schaef, and E. A. Rodriguez, Waste Form Release Data Package for the 2001 Immobilized Low-Activity Waste Performance Assessment, PNNL-13043, Pacific Northwest National Laboratory, Richland, Washington, December 1999. Also Appendix $\mathrm{K}$ of Mann/Puigh 2000.

Mehuys 1975, G.R. Mehuys, L.H. Stolzy, J. Letey, and L.V. Weeks, Effect of Stones on the Hydraulic Conductivity of Relatively Dry Desent Soils. Soil Sci. Soc. Am. Proc. 39:37-42.

Meyer 1999, P. D. Meyer and R. J. Serne, Near Field Hydrology Data Package for the Immobilized Low-Activity Waste 2001 Performance Assessment, PNNL-13035, Revision 1, Pacific Northwest National Laboratory, Richland, Washington, December 1999. Also Appendix L of Mann/Puigh 2000.

Mualem 1976, Y. Mualem, A New Model for Predicting the Hydraulic Conductivity of Unsaturated Porous Media, Water Resour. Res. 12:513-522.

Mualem 1984, Y. Mualem, Anisotropy of unsaturated soils, Soil Sci. Soc. Am. J., 48, 505-509, 1984. 
RPP-6702, Rev. 0

Formerly HNF-SD-WM-PAP-062 Rev. 4

Murphy 1996, E.M. Murphy, T.R. Ginn, and J.L. Phillips, Geochemical estimates of paleorecharge in the Pasco Basin: Evaluation of the Chloride Mass Balance Technique. Water Resources Research, 32: 2853-2868, 1996.

Narbutovskih 1996, S. M. Narbutovskih, D. F. Iwatate, M. D. Sweeney, A. L. Ramirez, W. Daily, R. M. Morey, and L. Christensen.. Feasibility of CPT-Deloyed Vertical Electrode Array in Single Shell Tank Farms. WHC-SD-EN-TA-004, Rev. 0, Westinghouse Hanford Company, Richland, Washington.

National Research Council, 1995. Ward Valley, An Examination of Seven Issues in Earth Sciences and Ecology, National Academy Press, Washington, D.C., 1995.

Nkedi-Kizza 1983, P. Nkedi-Kizza, J. W. Biggar, M. T. van Genuchten, P. J. Wierenga, H. M. Selim, J. M. Davidson, and D. R. Nielsen. 1983. Modeling Tritium and Chloride 36 Transport through an Aggregated Oxisol. Water Resources Res. 19:691-700.

Piepho 1995, M.G. Piepho, Selection of Flow and Transport Code for the Hanford Low-Level Tank Waste Interim Performance Assessment, WHC-SD-WM-CSWD-074, Westinghouse Hanford Company, Richland, Washington, February 1995.

Parker, G.W., Creek, G.E., Herbert, G.M., Lantz, P.M. (1949) Radiations and half-life of longlived fission selenium. Oak Ridge National Laboratory, ORNL-499, p 45-51.

Petersen 1995, K.L. Petersen, S.O. Link, and G.W. Gee, Hanford Site Long-Term Surface Barrier Development Program: Fiscal Year 1994 Highlights, PNL-10605, Pacific Northwest Laboratory, Richland, Washington, 1995.

Puigh 1999a, R.J. Puigh II and F.M. Mann, Statements of Work for FY 2000 to 2005 for the Hanford Low-Level Tank Waste Performance Assessment Project, HNF-SD-WM-PAP062, Rev. 4, Lockheed Martin Hanford Company, Richland Washington, July 1999.

Puigh 1999b, R. J. Puigh II, Disposal Facility Data for the Hanford Immobilized Low-Activity Tank Waste, HNF-4950, Rev. 1, Fluor Federal Services, Richland, Washington, December 1999. Also Appendix I of Mann/Puigh 2000.

Puppe and Aktiengesellschaft 1990, L. Puppe, and B. Aktiengesellschaft, Process for the removal of iodine and organic iodine compounds from gases and vapors using silvercontaining zeolite of the Faujasite type, US Patent 4,913,850, Washington, DC, 1990.

Rawlins 1994, J. A. Rawlins, R. A. Kamesky, R. Khaleel, F. M. Mann, B. P. McGrail, W. J. McMahon, M. G. Piepho, P. D. Rittmann, and F. Schmittroth, Impacts of Disposal System Design Options on Low-Level Glass Waste Disposal System Performance, WHC-EP-0810, Rev. 0, Westinghouse Hanford Company, Richland, Washington, September 1994.

Reidel 1995, S.P. Reidel, A.M. Tallman, V.G. Johnson, C.J. Chou, and S.M. Narbutovskih, and J.P. Kiesler, Characterization Plan for the Proposed TWRS Treatment Complex, WHCSD-EM-PLN-109, Westinghouse Hanford Company, Richland, Washington, July 1995. 


\section{RPP-6702, Rev. 0 \\ Formerly HNF-SD-WM-PAP-062 Rev. 4}

Reidel 1997, S.P. Reidel and K.D. Reynolds, Characterization Plan for the Immobilized LowActivity Borehole, November 1997. This plan was transmitted to Bechtel Hanford Company on December 10, 1997 as the attachment to "Subcontract Number 802327649-K001 - Transmittal of "Characterization Plan for the Immobilized Low-Activity Waste Borehole" and Instructions for Drilling the First Characterization Borehole at the Immobilized Low-Activity Waste Disposal Complex", a letter sent from R.J. Murjowski to A.J. Knepp on December 10, 1997.

Reidel 1999, S. P. Reidel and D. G. Horton, Geologic Data Packages for 2001 Immobilized Low-Activity Waste Performance Assessment, PNNL-12257, Rev. 2, Pacific Northwest National Laboratory, Richland, Washington, December 1999. Also Appendix $G$ of Mann/Puigh 2000.

Rittmann 1999, P. D. Rittmann, Exposure Scenarios And Unit Dose Factors For The Hanford Immobilized Low-Activity Tank Waste Performance Assessment, HNF-SD-WM-TI-707, Rev. 1, Fluor Federal Services, Richland, Washington, December 1999. Also Appendix $O$ of Mann/Puigh 2000.

Rockhold 1995, M.L. Rockhold, M.J. Fayer, C.T. Kincaid, and G.W. Gee, Estimation of Natural Ground Water Recharge for the Performance Assessment of a Low-Level Waste Disposal Facility at the Hanford Site, PNL-10508, Pacific Northwest Laboratory, Richland, Washington, March 1995.

RWTSP 1994, A Compilation of DOE Performance Assessment Peer Review Comments and Recommendations, DOE/LLW-216, Radioactive Waste Technical Support Program, Idaho National Engineering Laboratory, Idaho Falls, Idaho, 1994.

Salbu et al. 1994, B. Salbu, D. H. Oughton, A. V. Ratnikov, T. O. Zhigareva, X. V. Kruglov, K. V. Petrov, N. V. Grebenshakikova, S. K. Firsakova, N. P. Astasheva, N. A. Loshchilov, K. Hove, and P. Strand, The mobility of Cs-137 and Sr-90 in agricultural soils in the Ukraine, Belarus, and Russia, 1991, Health Physics, 67, 518-695, 1994.

Saripalli et al., 2000, Saripalli, K. P., R. J. Serne, P. D. Meyer, and B. P. McGrail. 2000. "Prediction of Diffusion Coefficients in Porous Media using Tortuosity Factors based on Interfacial Areas." J. of Contam. Hydrol. submitted

Schmittroth 1995, F. Schmittroth, T.H. DeLorenzo, D.W. Wootan, and D.Y. Garbrick, Inventories for Low-Level Tank Waste, WHC-SD-WM-RPT-164, Westinghouse Hanford Company, Richland, Washington, June 1995.

Serne 1993, Solid-Waste Leach Characteristics and Contaminant-Sediment Interactions, Volume 1: Batch Leach and Adsorption Tests and Sediment Characterization, PNL8889, Vol. 1, Pacific Northwest Laboratory, Richland, Washington, 1993.

Sonsheng, et al. 1997, Determination of the half-life of 79Se with the accelerator mass spectrometry technique. Nuc. Instr. and Meth. in Phys. B. vol. 123, pp. 405-409.

Talbott 1994, M. E. Talbott and L. W. Gelhar, Performance Assessment of a Hypothetical LowLevel Waste Facility: Groundwater Flow and Transport Simulation, NUREG/CR-6114 Vol. 3, U.S. Nuclear Regulatory Commission, Washington, D.C., 1994. 
RPP-6702, Rev. 0

Formerly HNF-SD-WM-PAP-062 Rev. 4

Taylor 1999, W. J. Taylor, Contract No. DE-AC06-99RL14047 - Decision to Change the Immobilized Low-Activity Waste (ILAW) Disposal Baseline to Proceed with the RemoteHandled Trench Alternative, letter 99-DPD-066 (correspondence control number 9958849), Department of Energy, Richland, Washington, December 1, 1999.

Tessier et al. 1979, A. Tessier, P. G. C., Campbell, and M. Bisson. Sequential extraction procedure for the speciation of particulate trace metals, Analyt. Chem. 51, 844$851,1979$.

TWRS ROD, Record of Decision for the Tank Waste Remediation System, Federal Register. Vol. 62, page 8693, U.S. Government Printing Office, Washington, DC, February 26, 1997.

Tyler 1996, S.W. Tyler, J.B. Chapman, S.H. Conrad, D.P. Mammermeister, D.O. Bout, J.J. Miller, M.J. Sully, and J.M. Ginanni, Soil-water flux in the southem Great Basin, United States: Temporal and Spatial Variations over the Last 120,000 Years, Water Resources Research, 32: 1481-1499.

van Genuchten 1980, M.Th. van Genuchten, A closed-form solution for predicting the conductivity of unsaturated soils. Soil Sci. Soc. Am. J. 44:892-898.

van Genuchten 1991, M.Th. van Genutchen, F.J. Leij, and S.R. Yates, The RETC Code for Quantifying the Hydraulic Functions of Unsaturated Soils, U.S. E.P.A., EPA/600/291/065.

Voogd 1999, J. A. Voogd, F. M. Mann, and A. J. Knepp, Recommendations for Computer Code Selection of a Flow and Transport Code to be Used in Undisturbed Vadose Zone Calculations for TWRS Immobilized Wastes, HNF-4356, Lockheed Martin Hanford Corporation, Inc., April 1999.

Wagoner 1996, J.D. Wagoner, Single Groundwater Project for the Hanford Site, letter to Contractors, Richland, Washington, Department of Energy, Richland, Washington, September 5, 1996.

Wing 1994, N.R. Wing, Permanent Isolation Surface Bamier Development Plan., WHC-EP-0673, Westinghouse Hanford Company, Richland, Washington, 1994.

Wood 1994, M.I. Wood, R. Khaleel, P.D. Rittmann, A.H. Lu, S.H. Finfrock, R.J. Seme, and K.J. Cantrell, Performance Assessment for the Disposal of Low-Level Waste in the 200 West Area Burial Grounds, WHC-EP-0645, Westinghouse Hanford Company, Richland, Washington, November 1994.

Wood 1995, M.I. Wood, R. Khaleel, P.D. Rittmann, A.H. Lu, S.H. Finfrock, and T.H. DeLorenzo, Environmental Remediation Disposal Facility Performance Assessment, BHI-00169, Revision 00, Bechtel Hanford Company, Richland, Washington, August 1995.

Wood 1996, M.I. Wood, Performance Assessment for the Disposal of Low-Level Waste in the 200 East Area Burial Grounds, WHC-EP-0875, Westinghouse Hanford Company, Richland, Washington, September 1996. 
RPP-6702, Rev. 0

Formerly HNF-SD-WM-PAP-062 Rev. 4

Wootan 1999, D. W. Wootan, Immobilized Low Activity Tank Waste Inventory Data Package, HNF-4921, Rev. O, Fluor Daniel Northwest, Inc., September 1999. Also appendix H of Mann/Puigh 2000.

WSRC 1992, Radiological Performance Assessment for the Z-Area Saltstone Disposal Facility, WSRC-RP-92-1360, Westinghouse Savannah River Company, Aiken, South Carolina, December 1992.

Yeh 1985, T.-C. Yeh, L.W. Gelhar, and A.L. Gutjahr, Stochastic Analysis of Unsaturated Flow in Heterogeneous Soils, 1, Statistically Isotropic Media, Water Resources Research, 21(4), 447-456, 1985. 
RPP-6702, Rev. 0

Formerly HNF-SD-WM-PAP-062 Rev. 4

APPENDIX A

FORMATS AND CONTENTS

Each major subactivity (as listed in Table 1.0-1) has its own chapter. Each chapter is organized as follows.

\section{A. SUMMARY}

Provide a one paragraph statement that summarizes the effort and purpose for the subactivity.

B. GENERAL

i. Background

Identify the need for this activity.

Describe any previous work including studies, functions and requirements, design criteria, etc. The criteria to be met by the end product(s) of the subactivity must either be referenced or contained in the statement of work. If the criteria have not been established, then the criteria must be established as a deliverable from one or more subtasks.

ii. List of Deliverables

Provide a list of major deliverables for the subactivity in table format that contains the description of the deliverable, the due date of the deliverable, the level of the deliverable, and the Schedule Identifier of the deliverable. This information shall be consistent with the Multiyear Program Plan.

iii. Cost Summary

Provide the Work Breakdown Structure (WBS) and Task Program Control Number (TPCN) for the subactivity.

Provide a list of cost by fiscal year (starting with fiscal year 1997) and by organization in table format. If more than one organization is included in a fiscal year, then a entry given the total expenditures for the year shall be given. A entry providing the grand total for the subactivity shall also be given. Note should be given for the amount of capital funds included.

iv. Interfaces

Provide a description of the subtasks (and deliverables) feeding into this subactivity and of the subactivities, tasks, or subtasks using the deliverables of this subactivity. If convenient, the information can be entered in table format.

v. Organization

Provide a description of the organizations involved in the subactivity. Justify why the organizations are the appropriate ones to perform the work. 
RPP-6702, Rev. 0

Formerly HNF-SD-WM-PAP-062 Rev. 4

\{Note if there is only one task under the subactivity, [see, for example, Section 1.0], then section v. Is replaced with the following:

v. Detailed Description (described below under C.n.d)

vi. Organization (described below under C.n.f)

vii. Quality Assurance (described under C.n.g)

viii. Effect of Not Performing Task (described under C.n.h)

ix. $\quad$ Cost and Schedule (described below under C.n.i)\}

\section{TASK DESCRIPTIONS}

i. Summary List of Tasks

Provide a list of tasks to performed (starting with Fiscal Year 98)

\{For each task provide the following\}

n. Task Description

\section{a. Background}

Provide background needed to understand the purpose, the justification, and the description of the task that is not provide in the Background Section above.

In particular, describe fiscal year 1997 tasks, the status of those tasks, and how they feed into proposed tasks.

b. List Of Deliverables

Provide a list of all deliverables for the task in table format that contains the description of the deliverable, the due date of the deliverable, the level of the deliverable, and the Schedule Identifier of the deliverable. Except for level of effort subtasks, each subtask should have a deliverable. This information shall be consistent with the Multiyear Program Plan.

c. Cost Summary

Provide the Work Breakdown Structure (WBS) and Task Program Control Number (TPCN) for the subactivity.

Provide a list of cost by fiscal year (starting with fiscal year 1997) and by organization in table format. If more than one organization is included in a fiscal year, then a entry given the total expenditures for the year shall be given. An entry providing the grand total for the subactivity shall also be given. Note should be given for the amount of capital funds included. 
RPP-6702, Rev. 0

Formerly HNF-SD-WM-PAP-062 Rev. 4

d. Detailed Description

Provide a detailed description of each subtask, including its purpose and deliverable. The number of subtasks should be determined by the requirement to track progress of the task. Therefore, except for level of effort tasks, a subtask should extend for no more than 3 months or consume more than $\$ 50,000$.

e. Interfaces

Provide a description of the subtasks (and deliverables) feeding into this task and of the subactivities, tasks, or subtasks using the deliverables of this subactivity. If convenient, the information can be entered in table format.

f. Organization

Provide a description of the organizations involved in the task and subtasks. Justify why the organizations are the appropriate ones to perform the work.

g. Quality Assurance

Define the quality assurance plan and level under which the work is to be performed.

h. Effect of Not Performing Task

Describe added risks that the RPP Program or Richland Operations would occur if the task was not completed.

i. Cost and Schedule

Provide a table listing

the schedule identifier of each subtask the fiscal year in which the subtask occurs, the description of each subtask, the start and finish dates of the subtask, the organization(s) performing the subtask along with the funds needed to completed the subtask, and the schedule identifiers of the subtasks which succeed this subtask. (if the schedule identifiers are not in the current table, then a footnote to the table shall indicate where the subtasks can be found.)

Following the table, a justification for the costs for the schedule and schedule for each subtask shall be given. 